UNIVERSIDADE DE SÃO PAULO

FACULDADE DE FILOSOFIA, LETRAS E CIÊNCIAS HUMANAS

DEPARTAMENTO DE HISTÓRIA

PROGRAMA DE PÓS-GRADUAÇÃO EM HISTÓRIA SOCIAL

IVETE BATISTA DA SILVA ALMEIDA

AS FACES DO HÉRCULES-QUASÍMODO: REPRESENTAÇÕES DO NORDESTE E DOS NORDESTINOS DURANTE A ERA VARGAS

SÃO PAULO 
IVETE BATISTA DA SILVA ALMEIDA

\section{AS FACES DO HÉRCULES-QUASÍMODO: REPRESENTAÇÕES DO NORDESTE E DOS NORDESTINOS DURANTE A ERA VARGAS}

Tese apresentada ao Programa de Pós-Graduação em História Social do Departamento de História da Faculdade de Filosofia, Letras e Ciências Humanas da Universidade de São Paulo, para a obtenção do título de Doutor em História sob a orientação da Profa. Dra. Maria Inez Machado Borges Pinto.

SÃO PAULO

2014 
ALMEIDA, Ivete Batista da Silva

As Faces do Hércules-Quasímodo: Representações do Nordeste e dos Nordestinos Durante a Era Vargas

Tese apresentada à Faculdade de Filosofia, Letras e Ciências Humanas da Universidade de São Paulo para obtenção do título de Doutor em História.

Aprovado em:

Banca Examinadora

Profa. Dra. Maria Inez Machado Borges Pinto

Universidade de São Paulo

Profa Dra Solange Ferraz de Lima

Universidade de São Paulo

Prof. Dr. José Geraldo Vinci de Moraes

Universidade de São Paulo

Prof. Dra Vera Lúcia Puga

Universidade Federal de Uberlândia

Prof. Dr. Isnard de Albuquerque Câmara Neto

Universidade de Taubaté 


\section{DEDICATÓRIA}

À minha mãe, Dona Ivone, mulher de fibra, fonte de força e inspiração.

Ao meu pai, José Lino (in memoriam), que do seu jeito, me inspirou a ser quem sou. 


\section{AGRADECIMENTOS}

Em primeiro, lugar agradeço a Professora Doutora Maria Inez Machado Borges Pinto, orientadora atenciosa em meu mestrado e em meu doutorado, que me estimulou e mostrou sempre o melhor caminho a ser seguido.

Ao professor Dr José António Martin Moreno Afonso, meu orientador durante o Estágio Científico Avançado - doutorado sanduiche - realizado em Portugal; agradeço pela meticulosa orientação, pelas conversas, pela paciência e pela amizade.

À PRPG da USP, pelo financiamento de meu Estágio Científico em Portugal.

Aos colegas da Universidade do Minho, colegas da sala 007, aos funcionários da Biblioteca Geral do Campus Gualtar, aos funcionários da Biblioteca Municipal de Braga-Portugal, funcionários e estagiários da Biblioteca do MASP (Museu de Arte de São Paulo), em especial ao bibliotecário Romeu Loreto que pacientemente auxiliou-me com os pesados volumes a serem consultados. Aos funcionários do IEB e da ECA-USP; do CEDIC da PUC e do CEDHIS da UFU; sem vocês esta pesquisa não existiria.

Agradeço ainda ao amigo Diogo Farias pelas explicações técnicas.

Aos meus filhos, que tanto amo, à minha mãe e minha irmã, meu agradecimento eterno por tudo o que representam para mim.

Ao meu marido, José Benedito, pelo amor, pelo carinho, pelo apoio e por sempre acreditar que esta ideia poderia se tornar uma tese.

E a todos aqueles que participaram desta longa e tortuosa jornada, meu sincero agradecimento. 
O método para compreender os fenômenos seria: não tentar interpretá-los, mas olhá-los até que jorre a luz. Em geral, método de exercer a inteligência que consiste em olhar.

Simone Wiel 


\section{RESUMO}

ALMEIDA, I. B. S. (2014) As Faces do Hércules-Quasímodo: Representações do Nordeste e dos Nordestinos Durante A Era Vargas. Tese de Doutorado, Faculdade de Filosofia, Letras e Ciências Humanas, Universidade de São Paulo, São Paulo.

Este trabalho tem por objetivo reconstruir as representações coletivas, do Nordeste e do Nordestino, elaboradas pela imprensa escrita e de grande circulação no Brasil, mais precisamente as grandes Revistas Ilustradas Semanais, durante o primeiro e o segundo governo Vargas. Em meio ao cenário de transformações das décadas de 1930 a 1950, causadas por questões políticas e ideológicas a imprensa ao representar o Nordeste e o nordestino, condensava a experiência do vivido na expressão de uma sensibilidade feita texto, dando ao leitor um Nordeste reconstruído como imagem e como discurso, a partir de referenciais permeados por novas e por velhas ideologias. Tomando tais representações como símbolos de uma época, buscamos reinterpretá-los à luz dos processos históricos, dos sistemas de ideias e imagens com as quais estabelecem contato, com o objetivo de compreendermos qual Nordeste e nordestino teria sido construído por essas mídias àquela época e quais as implicações sociais desta construção. Para trilharmos este caminho, seguimos os passos indicados por Chartier, que aponta para as "três realidades maiores" do estudo das representações: a compreensão das representações coletivas; a exibição do ser social por meio da estilização da vida; a construção de identidades a partir dos novos significados e símbolos sociais adotados por um grupo, permitindo-nos ampliar a compreensão da relação entre sociedade, cultura e identidade no Brasil da virada do século XX.

Palavras-chave: História. Representações. Nordeste. Nordestinos. Era Vargas. 


\begin{abstract}
ALMEIDA, I. B. S. (2014). The faces of Hercules-Quasimodo: Representations of Northeast and northeasterns during Vargas' Era. Tese de Doutorado, Faculdade de Filosofia, Letras e Ciências Humanas, Universidade de São Paulo, São Paulo.

The objective of this study is to reconstruct the collective representations of Brazilian Northeast and the Northeastern population elaborated by the written press and greatly circulated in Brazil, more precisely by the important weekly illustrated magazines during the first and the second Vargas' administration. In the midst of the scenario of transformations of the 1930's to the 1950's caused by the political and ideological questions, the press, upon representing the Northeast and the Northeastern population, condensed lived experience into the expression of a sensibility transformed into text, giving the reader a Northeast referential permeated as image and as discourse as based on permeated by new and old ideologies. Taking such representations as symbols of an era, we seek to reinterpret them in the light of historical processes, of the systems of ideas and these media constructed images with which they establish contact, with the objective of understanding which Northeast and Northeasterner at that time and the social implications of that construction. To take this path, we follow the steps indicated by Chartier, who indicates the "three greatest realities" in the study of representations: understanding the collective representations; the exhibition of the social being by means of stylization of life; the construction of identities from new meanings and social symbols adopted by a group, allowing us to broaden understanding of the relationship between society, culture and identity in Brazil at the turn of the $20^{\text {th }}$ century.
\end{abstract}

Keywords: History. Representations. Northeast. Northeastern People. The Vargas Era. 


\section{LISTA DE FIGURAS}

Figura 1. Scenas do Ceará. $\quad 46$

Figura 2. Gravura da efígie de D. João II 48

Figura 3. Casal de Xavantes - Índio bororo. 48

Figura 4. Aracajú e Natal. $\quad 50$

Figura 5. Novo Recife e Fortaleza. Estrada de Ferro. 50

Figura 6. Salvador, Bahia. Faculdade de Medicina e Delegacia no Piauí. 51

Figura 7. Recife e Belém. $\quad 51$

Figura 8. Caatinga 53

Figura 9. Vaqueiro do Nordeste $\quad 53$

Figura 10. J. A. Correa. Foto para O Bezouro. 61

Figura 11. Retirantes 61

Figura 12. Quatro cartazes de Jean-Pierre Chabloz 71

Figura 13. Fotos de Pierre Verger. Canudos. 78

$\begin{array}{ll}\text { Figura 14. Arraial de Canudos. Cruz. } & 78\end{array}$

Figura 15. Canudos - Cidade Condenada $\quad 81$

Figura 16. Moradores de Canudos $\quad 81$

Figura 17. A fuga da seca e da miséria. $\quad 82$

Figura 18. Os paus de arara $\quad 82$

Figura 19. Sede e fome no Nordeste. 86

Figura 20. Nas caatingas de Pernambuco 86

Figura 21. Salvem-se ao menos as crianças. 95

Figura 22. Salvem-se ao menos as crianças 2. 95

$\begin{array}{ll}\text { Figura 23. Na América } & 102\end{array}$

Figura 24.Cartaz publicitário da Hamburg-Sud 102

Figura 25. Fatia de mortadela. $\quad 106$

Figura 26. Posição atual da perseguição aos judeus 115

$\begin{array}{ll}\text { Figura 27. Os refugiados de hoje. } & 117\end{array}$

$\begin{array}{ll}\text { Figura 28. Na hecatombe da guerra } & 117\end{array}$

$\begin{array}{ll}\text { Figura 29. Sertanejos do asfalto. } & 130\end{array}$

Figura 30. Sertanejos do asfalto. $2 \quad 130$

Figura 31. Sertanejos do asfalto.3 131

Figura 32. Gado Humano. 131

Figura 33. As 5 Marias de São Paulo. 133

Figura 34.O dia das mães. 133

Figura 35. São crianças, meu Deus! 135

Figura 36. São crianças, meu Deus! 2

Figura 37. São crianças, meu Deus.3 136

$\begin{array}{ll}\text { Figura 38. Favela no asfalto } & 139\end{array}$

Figura 39. Os párias. 139

Figura 40. Os párias.2 140

Figura 41. Moradores de Estátua $\quad 143$

Figura 42. Moradores de Estátua: o perigo de epidemia 143

Figura 43. Álbum comemorativo de Luís Gonzaga 148 
Figura 44. Itália e Alemanha. $\quad 152$

Figura 45. Os sete séculos de Berlim. 154

Figura 46. Feira de Leipzig. 154

Figura 47. Corpo e Alma da Juventude Contemporânea. 158

Figura 48. Corpo e Alma da Juventude Contemporânea. 158

Figura 49. Educando para a morte. 161

Figura 50. O desfile da juventude 161

Figura 51. Viagem Maravilhosa. $\quad 165$

Figura 52. A côr de São Paulo. $\quad 165$

Figura 53. Vista aérea de Recife 166

Figura 54. Rio e São Paulo: roteiro econômico e social. 166

Figura 55. Percorrendo as instalações da Cia Paulista. 168

$\begin{array}{ll}\text { Figura 56. Quarto centenário. } & 170\end{array}$

$\begin{array}{ll}\text { Figura 57. } 400 \text { anos sem rugas. } & 170\end{array}$

Figura 58. Manuais portugueses. Café. 174

Figura 59. São Paulo. 174

Figura 60. Estrada de Ferro entre Santos e São Paulo. 175

$\begin{array}{ll}\text { Figura 61. Rio de Janeiro. } & 175\end{array}$

Figura 62. Turbilhão de Paulo Afonso. $\quad 179$

$\begin{array}{ll}\text { Figura 63. Um novo surto de prosperidade. } & 179\end{array}$

Figura 64. Miséria e riqueza de Paulo Afonso. 181

Figura 65. Miséria e riqueza de Paulo Afonso.2 181

Figura 66. A Bahia também dá gasolina. 183

$\begin{array}{lr}\text { Figura 67. Petróleo } & 183 \\ & 186\end{array}$

Figura 68. No El-Dorado da Mica. $\quad 186$

Figura 69. Transporte de mica. 186

$\begin{array}{ll}\text { Figura 70. Os operários: homens e mulheres. } & 187\end{array}$

$\begin{array}{ll}\text { Figura 71. No interior da mina } & 187\end{array}$

Figura 72. Ford. Açúcar. $\quad 189$

$\begin{array}{ll}\text { Figura 73.Cacau } & 189\end{array}$

Figura 63. Josué de Castro 195

Figura 75. Retirantes da violenta sêca de 1877. Percy Lau. 195

$\begin{array}{ll}\text { Figura 76. O povo brasileiro em guerra. } & 198\end{array}$

Figura 77. Asas para a Juventude em Recife $\quad 200$

Figura 78. Asas para a Juventude de São Paulo. 200

Figura 79. No coração da África selvagem 204

Figura 80. No mystério e no silêncio das selvas africanas. 204

$\begin{array}{ll}\text { Figura 81. Safari. } & 206\end{array}$

Figura 82. O leão foi morto. 206

Figura 83. O homem é o alvo do rinoceronte ferido. 207

$\begin{array}{ll}\text { Figura 84. Meus sonhos africanos. } & 207\end{array}$

Figura 85. Amazônia. Nos mystérios das selvas. $\quad 210$

$\begin{array}{ll}\text { Figura 86. A deusa da borracha } & 210\end{array}$

Figura 87. Inferno ou paraíso? $\quad 212$

Figura 88. As Damas do roncador. $\quad 212$

Figura 89. Evolução de Portinari. 225

Figura 90. Cangaceiros. 226 
Figura 91. Cangaceiros.2 226

Figura 92. Cangaceiros.3 227

\begin{tabular}{ll} 
Figura 93. Cangaceiros.4 & 227 \\
\hline
\end{tabular}

$\begin{array}{ll}\text { Figura 94. O Cangaceiro } & 233\end{array}$

Figura 95. Vanja Orico 233

Figura 96. Volta Sêca no Rio. 235

Figura 97. O cangaceiro Volta Sêca. 235

Figura 98. As noivas dos deuses sanguinários $\quad 240$

$\begin{array}{ll}\text { Figura 99. Iniciação das yaôs. } & 240\end{array}$

Figura 100. Eu fui girar na linha da umbanda 243

Figura 101. Pai de santo, durante cerimônia. 243

Figura 102. Detetive do além. 244

$\begin{array}{ll}\text { Figura 103. Figuras que desaparecem. Typos e costumes } & 248\end{array}$

$\begin{array}{ll}\text { Figura 104. Figuras typicas nacionais. } & 248\end{array}$

Figura 105. Carmen. 253

Figura 106. Carmen Miranda no cinema. 253

Figura 107. Você já foi à Bahia? 256

Figura 108. Pato Donald na praia $\quad 256$

Figura 109. Acontece que são baianos $\quad 259$

Figura 110. A dinastia dos Xaxá de Souza. 259 


\section{SUMÁRIO}

APRESENTAÇÃO DA TESE...................................................................... 13

Representações do Nordeste nas revistas ilustradas .........................

Delimitação do Tema …………………………………………....

Divisão dos capítulos $\quad$.................................................................... 16

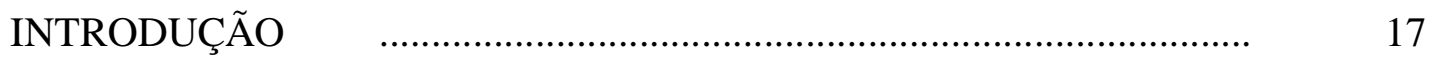

Sobre representações e imagens $\quad$.............................................................

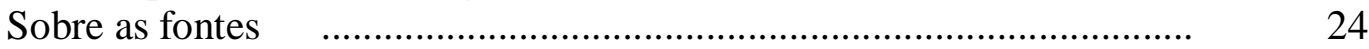

Os manuais escolares brasileiros.............................................................. 24

As revistas ilustradas $\quad$....................................................................

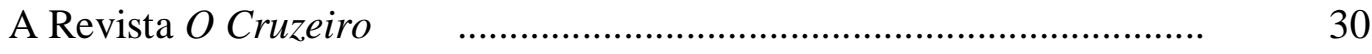

A Revista Vamos Lêr! ………………………………………....

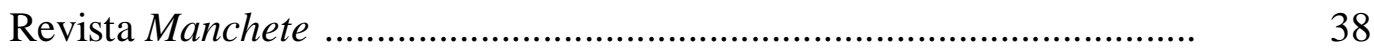

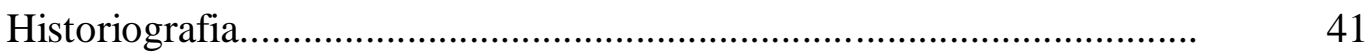

\section{PARTE I - O NORDESTE-QUASÍMODO}

I - O NORDESTE REPRESENTADO PELAS SECAS 44

1.1 A dura face do Nordeste seco ..........................................................

1.2 As secas como representação do sertão...............................................

1.3 O Nordeste nas páginas dos manuais escolares................................... 46

1.3.1 Sertão versus civilização............................................................... 54

1.4 Finalmente, o sertão chega ao Sudeste............................................. 56

1.5 A cobertura jornalística da seca: $1877-1879$..................................... 58

1.6 A Seca em O Bezouro ………………………………………..... 59

1.7 A seca e o Nordeste no período Vargas................................................

1.8 Representações do Sertanejo nas Revistas ilustradas.......................... 76

2 - MIGRANTE: O HOMEM SEM LUGAR 91

2.1 A necessidade histórica de mão de obra ……………………...... 100

2.2 A apologia ao estrangeiro versus a defesa da brasilidade.................. 106

2.2.1 O Brasil e a questão da identidade $\quad$......................................... 107

2.3 A situação dos estrangeiros ............................................................. 111

2.4 A aversão ao estrangeiro …………………………………...... 119

2.5 A migração para o Sudeste: solução para o problema da mão de obra 122

$2.6 \mathrm{O}$ trabalhador nacional e a guerra.................................................... 125

$2.7 \mathrm{O}$ atopos como representação do nordestino ..................................... 128

PARTE II - O NORDESTE-HÉRCULES

3 - A FORÇA POTENCIAL - A PROMESSA PARA O

DESENVOLVIMENTO...............................................................................

3.1 Progresso e desenvolvimento nos anos 30: o modelo alemão............ 151 
3.1.1 Nem sempre o apoio era total ……………............................ 156

3.2 O modelo brasileiro de desenvolvimento - Rio e São Paulo............. 164

3.3 Finalmente: o Nordeste como promessa........................................... 178

3.4 Nacionalismo, produção e educação.................................................. 190

4 - O EXOTISMO, A MAGIA E O BERÇO DA BRASILIDADE

4.1 A imprensa ilustrada, o Brasil e a guerra......................................... 198

4.2 Civilização e barbárie: o mundo moderno e o distante mundo selvagem 201

4.3 Amazônia e Nordeste: wildernessess brasileiros............................... 208

4.3.1 Amazônia....................................................................... 208

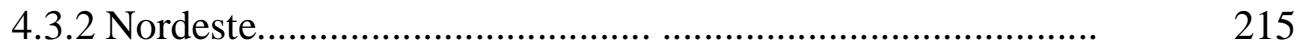

4.4 Cangaço - O western brasileiro....................................................... 216

4.5 Religião e religiosidade pelas lentes da fotorreportagem................. 236

4.6 Figuras típicas e costumes que desaparecem.................................... 247

4.7 South American way......................................................................

CONSIDERAÇÕES FINAIS ................................................................ 264

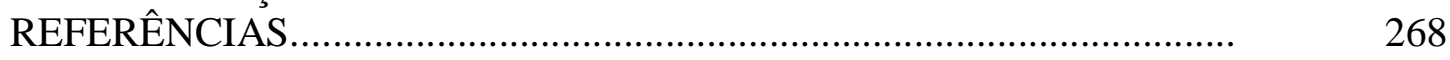




\section{APRESENTAÇÃO DA TESE}

Esta pesquisa busca a compreensão das representações sociais do Nordeste e dos nordestinos a partir da análise das imagens e das ideias veiculadas pelas revistas ilustradas, entre os anos de 1930 e 1954, período do primeiro e do segundo governo de Getúlio Vargas. Com este estudo, ensejamos compreender quais eram essas representações e seus efeitos no processo de construção das identidades e da memória histórica brasileira.

Este tema nasceu da continuidade das pesquisas realizadas durante nosso mestrado, no qual desenvolvemos, com apoio da CAPES, pesquisa sobre o lugar do imigrante no discurso regionalista em São Paulo durante as primeiras décadas do século XX, analisando o discurso constitucionalista nos jornais da imprensa paulistana.

A seca e a emigração se tornaram, praticamente, sinônimos do Nordeste e da nordestinidade. Impressionando pela brutalidade de seus resultados, as secas periódicas, conhecidas e registradas desde o período colonial, causadoras de grandes desastres naturais, eram temas recorrentes nas notícias que os sulistas liam sobre a vida nas terras do Norte, como era chamada a porção do Brasil correspondente ao Sul e ao Sudeste juntos. Nas palavras de Freyre:

A expressão "obras do Nordeste" quer dizer: "obras contra as secas". E quase não sugere senão as secas. Os sertões de areia seca rangendo debaixo dos pés. Os sertões de paisagens duras doendo nos olhos. Os mandacarus. Os bois e os cavalos angulosos. As sombras leves como umas almas do outro mundo com medo do sol. (FREYRE, 2004, p. 45)

O cenário da caatinga, descrito pelo intelectual de Apipucos tornou-se modelo para a representação imagética de toda uma região, ignorando-se assim, sua diversidade humana, física e cultural.

O tema desta pesquisa surge, portanto, da busca pela resposta a algumas questões fundamentais para a compreensão dos elementos que irão compor o discurso sobre cultura, representações e identidade no Brasil. Do final do século XIX até os nossos dias, encontramos na narrativa construída pelas mídias, ora a apresentação da narrativa sobre um Nordeste reduzido ao solo queimado e ao nordestino reduzido à figura do retirante, ora a representação de um povo nordestino rico em cultura e um Nordeste de grande potencial para o crescimento econômico. Compreender o porquê e em que dimensão estas imagens rompem com uma visão monocromática 
de Nordeste, são os objetivos que nortearão o nosso olhar na busca por indícios de mudanças e também de permanências.

Tomando tais representações como "sintomas de uma época", como nos sugere Pesavento (1999), nossa pesquisa pretende reinterpretá-las à luz dos processos históricos, dos sistemas de ideias e imagens com as quais estabelecem contato, com o objetivo de compreendermos qual (ou quais) Nordeste e nordestino teria sido construído por essas mídias e quais as implicações sociais desta construção.

\section{Representações do Nordeste nas revistas ilustradas}

As revistas ilustradas $O$ Cruzeiro, Manchete e Vamos Lêr! foram escolhidas como fontes documentais por conterem um riquíssimo registro sobre a forma de ver o mundo no período. Nelas, podemos perceber tanto a permanência da perspectiva do Nordeste como um espaço imaginário, coletânea de diferentes lugares, representação do não-lugar (SILVA, 1999), quanto indícios de outras leituras e construções imagéticas sobre um Nordeste que não fosse somente seca.

\section{Delimitação do Tema}

A pesquisa se desenvolve no recorte entre os anos de 1930 e 1954, por corresponder igualmente ao período de consolidação e queda de um projeto de identidade nacional - do governo Vargas - e ao mesmo tempo, por ser o período de consolidação do fotojornalismo no Brasil. É ainda nesse período em que se faz a transição, das antigas políticas em favor da mão de obra imigrante, para as políticas de incentivo à mão de obra nacional num contexto de desenvolvimento de um projeto nacionalista e de reformas educacionais profundas; mudanças que legariam à escola, à imprensa e ao cinema um papel relevante, na reconstrução da identidade.

O discurso e as interpretações da imprensa que pretendemos recuperar serão confrontados a outras fontes, igualmente importantes no processo de produção e reprodução de imagens do Brasil, como os manuais escolares brasileiros de História e Geografia, de 1920 a 1940, que compõem o acervo da FEUSP. Ao analisarmos a projeção das representações de um Brasil desenvolvido durante o Estado Novo, observaremos as imagens do Brasil presentes nos manuais escolares Portugueses de História e Geografia, de 1930 a 1945. As imagens dos manuais, foram coletadas do acervo da Biblioteca Municipal de Braga - Portugal. Outras fontes serão utilizadas, 
como a Revista de Imigração e Colonização, que trazia com frequência a narrativa de iniciativas nas quais a ciência aparecia como grande promessa para alçar o Nordeste a um novo patamar de desenvolvimento e alguns exemplares da Folha da Manhã e da Folha da Noite.

Nossa tese é a de que, o antagonismo entre Sudeste-civilização e Nordeste-barbárie, construído com maior intensidade a partir da Primeira República, conviveu com outras representações, a partir da instituição do projeto nacional do Estado Novo.

Nossa hipótese é de que, o início da década de trinta estaria ainda fortemente marcado pelo discurso das teorias raciais e, dessa forma, as representações sobre o Nordeste estariam ainda marcadas pela oposição entre civilização e barbárie. Por sua vez, a sociedade do pós-guerra, tendo vivenciado o holocausto e a queda das ideologias totalitárias, teria substituído o discurso das teorias raciais, pelo do desenvolvimento em oposição ao subdesenvolvimento ${ }^{1}$, fazendo com que a imprensa, do período, passasse a eleger novos temas e imagens que pudessem atualizar e corresponder a uma reconstrução das representações coletivas sobre o Brasil e particularmente, sobre o Nordeste.

Cientes de que uma sociedade inteira não pode ter a mesma impressão ou crença sobre um fenômeno, da mesma forma que o pensamento de um indivíduo não representa o pensamento coletivo, acreditamos que, a partir da interpretação dessas representações, estaremos em busca de indícios, pistas que possam nos fazer compreender melhor algumas das dimensões das complexas relações socioculturais do passado e seus ecos no mundo de hoje.

\section{Divisão dos capítulos}

Para que possamos alcançar nosso objetivo, dividiremos o trabalho da seguinte forma:

\section{Parte I - O Nordeste-Quasímodo}

Capítulo I-O Nordeste representado pela seca. Utilizando a metáfora criada por Euclides da Cunha, em Os Sertões, quando descreve o sertanejo como o "Hércules-Quasímodo", iniciamos o trabalho analisando as imagens do Nordeste representado pelo sertão e pelo sertanejo (a face

1 Há aí uma distância considerável. Acreditamos que a visão eugênica do mestiço como raça inferior, seria substituída pelo discurso da busca pelo desenvolvimento do potencial produtivo, materializado, no caso do Nordeste, por exemplo, pelo Banco do Nordeste e pela SUDENE. 
Quasímodo do Nordeste); as formas como o sertão fora compreendido no passado e como era dado a ver durante a Era Vargas, no momento do nascimento da fotorreportagem.

Capítulo II -Migrante: o homem sem lugar. Além de sua representação como o homem flagelado pela seca no semiárido, o sertanejo, ao emigrar de sua terra em direção ao Sudeste recebe uma nova identidade, a de retirante. A segunda face do Nordeste-Quasímodo é a face do retirante das secas, e sua saga nas metrópoles brasileiras retratada pelas páginas das revistas ilustradas.

\section{Parte II - O Nordeste-Hércules}

Capítulo III - A força potencial. A promessa para o desenvolvimento. Ainda utilizando a metáfora de Euclides, iniciamos a exploração da face do Nordeste-Hércules. Discutiremos o lugar do Nordeste e dos nordestinos no discurso de crescimento nacional, difundido durante a Era Vargas, as grandes obras e também o incentivo à migração para suprir a necessidade de mão de obra no Sudeste, como esses temas eram apresentados nas revistas e como serão ressignificados pelos produtos culturais, como a música e a literatura.

Capítulo IV - O exotismo, a magia e o berço da brasilidade. Neste capítulo final, discutiremos a outra face de um Nordeste que se tornaria fascinante nas páginas ilustradas; o Nordeste o western brasileiro; o Nordeste representado como lugar de ancestralidade e misticismo; a presença do discurso antropológico na imprensa e as ressignificação do Nordeste exótico pela cultura.

Por fim, pretendemos, em nossas Considerações Finais, fazer a reflexão sobre o desenvolvimento da pesquisa e a relação entre o produto da análise das fontes e as hipóteses inicialmente levantadas. 


\section{INTRODUÇÃO}

A pesquisa histórica vive hoje momentos muito prolíficos. A Nova História, e em particular a Nova História Cultural, trouxeram consigo a concepção de uma História que busca a compreensão das transformações sociais a partir da interpretação das práticas culturais, suas representações e relações com os processos e sujeitos históricos.

Com o desenvolvimento das pesquisas nessa área, que mantém um estreito diálogo com a Antropologia Interpretativa de Clifford Geertz, uma vasta gama de possibilidades surgiu diante do historiador, ampliando seu campo de trabalho, não apenas em relação aos estudos do passado, mas principalmente lhe dando suporte para a melhor compreensão das particularidades sobre as sociedades e as culturas do tempo presente.

Entende-se hoje que a sociedade contemporânea, plasmada em imagens, estrutura-se em meio a uma cultura visual, na qual representações, percepções, identidades e papéis sociais encontram-se em construção, tendo por substrato as imagens que são produzidas e ressignificadas, e que circulam por diferentes espaços e em diferentes suportes. Mais do que nunca, a sociedade expressa suas intenções e ideais por meio da imagem e da apresentação simbólica de objetos, personalidades, fenômenos e lugares. Entender esse processo de substituir, representar e apresentar, torna-se, fundamental para que possamos compreender as escolhas e os significados atribuídos aos sujeitos da história. ${ }^{2}$

\section{Sobre representações e imagens}

Em On Representation, Louis Marin (2001) inicia sua reflexão sobre o conceito de representação retomando os vários significados do ato de "representar"; começando pelo dicionário de Furitière, do séc. XVII, no qual representar é definido como "substituir algo ausente por algo presente", mas também como, “dar a ver" algo que existe, algo presente. Dessa forma,

2 Segundo Meneses, estamos diante da necessidade de construirmos uma História Visual, que, portanto, deveria "estudar a cultura visual (ou, ainda melhor, o regime visual) sob a óptica da dinâmica, da transformação da sociedade." Para o autor, a atenção dos historiadores dever-se-ia deslocar "do campo das fontes visuais para o da visualidade como objeto detentor, ele também, de historicidade e como plataforma estratégica de elevado interesse cognitivo" (MENESES, 2003, p. 27). 
conclui o autor que o ato de apresentar constrói a identidade do que é representado (MARIN, 2001). Entendemos que aqui, identidade esteja sendo compreendida como a representação do real que cria uma comunidade simbólica de sentido, permitindo tanto a sensação de pertencimento, quanto da noção de alteridade. (PESAVENTO, 1999, p. 24)

No campo das representações, para Marin, cada representante, compreende duas dimensões: a dimensão reflexiva e a dimensão transitiva. A dimensão reflexiva seria a apresentação de um sujeito, ou seja, a representação na sua dimensão reflexiva apresenta algo a alguém; enquanto que a dimensão transitiva seria entendida como a representação de um ausente (MARIN, 2001) $)^{3}$.

Nessa perspectiva, estudar as representações do Nordeste no período Vargas seria, uma busca por ferramentas que nos possibilitem entender o presente que funciona no lugar do ausente, e conseguir compreender como aquele mundo distante de sertanejos e sol à pino, era apresentado aos leitores das revistas ilustradas. Seria ainda, procurar entender as escolhas na seleção dos elementos utilizados na construção desse imaginário sobre o Nordeste, representado como, por quem e por quê. Pois, a forma como o público leitor via o Nordeste estará diretamente associada à forma como ele era dado à ver; tomando aqui por imaginário, "um sistema de e imagens de representação coletiva que os homens, em todas as épocas, construíram sobre si, dando sentido ao mundo." (PESAVENTO, 2012, p.43)

Em seu artigo A História hoje. Dúvidas, desafios, propostas, Roger Chartier (1994) discute as características e os caminhos do trabalho com as representações. Apontando as "três realidades maiores" para tais estudos, Chartier conclui que, primeiramente, haveria a necessidade de compreensão das representações coletivas, "que incorporam nos indivíduos as divisões do mundo social e estruturam os esquemas de percepção e de apreciação a partir dos quais estes classificam, julgam e agem" (CHARTIER, 1994, p. 108), que corresponderia ao ato de classificação.

Em um segundo momento, dever-se-ia observar, "as formas de exibição do ser social ou do poder político tais como as revelam signos e performances simbólicas através da imagem, do

3 Ao analisar a forma como Marin trabalha com o conceito de representação, Chartier, em seu Escribir las prácticas. Observa que o efeito-representação contém um duplo sentido: o de presentificação do ausente e o de autorrepresentação, que institui uma forma de ver-se o sujeito. CHARTIER, Roger. Poderes y limites de la representación, Marin, el discurso y la imagem, pp. 77-78. In: CHARTIER, R. Escribir las prácticas. Foucault, De Certeau, Marin. Buenos Aires: Manantial, 2006. 
rito ou daquilo que Weber chamava de estilização da vida" (CHARTIER, 1994, p.108). Este seria o momento da simbolização.

Por fim, chegar-se-ia ao momento da presentificação, no qual os "representantes, (instâncias coletivas ou indivíduos singulares) marcam de modo visível e perpétuo a existência do grupo" (CHARTIER, 1991, p. 183), interferindo na construção de uma identidade, correspondendo, assim, ao momento da institucionalização.

Assim, enquanto Marin nos esclarece sobre a natureza e sobre o processo de composição de uma representação, Chartier nos questiona quanto às suas formas de produção, reprodução e assimilação coletiva. Prosseguindo a análise do tema, temos que em Representações sociais: investigações em psicologia social, Serge Moscovici (2007) reflete sobre o processo social de produção de conhecimento e a definição de sociedade a partir da questão das representações sociais. Para o autor:

A representações sociais devem ser vistas como uma maneira específica de compreender e comunicar o que nós já sabemos. Elas ocupam, com efeito, uma posição curiosa, em algum ponto entre conceitos, que têm como seu objetivo abstrair sentido do mundo e introduz nele ordem e percepções, que reproduzam o mundo de uma forma significativa. Elas sempre possuem duas faces, que são interdependentes, como duas faces de uma folha de papel: a face icônica e a face simbólica [...] em outras palavras, a representação iguala toda imagem a uma ideia e toda ideia a uma imagem. (MOSCOVICI, 2007, p. 2006)

Partindo da relação entre ideia e imagem, colocada por Moscovici, conclui-se que, algumas imagens que se associam a uma ideia, devem ser consideradas como ícones canônicos, ou seja referenciais que permitem uma associação imediata à uma ideia, pois, conforme Saliba:

Ícones-canônicos seriam aquelas imagens padrão ligados a conceitos-chave de nossa vida social e intelectual. Tais imagens constituem pontos de referência inconscientes, sendo portanto, decisivas em seus efeitos subliminares de identificação coletiva. (2007, p. 88)

Nessa perspectiva, o estudo das imagens veiculadas pela imprensa ilustrada, faz-se necessário para compreendermos a natureza do conjunto de imagens canônicas sobre o Nordeste.

Quanto ao trabalho de interpretação das imagens, para Meneses, as fontes visuais ultrapassam a função de meros documentos, constituindo-se em elementos da estrutura social em sua complexidade e heterogeneidade. Nas palavras do autor "as imagens não são puros conteúdos em levitação ou meras abstrações, mas, antes de qualquer coisa, constituem coisas materiais, objetos físicos, artefatos" (MENESES, 2005, p. 8) e, justamente por ser um artefato, a imagem 
exige uma forma específica de abordagem. Sobre esta questão, Marin (2001), afirma que a imagem, embora construa um discurso, não pode ser lida como um texto; ela exige uma leitura própria, orientada por ferramentas específicas.

Para os historiadores, a tarefa de interpretar as imagens vai muito além da simples análise iconográfica, cabendo ao pesquisador reconstituir o contexto de produção da mesma, enxergandoa de uma maneira culturalmente específica. É justamente sob esse aspecto que a arte e a história estabelecem entre si uma verdadeira parceria, pois para se conhecer a arte do presente é imprescindível que se estruture sua trajetória ao longo do tempo. Além do mais, um mesmo objeto pode adquirir diferentes conotações com o decorrer do tempo. De acordo com Gaskell (1992, p. 266), "na verdade, o passado recente é cada vez mais conhecido através de imagens parcialmente fortuitas e instantâneas". Quanto à relação entre o historiador e as imagens, o autor ressalta a necessidade de estar, o historiador, preparado para esse trabalho específico:

Embora eu, sinceramente, espere que os historiadores cada vez mais voltem sua atenção para o material visual, lamento que poucos até agora tenham demonstrado suficiente percepção das questões necessariamente envolvidas, ou das habilidades particulares necessárias para se enfrentar tal material. A contribuição para o estudo do material visual que o historiador está provavelmente mais bem equipado para realizar é a discussão de sua produção e de seu consumo como atividades sociais econômicas e políticas. (GASKELL, 1992, p. 259-260)

Tradicionalmente para a interpretação das imagens, os historiadores, se valem da Sociologia, da Antropologia e da Linguística no exercício de distinção entre o visível e o invisível, com o objetivo de separar aquilo que tem um caráter diretamente perceptível, e que representa o domínio do poder, daquilo que está, de certa forma, desmaterializado na sociedade contemporânea. Todavia, a sociedade pós-moderna convive com outras relações de poder, na qual este se manifesta, sobretudo, de forma simbólica. Segundo Meneses:

Tais mudanças levantaram questões sobre o corpo e operação do poder social (formas institucionais e discursivas do poder) e redefiniram o status do sujeito que observa. Fica patente, assim, que a visão é uma construção histórica, que não há universalidade e estabilidade na experiência de ver e que uma história da visão depende de muito mais do que de alterações nas práticas representacionais. (MENESES, 2005, p. 3)

Sendo a imagem, por vezes, mais incógnita do que reveladora, Meneses chama-nos a atenção para o fato de que o historiador, por vezes, não se encontra devidamente preparado para a abordagem desse tipo específico de fonte: 
Tal dificuldade, sem dúvida, deriva da formação logocêntrica do historiador e da natureza igualmente centrada na palavra de quase toda sua atividade profissional. Assim, além do ônus de um "analfabetismo visual" (a própria necessidade de recorrer a uma expressão de marca verbal já indica a dimensão do problema...) ele não necessita de experiência de campo e, trabalhando em geral, apenas com representações e abstrações, elimina qualquer risco de contaminação com o concreto e o empírico. (MENESES, 2005, p. 4)

Quanto às ferramentas disponíveis para esse trabalho, o autor conclui que, com relação à correspondência existente entre as representações verbais e visuais, devemos levar em consideração que, embora exista uma associação, nem sempre haverá uma relação direta de significados. Dessa forma, o uso da semiótica como ferramenta de auxílio à análise do historiador encontraria algumas limitações:

Em conclusão, pode-se afirmar que a análise semiótica é um precioso instrumento de trabalho para o historiador. Mas não para trazer respostas: essas devem ser produzidas a partir das hipóteses formuladas pela interpretação histórica. O auxílio principal está, sim, na ampliação do leque de questões a levantar e que incluem o conhecimento do potencial semiótico dos documentos mobilizados. Portanto, perguntas, não respostas. De qualquer modo, o alcance da Semiótica decai quando se passa ao domínio das imagens para o fato, tão importante para a História, de que a imagem, além de signo, também age, executa o papel de ator social, produz efeitos. (MENESES, 2005, p. 7)

No caso específico das imagens que acompanham o texto, há ainda que se atentar para a relação entre ambos. Barthes (1990), entende a interpretação da imagem como mensagem visual que, em virtude de sua potência, dispensaria o texto escrito; este, por sua vez, teria somente uma função conotativa ${ }^{4}$ em relação à imagem. Ao contrário de Barthes, Sophie Van der Linden, em seu trabalho Para ler o livro ilustrado (2011), encontra nas diferentes relações entre texto e imagem, situações nas quais a presença do texto torna-se fundamental para a compreensão do todo como mensagem. Van der Linden afirma que existem três tipos básicos de relação entre texto e imagem que devem ser observadas. A primeira delas é a de redundância, na qual a imagem não vai além

\footnotetext{
4 Em $O$ óbvio e o obtuso, Barthes afirma que embora anteriormente a imagem tenha surgido no texto como forma de complementá-lo, hoje, é o texto que se vê reduzido a um complemento da imagem. "Em primeiro lugar: o texto é uma mensagem parasita, destinada a conotar a imagem, isto é, 'insuflar-lhe' um ou vários significados segundos. Melhor dizendo (e trata-se de uma importante inversão histórica), a imagem já não ilustra a palavra; é a palavra que, estruturalmente, é parasita da imagem[...]a imagem já não vem esclarecer ou 'realizar' a palavra; é a palavra que vem sublimar, patetizar ou racionalizar a imagem”. BARTHES, Roland. O óbvio e o obtuso. Ensaios críticos III. Rio de Janeiro: Nova Fronteira, 1990, p. 20.
} 
do que está sendo apresentado no texto. A segunda é a de colaboração, na qual o sentido da mensagem não se encontra exclusivamente no texto ou na imagem, mas sim na relação entre ambos; ou seja, um preenche as lacunas do outro. O terceiro caso é o de disjunção, no qual texto e imagem assumem narrativas paralelas, sem um ponto de contato objetivo, apenas subjetivo.

Sobre as relações entre texto e imagem, e da subordinação de um sobre o outro, Van Der Linden argumenta que:

Cada obra propõe um início de leitura quer por meio do texto, ou da imagem, e tanto um como outro pode sustentar majoritariamente a narrativa. Se o texto é lido antes da imagem e é o principal veiculador da história, ele é percebido como prioritário. A imagem, apreendida num segundo momento, pode confirmar ou modificar a mensagem oferecida pelo texto. Inversamente, a imagem pode ser preponderantemente no âmbito espacial e semântico, e o texto ser lido num segundo momento. [...] Conforme os casos e a convergência desses diferentes dados será possível determinar quem - texto ou imagem - tem a atuação secundária e apresenta portanto uma função específica em relação à instância prioritária. (VAN DER LINDEN, 2011, p. 122)

Além da relação entre texto e imagem, a autora aponta que se deve observar ainda a existência das funções que um exerce em relação ao outro. A primeira a ser destacada é a de repetição, na qual não há complementaridade entre ambos, sendo que essa função associa-se à relação de redundância. Já a função de seleção, como a próprio nome indica, ocorre quando a imagem dá maior ênfase a uma parte específica do texto. Outra função é a de revelação, na qual um dos meios - texto ou imagem - confere sentido, ou seja, revela o outro. Semelhante à relação de revelação, teríamos a completiva, que seria a contribuição de um para o entendimento do outro. Quanto à função de contraponto, embora de certa forma também realize uma ação completiva, teria por finalidade apresentar outra face da mesma moeda, outro lado da mesma verdade. A última função destacada é a de ampliação, na qual um dos discursos - textual ou imagético - acaba por informar mais que o outro, sem contradizê-lo, abrindo espaço para novas interpretações. Embora tendo mapeado as funções e as relações, a autora adverte que:

Muitas vezes, texto e imagem cumprem simultaneamente, um em relação ao outro, uma função distinta - que se realiza no percurso da leitura: descoberta de uma imagem, leitura do texto e retorno à imagem. Esta pode então, após a leitura do texto fornecer nova mensagem. Do mesmo modo, uma imagem ou um texto, mediante os diferentes níveis de significação que está apto a organizar pode abrigar diversas funções. Uma primeira função evidente pode ocultar outra, que se revela mais sutilmente. (VAN DER LINDEN, 2011, p. 122)

Não se trata da apresentação de uma regra incontestável, mas de uma, dentre muitas, possibilidades de exploração do potencial comunicacional e informativo das imagens. 
Embora diferentes meios e suportes possam fornecer informações sobre as representações coletivas produzidas a respeito de um grupo, em um determinado período escolhemos aqui como principal fonte visual neste trabalho, as imagens impressas nas revistas semanais ilustradas, mais precisamente na Revista Cruzeiro, por sua circulação cobrir todo o período dos dois governos Vargas e, principalmente, em virtude de sua importância como veículo de comunicação, formador de opinião e ainda, por ser a mais importante revista a utilizar o fotojornalismo no período de 1930 a 1954, período em que a educação visual de nossa sociedade dependia basicamente da imprensa ilustrada, da escola e lentamente, do cinema. Para estabelecer o diálogo com a Revista Cruzeiro, selecionamos a Revista Vamos Lêr! - que começa a circular somente em 1936 - e a Revista Manchete, revista que começou a circular em 1952 e que ultrapassou a casa de um milhão de exemplares vendidos já em seu primeiro ano, ambas valorizavam uma pauta variada de temas, somada à utilização da imagem como elemento fundamental na composição da mensagem.

O impacto produzido pela fotorreprodução provocou grandes mudanças nos padrões da visualidade das sociedades ocidentais, a partir de meados do século XIX. Artes, ciências e meios de comunicação mudam definitivamente com o desenvolvimento das técnicas de reprodução fotomecânicas, mas, sobretudo, a imprensa se transforma, utilizando a fotografia como recurso de potencialização do texto, surgindo uma categoria nova e específica de jornalismo: a fotorreportagem. "A fotorreportagem é uma narrativa que resulta da conjugação de texto e imagem, ou seja, da conjugação de duas estruturas narrativas totalmente distintas e independentes, dentro de uma amarração própria realizada pela edição" (COSTA, 1992, p. 83).

Seguindo o modelo europeu ${ }^{5}$, no Brasil, a fotorreportagem assume desde seu surgimento uma postura de "testemunha dos fatos". Embora a relação entre texto e imagem em fosse inicialmente redundante ou completiva, sua função era, via de regra, seletiva, pois o enquadramento, por excelência, já se constitui em um instrumento de escolha, incluindo ou excluindo aquilo que será ou não dado a ver.

Ao definir o recorte do que será mostrado, fotógrafo e jornalista, recontam e reconstroem

5 Ao descrever a história do fotojornalismo, Gisele Freund em La fotografia como documento social, (19 ) destaca que, quando de seu surgimento, na imprensa européia, os primeiros repórteres fotográficos faziam fotos somente para ilustrar as reportagens. No final dos anos vinte a prórpia imagem se converteria em texto. FREUND, Gisele. La fotografia como documento social. Editorial Gustavo Gili: Barcelona, 2006, p. 99 e 123. 
o real. Para Marin, essa é a função do enquadramento:

Em uma palavra, o enquadramento é um parergon necessário, um suplemento indispensável. Ele dá autonomia ao trabalho no interior do espaço visível, ele coloca a representação em um estado de presença exclusiva, que dá a definição apropriada das condições para a recepção visual e contemplação da representação como tal. (MARIN, 2001, p. 356, tradução nossa) ${ }^{6}$

O enquadramento delimita o mundo real que será dado a ver na fotografia, representa a seleção, a escolha do fotógrafo, sendo que uma vez selecionada, a imagem enquadrada passa a ser compreendida, ela própria, como um todo e não mais como parte. No caso da fotorreportagem fica claro que o enquadramento - a seleção - será o responsável por definir qual posição o espectador deverá tomar diante do fato.

\section{Sobre as fontes}

No segundo parágrafo da introdução de Montaillou, Emmanuel Le Roy Ladurie nos ensina que: "Todo estudo histórico deve ou deveria começar por uma crítica das fontes" (1997, p. 12). Desejando seguir as orientações do grande mestre, se fazem necessárias algumas palavras sobre as revistas ilustradas utilizadas nesta pesquisa.

\section{Os Manuais Escolares brasileiros}

Embora o foco central desta pesquisa seja o estudo das imagens veiculadas pelas revistas ilustradas, acreditamos que observar a dimensão e a diversidade dos espaços discursivos pelos quais circulavam as imagens-ícone do Brasil e principalmente do Nordeste brasileiro, seja fundamental para a compreensão mais ampla da relação entre a imprensa e os outros meios de construção do repertório imagético sobre o Nordeste. Nesse aspecto, as imagens presentes nos manuais escolares surgem como um precioso conjunto documental.

A partir da análise dos exemplares organizados pelo acervo da Biblioteca da Faculdade de Educação da Universidade de São Paulo, pelo projeto LIVRES, foi possível observar que, no caso

6 "In a word, the frame is a necessary parergon, a constitutive supplement. It autonomizes the work within the visible space, it puts the representation in a state of exclusive presence; it gives the appropriate definition of the conditions for the visual reception and contemplation of the representation as such" (MARIN, 2001, p. 356). 
dos manuais escolares publicados entre os anos de 1880 e 1945, o Brasil ali representado era previsível e homogêneo, a escolha das imagens demonstrava a preocupação em apresentar as semelhanças e não as particularidades das cidades e províncias. No caso do Nordeste, não há imagens do sertão, não há imagens da caatinga, não há imagens do sertanejo ou das secas. As imagens que se remetem ao Nordeste acompanham o mesmo roteiro de temas daquelas do Sudeste:

força da natureza, representada pelas águas ou, raramente, por uma mata sendo desbravada; o rio como via para levar o progresso para todos os recantos do país, e as cidades em crescimento e os perfis de uma arquitetura urbana e republicana.

Essa padronização dos temas gerava uma regularidade que poderia ser interpretada como um desejo de expressar ordem e estabilidade; um desejo de apresentar o Brasil como uma sociedade em processo de desenvolvimento e urbanização; um Brasil civilizado. Somente a partir da década de 1920 é que começaríamos a observar a presença de referenciais regionais, humanos como o caipira, e naturais, como a vegetação do agreste e os significados à eles atribuídos.

\section{As revistas ilustradas}

Desde as primeiras décadas do século XX, a principal característica das revistas semanais ilustradas era possibilitar ao leitor o contato com o universo da cultura que, por sua vez, era compreendida não somente como a alta cultura - produto das sete artes como fora definida por Ricciotto Canudo em seu Manifesto das Sete Artes de 1911 - mas sim, produto de uma somatória de elementos dessa e também da cultura de massas - o cinema, o rádio - que então se consolidava. A cultura marcadamente urbana, preconizada pelos magazines, estaria associada, na visão de Ortiz, a outros novos elementos:

A interpenetração da esfera de bens eruditos e a de bens de massa configura uma realidade particular que reorienta a relação entre as artes e a cultura popular de massa. Esse fenômeno pode ser observado com clareza quando nos debruçamos nos anos 40 e 50, momento em que se constitui uma sociedade moderna incipiente e que atividades vinculadas à cultura popular de massa são marcadas por uma aura que a princípio deveria pertencer à esfera erudita da cultura. (ORTIZ, 1994, p. 65)

Ortiz se refere objetivamente à valorização de produtos culturais nos anos de 1940 e 1950, como o samba, o circo e mesmo de elementos da cultura popular alçados à categoria de símbolos da identidade nacional, como o futebol e o carnaval. 
A veiculação da informação transformava-se em negócio, passando a ser vista como uma atividade empresarial, sendo que, acompanhando o ritmo de crescimento das cidades, o mercado da informação cresceria significativamente do final do século XIX ao início do século XX. Neste novo ramo de investimentos, não apenas os diversos estilos de jornais, mas também as revistas ganhavam seu espaço. Dentre as primeiras revistas a ganhar notoriedade nesse universo em magazine, temos $O$ Malho, revista humorística de Crispim do Amaral, criada em 1902 e empastelada em 1930 pelo governo Vargas; e a Revista Fon Fon, criada e idealizada por Gonzaga Duque em 1907, que encerrou atividades em 1958. A principal característica da revista fora a atenção dada às ilustrações, tendo como colaborador, em 1914, o pintor Di Cavalcante e posteriormente, também os ilustradores Nair de Tefé e Raul Pederneiras. O Malho e Fon-Fon corresponderam às primeiras grandes revistas de destaque. A caricatura teria sido a principal marca da imprensa das primeiras décadas do século XX, conforme Saliba (2002), os humoristas do período da Primeira República, encontravam-se comprimidos entre os modelos da alta cultura, representada, sobretudo, pelos parnasianos e simbolistas e a atuação em outras tantas atividades como a redação de artigos para jornais e revistas, confecção de textos e desenhos para a crescente demanda por reclames, legendas e cartazes para filmes mudos, produção para teatro de revista e uma série de funções específicas nas áreas das artes, destinadas a um público diversificado. Além disso, a participação de grandes nomes da literatura, como colaboradores constantes nestes periódicos, também se constituiu em uma das características marcantes do período (SALIBA, 2002).

Entre o final da década de 1910 e os anos 1930, temos um período com grandes índices de crescimento do mercado de periódicos, no qual novos títulos surgiam constantemente, passando também as revistas a serem editadas a partir da escolha de diferentes linhas e ramos temáticos. Entre 1912 e 1930, o crescimento e a diversificação dos temas seriam visíveis; o campo dos noticiosos cresceria de 882 títulos para 1.519; os literários de 118 para 297; os científicos de 58 para 212; os humorísticos de 57 para 99; os almanaks de 14 para 66; os didáticos de 8 para 33; os históricos de 7 para 14; os cinematográficos, de nenhuma publicação até 1912 para 10 em $1930^{7}$. Era o início do processo de segmentação do mercado editorial.

7 A lista é ainda maior, pois na linha da segmentação do mercado de periódicos, há ainda as revistas especializadas em temas ligados aos assuntos Religiosos, Humorísticos, Comerciais, Anunciadores, Esportivos, 
Das décadas de dez e vinte, destacaríamos A Cigarra, que circulou de 1914 a 1917, em São Paulo; e A vida doméstica, de 1920, ambas destinadas ao público feminino e o Almanaque Eu sei tudo, de 1921, uma revista de informação sobre assuntos gerais.

A definição de temas e linguagens estaria diretamente associada ao público-alvo da revista, mas a mera análise da linguagem utilizada não seria, como vimos, o suficiente para entendermos quem, de fato, eram os receptores dessas mensagens, e muito menos para entendermos como eram recebidas. Rafael Winter Ribeiro, em seu artigo Seca e determinismo, publicado pelo Instituto de Geociências da UFRJ, nos lembra a crítica de Pierre Bourdieu (1983) aos modelos de análise:

[...] critica todos os modelos tradicionais de análise ligados excessivamente à linguística, entre os quais, o modelo criado por Michel Pêcheux. Bourdieu, em seu trabalho, está preocupado principalmente com os mecanismos de circulação dos discursos, onde o grau de legitimidade do locutor definiria, em grande parte, o grau de aceitabilidade do discurso." Para ele, é um erro procurar a "força locutória" no próprio discurso, já que o que "fala" nunca é o discurso, mas toda a pessoa social. Para realizar uma análise verdadeira é necessário identificar "quem fala" (o produtor), "para quem" (o leitor), "de onde" (a instituição a que pertence e o veículo) e "como" (a forma discursiva) estabelecendo seus graus de legitimidade. (RIBEIRO, 1999, p. 60)

No caso de nossa investigação, quem nos falará sobre o imaginário constituído sobre o Nordeste dos entre as décadas de 1930 e 1950, serão elas, as revistas ilustradas. Formadoras de opinião e produzidas a partir do roteiro de interesses de um público urbano, letrado, observador do mundo a partir da realidade das capitais brasileiras, consumidor dos novos produtos de consumo do momento - colônias, sabonetes, novidades para o lar, eletrodomésticos - frequentador de salas de cinema. Ela, a imprensa ilustrada, escreverá para esse público do alto de sua posição de portavoz da modernidade, ela irá interpretar e selecionar os fatos para o seu público, apresentando o seu recorte da realidade por meio da forma mais viva que a tecnologia do período permitia: a fotografia.

Para as primeiras as revistas semanais seria importante a manutenção de seções, que indicavam o roteiro de temas de maior interesse do público-alvo, como esportes, cinema, as notícias sobre os astros da música, um pouco de novidades da política, sendo tais reportagens

Corporativos, Oficiais, Agronômicos, Estatísticos, Espíritas, Militares, Industriais, Infantis, Maçônicos, Marítimos, Filosóficos. Conforme Estatística da Imprensa Periódica no Brasil. Rio de Janeiro: Tipografia do Departamento Nacional de Estatística, 1931. 
criativamente ilustradas por desenhos e fotografias que tinham por objetivo funcionar como atrativo e como linguagem.

A linguagem visual das revistas buscava estabelecer uma sintonia tanto com a linguagem escrita quanto com a própria identidade do periódico, ratificando-a e complementando-a, por meio de diferentes recursos gráficos, desde a diagramação, os tipos de letra escolhidos, as charges, os desenhos, as bordas, as fotografias, às tirinhas de humor. Isso porque, como produto de um mercado que se expandia, o objetivo maior de um periódico de grande circulação seria alcançar reconhecimento, satisfazer o seu público alvo e conquistar patrocinadores. Portanto, esse código de linguagem, formado pelo conjunto, dos elementos verbais e não verbais, seria responsável por apresentar a revista ao leitor. Segundo Lage (1998), essa correspondência entre assunto e forma reporta-se à questão do hábito, ao uso, não representando necessariamente uma analogia do mundo real; dessa maneira, as imagens, os espaços concedidos, a cor, as formas dadas a uma notícia, estariam diretamente associados à representação usual daquele tema.

A partir do final dos anos de 1920, somado ao crescimento das classes médias e ao consequente crescimento da demanda por bens culturais, transformados agora em bens de consumo, temos as editoras dispondo de melhores recursos técnicos e promovendo transformações, tais como o surgimento do mercado do livro, o incremento da propaganda e a presença do Estado como fomentador de cultura. Um crescente número de literatos passariam a exercer funções de colunistas, colaboradores ou mesmo de editores de revistas e jornais. Com o crescimento do mercado dos livros, os romancistas passavam a ter mais visibilidade no cenário cultural e as casas editoriais que antes se limitavam a importar títulos para o Brasil, passavam também a editar títulos nacionais. Nesse período temos o surgimento da editora José Olympio, no Rio de Janeiro; da Editora Monteiro Lobato \& Cia, de São Paulo; da editora Ariel e da livraria Globo, do Rio Grande do Sul. O precursor da visão do livro como objeto de consumo, Monteiro Lobato, afirmava que o livro é sobremesa: tem que ser posto debaixo do nariz do freguês ${ }^{8}$. Com grande visão de mercado, a editora de Lobato inovou com publicidade e publicações de qualidade,

\footnotetext{
${ }^{8}$ MILTON, John. Monteiro Lobato and translation: "Um país se faz com homens e livros". D.E.L.T.A., DELTA: Documentação e Estudos em Linguística Teórica e Aplicada. no 19: ESPECIAL, 2002, p. 123. Acesso em 10 de outubro de 2012. Disponível em < http://www.scielo.br/pdf/delta/v19nspe/08.pdf>
} 
não sobrevivendo, contudo, à crise de energia e à desvalorização da moeda em 1925, quando abriu falência.

Mas não somente os livros eram o espaço propício para a veiculação dos contos infantis e de temas de curiosidade científica, as revistas semanais também cumpriam esse papel. Em entrevista à revista Pesquisa FAPESP, o pioneiro das pesquisas genéticas no Brasil, o cientista Oswaldo Frota-Pessoa, aos 88 anos, comentava sobre o espaço concedido às ciências pela imprensa brasileira do período Vargas. Frota-Pessoa destaca que, entre os anos de 1930 e 1950, publicou mais de setecentos artigos; tendo sido colaborador em vários jornais como A Manhã, Diário Carioca e o Jornal do Brasil, o professor aponta ainda que seu primeiro artigo, contudo, fora publicado na Revista Vamos Lêr!, veículo que em relação à sua circulação e seu impacto como formador de opinião era, na época, "feito a Veja, hoje” (MOURA, 2005, online).

No que tange ao universo do texto escrito, as revistas traziam consigo fundamentalmente, dois diferentes espaços: o das notícias e o das reportagens. As primeiras seriam apresentações de pautas, informações sobre fatos e eventos em curso ou já ocorridos e que, contudo teriam um desdobramento no interior da revista. Já as reportagens, estão mais associadas a um roteiro de áreas de interesse do público alvo da revista, dessa forma, os mesmos temas, com frequência estariam disponíveis em seções, podendo ou não ser atualizados por um novo acontecimento (LAGE, 1987). Dessa forma, temos que, no planejamento visual de uma revista, as matérias são elaboradas, as imagens escolhidas, as cores e os formatos, serão decisivos para a construção de sua identidade visual e linguística.

Alcançar o público, atraí-lo, por meio das investigações de casos polêmicos ou por meio do debate de assuntos do momento, eis o objetivo dos magazines. Identificadas por meio de subtítulos como Revista de Variedades, Revista Ilustrada e Revista Literária, as revistas semanais, tal e qual os jornais da época, reservavam espaços frequentes para temas de grande apelo popular, ou mesmo para modismos, alterando, em razão dos mesmos, seus subtítulos, frequentemente para Revista Esportiva, literária e de humor, mesmo quando o conteúdo não correspondia exatamente àquilo que era anunciado. Diferenciam-se dos jornais diários, basicamente em razão da relação entre fato e tempo; o jornal deveria atender a questões e acontecimentos mais imediatos, os fatos do dia; já as revistas criavam e acompanhavam tendências, temas que se mantinham em debate, assuntos e personalidades que estavam em foco. Sodré (1986) aponta ainda que, a revista, em seu conceito clássico, seria uma extensão da imprensa diária, com o objetivo de comentar e opinar 
sobre diversos assuntos ou dar uma visão mais aprofundada aos temas de ordem humana, diferindo do jornal por ser visualmente sofisticada e com textos que lançam mão de uma dose maior de criatividade.

Para Vilas Boas, poderíamos dividir as revistas em dois grupos estilísticos: as de informação geral e as de variedades, sendo que:

A diferença a ser destacada, então, ficará por conta da periodicidade. As revistas de informação geral, em sua maioria, são publicadas semanalmente, resumindo tudo o que foi lido e visto nos meios de comunicação durante todo esse período. Fazem jornalismo daquilo que ainda está em evidência nos noticiários, somando a estes pesquisas, documentação e riqueza textual. (BOAS, 1996, p. 9)

Sendo o conteúdo - assuntos gerais - semelhante para ambas, as revistas de variedades seriam aquelas com periodicidade mais dilatada, como as revistas mensais e trimestrais. Um exemplo clássico do período seria a americana Reader's Digest, revista mensal de variedades lançada em 1922. Nas revistas semanais, portanto de informação geral, os exemplares seriam publicados semanalmente, as reportagens teriam um cunho mais interpretativo, acompanhando o rol de assuntos levantados durante a semana anterior pelo jornalismo diário, assim haveria uma menor preocupação em aprofundar os temas, sendo que primam apenas pela atualização superficial da informação. Boas aponta ainda que outra característica da revista semanal de informação é ser uma formadora de opinião, justamente por ter como missão atualizar a visão do leitor sobre os fatos (BOAS, 1996). Por terem publicação semanal, as revistas de informação geral, podem ser entendidas ainda como um produto de consumo mais imediato, enquanto as revistas mensais de variedades, permitiriam ao leitor um tempo maior para a leitura e a espera por mais novidades. Exemplos de revistas semanais de grande sucesso foram as revistas Vamos Lêr, do Jornal A Noite! (que começou a circular em 1936), a revista $O$ Cruzeiro (que iniciou publicação a partir de 10 de novembro de 1928, editada pelos Diários Associados de Assis Chateaubriand) e a Revista Manchete (lançada em 25 de novembro de 1952, pela Bloch Editora).

\section{A Revista $O$ Cruzeiro}

No dia 5 de novembro de 1928, eram lançados, sobre a cidade do Rio de Janeiro mais de quatro milhões de folhetos, anunciando a chegada de uma revista que seria moderna, na qual todas as novidades poderiam ser encontradas e no verso, os anúncios dos muitos 
patrocinadores que mais tarde estariam presentes no interior da revista. No dia 10 de novembro, simultaneamente em várias capitais brasileiras, era lançada a Cruzeiro, "Revista Semanal Ilustrada" com uma capa chamativa, que trazia a imagem de uma colorida melindrosa, enfeitada com as cinco estrelas do Cruzeiro Sul por sobre a sua cabeça, como confetes que caem. Segundo Accioly Netto, a revista propalava em defesa de - e expressava isso em sua concepção visual - uma visão de modernidade, progresso e nacionalismo ${ }^{9}$. A revista Cruzeiro marcaria época em razão da forma como escolheu trabalhar com a imagem, que não teria ali apenas a função de ratificar o texto, mas sim, de construir, ela própria, um discurso sobre a realidade, porque dentro da revista a fotografia se transforma, deixa de ser apenas fotografia, passando a ser página de revista, ou seja, imagens sobre outro suporte, selecionadas com um propósito; nelas, imagem e texto se aliam, construindo um discurso próprio, que é a fotorreportagem:

A fotorreportagem constituiu-se numa forma jornalística historicamente determinada que teve suas origens na imprensa alemã do final da década de 20. Tratava-se de um novo tipo de relacionamento entre texto e imagem que encontrou na revista ilustrada o veículo ideal para sua expressão. A aplicação do modelo de fotorreportagem teve desdobramento em diversos países da Europa. No entanto, a exploração sistemática de seu potencial narrativo ocorreu nos Estados Unidos, mais especificamente na revista Life. Após o seu lançamento surgiram inúmeras publicações semanais do mesmo gênero em todo o mundo: no Brasil o melhor exemplo foi O Cruzeiro." (COSTA, 1994, p. 90)

Com fotos ampliadas, diagramação cuidadosa, seções de reportagens, contos e crônicas, nas quais a imagem tinha papel fundamental para potencializar a mensagem, além de um grande número de anunciantes - é impossível não observar que praticamente metade das páginas do primeiro exemplar vinham marcadas por propagandas dos patrocinadores ${ }^{10}$ - a revista nascia com claras intenções de tornar-se um ícone da imprensa escrita, ela própria apresentava-se dessa forma, fazendo questão de declarar as diferenças entre ela e as outras mídias impressas. Enfatizando seu pioneirismo e cuidados quanto à valorização extrema de diferentes recursos visuais, lia-se no editorial do primeiro volume:

9 Sobre esse tema veja o livro de Accioly Netto - O Império de Papel: os bastidores de O Cruzeiro - Editora Sulina, Porto Alegre, 1998.

10 Sobre as características da revista Cruzeiro, ao ser lançada, veja $O$ império de papel: os bastidores de O Cruzeiro, de Accioly Neto, organizado por Heloísa Seixas. Baseamo-nos ainda nas obras de Fernando Morais, Chatô o rei do Brasil, e de Luiz Maklouf Carvalho, Cobras criadas, autores que resgatam historicamente a trajetória da revista, do maior empresário de comunicação no período e de personagens como David Nasser e Jean Manzon, a dupla de jornalistas que mudaria a história da fotorreportagem no Brasil, a partir de 1946. 
Um jornal pode ser um órgão de um partido, de uma facção, de uma doutrina [...] A compreensão da gravura e do texto concede à revista o privilégio de poder tornar-se obra de arte. A política partidária seria tão incongruente numa revista do modelo de Cruzeiro, como num tratado de geometria [...] Uma revista deverá ser, antes de tudo, uma escola de bom gosto. ${ }^{11}$

Participando do maior conglomerado de empresas de mídia do Brasil daquela época - os Diários Associados, de Assis Chateaubriand - Cruzeiro, tinha em sua direção Carlos Malheiro Dias - fundador da revista Ilustração Portuguesa e criador da Academia Portuguesa de História. Iniciando com uma tiragem mensal de cinquenta mil exemplares, conforme anunciava seu número de lançamento ${ }^{12}$, a revista chegava ao público trazendo um discurso que tinha por objetivo estabelecer um contato direto com o leitor. Havia seções dedicadas às dúvidas médicas, jurídicas, à arquitetura doméstica, e em todas solicitava-se a participação do leitor, colocando-se a revista à disposição para responder-lhes as perguntas. Quando de seu lançamento, o público feminino das classes médias urbanas, tal qual no caso da Vamos Lêr!, correspondia ao público alvo da revista Cruzeiro. Seções como Cinelândia, Dona, Vênus de Milo, As Garotas, Cartas de Mulher, ${ }^{13}$ dentre outras seções voltadas para um mundo marcadamente feminino, falavam sobre moda, culinária, além da coluna social e as curiosidades sobre os atores e atrizes do cinema.

Os anos de 1930 marcariam as primeiras mudanças expressivas na revista: Cruzeiro, passaria a ser $O$ Cruzeiro, ampliaria seu conteúdo e pontuaria seu desejo de oferecer, ao leitor, o melhor:

Essas reformas representam em seu conjunto, um dos mais arrojados empreendimentos editoriais até hoje realizados no Brasil, e compreendem a execução semanal de 64 páginas em rotogravura e cromo-rotogravura e uma vasta colaboração literária e artística, confiada aos nossos mais notá veis escritores e ilustradores. ${ }^{14}$

Marca registrada de $O$ Cruzeiro, até então, as páginas ilustradas e as reportagens acompanhadas por fotografias passariam a contar agora com fotos que tomavam páginas inteiras,

11 Cruzeiro, Rio de Janeiro, ano 1 número 1, editorial, 10/11/28

12 Na década de 1960 O Cruzeiro chegaria a uma tiragem de 700 mil exemplares, e um público de mais de quatro milhões de leitores, segundo SERPA, Leoni Terezinha Vieira. A máscara da modernidade: a mulher na revista O Cruzeiro (1928-1945). Universidade de Passo Fundo, 2003.

13 A máscara da modernidade: a mulher na revista O Cruzeiro (1928-1945) Leoni Terezinha Vieira Serpa. Universidade de Passo Fundo, 2003.

14 O Cruzeiro, Rio de Janeiro, 25 de outubro de 1930. 
provocando forte impacto no leitor. Em 1935, surge mais uma coluna, a Novidades da RKO, sobre os artistas e cantores norte-americanos. No início dos anos de 1940, tempos de guerra, nova mudança, a revista passa a utilizar a fotografia como parte fundamental para o jornalismo e para a apresentação das reportagens. Iniciava-se a era do fotojornalismo. Durante as décadas de 1940 e 1950, amparada pelas fotografias de Ubiratan Lemos, Luciano Carneiro, Pierre Verger e da grande estrela da revista, o ex-fotógrafo da Paris Match, Jean Manson, - que trabalhou no Departamento de Imprensa e propaganda (DIP) e que posteriormente, migraria para a rival da $O$ Cruzeiro, a revista Manchete - somadas às reportagens de David Nasser, Mario Moraes e Arlindo Silva, dentre outros, as matérias jornalísticas na revista ganhariam nova dinâmica, movimento e dramaticidade.

\section{A Revista Vamos Lêr!}

Uma das revistas que marcou época consolidando o estilo dos magazines foi a revista Vamos Lêr!, dirigida por Raimundo de Magalhães, do Jornal A Noite, também responsável pela criação das revistas Noite Ilustrada, Carioca e pela criação da Rádio Nacional. Em 1940, o governo Vargas encampou o jornal A Noite, pois queria torná-lo, bem como à Rádio Nacional, veículos de afirmação do regime. (MARTINS, 2008). Inicialmente dirigido por Irineu Marinho, no Rio de Janeiro, A Noite iniciou circulação em 1925 e com o seu sucesso, Irineu logo lançaria um segundo jornal, $O$ Globo, para concorrer com O Correio da Manhã, A Gazeta de Notícias, o Diário Carioca, entre outros. Irineu seria sucedido por seu filho, Roberto Marinho, que continuou investindo ativamente em jornalismo, inaugurando em 1944, a Rádio Globo. ${ }^{15}$

Em uma de suas crônicas para a BBC Brasil, Ivan Lessa, um dos criadores d'O Pasquim, lembra que, quando criança, tinha sempre em sua casa a revista Vamos Lêr! e que, embora não se recorde de lê-la, quando ainda pequeno, lembra-se de seu encantamento pelas ilustrações, fotografias e quadrinhos trazidos pela revista semanal. A Vamos Lêr! principalmente nos anos de 1940, teria alcançado grande popularidade - como destacam as memórias de Lessa e de Oswaldo Frota-Pessoa, como vimos anteriormente.

15 Sobre a Vamos Lêr! ver mais em MARTINS, Ana Luiza. Revistas em revista: Imprensa e Práticas Culturais em Tempos de República, São Paulo (1890-1922). São Paulo: Editora da Universidade de São Paulo, Fapesp, 2008. 
Em carta a Carlos Drummond de Andrade, João Cabral de Mello Neto, é possível observar o peso que o primeiro atribui ao veículo, como formador de opinião tanto entre os populares quanto entre os pares:

Recife, 30 de outubro de 1940

Meu caro Carlos Drummond de Andrade.

Eu estava para lhe escrever desde a minha volta ao Recife. Não o havia feito até agora, porém não só com o receio de provocar uma correspondência que bem sei inoportuna, como também por adivinhar que não me poderia ver livre, nem mesmo numa carta de certa dificuldade de comunicação que me é particularmente penosa, principalmente tratando-se de uma das pessoas com quem mais no mundo eu gostaria de vê-la desaparecer.

É pena que a primeira vez que eu lhe escrevo seja para pedir um favor. Trata-se de uma coisa de que não sei se você já teve conhecimento: o Congresso de Poesia do Recife, cujo manifesto foi subscrito por alguns amigos e por mim próprio. Quando tivemos a ideia, não imaginamos que viesse ter projeção que, ao que parece, está alcançando. Digo isso porque a revista Vamos Lêr! está publicando umas entrevistas em torno de sua próxima realização, entrevistas aliás, com pessoas mentalmente incompatibilizadas com o espírito do Congresso. Com a vulgarização do manifesto aí, talvez se venha a fazer uma ideia falsa do que é realmente o Congresso, mando-lhe algumas cópias do manifesto que foi publicado aqui, pedindo-lhe, no caso de não haver nenhum inconveniente, publicá-lo em algumas revistas do Rio, se possível na própria Vamos Lêr! a fim de que se possa fazer um cálculo da enorme incompreensão que está provocando esses ataques. Isso para não admitir que seja tudo o produto de um alarmante complexo de cartaz, muito generalizado aqui. Devo esclarecer que nos importa pouco responder a esses ataques. Eles partiram de pessoas que absolutamente não contam. Acho mesmo que suas restrições são a melhor propaganda que o Congresso poderia ter. Mas é que outro movimento começa a se esboçar, chefiado pelo eminente sociólogo Gilberto Freyre - Ditador intelectual desta província - obedecendo ao slogan de que "os tempos não estão para poesia". Como força de argumento, entendo que este último não é nada mais persuasivo do que os outros. No entanto, você sabe (acaso você já não exprimiu tantas vezes esse sentimento de necessidade da poesia?) como é tristonho ver-se a arte e a poesia em particular relegadas ao plano de simples divertimento, indigno das "duras horas que estamos vivendo". Relativamente a este - que possui elementos de propaganda mais organizados - gostaria de poder, mediante a divulgação do manifesto, desfazer a má impressão que porventura exista, principalmente entre aqueles com cuja colaboração contamos para o sucesso do Congresso, como você Murilo, Aníbal Machado, Portinari, Mario de Andrade, Manuel Bandeira, Jorge de Lima, Emílio de Moura, etc. Junto a esses, sem os quais nunca nos ocorreu fazer o Congresso, gostaria que você agisse, no sentido de conseguir a adesão. Imagino agora, o quanto já o incomodei. E por isso não prolongo mais esta carta, com a narração de todas as sabotagens que o Congresso tem sofrido nesta terra de sociólogos...

Contando com a sua atenção, espero suas breves notícias.

Com um abraço do amigo agradecido

João Cabral de Melo Neto. (Jornal do Comércio, 2008, online)

Apesar de se terem conhecido naquele mesmo ano, a empatia deve ter sido significativa, para mover o escritor a solicitar a ajuda de Drummond, na tentativa de não permitir que os 
interesses e inclinações do Movimento Regionalista, liderado por Gilberto Freyre - primo de João Cabral - eclipsasse o Congresso de Poesia. O Congresso de fato aconteceu, a aliança com os poetas colaboradores permaneceu firme, e João Cabral pode então ler o seu Considerações sobre o Poeta Dormindo $^{16}$. Em sua carta, publicada pelo Jornal do Commercio de Recife, podemos observar não somente a importância dada à Revista Vamos Lêr! como formadora de opinião, mas também, a crítica à posição de Gilberto Freyre que, consagrado como intelectual e conhecido pelo largo apoio ao governo Vargas, é citado como "o ditador cultural do Recife".

A revista teve entre seus colaboradores nomes como Jorge Amado, entre 1939 e 1941 - na época, militante ativo da esquerda comunista e editor chefe da revista Dom Casmurro - e Graciliano Ramos - igualmente ligado aos intelectuais da esquerda comunista. Juntos, em 1942, os dois colegas de ofício viriam a escrever em parceria Brandão entre o mar e o amor. Também pela revista passou o escritor Fernando Sabino que trabalhava como redator n'A Folha de Minas, colaborando no jornal literário Dom Casmurro e no Anuário Brasileiro de Literatura. Clarice Lispector também passou pela Vamos Lêr!, primeiramente concedendo ao jornalista Tasso da Silveira uma longa entrevista, em 19 de outubro de 1940, e depois, concedendo à revista o direito da publicação do conto Trecho, publicado na edição de 09 de janeiro de 1941.

A Vamos Lêr! possuía uma seção intitulada "Panorama Literário", dedicada a discutir o que estava acontecendo no cenário literário brasileiro. Novos nomes e também os clássicos de Norte ao Sul do país, eram comentados frequentemente. Mas o campeão absoluto de artigos a seu respeito foi, sem sombra de dúvidas, Euclides da Cunha. A literatura aparecia como uma das nobres artes que possibilitaria ao leitor, transpor seus próprios limites e lançar-se no mundo. $O s$ Sertões era uma obra sempre relembrada em matérias que tinham por objetivo discutir a qualidade da prosa euclidiana e o universo tido como exótico descrito pelo autor.

Mas nem só de literatura vivia o periódico. Seguindo a tendência de tornar a revista de variedades uma espécie de janela para o mundo, a Vamos Lêr! trazia também seções que tinham como compromisso apresentar "um pouco sobre tudo", era o Mixed pickles, dando trato breve e

\footnotetext{
16 Embora João Cabral tenha conseguido seu objetivo de realizar o congresso de Poesia, aparentemente, as diferenças com Freyre não foram de todo resolvidas, posto que em Morte e Vida Severina, lembra que cada "casebre se torna um mucambo modelar que tanto celebram os sociólogos do lugar. ”Jornal do Commercio - JC CulturalCaderno C: Especial Gilberto Freyre II - Recife, quarta-feira, 13 de março de 2000. Versão eletrônica, JC On Line. Disponível em <http://www2.uol.com.br/JC/_2000/2003/cu1503b.htm>. Acessado em 05 de maio de 2008.
} 
superficial a questões que envolviam desde fragmentos da biografia de Luiz XIV até notícias sobre o desembarque de um cavalo em Madagáscar, ou ainda o término da restauração do Arquivo dos Fari, em Veneza.

Essa concepção de "variedades", trazida pela revista está diretamente ligada à visão que seus editores construíram sobre seu público-alvo, neste caso, majoritariamente, o público feminino e de classe média. As propagandas na revista indicam a quem se pretende vender os produtos anunciados pelos patrocinadores e, consequentemente, a quem a revista se dirige. Exatamente como na O Cruzeiro, a Vamos Lêr! trazia em seu interior propagandas de cremes para a pele, maquillage, esmalte, "leite de colônia", produtos da higiene íntima feminina, eletrodomésticos, sapatos e uma infinidade de objetos associados ao consumo doméstico, vinculados - produto e discurso da propaganda - a uma ideia de mulher moderna. É com essa mulher - agora mais independente mais escolarizada e de classe média - que a revista está dialogando. Todavia, a mulher não apareceria somente como receptora desse discurso sobre o consumo, mas também como personagem de diversas matérias sobre cinema, moda, vida doméstica e mesmo protagonizando reportagens de cunho social e científico. Temas como "A mulher trabalha mais do que o homem" (apresentando a breve história de mulheres que trabalhavam na roça, e donas de casa na $\operatorname{cidade}^{17}$ ), apresentavam uma mulher dinâmica e que, mesmo com a presença das máquinas que invadiram os lares, permaneceria sobrecarregada em seus afazeres domésticos. Mas não somente a mulher burguesa - dona de casa que agora tinha que aprender a lidar com a enceradeira e com a máquina de lavar à manivela - protagonizou matérias, também as "grandes mulheres" eram tema das reportagens mais longas de teor biográfico (nestes espaços, encontramos Marie Curie, Rainha Vitória, Heloisa - tendo em destaque seu romance com Abelardo - dentre outras). As biografias eram, na verdade, traduções de biografias publicadas por revistas estrangeiras, que eram compradas e traduzidas para a revista.

O humor aparecia na seção Vamos Rir, na forma de piadas, enviadas pelos leitores e selecionadas pela redação da revista. Além de gerar a curiosidade entre aqueles que desejavam saber se teriam suas piadas publicadas, criava-se uma torcida em torno da disputa da melhor piada do ano. Todos os tipos de motes eram contemplados: piadas de cunho político, social, além de todo 
tipo de deboche ligado aos tipos populares: a mulher bonita, o mulherengo, a feia, o gordo, o negro, o nordestino. Conforme Saliba, em Raízes do Riso, as representações humorísticas, desempenharam papel de relevo no processo de invenção das imaginações nacionais, e se fomentaram estereótipos, também contribuindo para modificá-los e desmistificá-los.

[...] o recurso cômico era não apenas pouco difundido devido à inexistência dos próprios meios de difusão, mas também havia um mal disfarçado desprezo da cultura em geral pela produção humorística, a não ser quando esta se mostrava suscetível de ser incluída - ou classificada - nos moldes estéticos consagrados do romance, do drama ou da epopeia. (SALIBA, 2002, p. 43)

As seções de humor eram muito populares entre os leitores, não somente a Vamos Lêr! mas também a Manchete, com os cartuns de Borjalo - Mauro Borja Lopes - e Nássara ${ }^{18}$; pela Cruzeiro: o Amigo da Onça ${ }^{19}$, de Péricles, e as Garotas do Alceu, de Alceu Penna, dentre outros.

Porém, a seção que melhor nos traduz quem eram os leitores de Vamos Lêr! era a de auxílio emocional, que associava misticismo e ciência. Entre os anos de 1936 até novembro de 1940, funcionou na revista a seção Retratos Antropológicos: Conheça a si mesmo revelando o futuro pelos caracteres fisionomicos, que transformava o roteiro de critérios da Frenologia e da "Fisiognomia" em oráculo. O consultor recebia as fotos dos consulentes e, a partir dos traços fisionômicos da face da pessoa, interpretava sua personalidade, seu caráter e seu futuro.

A seção era frequentada por leitores que enviavam cartas, homens e mulheres, identificavam-se por meio de nomes e sobrenomes ou por apelidos como "Jarrinho de 27 anos, Belo Horizonte"; "Romeu, 20 anos - em foto descrita ao lado de sua Julieta, 15 anos - ambos do Distrito Federal de então)"; "Saudosa, 17 anos, Belo Horizonte"; "Incrédulo Mistificado, 22 anos, Hospital Central da Marinha); "Albatroz, 22 anos, João Pessoa"; "Tom Mix, 16 anos, Recife"; “Cleópatra, 19 anos, Belém do Pará"; "Pagé, 16 anos, Goiaz"; "Salam Aleikum, 18 anos, Belo Horizonte"; entre outros tantos, que se utilizavam dos mais diversos pseudônimos para enviar suas fotos e receber a análise e o vaticínio do especialista que, via de regra, reproduzia os pré-conceitos criados por modelos antigos arraigados desde as interpretações sobre os mulatos em Antonil, passando pelo sertanejo de Euclides e até mesmo as teorias raciais de Lapouge. Nas interpretações

18 Antônio Nássara foi um cartunista e compositor carioca que colaborou no Jornal A Noite, nas revistas Vamos Lêr, Manchete, Cruzeiro, no Pasquim, dentre outros.

19 Sobre as relações entre $O$ Amigo da Onça, e o contexto da Era Vargas, ver o estudo de SILVA, Marcos. Prazer e poder do amigo da onça. Paz e Terra: Rio de Janeiro, 1989. 
do dito 'especialista', para as fisionomias dos consulentes nordestinos encontramos descrições de: "mulatas e mulatos faceiros e sensuais; sertanejos de espírito, desconfiados, destemidos, com aptidão para os trabalhos manuais". Quanto ao "temperamento", em geral, são apresentados como de "gênio chistoso, pouco confiável ou com traços de humorismo".

Com o transcorrer da Segunda guerra e o enfraquecimento de um discurso pautado em teorias raciais, ocorreria uma mudança tanto no corpo da revista quanto em seu oráculo, que na edição de 05 de dezembro de 1940, passa de uma leitura do futuro baseada na interpretação fisionômica, para previsões do futuro baseadas na "leitura das mãos" e na "orientação astrológica" 20 .

A guerra colocaria um fim, de uma vez só, tanto à frequente apologia à ordem social e econômica da Alemanha hitlerista quanto ao espaço legado ao oráculo impregnado de pseudo interpretações baseadas nas teorias raciais.

\section{Revista Manchete}

Enquanto a $O$ Cruzeiro trazia na semana de 25 de novembro de 1952, um número com a reportagem de David Nasser sobre Carmem Miranda, a mais querida cantora do momento, na qual tecia-lhe a crítica, de estar "se tornando americanizada"21; Adolpho Bloch, com a intenção de competir num mercado, até então dominado pela revista de Assis Chateaubriand, lançava a revista Manchete, trazendo a bailarina Inês Litowski, na capa, entrevistas e fotos das concorrentes ao Concurso Mundial de Beleza e uma entrevista ilustrada com fotografias do irreverente Pietro Maria Bardi.

A tipografia da família Bloch, àquela época, em franca expansão graças ao mercado favorável do pós-guerra, atendia a uma gama variada de clientes que, com eles, contratavam a impressão de rótulos, bulas, cartazes, folhetos embalagens e revistas para a Editora do Brasil e para a Rio Gráfica. Segundo Gonçalves, mesmo com todo esse movimento, Bloch desejava otimizar sua tipografia:

$20 \quad$ Vamos Lêr! Edição de 05 de dezembro de 1940, p. 56.

Não era a primeira vez que Carmen era acusada de perder sua brasilidade. Em 1940, após sua primeira estada mais longa nos Estados Unidos, a imprensa também a acusou de estar se americanizando. Como resposta, Luís Peixoto e Vicente Paiva compuseram para ela a canção: Dizem que voltei americanizada, canção gravada por Carmen, pela Odeon. 
As luzes apagadas, a ausência dos zumbidos do equipamento, a falta do ruído seco da guilhotina em ação, toda essa trilha sonora industrial em off incomodava Adolpho Bloch. O empresário, estimulado por seus amigos de boemia intelectual - Henrique Ponguetti era seu companheiro de praia, Raymundo Magalhães Jr. era seu parceiro de noitadas no Assirius, onde a dupla angariava damas para dançar maxixes e tangos - topou o desafio de unir o útil ao agradável: acionar as rotativas em tempo integral e editar uma revista ilustrada. Foi assim que Manchete nasceu. (GONÇALVES; BARROS, 2008, p. 26)

Bloch apostaria em sua capacidade de oferecer ao público aquilo que vinha se consolidando cada vez mais como componentes ideais para uma revista semanal; o mercado pedia por uma revista moderna e que também fosse "uma janela para o mundo"; ilustrada, dinâmica, que falasse diretamente com seu leitor, trazendo-lhe a possibilidade de ver e entrar em contato com um mundo novo, de glamour e também de exotismo. O Cruzeiro oferecia tudo isso ao leitor, contudo, Bloch acreditava que haveria espaço para mais um, principalmente porque tinha como objetivo investir ainda mais na imagem e ir além dos modelos já consagrados pelas revistas de sua época.

Em sua primeira edição, o papel e a diagramação não eram de primeira qualidade, apenas a capa era colorida e o corpo interno da revista em preto e branco, mesmo assim, trazendo matérias como uma polêmica entrevista com Pietro Maria Bardi, a crônica de Carlos Drummond e ainda uma fotorreportagem da grande estrela do fotojornalismo de então, Jean Manzon, ex-Cruzeiro, a primeira tiragem da revista esgotou-se das bancas em três dias.

As máquinas de Bloch tinham capacidade para a impressão de uma tiragem inicial de 200 mil exemplares semanais e durante o ano de 1952 foram vendidos, no total, 1.146.329 exemplares (em um mês e uma semana), o equivalente a $79 \%$ do total impresso; para Bloch, ainda não era o ideal, todavia, o bom desempenho da revista demonstrava que havia espaço no mercado, desde que houvesse investimento em colaboradores e imagem. Em 1953, a tiragem subiu para 2.863.374 exemplares/ano (uma média de 230 mil exemplares vendidos por mês) e o percentual de vendas chegou aos 93\%. Mas seria o ano de 1954 - ano em que a concorrente, O Cruzeiro alcançaria a marca recorde de quase 1 milhão de exemplares semanais vendidos - que a Manchete iria rever sua estratégia de mercado e a compreensão sobre si mesma como declara o próprio Bloch:

Só comecei a compreender um pouco do jornalismo quando Getúlio Vargas se suicidou, em 1954. A capa já estava impressa, era com o brigadeiro Eduardo Gomes, adversário do presidente. Eu tive de imprimir nova capa com o presidente Vargas. À tarde, a edição estava esgotada. Depois da morte de Vargas vieram as crises políticas de 1955. Havia muito assunto e as vendas aumentavam. (GONÇALVES; BARROS, 2008, p. 30) 
Em 1956 a revista passou por uma grande reformulação, visando um salto no mercado; houve a aquisição de novas máquinas e a equipe de redatores passa a contar com um grupo de pessoas de destaque no meio intelectual: Carlos Drummond de Andrade, Rubem Braga, Joel Silveira, Orígenes Lessa, Raimundo Magalhães Júnior, Guilherme Figueiredo, Otto Maria Carpeaux, Manoel Bandeira, Fernando Sabino, Antonio Maria, Nelson Rodrigues, Marques Rebello, Paulo Mendes Campos, Lígia Fagundes Telles, Antonio Callado, Sérgio Porto, Ciro dos Anjos, Olegário Mariano, Jânio de Freitas, e como principal fotógrafo, Jean Manzon. Segundo aponta Gonçalves (2008), a partir das reformulações técnicas e editoriais de 1956 a revista não parou mais de crescer, alcançando um apuro gráfico exemplar, logo superaria $O$ Cruzeiro nesse quesito e partiria para dominar o mercado, o que aconteceria a partir dos anos de 1960, quando a revista dos Diários Associados já não mais apresentava o brilho de outrora ${ }^{22}$.

Com destaque para as belas e chamativas fotos da capa, Manchete, já nos primeiros anos de circulação colocava-se ao lado de $O$ Cruzeiro, tornavam-se assim as duas grandes vitrines do que se pensava sobre um Brasil moderno; eram as duas janelas que ao mesmo tempo selecionavam, apresentavam e interpretavam o mundo para o leitor, por meio delas, o Brasil discutia cinema, rádio, política, curiosidades culturais e científicas, povos desconhecidos e estranhos costumes eram revelados, catástrofes, guerras, mas também o mundo feminino era valorizado, bem como os esportes $^{23}$. No humor; fórmula eternizada pela $O$ Cruzeiro e pela Manchete e que, posteriormente

22 Passaram pela redação da Manchete muitos jornalistas, músicos hoje famosos homens da mídia: "Paulo Coelho foi correspondente em Londres; o saxofonista Leo Gandelman foi fotógrafo. Os escritores Carlinhos de Oliveira, Ruy Castro, José Louzeiro e Flávio Moreira da Costa; o dramaturgo Nelson Rodrigues e o poeta Paulo Leminski (que trabalhava no Departamento de Pesquisa) colaboraram com textos para a revista. Ronaldo Bôscoli, um dos inventores da Bossa Nova, era redator, e o dançarino Carlinhos de Jesus era do Departamento Pessoal. Júlio Barroso, jornalista e roqueiro, foi correspondente em Nova York, até escolher viver de música e fundar a Gang 90\&Absurdetes, banda Cult dos anos de 1980. Gilberto Tumscitz foi repórter de Manchete. Quem é Gilberto Tumscitz? Ele mesmo, o Gilberto Braga das novelas da Globo. E Rubem Gerchman foi paginador da revista.” Gonçalves, José Esmeraldo e Muggiatti, Roberto. A Janela do Russell. In: Gonçalves, José Esmeraldo; Barros, J.A. Aconteceu na Manchete: as histórias que ninguém contou. Rio de Janeiro: Desiderata, 2008, p. 36.

23 A ciência também era tema frequente, embora não fosse criada uma seção específica para as reportagens sobre esse assunto. Em seu artigo Aconteceu, virou Manchete, Andrade e Cardoso, do Museu de Astronomia e Ciências Afins (RJ) apontam para o fato de que o cientista estava, àquela época, no mesmo patamar de outras personalidades públicas, como jornalistas e intelectuais. A ciência, embora não tivesse espaço fixo na revista, apareceria em suas páginas com frequência, em matérias como "A medicina progride: Novas aplicações da eletroterapia" ou "Físicos discutem Física", ambas do mês de julho de 1952; ou ainda a matéria de março de 1955 "O Brasil quase vence Cesar Lattes”, sobre a saga da criação do Centro Brasileiro de Pesquisas Físicas. Manchete, ano III, 12 de março de 1955 , p.06 e 07; ANDRADE, Ana Maria Ribeiro de e CARDOSO, José Leandro Rocha. Aconteceu, virou Manchete. Revista Brasileira de História, vol.21, n. 41, São Paulo, 2001. 
serviria de base para a estruturação da pauta de programação das revistas eletrônicas e programas televisivos que, até os nossos dias, têm por objetivo, apresentar ao espectador um roteiro de variedades, somando notícia e entretenimento, exatamente na mesma medida em que o fizeram as grandes revistas ilustradas dos anos 30, 40 e 50.

\section{Historiografia}

$\mathrm{Na}$ historiografia, das últimas décadas, foram vários os trabalhos que refletiram sobre o Nordeste, o nordestino e também sobre a questão das migrações internas no Brasil. Sobre a adaptação e a assimilação do elemento migrante, destacamos os trabalhos de Dulce Maria Tourinho Baptista, Nas terras do Deus dará: Nordestinos e suas redes sociais em São Paulo, onde a autora analisa a organização do cotidiano do migrante que se estabelece na favela, realizando o estudo de caso da favela Jardim Colombo, aonde os migrantes vêem por ter em seus "conterrâneos" uma referência além de outros pólos desta rede, como a Casa do Migrante e a igreja, nas ações da Pastoral do Migrante. Na linha da análise do cotidiano, se encontra ainda o trabalho de Rigamonte, Sertanejos Contemporâneos e o de Ely Souza Estrela, Os sampauleiros: cotidiano $e$ representações. $\mathrm{Na}$ perspectiva de análise das relações cotidianas e também de inserção do migrante no universo do trabalho e da economia produtiva da cidade de São Paulo, destacamos o trabalho de Margarida Maria Andrade, Bairros Além-Tamanduateí: o imigrante e a Fábrica no Brás, Mooca e Belenzinho e o trabalho de Odair da Cruz Paiva Caminhos Cruzados. Migração e Construção do Brasil Moderno, no qual o autor explora meticulosamente as questões que associam o crescimento da economia industrial e a movimentação da mão-de-obra migrante em busca de trabalho e sobrevivência. ${ }^{24}$

Maura Penna em O que faz ser nordestino: identidades sociais, interesses e o "escândalo" Erundina, expõem as relações entre o preconceito regional, social e de gênero, e suas relações com

\footnotetext{
${ }^{24}$ Num olhar retrospectivo, destacamos ainda os trabalhos clássicos sobre migração interna e particularmente sobre a migração para São Paulo, como o de Antonio Jordão Netto - Aspectos econômicos e Sociais das migrações internas para o Estado de São Paulo. 1973; Ângela Maria de Castro Gomes: Burguesia e Trabalho, políticas e legislação social no Brasil, 1917-1937; além do trabalho de Aníbal Villanova Villela e Wilson Suzigan: Política do governo e crescimento da economia brasileira: 1889-1945 (1973), uma das referências na análise sobre as relações entre as políticas econômicas do governo e seu efeito sobre a oferta de mão-de-obra.
} 
as interpretações dadas pelos políticos, imprensa e senso comum à gestão de Luiza Erundina na prefeitura de São Paulo.

Em Abastecimento: crises, motins e intervenção, Pinto de Aguiar, a partir das fontes da época - basicamente, os telegramas do presidente da província a quem lhe pudesse prestar socorro e os jornais - questiona as razões do curioso silêncio dos jornais baianos do período sobre a problemática da seca na Bahia, quando neles se encontra, no entanto, frequentes referências ao Ceará e até as outras províncias do norte do Império. Mais curiosas ainda são as notícias alusivas às campanhas beneficentes engendradas na Bahia para o socorro dos irmãos cearenses. A importância da obra de Aguiar reside na discussão sobre a relação entre política, seca e representações, uma vez que, em razão da disputa política que ocupava os jornais nos primeiros meses de 1878, a calamidade que assolava o nordeste perderia deliberadamente, visibilidade.

Sobre as representações das secas e dos retirantes-das-secas, Frederico de Castro Neves em Imagens do Nordeste. A construção da memória regional. A multidão e a História: saques e outras ações de massas no Ceará, baseando-se, do ponto de vista teórico, principalmente, nas contribuições do historiador inglês E.P. Thompson sobre a história dos movimentos populares, estuda as ações de massas no Ceará. Desde a grande seca de 1877 até os anos 1950, mapeando os movimentos populares e tratando-os como um sujeito político coletivo.

Marco Antonio Villa em Vida e morte: história das secas no Nordeste nos século XIX e $X X$ resgata o impacto das grandes secas desde o XIX, com a grande seca de 1877-1879 até as décadas de 1960, do século XX. Questionando o imobilismo do governo, com suas tímidas ações paliativas, aponta numa operação de mórbida matemática, como afirma Martinez, uma cifra que, até agora, ultrapassa 3 milhões de mortos vitimados com as secas. Lança aos historiadores o desafio de responder o motivo da permanência da imutabilidade no rol de problemas do Nordeste. Discutindo desde os interesses que envolvem a indústria da seca, à permanência das estruturas de poder dos coronéis, Villa nos conduz a uma bem orientada análise sobre o desenvolvimento de cem anos da seca como fenômeno social e político.

Muitos são os trabalhos da historiografia recente sobre esta questão das representações sobre o sertão. Em sua dissertação de Mestrado, Edneila Rodrigues analisa a região de Rio Pardo, localizado no norte de Minas Gerais e observa como se percebeu no cotidiano local a ideia de um mundo sertanejo e, mais importante ainda, questiona em que dimensão a visão dicotômica (litoralcivilizado X sertão-bárbaro) era percebida e vivida pelas pessoas no século XIX. É importante 
notar que a construção do conceito de um universo sertanejo geralmente se dá a partir de um referencial externo, o que, inevitavelmente, prejudica a análise do locus pesquisado, uma vez que ele é visto sempre como um referencial de oposição a algo "civilizado", a um modo de vida entendido como superior. Conforme destacado pela autora, "o sertão existia enquanto espaço de ausência das características vistas como positivas do outro, assim foram definidos pelo que não eram" (CHAVES, 2004, p. 19). Também Célia Nonata da Silva, em sua tese de Doutorado, estuda a região do sertão mineiro. Focando a sua análise na atuação dos mandões e dos bandidos na capitania, ao longo do século XVIII, a autora deixa clara a percepção do seu universo de pesquisa como um espaço de "relações culturais diferenciadas", com relações políticas costumeiras, baseadas em um "código moral da valentia" e em uma "tradição do poder de mando". Trabalhos já clássicos como o de Durval Muniz de Albuquerque Jr, A invenção do nordeste e outras artes, que desenvolve a análise das formas e dos processos de construção das "dizibilidades e "visibilidades" do Nordeste, partindo de uma perspectiva foucaultiana na abordagem de histórias, músicas e produções artísticas diversas - televisão, rádio - que possuem o Nordeste e o nordestino como personagem central.

Em Os Sertões, Euclides da Cunha descreve o sertanejo a partir de uma metáfora. Para apresentar um indivíduo que possuiria em si a força para lutar contra uma natureza rude e inóspita, e ao mesmo tempo, ressaltar-lhe, o que descrevia como, fealdade, aspecto desgracioso, desengonçado, torto; o autor define o sertanejo como o Hércules-Quasímodo, unindo em um único representante, a força olímpica do semideus grego à imagem de Quasímodo, o 'Corcunda de NotreDame', do romance Notre-Dame de Paris, de Vitor Hugo. Utilizamos aqui a metáfora de Euclides para representar as duas faces possíveis de serem vistas nas representações coletivas, não somente sobre o sertanejo nordestino, mas da própria região do Nordeste.

Observar de que maneira estes veículos apresentavam o nordestino e o Nordeste, bem como os resultados culturais da substituição do real por sua representação, é o que nos interessa agora. Compreender de que maneira e em quais momentos as representações muitas vezes antitéticas como na metáfora de Euclides da Cunha, do sertanejo como um Hércules-Quasímodo, a miséria e a riqueza natural, o exótico e o nacional (na figura do nordestino como o braço nacional necessário para o desenvolvimento), a barbárie e a civilização - viriam a se articular com o tempo e com a sociedade, é o que se pretende nestas páginas, a partir de agora. 


\section{PARTE I - O NORDESTE-QUASÍMODO}

\section{I - O NORDESTE REPRESENTADO PELAS SECAS}

Então, a travessia das veredas sertanejas é mais exaustiva que a de uma estepe nua. Nesta, ao menos, o viajante tem o desafogo de um horizonte largo e a perspectiva das planuras francas. Ao passo que a caatinga o afoga; abrevia-lhe o olhar; agride-o e estonteia-o.

Euclides da Cunha. (1982)

\subsection{A dura face do Nordeste $\operatorname{seco}^{25}$}

A palavra "nordeste" é hoje uma palavra desfigurada pela expressão "obras do Nordeste" que quer dizer: "obras contra as secas". E quase não sugere senão as secas. Os sertões de areia seca rangendo debaixo dos pés. Os sertões de paisagens duras doendo nos olhos. Os mandacarus. Os bois e os cavalos angulosos. As sombras leves como umas almas do outro mundo com medo do sol. Mas esse Nordeste de figuras de homens e de bichos se alongando quase em figuras de El Greco é apenas um lado do Nordeste. (FREYRE, 2004, p. 45)

A narrativa de Freyre refere-se à poderosa ligação entre o clima do semiárido do Nordeste brasileiro e a representação do Nordeste e suas gentes como um todo. Conhecidas desde o período colonial, impressionando pela brutalidade de seus resultados, com intermitência de aproximadamente dez anos e duração de até cinco, as secas periódicas e seu produto social, a emigração, se transformaram em um signo natural, um representante absoluto da paisagem nordestina, principalmente para as populações dos estados do Sudeste.

Na reconstrução imagética do Nordeste, o sertão vem sendo escolhido como imagem que nos apresenta e nos introduz ao universo físico e humano das terras do semiárido do país, passando assim ele, sertão, a representar o que de fato é tão maior e tão mais heterogêneo. Todavia, embora se possa afirmar que o Nordeste não seja representado, principalmente pela imprensa, unicamente como sertão, o sertão, por sua vez, é insistentemente reduzido à descrição da crueldade implacável da natureza, na forma da seca. O sertão, em sua apresentação jornalística, não possui cultura, não possui história, ele é atemporal, imutável e inóspito. Embora seja esse um processo de substituição

25 A expressão Nordeste seco, é utilizada por Azis Ab’Saber para definir a região do semiárido brasileiro, que corresponde à área de incidência do fenômeno das secas periódicas. AB'SABER, Aziz. Sertões e sertanejos: uma geografia humana sofrida. Dossiê Nordeste Seco In Revista de Estudos Avançados ano 13, v. $36,1999$. 
muito frequente, como aponta Freyre, sua intensidade e dimensão podem ser observadas e analisadas a partir do estudo de fontes que nos esclareçam sobre os meios e as formas com que essas representações circularam e formularam as bases de nosso repertório imagético sobre o Nordeste.

\subsection{As secas como representação do sertão}

Nos anos de 1929 e 1930, a revista O Cruzeiro, campeã de vendagem desde seu lançamento, trouxe consigo, logo na abertura dos trabalhos, os contos Scenas do Ceará (figura 01). Uma sequência de contos escritos por Valdez Corrêa ${ }^{26}$. Neles, a imagem construída não nos é estranha, ela traz consigo alguns elementos-chave para que possamos reconhecer, o cenário do semiárido nordestino assolado pelas secas.

O solo queimado e gretado pelo sol, misticismo e fé, animais mortos de sede e fome, homens e mulheres vencidos pela seca, eram descrições que frequentavam as páginas dos jornais do Sudeste e do Nordeste, levando às populações urbanas uma narrativa composta por elementos de uma gramática que sustentava a construção do cenário do fenômeno natural que ceifava vidas e destruía a organização de cidades inteiras.

Chama-nos a atenção o fato do texto, embora em posição de destaque - a página de abertura da revista - não trazer nenhuma imagem - ilustração ou fotorreprodução - das cidades ou das populações atingidas pelas secas, respectivamente cenário e personagens dos contos. As Scenas eram construídas somente pela palavra. A narrativa aparece, as imagens não. Outras fontes escritas do período também traziam em suas páginas descrições sobre o sertão, mas as imagens, ainda rareavam. Para que se possa compreender o porquê da escassez de imagens, faz-se necessário, relembrar que, mesmo com o advento da fotografia, o Nordeste, e mais ainda o sertão nordestino, permaneceriam, por muito tempo como um mundo visualmente distante para as populações do Sul e Sudeste.

26 José Valdez Corrêa foi redator de O Jornal no mesmo período em que escreveu para $O$ Cruzeiro. Fundado em 1919, O Jornal foi comprado em 1924 por Assis Chateaubriand, tornando-se o "órgão líder dos Diários Associados". Sua circulação chegou a 60 mil exemplares por dia. Ver mais em ABREU, Alzira Alves. A modernização da imprensa (1970-2000). Rio de Janeiro: Zahar Editora, 2002, 1ª edição. 
Figura 1. Scenas do Ceará.
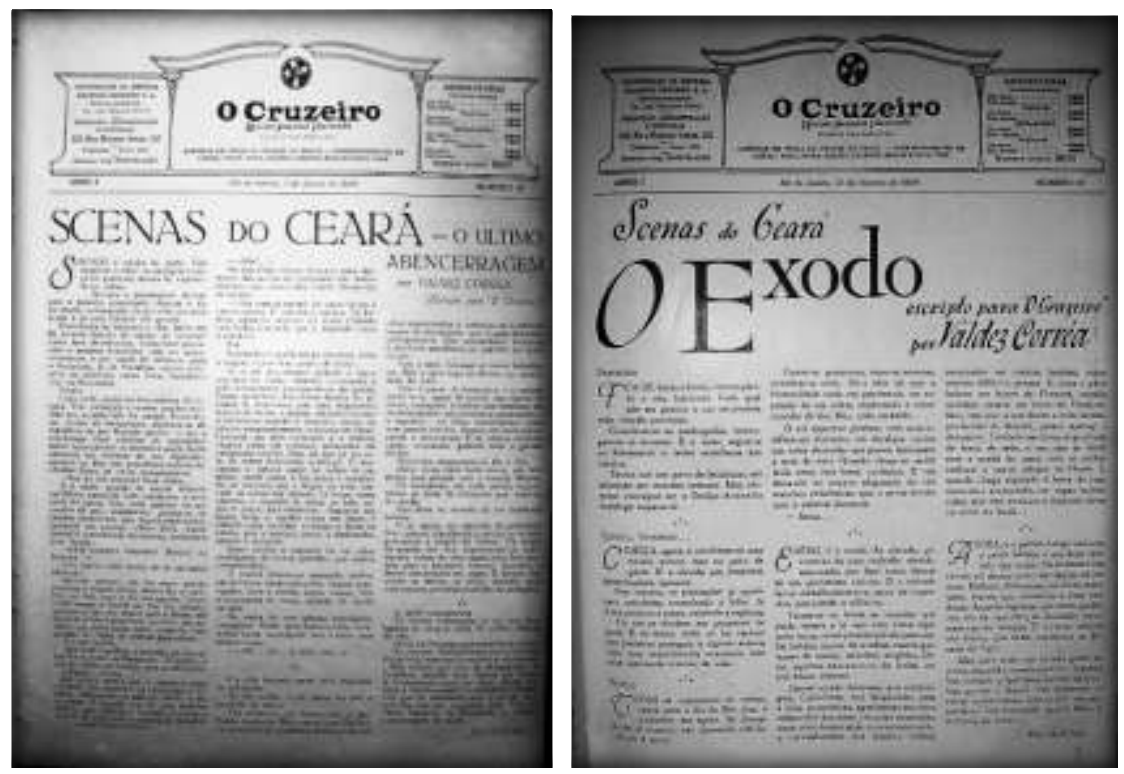

Fonte: Revista O Cruzeiro, 03 de agosto de 1929, p.03. O Cruzeiro, 12 de outubro de 1929, p. 3. Textos de Valdez Correa. Coleção MASP.

Para os leitores do Sudeste, o Nordeste e seus diferentes biomas constituíam-se em um mundo desconhecido, que lhes era dado a ver por meio de alguns poucos suportes, como as antigas gravuras publicadas em poucos livros sobre a Geografia e a natureza brasileira, ou ainda, depois do advento da fotografia, por meio da reprodução de imagens impressas ${ }^{27}$. Circulando, num momento inicial, timidamente na forma de foto reproduções, principalmente no formato de cartede-visite, as imagens dos diferentes tipos humanos e as paisagens do Brasil e do Nordeste brasileiro, em particular, podiam ser encontrados em alguns espaços discursivos de maior amplitude como a imprensa ilustrada e os manuais escolares.

\subsection{O Nordeste nas páginas dos manuais escolares}

No caso de São Paulo e Rio de Janeiro, temos o fotoclubismo, representado, por exemplo, pelo Photo Club do Rio de Janeiro, fundado em 1910 ou a Sociedade Paulista de Fotografia, fundada em 1926; espaços por onde a imagem fotográfica também circulava, todavia, tratavam-se de sociedades fechadas, reservadas aos amantes da fotografia, dispondo, no tempo de sua formação, de pouco espaço e poucos recursos. COSTA, Heloisa. A fotografia moderna no Brasil. São Paulo: Cosac Naif, 2012, p. 25. Ver também PEREGRINO, Nadja Fonseca e MAGALHÃES, Angela. Fotoclubismo no Brasil. $O$ legado da sociedade fluminense de fotografia. Rio de Janeiro: SENAC Nacional, 2012. 
A reprodutibilidade da imagem trouxe o mundo para os manuais escolares e, consequentemente, o Brasil também. Investido da função de difundir valores e ideias nas quais os contemporâneos se veem ou se deviam ver (MAGALHÃES, 2008), o manual escolar deve ser entendido como um produto que repercute em diferentes aspectos da ordem social, do conhecimento, da cultura e mesmo como meio para a divulgação de um projeto político e ideológico.

No Brasil, no caso dos manuais de História, temos que, do final do século XIX até a primeira metade do século XX, praticamente não havia um trabalho voltado para o uso de imagens, a grande maioria dos manuais sequer as trazia e, naqueles em que encontramos imagens, limitamse a uma função de redundância e não de colaboração com o texto escrito ${ }^{28}$.

Seguindo a perspectiva de uma história metódica, os manuais brasileiros de História, eram organizados a partir de uma narrativa marcadamente factual e, quanto às imagens, limitavam-se essas, basicamente, às efígies dos heróis da história - jesuítas e bandeirantes - e também foto reproduções de pinturas dos heróis da luta pela independência do Brasil durante o período colonial, (figura 02) além das imagens dos governantes brasileiros dos períodos monárquico e republicano. A imagem, nos manuais de História, tinha por objetivo apenas a ilustração de personagens pontuais presentes no texto escrito; não lhe ampliava a mensagem, não a contrapunha, não a complementava. A imagem era apenas um dado de redundância no interior do texto, sendo que as capas e contra capas dos manuais mantinham a ausência de imagens.

Seriam, todavia, os manuais de Geografia os responsáveis por dar aos jovens estudantes alguma ideia da diversidade natural e humana brasileira. Embora não fosse realizada uma abordagem mais antropológica sobre as regiões e suas gentes, em raros momentos, encontramos ilustrações sobre os tipos humanos.

28 Segundo Van der Linden, na relação de redundância não haveria nenhum sentido suplementar. A imagem repete a mensagem do texto, porém pode haver um volume maior ou menor de informação em um dos dois, uma vez que seria impossível que tivessem conteúdos idênticos. Já na relação de colaboração ou complementaridade, o significado não se encontra totalmente em nenhum dos dois - texto ou imagem - mas sim na relação entre ambos. VAN DER LINDEN, Sophie. Para ler o livro ilustrado. Cosac Naify, 2011, pp. 120-121. 
Figura 2. Gravura da efígie de D. João II e gravura do quadro de V. Brazile: Colombo explicando o seu projeto a Isabel e Fernando.
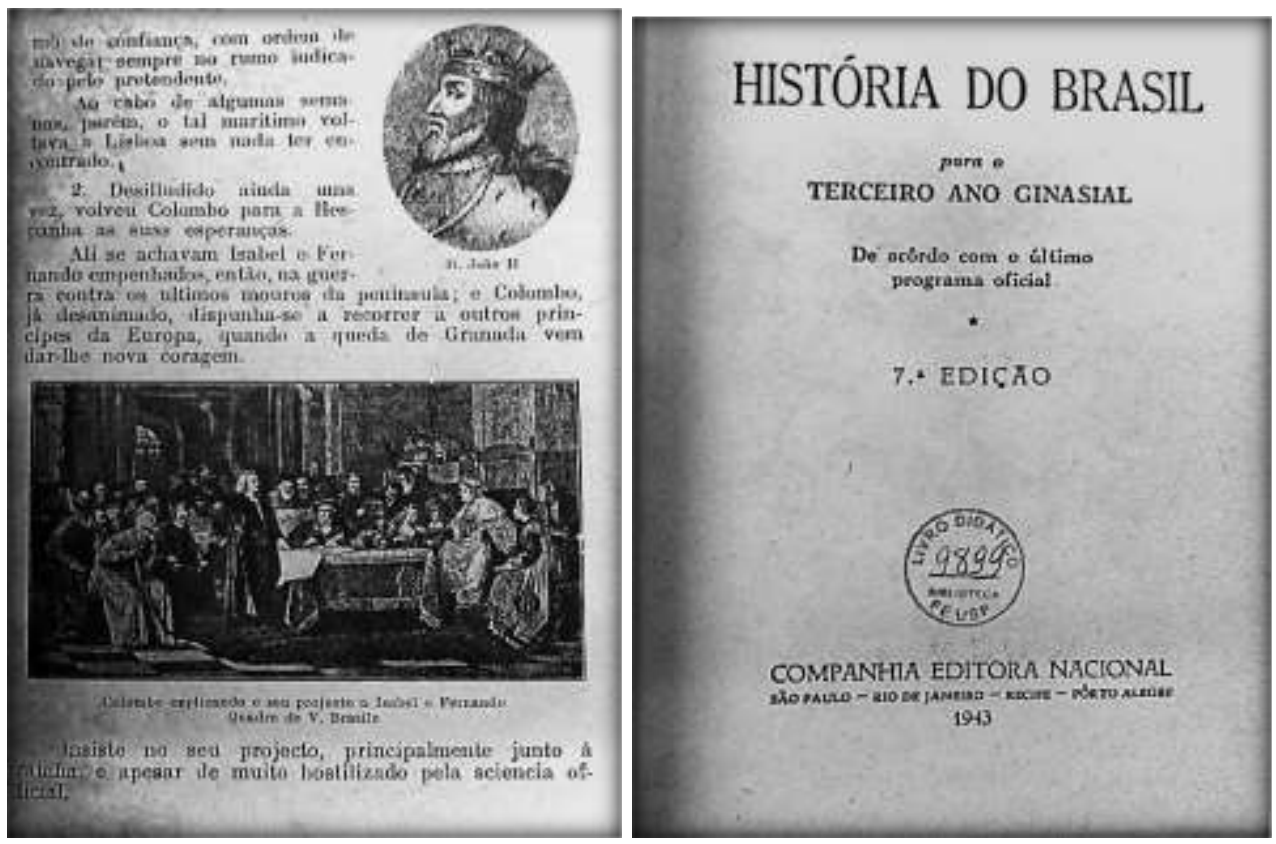

Fonte: História do Brasil para o terceiro ano ginasial. $7^{a}$ Edição. Companhia Editora Nacional: São Paulo Rio de Janeiro - Pôrto Alegre, 1943. Ao lado, foto da capa do livro. Coleção LIVRES da FEUSP.

Figura 3. Casal de Xavantes - Índio bororo.
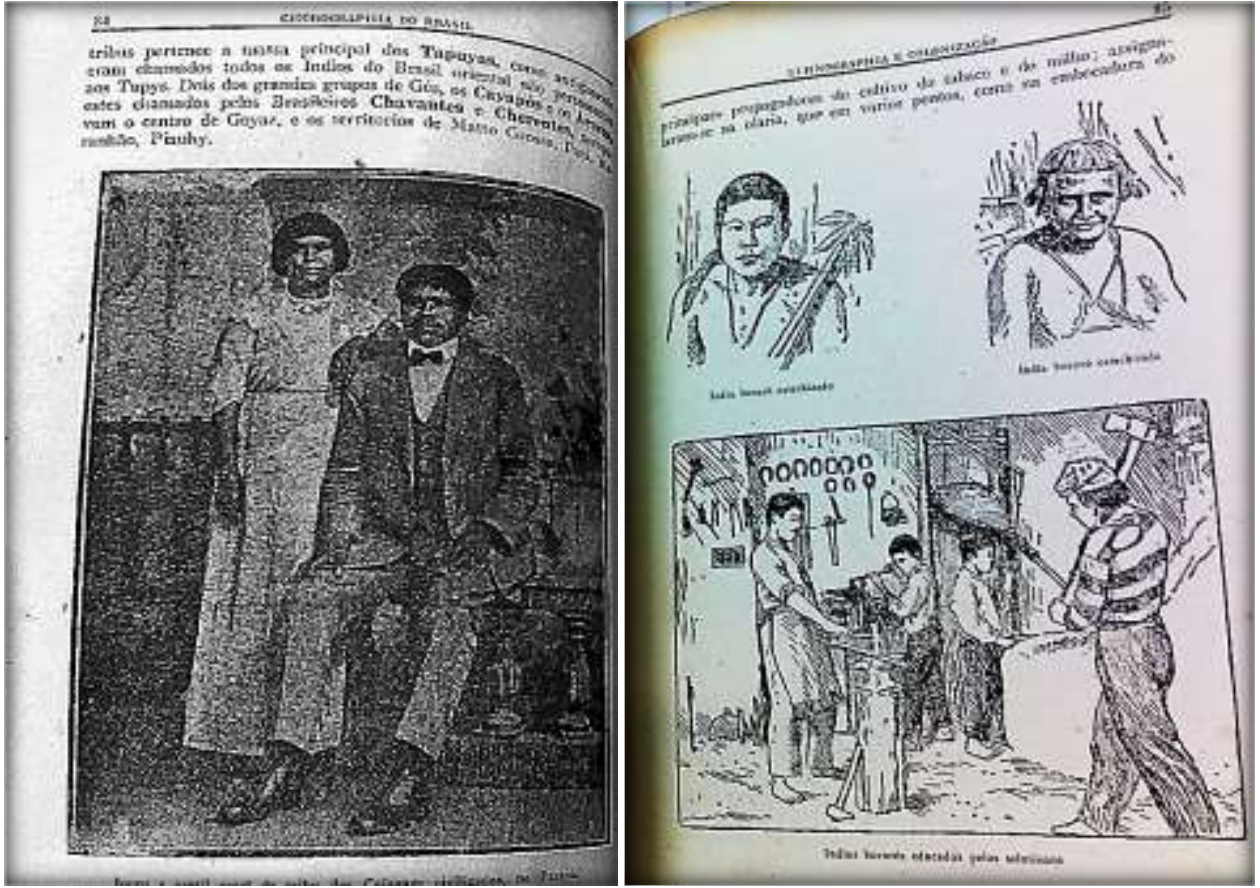

Fonte: Horácio Scrosoppi. Chorographia do Brasil. Quinta edição. Livraria Francisco Alves: Rio de Janeiro, 1927. p. 84 e 85. Coleção LIVRES da FEUSP. 
Em sua grande maioria, as imagens de pessoas, nos manuais, eram constituídas por recortes que traziam poucos elementos próprios de um tempo ou de um espaço específico (figura 3). Com enquadramentos que privilegiavam os traços fisionômicos expostos em posição de frontalidade, destacavam-se as particularidades fenotípicas dos retratados, apresentados de maneira descontextualizada, ou em cenários com poucos ou nenhum elemento da cultura material do grupo descrito. Dessa forma, entende-se que o trabalho iconográfico perderia sua capacidade de apresentar o objeto em toda a sua amplitude, quando dissocia de sua narrativa o tempo e o espaço.

Além disso, as imagens escolhidas para representar o espaço físico ocupado mostravam, via de regra, espaços urbanos ou áreas em processo de urbanização (figura 4). O Brasil rural, a fazenda, o roçado, o sertão não eram apresentados. A preferência era dada às cenas e perfis arquitetônicos urbanos, o objetivo era procurar pelas semelhanças entre as cidades brasileiras e não seus elementos de ipseidade.

No caso da apresentação das capitais nordestinas, os elementos que poderiam caracterizar uma identidade regional, também desapareciam; os enquadramentos escolhidos, privilegiavam os perfis que aproximavam as imagens das cidades do Norte e Nordeste às do Sudeste (figura 4, figura 5, figura 6 e figura 07). Fosse qual fosse a capital, todas se assemelhavam dando ao leitor a impressão de que todas elas, na verdade seriam muito semelhantes.

O plano diagonal conferia profundidade à imagem que se prolongava para além do enquadramento da fotografia. Os edifícios retratados obedeciam sempre a um mesmo estilo, criando uma estética que embora se remeta ao Brasil republicano é, contudo, atemporal. Compunha-se assim, um Brasil homogêneo, civilizado, urbanizado, que seguia basicamente, os padrões arquitetônicos das metrópoles europeias, privilegiando as imagens das construções em padrão neoclássico, em seus jardins e bulevares constituindo um conjunto de imagens-ícone - que seriam utilizadas tanto na estruturação imagética dos manuais escolares quanto das revistas ilustradas do período - que associavam o Brasil a um novo mundo civilizado.

Após a análise das ilustrações e fotorreproduções presentes nos manuais, nota-se que, não há a presença de imagens que representem o sertão, como também não há imagens que representem o sertanejo ou as secas, tanto na abordagem de aspectos físicos quanto de aspectos humanos. Não há imagens do sertanejo ou das secas, as imagens são atemporais e desprovidas de elementos antropológicos significativos. 
Figura 4. Aracajú e Natal.
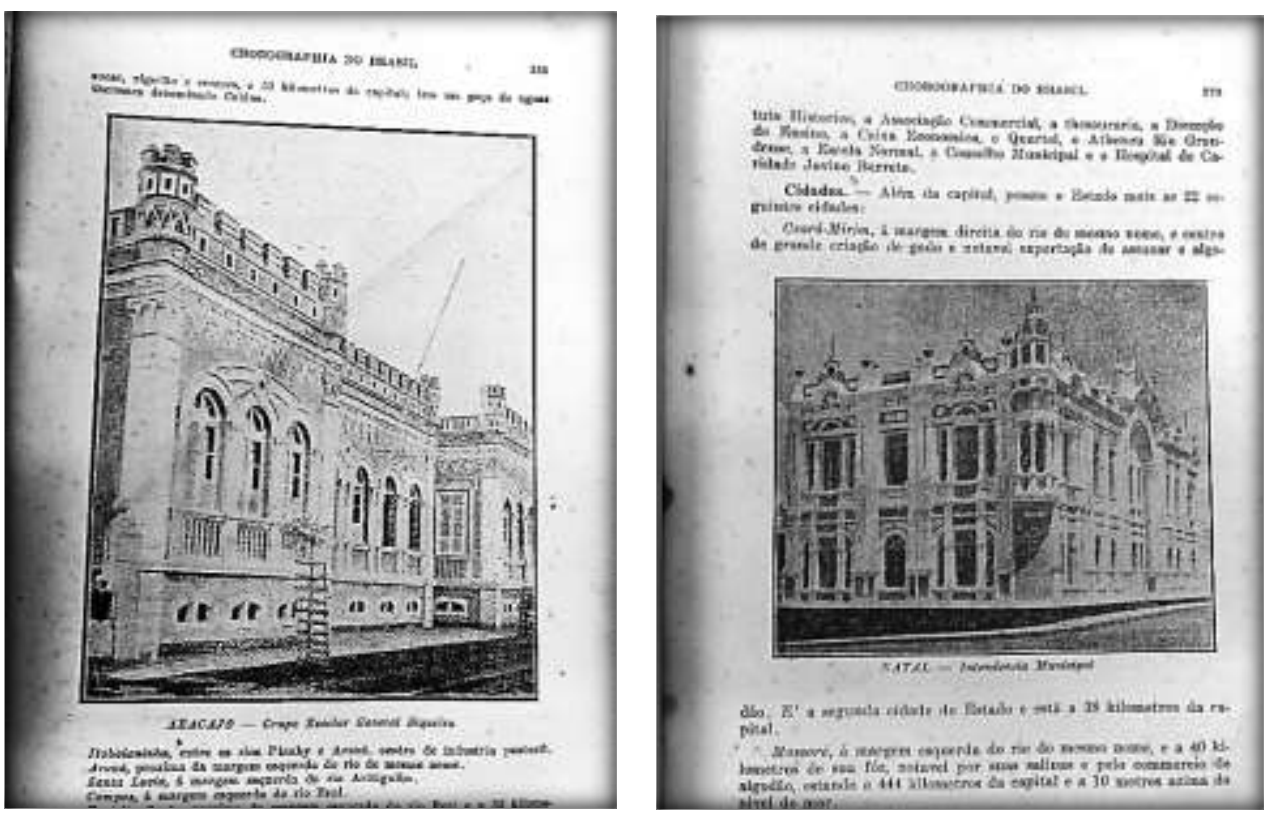

Fonte: Compendio de Chorographia do Brasil. 20ª edição. Livraria Jacintho Editora: Rio de Janeiro, 1933, Aracajú - p. 335. Intendência municipal. Natal - p. 275. Coleção LIVRES da Biblioteca FEUSP.

Figura 5. Novo Recife. Rua XV de Novembro e Estação da Estrada de Ferro. Fortaleza.
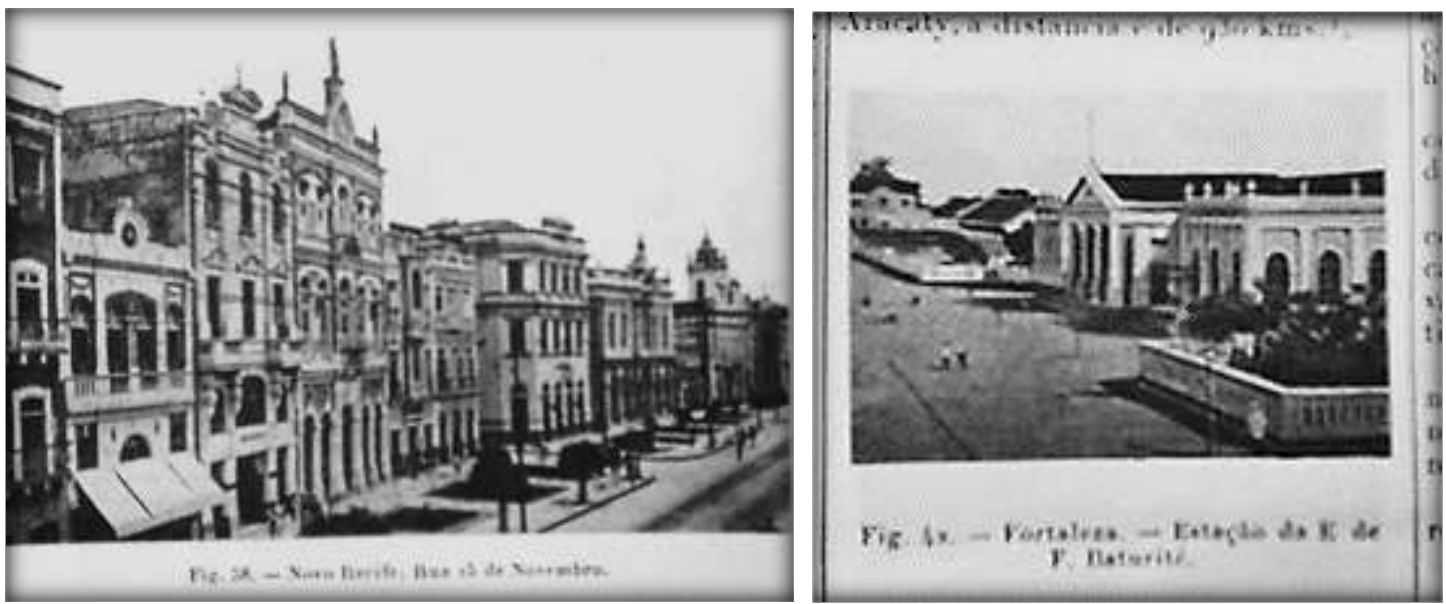

Fonte: HOMEM DE MELLO. Geographia. Atlas do Brasil e das cinco partes do Mundo, 1923. Coleção LIVRES da FEUSP. 
Figura 6. Salvador, Bahia. Faculdade de Medicina e Delegacia no Piauí.
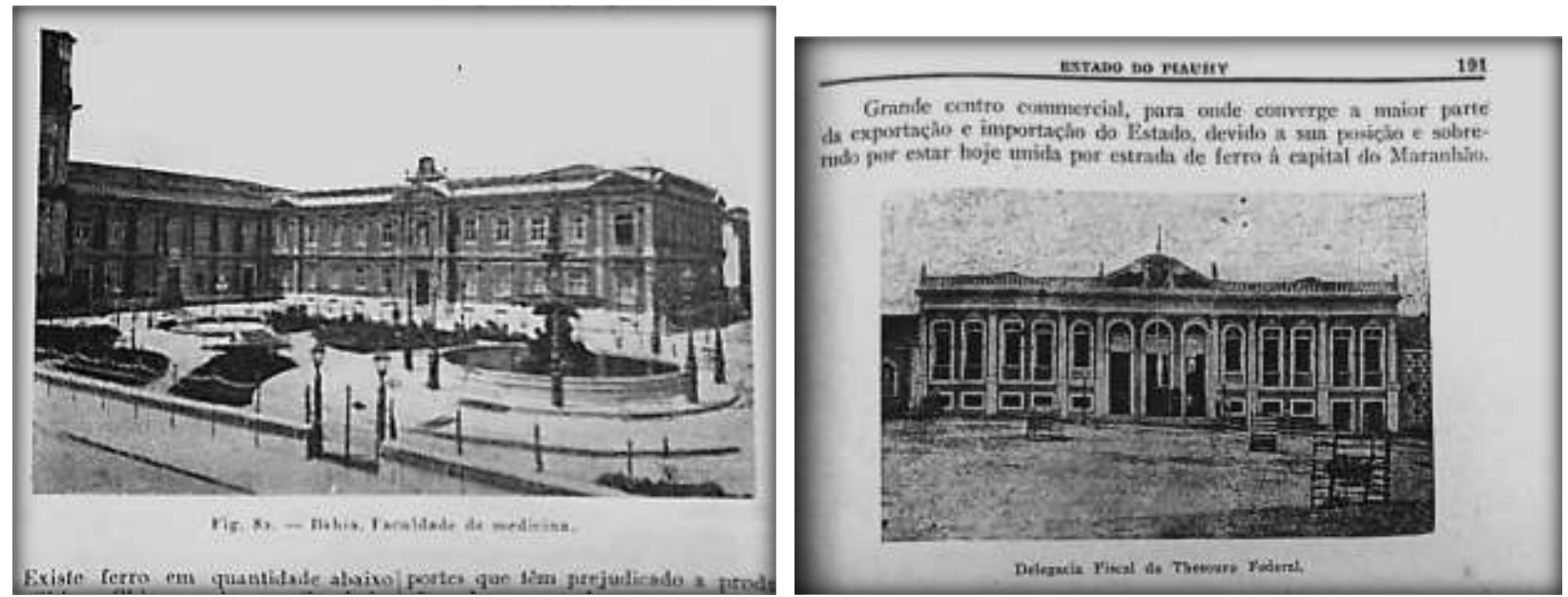

Fonte: HOMEM DE MELLO. Geographia - Atlas do Brasil e das cinco partes do Mundo, 1923. SCROSOPPI, Chorographia do Brasil, 1927, p. 191. Coleção LIVRES da FEUSP.

Figura 7. Recife e Belém.
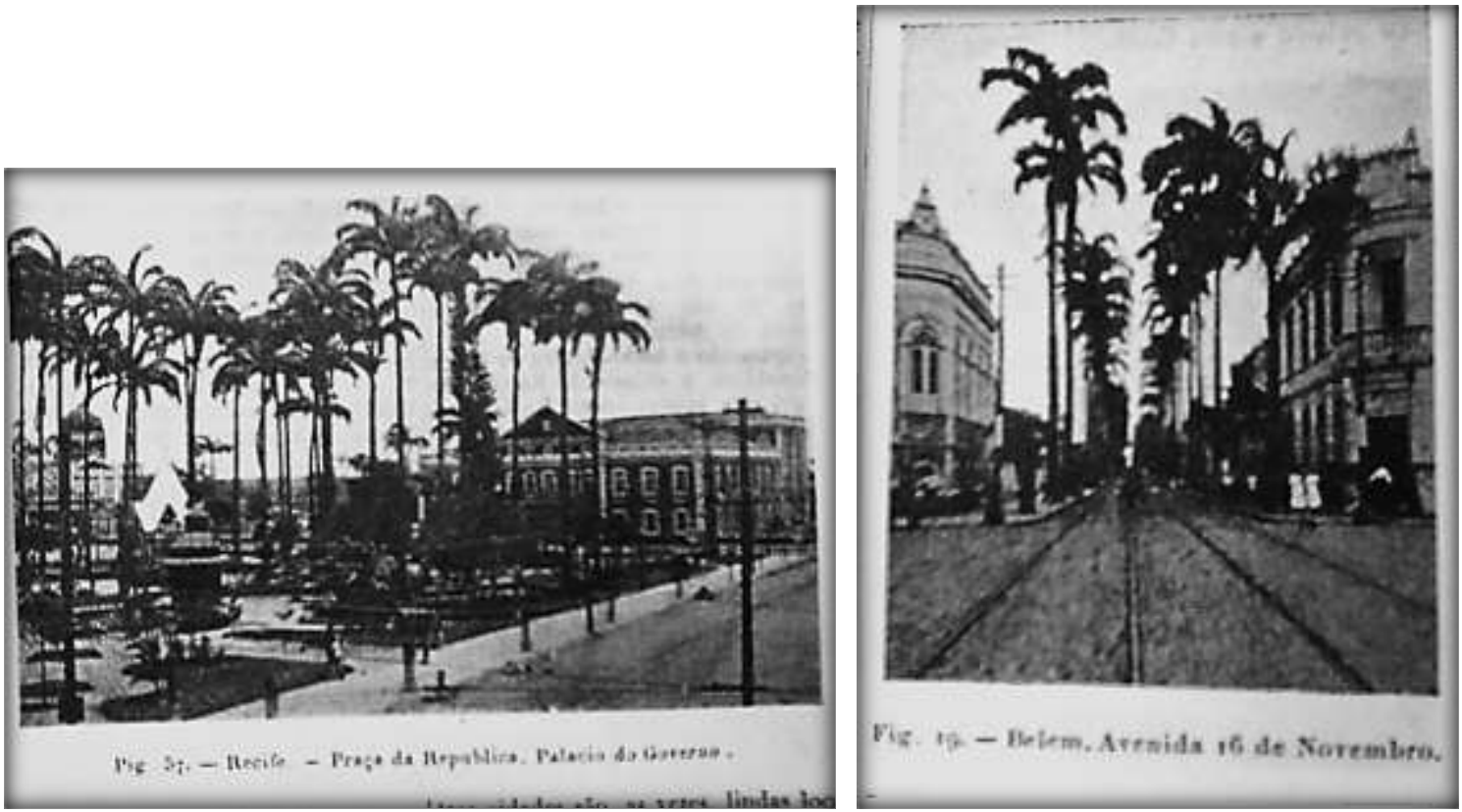

Fonte: HOMEM DE MELLO. Geographia - Atlas do Brasil e das cinco partes do Mundo, 1923. Palácio do Governo. Recife. Coleção LIVRES da FEUSP. 
Essa padronização dos temas gerava uma regularidade que poderia ser interpretada como um desejo de expressar ordem e estabilidade; um desejo de apresentar o Brasil como uma sociedade em processo de desenvolvimento e urbanização; um Brasil civilizado, do qual, nessa perspectiva, o sertão não faria parte. Até meados da década de 1930, e mesmo por algum tempo depois, o Brasil dos manuais era descrito a partir de um roteiro previsível e homogêneo, a escolha das imagens demonstrava a preocupação em apresentar as semelhanças e não a particularidade das regiões.

Exceção se faz à publicação de excertos da Revista Brasileira de Geografia Tipos e aspectos do Brasil, de 1939. Ilustrado por Percy Lau, a publicação traz um conjunto de desenhos, a bico de pena, que fazem parte de uma visão iconográfica do Brasil, são tipos e cenas emblemáticas, que podem ser reencontrados nas descrições regionais de intelectuais, artistas, viajantes. Os desenhos de Percy Lau são de um realismo espantoso, valorizando a geografia física (Figura. 8) e humana (Figura. 09) das regiões. Sobre as ilustrações de Tipos e aspectos do Brasil, Angotti-Salgueiro ${ }^{29}$, escreve:

As imagens dos Tipos e aspectos são cenas concretas de uma realidade muitas vezes intemporal que apenas se deslocou para mais longe. Estamos diante de paisagens que existem ainda em algum lugar do Brasil, de aspectos materiais da vida dos homens do campo, de técnicas pastorais e de formas artesanais de extração de produtos da natureza, de indústrias regionais tradicionais, de hábitos alimentares, de meios de transporte, dos ciclos econômicos da história do Brasil (da colheita de cana ao garimpo e ao cafezal) [...] (ANGOTTI-SALGUEIRO, 2005, p. 61)

Os personagens encontram-se sempre em ação, imersos em sua realidade viva, atuando no cenário de suas identidades regionalizadas; "na dureza do trabalho e na precariedade do meio ambiente (ANGOTTI-SALGUEIRO, 2005, p. 42). Para a autora o homem, em Percy Lau, é representado como aquele que precisa domar a natureza hostil, os tipos estão flagrados num combate, numa confrontação com a natureza. O meio ambiente representado é raramente aprazível e agradável, ao contrário, mostra-se como um obstáculo para o desenvolvimento da sobrevivência, sendo assim descrita, por exemplo, a caatinga.

\footnotetext{
${ }^{29}$ Em seu artigo, analisa os desenhos de Percy Lau, colocando-os em relação com outras "visões iconográficas" do Brasil moderno - no caso, as fotografias dos franceses Pierre Monbeig e Marcel Gautherot, publicadas na década de 1940. ANGOTTI-SALGUEIRO, Heliana. A construção de representações nacionais: os desenhos de Percy Lau na Revista Brasileira de Geografia e outras "visões iconográficas" do Brasil moderno. Anais do Museu Paulista. Volume. 13. n.2. Julho. Dezembro de 2005.
} 
Figura 08. Caatinga, desenho de Percy Lau para Tipos e aspectos do Brasil.

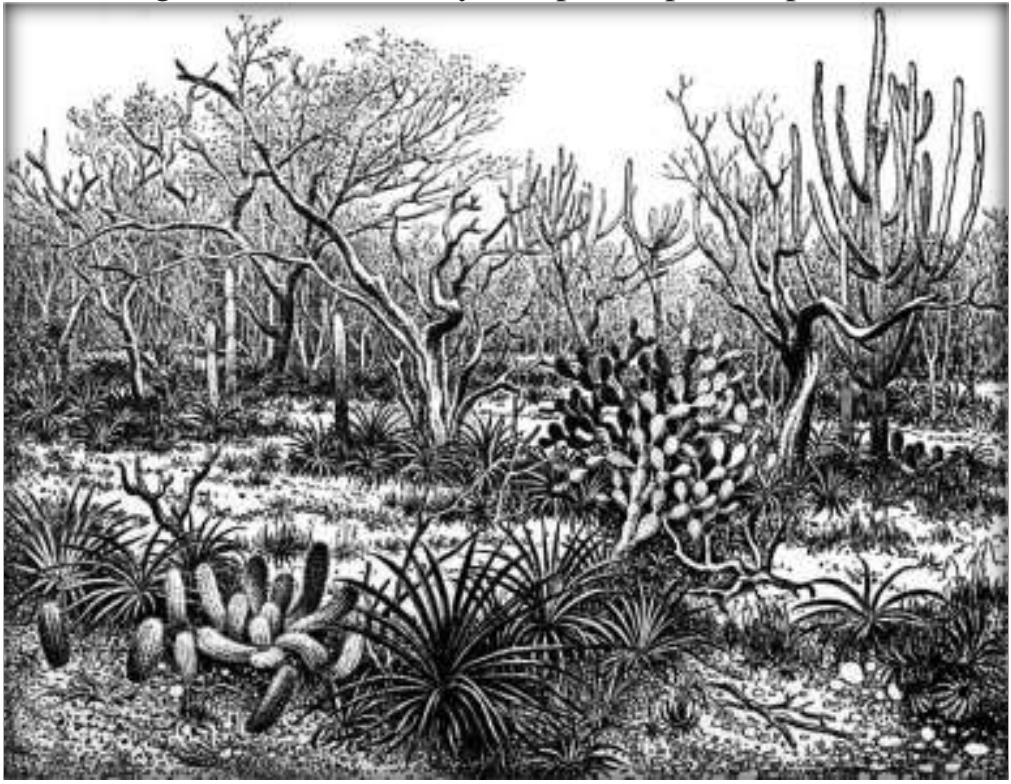

Acervo da biblioteca do Instituto de Estudos Brasileiros da Universidade de São Paulo.

Figura 09. Vaqueiro do Nordeste, desenho de Percy Lau para Tipos e aspectos do Brasil.

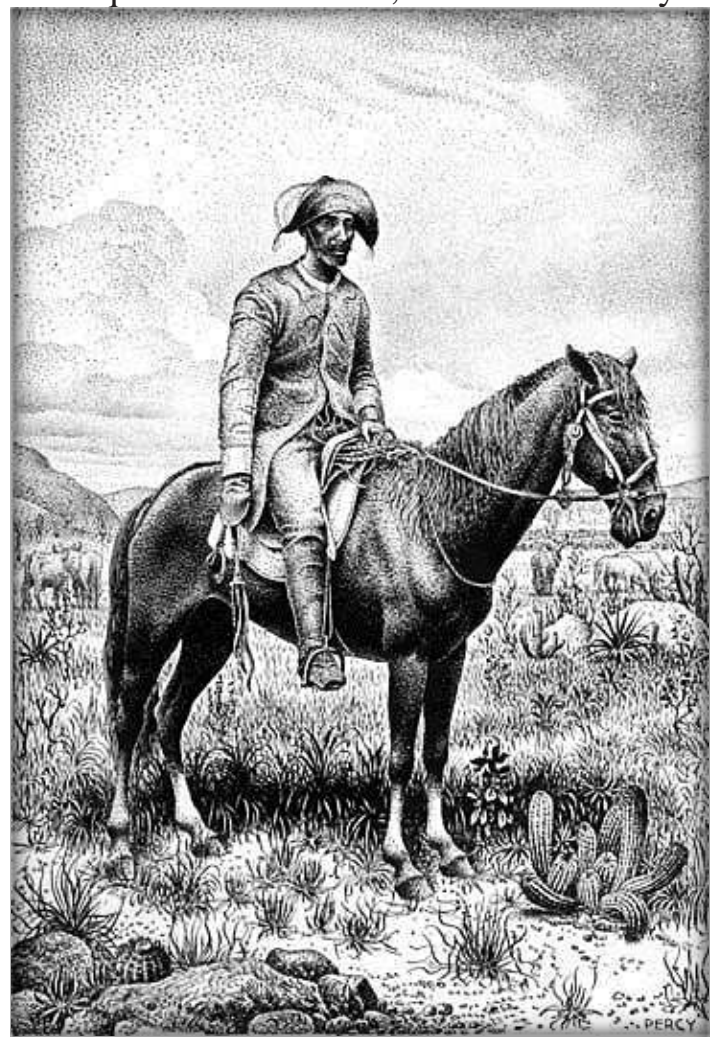

Acervo da biblioteca do Instituto de Estudos Brasileiros da Universidade de São Paulo. 


\subsubsection{Sertão versus civilização}

No século XVIII, o Vocabulario Portuguez e Latino, do padre londrino radicado em Portugal, Raphael Bluteau, trazia a seguinte definição: "Sertã̃. Regiã̃ apartada do mar, \& por todas as partes, metida entre terras [...] "30; atribuindo simplesmente uma conotação geográfica ao conceito. Porém, será no discurso sobre o semi-árido e no uso do termo, que perceberemos o peso das representações associadas ao sertão.

No século XIX, tanto durante o Segundo Reinado quanto na Primeira República, algumas preocupações frequentavam o discurso oficial, que demonstrava grande preocupação em transformar o Brasil numa nação civilizada e, para isso um dos pontos que se colocava em questão era o da formação racial do povo brasileiro. Nessa perspectiva, o sertão estaria na contramão do processo civilizatório, não só por estar mais distante do modo de vida europeu, mas também por ter uma população fortemente mestiça. Nos escritos de Paulino José Soares, Ministro do Império

- Visconde do Uruguai lia-se que: “A população do sertão não participava dos benefícios da nação [...]". E seguia, afirmando que "era preciso distinguir a rebelião do Sul e as dos sertões. No Sul os crimes são políticos; no sertão os crimes são frutos de outras paixões que não a política”.

Em sua tese, Célia Nonata Silva define sertão como "mestiço", a autora identifica-o como um espaço propício para o fenômeno da mestiçagem por apresentar uma cultura de fronteira. Porém, objetivando distanciar-se de trabalhos que reafirmam a oposição litoral versus sertão, ou seja; civilização versus barbárie, a autora busca por uma compreensão endógena do sertão; no entanto, acaba frequentemente por recorrer aos mesmos mecanismos da comparação entre Nordeste e Sudeste para caracterizar o sertão:

O ritmo do sertão, que não será o mesmo das vilas urbanas - centros de poder da metrópole -, estruturou um modo de vida sertanejo, uma cultura tradicional e concentrou um processo de poder de mando peculiar, dando origem a uma cultura política particular no setecentos mineiro. O sertão, então, esboçou já no século XVIII uma tradição cultural sertaneja mestiça que lhe outorgaria uma forma de poder de mando sustentada numa prática costumeira do uso da valentia, das mostras da honra e no resguardo da vingança. (SILVA, 2004, p. 173)

30 Conforme o verbete "Sertão" em Vocabulario Portuguez e Latino, hospedado no site do IEB: Disponível em <http://www.brasiliana.usp.br/pt-br/dicionario/edicao/1 >. Acesso em 05 de maio de 2008. 
Silva, em sua tese, discute algumas características próprias desse ambiente cultural e que dentre as quais se destacam a "valentia" e a "defesa da honra", observadas como integrantes de um jogo de poder típico do mundo rural, pois a cultura política do mandonismo local ${ }^{31}$ não fora abafada pelas pretensões centralizadoras das câmaras municipais (SILVA, 2004, p. 173-4).

Observemos, contudo que a imagem do sertão e do sertanejo são indissociáveis, sendo que as imagens e ideias que se remetiam ao sertão, e por extensão, ao sertanejo, tendiam sempre a estabelecer uma relação de completa oposição entre os valores do litoral-civilizado e do sertãobárbaro. Ocupação-urbanização e missão civilizadora estariam assim definitivamente associadas, donde, durante os primeiros cinquenta anos da república, ocupar os vazios do território brasileiro constituía-se em uma prioridade, não somente para garantir a integralidade do território, mas também e principalmente para alcançar a diluição da presença e da influência dos elementos étnicos indesejáveis. Ou seja, o que podemos concluir é que, embora o sertão fosse descrito como "o não-lugar"; "como o espaço em oposição à", tanto no período colonial, quanto no segundo reinado e também da Primeira República; as questões que se apresentavam eram distintas: inicialmente temos o sertão como lugar de ausência, em oposição ao litoral no confronto entre civilização e barbárie; enquanto que, no segundo momento, há o acréscimo da questão racial, a condição de civilização não estaria sinalizada somente pelo modo de vida, mas pelo tipo de indivíduo; no caso do sertão, como colocara Euclides, o homem seria o produto, o espelho do meio sendo, portanto, o sertanejo, o resultado dos efeitos do espaço bárbaro e brutalizado dos sertões sobre a natureza humana.

Sobre a questão do valor da civilização, segundo Zimmermann (2008), para Norbert Elias, o conceito de civilização nasce no Ocidente associado a diferentes variáveis, como o desenvolvimento das técnicas, o desenvolvimento das ciências, a transformação dos costumes, as transformações na visão de mundo e também, as transformações na compreensão da intervenção divina na vida dos homens.

Primeiramente, expressava o sentimento de superioridade das chamadas classes superiores sobre as consideradas inferiores e depois passou das nações ocidentais como um todo sobre as demais regiões no mundo com vistas à legitimação da colonização. Essas sociedades procuravam caracterizar-se pelas suas especificidades e com aquilo que lhes conferia orgulho [...]. Essas

31 Sobre esta questão ver também o artigo de JESUS, Alysson Luiz Freitas de. O sertão e sua historicidade: versões e representações para o cotidiano sertanejo - séculos XVIII e XIX. In História e Perspectiva, Uberlândia, $\mathrm{n}^{\circ}$ 35, p. 256-259, Jul-Dez 2006. 
especificidades, tais como atitudes, sentimentos e modos de conduta, eram tidas como "naturais". (ZIMMERMANN, 2008, p. 2)

Chama-nos a atenção, o fato de que, nesse processo, tanto as sociedades ditas civilizadas, assumem a posição e a missão civilizadora, quanto àquelas ditas não-civilizadas, em grande medida aceitam a rotulação imposta. Portanto, quanto mais distante do modo de vida europeu, mais bárbaro.

Embora Durval Albuquerque (1999) discuta em A invenção do Nordeste a redução do Nordeste à seca, tal qual dissera Freyre em Nordeste, acreditamos que no caso das imagens difundidas nos manuais ou pela imprensa, não se trate de reduzir o Nordeste ao sertão, pois, como apresentaremos em nossa tese, as imagens de sertão, desenvolvimento e exotismo circulavam concomitantemente. Trata-se, todavia, de questionarmos a representação limitada do sertão; o que se coloca em questão aqui nesta etapa é, portanto, não a redução do Nordeste ao sertão, mas a redução do sertão à seca, à miséria, à barbárie e ao sofrimento.

Portanto, enquanto os valores de civilização e modernidade fossem significativos - para o Estado e para a imprensa - o sertão seco pouco apareceria, pois representava justamente aquilo que se desejava eliminar no projeto de construção de um novo Brasil republicano e moderno.

\subsection{Finalmente, o sertão chega ao Sudeste}

Quando de seu surgimento, os primeiros jornais ilustrados brasileiros tinham por modelo as publicações francesas, os mais elaborados daqui eram caros e muitos sequer eram rodados em terras nacionais, mas sim na Europa. Além das publicações de preços elevados, havia também publicações mais acessíveis, os periódicos populares eram os que mais investiam nas caricaturas. Naqueles de custo mais elevado, viam-se as ilustrações de vistas do Brasil e bustos de personalidades importantes. Tal e qual os manuais escolares do período, as ilustrações nos jornais também seguiam um padrão temático: as vistas das cidades, as personalidades, as caricaturas e, a partir da década de 1860 , os fatos marcantes. ${ }^{32}$

\footnotetext{
${ }^{32}$ Sobre o tema, ver os trabalhos de ANDRADE, Joaquim Marçal Ferreira de. História da fotorreportagem no Brasil: A fotografia na imprensa do Rio de Janeiro de 1839 a 1900. Rio de Janeiro: Elsevier, 2004, $3^{\text {a }}$ reimpressão, e também
} 
A fotografia trazia para a imprensa a possibilidade de apresentar os acontecimentos com a velocidade e o detalhamento que os novos tempos exigiam. Inicialmente, a função da fotografia na imprensa era somente a de ilustrar uma história, com o tempo, ainda no final do século XIX, a apresentação de lugares distantes e a glamourização da vida luxuosa das elites; com a chegada do cinema, surgiriam ainda as seções especializadas nas curiosidades sobre a vida das celebridades, e os escândalos amorosos; com as guerras, as imagens do horror nas frentes de combate, dos refugiados e famintos. Para Gisele Freund (2006) a fotografia seria o típico meio de expressão de nossa sociedade tecnológica, aceito por todos os grupos como instrumento capaz de reproduzir a realidade, todavia, a autora alerta para o fato de que:

[...] mais que qualquer outro meio, a fotografia possui a capacidade de expressar os desejos e as necessidades dos grupos sociais dominantes, e de interpretar à sua maneira os acontecimentos da vida social. Pois, a fotografia, ainda que estritamente unida à realidade, teria somente uma objetividade fictícia. A lente, esse olho supostamente imparcial, permite todas as deformações possíveis da realidade, dado que o caráter da imagem se encontra determinado pela maneira de ver do operador (da câmera) e pelas exigências de seus patrocinadores. (FREUND, 2006, p. 08)

Entre 1866 e 1870, a guerra do Paraguai tornou-se o primeiro evento a marcar presença nas páginas dos periódicos ilustrados, apresentando a reprodução de cenas do campo de batalha. Terminada a guerra, os fatos marcantes, como os crimes, assumem seu lugar nas páginas ilustradas, mas em 1877, a seca que assolava os estados do Nordeste, levando milhares de flagelados a migrarem em direção às capitais, chamou a atenção de alguns editores; inicialmente, dos jornais nordestinos e, em seguida, dos jornais do Rio de Janeiro.

Entre os jornais cearenses que mais espaço dedicavam àquela situação calamitosa, destacaríamos $O$ Cearense e $O$ Retirante: órgão das vítimas da seca - este, criado exclusivamente para denunciar os horrores da seca sobre a população local e através do qual eram disparadas denúncias e severas críticas ao imperador e a seus encarregados de administrar e, segundo o periódico, 'abafar' o problema da seca do Nordeste - em especial, o conselheiro João José Ferreira de Aguiar. (ANDRADE, 2004, p. 187)

Embora entre 1866 e 1870, durante a guerra do Paraguai, tivéssemos a publicação de páginas com fotos de escombros e armas de guerra, como explica Andrade, não eram publicadas imagens de flagelo humano. A seca de 1877 traria mudanças no conteúdo dessas publicações. Se

CARDOSO, Rafael (org.). O design brasileiro antes do design: aspectos da história gráfica, 1870-1960. São Paulo: Cosac Naif, 2005. 
antes os finos jornais ilustrados e os manuais escolares apresentavam um Nordeste domado, o que agora seria representado nas fotorreportagens de alguns jornais sobre a seca não seria o mesmo, não haveria cachoeiras, portos ou matas; em 1877, a imagem é utilizada para apresentar aos leitores a seca como fato, em toda a sua dramaticidade.

\subsection{A cobertura jornalística da seca: $1877-1879$}

O impacto da seca de 1877-1879, não apenas por seus números alarmantes, mas pelo volume de notícias e registros sobre o assunto, teria de fato impressionado a sociedade do final do XIX; memorialistas como Rodolfo Theophilo e Pinto de Aguiar, registraram os horrores da seca, quando centenas de milhares de pessoas deixaram o alto sertão em direção às cidades, em busca de assistência. Foi um momento em que a ausência de uma estrutura apropriada para a recepção desses indivíduos fez com que um verdadeiro caos urbano se instalasse, embora nos relatos oficiais a desordem e o desequilíbrio tenham sido associados diretamente à figura do retirante e não ao despreparo dos administradores públicos.

Conforme a documentação oficial da época, a seca de 1877-1879 fora devastadora nos Estados do Piauí, Ceará, Rio Grande do Norte e Paraíba, provocando um incrível aumento dos preços dos alimentos, num processo de evasão que, segundo as estimativas, atingira a quarta parte da população desses estados. Também na Bahia o impacto da seca teria sido grande, como sugere a troca de mensagens entre o Presidente da Província da Bahia e o vigário da Vila de Alcobaça, sobre o envio de uma quantia de $160 \$ 280^{33}$, encaminhada à vila como auxílio às vítimas flageladas pela seca das províncias do Norte ${ }^{34}$.

${ }^{33}$ Revista de Imigração e Colonização, ano III, agosto 1942, Rio de Janeiro, Brasil, p. 36-37.

${ }^{34}$ A intensidade dos danos causados pela seca de 1877, porém, constitui-se em tema controverso. Em seu livro Abastecimento: crise, motins e rebeliões, escrito a partir de fontes da época, como os telegramas do presidente da província e relatos, o pesquisador e memorialista Pinto de Aguiar, questiona as razões do curioso silêncio dos jornais baianos acerca do período sobre a problemática da seca na Bahia. A importância da obra de Aguiar reside na discussão sobre a relação entre política, seca e representações, uma vez que, em razão da disputa política que ocupava os jornais nos primeiros meses de 1878, a calamidade que assolava o Nordeste perderia deliberadamente, visibilidade. Para ele, os jornais locais teriam silenciado quanto ao fato, em virtude de questões políticas. AGUIAR, Manoel Pinto de. Abastecimento: crises, motins e intervenção. Rio de Janeiro: Philobiblion, 1985 (Coleção Redescobrimento do Brasil, 4). 
Em 1877, as imagens da cobertura da seca procuraram demonstrar justamente o grau de degradação e sofrimento dos retirantes: corpos deformados pela fome, rostos embrutecidos pelo sofrimento. Essas imagens materializam o momento em que construção de um repertório de imagens de uma natureza controlada, ordenada, se rompe e as mazelas da pobreza profunda de uma comunidade numerosa e esquecida pelos governantes se consolida na figura do retirante. Quanto à imprensa carioca, as dimensões da calamidade irão chamar a atenção do editor d' $O$ Bezouro, que decide enviar um correspondente para as áreas afetadas.

\subsection{A Seca em O Bezouro}

Criado em março de 1878, O Bezouro, jornal do editor e caricaturista Raphael Bordallo Pinheiro, surge como uma folha ilustrada humorística e, assumindo uma postura crítica, em abril de 1878, lança o artigo “A seca do Ceará”, onde descreve de forma sarcástica o socorro dado pela Companhia de Feno Nacional aos animais que morriam de fome, enquanto os retirantes permaneciam sem socorro (ANDRADE, 2004, p. 189-190).

Em maio, o jornal enviava para uma cobertura da seca, o jovem José do Patrocínio, que já no caminho registrava suas impressões, que seriam enviadas e publicadas pela $A$ Gazeta de Notícias:

Criancinhas nuas e seminuas, com os rostos escaveirados, cabelos emaranhados sobre crânios enegrecidos pelo pó das longas jornadas, com as omoplatas e vértebras cobertas apenas por pele ressequida, ventres desmesurados, pés inchados, cujos dedos e calcanhares foram disformados por parasitas animais, vagam sozinhas ou em grupo, tossindo a sua anemia e invocando, com a voz fraquíssima, o nome de Deus em socorro da orfandade. (ANDRADE, 2004, p. 191)

Essa descrição seria potencializada pela força das imagens captadas pelas lentes de J. A. Correa, fotógrafo cearense que, em formato de carte-de-visite, registra as imagens dos flagelados das secas.

$\mathrm{O}$ formato em carte-de-visite sugere que as fotos não circularam somente no meio jornalístico, mas devem ter ido além, circulando por diferentes ambientes, comercializadas em casas em cujas prateleiras, as imagens da seca partilhavam o espaço, com imagens de panoramas da Baia de Guanabara ou talvez de tipos humanos característicos, como aqueles fotografados

durante as expedições de Marc Ferrez. Observando a imagem do meio (figura 10), nota-se a presença de suportes atrás da nuca do fotografado, tal aparato teria por função garantir que o 
fotografado não sairia da pose combinada, facilitando o trabalho do fotógrafo, mas também produzindo uma realidade construída: o que era publicado como um registro espontâneo, um flagrante da realidade era, de fato, não uma mentira, mas uma representação, uma recriação da verdade. Assim, embora a seleção do fotografado, dos trajes e da pose, indiquem o desejo de criar uma imagem chocante, isso não diminui o valor da denúncia, posto que até então, embora as secas sempre tenham existido, os leitores cariocas não tivessem referencial visual sobre o que de fato seria essa calamidade. As matérias escritas por José do Patrocínio e ilustradas por J. A. Corrêa, na leitura de Andrade constituem-se no primeiro passo do "sistema que seria conhecido como fotorreportagem, ou seja, uma reportagem na qual as fotografias constituem a parte mais importante, acompanhadas de legendas ou textos explicativos" (ANDRADE, 2004, p. 199).

Embora possamos encontrar ainda nos anos de 1930 e a representação atemporal das capitais nordestinas como centros urbanizados, a partir das narrativas de José do Patrocínio, Rodolfo Teófilo e das fotografias de A. Correia, as paisagens do sertão seco, natureza inóspita, aos símbolos de morte - como a imagem que encontramos em um manual de Geografia de 1935, em que vemos urubus espreitando um retirante passariam timidamente a surgir.

Na comparação entre a ilustração do homem no livro de Espinheira, de 1935, e a fotografia de Corrêa, (figura 11) podemos observar além das semelhanças físicas - até mesmo nos traços do rosto - entre ambos, uma semelhança na dinâmica do gestual, ambos se encontram acocorados, braços apoiados nos joelhos, mirando, de frente o seu observador. Tradicionalmente reconhece-se no texto de Euclides a gênese das representações que iriam constituir o imaginário coletivo sobre o Nordeste e o sertanejo nordestino. O impacto e a importância de seu trabalho, tanto como relato jornalístico de seu tempo, quanto como uma narrativa elaborada e inovadora, transformaram suas palavras em tradução do sertão. Em seu trabalho, Odair Paiva (2004) vê na obra de Euclides da Cunha o momento de criação das representações sobre o retirante. Ao contrário dele, Ferreira e Dantas, pensam na inauguração dessas representações numa data anterior. 
Figura 10. J. A. Correa. Foto para O Bezouro.
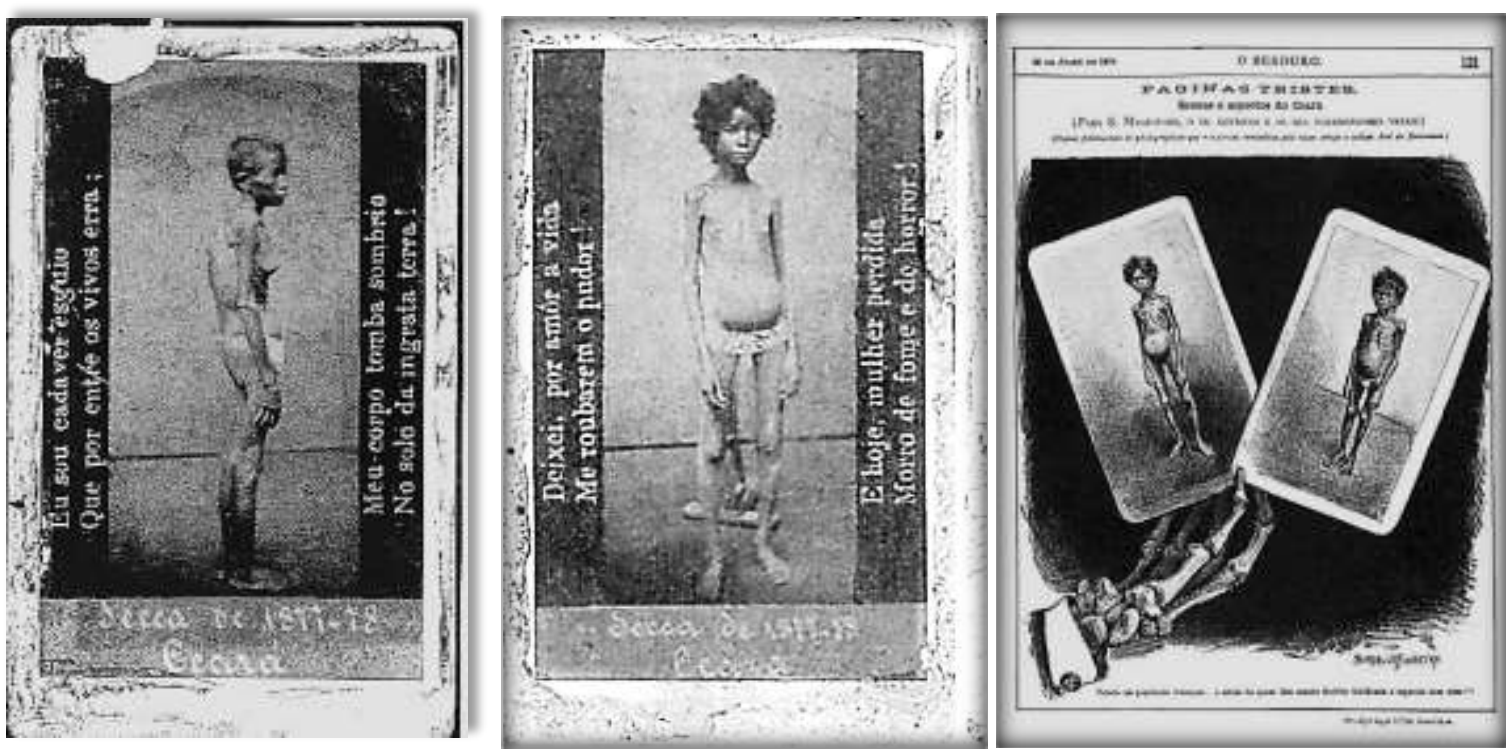

Fonte: No original em modelo carte-de-visite, 1877-1878 e Reprodução das fotos de Correa na página de O Bezouro, In: $O$ design brasileiro antes do design. Rio de Janeiro: Elsevier, 2004, $3^{\text {a }}$ reimpressão, p. 192193.

Figura 11. Retirantes.
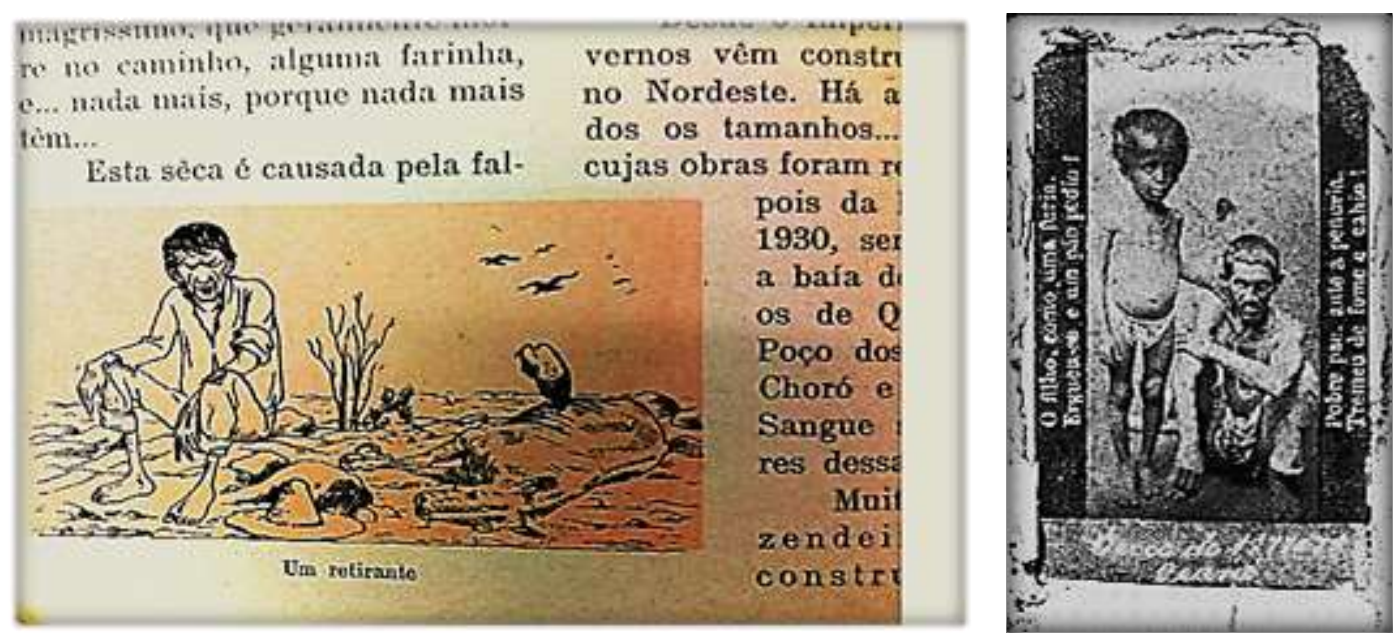

Fonte: (à esquerda) Retirante. ESPINHEIRA, Viagem através do Brasil, 1935, p. 20. (à direita) J. A. Correa. Foto para $O$ Bezouro. No original em modelo carte-de-visite, 1877-1878. 
Apoiados na análise dos jornais da época, defendem que, dada a larga divulgação do fenômeno emigratório durante a grande seca de $1877-1879^{35}$, teria ocorrido, naquele momento, o nascimento de um novo sujeito coletivo: o retirante. Identificado com o homem derrotado pela natureza e sendo obrigado a abandonar sua terra, em busca de um novo lugar, mas também associado à desestabilização da ordem de jovens centros em processo de urbanização, como as cidades como Mossoró, Aracati e, principalmente Fortaleza; cidades que entre 1877 e 1878 receberam cerca de 110 mil retirantes, alojados em colônias de recepção improvisadas. O retirante, como representação, nasceria, portanto, como fruto de um contexto de sofrimento e caos urbano, binômio que por sua vez, o acompanhará sempre que sua presença for descrita nas páginas das revistas ilustradas ${ }^{36}$. Faz necessário ainda, observar que, no caso dos jornais, o sertão e o retirante foram lentamente passando da situação de invisibilidade para a de uma pequena e ainda incompleta visibilidade, como é possível observar na fala de Oswald de Andrade, que em vigem ao Recife, em 1925, “[...] falara da ignorância dos sulistas em relação àquela cidade, embora fosse uma das maiores do país. As primeiras imagens do Norte para a maioria dos sulistas eram aquelas trazidas pelos jornais sobre seu flagelo" (ALBUQUERQUE, 1999, p. 69). Mas a imprensa foi fundamental para alterar essa realidade. A veiculação de textos e imagens foi, mesmo que lentamente, atualizando a população do Sul sobre as secas.

No início dos anos 50, em viagem pelo Nordeste, registrada em Visão da Sêca do Nordeste, Carlos Lacerda, registra suas impressões, afirmando que o Sudeste não entende as secas:

35 Sobre esta questão, Albuquerque Jr, afirma que a seca de 1877-1879 fora a primeira a ter grande repercussão nacional pela imprensa e a atingir setores médios dos proprietários de terras. Albuquerque Jr, D.M. A invenção do nordeste e outras artes. Ed. Cortez: São Paulo, 1996, p. 68. Em consonância com a leitura de Albuquerque Jr, temos a obra de Rodolfo Teófilo A Fome, publicada pela primeira vez em 1890, na qual, em forma romanceada o autor mostra, justamente, a jornada de um proprietário de terras de posses medianas e que se vê obrigado a migrar com sua família, a pé, do sertão para a cidade, assistindo, pelo caminho perecerem a vida e os princípios que nos tornam humanos, todavia, insistia Teófilo que, o que embrutece não é a seca, mas sim, a fome. TEÓFILO, Rodolfo. $A$ Fome. Cenas da seca do Ceará. Organização e notas de Waldemar Rodrigues Filho; posfácio de Lira neto. São Paulo: Tordesilhas, 2011. Quanto à visibilidade conferida aos retirantes a partir da cobertura realizada sobre a seca de 1877 , é compartilhada também por Lima, Ariza Maria Rocha. A seca, o sertanejo e a ginástica sueca na batalha da borracha (1942-1945). In: Cavalcante, Maria Juraci Maia et al. História e Memória da Educação no Ceará. Fortaleza: Imprensa Universitária, 2002. Disponível também em EFDEPORTES - Revista Digital. Buenos Aires - Año 8 - no 58 - Marzo de 2003. Ver também Neves, Frederico de Castro. A memória do Nordeste e o Nordeste na memória. Comunicação datilografada. Acervo do Centro de Estudos Migratórios.

36 FERREIRA, A.L.A. e Dantas, G.A.F. Os indesejáveis na cidade: as representações do retirante da seca (Natal, 1890-1930). Scripta Nova - Revista Eletrônica de Geografia y Ciências Sociales. Universidad de Barcelona, nº 94, Migración y Cambio Social, 01 de agosto de 2001. 
O que existe hoje no Nordeste e confunde os que estão distantes, é que, antigamente, o Sul só tomava conhecimento do flagelo da sêca no segundo ou terceiro ano. Então, toda a gente se espantava quando sabia que por lá morriam, de fome e de outras consequências, milhares de pessoas. Hoje, a grita surge logo no começo do flagelo, e muitos pensam que isso é exploração, que não existe, que intriga da oposição. [...] Cada sêca que vem retira um pouco da capacidade de resistir, da capacidade de esperar para ver como fica o tempo. (LACERDA, [195-], p. 57)

Embora a visibilidade parcial dos jornais já suscitasse o questionamento de alguns, quanto às notícias e imagens do Nordeste, no caso específico da revista $O$ Cruzeiro, campeã de vendagem do período, o sertão e a seca permaneceriam invisíveis até a década de 1940.

\subsection{A seca e o Nordeste no período Vargas}

Se por um lado, as Scenas do Ceará, no caso da revista $O$ Cruzeiro, durante os anos de 1930, tenham sido um dos poucos espaços em que se podia observar referências sobre o sertão, nas páginas da literatura brasileira a situação era bem outra. Os anos 1930 trouxeram consigo a literatura regionalista, fruto do projeto modernista, do Movimento Regionalista, de Gilberto Freyre, e também, fruto do desejo de registrar os dramas das regiões a que pertenciam, e não apenas isso, mas também uma resposta à sensível presença das secas nos jornais; com a geração regionalista o sertão representado pela seca e o sertanejo representado pelo retirante tornar-se-ão imagens definitivas do sertão nordestino. Analisando a literatura do período, Albuquerque aponta que:

A crítica nordestina vai caracterizar o 'romance de trinta' como uma literatura que atendia às exigências do ambiente físico e social em que se produziu, como 'expressão de seu espaço', como uma 'reação nordestina aos cânones antigos sem perder o sentido universal da cultura brasileira', o encontro com os traços diferenciais em relação à realidade europeia, prosa brasileira nascida do encontro com suas paisagens, seus costumes e suas paixões. O Nordeste, espaço brasileiro, ao ser representado literalmente, produziria a originalidade de nossa produção literária. Espaço em crise que deveria se expressar por meio da denúncia e da polêmica. (ALBUQUERQUE, 1999, p. 108)

Se por um lado, o sertão se mantinha ausente das páginas, o Nordeste se fazia presente nas reportagens sobre a política nacional. O Cruzeiro, desde sua criação, manteve espaço para as notícias ligadas às ações do governo Vargas e, no ano de 1932, uma grande seca exigiu que o governo Vargas se articulasse em prol das regiões flageladas.

No que se refere ao Estado, quando a seca se instalou, em 1932, o Governo Vargas, tal e qual os anteriores, não possuía uma política própria para a superação do problema. Muitos retirantes foram aproveitados em obras públicas, todavia, a carência de projetos e a falta de 
ferramentas não permitiram o aproveitamento da força de trabalho de todos os flagelados. Em 1932, foram recriados os campos de concentração, descritos por Rachel de Queiroz em O Quinze, publicado em 1930. No caso do Ceará, para evitar a “afluência tumultuária de retirantes famintos", como explica Neves:

Cinco campos localizavam-se nas proximidades das principais vias à mercê da caridade pública ou privada. Dois campos menores situavam-se em locais estratégicos de Fortaleza, conectados às estações de trem que traziam os famintos, impedindo que eles circulassem livremente pelos espaços da capital. Uma vez dentro do campo, o retirante era obrigado não só a permanecer nele durante todo o período considerado da seca, mas deveria submeter-se a condições de moradia, relacionamento, trabalho e comportamento regulados pelas normas irredutíveis ditadas pelos dirigentes indicados pelo interventor [...] os campos pretendiam impedir a mobilidade física e política dos retirantes através de concessões diárias de rações e de assistência médica. (NEVES, 2001, p. 109)

A ideia era de fato, promover o confinamento das multidões e impedir que Fortaleza e as outras capitais revivessem os dias tumultuados de 1877-1879, ainda mais, porque a possibilidade de mobilização popular no Nordeste preocupava o governo que já estava envolvido em um conflito no Sudeste: a Revolução Constitucionalista, que arregimentava detratores e simpatizantes por todo o país.

Como as atenções estavam voltadas para o Sudeste e para a revolução, mesmo diante de uma seca intensa, como a de 1932, não encontramos matérias em $O$ Cruzeiro, além dos textos de Valdez, de 1929 e 1930, sobre a seca ou sobre a situação do sertão. Algumas matérias destacavam cenários da produção no agreste ou no litoral. As únicas imagens do sertão, publicadas no período se referem às fotografias selecionadas no concurso de fotografias, no qual os leitores concorriam, enviando fotos tiradas por eles mesmos ${ }^{37}$.

Acreditamos que a revolução teria, de certa maneira, eclipsado as notícias sobre a seca naquele ano, não somente no Sudeste, onde o envolvimento com a revolução foi direto, mas também, no Nordeste, onde principalmente o estudantado universitário mostrou-se interessado na questão constitucionalista. ${ }^{38}$

37 Exemplo disso são as fotografias de cafezais e canaviais da Paraíba e Pernambuco em 1930 na O Cruzeiro, $\mathrm{n}^{\circ} .83$, ano II, pp. 4 e 5 .

38 Sobre esse assunto ver ALMEIDA, Ivete Batista da Silva. O olhar de quem faz: São Paulo durante a revolução de 1932. São Paulo: I.B.S.A/ Café, 2001. 
Embora contassem com simpatizantes no Nordeste, ainda havia aqueles que reagiram negativamente à revolução, e tal reação pode ser compreendida não somente como desaprovação aos interesses políticos das lideranças paulistas, mas também como apoio ao governo revolucionário de 1930, uma vez que a administração getulista prometia trazer algumas vantagens no que tange à implementação de ações contra os efeitos das secas sobre os sertanejos. De acordo com Frederico de Castro Neves, a centralização política do governo Vargas, em um primeiro momento, favorecera a tomada de decisões e a execução de soluções, sem que fossem necessárias as intermináveis consultas aos potentados locais, como era costume no passado, sem contar que, com a centralização, não haveria, "perda de tempo" com os trâmites burocráticos de participação política $^{39}$. Contudo, aos olhos da opinião pública, o governo desviava-se de seu verdadeiro foco ao voltar suas atenções aos revoltosos de São Paulo e não às vítimas das secas. A esperança de auxílio mais eficaz do que os campos de concentração, veio após o armistício paulista, como destaca Neves, resgatando o discurso da imprensa:

Com a rebelião paulista a attenção de nosso povo voltou-se para o Sul. Enquanto se falava no front, no movimento de tropas e na organização de batalhões provisórios, enquanto se exaltava o desassombro das forças dictatoriais e a estratégia do general Klinger, os nossos pobres do Campo de Concentração eram de algum modo esquecidos. Hoje, porém, quando a Pátria Brasileira foi integralizada no regime da ordem e da paz, chamamos attenção de nossos leitores, novamente, para o Estado do Campo de Concentração do Ipú, o qual acabamos de visitar. (NEVES, 2001, p. 110)

Os números comprovam que o término do conflito armado, se não trouxe, de fato, uma renovação da política de assistência às vítimas da seca, trouxe, sem dúvida, a elevação da verba concedida pelo Ministério da Viação ao Governo do Ceará; passando de 200:000\$000 de abril a agosto de 1932, para 800.000\$000 em novembro e 1.500.000\$000 em março de 1933.

Além dos sete campos de concentração em Fortaleza (Urubu e Otávio Bomfim), Patú, Quixeramobim, Crato (Buriti) Cariús e Ipú, nos quais estiveram mais de 100.000 retirantes, segundo o governo, a Inspetoria Federal de Obras contra as Secas teria mantido 46 postos médicos de socorro ou assistência às vítimas "despendendo a quantia de 2.219:015\$530, sendo 1.152:364\$400 com pessoal, 1.041:619\$730 com material e 25:031\$400 com vacinas"40.

39 NEVES, Frederico de Castro. Getúlio e a Seca: políticas emergenciais na Era Vargas. Revista Brasileira de História, vol.21, nº 40, 2001, p. 110.

$40 \quad$ As secas sempre provocaram um impacto direto sobre as capitais nordestinas, posto que, era para lá que os refugiados buscavam auxílio. Segundo Melo, anteriormente, durante a seca de 1877, a capital da Paraíba recebera, 
Mais à diante, ainda durante o governo Vargas, em 1942, com a volta da seca, retornaria a inquietação; o medo do caos urbano, das epidemias, o medo da falta de alimentos e da carestia; o período da seca era o momento em que a realidade quase distante das dificuldades da vida do sertão tornava-se presente, literalmente invadindo a vida e as ruas dos moradores das capitais do litoral nordestino. Contudo, em 1942, as páginas ilustradas da $O$ Cruzeiro teriam a maior parte de seu espaço dedicado às reportagens sobre a guerra. Na verdade, revistas como a Vamos Lêr! e $O$ Cruzeiro, desde 1939, concediam grande destaque às matérias sobre a guerra. Com reportagens nacionais e outras adquiridas de agências de notícia europeias e norte americanas, as fotorreportagens sobre a guerra, ocupavam páginas duplas com imponentes imagens da aviação, dos exércitos aliados, ou mesmo dos temidos avanços de Hitler. Enquanto isso, nas cidades que recebiam os retirantes a tensão permanecia:

Aumenta dia a dia e assustadoramente, a falange dos famintos, dos desabrigados e dos miseráveis, que perambulam pelo sertão em fora, batendo em verdadeira retirada, com o corpo cansado e o organismo combalido, à procura do trabalho, que lhes permita acudir à fome da mulher e dos filhos. [...] Quem se der ao sacrifício de percorrer os sertões nordestinos, como acabamos de fazer, sentirá a alma confranger-se lhe de piedade, aterrorizado ante os quadros dolorosíssimos, que passam pelos seus olhos. (Revista de Imigração e Colonização, agosto de 1942, p. 28)

Em 1942, a preocupação dos governos municipais não era muito diferente daquela do passado, pois do momento em que os migrantes iam chegando, medidas emergenciais eram tomadas para que, na linguagem dos documentos da época, 'não se aglomerassem pelas ruas' de Fortaleza. Os emigrados da seca, procedentes não só do Estado do Ceará como dos Estados da Paraíba e Rio Grande do Norte, eram alojados em galpões da Polícia Marítima e Aérea. Outro grupo encontrava-se num antigo pavilhão da inspetoria Federal de Obras Contra as Secas. Esses chegantes eram então registrados pela Inspetoria da Polícia Marítima e Aérea e encaminhados para

aproximadamente, 35 mil flagelados - que foram alojados em colônias, que comportariam, por volta de 12 mil pessoas. Em Natal, teriam sido 80 mil pessoas refugiadas e alimentadas com o auxílio do governo imperial que criara um depósito de alimentos; no Rio Grande do Norte, os números chegavam a 117 mil refugiados necessitando de socorro; em todo o Nordeste, o total de flagelados atingiria, àquela época, a casa dos dois milhões de habitantes. No caso de Natal, até 1882, ainda era grande o número de flagelados que permanecia abrigado na cidade, o que moveu o presidente da província a solicitar reforços, para garantir a civilidade do espaço urbano. Livrar a cidade da presença das desordens causadas pelas multidões era o resultado de uma representação do espaço urbano que, tanto entre as cidades do Sul, quando entre as do Nordeste, teria nascido durante a segunda metade do século XIX. Sobre os valores, ver Revista de Imigração e Colonização, ano I, nº 1, 1940, Rio de Janeiro, Brasil, p. 33. 
os albergues, enquanto aguardavam a chegada de navios que os encaminhassem para o Norte ou para o $\mathrm{Sul}^{41}$;

A organização dos albergues, não tinha como objetivo principal o auxílio às vítimas, mas sim "salvaguardar" a cidade - e o patrimônio de seus moradores - da presença dos retirantes da seca, porém, mesmo com o auxílio das polícias marítima e aérea, a cidade não se viu livre da presença dos flagelados. Em 01 de maio de 1942, o interventor do estado do Ceará, enviava telegrama ao conselheiro Dulphe Pinheiro, referente ao impacto da seca na cidade de Fortaleza. Naquela ocasião, os comerciantes de Palmas, Ceará, apelaram ao poder público para que tomassem uma providência, segundo o interventor do Estado, apelaram para o alto espírito humanitário do Governo, no sentido de amparar as classes trabalhadoras rurais do município, uma vez que mediante a perda das plantações, em função das secas que assolavam a região durante os anos de 1941 e 1942, consecutivamente, estariam sofrendo “o maior flagelo até então nunca visto".

Iguatu - Os abaixo assinados, comerciantes nesta praça, veem comunicar-vos que esta cidade se encontra superlotada de flagelados sem pão. A invasão triste da miséria obrigou o comércio a cerrar as portas, sem, entretanto, evitar o pânico, caso não sejam tomadas pelos poderes públicos, imediatas providências. Diante da horrorosa situação, urge vossa providência amparando a situação aflitiva. (Revista de Imigração e Colonização, 1942, p. 34)

A principal queixa, contudo, não se remetia à questão humanitária. Tal qual havia ocorrido em 1877, 1915 e 1932, o grande medo dos comerciantes era em relação ao número de desocupados na cidade aumentando o receio em relação à violência e aos assaltos, embora o próprio interventor, em seu texto, demonstrasse compreender que as ações extremadas de roubo e violência seriam fruto da necessidade de "uns em estado desesperador, e outros assaltando o alheio, procurando saciar fome", as ações e os pedidos de auxílio governamental tinham por objetivo promover o saneamento da área urbana. O desejo, portanto de retirá-los dali, transferir o problema para outras freguesias, tinha sua solução tanto no envio para a Amazônia quanto na conclusão da rodovia que ligaria a zona urbana à ferrovia ${ }^{42}$ Transnordestina.

${ }^{41}$ Revista de Imigração e Colonização, agosto 1942, ano III, Rio de Janeiro, p. 35-36.

42 Segundo Melo, as ferrovias começaram a ser construídas no Brasil, a partir da lei ferroviária de 1852. A primeira foi a curta estrada privada do banqueiro Irineu Evangelista de Souza (Barão e Visconde de Mauá) em 1854. Depois, são os ingleses no Nordeste, com a Recife - São Francisco, em 1858. Somente o período da guerra do Paraguai teria correspondido a uma redução no avanço das ferrovias, depois, a partir de 1873, com o novo regimento de ferrovias, elas voltariam a crescer. MELO, J.C. Secas Ferrovias e mão de obra. Revista RAÍZES, Campina Grande, 
A curiosa situação dos emigrados da seca considerados como invasores indesejados mesmo dentro de seus próprios estados de origem, fica clara no conteúdo do telegrama, do conselheiro Dulphe Pinheiro, que pede para que os nordestinos sejam transportados de Fortaleza para o Amazonas, ou seja, nordestino aqui assume nitidamente a conotação de "flagelado" e mais ainda, de "indivíduo exógeno", o que para qualquer leitor, causaria espanto, uma vez que, geograficamente, todo cearense é também um nordestino. Em Errantes do fim do século, Maria Aparecida de Moraes Silva, mantendo em foco as relações entre sociedade, políticas e trabalho, analisa o fenômeno migratório apontando que tais desigualdades e incongruências do sistema político-econômico, no caso brasileiro, seriam produto de um longo processo de expropriação sofrido por homens e mulheres das áreas rurais e periféricas, que, formando um exército de mão de obra, teriam suas identidades culturais esquecidas, sendo reduzidos a uma classificação que teria como referência apenas as semelhanças étnico-raciais e de gênero. Para a autora, haveria duas formas de olhar-se o migrante: uma imagem para aqueles que vêm das migrações intrarregionais - os de dentro - outra, para o migrante que vem dos sertões do Nordeste para as áreas urbanas do Centro Sul, para esses há ainda o peso de serem "os de fora", sendo assim negados. Silva acrescenta que, aqueles que vivenciam a exclusão são considerados marginais, mendigos ou pingaiada (SILVA, 1999, p. 19).

No caso da fala do conselheiro Dulphe Pinheiro, sobre os emigrados da seca, definidos como nordestinos, em face da reação negativa dos comerciantes e dos jornais à chegada dos flagelados, fica a ideia de que mesmo para a migração interna, os indivíduos que se deslocavam do sertão para a cidade eram vistos como os de fora.

Tanto os canteiros de obras, como o da construção da estrada de Encruzilhada a Afogados das Ingazeiras e Tabira, em uma extensão de 148 Km - que absorveu a mão de obra de mais de dois mil flagelados - quanto a organização da arregimentação de mão de obra para a construção de outras estradas, e mesmo a seleção de voluntários para os seringais do Amazonas, eram ligados ao Instituto de Obras Contra as Secas (IFOCS). Dessa forma, se por um lado, durante as grandes secas de 1915 e 1932, os campos de concentração representaram a opção do governo pelo isolamento do migrante, nos currais, como eram chamados os campos de concentração, como forma de 
solução dos conflitos urbanos, em 1942, a remoção-planejada seria o modelo adotado em matéria que marca a abertura dos trabalhos do Conselho de Imigração e Colonização, o ${ }^{\circ}$ 01, volume 01 da Revista de Imigração e Colonização, a secretaria do Conselho define que, quanto à política de migração interna:

[...] o problema migratório de hoje não poderá ser mais resolvido como no século XIX, pela livre migração. As condições existentes naquele século foram muito favoráveis à liberdade do movimento migratório. [...] A partir do século XX a situação mudou completamente, e essa modificação tem de ser levada em conta para a solução dos problemas atuais. A época das migrações incontroladas, mais ou menos espontâneas, já passou. Hoje, os movimentos migratórios deverão ser cuidadosamente preparados e disciplinados pelo Estado, de forma a se adaptarem às necessidades dos países de emigração e imigração e aos interesses do próprio imigrante." (Revista de Imigração e Colonização, 1940, p. 6)

Além das frentes de trabalho nas rodovias e ferrovias, a mão de obra ociosa do retirante, redirecionada pelo programa de migração-planejada, também seria desejada por outro investimento em ascensão: a produção da borracha. Importante para o mercado exportador desde o final do século XIX, a borracha brasileira tornara-se produto precioso durante a guerra, principalmente após a ocupação de áreas produtoras, na Ásia, pelos exércitos japoneses e da entrada dos Estados Unidos da América na guerra. Era necessário produzir mais borracha e, para tanto, era necessário conduzir um grande número de trabalhadores para os seringais. Todavia, embora envolvesse um número elevado de pessoas e recursos, a transferência dos emigrados das secas para a Amazônia, receberia certa atenção dos jornais, mas não obteve destaque entre as manchetes da $O$ Cruzeiro, que, no tocante à borracha, limitou-se a apoiar a campanha "Borracha para a Vitória”, da Liga Brasileira de Assistência (LBA) para a coleta de borracha usada (pneus) para auxiliar o exército brasileiro ${ }^{43}$.

Em número relativo aos meses de out/dez de 1939, do Boletim do Ministério da Agricultura, uma nota chamava a atenção para o fato de que "as indústrias americanas empregaram 577.591 toneladas de borracha durante o ano - um recorde, representando um aumento de $32 \%$ sobre o consumo em 1938. As fábricas de pneus e câmaras de ar consumiram $77 \%$ de toda a borracha industrializada". ${ }^{44}$ Seria com vistas no abastecimento deste mercado que o governo passaria a incentivar a migração para o Norte do país.

43 Revista $O$ Cruzeiro, ano XV, número 38, 17 de julho de 1943, pp. 8-9.

$44 \quad$ Boletim do Ministério da Agricultura, 1939, ano 28, p. 78. 
Frente ao colapso do fornecimento da borracha e a crescente demanda, um acordo entre Getúlio Vargas e Franklin Roosevelt determinaria os parâmetros da operação de guerra que passaria a ser conhecida como a Batalha da Borracha e seus "combatentes", como os Soldados da Borracha. Segundo Lima (2002), a Rubber Development Corporation instalou-se no Brasil com o objetivo de organizar e fiscalizar o processo de extração e obtenção do látex, contudo, não havia mão de obra suficiente na Amazônia para explorar de maneira eficiente as, aproximadamente, 300 mil árvores.

A solução foi investir no transporte dos flagelados da seca que se concentravam em Fortaleza, para a Amazônia; o Estado faria a propaganda e garantiria o transporte. De acordo com o plano, os sertanejos recrutados, por ocasião da estada temporária em hospedarias governamentais, receberiam assistência alimentar e médica, intensivas. Teriam todas as despesas pagas e às famílias, seriam assegurados recursos para que pudessem sobreviver durante as suas ausências. Havia, ainda, a previsão de assinatura de contratos legais para os trabalhadores e de assentamento posterior com suas famílias para efeito de povoamento da Amazônia (LIMA, 2002, online).

Naquela época, o país passava por um período de grande inflação, em função do racionamento de bens de consumo em virtude da guerra, pois era difícil importá-los. No Amazonas, novos empregos e promessas de bons salários começavam a ser oferecidos pelos diversos escritórios ligados aos investimentos públicos da Campanha da Borracha. Se bem que os gêneros alimentícios escasseassem e um pequeno, mas ativo, mercado negro estivesse em franca atividade, havia uma distribuição controlada pelos americanos, impedindo que faltassem no mercado artigos de primeira necessidade. Assim, os jornais encaravam a situação com grande otimismo estimulando o retirante a voluntariar-se.

Fazia-se, então, a propaganda para arregimentar voluntários. Nessa campanha, a interpretação sobre o sertanejo, construída por Euclides, seria estrategicamente resgatada e reorientada, recuperando da própria narrativa euclidiana a construção paradoxal sobre o sertanejo, assim, a propaganda de arregimentação retirava-lhe a rusticidade, resgatando da narrativa de Euclides a face do sertanejo como um forte, como nas imagens de Chabloz.

Colaborando com a causa da mão de obra, o artista Jean-Pierre Chabloz, cartazista suíço, radicado em Fortaleza, contratado pelo SMTA - Serviço Especial de Mobilização de Trabalhadores para a Amazônia - criou cartazes para ilustrar as campanhas: 
Figura 12. Quatro cartazes de Jean-Pierre Chabloz para o SEMTA, durante a Campanha da Borracha.
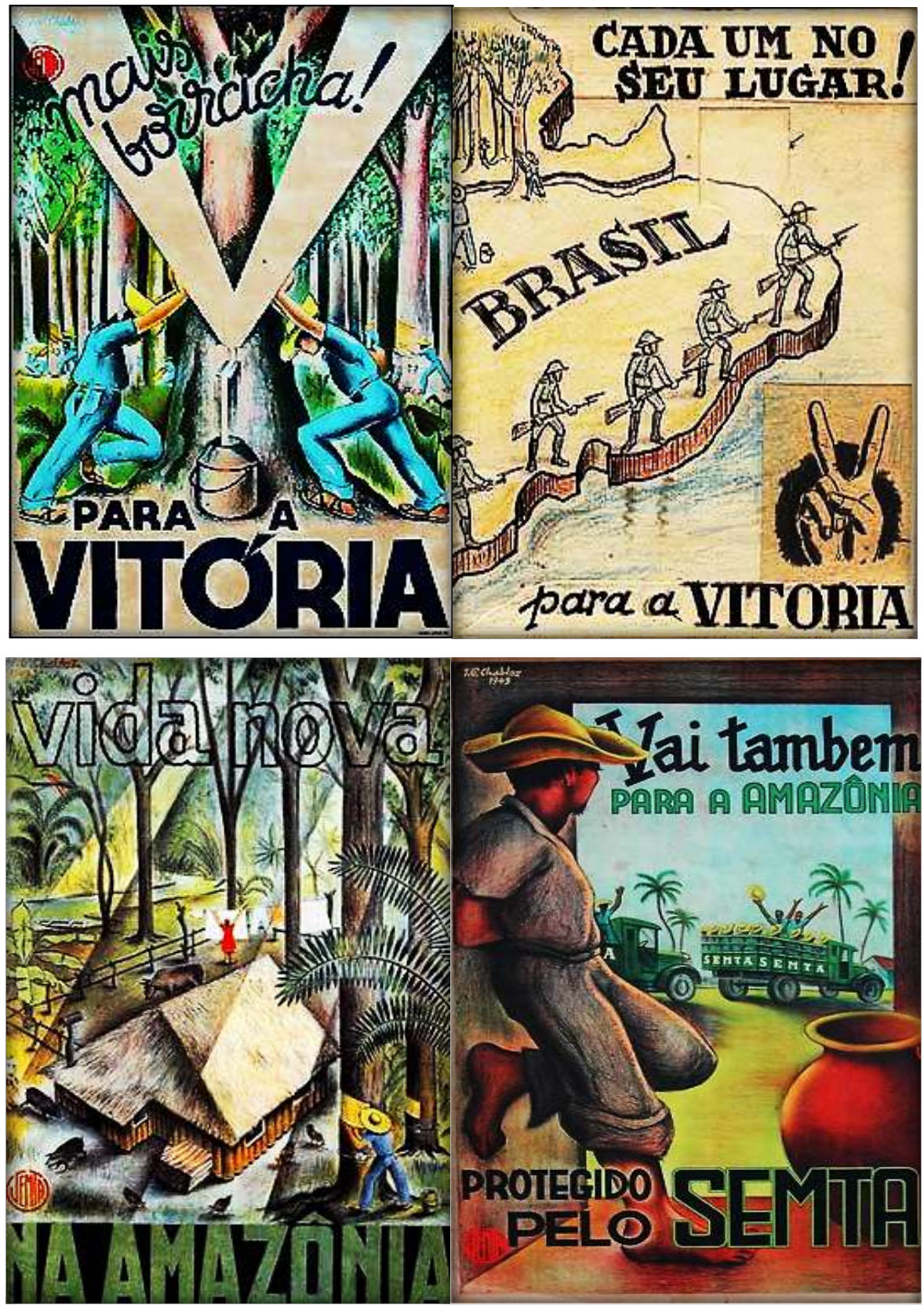

Fonte: Cartazes do SEMTA. Acervo MIS Fortaleza. 
Utilizando ora cores primárias e muito vivas, como no primeiro pôster (figura 12) produzindo uma forte impressão de luminosidade e vivacidade que nos remete à floresta ou cores terrosas, como no segundo pôster que, juntamente com a imagem do perfil do mapa do Brasil e a representação dos soldados guardando o litoral, nos remete à ideia de terra/solo - pelas cores - e terra/pátria - pela imagem - ou ainda destacando o verde, justamente nas letras de "na Amazônia", em alusão à floresta, Chabloz enfatiza elementos como o trabalho, "a terra", a promessa de construção de uma nova vida estruturada - como no terceiro cartaz em que vemos uma casa, um cercado, uma mulher, bois e um homem trabalhando no seringal - e a necessidade de defender sua natureza e seu povo. Tais elementos se associam muito bem a um discurso nacionalista e de mobilização civil. As imagens são expressivas e prescindem de texto, todavia, palavras de ordem como "vitória" e "vida nova", são colocadas como recurso enfático.

É importante lembrarmos que, num primeiro momento, entre o final do século XIX e os anos de 1940, o retirante era um indesejável, não exatamente para as cidades do sul - onde sua presença numericamente era pequena -, mas sim para as capitais nordestinas; ele é estigmatizado fortemente pela imprensa dos centros do Nordeste porque lá se encontravam as capitais em pleno projeto de urbanização, abraçavam a modernidade, realizavam suas reformas urbanas dentro dos princípios higienistas da época e o sertanejo representava justamente o oposto desses princípios; o atraso e a barbárie. ${ }^{45}$

O incentivo à migração para o Amazonas se consolida como ação do Estado, e dessa forma, desde agosto de 1940, a partir da Resolução $n^{\circ}$ 74, decide-se pela concessão de Passagens gratuitas para nordestinos que se destinassem ao território do Acre e Amazonas.

No artigo, Encaminhamento de trabalhadores nordestinos para a Amazônia, o Conselho de Imigração denuncia que entre 1940 e 1942, como era de se esperar, a migração interna de trabalhadores para a Amazônia se processou de forma irregular e inconstante, sem qualquer organização sistemática - apesar do próprio conselho ter definido anteriormente o processo como migração-planejada - sem qualquer atenção à alocação dos migrantes, à sua assistência em trânsito e às condições de trabalho nos seringais - “e todos esses vícios profundos da migração, acentuados

$45 \quad$ Na seca de 1952, não foi diferente: as soluções foram os campos de concentração e a migração. Dessa forma, podemos delimitar as secas de 1877 a 1952, como momentos em que o Ceará fora polo de emigração nacional. A matéria da Revista O Cruzeiro de 13 de setembro de 1952, “Abrigos do Ceará”, descreve essa realidade. Cruzeiro, 13/09/52, ano XXIV, número 15, p. 60-63. 
com o decurso de lustros e lustros de encaminhamento desordenado, impediram que aquelas providências pudessem executar-se de forma proveitosa" ${ }^{46}$. Urgia que todo o sistema fosse revisto, e que nova organização de encaminhamento, assistência, localização e trabalho fossem traçadas e tornadas efetivas.

O Conselho teria sido incumbido, pela presidência, de resolver o problema e teria como fazê-lo, uma vez que havia detectado o centro do problema: a forma de aliciamento. As tentativas anteriores foram determinantes para detectar que as falhas no encaminhamento daqueles trabalhadores começavam na fase de escolha e aceitação da mão de obra, já nas áreas de concentração dos sertanejos, onde dever-se-ia recrutar apenas aqueles que fossem aptos para os trabalhos nos seringais, porque segundo os relatos da época, era:

[...] comum que se permitisse que elementos indesejáveis, empregados em pequenos misteres citadinos, transmigrassem também para o norte, no regime de favor, autorizados pelo Senhor Presidente da República. Essa gente, inapta, para os trabalhos rurais, ia-se deixando ficar nos centros urbanos, onde sua permanência criava outros problemas locais de alojamento e trabalho. (Revista de Imigração e Colonização, 1942, p.12)

O texto deixa claro que o objetivo não era resolver o problema da mão de obra ociosa, produto da falta de investimento no sertão nordestino, mas sim, única e exclusivamente, resolver o problema da carência de mão de obra na área da extração da borracha, nos seringais do Amazonas e do Acre. O encaminhamento dos trabalhadores ao seu destino fora confiado ao Departamento Nacional de Imigração, ao qual se incumbiu também o arrolamento do pessoal e sua hospedagem nos pontos de transbordo. Em virtude de os navios do Lloyd Brasileiro só levarem os trabalhadores até Manaus, os transportes da capital do Amazonas até os altos rios eram feitos pelos vapores do Serviço de Navegação e Administração dos Portos do Pará (S.N.A.P.P.). Em Boca do Acre, dada a escassez da navegação até os seringais na época da seca, os migrantes permaneciam muito tempo, razão pela qual o Conselho de Imigração julgou necessária a manutenção de seu antigo projeto de construção de uma hospedaria naquela localidade ${ }^{47}$.

46 Revista de Imigração e Colonização, agosto de1942, ano III, Rio de Janeiro, Brasil p. 10.

47 O documento governamental, publicado na Revista de Imigração informava quanto aos detalhes sobre como os agentes deveriam proceder no aliciamento adequado in loco, exigia também a inspeção médica dos trabalhadores selecionados, construção da hospedagem, fornecimento de passagens de navio, confecção de contratos de trabalho, ficando a cargo dos departamentos de saúde dos respectivos Estados que recebessem migrantes, os cuidados com assistência médica, bem como à Divisão de Fomento Agrícola o fornecimento e o controle dos preços dos víveres e utilidades aos trabalhadores, que por sua vez poderiam adquirir os gêneros alimentícios e utilidades onde lhes 
Quanto às estratégias de arregimentação, o que acontecia de fato era que os retirantes albergados eram compreendidos "naturalmente como voluntários", sendo encaminhados, independentemente de sua vontade, para os seringais da Amazônia. Alguns seguiam voluntariamente, envolvidos, pelo discurso de civismo - a Vitória da Borracha - e também pelas promessas de riquezas a serem conquistadas no Eldorado brasileiro. Em reportagem sobre a saga dos soldados da borracha no Acre publicada pelo jornal The New York Times, em 23 de novembro de 2006, o jornalista Larry Rohter, apresenta, a partir de pesquisa e algumas entrevistas, as angústias vividas pelos emigrados arregimentados, para servirem como voluntários na Segunda Guerra Mundial na extração do látex, no Acre.

Embora muitos dos soldados da borracha fossem forçados ao serviço, alguns se alistavam na esperança de aventura e riquezas. José Araújo Braga, 82, descreveu a si mesmo como "um garoto rebelde que queria ver o mundo" e, portanto, fora facilmente influenciado pela propaganda do governo que falava da Amazônia como um El Dorado, onde, com os esforços pela "Borracha para a Vitória", quem trabalhasse pesado poderia alcançar uma fortuna. ${ }^{48}$

$\mathrm{Na}$ verdade o que os esperava não era a fortuna. A história não seria bem essa. O envio de migrantes nordestinos para a Amazônia era uma solução antiga, que datava dos tempos de outras secas, permanecendo a mesma estrutura de exploração que Euclides da Cunha, em Um Paraíso Perdido (2000), denunciava a situação. Tamanho era o descalabro que, em sua narrativa, o autor não poupou palavras para descrever um sistema que era de semiescravidão:

Repitamos: o sertanejo emigrante realiza, ali, uma anomalia sobre a qual nunca é demasiado insistir: é o homem que trabalha para escravizar-se. Enquanto o colono italiano se desloca de Gênova à mais remota fazenda de São Paulo, paternalmente assistido pelos nossos poderes públicos, o cearense efetua, à sua custa e de todo em todo desamparado, uma viagem mais difícil, em que os

aprouvesse. Quanto ao pagamento pelo trabalho nos seringais, ficava determinado que deveria ser feito semanal ou quinzenalmente, "não sendo permitida a emissão de vales". ${ }^{47}$ Chama-nos a atenção o fato de que a aprovação do plano coincidiu com dois acontecimentos: a assinatura, em Washington, de novos acordos de cooperação econômica entre o Brasil e os Estados Unidos da América - com a consequente obrigação de nossa parte de intensificação da produção de artigos básicos e estratégicos, entre os quais se incluía a borracha - e o recrudescimento da seca do Nordeste Sobre os estados que forneceram trabalhadores, ver: "Estados fornecedores de braços: Piauí, Ceará, Rio Grande do Norte, Paraíba, Pernambuco, Alagoas, Minas e Baía" Revista de Imigração e Colonização, agosto 1942, ano III, Rio de Janeiro, Brasil, p.12 a 18.

$48 \quad$ "Though many of the rubber soldiers were forced into service, a few enlisted, hoping for adventure and riches. José Araujo Braga, 82, described himself as "a rebellious kid who wanted to see the world" and thus was easily swayed by government propaganda that spoke of the Amazon as an El Dorado where the "Rubber for Victory" effort could earn a hard worker a fortune". Of rubber and blood in Brazilian Amazon. The New York Times, em 23 de novembro de 2006. Disponível em:

http://www.nytimes.com/2006/11/23/world/americas/23brazil.html?_r=2\&pagewanted=2\&oref=slogin. Acesso em 10 de março de 2008. 
adiantamentos feitos pelos contratadores insaciáveis, inçados de parcelas fantásticas e de preços inauditos, o transformam as mais das vezes em devedor para sempre insolvente. (CUNHA, 2000, p. 153)

Durante os anos 40, muitos sertanejos morreram durante o difícil trajeto ao "eldorado amazônico", além disso, muitos dos que conseguiram chegar aos seringais, depois de três meses ou mais de viagem, deparavam-se com um ofício desconhecido, em meio a uma floresta repleta de insetos de picadas letais, animais selvagens e um regime de trabalho que em nada se assemelhava àquele descrito pelos relatórios das agências de imigração. Ao contrário do que os documentos apontam, o trabalhador não possuía liberdade para comprar seus suprimentos na venda de sua escolha, porque ao chegar ao seringal o trabalhador, logo abria a conta, com o patrão. Era o sistema de aviamento, pelo qual, prendia-se o trabalhador por meio de suas dívidas contraídas junto ao patrão na aquisição de produtos de subsistência (mantimentos, ferramentas etc.), no final da safra, a dívida era abatida do valor da produção. Segundo os relatos, "o patrão escolhia os mais fortes para trabalhar em seus seringais e registrava tudo o que gastava com os migrantes. [...] Jogados no meio da mata tinham que conviver com todo tipo de doenças e ferimentos" (LIMA, 2002, s/n).

A migração de um expressivo número de retirantes chamou a atenção da cidade de Fortaleza e eram frequentes nos jornais as notícias do embarque das "levas de flagelados". Quando a guerra e os interesses americanos acabaram, em relação à Amazônia, os responsáveis pela organização dos seringais, preocuparam-se, pois temiam que seus trabalhadores deixassem os seringais, por isso, ocultaram a informação da vitória dos aliados, mantendo os soldados da borracha, completamente desinformados quanto ao término da guerra. ${ }^{49}$ Segundo o depoimento do ex-seringueiro, Lupércio Freire Maia, de 86 anos, só depois de 1946 é que soube do término da

49 O artigo $54 \S 1^{\circ}$, do Ato das Disposições Constitucionais Transitórias (ADCT) determina que "os seringueiros recrutados nos termos do Decreto lei 5.813, de 14 de setembro de 1943 e amparados pelo Decreto lei - 9.882 , de 16 de setembro de 1946, receberão, quando carentes, pensão mensal vitalícia no valor de dois salários mínimos”. Conforme Processo n ${ }^{\circ}$ 2005.30.00.712535-8, Classe: 51201 - ORD/PREV/COM/BEM. Autor: Francisco Barbosa Cavalcante, Réu: Instituto Nacional de Seguro Social - INSS. Poder Judiciário Federal, Seção Judiciária do Estado do Acre. p. 04. Os anos se passaram e os soldados da borracha caíram no esquecimento. Somente em 1988, com a nova constituição Federal do Brasil, hoje em vigência, os soldados da borracha passaram a ter direito ao benefício assistencial no valor de dois salários mínimos. Pouco, para quem viveu o que eles viveram. 
guerra, não tendo rádios no lugar, ficavam completamente alheios às notícias do mundo; conforme o The New York Times, o senhor Maia relata que:

Até 1946 eu não sabia que a guerra tinha acabado. Nós não tínhamos rádios e nós estávamos completamente isolados do mundo exterior. Quando eu assisto as cerimônias do Dia da Independência na televisão e vejo os soldados que lutaram na Europa desfilando em seus uniformes sinto tristeza e desapontamento", disse o Sr. Maia. "Nós éramos combatentes também. Todo mundo nos deve um grande favor, incluindo os americanos, porque a guerra não poderia ser vencida sem a borracha e sem os soldados da borracha. (LIMA, 2002, s/n)

Com o retorno dos tempo de paz novas concepções sobre as possibilidades econômicas para o Nordeste e para os nordestinos inevitavelmente viriam a florescer e o êxodo do trabalhador rural, que já se processava durante os anos de 1940, só tendia a se acentuar durante a década seguinte.

É exatamente nesse contexto de migração do Nordeste para o Sudeste, no pós-guerra, que finalmente os sertanejos e o sertão surgem em nossas páginas ilustradas, emergindo sob duas formas de apresentação: a do retirante como atopos e a do sertão como terra desolada.

\subsection{Representações do Sertanejo nas revistas ilustradas}

Embora durante as décadas de 1930 e 1940 o sertão nordestino tenha passado por duras estiagens e, embora a seca e os retirantes fossem associados com facilidade a um retrato dos estados do Nordeste, o que se verifica é que não se viam imagens sobre as secas nas páginas ilustradas da mais lida revista da época, a $O$ Cruzeiro e, não somente nela mas ausente também da Vamos Lêr!, uma revista não tão diversificada quanto O Cruzeiro, e que tinha como objetivo divulgar temas gerais sobre o Brasil e o mundo. Essa ausência é de grande relevância, pois demonstra não haver lugar para o sertão nas páginas do Brasil moderno.

Todavia, muitas das certezas e das tendências nutridas pelos anos de 1930 cairiam por terra com o término da guerra. Na imprensa não seria diferente.

A cobertura da guerra traria para a Cruzeiro um novo olhar sobre os fatos. Segundo Heloise Costa, a partir dos anos de 1940, a objetividade passaria a ser maior, as reportagens ficariam mais jornalísticas, buscando a imparcialidade; a revista perderia o caráter literário, tornando-se mais 
preocupada com a informação e com a busca por matérias de impacto. ${ }^{50}$ A partir do término do conflito mundial as preocupações com os problemas e dramas nacionais tomariam o espaço outrora ocupado pelas manchetes da guerra, dessa forma os problemas urbanos, os projetos econômicos, as imagens de lugares extremos do país - principalmente a Amazônia - ganhariam destaque e tratamento jornalístico. É neste contexto que o sertão e o sertanejo passariam a receber uma maior atenção das lentes dos fotógrafos não só da Cruzeiro, mas também de sua concorrente - a partir dos anos de 1950 - a Revista Manchete, da Editora Bloch.

Se Euclides e Os Sertões foram determinantes para a entrada do sertanejo e do sertão seco no imaginário do Sudeste, novamente caberia aos dois, introduzirem o sertão no repertório imagético das ontológicas fotorreportagens de $O$ Cruzeiro.

Em 1947, marcando os cinquenta anos da Guerra de Canudos, Odorico Tavares jornalista pernambucano radicado na Bahia ${ }^{51}$, e Pierre Verger, fotógrafo e etnólogo francês, foram escalados para a elaboração de uma matéria especial: "Roteiro de Canudos - o reduto de Antônio Conselheiro". A edição, de 19 de julho, foi considerada por Luiz Makhlouf Carvalho (2001) como “a melhor revista do ano". O texto de Odorico Tavares resgatava depoimentos de sobreviventes que descreviam um Antonio Conselheiro bondoso, um verdadeiro líder. Os depoimentos eram marcados pela dor ainda presente do genocídio vivido pelo arraial há cinquenta anos. Ao perguntar sobre as lembranças do massacre, a sobrevivente Maria Avelina respondia:

Para que adianta estar falando nestas coisas? Já passou. Estou velha e quero morrer em paz.

- E o Conselheiro?

Também morreu, deixe êle em paz. Por êle, não havia mal no mundo. Perseguiram êle e está aí a desgraceira que aconteceu. Moço, não adianta estar mexendo com essas coisas. (SÁ, 2010. p. 370)

50 COSTA, Helouise e BURGI, Sérgio. (orgs) As origens do fotojornalismo no Brasil. Um olhar sobre $O$ Cruzeiro. 1940-1960. São Paulo: Instituto Moreira Salles, 2013.

$51 \quad$ Odorico Tavares (1912 - 1980) nasceu em Pernambuco mas radicou-se na Bahia onde construiu sua carreira de jornalista, escritor, poeta e colecionador de arte. Foi diretor do Diário de Notícias, jornal que pertencia aos Diários Associados de Assis Chateaubriand. Organizou, juntamente com Jorge Amado (1912 - 2001) em 1944, a primeira exposição de arte moderna brasileira na Bahia e em 1947, realizou reportagens para a revista O Cruzeiro, reunindo-as no livro Bahia, Imagens da Terra e do Povo, de 1951, com ilustrações de Carybé. 
Figura 13. Fotos de Pierre Verger. Canudos.
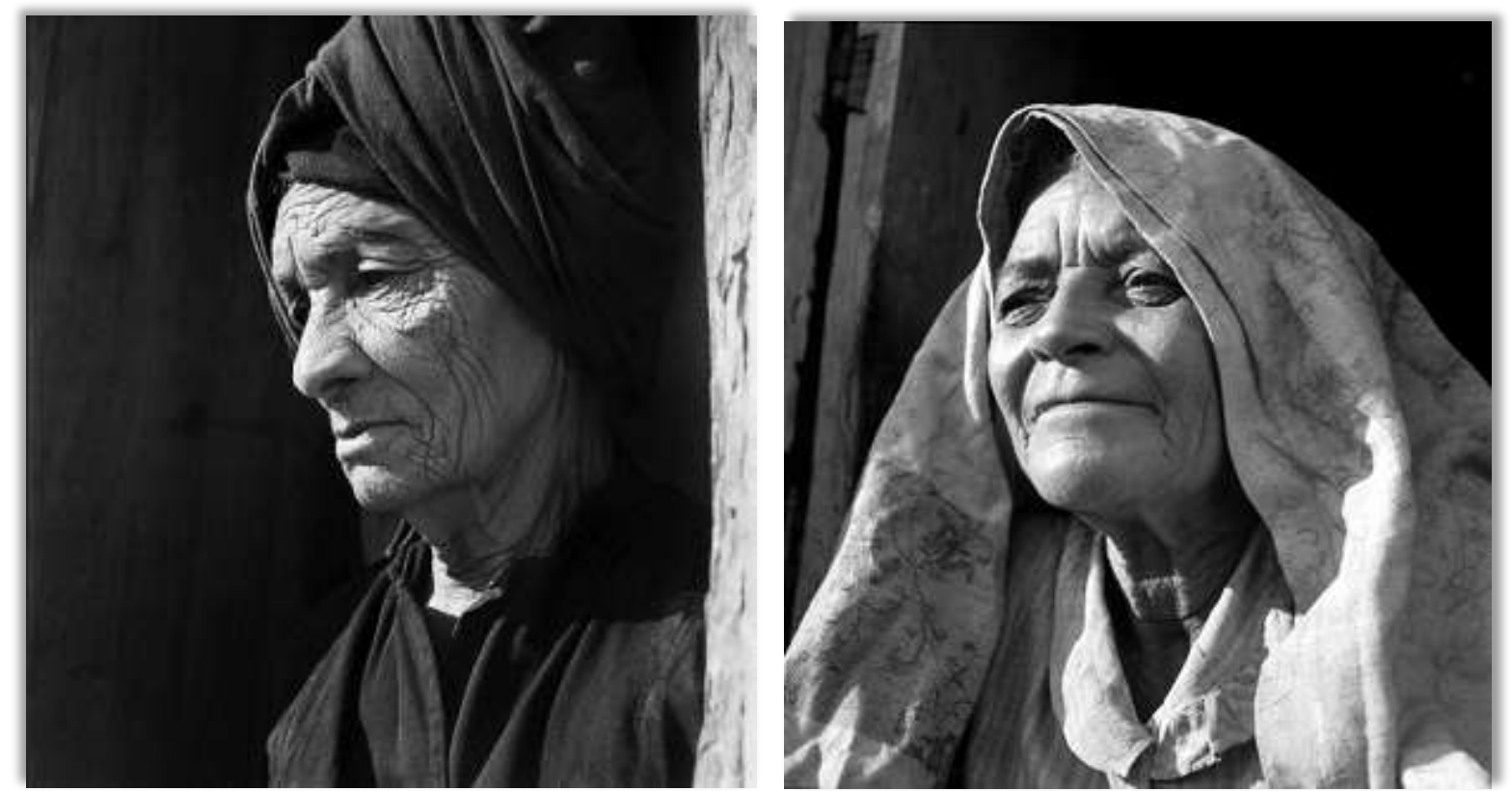

Fonte: Revista O Cruzeiro, julho de 1947. COSTA, Helouise e BURGI, Sérgio. (orgs) As origens do fotojornalismo no Brasil. Um olhar sobre O Cruzeiro. 1940-1960. São Paulo: IMS, 2013.

Figura 14. Arraial de Canudos. Cruz.

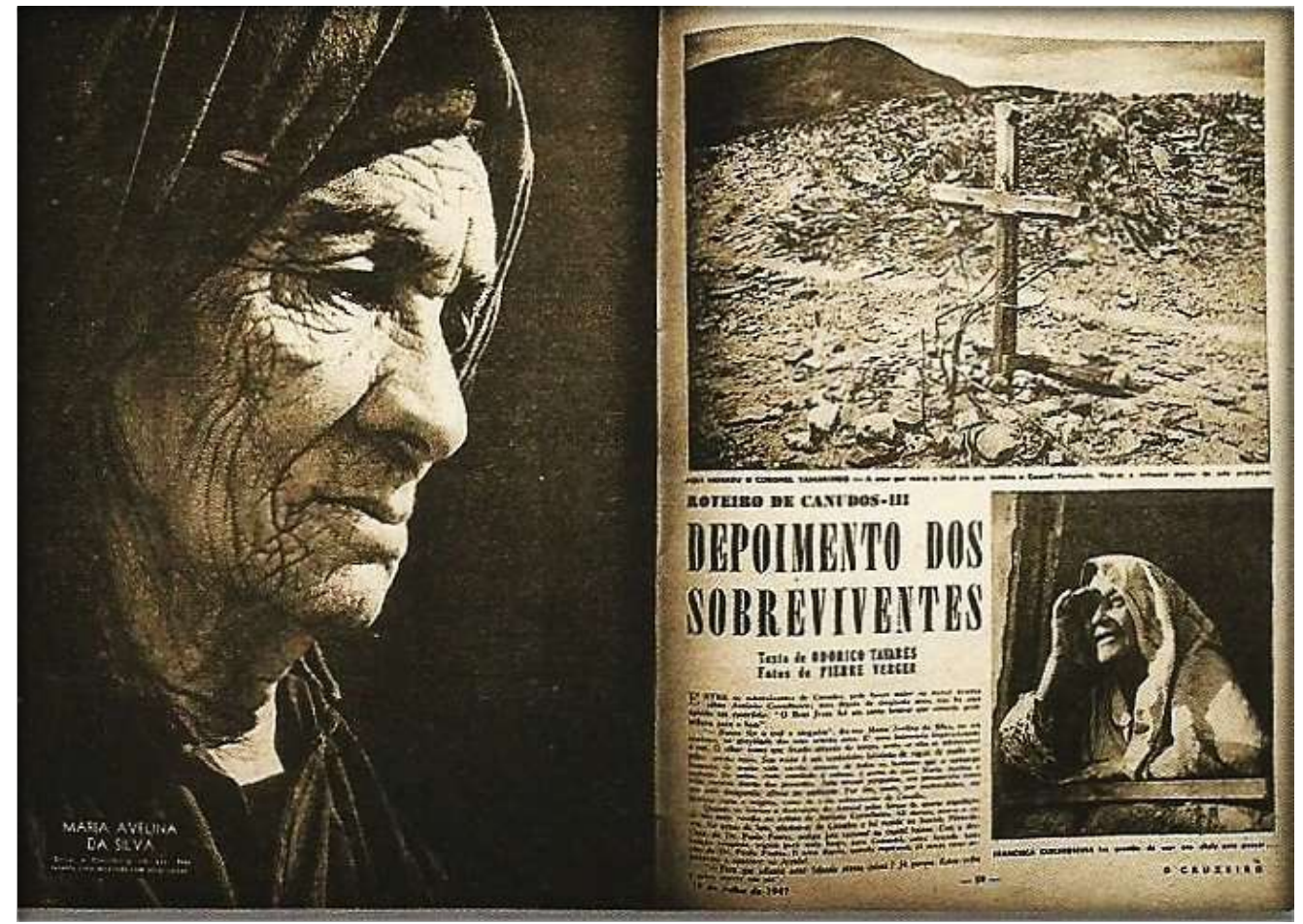

Fonte: Revista O Cruzeiro, julho de 1947. COSTA, Helouise e BURGI, Sérgio. (orgs) As origens do fotojornalismo no Brasil. Um olhar sobre O Cruzeiro. 1940-1960. São Paulo: IMS, 2013. 
Apresentados a partir de um enquadramento em perfil e meio perfil, os rostos fortemente marcados de duas senhoras idosas (figura 13), enfatizavam a passagem do tempo; uma com o olhar perdido no horizonte, e outra com o olhar sem foco, porém lançado ao chão, remetiam o leitor a um passado remoto, a uma ideia de passado distante, todavia marcado pelo sofrimento e pela morte, representados ainda pela cruz solitária, fincada no solo seco gretado.

Nas fotografias de Verger $^{52}$, realizadas com sua Rolleiflex ${ }^{53}$, encontramos a valorização dos tipos humanos e suas expressões faciais, em primeiríssimo plano (big close up), imprimindo grande dramaticidade às imagens. A abertura da matéria vinha em página dupla, composta somente por três fotografias e o título, não havia texto. A fotografia, prescindindo de auxílio textual, fora um recurso característico da fotorreportagem, inspirando-se cada vez mais no noticiário telegráfico dos tempos da guerra, o texto, ali, assumia uma função de revelação, ao apontar, com o título, que o cenário apresentado era o do arraial de Canudos, concentrando assim, a força da mensagem na expressão e no impacto produzido pela imagem.

O olhar de Verger estaria profundamente pautado pelo diálogo que estabeleceu na época com pesquisadores como Alfred Métraux, Roger Bastide e Ben Zimmerman, sendo a reportagem sobre Canudos, em 1946, um marco em seu trabalho sobre o sertão.

Sobre o texto da reportagem, em seu livro Canudos, Cinquenta anos depois, Odorico Tavares descreve que no caminho da cruz do Coronel Tamarindo, encontrou José Travessia, que narrara recordações do tempo da guerra. Ele tinha uns doze anos quando o "negócio" começou a

\footnotetext{
52 Pierre Verger, veio para o Brasil primeiramente em 1941, mas somente em seu retorno, em 1946, começou a colaborar na $O$ Cruzeiro, por indicação da escritora Vera Pacheco Jordão A Contribuição Do Fotógrafo Pierre Verger no Processo Identitário do Nordeste Brasileiro. In I Congresso Nacional Educação e Diversidade, UFS - Itabaiana/Se, Brasil, Setembro De $2011 . \quad$ Disponível em http://200.17.141.110/forumidentidades/Vforum/textos/Vanessa_Alves_Menezes.pdf. Acesso em 20 de dezembro de 2013.

${ }^{53}$ Verger manteve sua preferência pelo equipamento em formato reflex, (Twin Lens Reflex) que, devido ao seu tamanho maior, gerava ampliações mais definidas e com bem menos ruído. Com a chegada da Leica M3, nos anos 50, vários fotógrafos e repórteres fotográficos optaram pela novidade, dentre os de fora Henri-Cartier Bresson, Robert Capa, que utilizaram a Leica em seus trabalhos, em função de sua qualidade e maior leveza e praticidade, em comparação com a Rolleiflex. Na Cruzeiro, Jean Manzon representaria o grupo daqueles que valorizavam fotografias cinematograficamente elaboradas, 'posadas', que necessitavam da garantia da qualidade da imagem durante o processo de ampliação. Do lado da modernidade da Leica, estavam aqueles que valorizavam o flagrante, a fotografia mais espontânea, como José Medeiros e Luciano Carneiro. Sobre esse assunto, ver mais em FRANCISCHETT, Leandra. 50 anos do assassinato de Aída Curi - O fotojornalismo fazendo escola na revista O Cruzeiro. Revista da Biblioteca on-line de Ciências da Comunicação. Portugal, 2008.
} 
apertar, a vida se tornando um "inferno". Em cortantes palavras, ele afirmava: "Fui para o mato, comer gravatá e dormir ao Deus dará, para ver se escapava com vida. Meu pai morreu, lutando ao lado de João Abade que era um homem direito e com ele não havia moleza. Caiu no arraial tinha que pegar no pau de fogo, mesmo". Para ele, foi "um erro, ter se feito o arraial novamente onde está”, pois é um “cemitério vivo”, “cavou dá um osso de defunto”. (SÁ, 2010, p. 373).

Já na reportagem da Manchete sobre Canudos, em 1953, a tônica era outra. O título suscitava uma narrativa trágica, "Canudos: cidade condenada"; havia, como na Cruzeiro o destaque às memórias dos remanescentes do massacre, todavia as imagens e o texto de Darwin Brandão ${ }^{54}$ apresentavam a cidade como um espaço em reconstrução.

Na figura 16, a página da esquerda se contrapõe à da direita, como passado e futuro; na primeira, as imagens dos idosos que ainda traziam na memória cenas do massacre e no rosto as marcas do tempo; já na página seguinte, as jovens na janela, a sorrirem para o fotógrafo, imprimem um sentido de renovação; a história, em Canudos, não parou, as novas gerações estariam reconstruindo e mesmo ressignificando os elementos constitutivos da memória e da história daquela cidade, representados, no canto inferior direito da página, pelas imagens e pela afirmação: "Ficará o Folclore" e pelo subtítulo da última página: "Uma cidade que morreu, e uma nova Canudos".

No início da década de 1950, frente à nova postura das revistas ilustradas diante da notícia, a seca tornar-se-ia, finalmente, entre 1952 e 1953, um tema largamente explorado no formato de fotorreportagem. Anteriormente descrita como produto do flagelo das secas, a saga desses emigrados, que se arriscavam nas estradas em direção ao Rio de Janeiro e São Paulo, renderia para a $O$ Cruzeiro uma reportagem histórica e premiada.

\footnotetext{
${ }^{54}$ Darwin Brandão, baiano radicado nos Rio de Janeiro desde 1950, foi chefe de reportagem na Revista Manchete, um dos mais importantes repórteres da Manchete entre os anos de 1950 e 1960, tendo tido como grande parceiro o também baiano Gervásio Batista. Muito ativo, ele e sua esposa Guguta Brandão faziam parte de um politizado círculo de intelectuais e artistas do qual faziam parte Chico Buarque, Paulo Pontes, Fernando Peixoto, Zuenir e Mary Ventura dentre outros. Brandão era um livre estudioso da cultura baiana, tendo escrito A cozinha baiana, publicado pela Ediouro em 1952.
} 
Figura 15. Canudos - Cidade Condenada.

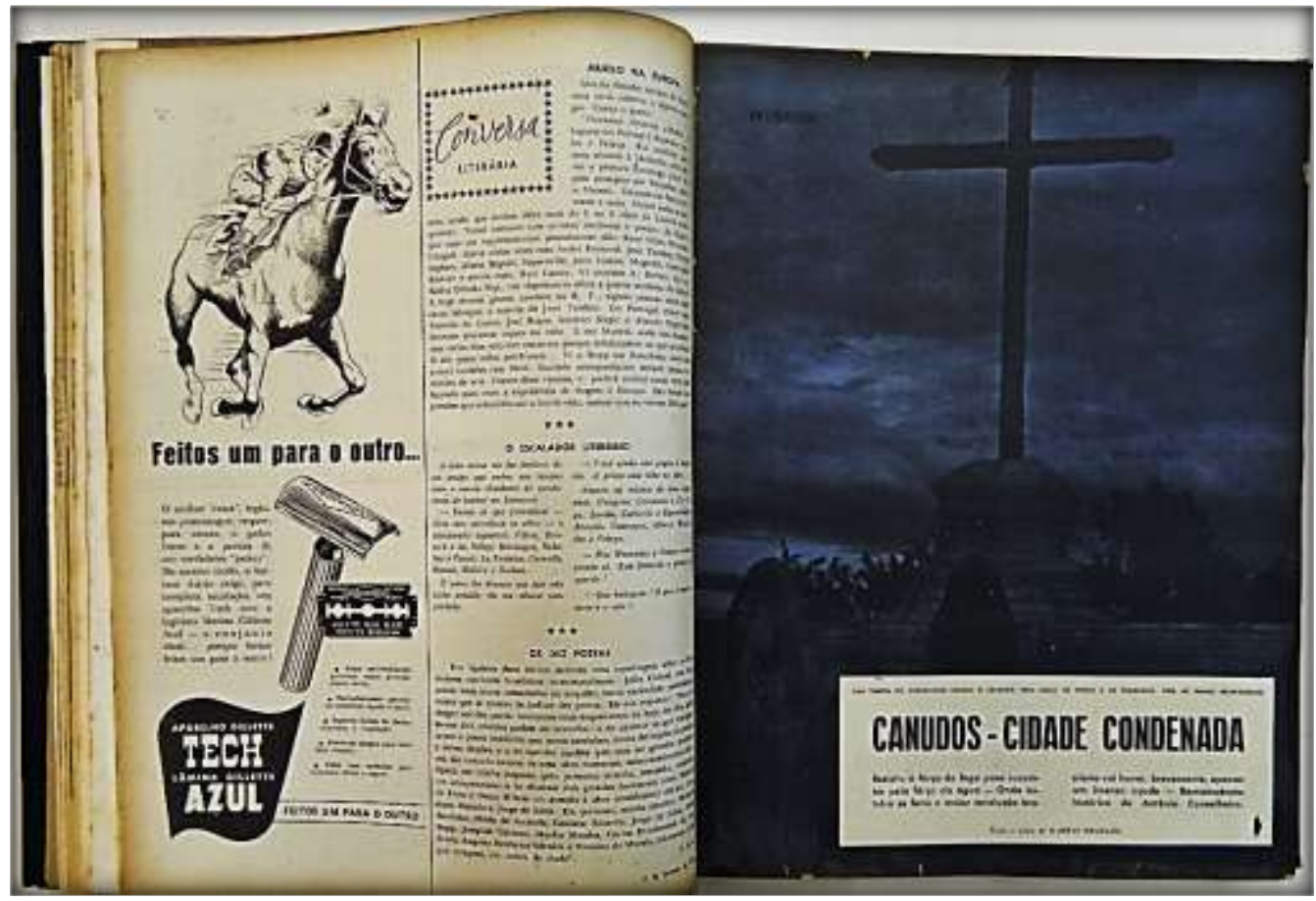

Fonte: Revista Manchete, 14 de fevereiro de 1953, p. 19. Acervo: Biblioteca Florestan Fernandes-USP

Figura 16. Moradores de Canudos.

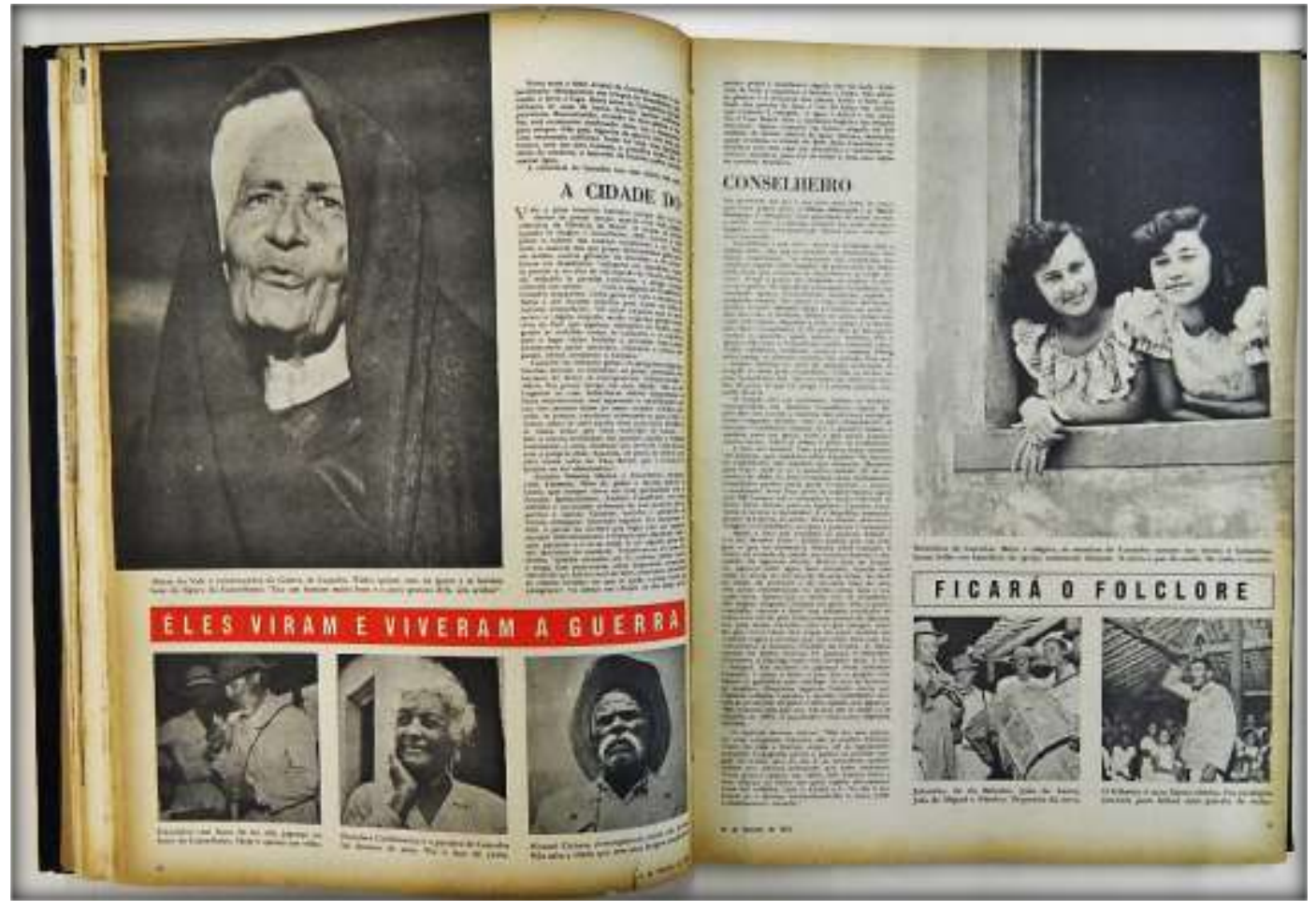

Fonte: Revista Manchete, 14 de fevereiro de 1953, p. 20 e 21. Acervo: Biblioteca Florestan FernandesUSP 
Figura 17. A fuga da seca e da miséria.

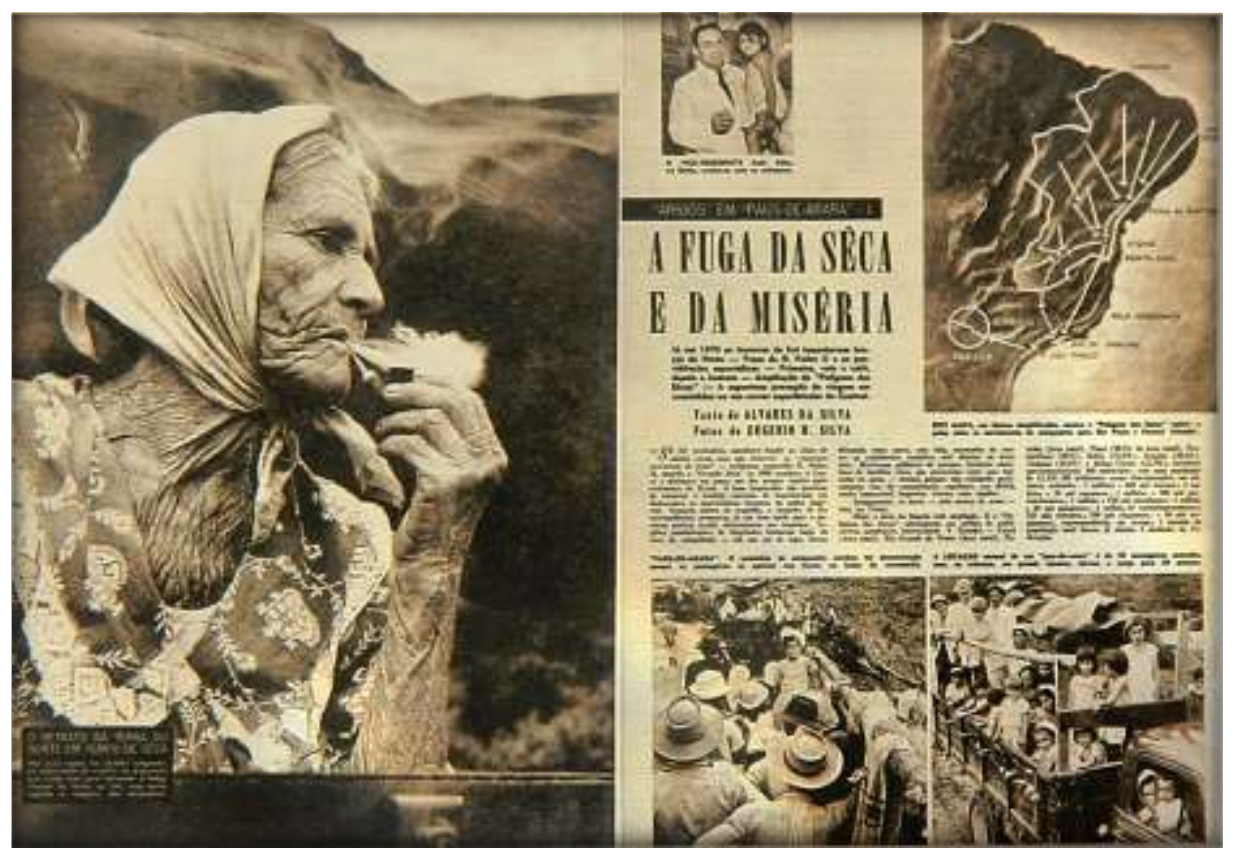

Fonte: Revista $O$ Cruzeiro, 12 de abril de 1952.COSTA, Helouise e BURGI, Sérgio. (orgs) As origens do fotojornalismo no Brasil. Um olhar sobre O Cruzeiro. 1940-1960. São Paulo: IMS, 2013, p. 184.

Figura 18. Os paus de arara.

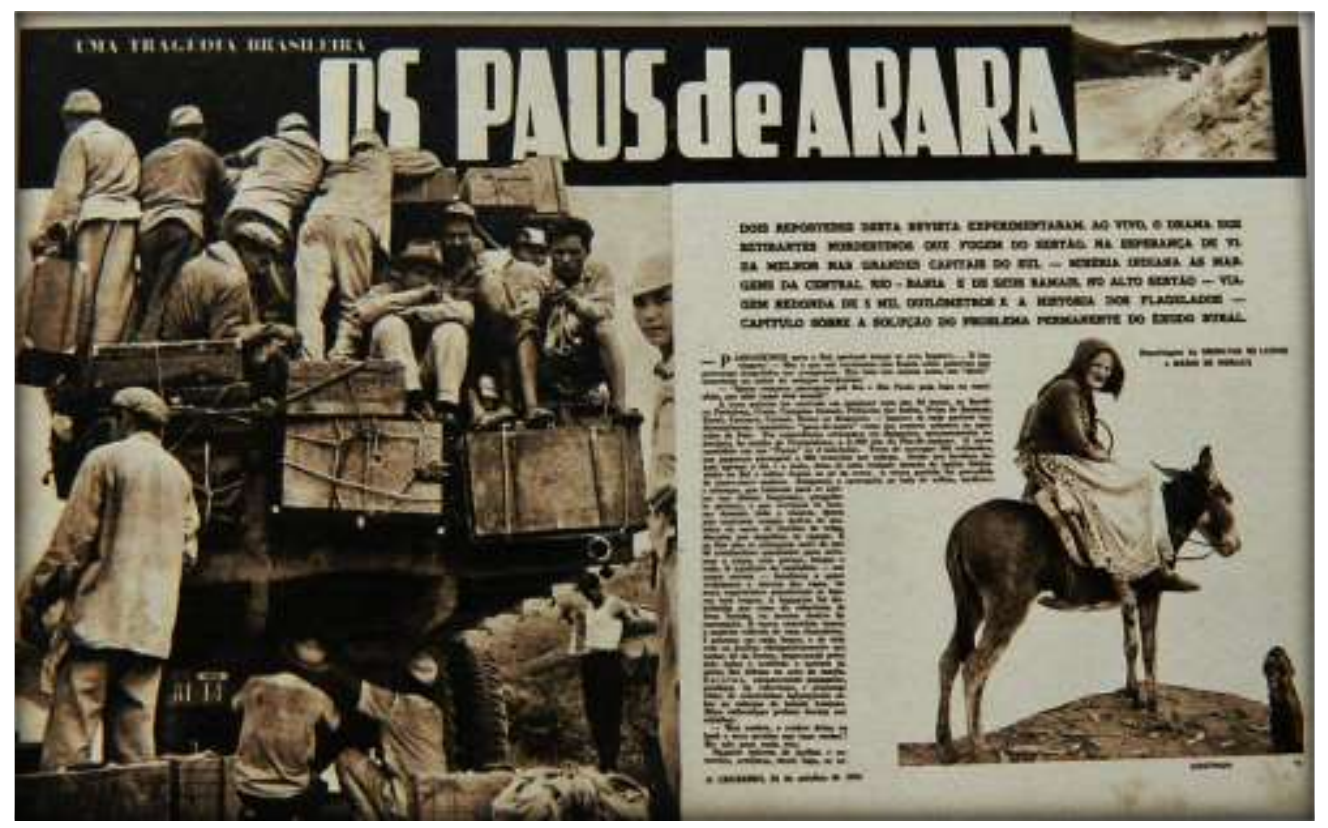

Fonte: Revista $O$ Cruzeiro, 12 de abril de 1952.COSTA, Helouise e BURGI, Sérgio. (orgs) As origens do fotojornalismo no Brasil. Um olhar sobre O Cruzeiro. 1940-1960. São Paulo: IMS, 2013, p. 184 
Em 1955, Mário de Moraes repórter da revista O Cruzeiro, juntamente com Ubiratan de Lemos ganhariam o primeiro Prêmio Esso de Jornalismo, com a reportagem "Os pau de arara, uma tragédia brasileira" (figura 18). A ideia de fazer essa matéria surgiu porque Mário queria fazer um trabalho com Ubiratan de Lemos. Inicialmente o objetivo seria trabalhar com a questão do migrante chegado à cidade do Rio de Janeiro, então, a matéria seria intitulada: "Araras constroem o Rio", posto que a maior parte desses migrantes acabasse sendo absorvidos pela construção civil. De acordo com o próprio Mário, a matéria prosseguiu com o intuito de apresentar o migrante na cidade, dentro do perfil daquelas outras publicadas no início dos anos de 1950, sobre migrantes nordestinos e suas vidas na capital do país, até o momento em que um dos emigrados com quem conversavam disse: "Isso é sopa. Eu quero ver vocês viajarem em um caminhão pau de arara".

Segundo Mário, mesmo depois de terem ouvido todo o tipo de história assustadora sobre as condições e as situações que se seguiam pela viagem, os repórteres foram para a redação propor a viagem, que seria o palco para a premiada matéria.

Em 1955, Mário e Ubiratan embarcaram em cima da carga de um caminhão (não era um pau de arara), em uma viagem de onze dias, rumo a Campina Grande (PB).

Chegamos à Campina Grande. Fomos para um hotel vagabundo, porque a gente tinha que continuar com a mentira de que éramos pobretões, vindos do sertão, fugindo da seca". Decidiram dar uma volta pela cidade à procura de um pau de arara. Haviam dito que em breve chegaria um na praça. "Mas aí o Ubiratan cometeu um erro": contou para um amigo radialista, sobre a reportagem que pretendíamos fazer. "O rapaz, mais idiota que o Ubiratan, foi ao ar e disse: Aqui estão dois jornalistas que vão acabar com o escândalo dos pau de arara, com a exploração dos nordestinos". Outro jovem foi ao hotel dos jornalistas e aconselhou que fugissem, pois já haviam contratado um matador para acabar com eles. (CARVALHO, 2001, p. 326)

O transporte no pau de arara constituía-se num negócio extremamente lucrativo. Segundo, Mário e Ubiratan, "tinha gente milionária. Uma passagem custava, na época, $\mathrm{Cr} \$ 500$. O agenciador ficava com Cr\$ 300 e dava Cr\$200 aos motoristas”. Conseguiram a ajuda de um caixeiro-viajante que ia em direção a Salgueiro. Chegando lá, os repórteres se hospedaram em uma pensão e pediram que informassem sobre a próxima saída de um pau de $\operatorname{arara}^{55}$.

55 A presença das rodovias fora um facilitador para a intensificação do fluxo de migrantes do Nordeste para o Sudeste. Anteriormente, a ferrovia e o Porto de Santos eram as vias de entrada dos emigrados das secas, a partir da abertura do trecho Rio-Bahia, da BR101, a estrada passaria a ser a via mais rápida de acesso ao Sudeste, mas não a mais segura. 
O texto de Mário narra a triste aventura daqueles que se sujeitavam a vinda para o Sul nos pau de arara.

"Passageiros para o Sul, queiram tomar os seus lugares... E boa viagem!" Mas o que nós escutamos não foram estas palavras que provocam despedidas nos aeroportos. Era uma voz sonora como um "aboio", arrastada ao sabor do sotaque nordestino:

"Quem comprou passagem prô Rio e São Paulo pula logo no caminhão que nós vamos virá mundo. [...]

Gaiolas encarcerando papagaios pendiam da cobertura, e pequenas redes de crianças balançavam sobre as cabeças da boiada humana. Mães enfermiças pediam licença aos vizinhos:

- Meu senhor, o senhor deixa eu botá meu menino nas suas costas? Ele não pesa nada não.

Naquele inferno de joelhos e cotovelos, sentimos, desde logo, os cabos das peixeiras que nos cutucavam os rins. As caras, em geral, eram admiráveis close-ups. Rostos terrosos, vincados derugas. Outros amarelos e empapuçados. Outros esquivos, estilo Belzebu de telas renascentistas.

- Tá todo o mundo dentro do caminhão?

- Tá, sim, Edmundo. Pode arrastar essa 'bexiga'."[...]

"Não, não há quem se acostume com a dureza dos bancos de um caminhão "pau-de-arara".

Basta uma hora de 'apertacunha' no lombo de um desses transportes, para se fica dormente da cintura para baixo. O remédio é estrebuchar, levantar de qualquer jeito, mesmo que seja para piorar a situação. $\mathrm{O}$ que interessa é mudar de posição, permitir a circulação do sangue pelo corpo, desenferrujar as juntas. [...] (Revista O Cruzeiro, 22 de outubro de 1955, p. 71-73)

Desde o contato com o "capataz", ou seja, o encarregado que organizava a entrada daqueles que desejavam fazer a viagem, até o trajeto, dificuldades, desconfortos, normas de conduta. Sobre esta última, descrevem o fato de que, exigia-se respeito às mulheres e que, caso o motorista faltasse com o respeito a alguma mulher do grupo, mesmo que solteira, os homens reuniam-se e vingavam a honra da moça, tirando a vida do motorista. Viajaram num caminhão com 108 pessoas, num fardo de oito toneladas. Segundo Mário, "Realmente era um negócio terrível. Mulheres com crianças e mulheres grávidas passavam mal. Em um saco, os viajantes levavam a comida: jabá (carne-seca) e farinha. Bebida, só quando paravam em um córrego.” Ainda segundo Mário, ao final de tudo isso, por pouco a reportagem não deixou de ser publicada, acabou sendo, e recebendo o maior prêmio nacional da época.

Orientando a leitura visual de uma página que trazia a imagem de pessoas com aparência desolada e o rosto angustiado de uma criança, lia-se: “O sertanejo foge do torrão natal para não morrer de fome".

O próprio autor se utilizava de um olhar autocrítico, ao legendar as páginas seguintes, divididas em 18 pequenos trágicos quadros, com adultos e crianças esmolando, vagando sem rumo, solo queimado, córrego seco, com a frase: "Nada mais fotogênico que a pobreza”. Única orientação 
textual da página, apontando para o que de fato vinha acontecendo e que se tornaria cada vez mais frequente na imprensa ilustrada: a imagem da miséria tornar-se-ia uma forma de espetáculo.

Além das expressões de dor do sertanejo, um conjunto de imagens característico de reportagens será o daquelas que dessem destaque à natureza desolada (figura 19 e 20). Na figura 19, a primeira foto nos coloca, em primeiro plano, diante do solo seco e das cactáceas que recobrem o terreno amplo, que se estende num segundo e num terceiro plano sem presença humana, numa vastidão de solo seco. Na página seguinte, uma fila de pessoas, munidas de latas e tonéis, é acompanhada por uma legenda totalmente disjuntiva que descreve uma situação que não se vê na imagem: "Campina Grande é hoje o quartel general dos flagelados do nordeste. A cidade está cheia de mendigos, pois outra coisa não são em aspecto e realidade, caboclos que chegam a toda hora do interior paraibano." A falta de conexão entre legenda e imagem, somado ao impacto do ambiente desértico da primeira imagem demonstra a intenção induzir o leitor a uma interpretação mais trágica sobre a cena.

Na figura 20, de 1956, novamente os elementos icônicos se fazem presentes: o solo seco, as árvores caducifoliadas, os restos do esqueleto do gado morto. O plano geral do cenário desértico da primeira imagem, acompanha a ideia de abandono, descrita no texto e na segunda imagem, na qual um sertanejo, em retirada, para um breve descanso. A seca dos primeiros anos da década de cinquenta fora violenta. O Ministério da Viação e Obras Públicas, na figura de seu ministro José Américo, enfrentou o período de forte seca, traçando para isso um plano de ação juntamente com organismos vinculados ao DNOCS - Departamento Nacional de Obras Contra as Secas, DNER Departamento Nacional de Estradas e Rodagens e DNEF - Departamento Nacional de Estradas de Ferro.

Com o objetivo de aquilatar os problemas advindos da seca, durante 15 dias o Ministro José Américo percorreu todo o Nordeste, para ter a dimensão do problema e, em uma Exposição que fez na Câmara dos Deputados, em 10 de novembro de 1953, informava ele que: 
Figura 19. Sede e fome no Nordeste.

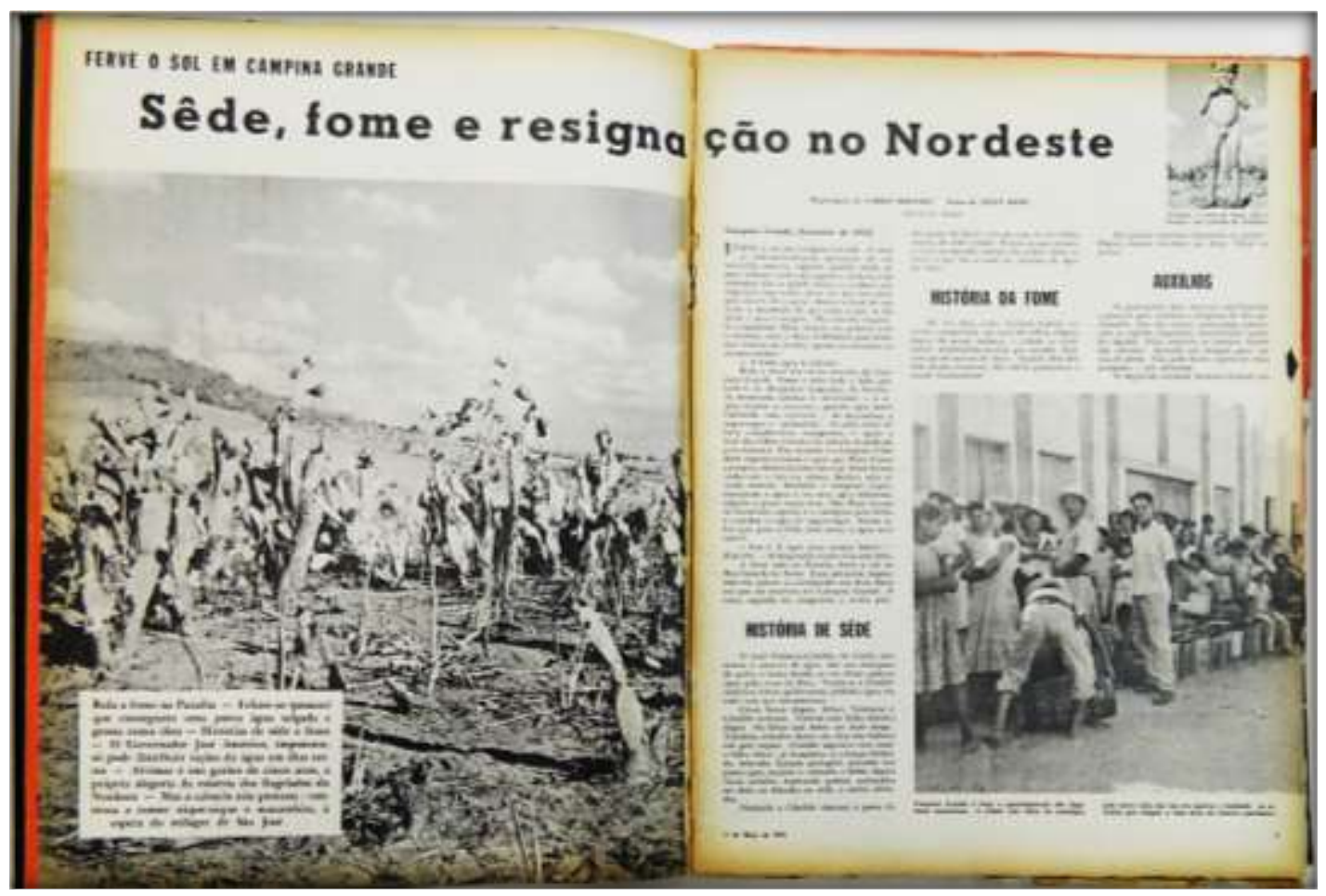

Fonte: Revista Manchete, 07 de março de 1953. Acervo Biblioteca Florestan Fernandes-USP.

Figura 20. Nas caatingas de Pernambuco.

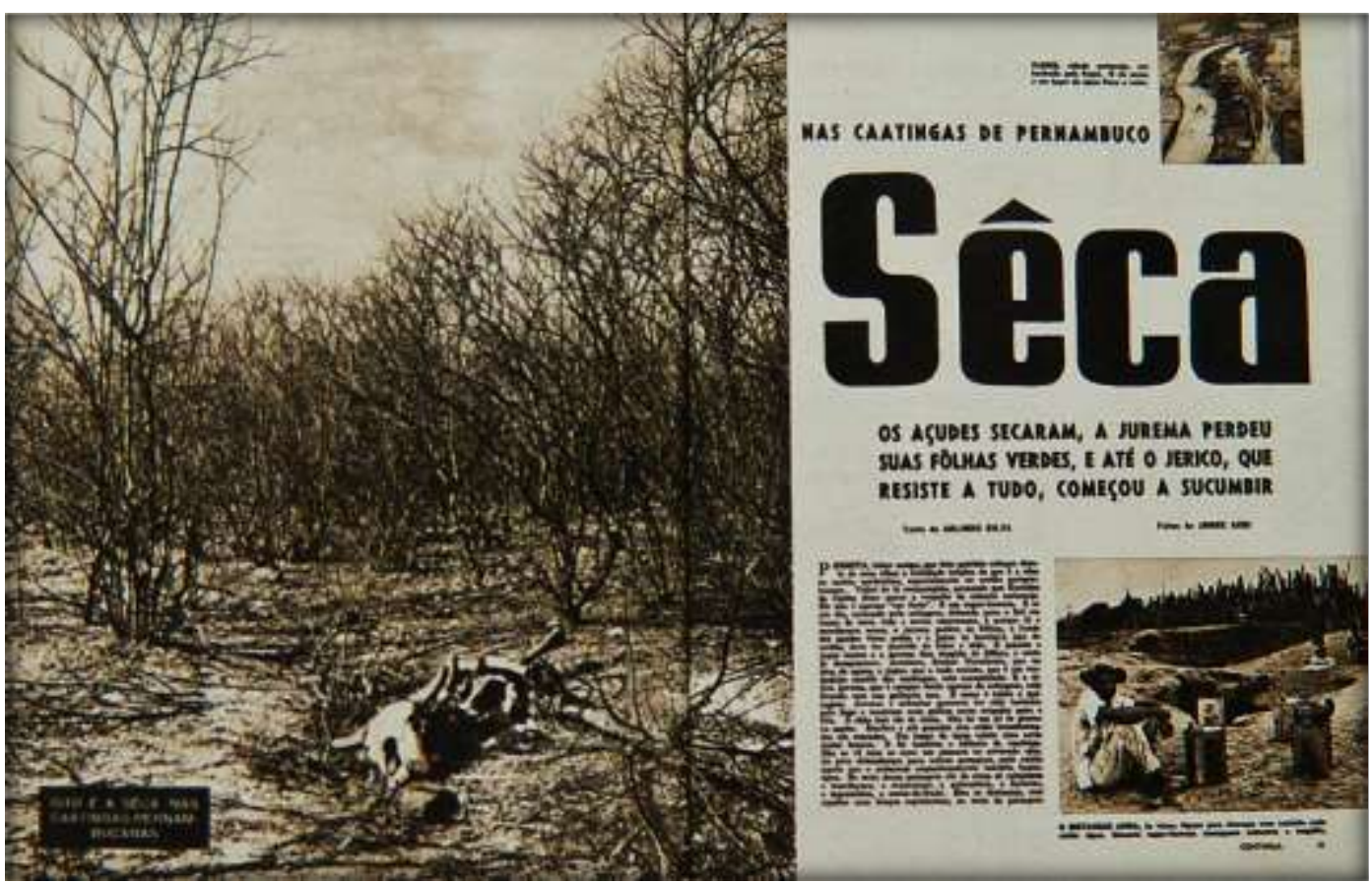

Fonte: Revista O Cruzeiro, 24 de março de 1956. COSTA, Helouise e BURGI, Sérgio. (orgs) As origens do fotojornalismo no Brasil. Um olhar sobre O Cruzeiro. 1940-1960. São Paulo: IMS, 2013. 
A seca é niveladora. Os pequenos fazendeiros chegaram a um estado de exaustão que os obriga a dispensar o pessoal e a pedir colocação. É uma agonia silenciosa. Só pedem o que fazer para viver. Nós aqui, tendo tudo, sentimos falta de tudo. Eles só têm uma necessidade; só precisam comer. Não é mais, propriamente, seca, apesar da falta de chuva. É pobreza e esgotamento. Se ainda há céticos, podemos ir até lá. Vamos ver a terra morta sustentando uma gente semimorta. E esgotam-se os mananciais, aprofunda-se o lençol freático. Cidades inteiras estão sedentas e muitas, por falta d'água, ameaçadas de evacuação. Foi o que vi. ${ }^{56}$

Embora a presença do clima semiárido ${ }^{57}$, seja um fator determinante para a ausência de oportunidades de trabalho nas áreas do sertão seco, o tipo de propriedade - como apontam os relatórios publicados no Boletim do Conselho de Colonização e Imigração, nos anos de 1940 - as relações de trabalho e o atraso tecnológico, juntos formariam um conjunto de fatores que contribuíram para a manutenção dos baixos níveis de vida das populações nordestinas. Em $O s$ “indesejáveis" na cidade: as representações do retirante da seca, Ferreira e Dantas (2001), apontam para uma questão importante para os autores, nem toda leva de migrantes formava-se por conta de catástrofe natural, mas também e principalmente pelas escolhas, desmandos e descasos das políticas públicas do período. A seca teria sido eleita, tanto pelos estudiosos das primeiras décadas do século XX, quanto pelo governo e também pelas elites locais, como a verdadeira responsável pela emigração; compreendido o fenômeno dessa maneira, para Ferreira e Dantas, os agentes sociais isentavam-se da responsabilidade em relação ao processo de expulsão do homem de sua terra. Entre os períodos de 1919 e de 1931, houve migração - porque não houve investimento - mas não houve seca. Dessa forma, num período como o do entre guerras, os investimentos no café e na indústria paulista, estimularam, não apenas a migração do capital, mas também a dos homens, em busca de oportunidades.

Tal qual fora feito anteriormente durante a seca de 1932, entre 1951 e 1953, as principais ações para conter o problema estavam relacionadas à criação de frentes de trabalho, nas rodovias e ferrovias, os homens partiam para as frentes de trabalho e, em grande número, enquanto as

56 Conforme pronunciamento feito por Joaquim Osterne Carneiro, quando do lançamento da plaqueta "José Américo no contexto da problemática da região semi-árida do nordeste brasileiro" ocorrido na fundação casa de José Américo, em 14 de junho de 2005. Disponível em: http://www.alanepb.org/downloads/osterne_11.pdf. Acesso em 10 de maio de 2010.

57 OLIVEIRA, Lucia Vanir Alves. O migrante nordestino, a cultura e a formação de territórios em Caldas Novas/Goiás. Uberlândia, Dissertação de Mestrado, 2005. 
mulheres ficavam com os filhos, à espera do retorno do marido. Muitos não retornavam e, à medida que o trabalho acabava e o salário não vinha, migravam para o Sudeste.

Entendamos, portanto, que os países do Norte, como os entrevistados de Ely Estrela chamavam os estados do Nordeste, compunham um universo imagético distante para as populações ao sul, a imprensa, mais esta que a literatura - em virtude do baixo índice de escolarização e também da precariedade da produção e distribuição das obras literárias - era a principal responsável por informar sobre os fatos e as formas daquele mundo distante. Segundo Albuquerque, era por meio de espetáculos, jogos, festas, feitas para arrecadar fundos para as vítimas do flagelo, que os sulistas ouviam falar de seus irmãos do Norte. ${ }^{58}$

O esforço por entender os valores culturais do outro, não eram o foco do jornalismo naquele momento, na reportagem sobre as feiras do sertão nordestino, por exemplo, Carlos Moreira, pela Manchete $^{59}$, abria sua reportagem com duas fotos, tomando praticamente a página inteira, com o seguinte rodapé: "Enquanto a mãe vende a colheita de uma semana, a menina se inicia nos mistérios do comércio feirense. Porque na miséria já está iniciada já há muito. Desde que nasceu”.

As feiras livres estão inteiramente ligadas à paisagem do Nordeste. Com seus tipos característicos - que são os próprios tipos nordestinos - não há Nordeste sem feira. [...] A feira mais triste que eu já vi na minha vida de andanças nordestinas foi em Canudos. A tristeza da feirinha era a tristeza da cidade e tristeza de uma gente marcada por uma vida de horrores numa paisagem agressiva e de perspectivas. Uma feira sem barracas e sem farturas, apenas um amontoado de coisas que não iam além da farinha ou da carne de bode salgada. Mas há outras famosas. Três delas principalmente: a de "Caruaru", a de "Campina Grande" e a de "Feira de Santana". ${ }^{60}$

A paisagem e o homem permaneceriam ainda integrados, como na leitura de Euclides, dando a impressão de que os limites da natureza física refletiam como limites para a realização das gentes do sertão. A frase final da matéria: "Feiras são retratos do Nordeste em seus contrastes gritantes: fartura imensa de uma terra esgotada e a miséria do homem mais esgotado do que a

58 ALBUQUERQUE JR. D. M. A invenção do nordeste e outras artes. Recife: Fundação Joaquim Nabuco, Ed. Massangana; São Paulo: Ed. Cortez, 1999, p. 69. Coloca a questão da construção das representações a partir de alguns modelos como a literatura, a música e a telenovela.

$59 \quad$ Na matéria, a intensidade do choque que o repórter deseja exprimir, diante da pobreza, é marcada por frases como: "Esta mulher é do Nordeste, da Bahia, Feira de Santana, para ser mais preciso. Mas poderia ser da índia, porque não há nenhuma diferença. Seu único alimento é a farinha." Feiras livres. Grandeza e Miséria do Nordeste. Revista Manchete, 18 de junho de 1953. Reportagem de Carlos Moreira, p. 49.

60 Revista Manchete, 18 de julho de 1953. Feiras livres. Grandeza e Miséria do Nordeste. Reportagem de Carlos Moreira, p. 50. 
terra”, é a confirmação desta percepção. A feira era descrita em comparação às dos centros mais urbanizados do sertão, sem que se tivesse a preocupação em entender a relação entre a cultura local de Canudos e seus próprios fenômenos culturais, no caso, a feira.

Pensamos cultura, aqui, na mesma perspectiva que a coloca Geertz, que, ao criticar a concepção estratigráfica - que compreenderia o homem como a sobreposição dos fatores biológicos, psicológicos, sociais e culturais entre si - aponta a impossibilidade de pensarmos as culturas a partir de "universais" que norteariam sua compreensão. Para Geertz, em virtude do impasse criado pela inadequação da teoria de conceito estratigráfico, a compreensão adequada de "homem”, não estaria na busca por universais, mas pelas particularidades. Geertz acreditava que “nas particularidades culturais dos povos, suas excentricidades e 'esquisitices' pudéssemos encontrar algumas das revelações mais instrutivas sobre o que é genericamente humano, sendo que a principal contribuição da ciência antropológica à construção - ou reconstrução - de um conceito do homem, talvez fosse, justamente, mostrar-nos como encontrá-las" ${ }^{\prime 61}$.

Quanto ao homem do sertão, o que as fontes nos mostram é que, o sertanejo, em especial, e principalmente, o sertanejo-ícone eternizado por Euclides da Cunha, apresenta duas faces, uma, tal qual seria posteriormente a do caipira de Lobato, como um homem vencido pelo meio, um homem sem forças:

O sertanejo é, antes de tudo, um forte. Não tem o raquitismo exaustivo dos mestiços neurastênicos do litoral. A sua aparência, entretanto, ao primeiro lance de vista, revela o contrário. Falta-lhe a plástica impecável, o desempeno, a estrutura corretíssima das organizações atléticas. É des gracioso, desengonçado, torto. Hércules-Quasímodo, reflete no aspecto a fealdade dos fracos. O andar sem firmeza, sem aprumo, quase gingante e sinuoso, aparenta translação de membros desarticulados. Agrava-o a postura normalmente abatida, num manifestar de displicência que lhe dá um caráter de humildade deprimente. A pé, quando parado, recosta-se invariavelmente ao primeiro umbral ou parede que encontra; a cavalo, se sofreia o animal para trocar duas palavras com um conhecido, cai logo sobre um dos estribos, descansando sobre a espenda da sela. Caminhando, mesmo a passo rápido, não traça trajetória retilínea e firme. Avança celeremente, num bambolear característico, de que parecem ser o traço geométrico os meandros das trilhas sertanejas. E se na marcha estaca pelo motivo mais vulgar, para enrolar um cigarro, bater o isqueiro, ou travar ligeira conversa com um amigo, cai logo - cai é o termo - de cócoras, atravessando largo tempo numa posição de equilíbrio instável, em que todo o seu corpo fica suspenso pelos dedos grandes dos pés, sentado 
sobre os calcanhares, com uma simplicidade a um tempo ridícula e adorável. (CUNHA, 1982, p. 91)

Mas existe também uma outra face, apontada pelo próprio Euclides, que seria pouco explorada nos romances regionalistas de 1930 e nas reportagens sobre o flagelo das secas, mas que seria um dos motes para o olhar da música e do cinema sobre o sertanejo no final dos anos de 1940 e durante a década de 1950. Falamos do sertanejo como homem forte, de coragem, que reage com fúria contra os problemas; esta representação do sertanejo, que irá consolidar-se na figura do cangaceiro e dos "cabras", também tem no olhar de Euclides ${ }^{62}$ suas origens:

Entretanto, toda esta aparência de cansaço ilude. Nada é mais surpreendedor do que vê-la desaparecer de improviso. Naquela organização combalida operam-se, em segundos, transmutações completas. Basta o aparecimento de qualquer incidente exigindo-lhe o desencadear das energias adormecidas. O homem transfigura-se. Empertiga-se, estadeando novos relevos, novas linhas na estatura e no gesto; e a cabeça firma-se-lhe, alta, sobre os ombros possantes aclarada pelo olhar desassombrado e forte; e corrigem-se-lhe, prestes, numa descarga nervosa instantânea, todos os efeitos do relaxamento habitual dos órgãos; e da figura vulgar do tabaréu canhestro reponta, inesperadamente, o aspecto dominador de um titã acobreado e potente, num desdobramento surpreendente de força e agilidade extraordinárias. Este contraste impõe-se ao mais leve exame. Revela-se a todo o momento, em todos os pormenores da vida sertaneja - caracterizado sempre pela intercadência impressionadora entre extremos impulsos e apatias longas. (CUNHA, 1982, p.179-180)

Torna-se, portanto, importante notar que, embora, o sertão e o sertanejo tenham sido, com o tempo, fortemente associados às secas e a toda sorte da miséria humana, o Nordeste, mesmo aos olhos da imprensa, não se reduzia ao sertão.

62 Sobre a interpretação antitética do sertanejo, em Euclides, a Profa. Dra. Sandra Vasconcelos, em seu artigo Migrantes dos Espaços (sertão, memória e nação) explica que: “As célebres antíteses que consagraram o sertanejo, na pena euclidiana, como guerreiro combativo e valente mas feio e mirrado se marcaram as contradições de um intelectual orientado pelas teorias raciais de seu tempo, também demonstram o quanto a capacidade de resistência desses homens em situações muito adversas acabou por ganhar a admiração do escritor, impactado pela tragédia que se descortinou diante de seus olhos e da qual foi testemunha e repórter. A condenação inicial da "sub-raça" do lugar então à denúncia da violência, do atraso secular, do abandono social e do isolamento a que foram submetidas essas populações pelo "litoral civilizado" e a conclusão, nas últimas páginas do livro, é no mínimo potente: o sertanejo é a rocha viva da nossa raça, constitui o cerne de uma nacionalidade. Espaço da barbárie e do atraso cultural, os sertões surgiam, assim, como o lugar onde iriam se desenvolver a verdadeira nacionalidade e o brasileiro do futuro, ao passo que o sertanejo ganhava estatuto de personagem definitivo nas letras nacionais." VASCONCELOS, Sandra Guardini Teixeira. "Migrantes nos espaços (sertão, memória e nação)". Revista do CESPUC, Belo Horizonte, UFMG, v. 22, n. 30, pp. 67-81, jan./jun. 2002. 


\section{2 - MIGRANTE: O HOMEM SEM LUGAR.}

O sertanejo, assoberbado de reveses, dobra-se afinal. Passa certo dia, a sua porta, a primeira turma de "retirantes". Vê-a, assombrado, atravessar o terreiro, miseranda, desaparecendo adiante numa nuvem de poeira, na curva do caminho... No outro dia, outra. E outras. É o sertão que se esvazia.

Euclides da Cunha

Em seu livro Os sampauleiros: cotidianos e representações, Ely Souza Estrela, ao pesquisar aqueles que deixavam o interior da Bahia em direção a São Paulo, opta por não referirse a eles como migrantes, decidindo pelo termo "sampauleiros", primeiramente, por reconhecer no termo maior potencial para exprimir o fenômeno estudado, e também porque o termo migrante, não fora utilizado em nenhum momento pelos próprios indivíduos entrevistados. Durante a pesquisa, estes definiam a si e aos outros, que haviam deixado o sertão em direção a São Paulo retornando, posteriormente como "sampauleiros" (ESTRELA, 2003).

A expressão sampauleiro, como demonstra Estrela, é utilizada há muito tempo no Alto Sertão da Bahia, para identificar o retornado das terras do Sul, o sertanejo que vai e volta de São Paulo. Em seu artigo Sampauleiros traficantes: Comércio de Escravos do Alto Sertão da Bahia para o Oeste Cafeeiro Paulista, Erivaldo Fagundes Neves (2000), nos apresenta o comércio de escravos empreendido por sampauleiros, baianos retornados de São Paulo - associados a parentes e conterrâneos, fazendeiros no Alto Sertão.

Neves utiliza a antiga expressão e apresenta o registro do costume de empregá-la, feito por João Antônio dos Santos Gumes, memorialista e autodidata que, em 1927, publicou de prelo próprio peças teatrais e romances, dentre eles $O$ Sampauleiro: romance de costumes sertanejos, (Neves, 2000) que abordava justamente este movimento de emigração e retorno de indivíduos, entre São Paulo e os sertões do Nordeste. Estrela apresenta a interpretação poética de Pedro Calmon sobre o sampauleiro:

Sampauleiro - é o nome que se dá, no sertão da Bahia, ao lavrador que emigra. É o homem que São Paulo attrahe. É a árvore desraizada, o retirante, o que abandona a própria terra, o descrente, o ambicioso, o despeitado, o caçador de riquezas, andejo e inquieto descendente dos bandeirantes e 
dos povoadores. No phenomeno dos rytmos migratórios, o sampauleiro é um irmão germano do cearense, que vae fartar nas caudaes da Amazônia a sede trágica dos seus cacimbaes. Eterno iludido, a miragem da prosperidade e da abastança lhe sorri para além dos horizontes chãos da sua terra, quente e amarella. Tudo sacrificou ao seu sonho, a fazenda, a criação, o amor de filho, o amor de pae. (ESTRELA, 2003, p. 71)

No que se refere ao campo das representações, o sampauleiro era, desde há muito compreendido como um aventureiro, aquele que se lança em busca de oportunidades e volta trazendo as notícias das terras distantes ${ }^{63}$. Ainda em Estrela, lemos que:

O sampauleiro era também um desbravador e, de certo modo, modernizador das comunidades do alto sertão [...] não custa lembrar que, quando os meios de comunicação de massas praticamente inexistiam, no Brasil, o viajante tinha importante papel social. Assim sendo, a prática do constante ir-e-vir colocava o sampauleiro numa posição singular. Ele era um dos poucos meios de comunicação de que dispunham as comunidades sertanejas, constituindo fator de unidade nacional, colocando-se como elo entre o moderno estado capitalista e as regiões sertanejas da Bahia. (ESTRELA, 2003, p. 73)

A autoimagem dos sertanejos emigrados, entrevistados por Estrela é, portanto, diferente daquelas representações construídas pelas fotorreportagens de Mario Moraes - em Os paus-dearara (figura 18). Em Moraes, o destaque era todo para o sofrimento e para a degradação a que os migrantes se submetiam, para fugirem da miséria do sertão. Em Estrela, os entrevistados, ao identificarem quem migra com o sampauleiro, destacam o ímpeto e a coragem daquele que se aventura a ir em busca de novas oportunidades e novas terras. A utilização do antigo termo sampauleiro - em detrimento de migrante, na fala dos sertanejos, é ainda explicada pela autora a partir da apresentação de duas outras hipóteses.

A primeira hipótese da autora seria a de que os termos migração e migrante teriam assumido uma conotação extremamente pejorativa através do tempo e que, desta forma, as pessoas envolvidas nesse processo de emigração, perceberiam as implicações sociais do termo e assim, sabiamente, não usam o epíteto com o intuito de se preservarem dos sofrimentos e das humilhações sofridas quando de seu deslocamento. Estrela destaca ainda que, ao descrever o deslocamento, os entrevistados se referiam à mudança, termo que conseguiria de fato abarcar o processo vivido pelos entrevistados de forma bastante ampla, uma vez que estaria ao mesmo tempo apontando para a 
mudança de cidade, estado bem como a mudança de vida e mesmo de referenciais. Jader Moreira Lopes (2003) descreve a mesma situação ao entrevistar um grupo de crianças que concluem, após conversa com o pesquisador, que o conceito de migrantes não deveria ser atribuído a elas que, por terem se deslocado numa mesma cidade, consideravam-se mudantes. ${ }^{64}$

Sobre essa característica de mobilidade, Maria Cristina Wissembach nos explica que se trata de uma antiga solução de nossas populações pobres:

É necessário pontuar as interseções entre mobilidade e a sobrevivência de brancos pobres, mestiços e forros: eram as transumâncias que lhes davam maleabilidade necessária para escapar da penúria e da fome, da violência que se entrelaçava ao mandonismo local e aos recrutamentos forçados, que permitiam que fosse contornada a posse desigual das terras, dos latifúndios, fugir das intempéries que inviabilizavam o sobreviver. (WISSEMBACH, 1998, p. 59)

No mesmo caminho da análise de Estrela, que apresenta como hipótese de rejeição aos termos migrante e migração a existência de uma carga pejorativa neles implícita, Abdelmalek Sayad, em A Imigração: ou os paradoxos da alteridade, vê nos dois conceitos, além da carga pejorativa que se consolida por meio da interpretação do olhar do outro sobre aquele que parte, também uma grande força de negação que se produz no interior de quem migra, pois o ato de partir e novamente fincar raízes, produziria uma dupla e sofrida contradição: não se sabe mais se se trata de um estado provisório que se gosta de prolongar indefinidamente, ou ao contrário, se se trata de um estado mais duradouro, mas que se gosta de viver com um intenso sentimento de provisoriedade $^{65}$. A relação paradoxal entre o provisório e o definitivo, consagra um momento muito forte na reflexão de Sayad, que assim, amplia a dimensão da questão proposta em Estrela, uma vez que para Sayad o que está em questão não é a migração como sinônimo de uma qualificação pejorativa, mas a migração como experiência traumática. Este sentimento paradoxal, ao qual se refere Sayad, pode ser observado, por exemplo, tanto na fala de imigrantes italianos, das primeiras décadas do século, quanto na fala dos migrantes vindos do sertão nordestino, que embora optem pelo abandono da terra, lutam para que não se percam dos valores que definem sua própria identidade. O sentimento de provisoriedade seria alimentado, porque, no limite, expressa uma luta interna do migrante, o conflito entre a perda do referencial de identidade, o desejo de

64 LOPES, Jader Janer Moreira. Então somos mudantes: espaço, lugar e territórios de identidades em crianças migrantes. Tese de doutorado UFF, julho de 2003.

65 SAYAD, Abdelmalek. A Imigração ou os paradoxos da alteridade. São Pulo: EDUSP, 1998, p.45. 
continuar pertencendo ao seu território e, de outro lado, a realidade que se impõe, concretizandose na necessidade de adaptação, de recriação de novos laços identitários, novos costumes, novas redes de solidariedade, que poderão fundamentar as bases de uma cultura própria, de uma cultura migrante.

Entre os anos de 1930 e 1950 o deslocamento interno de mão de obra seguiu, fundamentalmente, a direção das fronteiras agrícolas do Centro-Oeste e do Norte e também, rumo às metrópoles do Sudeste, conforme registros da SUDENE. Em 1940, mais de setecentos mil nordestinos emigraram, sendo que deste total, aproximadamente, $30 \%$ dirigiu-se para o CentroOeste e Norte e $67 \%$ dirigiram-se para o Sudeste, destes, a metade para São Paulo. Entre os anos de 1950 e 1970, esta tendência se acentuou, subindo os números as escalas elevadas: um milhão de emigrados dos estados do Nordeste em 1950; mais de dois milhões em 1960 e mais de três milhões e meio em $1970^{66}$. Com duas tônicas muito diferentes, os retirantes e a seca apareceram em matérias de 1953 e 1954, da Revista Manchete, ambas colocando a questão da presença dos emigrados das secas nas cidades.

Em, Salvem-se ao menos as crianças, com reportagem de Carlos Oliveira e fotos de Gervásio Batista ${ }^{67}$, embora o foco sejam as crianças abandonadas "que infestam a Central, a Galeria Cruzeiro e os bares da Esplanada e a Rua do Ouvidor”, na segunda página da reportagem, tomando metade da área de impressão se encontra uma foto em preto e branco, de um grupo de pessoas sentadas numa escadaria. A foto (figura 21) de Gervásio Batista, é acompanhada pela legenda: "Os nordestinos saltam no Rio com a filharada atrás. Sentam-se em qualquer escada e pedem. As crianças choram, rolam no chão, perseguem os transeuntes. Quem as salvará?”

Embora a foto traga consigo um grande teor dramático, a matéria segue falando das crianças, seu estado de abandono dado o crescimento da miséria, da criminalidade e das favelas na cidade.

66 SUDENE $n^{\circ}$ 24. Série População e Emprego. Tendências das migrações no Nordeste de 1940-1980, p.14 e 15 , tabelas 05 e 06.

67 Carlos Oliveira foi parceiro de reportagem de Gervásio Batista - que fotografava para também para Darwin Brandão, que costumava fazer, ele próprio texto e imagem de suas matérias. Jornalista e fotógrafo, o baiano Gervásio Batista, mudou-se para o Rio de Janeiro nos anos 50, a convite de Assis Chateaubriand, para trabalhar em O Cruzeiro, mas em 1954, foi para a revista Manchete onde permaneceu até o fechamento da mesma, em 2000. 
Figura 21. Salvem-se ao menos as crianças.

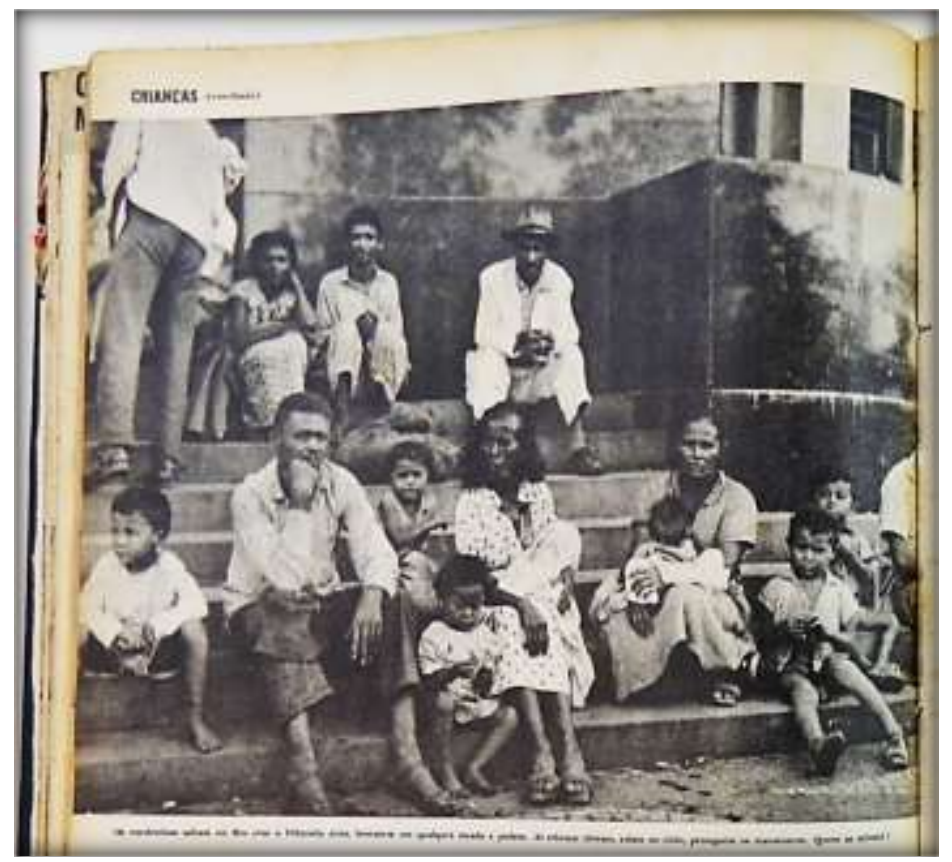

Fonte: Revista Manchete. 21 de novembro de 1953, p. 26. Acervo Biblioteca Florestan Fernandes - USP. "Os nordestinos saltam no Rio com a filharada atrás. Sentam-se em qualquer escada e pedem. As crianças choram, rolam no chão, perseguem os transeuntes. Quem as salvará?”

Figura 22. Salvem-se ao menos as crianças.2
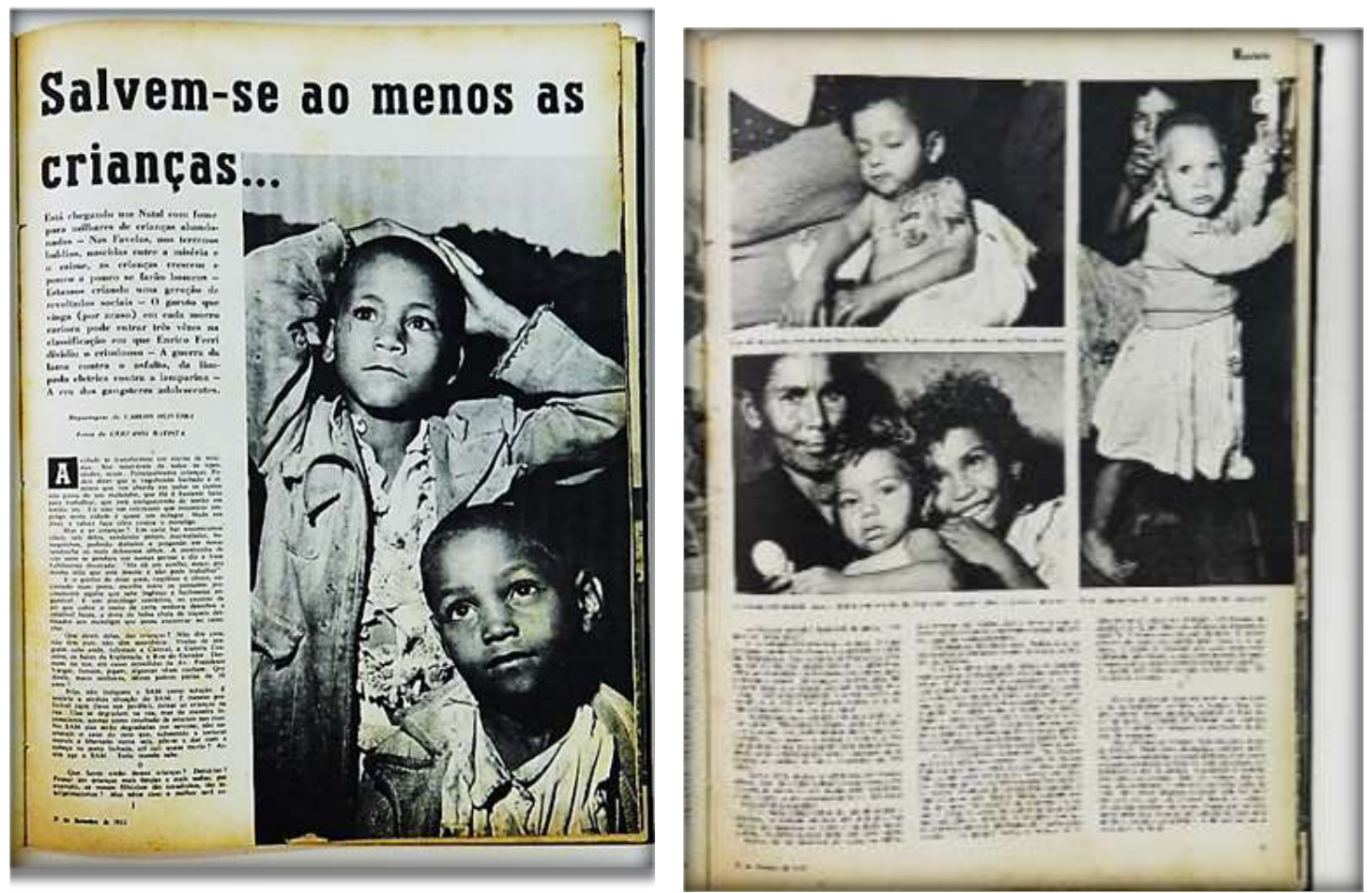

Fonte: Revista Manchete. 21 de novembro de 1953, p. 25, 26, 27. Acervo Biblioteca Florestan Fernandes. 
O texto que segue à foto (figura 22), enfatiza o fato do Estado não ter como abrigar as crianças abandonadas, e segue pontuando o que o repórter considera o cerne da questão: a migração traria o abandono infantil, e esse, por sua vez, o crime e a violência.

Você conhece um morro carioca? Concedo que não conheça. Mas não pode negar que a maior praga dessa terra é o bando de malandros que infesta determinadas zonas. Entrou pro samba, virou lenda e extravagância contada como oitava maravilha nos Estados Unidos e adjacências, um tipo curioso muito nosso familiar: um negro alto e fino metido dentro de um paletó cintado e umas calças boca "padilha", calçando sapatos "carrapeta" - de preferencia bicolores - e debaixo de um chapéu pontudo. Objetos de uso: lenço branco no bolso da frente, navalha prêsa na meia e, quase sempre, um dente de ouro (ou dois). O oficio desse tipo aparece todos os dias nos jornais. Ora é batedor de carteiras, ora assaltante, ora gigolô. [...] Geração perdida! Resultado da Guerra. [...] Mas é outra coisa. Se há guerra, provocando o nascimento desses facínoras, é não a segunda guerra mundial, mas a eterna, feroz, vergonhosa guerra dos morros, não contra canhões e bombas atômicas, contra a fome e a própria sociedade, que armou uma fronteira convencional mas impecável e, para quem se vê restringido por ela, palpável, uma barreia erguida entre o asfalto e o morro, entre o edifício de apartamentos e o barracão pendurado na ladeira. (Revista Manchete. Salvem-se ao menos as crianças. 21 de novembro de 1953, p. 26)

A imagem dos retirantes aparece mais para exemplificar, para ilustrar, o que o repórter e o fotógrafo acreditam ser uma situação típica das cidades, geradora do abandono infantil e, portanto, responsável pela deformação da geração seguinte:

O pirralho cresce hoje no morro da Mangueira está aprendendo a adorar Mauro Guerra e Lilico ${ }^{68}$. Quando fizer vinte anos êle comprará um revólver e nos tocaiará num terreno baldio. Iremos morrendo um atrás do outro, e êle nos saqueando e fugindo, até que a polícia o agarre em sensacional diligência (no outro dia os jornais dirão em letras garrafais: "O crime não compensa"). Imediatamente oitenta cronistas escreverão sobre o acontecimento e vinte estudiosos exclamarão: - Geração perdida! Resultado da guerra! Não pode ser outra coisa! (Revista Manchete. 21 de novembro de 1953, p. 26)

A reação descrita associa-se àquela, muito anterior, dos moradores das capitais nordestinas que, nas secas de 1877 e 1915, solicitavam às autoridades que impedissem a entrada dos retirantes, temendo a desordem. A imagem da figura 21, está associada ao texto maneira tangencial. A

\footnotetext{
${ }^{68}$ Sobre a quadrilha de Mauro Guerra, do Morro da Mangueira, Michel Misse, explica que, "No final de 1953, montou uma quadrilha com os « irmãos » Balico, Gazinho, Mimi, Misael, Cutu e Batatinha. Meteu bronca nos assaltos, apavorou a população. Perpétuo resolveu prender o bando. A caçada durou uns seis meses. A turma não dava refresco, atirava pra matar. » Apud Ribeiro, Octavio. Barra pesada. Rio de Janeiro: Editora Codecri, 1944, p. 255. Sobre Lilico, no tópico Bandidos, quadrilhas e suas áreas, Michel Misse, explica que se tratava de um conhecido bandido dos anos de 1950: Lilico (Manuel Mendonça Sereno), expulso do exército por assalto à mão armada. O marginal praticara os roubos quando ainda soldado. Misse, Michel. MALANDROS, MARGINAIS E VAGABUNDOS \& a acumulação social da violência no Rio de Janeiro. Tese apresentada ao Instituto Universitário de Pesquisas do Rio de Janeiro, em 20 de dezembro de 1999.
} 
legenda da imagem explica uma primeira intenção: demonstrar que os retirantes não têm onde ficar, e que suas crianças ficariam ao léu; enquanto isso, o corpo do texto se atém a falar da violência crescente nas cidades, e da marginalidade crescente nas favelas. Dessa forma a associação entre retirantes, favelização da periferia, abandono, violência e criminalidade não é feita de maneira explícita e direta, mas de forma associativa e indireta, fechando a mensagem com a ideia de que se nada for feito, essas crianças - semi-abandonadas - seriam os marginais de amanhã, uma geração perdida.

Já no texto de Henrique Ponguetti ${ }^{69}$, o autor se utiliza de uma boa dose de ironia para o texto da abertura da Revista Manchete de janeiro de 1954, a seca, a migração e o migrante se tornam um mote, para o jornalista dissertar sobre a frivolidade da elite carioca:

Algumas famílias de Copacabana, sem água há vários dias, precipitaram suas férias de verão e foram esperar o ano novo na montanha, perto das nascentes. Escrevi a um amigo meu nordestino dando nome e endereço dos retirantes. Êle vinha me escrevendo, em estilo euclidiano, uma série de cartas sobre a última sêca: assumia comigo ar um pouco jactancioso de dono do flagelo, e eu procurei documentar-me bem para humilhá-lo. Sim, meu caro Erastóstenes Feijó, retirantes há também aqui, perto do mar. Não explore mais o privilégio geográfico do polígono sinistro: nós também temos. (Revista Manchete, 16 de janeiro de 1954, p. 3.)

Apresentando os "retirantes de Copacabana" como vítimas de uma seca de luxo, Ponguetti, vai descrevendo um Rio de Janeiro frívolo e sensual, onde o asseio seria levado à sério, a ponto das senhoras da sociedade não se furtarem aos banhos de banheira com água mineral, acrescida de perfume, colocado meticulosamente em sua superfície. Após tais descrições, contudo, Ponguetti pondera sobre o que lhe parece ser o Nordeste:

Lá em cima é bem diferente, eu sei. Vocês vivem uma vida ascética numa natureza sem sensualidades, torturante como um cilício. A água difícil das cacimbas lembra-lhes a com que jesus lavou os pés dos discípulos, e não a do banho meticuloso e voluptuoso da mulher adúltera. Água reduzida e santa, de pia de igreja, água de puros, mais preocupados com a sede da terra do que com a limpeza do corpo. Esse corpo que se fecunda sem olfato nos bivaques do êxodo enquanto crianças

69 Henrique Pongetti (1898 - 1979). Amigo pessoal de Adolfo Bloch, autor, comediógrafo, conhecido pelas várias obras comercialmente bem-sucedidas, encenado por Raul Roulien, Renato Viana, Ziembinski e Eugênio Kusnet, entre outros. Em 1950, uma das peças que, sob a direção Ziembinski, revela o talento de Tônia Carrero, tornando-se um fenômeno de bilheteria e rendendo-lhe a consagração definitiva. Em plena ditadura de Getúlio Vargas, Pongetti dirige o Teatro Trianon, onde encena Tibério, satirizando os regimes autoritários, e Sem Coração, um musical despretensioso. Funda, a seguir, uma companhia de micro-revistas denominada Novíssima, associado a Francisco Pepe. No Palácio do Catete, a pedido de D. Darcy Vargas, mulher do ditador, encena o espetáculo Joujoux e Balangandans, evento que reúne 300 integrantes da alta sociedade carioca. Enciclopédia Itaú Cultural. Disponível em http://migre.me/hMahD. Acesso em 20 de novembro de 2013. 
exaustas e de sangue aguado pela fome e pela sede expiram vendo repuxos e cascatas em miragens. (Revista Manchete, 16 de janeiro de 1954, p. 3.)

Servindo-se um da imagem que impacta e constrange e o outro da ironia, os dois jornalistas colocaram no papel uma questão que já vinha sendo discutida desde a década de 1940, mas que no pós-guerra, se tornava mais presente: a presença dos emigrados da seca (ora como mão de obra, ora como "sem lugar") nas metrópoles brasileiras.

Sobre as dimensões da migração nordestina para o Sudeste, entre as décadas de 1930 e 1950, o que se pode inferir é que, dadas as suas dimensões e características, alguns processos emigratórios podem e devem ser compreendidos como movimentos diaspóricos. O volume de indivíduos envolvidos, as dimensões temporais, culturais, sociais e econômicas do fenômeno, a formação de memória ligada ao processo de partida e mesmo um status próprio adotado por aqueles que foram e por aqueles que retornaram, caracterizam movimentos populacionais que produzem profundas marcas na história de uma sociedade. No caso brasileiro, do final do século XIX, bem como por todo o transcorrer do século XX, a transferência das populações nordestinas, afetadas pelas secas e pela falta de políticas efetivas de desenvolvimento, para a Amazônia e para o Centro-Sul, constitui-se em nosso caso mais concreto de diáspora. Sobre a diáspora dos nordestinos, nos diz Aziz Ab'Saber:

Os nordestinos em sua fantástica diáspora ajudaram a povoar distantes regiões da Amazônia. Nos últimos 50 anos colaboraram na construção de significativa parte das grandes e médias cidades brasileiras, além de ter ajudado a levantar edifícios de hospitais, cidades universitárias, fábricas, estádios e aeroportos, um pouco por toda a parte do mundo urbano-industrial de um país verdadeiramente continental. (AB'SABER, 1999, p. 44)

Na busca pelo dimensionamento dos efeitos do fenômeno migratório para o indivíduo, para as sociedades e para a cultura, tanto no cenário nacional quanto no cenário internacional, o aparato conceitual de cada uma das Ciências Humanas tem nos auxiliado a compreender, por meio de pesquisas sobre os lugares de origem dos migrados, bem como por meio dos estudos sobre um ou mais lugares de destino das migrações, não somente os efeitos de ordem econômica, mas também as mudanças nas relações interpessoais e interculturais, as contestações, as transformações e negações de valores socioculturais.

Segundo Nigel Rapport (2002), nas discussões atuais sobre História e Antropologia, "diáspora" tornou-se uma palavra-chave para os estudos da preservação e da regeneração das identidades culturais originais das diferentes comunidades que foram levadas à dispersão. 
Cotidianos, ideais de liberdade, equilíbrio e honra, são experimentados pelo recontar de histórias sobre práticas e façanhas (de um passado vivido ou recriado), que sobrevivem graças a um esforço conjunto, produto da solidariedade e das relações entre aqueles de mesma sorte. Solidariedade esta que, por sua vez, é construída e mantida por meio de complexas redes de auxílio e mecanismos de representação sociocultural, instituições nacionais e mesmo transnacionais que transmutam continuamente espaço em lugar ${ }^{70}$.

Embora nos últimos séculos alguns grupos humanos tenham vivido essa mesma experiência de emigração e dispersão numa dimensão de incontestável dramaticidade - como no caso dos povos africanos e judeus - esse destino movediço de diferentes grupos, em diferentes lugares do globo, tem se tornado cada vez mais característico de nossos tempos. Não tendo surgido apenas nos tempos modernos e não tendo desaparecido com o término do escravismo colonial e das Grandes Guerras, o intenso trânsito de diferentes grupos humanos marca, cada vez mais, as sociedades do mundo contemporâneo, onde milhões de pessoas deslocam-se diariamente fugindo, da violência provocada pelas guerras, da fome, e principalmente, da desigualdade. Ao analisar esse processo, de abandono do lugar de origem, temos que, para os indivíduos e para as sociedades, uma de suas consequências mais marcantes é o sentimento de perda. Sobre esse sentimento, Rapport (2002) recorre às palavras do ensaísta sul-africano Lewis Nkosi, para quem, a sensação de falta de lar - homelessness - é uma marca profunda das culturas afro-americanas, uma vez que todas, sem exceção, ter-se-iam formado, no bojo da diáspora atlântica, do processo de abandono e resgate de referenciais; indo além, a análise de Rapport, estende o sentimento de homelessness a todos os grupos migrantes da atualidade compreendendo-o como a marca fundamental de nossos tempos, posto que não haveria volta ao lar para ninguém no mundo moderno, uma vez que a "consciência moderna" seria em si "alienada ou marginalizada", sendo, portanto obrigada a suportar a instabilidade radical da ruptura, do abandono, da partida e do deslocamento. Ao falar sobre os indivíduos oriundos da diáspora africana que se estabeleceram na América, Mintz e Price, discutem a questão da perda e da difícil reconstrução dos referenciais da cultura, apontando que:

Uma cultura, nesses termos, fica intimamente ligada aos contextos sociais em que são vivenciados e percebidos os laços afetivos. Com a destruição desses laços, a bagagem cultural de cada indivíduo

70 Pensamos lugar, conforme utilizado frequentemente pela geografia humana, como conceito que se remete ao sentimento de pertença, "o lugar é o espaço ao qual pertenço e me identifico". Ver em Santos, Milton. Pensando o Espaço do Homem. São Paulo: EDUSP, 2004. 
sofre uma transformação fenomenológica, até que a criação de novas estruturas institucionais permita a refabricação do conteúdo, baseado no passado - e muito distante dele. (MINTZ; PRICE, 2003, p. 71)

Este seria, portanto o drama dos grupos que possuem identidades hifenizadas, que experimentam o "viver entre dois mundos", no qual o movimento de abandono teria como resposta a necessidade de preservar e recriar costumes e memórias, como estratégia de sobrevivência dos princípios e valores mais profundos, da identidade e da cultura de um povo.

Ainda pensando nas sociedades contemporâneas, é importante observar que, embora a migração rural-urbana não seja um fenômeno recente, o êxodo rural, promovido pelo intenso processo de atração das cidades e consequente expulsão das áreas rurais ${ }^{71}-$ ou, nos dizeres de Rapport "o centripetismo global e o centrifuguismo regional" - seria, este sim, um resultado das transformações provocadas pela inserção das nações emergentes no processo de globalização. Contudo, embora a realidade do homem contemporâneo esteja definitivamente marcada pela condição global, na qual valores, costumes e princípios se mantenham em constante intercâmbio, não podemos nos esquecer das particularidades regionais que envolvem causas e efeitos, tanto dos movimentos de população, quanto da inserção nas relações globalizadas, e, embora existam, de fato, pontos de contato entre os diferentes processos diaspóricos, como aponta Rapport (2002), tal exercício reflexivo, deve evitar o risco de eufemizar toda a experiência sociocultural como conjunto de versões de um mesmo fenômeno diaspórico, a partir da panaceia analítica da migração e da transnacionalidade .

\subsection{A histórica necessidade de mão de obra}

No caso brasileiro, desde o início do período colonial, associadas ao processo de povoamento e ocupação do território, as migrações transnacionais foram vistas como uma solução, tanto para a eliminação dos vazios populacionais - que representavam um problema para a

71 Ao observarmos a narrativa sobre o fascínio exercido pelas metrópoles, é possível reconhecer uma linha argumentativa que defende a ideia de que o migrante, que vem do campo, do interior, vem para a cidade não porque não tem condições de sobrevivência em sua terra, mas porque deseja fazer parte do progresso das metrópoles. Sobre isso ver PESAVENTO, s.j. o Imaginário da Cidade. Visões Literárias do Urbano. Porto Alegre: Editora da Universidade do Rio Grande do Sul, 1999; Revista de Imigração e Colonização, agosto de 1946. 
segurança do território nacional - quanto para a viabilização da produção. Com o surgimento de grandes áreas urbanas e mesmo das novas demandas da produção agrícola, estimulou-se, durante o século XIX, a vinda dos europeus, não somente para suprir o problema da oferta de mão de obra, como também, para atender a um projeto de "melhoria da mão de obra nacional".

Afirmando textualmente, como no cartaz italiano, (figura 23) que o Brasil abundava em terras e oportunidades, ou indicando-o como solução, de forma simbólica, como no caso do "gigante japonês" (figura 24), que traz os imigrantes japoneses aos braços, apontando com expressão segura e tranquila para o Brasil, ou ainda ratificando a escolha, demonstrando, com o auxílio do mapa, que outros europeus já estariam instalados em terras brasileiras, como no cartaz holandês, o fato é que o contexto socioeconômico do final do século XIX e início do XX facilitou o desenvolvimento do projeto brasileiro de atrair mão de obra estrangeira. Segundo Scarano (1996), em se tratando do trabalho agrícola pesado, como a abertura de picadas, derrubada de árvores, preparo da terra, o trabalhador nacional era sempre mal visto, tido como preguiçoso, diziase à época que "para discipliná-los, convinha a introdução da massa de trabalhadores de origem europeia" (SCARANO, LEMKE, 1996, p. 16).

As agências fomentadoras da imigração apresentavam o Brasil ao europeu pobre, que buscava por oportunidades, como um lugar ideal para que pudessem reconstruir suas vidas. Amparando esta propaganda imigrantista, a imprensa cumpria o seu papel. No jornal baiano $O$ Portuguez, (1838) lia-se matéria que tinha por objetivo estimular o estrangeiro a migrar para o Brasil. Intitulado como O Brasil e a Emigração européia. Artigo I, o texto se dirigia aos estrangeiros e nele o autor apresentava o Brasil e explicava que:

O Brasil he de todas as regiões conhecidas aquella, que offerece maiores vantagens aos que querem procurar fora da pátria um paiz para se estabelecerem, seja na agricultura, seja no commercio, seja nas artes fabris, ou em qualquer dos outros ramos da Industria: neste numero limitar-nos-hemos a ponderar algumas dessas vantagens na relação da agricultura e a economia rural". ${ }^{72}$

72 O Portuguez. Jornal Histórico, Político e Litterario. Coleção do Instituto de Estudos Brasileiros. Microfilmado. Salvador, Bahia, dezembro de 1838, pp. 22-25. 
Figura 23. Na América.

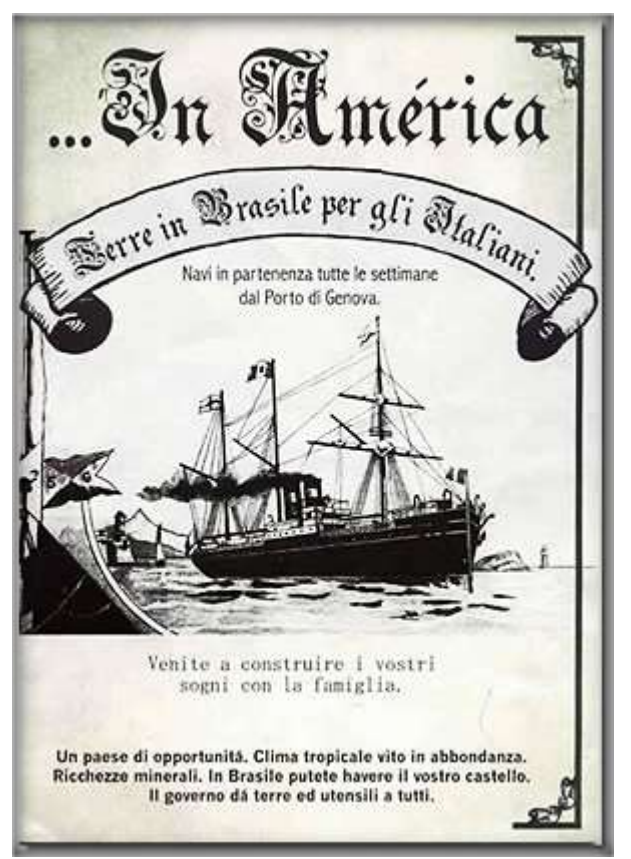

"Na América Terras no Brasil para os italianos. Navios em partida todas as semanas do Porto de Gênova. Venham construir os seus sonhos com a família. Um país de oportunidade. Clima tropical e abundância. Riquezas minerais. No Brasil voces poderão ter o seu castelo. O governo dá terras e utensílios a todos."

Fonte: Panfleto de propriedade da historiadora Assunta de Paris assunta.deparis@gmail.com. Arquivo Histórico Municipal de Bento Gonçalves. Acesso em 10 de maio de 2012. Disponível em http://www.bentogoncalves.rs.gov.br/a-cidade/historia-daimigracao. Panfleto, do final do século XIX, que os Agentes de Propaganda utilizavam para promover a emigração na Itália.

Figura 24. Cartaz publicitário da Hamburg-Sud e Cartaz de Propaganda. Imigração japonesa.
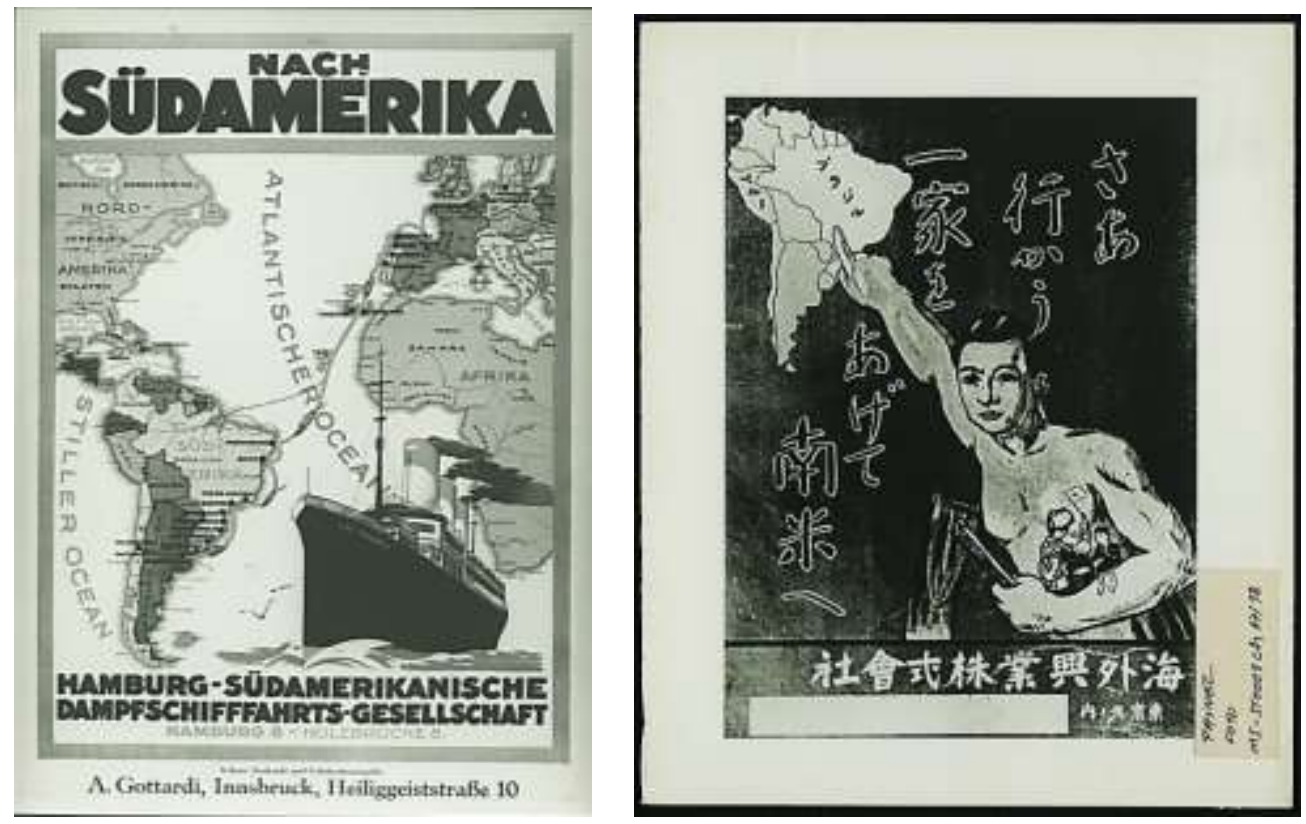

Fonte: Museu da Imigração, Japão Coleção Museu da Imigração. Acesso em 10 de dezembro de 2013. Disponível em http://museudaimigracao.org.br/acervodigital/pesquisageral.php?id=fotografias\&busca=CARTA $\underline{Z}$ 
No caso do citado jornal baiano, a matéria seguia explicando que a grande extensão do país seria composta por lugares de clima ameno e solos férteis; capazes de produzir gêneros do novo e do velho mundo; enfatizava ainda a "facilidade com que a terra dá abundantes riquezas", em função de estarem, tais terras em “descanso, desde o dilúvio, e talvez desde a creação". O texto destacava, mais à diante, a facilidade que existiria para a criação de cavalos, mulas e gados; concluindo com a chamada às autoridades que deveriam preocupar-se em facilitar a entrada da "boa gente da Europa às terras brasileiras""73.

Exacerbando-lhe as riquezas, que ainda estariam por serem exploradas, a linguagem do jornal insere o imigrante no cenário, no papel de desbravador de um paraíso, além de deixar explícito o desejo de que as autoridades trabalhassem para ter aqui a mão de obra do europeu, reconhecida como um fator importante para os projetos de desenvolvimento e modernização do império.

O interesse por essa mão de obra europeia cresceria com o passar do tempo, com destino especialmente voltado aos Estados do Rio de Janeiro e São Paulo, na segunda parte do século XIX, sobretudo devido à crescente produção do café, do surgimento da atividade industrial e da abolição da escravatura; sendo que, na capital do império encontrava-se a maior parte das sedes das companhias de colonização que atuavam no país (SCARANO, LEMKE, 1996, p. 18). Por sua vez, em São Paulo, a existência do Departamento de Migrantes situado à Rua Visconde de Parnaíba, no bairro do Brás vinculava-se, igualmente, ao do incentivo às migrações europeias ${ }^{74}$.

Na segunda metade do século XIX, dois grandes ciclos econômicos foram significativos para estimular da propaganda pró-imigração. Inicialmente, teríamos o primeiro ciclo da borracha, (1879-1912) que exigiu o deslocamento tanto da mão de obra de estrangeiros, quanto de nacionais, estes em geral, retirantes do Nordeste seco rumo à região Norte; o outro ciclo, o do café, que exigiu a transferência de mão de obra em maior quantidade e por mais tempo, envolvendo fluxos

\footnotetext{
${ }^{73}$ Idem, ibidem.

${ }^{74}$ Segundo Paiva, os serviços de recepção, triagem e encaminhamento estiveram ativos durante os noventa anos de funcionamento da Hospedaria (1888-1978), bem como a maior parte dos serviços que nela foram implementados. Evidentemente, durante este período houve profundas transformações na sociedade e na economia paulista, assim como alterações significativas nos fluxos migratórios. Sobre este assunto, há mais detalhes em: PAIVA, Odair da Cruz. Introdução à História da Hospedaria de Imigrantes em seus aspectos Institucionais e Guia do Acervo. São Paulo: Memorial do Imigrante/Museu da Imigração, 2000 v.1, 20 p. (Série Resumos n. 6). Ver também Paiva, Odair da Cruz e Moura, Soraya. Hospedaria de Imigrantes de São Paulo. São Paulo: Paz e Terra, 2008. Leia também a matéria no jornal O Migrante, out. 1976, p. 2.
} 
imigratórios de grande intensidade para o Sudeste. O Estado de São Paulo, que concentrava somente 7\% da população estrangeira do país em 1872, passou para 21\% em 1890 e 44\% em 1900, apresentando daí por diante, índices superiores a 50\%. Quanto à cidade do Rio de Janeiro, capital do império e posteriormente capital da República, teria sido o único centro a rivalizar com São Paulo no que se refere aos números da entrada de estrangeiros. O Rio de Janeiro concentrou cerca de $35 \%$ do total da população estrangeira do país até 1890, conforme o levantamento realizado por Levy (1996), a partir do número de estrangeiros entrados no Brasil e seus respectivos destinos. Já em 1900 contaria o Rio somente com 18\% do total de imigrados, percentual que se manteria, praticamente estável até por volta de $1980^{75}$. Sendo que os grandes centros urbanos de então correspondiam às regiões com maior número de imigrantes, seria correto afirmar que o trabalhador urbano era em maior número estrangeiro e que, à medida que cresciam as cidades do Sudeste, tornava-se mais visível a presença estrangeira entre nós.

Em quatro blocos de texto, que tomavam a página inteira, na Revista Cruzeiro 23 de fevereiro de 1929, na matéria Conhecendo o estrangeiro através de São Paulo, Luiz Lélio, dedica três quartos do espaço a uma cuidadosa descrição da "São Paulo italiana": "Meu caro leitor. Você que é brasileiro, mas que ainda não viajou em países estranhos, venha comigo até São Paulo. Acompanhe-me no passeio que vamos realizar pelo íntimo da cidade cosmopolita". A partir desse convite, o jornalista vai descrevendo os bairros da capital paulista, Brás, Parque Dom Pedro, Largo da Concórdia, Bresser. Ao descrever Avenida Celso Garcia, destaca a presença dos cortiços, indicando como principal característica desses espaços, a polifonia:

Você desconhecia o que era um "cortiço"? Pelo menos emquanto não viu "Castagnaro da festa" de Oduvaldo Vianna. É uma polychromia de vozes. Italianos, portugueses, alemães, húngaros, russos, tudo lá se amontoa. E vivem felizes, cantando sempre, olvidando até o árduo labor das fabricas que

\footnotetext{
75 No Brasil, segundo Paiva, tanto no plano interno quanto no plano internacional, a dinâmica dos deslocamentos populacionais foi pautada por demandas internacionais do cenário do pós-guerra. Desde o final dos anos 1920 , o refluxo da imigração para o Brasil foi patente. Na década de 1930 esta tendência se manteve, influenciada no plano interno pela política de nacionalização da mão de obra empreendida pelo governo Getúlio Vargas e, no plano externo, pela ascensão de regimes de direita em países de longa tradição emigrantista como a Alemanha, Itália, Espanha e Portugal além da crise econômica pós a quebra da Bolsa de Valores de Nova Iorque que se estendeu, ao menos, até meados dos anos 1930. PAIVA, Odair da Cruz. Migrações internacionais pós Segunda Guerra Mundial: A influência dos EUA no controle e gestão dos deslocamentos populacionais nas décadas de 1940 e 1960. In: XIX Encontro Regional de História da ANPUH - Seção São Paulo, 2008, São Paulo. Anais do v. 1. p. 1-8.
} 
estão ao lado. Gente de parcos recursos e que moureja de sol a sol. (Revista Cruzeiro 23 de fevereiro de 1929, p. 24)

A viagem prossegue, apresentando as comunidades do Extremo Oriente e do Oriente Médio, pelas quais o autor demonstra admiração menor: "Para compensar as canções latinas que tanto o surpreenderam, agora você tem que ouvir as músicas árabes gutturaes, que, francamente, nem a mim agradam...”. A São Paulo da Cruzeiro de 1929 é apresentada como um grande caldeirão cultural, no qual o elemento estrangeiro faz-se presente de forma bastante acentuada.

Já na publicação de 1954, da Revista Manchete, intitulada Uma fatia de mortadela no sanduíche geográfico do Brasil, (figura 25) como parte das comemorações dos quatrocentos anos da cidade, um novo elemento é acrescentado ao caldeirão cosmopolita de São Paulo. Desde há muito, o cosmopolitismo paulista era uma das marcas da cidade, como destacaram cronistas como Ernani da Silva Bruno e Jorge Americano.

Italianos, portugueses, japoneses, sírios, armênios e libaneses, tal qual na matéria da Cruzeiro de 1929, também aparecem aqui como personagens típicos, representantes dos grupos que construíram e que construíam a cidade, todavia, somados agora, ao mais novo personagem. Ocupando o último dos seis quadros expostos na página, temos o migrante nordestino. Lia-se na legenda:

Os nossos nordestinos entram nesta galeria não como estrangeiros, é claro, mas como os homens sôbre cujos ombros, desde 1937, repousa a construção civil. E com isto se pode dizer que coube ao sertanejo brasileiro a tarefa mais dura. São eles que, enfrentando salários de fome, têm emprestado o seu corpo franzino à obra ciclópica de construir os arranha-céus de São Paulo. (Revista Manchete, 23 de janeiro de 1954, p. 20)

Nordestino e sertanejo são expressões utilizadas para descrever o grupo, que não é identificado por seu estado de origem ou sua cultura. Cada um dos estrangeiros fora identificado por sua cultura de origem, sua cultura nacional, mas os migrantes nordestinos de São Paulo foram a presentado a partir de sua identidade de território - e nem apenas identificados como brasileiros. Foram identificados, outrossim, por um terceiro conjunto que os representa, identificados como nordestinos. 
Figura 25. Fatia de mortadela.

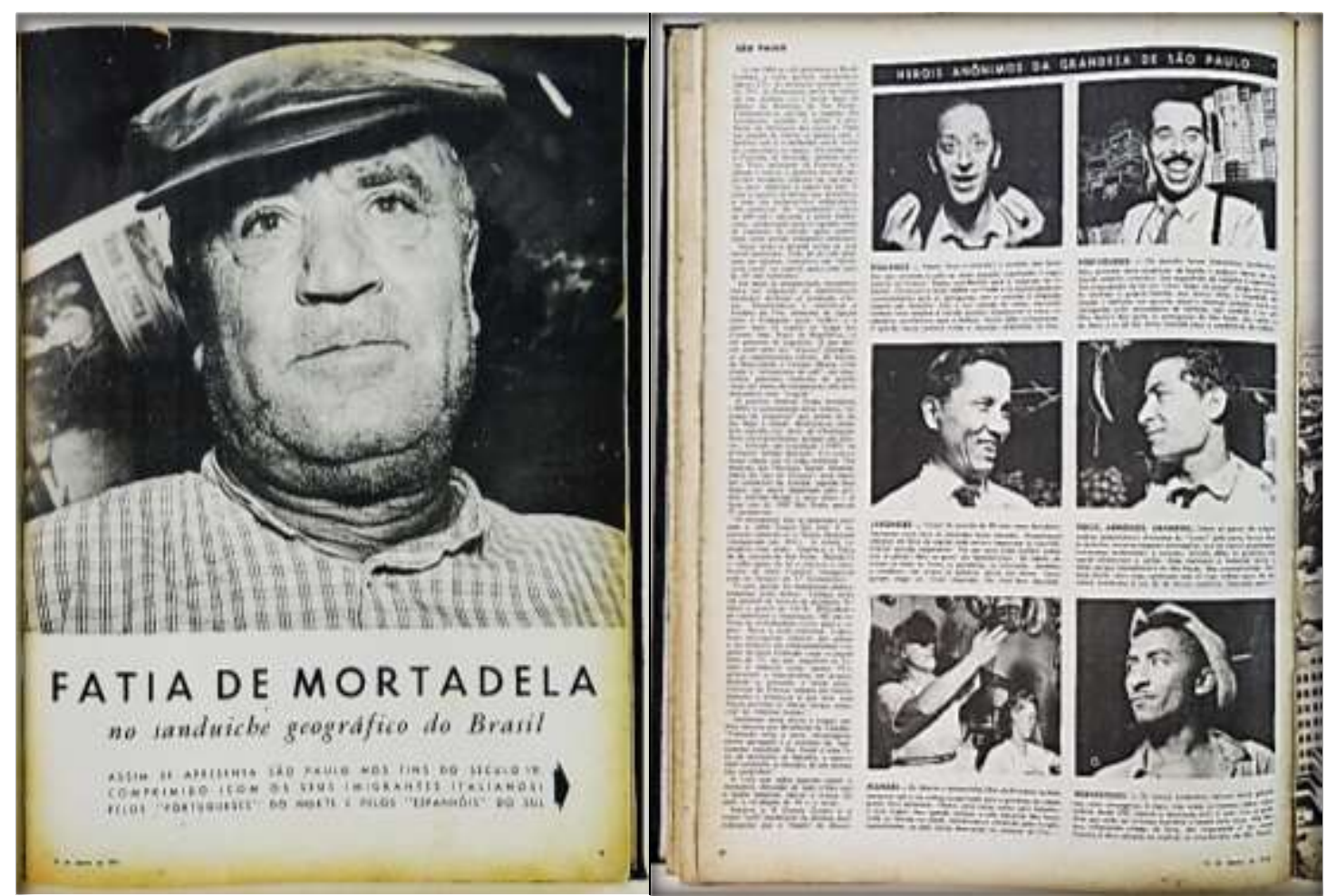

Fonte: Revista Manchete, 23 de janeiro de 1954, p 19-20. Acervo Biblioteca Florestan Fernandes - USP.

Uma identidade postiça que aglutina elementos das identidades regionais dos nove estados do Nordeste. Contudo, esse nordestino migrado para o Sudeste, identificado como a mão de obra que constrói cidades, seria uma representação elaborada a partir de um longo processo de transformação de ideias e ideologias sobre o que e quem seria a mão de obra ideal para o desenvolvimento do Brasil.

São sertanejos do Nordeste, emigrados em função de razões que também não ficam explicitadas pelo texto, e recebidos como mão de obra urbana, a partir de uma mudança das políticas públicas, pontuadas no texto pelo ano de 1937, mas construídas durante toda a década de 1930.

\subsection{A apologia ao estrangeiro versus a defesa da brasilidade}

Durante o início do período republicano, a questão da imigração via-se permeada pelo problema do povoamento e da introdução de uma mão de obra que se acreditava melhor qualificada, associando-se ainda os interesses do projeto positivista civilizador, impregnado de 
darwinismo social e, é claro, à questão racial, motivada pelas vozes que defendiam a necessidade do branqueamento da população.

Durante as três primeiras décadas do século XX a questão da imigração esteve profundamente ligada à consolidação de um projeto de povo e nação que colocava em contraposição o projeto de branqueamento e europeização da população ao projeto de valorização da brasilidade mestiça. Opunham-se, portanto diferentes perspectivas de compreensão da identidade nacional ${ }^{76}$.

Em 1930, embora a questão da ocupação do território estivesse, ainda àqueles tempos, na ordem do dia, para o governo revolucionário de outubro, as preocupações em relação à construção de uma nova nação passavam, fundamentalmente, pela questão da formação de uma identidade nacional.

\subsubsection{O Brasil e a questão da identidade}

O tema da identidade nacional estava na pauta do dia no Brasil dos anos de 1920 e 1930, desde a Semana de Arte Moderna. Entender nossas particularidades e encontrar o que nos fazia brasileiros, era o exercício de acadêmicos, literatos e jornalistas. No texto, O Brasil e a raça, de Batista Pereira, para a abertura da edição de janeiro de 1929 da Revista O Cruzeiro, lia-se um longo texto apologético, que descrevia os tipos regionais brasileiros, ou como expressava o autor "as raças brasileiras", destacando-lhes o caráter e seu papel como "energia" da nação. No texto, o sertanejo do Sudeste, é descrito da seguinte forma: "O matuto e o caipira de Minas e S. Paulo, menos épicos e mais utilitários, com as facilidades de comunicação dos dois grandes estados quase desapareceram, mas são a mesma falange de desbravadores de sertões, que estão fazendo no norte do Paraná um novo S. Paulo”. (Revista O Cruzeiro, 12 de janeiro de 1929, p. 03)

Ressaltando-lhes o ímpeto transformador, o autor destaca a obra do caipira de São Paulo e Minas Gerais, e prossegue, adiante, descrevendo o nordestino:

O sertanejo baiano, que desce dos rincões nataes para vir, a pé, fazer a colheita dos cafezais paulistas e volver alegremente aos lares, como se fossem um brinquedo as centenas e centenas de léguas de

\footnotetext{
${ }^{76}$ Esta questão está minuciosamente discutida em O caráter nacional brasileiro. Dante Moreira Leite. São Paulo: Editora Ática, 1992.
} 
ida e volta; o nordestino, que prefere a todas as outras, a sua terra ulcerada de sol, que só a sabe abandonar no auge das seccas, e que às primeiras chuvas repudia todos os interesses para volver ao seio materno, onde o refrigério das aguas curou as chagas solares. (Revista O Cruzeiro, 12 de janeiro de 1929, p. 03)

Acompanhando os dois excertos percebe-se que, enquanto o caipira do Sudeste é entendido a partir de sua obra transformadora, o baiano tem por característica sua presteza em realizar a migração sazonal para o trabalho da colheita do café, que não é descrito como uma viagem dura e penosa, em tempos em que a linha Central do Brasil ainda não ligava o Rio de Janeiro à Monte Azul, no sertão mineiro, próximo à divisa com o estado da Bahia, sendo a viagem feita à duras penas por terra e por mar, sem contrato de trabalho, ou quaisquer outras garantias. $\mathrm{O}$ homem do semi-árido, é definido como "nordestino", desprovido de indicação de pertencimento a um estado específico, esse personagem é identificado somente por sua persistência em permanecer numa terra em que, para o autor, não possui e nenhum atrativo, e nada produz, além de tristeza e esperanças vãs, trazidas pela chuva.

Se na década de 1920 e ainda até meados dos anos de 1930 o debate sobre uma identidade nacional buscava resolver uma equação de múltiplas variáveis, exposta pelo problema da mestiçagem e das identidades regionais, na década de 1930, com o fortalecimento do nazifascismo, seria a perspectiva totalitarista, de uma identidade construída a partir da instituição da uniformidade, que ditaria as regras. Em Sobre História, Hobsbawn aborda a questão do uso do discurso sobre uma cultura de identidade como instrumento característico de regimes nacionalistas, lembrando o historiador francês do século XIX, Ernest Renan, destacando que:

"Esquecer, ou mesmo interpretar mal a história, é um fator essencial na formação de uma nação, motivo pelo qual, o progresso dos estudos históricos muitas vezes é um risco para a nacionalidade". As nações são entidades historicamente novas fingindo terem existido durante muito tempo. É inevitável que a versão nacionalista de sua história consista no anacronismo, omissão, descontextualização e, em casos extremos, mentiras. Em um grau menor, isso é verdade para todas as formas de história de identidade, antigas ou recentes. (HOBSBAWN, 1998, p. 285)

A reflexão de Hobsbawn nos chama a atenção para um ponto fundamental: a busca por uma identidade nacional, pela valorização de símbolos nacionais, fazia parte de um projeto de consolidação do poder político de um grupo, que lançava mão do discurso amparado em princípios como o tempo, a história e a tradição, para forjar para si um passado para ilusoriamente, transformar o seu presente na continuidade de um projeto fictício de passado. Todavia, para além dos interesses do Estado, outros grupos também tinham a questão da compreensão de nossas 
identidades, nacional e regional, como um tema de grande apelo, pois durante os anos de 1920 e início dos anos 1930, tanto a partir da perspectiva da brasilidade dos modernistas paulistas, quanto a partir da perspectiva de outros grupos e de outros movimentos a identidade cultural brasileira estaria na ordem do dia. Embora tenham projetado sua leitura sobre a questão da identidade nacional de maneira impactante, não podemos afirmar que os modernistas paulistas representassem uma leitura de consenso entre a intelectualidade brasileira ${ }^{77}$. Nome de peso entre os intelectuais brasileiros, já àquela época, Gilberto Freyre, líder dos regionalistas - intelectuais do Nordeste que também desenvolviam um projeto de reinterpretação da cultura e do perfil nacional - achava que a verdadeira modernidade não deveria ser importada, mas atingida a partir da renovação das próprias tradições nacionais e regionais.

A questão regional tomou forma, e em 1926, com o objetivo de debater a questão da identidade cultural brasileira, realizou-se o $1^{\circ}$ Congresso Brasileiro de Regionalismo, na cidade do Recife. Na ocasião, Gilberto Freyre, o principal idealizador do evento, apresentando um manifesto, criaria o Movimento Regionalista, Tradicionalista e, ao mesmo tempo, Modernista, do Recife. O movimento, referendado por pensadores tanto de esquerda, quanto de direita, dizia-se apolítico e embora enfatizasse as diferenças entre as sub-regiões do Nordeste, seus participantes, negavam qualquer caráter separatista; como é possível observar no texto do Manifesto:

A maior injustiça que se pode fazer a um regionalismo como o nosso seria confundi-lo com separatismo ou bairrismo. Com anti-internacionalismo, anti-universalismo ou anti-nacionalismo. Ele é tão contrário a qualquer espécie de separatismo que, mais unionista que o atual e precário unionismo brasileiro, visa a superação do estadualismo, lamentavelmente desenvolvido aqui pela República - este sim, separatista - para substituí-lo por novo e flexível sistema em que as regiões mais importantes que os estados se completem e se integrem ativa e criadoramente em uma verdadeira organização nacional. Pois são modos de ser - os caracterizados no brasileiro por suas formas regionais de expressão - que pedem estudos ou indagações dentro de um critério de interrelação que ao mesmo tempo amplie, no nosso caso, o que é pernambucano, piauiense ou até maranhense, ou alagoano, ou cearense em nordestino, articule o que é nordestino em conjunto com o que é geral e difusamente brasileiro ou vagamente americano. (FREYRE, 1996, p. 48)

\footnotetext{
77 Albuquerque Jr tece sua crítica ao modernismo paulista, afirmando que: "O que o modernismo fez foi incorporar o elemento regional a uma visibilidade e dizibilidade que oscilavam entre o cosmopolitismo e o nacionalismo, superando a visão exótica e pitoresca naturalista. Esses elementos são retrabalhados ora para destruir sua diferença, ora para ressaltá-la, apagando aquela distância produzida pelo olhar europeizado. [...] o cacto, por exemplo, passa a ser um signo de brasilidade, do primitivismo, da aspereza de nossa realidade nacional, nos quadros de Tarsila do Amaral, surgindo em paisagens que nada têm a ver com as paisagens naturais da caatinga nordestina onde é predominante." $A$ invenção do Nordeste e outras artes. Recife: FJN, Editora Massangana; São Paulo: Cortez, 1999, p. 46.
} 
A leitura culturalista de Freyre, exposta no Manifesto, aponta para uma dimensão ampla do que seja identidade e brasilidade. $\mathrm{O}$ autor, com extrema perspicácia aponta para uma questão crucial: a necessidade de perceber-se que, se por um lado era inegável a existência de vários e não apenas um Nordeste, por outro, era igualmente importante reconhecer-se quais seriam os elementos que indicam pontos de contato entre essas culturas, permitindo o vislumbre de um conjunto que poderíamos chamar de identidade nordestina; bem como pontos de contato dessa com as culturas das outras regiões do Brasil, possibilitando aí a compreensão de uma brasilidade. No discurso de Freyre, o regionalismo - esse regionalismo não-estadualista - teria um papel decisivo, para promover uma verdadeira unidade nacional a partir de uma compreensão das complexidades e também das semelhanças dos elementos culturais que compunham a sociedade brasileira, defendendo ainda as tradições culturais regionais das influências externas. Justamente por isso, diverge do modernismo antropofágico paulista, fortemente marcado por elementos estéticos do modernismo europeu.

Ainda sobre a questão do território, ao contrário de Oliveira Viana que, em sua obra Populações Meridionais do Brasil, via nas dimensões continentais do país um empecilho para a formação de uma identidade nacional - além de considerar os "estados do Norte" condenados à decadência em função da raça e do clima $^{78}$, conforme Albuquerque - Gilberto Freyre (2004), procurou valorizar a extensão do Nordeste, mostrando-lhe a riqueza e a diversidade cultural, demonstrando em seus trabalhos o caráter heterogêneo da cultura nordestina e por extensão, de toda a cultura brasileira, defendendo a compreensão da identidade a partir da relação entre particularidades e semelhanças, ligadas às constituições não somente da geografia física, mas

\footnotetext{
${ }^{78}$ ALBUQUERQUE JR. Durval Muniz. A invenção do Nordeste e outras artes, p.58. Diferentemente de Freyre, Viana, em sua obra de 1920, apresentava o caráter mestiço do povo brasileiro, e também as dimensões continentais do país, como fatores negativos para o desenvolvimento de uma sociedade dita civilizada. Contudo, o pensamento de Viana traria também, elementos de originalidade que foram observados mais à frente, na obra pensador de Apipucos. Viana, distanciando-se das teorias de ufanistas como as de Ellis Júnior, entendia que mesmos princípios teriam norteado a formação das sociedades brasileiras, principalmente no que se refere ao sistema senhorial e patriarcal, ideia com a qual concordará Freyre. Apresentamos esta discussão, mais detidamente em OOlhar de quem faz. O paulistismo sob a ótica do operariado paulista durante a Revolução Constitucionalista de 1932. ALMEIDA, I.B.S. Dissertação de mestrado, São Paulo: Universidade de São Paulo, 1999.
} 
principalmente humana da região, sugerindo assim uma nova regionalização do país, a partir de uma diferenciação interna do Nordeste e também entre este e a região Norte ${ }^{79}$.

O fato é que com o fortalecimento do discurso nacionalista de Vargas, ganharia força, cada vez mais, uma ideia de nacionalismo que pretendia alcançar uma homogeneização da cultura e não a compreensão ou a valorização de seus diferentes atores sociais e suas respectivas singularidades culturais. No quadro internacional, era essa visão totalitarista que ganhava força com a ascensão dos governos nazi-fascistas, que logo despertaram a simpatia de grupos da sociedade brasileira que revisitavam a antiga ideia da migração estrangeira como forma da melhoria da raça. Durante a guerra, o governo brasileiro havia passado a autorizar a entrada, não de qualquer europeu que desejasse para cá imigrar, entrariam somente os "melhores", mais adaptáveis. Além das preocupações com o elemento humano, nos projetos de crescimento econômico e segurança nacional, os tempos de guerra haviam recuperado também, o discurso sobre a necessidade do povoamento para viabilizar o desenvolvimento.

\subsection{A situação dos estrangeiros}

Os vazios demográficos, somados ao desejo estratégico de guardar as fronteiras, se apresentavam frequentemente como argumentos que referendavam as iniciativas de apoio e incentivo à entrada de estrangeiros no Brasil, como é possível ler na Revista de Imigração e Colonização de 1946:

O conveniente aproveitamento do solo em todo o seu sentido deveria ser um dos pontos básicos de nosso programa econômico... Para o aumento da produção, há necessidade, no Brasil, do aumento do elemento humano. Fixar o homem ao solo é providência de alta sabedoria política e administrativa. Mas, para um país de vasto território e pequena densidade demográfica, é preciso estimular a vinda de pessoas de fora. (Revista de Imigração e Colonização, ano VII, 1946, p. 644)

Mesmo depois da guerra, ainda se fazia necessário, definir quem e como seria esse tipoideal de homem, cuja presença seria benéfica e desejável em território nacional:

Aparece, também, a questão de se saber qual o melhor imigrante para o nosso meio. [...] A imigração deverá ser feita, de preferência, de famílias, que se localizariam melhor no interior. [...] Entre os italianos, por exemplo, há que verificar os que mais convém ao Brasil. Os do Sul da Itália não são indicados para o nosso meio. Os do norte daquele país são os convenientes. Além disso, é

\footnotetext{
${ }^{79}$ ANDRADE, Manuel Correia de. “Gilberto Freyre e o Impacto dos Anos 30”. In Revista USP - Dossiê Intérpretes do Brasil - Anos 30. São Paulo, no 38, 1998, p. 41. Ver ainda BARBOSA, F.A., Introdução de MACHADO, António de Alcântara. Novelas Paulistanas, 6 a ed. Rio de Janeiro, Livraria José Olympio Editora, 1979, p. xiii e xiv.
} 
preciso apurar se os que pretendem vir para o Brasil, seja qual for a nacionalidade, estejam se dedicando à lavoura, com o que se evitará o ingresso do falso agricultor. O português é bom elemento. Mas o português dos campos, principalmente, não aquele que só quer permanecer nos grandes centros. O suíço é imigrante de primeira ordem. O holandês também. [...] Existem 'dois aspectos da população a ser considerados e que são de profunda importância para a sociedade. São eles: a quantidade e a qualidade. (Revista de Imigração e Colonização, ano VII, 1946, p. 646)

Nesse processo seletivo em função de suas características socioculturais, as populações advindas do interior das áreas rurais da Europa, seriam consideradas as mais adequadas. O objetivo era trazer mão de obra para fixar-se nas regiões de agricultura, que, desde a metade dos anos 30, por falta de projetos adequados de suporte e desenvolvimento, deixavam as zonas rurais rumo às cidades.

[...]entre os italianos, por exemplo, há que verificar os que mais convém ao Brasil. Os do Sul da Itália não são indicados para o nosso meio. Os do norte daquele país são os convenientes, [...] O português é bom elemento. Mas o português dos campos, principalmente, não aqueles que só quer permanecer nos grandes centros. O suíço é imigrante de primeira ordem. O holandês também... Existem dois aspectos da população a ser considerados e que são de profunda importância para a sociedade. São eles: a quantidade e a qualidade... Devemos trazer imigrantes, mas não esqueçamos o "aspecto qualidade". (Revista de Imigração e Colonização, ano VII, 1946, p. 646-647)

Daí a necessidade de uma política de seleção das correntes humanas que para cá se dirigiram. Essas correntes, pelas suas características raciais, deveriam constituir o generoso caudal que traria à tona riquezas que jaziam inexploradas, dessa forma contribuindo para o robustecimento da nossa jovem nação.

Ainda em matéria publicada pela Revista de Imigração e Colonização, em 1946 sugeria-se que o Brasil deveria atentar melhor para a qualidade de imigrante que aqui entrava, apontando que em sua opinião o "problema" deveria ser detectado no país de origem do emigrante, cabendo ao Brasil, um exame complementar. Para o médico, a função de um rigoroso exame seletivo teria por objetivo levar a termo a realização prática dos postulados da Política Biológica, apontando que tal seleção:

[...] (a imigração) pugna pela melhoria da raça; resguarda e controla o capital humano; [...] (permite a) realização indireta dos nobres alevantados princípios da eugenia; [...] realiza de fato uma melhor prevenção das doenças profissionais (tecnopatias) e ordinárias, comuns, pela seleção processada. (Revista de Imigração e Colonização, ano VII, 1946, p. 665)

O controle da imigração, não era, dessa forma, compreendido pelo Estado como racismo, mas como medida higiênica, ainda levada à cabo nos anos de 1940, mas tendo suas origens nas ideologias que ganharam força durante os anos 30. Fora o próprio Vargas quem havia 
materializado, na forma do Decreto-lei n 3.010 de 2 de agosto de 1938, uma série de condições necessárias para a admissão do estrangeiro em território nacional, exigindo comprovação de plena saúde. Tal política estaria, em pleno acordo com as práticas eugênicas implementadas pelo fascismo europeu ${ }^{80}$.

Embora a década de 1930 encerrasse com uma política de restrições, isso não significa dizer que, da noite para o dia, o imigrante passaria de solução, a problema; muitos ainda viam na imigração a solução para alguns dos principais problemas brasileiros. E haveria também aqueles, como o eminente intelectual pernambucano Josué de Castro que apontava para um novo cenário, no qual, o brasileiro já não teria porque desejar "europeizar-se", tendo a imigração, portanto, o papel de auxiliar no processo de povoamento, e não no processo de “civilização" de nosso país ${ }^{81}$.

Aspectos Biológicos da Imigração e colonização do Brasil. [...] Iniciando sua palestra, o dr. Josué de Castro frisou a importância das questões de que se occupa o Centro de Estudos de Problemas Brasileiros, o que demonstrava ao vibrante contraste existente entre o homem de hoje e o do fim do patriarchalismo brasileiro. Enquanto este era um sonhador, fugindo para a Europa alimentandose de sua civilização e vivendo 'impregnado de uma cultura de que não era possuidor', o homem de hoje sabia dizer francamente quaes eram as suas falhas e procurar um meio de corrigil-as. [...] Colaborando com o Centro de Estudos de problemas Brasileiros, vinha apresentar o seu estudo sobre a Imigração e a colonização no Brasil. [...] Hoje todos os paizes procuram intensificar sua densidade demographica e quanto a isto a nossa posição é má, pois que vamos de um mínimo de 0 e 0,5 a 200 no máximo por kilometro, enquanto muitos paizes da Europa possuem uma população de mil e quinhentos habitantes por kilometro quadrado. (Folha da Manhã, quarta-feira, 13 de junho de 1938)

80 O jornal Folha da Manhã em 08 de setembro, de 1938, trazia uma matéria sobre a exigência do governo italiano para que os oficiais do exército realizassem exames médicos pré-nupciais como condição para que os casamentos pudessem ser autorizados. Na matéria, o correspondente explicava que o objetivo das exigências era garantir que os casai não gerassem filhos doentes, mas apenas "homens fortes para a pátria".

81 Josué de Castro foi Livre-docente de Fisiologia da Faculdade de Medicina do Recife, 1932; Professor Catedrático de Geografia Humana da Faculdade de Filosofia e Ciências Sociais do Recife, 1933 a 1935 ; Professor Catedrático de Antropologia da Universidade do Distrito Federal, 1935 a 1938; Professor Catedrático de Geografia Humana da Faculdade Nacional de Filosofia da Universidade do Brasil, 1940 a 1964. Convidado oficial de Governos de vários países para estudar problemas de alimentação e nutrição. Entre eles: Argentina (1942), Estados Unidos (1943), República Dominicana (1945), México (1945), França (1947). Membro da "Comissão de Inquérito para Estudo da Alimentação do Povo Brasileiro", realizado pelo Departamento Nacional de Saúde, 1936. Delegado do Brasil na "Conferência de Alimentação e Agricultura das Nações Unidas,", convocado pela FAO (Food and Agriculture Organization) agosto de 1947. Segundo o Prof. Dr. Milton Santos, "Um dos traços fundamentais de Josué de Castro era a sua clarividência. A clarividência é uma virtude que se adquire pela intuição, mas, sobretudo pelo estudo. É tentar ver a parte do presente que se projeta no futuro." Site organizado pelo IBASE, FASE e pela Família Josué de Castro. Disponível em: http://www.josuedecastro.com.br/port/bio.html 
Para o autor, a solução do problema básico de ocupação do território seria dada pela imigração, pois seria um absurdo esperar-se o povoamento do Brasil exclusivamente pela reprodução do elemento humano aqui fixado. Diante de um cenário de guerra e conquistas territoriais, a necessidade de povoar o território para garantir sua segurança, se intensificaria, e para povoar, imprescindível se tornava a imigração, em massa. "Devemos incorporar o brasileiro à civilização occidental, para evitar que a civilização occidental, em seu movimento expansionista, incorpore a si o Brasil" (Folha da Manhã, quarta-feira, 13 de junho de 1938).

O conferencista seguia ainda, combatendo o mito da raça pura e apontando o valor da mestiçagem, na colonização, dizendo que "elle é o melhor meio de possibilitar o povoamento effectivo do paiz". Após citar casos de colonização em que o elemento autóctone desapareceu completamente, em nada contribuindo para a formação de uma civilização nova, como na Austrália, no Chile, no Peru, na Bolívia, etc, afirmava que na América, só três países realizaram uma obra verdadeiramente nova, no que se refere à construção de uma nação: os Estados Unidos, o México e o Brasil.

Embora existissem aqueles que defendiam as ideias de supremacia étnica e pureza de raças, vozes como a de Josué de Castro não estavam sós. Mesmo o racismo, na figura do antissemitismo, recebia críticas por parte de veículos da imprensa. A matéria de Tavares Bastos para a Revista Vamos Lêr! trazia um caso, no qual o antissemitismo era considerado inaceitável. Sob o título "A que extremos levam os racismos", (13 de abril de 1939, p. 18) a matéria, apresentava o autor perplexo, por ter sido o "Prêmio Nobel italiano, destituído de seu cargo na Universidade por ter origem judia por parte de mãe".

Ao observarmos a montagem com as fotografias (figura 26) o que temos é Mussolini com sua bancada apoiado por sobre a cabeça dos refugiados. Essa a posição atual do Duce. A composição fotográfica da reportagem traz à esquerda, em um enquadramento em perfil em meio plano, a figura de Mussolini, sob essa fotografia, outras três são colocadas, lado a lado. São imagens de jovens, rapazes e moças, em campos de refugiados, ou em marcha, em fuga de áreas ocupadas.

$\mathrm{O}$ anti-semitismo, tanto quanto um insensato preconceito, quanto como um instrumento nas mãos de políticos sem escrúpulos, dura há séculos, é do tempo anterior á nossa era cristã. Tem sido repetidamente aplicado em muitas partes do mundo, para auxilio a um vasto plano de projetos execráveis. Adolf Hitler não introduziu o anti-semitismo na Alemanha. Apenas utilizou o instinto secular dos preconceitos na Alemanha, o qual tem sido defendido por multidões de pseudos filósofos, tanto alemães como ingleses e franceses. (Revista Vamos Lêr! 27 de abril de 1939) 
Figura 26. Posição atual da perseguição aos judeus.

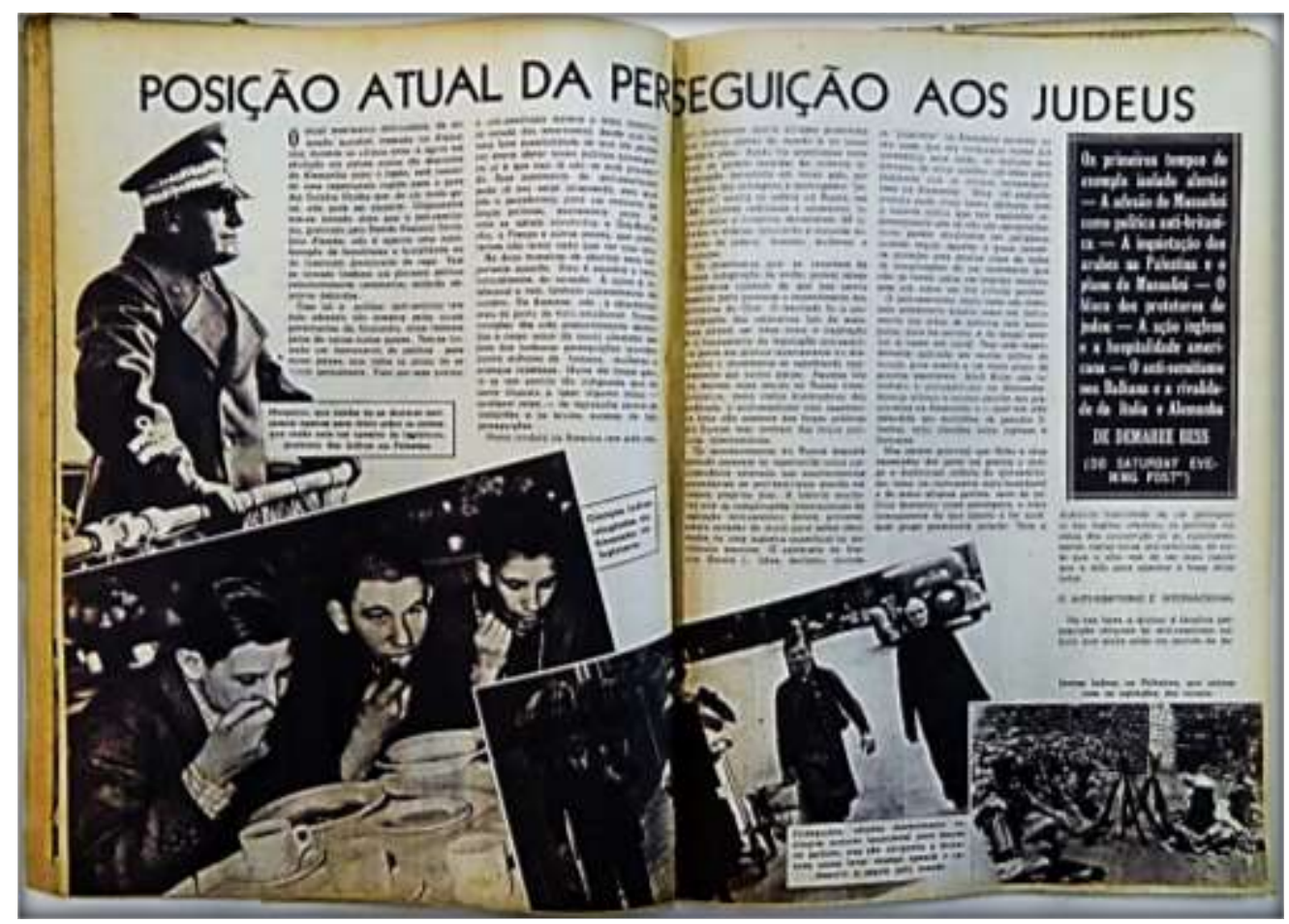

Fonte: Revista Vamos Lêr! 27 de abril de 1939.

De fato, o antissemitismo era a parte visível de uma concepção de povo e nação que transcendia as fronteiras da Alemanha, e encontrava aceitação em várias outras partes do mundo, principalmente na figura dos governos autoritários. Com o deflagrar da guerra, não apenas os critérios higiênicos para a entrada dos estrangeiros tornam-se mais rigorosos ${ }^{82}$, mas também as leis de permanência de estrangeiros no território nacional tornam-se mais rígidas. No artigo $2^{\circ}$ do Decreto-Lei n. 1532 de 23 de agosto de 1939, o Presidente da República definia que: “O ministro da Justiça e Negócios Interiores poderá prorrogar o prazo da permanência de temporários no país, ou torná-la definitiva, desde que se trate de cientistas, artistas ou técnicos de capacidade notória" ${ }^{83}$.

82 Paiva cita um artigo publicado no jornal O Estado de São Paulo na edição de 5-7-1947 intitulado A tragédia dos deslocados, no qual encontramos a informação de que o governo brasileiro intencionava receber cerca de 700.000 refugiados de guerra. Todavia, ainda segundo o autor, dados de 1949 demonstram que chegaram ao país pouco mais de 19.000 imigrantes e as cifras até 1951 não apontam mais do que 25.000 imigrantes classificados como refugiados ou deslocados de guerra. PAIVA, Odair da Cruz. Migrações internacionais pós Segunda Guerra Mundial: A influência dos EUA no controle e gestão dos deslocamentos populacionais nas décadas de 1940 e 1960. In: XIX Encontro Regional de História da ANPUH - Seção São Paulo, 2008, São Paulo. v. 1. p. 1-8.

83 Boletim do Ministério da Agricultura, jul/set 1939, ano 28, p. 217. 
$\mathrm{O}$ decreto indica que alguns refugiados seriam, portanto, de interesse nacional, enquanto outros não. O refugiado de guerra tornava-se assim, visível, não apenas nas letras da lei, mas nas páginas da imprensa ilustrada. Entre os anos de 1938 e 1940, a Revista Vamos Lêr! deu grande destaque ao tema, demonstrando o drama que alguns grupos já vivenciavam na Europa com o avanço de Hitler.

Em matéria estrangeira, publicada em maio de 1938 e assinada por Dorothy Thompson, a Vamos Lêr! destaca o crescimento do número de refugiados pelo mundo. Identificando-os não somente como minorias raciais, mas como vítimas dos conflitos que pululavam pela Europa, a matéria questionava a capacidade das nações livres conseguirem resolver o problema, dadas suas dimensões e a inexistência de um programa internacional que atendesse à essa demanda.

A fotomontagem da página 09 (figura 27) traz, ao fundo, um grupo de refugiados que fugiam de uma região ocupada e preparada como front de guerra, a imagem principal é de um homem de meia idade. As roupas, o chapéu e a barba o apresentam como um típico judeu. Representando os milhões de judeus que já àquela altura emigravam, a imagem do homem barbudo é acompanhada pela legenda: "Novamente soou para os judeus a hora sombria das perseguições. Os judeus austríacos estão se refugiando em vários países" (Revista Vamos Lêr! Os refugiados de hoje. 12 de maio de 1938, p. 09).

Para o Estado, a necessidade de controlar e garantir a qualidade dos refugiados estrangeiros que para cá imigravam, era fundamental. O regulamento, instituído em 1939, definia ainda, o prazo de trinta dias para o que o estrangeiro que desembarcasse no Brasil e desejasse aqui residir, se apresentasse ao Serviço de Registro de Estrangeiros e obtivesse a carteira de identidade modelo especial. O controle, em relação ao elemento estrangeiro seria muito mais rígido. A imprensa, que outrora pedia para que as autoridades facilitassem a entrada de estrangeiros, agora alertava os mesmos quanto às necessidades de legalização dos vistos.

Si o leitor é estrangeiro que tenha desembarcado no país, deve orientá-lo no sentido de se legalizar o mais depressa possível, afim de que não fique sujeito às penalidades legais e à expulsão. Para conhecer sua situação e a forma de requerer o registro e a carteira de identidade no Serviço de Registro de estrangeiros, aconselhamos sem reserva o trabalho do Dr. Péricles Mello Carvalho, intitulado: "Manual do Estrangeiro" [...] (Revista Vamos Lêr!, junho de 1939, p. 54) 
Figura 27. Os refugiados de hoje.

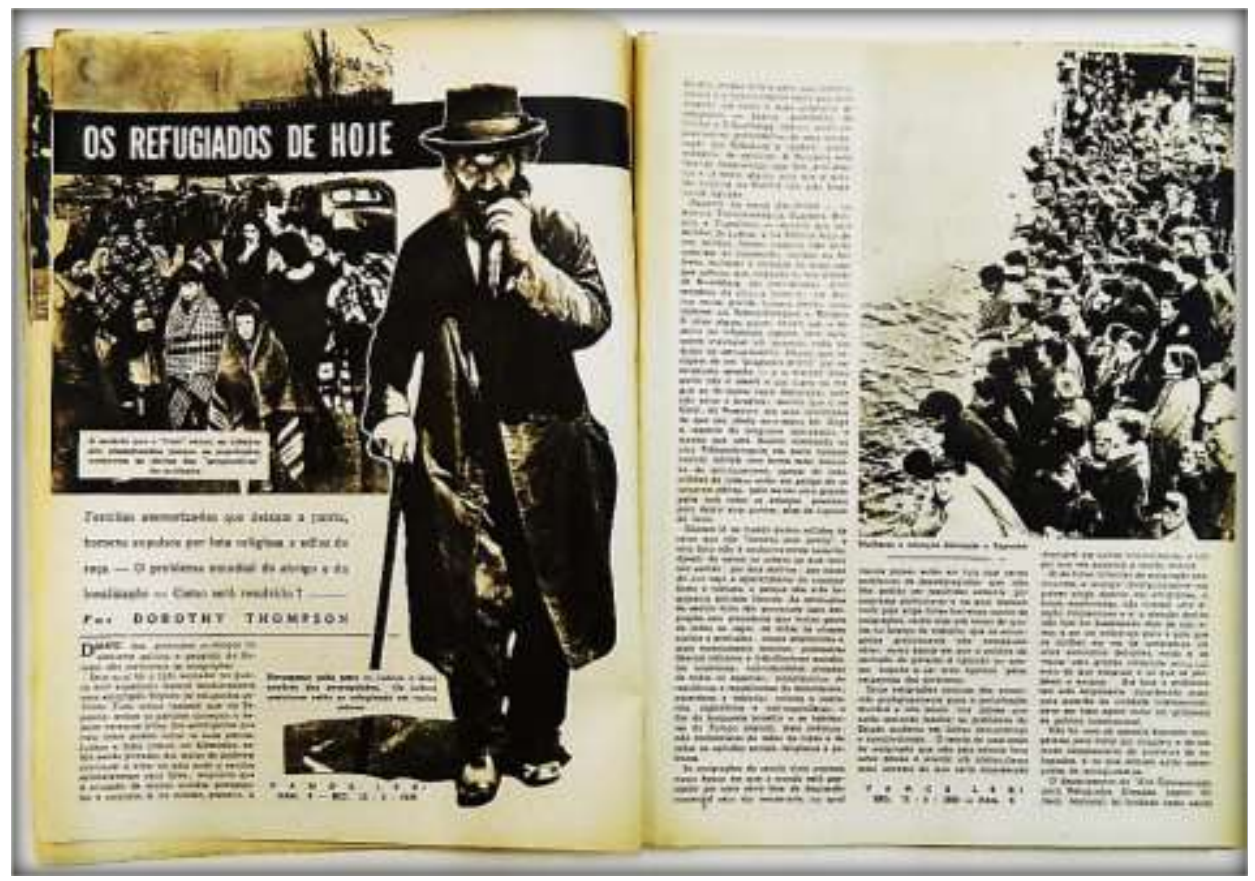

Fonte: Revista Vamos Lêr! 12 de maio de 1938, p. 09-10.

Figura 28. Na hecatombe da guerra.

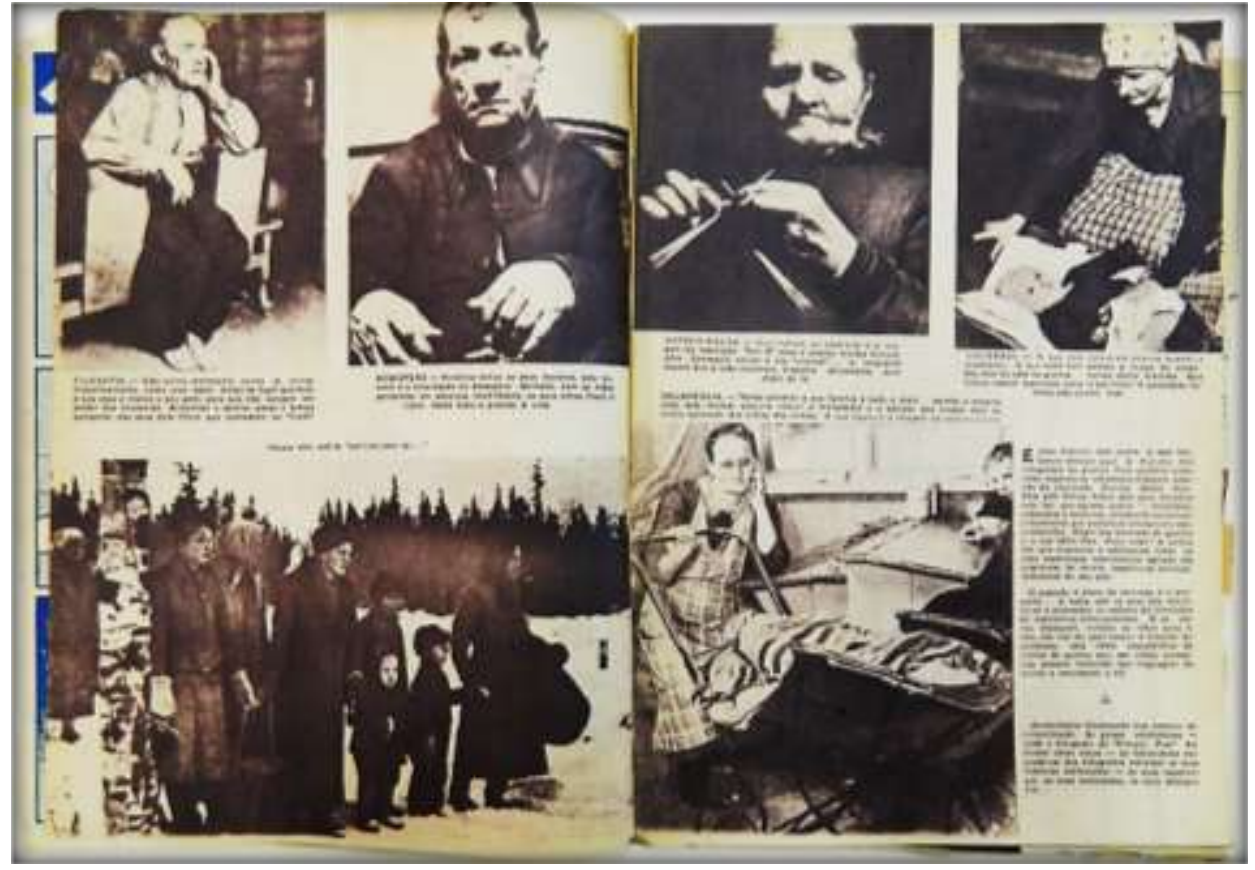

Fonte: Revista Vamos Lêr!, 05 de dezembro de 1940, p. 04-05. 
Vemos em artigo publicado na Revista de Imigração e Colonização, publicação oficial do Conselho de Imigração e Colonização do governo Vargas, na edição de abril de 1940, o franco apoio à imigração estrangeira:

[...] posto que não é mediante o simples crescimento vegetativo que um país novo pode criar a sua grandeza econômica, social e política, não é menos certo que as colônias estrangeiras só contribuirão para esse grau de aperfeiçoamento se nacionalizadas, assimiladas e fundidas integralmente." ideia defendida por aqueles que apoiavam as teorias de eugenia e que viam na migração de estrangeiros como parte de um projeto que possuía ao mesmo tempo o desejo nacionalista de preservar a cultura, mas que também almejava o uma solução para o "melhoramento da raça”. (MARQUES, 1940, p. 206-207)

O artigo, assinado por José de Oliveira Marques (1940), é um reflexo das ideias defendidas por aqueles que apoiavam as teorias de eugenia e que viam a migração de estrangeiros como parte de um projeto que possuía ao mesmo tempo o desejo nacionalista de preservar a cultura, mas que também almejava uma solução para o "melhoramento da raça". O autor segue defendendo a imigração somente de indivíduos selecionados, afirmando que:

O sentido da civilização e da cultura é inseparável da compreensão do problema étnico. Nenhuma civilização superior, nenhuma alta cultura humana jamais se derivou do conglomerado de contribuições pobre, oriundas de elementos étnicos caídos ao acaso no crisol das raças que, porventura, lhe tenham servido de berço. Foi da fusão dos melhores componentes de tipos raciais, e não dos piores, que as grandes nações, portadoras de uma alta civilização e cultura, argamassaram a sua formação étnica [...]. (MARQUES, 1940, p. 207-208)

Portanto, ao lado da falaciosa teoria da "melhoria da raça. Ou seja, no bojo de um projeto de Estado nacionalista e centralizador, o sucesso da transformação de 'estrangeiros' em 'brasileiros' seria uma preocupação constante.

O processo de aceitação do imigrantes em território nacional passaria, portanto pelo crivo do tipo de estrangeiro que precisaríamos para melhorar os nacionais, note-se que já não está mais em questão apenas a origem europeia como credencial que referendava a "qualidade" do indivíduo, alguns grupos eram tidos como indesejáveis, ou como incompatíveis, como os chineses, japoneses, judeus, e outros não-brancos, sendo que após a Segunda Grande Guerra, cresceram ainda mais as reservas em relação ao elemento estrangeiro, que deveria ser minuciosamente selecionado para garantir a "melhoria da raça".

Art $1^{\circ}$. Não será permitida a entrada de estrangeiros de um ou de outro sexo (quando):

I - aleijados ou mutilados, inválidos, cegos, surdos-mudos;

II - indigentes, vagabundos, ciganos e congêneres; 
III - que apresentem afecção nervosa ou mental de qualquer natureza, verificadas na forma de regulamento, alcoolistas ou toxicômanos;

IV - doentes de moléstias infectocontagiosas graves, especialmente tuberculose, tracoma, infecção venérea, lepra e outras feridas nos regulamentos de Saúde Pública.

$\mathrm{V}$ - que apresentam lesões orgânicas com insuficiência funcional; VI -VII - VIII - IX ...

O decreto continuava ainda estabelecendo as condições que levariam ao repatriamento:

Poderá ser repatriado o estrangeiro que dentro do prazo de seis meses, contados da data de seu embarque apresentar sintomas ou manifestações de doenças constantes na tabela anexa:

I - Doenças mentais:

Personalidades psicopáticas (especialmente alcoolistas, e outros toxicômanos, perversos, amorais, paranoicos).

Psicoses agudas e crônicas,

II - Doenças nervosas:

Mielopatias sistematizadas - esclerose lateral amiotrófica, pólio-mielite anterior crônica.

Mielopatias não sistematizadas - siringomielia, esclerose em placas, neuromielite.

Doenças hereditárias e familiares do sistema nervoso, heredo-ataxias, degeneração lenticular progressiva, coreia crônica, miopatias.

Doenças de Parkinson, parkinsonismo.

Neuro-lues (especialmente tábis), paralisia geral, mielopatias.

Encefalopatias.

III - Doenças de Basedow:

Mixedema.

Acromegalia.

Síndrome adiposo-genital.

Diabete grave.

IV - Outras doenças:

Lepra.

Câncer.

Cárdio-vasculopatias, nefropatias e hepatopatias com insuficiência funcional irredutível.

Síndrome hamítica grave - anemias perniciosas e leucemias." (Revista de Imigração e Colonização, 1946, ano VII, p. 666)

A medida, de caráter higienista, busca realizar, com auxílio de critérios médicos, uma primeira triagem qualitativa do estrangeiro que desejasse imigrar para o Brasil.

\subsection{A aversão ao estrangeiro}

Para o bem ou para o mal, o imigrante tornara-se um personagem importante para o funcionamento e crescimento do setor de produção. Mas, mesmo antes das leis de controle, a presença numerosa de trabalhadores estrangeiros, concorrendo com os nacionais, já era questionada pelos nacionalistas mais ferrenhos:

A gente tem de ser brasileiro até a medula do vão do dedo, dê no que der. Esse negocio de extrangeiro se metter na vida do próximo, mesmo com os seus capitães, não pode ir assim de arrastão. Talvez os senhores se lembrem de que ha ja alguns annos o governo cogitou de encampar a City de Santos, empresa respeitabilíssima que explora água e bonde na terra de Braz Cubas. Houve ate um deposito judiciário de cerca de 500 mil libras feito pelo estado, afim de se iniciarem 
as negociações para encampação daquella Empresa. Mas política vae, política vem, advogados brasileiros a serviço de interesses extrangeiros, impediram que se realizasse a independência santista do jugo bretão da poderosa companhia. [...] a gente não pode ser molle nessas coisas. É preciso entezar o negocio, arregalar bem os olhos pra elles, não permitir que a pestana se mexa e, firme na passoca, sacudir com os taes, sinão botam em cima do próximo, cangalha, barrigueira, loro rabicho, com espora por contrapeso. (Folha da Manhã, sexta-feira, 21 de maio de 1926) ${ }^{84}$

As críticas aos estrangeiros só aumentaram com o cenário de crise, como a dos anos que sucederam o crack da bolsa em 1929, a aversão ao estrangeiro se tornaria mais visível, como por exemplo, na imprensa carioca, durante a campanha constitucionalista de 1932, quando alguns jornais não pouparam ataques aos "estrangeiros de São Paulo". Para os nacionalistas, o imigrante era um intruso, não era nem paulista e muito menos brasileiro, como mostra o artigo do jornal carioca Às Armas:

Nós desejamos uma revolução mais radical. Por que não seguimos o exemplo que as próprias pátrias desses estrangeiros nos oferecem? Lá estrangeiros podem gozar de todas as regalias, menos porém, a do desempenho em função pública. Entre nós tem sido o contrário: enquanto brasileiros competentes e chefes de família passam fome, a mãe pátria prodigaliza toda a proteção e carinho à estranhos pançudos filhos do além mar. (Jornal Às Armas. nº 01, dias 25/26 de setembro de 1932)

Para os cariocas mais radicais, os imigrantes que viviam em São Paulo ocupavam, no mercado de trabalho, o espaço que deveria pertencer, por direito, aos nacionais. Lembremos que se tratava de um momento de crise econômica internacional, no qual fábricas fechavam a todo o momento e os índices do desemprego eram grandes ${ }^{85}$. Contrários a esta visão, os próprios imigrantes desde sua chegada, manifestavam seu orgulho por se considerarem os responsáveis pelo crescimento de São Paulo e do Brasil:

${ }^{84}$ Folha da Manhã. Juca Pato contra a privatização. Quinta-feira, 20 de junho de 1929. As críticas de Belmonte, estendiam-se a outras influências estrangeiras, como o futurismo, de Marinetti. Por ocasião da visita do artista, Belmonte escreveria: "Marinetti chegará amanhã. E, como elle mesmo diz que "a vaia é a suprema consagração do gênio", estão-lhe preparando uma recepção de assobios e ovos podres. Plínio Salgado, grande admirador de Marinetti, propõe, para externar tão grande admiração, se amarre Marinetti num poste e se o espanque delirantemente, até que o Gênio se consagre na Santa Casa ou no Necrotério!" Criticando ainda o estilo da moda da Sra. Marinetti, que estaria tão à frente de nossos padrões que se tornava difícil delimitar a fronteira entre o bom e o mau gosto, completa: "[...] enquanto o futurismo andou pelas babozeiras das reformas estheticas, ainda se lhe podia tolerar a burrice, mas metterse em questões de vestuário, tenha paciencia, desculpe o mau jeito, mas vá lamber sabão! [...]”

${ }^{85}$ Impossível não estabelecermos uma comparação com o quadro vivido pelos países - da Europa e também Japão e Estados Unidos - que receberam grande número de imigrantes durante os anos de 1990 e que hoje enfrentam os efeitos da crise econômica de 2008, que abalou a economia mundial. Nesses países, o fim de benefícios sociais para os estrangeiros, demissões de mão de obra imigrante e mesmo ações xenófobas e de caráter neonazista tornaram-se frequentes. 
Quem sois vós que gritais contra os estrangeiros? Brasileiros?! Quereis vos colocar em confronto com aqueles que apelidais de estrangeiros? [...] Dos vossos sapatos aos chapéus foi o estrangeiro que vos produziu tudo. Os estrangeiros vos vestem. A cerveja que bebeis é feita por estrangeiros [...]. As casas que habitais [...] são obra de estrangeiros [...]. As ferrovias são construídas por capital e mão de obra estrangeiros [...] De brasileiros somente a terra... que é trabalhada por estrangeiros. Enxotai o estrangeiro e tudo o que é estrangeiro e vereis o que vos sobrará! Retornareis ao antropóide [...]. (MAGNANI, 1982, p. 143) ${ }^{86}$

A mesma esquerda carioca que acusava os operários imigrantes de roubarem os empregos dos nacionais lhes criticavam o comportamento por serem vistos como 'maus hóspedes' de estarem tirando proveito do Brasil.

O comércio e a indústria paulista acham-se enfeixados nas mãos de imigrantes ou prepostos... a plutocracia paulista, constituída pelos maus estrangeiros, nossos hóspedes, e pelos políticos profissionais, preparou e planejou este bárbaro massacre... sim brasileiros, às armas! às armas contra os genuínos crimes de lesa pátria. (Bangú Jornal, seção do Às Armas, 26/27 de setembro de 1932)

É curioso observar que se, por um lado a visão do semanário carioca é a de que os imigrantes que viviam em São Paulo estariam a sugar a nação; por outro lado, por parte dos paulistas, existia a mesma mágoa, porém no que se referia a sua relação com os demais estados da nação, que eram vistos, por muitos dos simpatizantes da revolução constitucionalista, como regiões incapazes para o desenvolvimento, que viviam às custas de São Paulo. Uma imagem que frequentemente aparece nos trabalhos sobre este tema da exploração de São Paulo é a de um cartão postal da época, que apresenta desenhada, em seu centro, uma vaca gorda, simbolizando São Paulo; parada, amamenta homenzinhos de cartola e fraque, representando as elites aproveitadoras dos outros estados; no alto lê-se "Brasil, o que é que há?" e no rodapé, a resposta: "O que sempre houve" ${ }^{87}$. Era sem dúvida, um deboche, que procurava incitar os 'patriotas' à indignação pela situação de parasitismo que acreditavam estar se desenvolvendo, entre a São Paulo-Locomotiva e o restante do Brasil.

\footnotetext{
${ }^{86} \mathrm{Em}$ acordo com este discurso, Bruno apresenta outro, anterior, mas que reproduz o mesmo sentimento: "Os méritos e os resultados cabem em grande parte aos estrangeiros. Quero dizer que as grandes casas comerciais e os bancos estão nas mãos dos alemães; os ingleses possuem a estrada de ferro, os italianos constroem e decoram as casas e praticam cem outras diversas profissões; os franceses - helas! - exploram o politeama, local onde as pessoas se divertem" (BRUNO, 1981, p. 154).

${ }^{87}$ São Paulo, Onde Está Sua História. São Paulo, MASP/Secretaria do Estado da Cultura/Secretaria Municipal da Cultura, 1981, p. 157.
} 


\subsection{A migração para o Sudeste: soluçao para o problema de mão de obra}

O novo cenário internacional traria consigo uma reorganização das relações na economia nacional; à medida que o preço dos produtos primários subia e o Brasil passava a acumular reservas suficientes para negociar melhores termos para o pagamento de sua dívida externa. Estabilizada a situação das contas externas, o governo brasileiro, diante dos entraves colocados à importação, passou a incentivar a indústria, o que lentamente conduziu à retomada do crescimento.

A partir daí, o Estado foi gradativamente assumindo a responsabilidade pela produção de alguns insumos básicos, como parte do esforço de guerra ou movido por uma visão mais estratégica acerca do futuro desenvolvimento do país. ${ }^{88} \mathrm{E}$ se para alcançar o desejado progresso, a mão de obra estrangeira ainda fosse necessária para os projetos de Vargas, seria fundamental, portanto, nacionaliza-los - não apenas naturalizá-los, mas 'abrasileirá-los'.

Dessa forma, a necessidade de adaptar-se o estrangeiro ao Brasil ficaria patente, tanto nos relatórios sobre migração, quanto naqueles voltados para a questão da educação e da formação de uma identidade nacional:

De fato, nacionalizar o ensino, obra que o Estado Novo já realizou, foi apenas substituir a escola estrangeira pela nacional correspondente, sem permitir o funcionamento das primeiras. Uma vez conseguido este resultado, está virtualmente nacionalizado o ensino no país. Mas, a nacionalização do ensino não é um fim e sim um meio, tendente a apressar a absorção pelo meio nacional dos descendentes dos elementos alienígenas, radicados em nosso solo. E o trabalho que esse fim exige é que está a reclamar o esforço de todos os brasileiros e, principalmente, daqueles que estão encarregados da tarefa grandiosa de ensinar e educar esses jovens patrícios. (Revista de Imigração e Colonização, ano I, 1940, p. 236)

Preocupando-se com a importância da educação para o cumprimento da construção de uma identidade nacional o artigo, Língua nacional e espírito nacional expunha impressões sobre as zonas de colonização germânica e italiana. A matéria fora publicada no Correio da Manhã, em 26 de abril e, inspirou também uma matéria na, Revista de Imigração e Colonização, edição de abril/julho, sob o título A língua e o nacionalismo, sendo ainda foco de atenção nos comentários

\footnotetext{
88 Em 1940, assistiu-se à criação da Companhia Siderúrgica Nacional, em decorrência de acordo com os Estados Unidos. Em 1942, foi criada a Companhia Vale do Rio Doce, para a exploração das jazidas de ferro de Minas Gerais. Em 1943, foi a vez da Companhia Nacional de Álcalis, para a produção de soda e barrilha, e da Fábrica Nacional de Motores. Por fim, em 1945, foi constituída a Companhia Hidrelétrica do São Francisco, com vistas ao abastecimento de energia elétrica para o Nordeste do país. A Era Vargas. Cd-rom e acesso eletrônico em http://www.cpdoc.fgv.br/nav_historia/htm/ev_main.htm\#top.
} 
da redação do A Notícia em 29 de abril, sob o título A língua, elemento nacionalizador. O artigo de Ribeiro baseia-se na questão do interesse na assimilação dos descendentes de estrangeiros para o bem da formação de uma identidade nacional. Para tanto, o autor lança mão de argumentos embasados no pensamento de Oliveira Vianna, Gilberto Freyre, Alfredo Ellis Jr e Emílio Willems. Deste último, Ribeiro Couto apresenta pesquisa realizada no Sul, que demonstrava que: segundo observado nas comunidades germânicas, o mal não está em que muita gente das povoações rurais não sabe falar o idioma nacional: o mau está em que, nas próprias cidades, esse idioma não é empregado pelos que o sabem. A não ser para se comunicarem com pessoas de fora, os teutobrasileiros só se comunicariam entre si em alemão. Assim:

Os meninos que recebem instrução, nas escolas brasileiras, [...] tendem à assimilação, encontramse numa atmosfera cultural inteiramente não-brasileira logo que, findas as aulas, fecham os livros. A proibição de falar português em família é outro exemplo que reflete conflitos de gerações”! Em contato com outros meninos, no ambiente brasileiro da escola, os filhos de alemães começam a embeber-se do espírito nacional, se sentem tão brasileiros como quaisquer outros. Entretanto, a escola primária por si só não resolverá completamente o problema" [...]porque nas ruas, nos jardins, nas igrejas, nos estabelecimentos de comércio, por toda parte, os mesmos meninos só ouvem falar alemão e por toda parte sentem aquele desdém pelo idioma nacional, provocado pelo pejorativo conceito em que é tido o brasileiro. Os colonos não querem ver os filhos nem 'acaboclados' nem 'lusitanizados', conforme observa Emílio Willems ao registrar que se dá por vexes, como efeito do choque de culturas e de educação. (Revista de Imigração e Colonização, abril/julho, ano II, 1941, p. $790-791)^{89}$

O autor prossegue explicando que:

É o já citado pavor, (continua ele), que os colonos têm do verkaboclern (acaboclar) ou verlusen (lusitanizar-se) do filho, pois eles não conhecem outros padrões de vida brasileira senão a paupérrima, desamparada existência de caboclo litorâneo, sem recursos materiais, sem trabalho constante e metódico, infestado pelo alcoolismo e a sífilis. Verlusen, significa para o colono tornarse algo parecido com esse tipo de caboclo brasileiro. Daí explica-se também o fato, [...] da palavra caboclo ser usada como insulto. (Revista de Imigração e Colonização, abril/julho, ano II, 1941, p. 791)

Quanto ao colono estrangeiro, o que se tinha então já não é mais aquela imagem da imigração como caminho para uma melhoria da raça, como se pensava outrora; é, agora, praticamente o inverso. O imigrante bem-vindo, neste momento, é aquele disposto a adaptar-se aos costumes e à cultura brasileira, ou seja, era aquele que estivesse disposto à acaboclar-se, dessa

${ }^{89}$ Revista de Imigração e Colonização, abril/julho, ano II, 1941, pp. 790 - 791. 
forma, a importância do europeu não seria no sentido de melhoria a nossa cultura - não se trata de trazer costumes mais refinados ou mais civilizados - mas seria, isso sim, para ocupar nossos vazios demográficos e branquear o nosso povo.

Em A Notícia, os comentários sobre a questão apontavam que: "É preciso que a campanha nacionalizadora prossiga além da escola[...] Exija-se que o português seja obrigatoriamente falado não só nas escolas, já nacionalizadas, mas também nas fábricas, nas igrejas, e nas casas de comércio." Concluindo com: "Necessita-se de uma presença multiforme do Estado brasileiro, não apenas na farda do sargento-instrutor e na cartilha da professorinha 'lusa', mas em toda a organização da vida local. A começar pela igreja. A terminar pelo banco"

Segundo Rahmeier (2008), em 23 de abril de 1938, numa correspondência interna dentro do Ministério de Relações Exteriores da Alemanha, fora afirmado que "o embaixador alemão teria solicitado que as escolas alemãs no Brasil se adaptassem às leis nacionais”. Em seu artigo ${ }^{91}$, a autora apresenta detalhes das relações diplomáticas entre Brasil e Alemanha, afirmando que “o embaixador alemão Karl Ritter não estava contente com as medidas nacionalizadoras brasileiras que atingiram as comunidades de descendentes de imigrantes alemães, mas nada fez junto ao governo brasileiro para intervir” (RAHMEIER, 2008, p. 07).

Embora produzindo um flagrante contrassenso, o autor fala em triagem, para que se permita a entrada somente daqueles que tivessem o perfil que interessava à nação, e sobre a necessidade de garantir-se a assimilação da cultura por parte do imigrante, apontando que: "no nosso país não há preconceitos raciais nem de origem, e os brasileiros consideram seus patrícios todos aqueles trabalham pelo engrandecimento do Brasil" 92 .

Curioso notar que, na visão do autor do texto, embora haja uma crítica aos colonos de origem alemã, que não aceitam a língua e a cultura brasileira, por outro lado, há a descrição do caboclo do litoral como um personagem com qualificações negativas. "Sem recursos, sem trabalho

\footnotetext{
${ }^{90}$ Revista de Imigração e Colonização, abril/julho, ano II, 1941, p. 794-795.

${ }^{91}$ Andrea Helena Rahmeier utiliza como fonte, em seu trabalho, a documentação diplomática entre Brasil e Alemanha durante os anos de 1930. A autora afirma que a implantação do Estado Novo no Brasil foi acompanhada com atenção pela embaixada da Alemanha no Brasil, havendo envio regular de informações detalhadas. RAHMEIER, Andrea Helena Petry. Alemanha e Brasil: as relações diplomáticas em 1938. PUC-RS, IX Encontro Estadual de História, ANPUH-RS, 2008.
}

${ }^{92}$ Revista de Imigração e Colonização, ano II, 1940, p. 241. 
e infestado pelo alcoolismo e pela sífilis”. Descrição tão pejorativa e preconceituosa quanto aquelas que se lia nos jornais das capitais nordestinas, quando das secas de 1877, 1915 e 1932, sobre os retirantes que chegavam buscando abrigo Esta ideia de um respeito por todas as raças, para Maria Aparecida de Moraes Silva, serviu apenas para escamotear as diferenças de aceitação e integração social dos diferentes grupos étnicos. Nega-se a discriminação, nega-se que outrora, negros, indígenas e mestiços era considerados a "parte gangrenada" 93 da mestiçagem, que deveria ser expulsa. Silva destaca que embora a ideia de "parte gangrenada", tenha com o passar do tempo, desaparecido dos textos e dos pronunciamentos, não teria desaparecido das práticas e das relações cotidianas. A subvalorização do mestiço teria sobrevivido à substituição das teorias de supremacia racial, pelas interpretações culturalistas. Dessa forma, o desejo de impor a assimilação da cultura brasileira era - em tempos de nacionalismo - um objetivo a ser alcançado $^{94}$.

\subsection{O trabalhador nacional e a guerra}

Com a guerra, a economia nacional passaria por um momento turbulento e, como resultado das políticas restritivas, bem como em razão da imagem que fora construída em torno do imigrante, durante a guerra, a mão de obra do elemento estrangeiro começaria definitivamente a ser substituída, nas grandes metrópoles, pela mão de obra nacional, dando início a um intenso fluxo de migrantes, vindos principalmente do Nordeste, em direção às duas metrópoles nacionais. Uma valorização do elemento nacional pode ser percebida a partir do Decreto número 1843 de 1939, a Lei dos Terços, que definia a proporção de dois terços de mão de obra brasileiros em vários setores:

Decreto-lei n. 1.843 - de 07 de dezembro de 1939 - Dispõe sobre a nacionalização do trabalho e a proteção ao trabalhador nacional.

93 SILVA, Maria Aparecida de Moraes. Errantes do fim do século. São Paulo: Fundação Editora da UNESP, 1999, p.78.

${ }^{94}$ Folha da Manhã. Juca Pato contra a privatização. Quinta-feira, 20 de junho de 1929. as críticas de Belmonte, estendiam-se a outras influências estrangeiras, como o futurismo, de Marinetti. Por ocasião da visita do artista, Belmonte escreveria: "Marinetti chegará amanhã. E, como elle mesmo diz que "a vaia é a suprema consagração do gênio", estão-lhe preparando uma recepção de assobios e ovos podres. Plínio Salgado, grande admirador de Marinetti, propõe, para externar tão grande admiração, se amarre Marinetti num poste e se o espanque delirantemente, até que o Gênio se consagre na Santa Casa ou no Necrotério!" Criticando ainda o estilo da moda da Sra. Marinetti, que estaria tão à frente de nossos padrões que se tornava difícil delimitar a fronteira entre o bom e o mau gosto,, completa: “[...] enquanto o futurismo andou pelas babozeiras das reformas estheticas, ainda se lhe podia tolerar a burrice, mas metterse em questões de vestuário, tenha paciencia, desculpe o mau jeito, mas vá lamber sabão!...” Folha da Manhã, sextafeira, 21 de maio de 1926. 
Art $1^{\circ}$ - as empresas, ou os indivíduos, que explorem serviços públicos dados em concessão, ou que exerçam atividades industriais ou comerciais, são obrigados a manter, no quadro do seu pessoal, quando composto de três ou mais empregados, uma proporção de brasileiros, não inferior à estabelecida no presente decreto-lei.

$\S 1^{\circ}$ - Sob a denominação geral de atividades industriais e comerciais compreende-se, além de outras que venham a ser determinadas em portaria do Ministério do Trabalho, Indústria e Comércio, as exercidas:

a) nos estabelecimentos industriais em geral;

b) nos serviços de comunicações, de transportes terrestres, marítimos, fluviais, lacustres e aéreos;

c) nas garages, oficinas de reparos e postos de abastecimento de automóveis e nas cocheiras;

d) nas indústrias de pesca;

e) nos estabelecimentos comerciais em geral;

f) nos escritórios comerciais em geral;

g) nos estabelecimentos bancários, ou de economia coletiva, nas empresas de seguros e nas de capitalização;

h) nos estabelecimentos jornalísticos, de publicidade, e de radiodifusão;

i) nos estabelecimentos de ensino remunerado, excluídos os que neles trabalhem por força do voto religioso;

j) nas drogarias e farmácias;

k) nos salões de barbeiros;

1) nos estabelecimentos de diversões públicas, excluídos os elencos teatrais, e nos clubes esportivos que cobrem ingresso para as exibições;

m) nos hotéis, restaurantes e bares e estabelecimentos congêneres;

n) nos estabelecimentos hospitalares e fisioterápicos cujos serviços sejam remunerados, excluídos os que neles trabalhem por força de voto religioso;

o) as empresas de mineração.

[...]Art. $5^{\circ}$ A proporcionalidade será de dois terços de empregados brasileiros, podendo, entretanto, ser fixada proporcionalidade inferior, em atenção às circunstâncias especiais de cada atividade, mediante ato do Poder Executivo, e depois de devidamente apuradas pelo Departamento Nacional do Trabalho e pelo Serviço de Estatística da Previdência e Trabalho a insuficiência do número de brasileiros na atividade de que se tratar.

Parágrafo único. A proporcionalidade é obrigatória não só em relação à totalidade do quadro de empregados, como as exceções desta lei, como ainda em relação à correspondente folha de salários. ${ }^{95}$

A partir da lei, a mão de obra nacional tornou-se não só necessária, mas obrigatória. O estímulo à migração estava consolidado.

Contudo, achavam-se fora das exigências de proporcionalidade as atividades que estivessem ligadas à indústria extrativa, com exceção da mineração, as indústrias rurais, as indústrias de beneficiamento ou transformação dos produtos agrícolas e do extrativismo vegetal;

95 Lei dos Terços. Câmara dos Deputados. Acesso em 20 de maio de 2011. Disponível em: <http://www2.camara.leg.br/legin/fed/declei/1930-1939/decreto-lei-1843-7-dezembro-1939-411788publicacaooriginal-1-pe.html> 
ou seja, embora o programa de nacionalização da mão de obra garantisse a presença do trabalhador nacional qualificado frente ao crescente número de trabalhadores europeus que aqui chegavam fugindo da guerra, o trabalhador nacional não qualificado, o trabalhador braçal e o trabalhador rural não estavam protegidos pela lei.

Firmando-se desde os finais do século XIX como centro urbano e área de produção industrial, São Paulo já há muito, exercia um fascínio intenso sobre as populações migrantes e, principalmente sobre os migrantes vindos dos sertões dos estados do Nordeste.

O volume de trabalhadores nordestinos vindos para o Centro-Sul, não fora pequeno, entre os anos 1910 e 1926, 7.026 trabalhadores migrantes entraram em São Paulo; já no período entre 1927 e 1933, a média aumentou para 29.146, perfazendo um crescimento de 414\% em comparação ao período anterior. Paralelamente a este processo de entrada de trabalhadores nacionais, uma comparação entre os censos de 1920 e 1940, sobre a população estrangeira residente no Estado de São Paulo, demonstra uma queda de $9 \%$ na sua representatividade. Mesmo percentualmente pouco significativa esta queda representaria uma tendência irreversível: a diminuição da imigração e o crescimento da migração, que pode ser ratificada também pelos dados dos relatórios anuais do atual Memorial do Imigrante, antiga Hospedaria que, desde 1950, passaria a receber quase que exclusivamente os migrantes vindos dos estados do Nordeste para São Paulo ${ }^{96}$.

Como afirma Maria Aparecida de Moraes e Silva, nas grandes capitais nacionais, São Paulo e Rio de Janeiro, o trabalhador braçal, o trabalhador da construção civil, é facilmente identificado como "o baiano", principalmente se estivermos em São Paulo ou como "o paraíba", se estivermos no Rio de Janeiro. Isso, porque, os trabalhadores deste setor, passaram a ser associados à grande massa de trabalhadores emigrados do Nordeste que chegaram às grandes capitais do Sudeste a partir dos anos de 1940 chegaram. Ocupariam inicialmente as atividades ligadas ao trabalho braçal

\footnotetext{
96 A criação da Hospedaria está ligada às iniciativas dos senadores Vergueiro e Antonio de Queirós Telles III, o Visconde de Parnaíba, ligadas à substituição da mão de obra do escravo negro, pelo trabalho do imigrante branco e livre. O grande número de imigrantes que aqui chegariam, pelo Porto de Santos, trouxe consigo sérios problemas de recepção, alojamento e encaminhamentos. Em busca de uma solução para o problema, o conde de Parnaíba pôs à disposição de São Paulo, uma sua propriedade de 30 mil metros quadrados, onde se construiu a Hospedaria dos Imigrantes; hoje, patrimônio histórico do Estado. Com a proclamação da República, hospedaria de imigrantes passou para a Secretaria do Trabalho. Contudo, em virtude do caráter quase exclusivamente agrícola da imigração passou à Secretaria da Agricultura, e mais tarde, em razão de novas compreensões sobre a natureza e os objetivos da imigração, a responsabilidade passaria para a secretaria do comércio e do trabalho; depois, novamente à secretaria da agricultura, e em 1967 para a secretaria da promoção social. A história da hospedaria está registrada e analisada em PAIVA, Odair da Cruz e MOURA, Soraya. Hospedaria de Imigrantes de São Paulo. São Paulo: Paz e Terra, 2008.
} 
menos qualificado, como os serviços domésticos para o caso das mulheres e, a construção civil no caso dos homens e depois ainda, a partir dos anos de 1950, ocupando também funções entre o operariado fabril ${ }^{97}$ e como mão de obra no setor terciário.

\subsection{O Atopos como representação do nordestino.}

Com o final da guerra, os temas de impacto deveriam ser encontrados aqui dentro do próprio Brasil e, com a ocorrência da seca de 1951-1953, a imprensa voltou seus olhos não somente para a miséria do sertanejo lá no sertão, mas, pela primeira vez, seguiria sua saga, acompanhando o destino daqueles que vinham emigrados para as grandes capitais do Sudeste $^{98}$.

Ao retratarem o cotidiano e os problemas das duas metrópoles brasileiras, O Cruzeiro, tradicionalmente destacava questões como o trânsito urbano, as chuvas, as enchentes, mas a partir dos anos de 1950, a população marginalizada - principalmente as crianças abandonadas, os moradores de rua e os favelados - ganharia espaço entre as notícias de impacto. Dentre os desvalidos, encontramos, principalmente, os sertanejos emigrados das secas, identificados como indivíduos deslocados no contexto de progresso e desenvolvimento das metrópoles, descritos ora como vítimas, ora como problema social; e seria assim, como um problema, símbolo do caos urbano, que protagonizariam duas matérias de impacto: Sertanejos do Asfalto de 1951, (figura 29,

97 Pioneira nos trabalhos sobre a história do operariado de São Miguel Paulista, ao estudar a Companhia Nitro Química Brasileira, Antonia Sarah Aziz Rocha, em seu trabalho O Bairro à sombra da Chaminé, dá ênfase ás relações cotidianas que este operariado formado por migrantes nordestino estabelecia entre si. Posteriormente, Odair da Cruz Paiva, analisaria em Caminhos Cruzados, as políticas migratórias realizadas com o subsídio oficial pela Secretaria da Agricultura do Estado de São Paulo, observando nessas políticas aspectos associados a um processo de modernização conservadora da sociedade brasileira a partir dos anos de 1930. Para tanto, toma como objeto a Companhia NitroQuímica, situada no bairro de São Miguel Paulista e inaugurada em 1940, um dos primeiros pólos de concentração da mão de obra de migrantes nordestinos entre o operariado do setor metalúrgico em São Paulo. Paulo Fontes - professor e pesquisador do Centro de Pesquisa e Documentação de História Contemporânea do Brasil da Fundação Getúlio Vargas - em seu livro Um Nordeste em São Paulo, relata a história da migração interna e os impactos que o processo de urbanização causou, modificando a classe trabalhadora no Brasil a partir da Segunda Grande Guerra; tendo também como foco o bairro de São Miguel, diferencia-se de Paiva por estender sua análise até a chamada "era populista", 1945 - 1964. ROCHA, Antonia Sarah Aziz. O Bairro à sombra da Chaminé. Um estudo sobre a formação da classe trabalhadorada Cia Nitroquímica Brasileira em São Miguel Paulista (1935-1960). Mestrado, Pontifícia Universidade Católica de São Paulo, 1999; PAIVA, Odair da Cruz. Caminhos Cruzados. Migração e Construção do Brasil Moderno (1930-1950). Bauru/SP: EDUSC, 2004. FONTES, Paulo. Um nordeste em São Paulo. São Paulo: Editora FGV, 2008. 98 Em 1954, tem início a construção da estrada Rio-Bahia, a BR-101, que, por um lado trouxe algum desenvolvimento à região e, por outro, criou as condições para a devastação de boa parte da mata Atlântica que ainda existia ali. Com a conclusão da BR-101, a circulação de pessoas ficaria imensamente facilitada. Já a BR 135, iniciada por Getúlio, em 1944, e concluída por João Goulart, somente em 1962 seria a responsável por escoar todo o trânsito pesado que demanda o atendimento à região Nordeste. 
30 e 31) com texto de Alvares da Silva e fotos de Eugênio H. Silva; e Gado humano de 1952, (figura 32) com texto de Jorge Ferreira e fotos de Henri Ballot .

A primeira imagem, a da mãe que amamenta, nos é apresentada a partir de um enquadramento que nos coloca diante de um cenário que parece não ter fim - não há um final para a cena, que se prolonga para além do enquadramento; e parece não haver um fim para o sofrimento daquelas pessoas, apresentadas em um emaranhado humano. O olhar preocupado da mãe e da mulher que aparece imediatamente atrás, em segundo plano, contrasta com a leveza da figura do bebê e do menino que o observa, ambos inocentes e alheios ao drama representado nas páginas seguintes.

Em Sertanejos do Asfalto, a denúncia é quanto à presença dos retirantes nas grandes cidades o problema urbano que essa presença numerosa provocaria, o risco de distúrbios e mesmo contaminações, muito semelhantes aos alardes registrados nos jornais das primeiras décadas do século. Nos oito pequenos quadros (figura 30) que destacam os rostos e as expressões dos retirantes, o tom dramático é concedido pelo choro do bebê, no colo da mãe, ao lado, tomando uma página e um terço, em plano conjunto, em um ângulo vertical, vemos, de costas, homens, mulheres e crianças, carregando suas trouxas, dão o tom de desolação à marcha dos migrantes.

A escolha do enquadramento e da luz, conferem grande tensão à cena, as trouxas nas costas, ou arrastadas pelo chão, os corpos com aparência cansada, dão ao leitor a impressão de que os retirantes formariam uma horda de desolados à invadirem a cidade. Ainda utilizando o enquadramento para conferir intensão à cena representada, na figura (31), o emaranhado humano que se prolonga para além do espaço do enquadramento, em plano vertical, nos é apresentado a partir da divisão da cena em oito quadros, a imagem cria uma impressão de falta de espaço, e de dignidade às quais os recém-chegados se submetiam. A frequente presença de crianças entre os retratados se transforma num recurso que potencializa o teor dramático da cena.

Na figura 32, Gado Humano, a tensão da fotografia está nas crianças. Na foto principal, de página inteira, a dramaticidade e a tensão são construídas a partir da imagem em contra-plongée da mulher que equilibra duas trouxas no colo, por sobre o corpo de um bebê, ao mesmo tempo em que na outra mão carrega a mamadeira da criança, que mesmo encoberta pela pequena montanha de panos, parece dormir tranquilamente.

A construção do cenário, bem como o próprio título da matéria aponta, nos revela o drama de indivíduos levados a uma condição sub-humana e aporética. Não há para onde ir, não há para 
onde voltar. O sertanejo é apresentado novamente como um homem vencido, porque no discurso construído pela imagem, não há outros responsáveis por sua condição que não ele mesmo, a natureza ou o destino. A frequência com que o sertão e os sertanejos apreciam, nas reportagens no Figura 29. Sertanejos do asfalto.
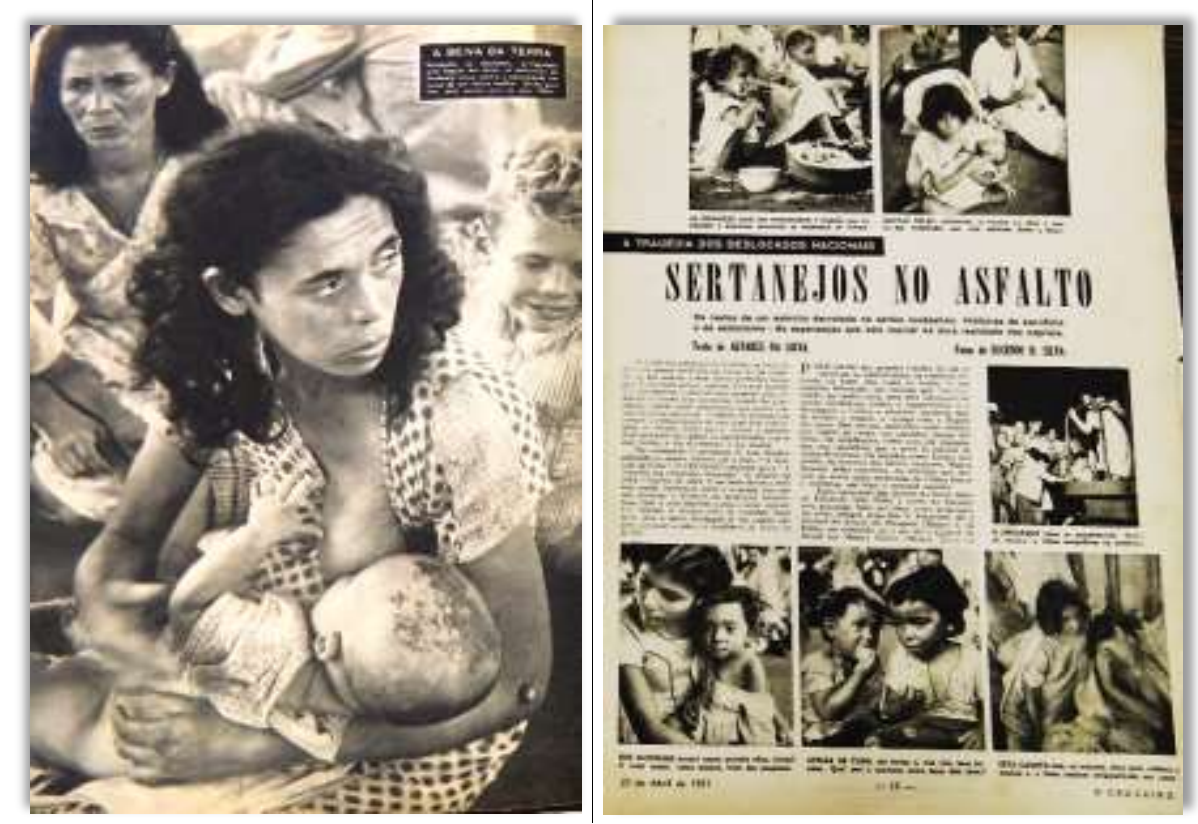

Fonte: Revista $O$ Cruzeiro, 21 de abril de 1951. Acervo do CDHIS-UFU.

Figura 30. Sertanejos do asfalto.2

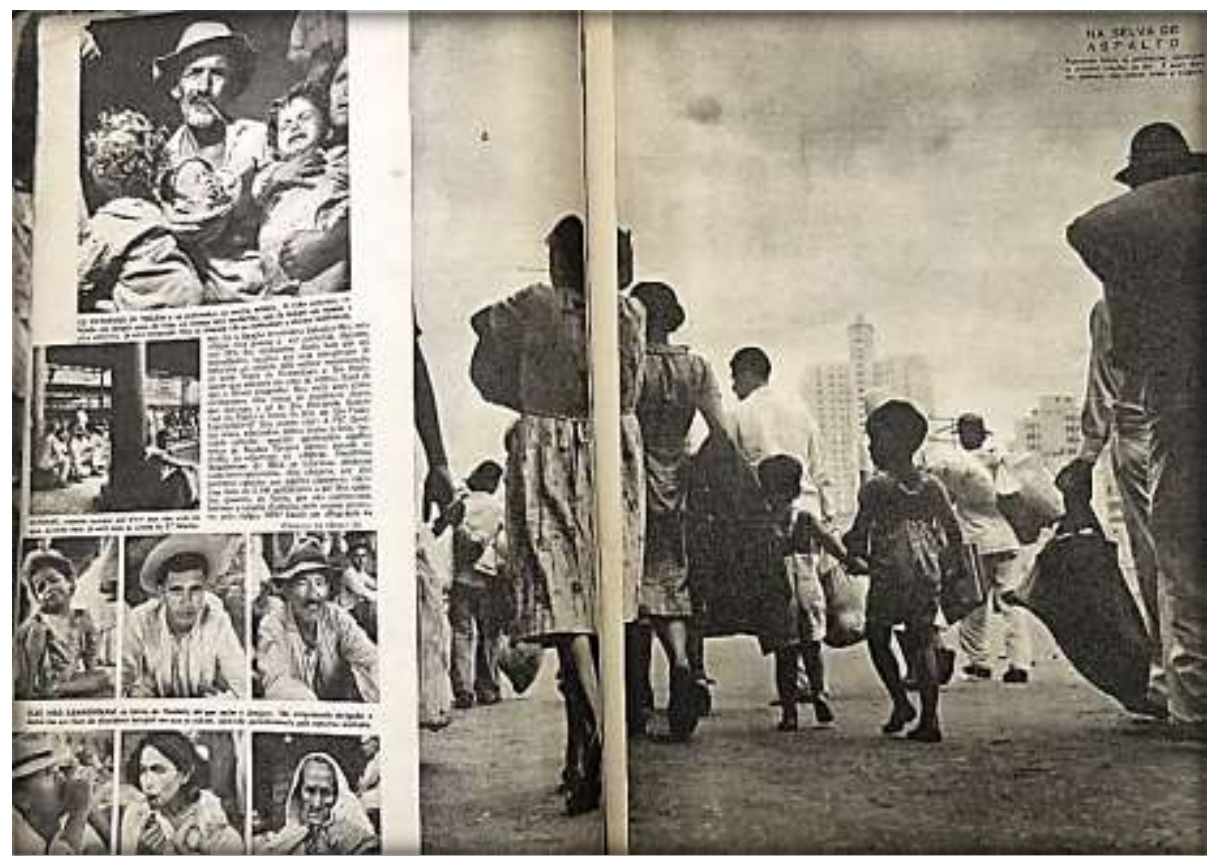

Fonte: Revista O Cruzeiro, 21 de abril de 1951. Acervo CDHIS-UFU. 
Figura 31. Sertanejos do asfalto.3

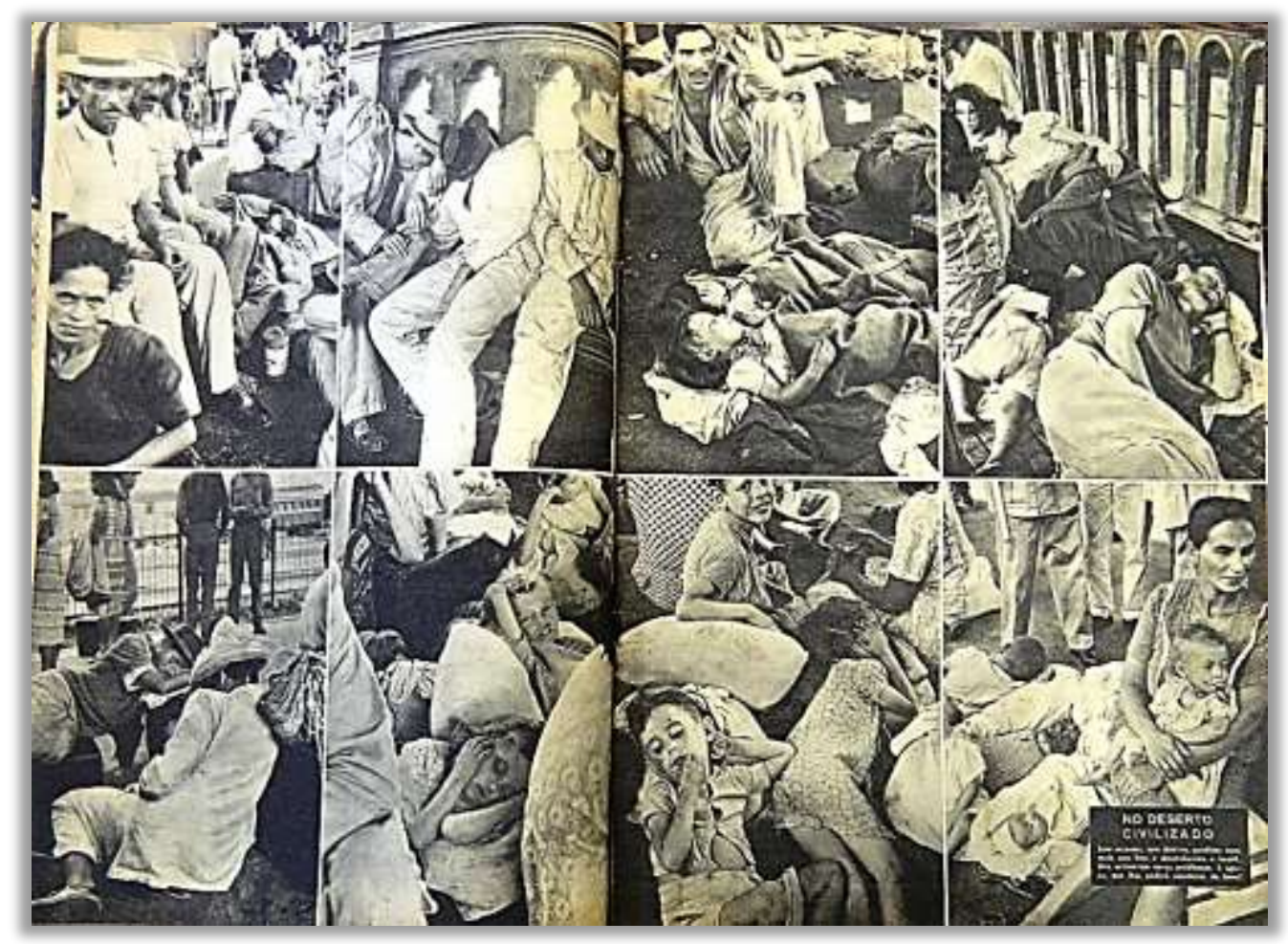

Fonte: Revista $O$ Cruzeiro, 21 de abril de 1951. Acervo CDHIS-UFU.

Figura 32. Gado Humano.

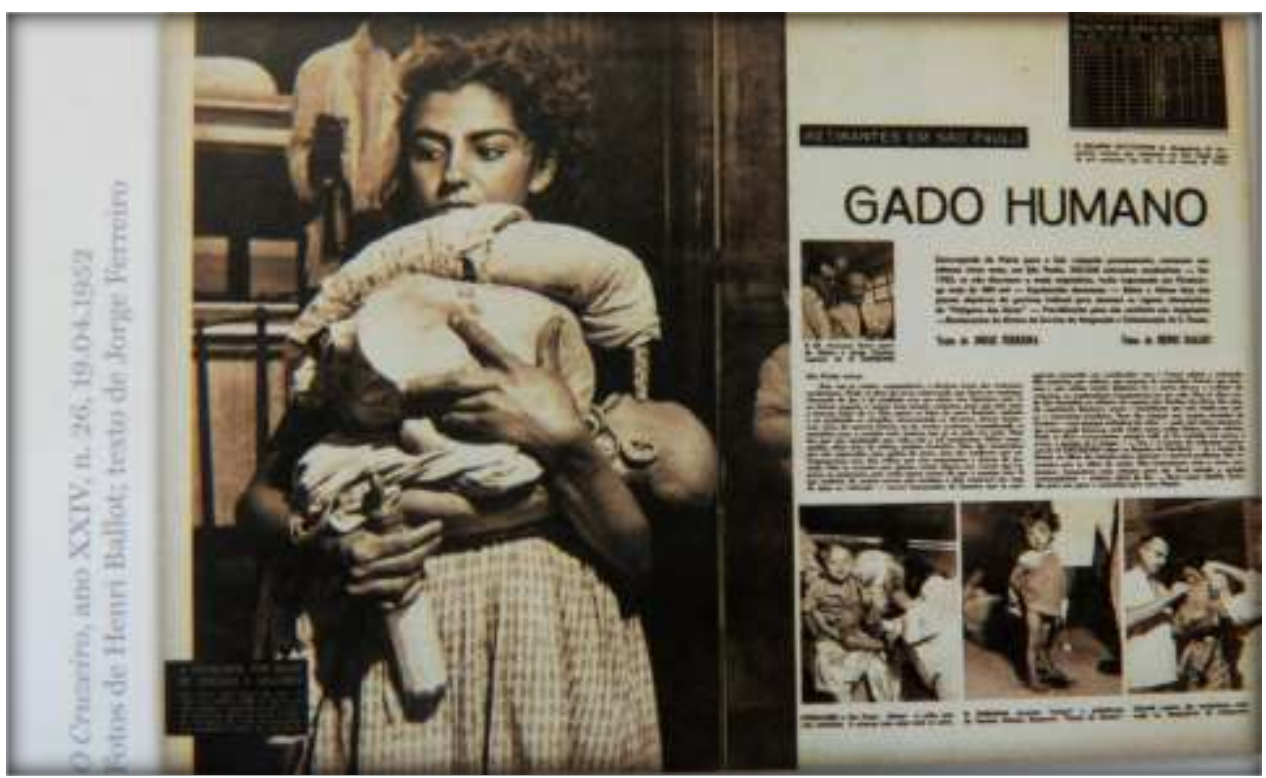

Fonte: Revista O Cruzeiro, 19 de abril de 1952. In COSTA, Helouise e BURGI, Sérgio. (orgs) As origens do fotojornalismo no Brasil. Um olhar sobre O Cruzeiro. 1940-1960. São Paulo: IMS, 2013. 
pós-guerra, nos indicam uma boa aceitação do tema, tanto é que também a Manchete, no mesmo período também adota o tema, e o apresenta em matéria de destaque em agosto de 1952.

Embora enfatizando, num primeiro momento, o incomum evento do nascimento de gêmeas quíntuplas, em São Paulo, a matéria, contudo, prosseguia mudando seu rumo, passando a descrever com detalhes a vida de privação e conforto de uma família de emigrantes, vindos da Bahia. As imagens (figura 33) definem o tom da reportagem, que, embora trouxesse no título a peculiaridade do nascimento quíntuplo, nas fotografias, construía um outro discurso, pautado pela ênfase na pobreza da família, tanto na terceira imagem superior, na qual o rosto preocupado do pai é apresentado em close up, quanto na imagem central em que, em plano geral nos apresenta o cenário humilde, ocupado por poucos objetos, no interior da casa da família:

Pela primeira vez no Brasil nasceram vivas cinco crianças gêmeas. E isto se deu em São Paulo no lar miserável de José Albano, na estrada do Vergueiro, justamente no local denominado Tanque da Pólvora, no bairro do Moinho Velho. Do sexo feminino e de cor preta são as cinco crianças nascidas no dia 19 de agosto: as cinco Marias [...] A mãe das cinco meninas, Maria Aparecida, também de cor, trabalha como doméstica e, de vez em quando serve de lavadeira. [...] Zé Albano, o pai das quíntuplas, é natural de Brotas e tem 36 anos de idade.

Os únicos parentes que possui são a mulher e os filhos. [...] (Zé Albano mora) num barraco no qual habitam cinco famílias somando ao todo vinte pessoas. Neste lar partilhado, cabe aos Albano um quarto de 3X4. Nesse quartinho existem uma cama de casal e dois berços. Um pequeno guardaroupa, uma peça que serve de guarda-comida e uma mesa feita de velhos caixotes. Um fogão que faz parte da mobília é a peça mais nobre da casa, embora nem sempre esteja aceso. (Revista Manchete. 02 de agosto de 1952, p. 8-9)

O pai servente de pedreiro, a mãe doméstica, ambos vindos da Bahia. Trabalhadores do mercado informal, moradores de um cortiço, negros ambos, moradores de um cômodo no qual "o fogão nem sempre está aceso". O texto amplia, potencializa a angústia que a expressão do home, na fotografia demonstra. Era uma típica família migrante, que embora encontrasse trabalho, não encontrava um lugar na metrópole.

A medida que vai se observando a sucessão de reportagens, é possível observar que essa temática, a do homem fora do lugar, seria um das representações que se consolidaria no imaginário coletivo sobre o migrante no início dos anos cinquenta. No dia das mães, o tema da pobreza e as condições precárias de vida dos migrantes, também se fazia presente. 
Figura 33. As 5 Marias de São Paulo.

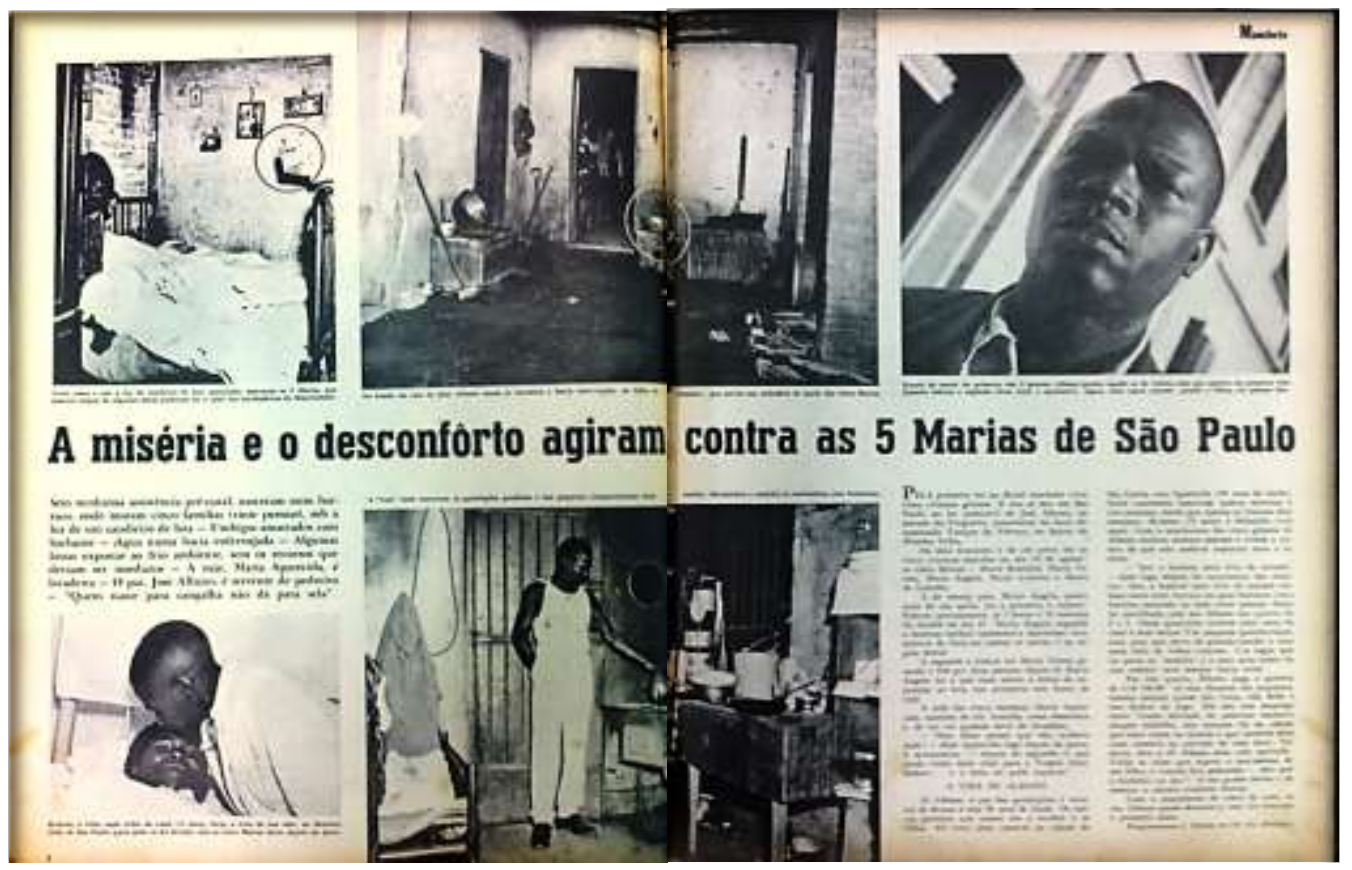

Fonte: Revista Manchete, agosto de 1952. Acervo Biblioteca Acervo Biblioteca Florestan Fernandes.

Figura 34. O dia das mães.

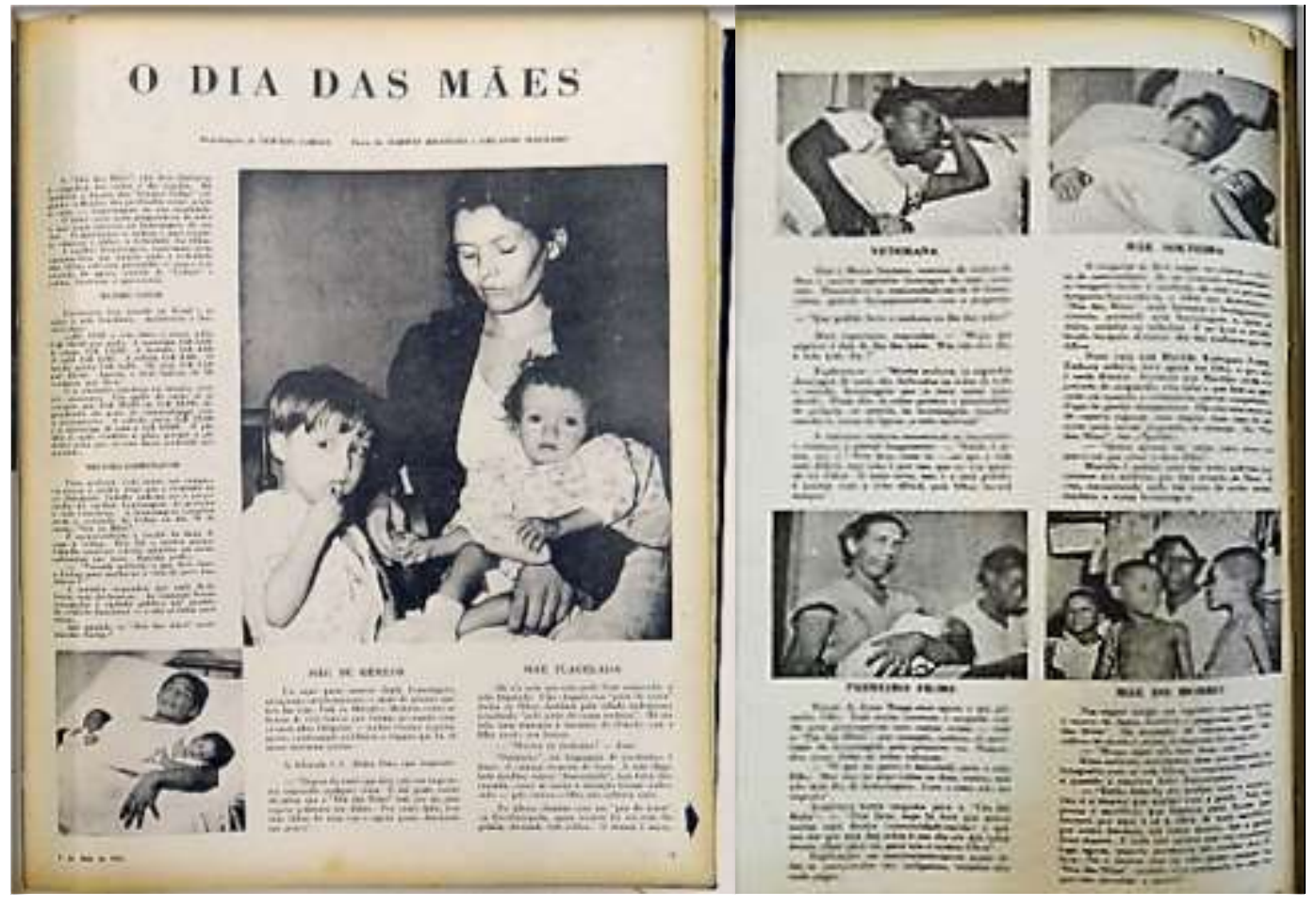

Fonte: Revista Manchete, 09 de maio de 1953, p. 17, 18. Acervo da Biblioteca Florestan Fernandes - USP. 
Em 1953, com texto do carioca Newton Carlos - que iniciava sua passagem pela Manchete, mas trazendo sua experiência como repórter do Jornal da Manhã e Correio da Manhã - e fotos de Darwin Brandão e Orlando Machado, vários "tipos" de mães são descritas e homenageadas: A mãe de gêmeos; a mãe flagelada; a mãe veterana; a mãe solteira; a mãe de primeiro filho e a mãe do morro.

A mãe flagelada, apresentada como uma mulher, que abraça seus dois filhos, e que só nos remete ao triste destino dos emigrados do Nordeste, pela tomada, em meio perfil, destacando a cabeça levemente inclinada, com um ar de desalento. Sobre a mãe flagelada, o jornalista diz:

Há u'a mãe que não pode ficar esquecida: a mãe flagelada. Elas chegam nos "paus de arara" cheias de filhos, desfilam pela cidade andrajosas, esmolando "pelo amor de nossa senhora." Há um mês, uma transpôs a barreira do Distrito com o filho morto nos braços. _ "Morreu de dasânimo" - disse. "Desânimo", em linguagem de nordestino, é fome. A criança morrera de fome. A mãe flagelada também estava "desanimada", mas falou descansada, como se assim a situação tivesse melhorado - pelo menos o filho não sofreria mais. No último desastre com um "pau de arara", na RioPetrópolis, quem morreu foi u'a mãe flagelada, deixando três órfãos. O drama é assim. (Revista Manchete, 09 de maio de 1953, p. 17)

A mãe flagelada é a mãe emigrada do Nordeste - assim, sem particularização de origem vem para o Sudeste como ultima ratio, mas acaba vítima de sua miséria, despreparo e desamparo. A mãe do morro, (figura 34, página da direita, quarto quadro) representada pela foto de uma mulher negra acompanhada por seus três filhos, é descrita pelo jornalista:

Faz algum tempo um repórter resolveu subir o morro de Santo Antônio e perguntar pelo "Dia das mães". Na sucessão de barracos que vasculhou de ponta a ponta, a resposta foi uma só: - Moço, aqui não tem disso não!" Uma senhora, entretanto, essa que aparece na fotografia com os três filhos, compreendeu melhor a questão e resolveu falar francamente: - "Estão falando em acabar com o morro. Isso é o mesmo que acabar com a gente. Não foi pouco o sacrifício que fizemos para fincar esse barraco por aqui e só a ideia de mais sacrifício por outro barraco, em outro morro, faz a gente ficar doente. [...] Vê o senhor que eu não posso pensar no Dia das Mães, quando vivo pensando no dia em que vão derrubar o morro. (Revista Manchete, 09 de maio de 1953, p. 18)

Nessa mesma linha editorial, de denúncia aos problemas sociais que envolvem um grupo que se encontra sem-lugar, tentando sobre-viver, temos a matéria com texto de ninguém menos que Vinícius de Moraes, sobre as crianças dos mocambos, na qual ele descreve cenas da capital pernambucana. Com o título "São crianças, meu Deus!" Trazendo no boxe à direita a frase: "Nascem à revelia, vingam por acaso e morrem antes do tempo", a reportagem, como em "Salvemse ao menos as crianças", de 1953, explora a imagem das crianças, para complementar e potencializar o discurso sobre a situação de abandono das famílias pobres, nesse caso, emigrados 
do interior, para a capital nordestina. A fotografia de Humberto Morais Franceschi valoriza o rosto da menina, que posa para a primeira fotografia (figura 35) com uma postura que lembra a dos santos e anjos, cabeça inclinada, mãos entrecruzadas por sobre o peito, em postura de súplica. $\mathrm{Na}$ foto da figura 36, o menino, vestindo apenas uma camiseta, muito maior que seu tamanho tem, no plano de fundo, o que seria um espaço improvisado, onde os poucos pertences da família são guardados - panos encardidos e esgarçados, potes etc - o sorriso tímido da criança, contrasta com a profunda miséria do lugar. Essa imagem comunica uma ideia de que essas crianças seriam vítimas de uma situação sobre a qual não têm arbítrio, portanto, comentando o texto de Vinícius, que diz:

As crianças dessas páginas nasceram porque a miséria não conhece o uso de anti-concepcionais. Nascem porque, mesmo na lama, a vida faz vigorar suas leis eternas e imutáveis. Quanto a crescer, conseguem-no por obra e graça do Espírito Santo, como dizia minha santa avozinha. Seus pulmões são em geral, corroídos pela tuberculose e seus intestinos, de vermes [...] São as crianças dos mocambos do Recife. Nascem à revelia, vingam por acaso e morrem antes do tempo. Doloroso, não é? (Revista Manchete, 30 de maio de 1953 p. 12 e 13)

Figura 35. São crianças, meu Deus!

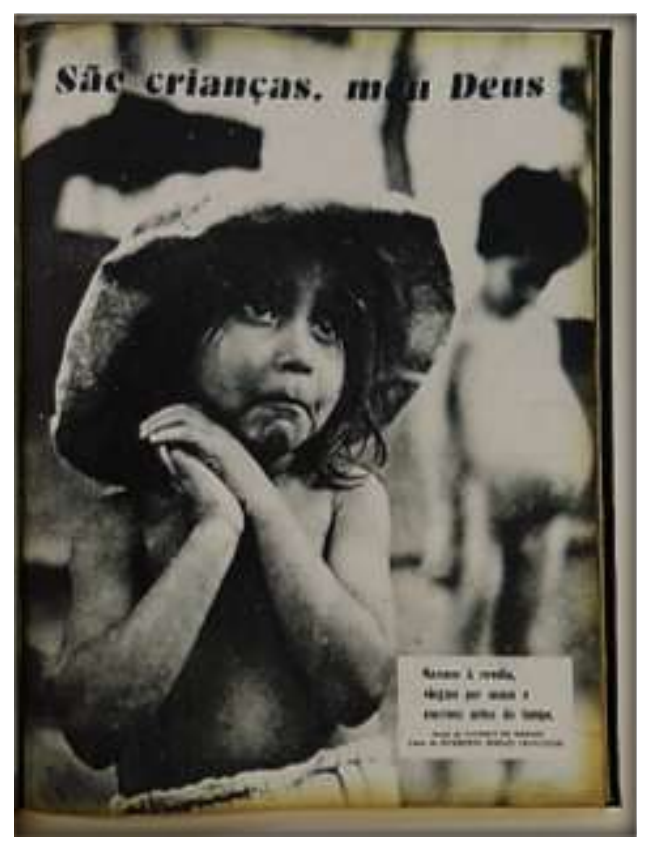

Fonte: "Eu vi crianças como as destas páginas, permanentemente tristes de fome crônica, os pequeninos rostos ausentes de qualquer alegria [...]." Revista Manchete, 30 de maio de 1953 p. 11. Acervo Biblioteca Florestan Fernandes USP.

No texto da reportagem, o poeta descrevia os recantos da cidade do Recife, onde a miséria afetava diretamente às crianças. 
Figura 36. São crianças, meu Deus!2

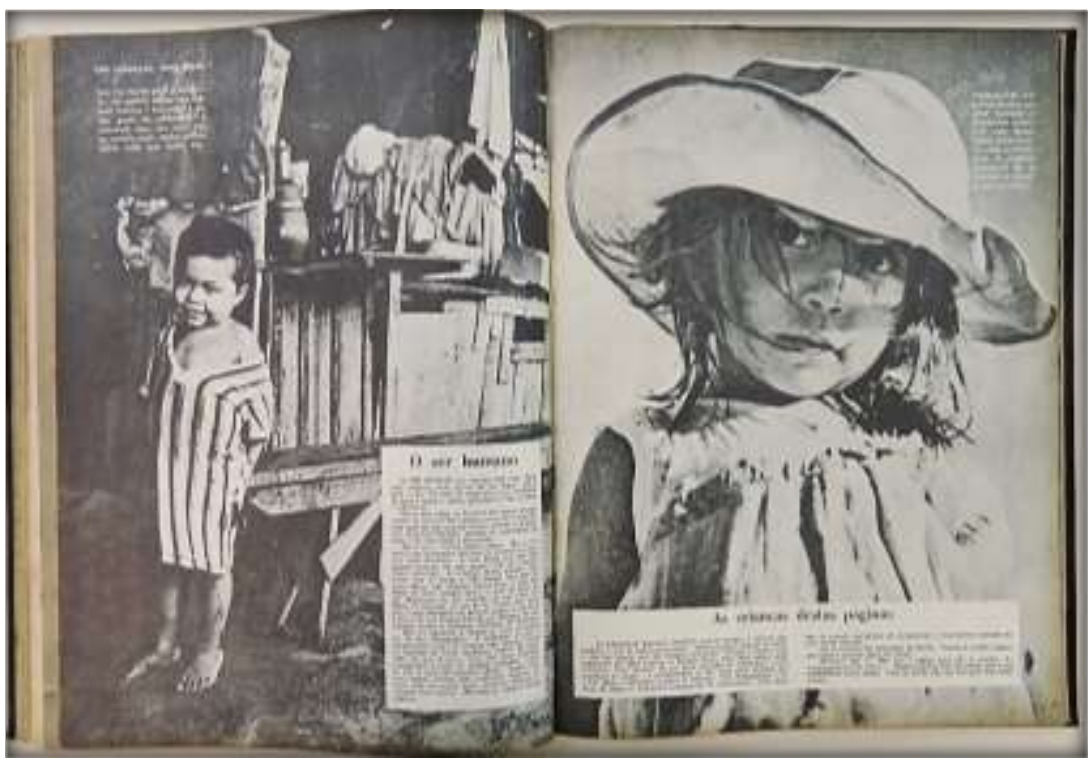

Fonte: Revista Manchete, 30 de maio de 1953 p. 12 e 13. Acervo Biblioteca Florestan Fernandes.

Figura 37. São crianças, meu Deus!3

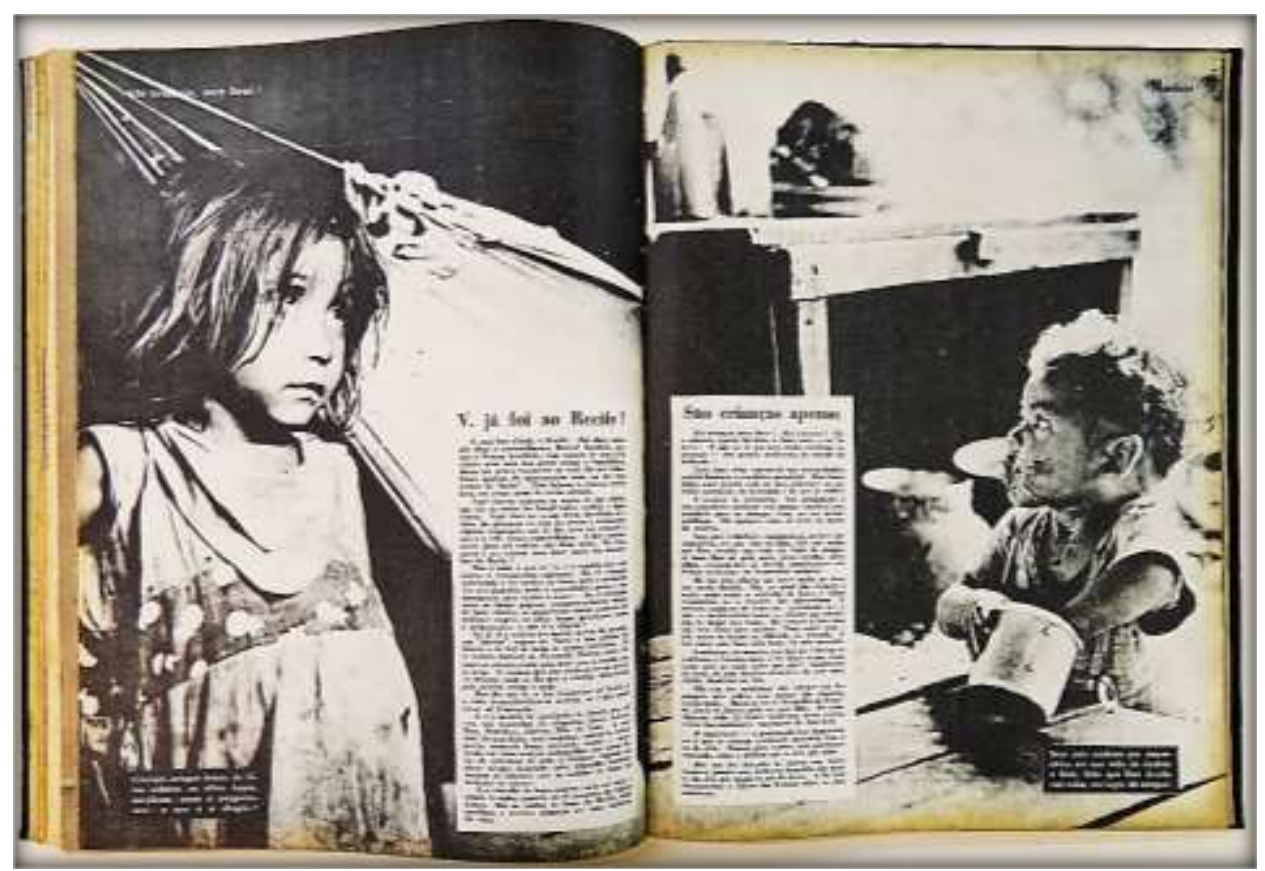

Fonte: Revista Manchete, 30 de maio de 1953 p. 14 e 15. Acervo Biblioteca Florestan Fernandes. 
É uma boa cidade, o Recife. Não direi como não disse o pernambucano Manoel Bandeira, que seja a Veneza brasileira; mas trata-se de uma bela cidade, com uma boa gente amiga e hospitaleira. [...] Você de certo desconhece os males de sua cidade, que são os males do Brasil todo: miséria e ignorância. Você deve ter a sua linda favelinha aí a vista, tão pitoresca no colo do morro e certamente alguma empregada sua já lhe deve ter contado o que é a vida nessa comunidade. A bem pensar, talvez fosse até melhor não dizer nada. De fato, quem é um carioca para falar assim dos mocambos do Recife? Mas a coisa é que eu vi, e a miséria não está sujeita a preconceitos regionais. Eu vi crianças patinhando o dia inteiro na lama, pois o mocambo vive dos alagados, onde o mocambeiro pesca o seu caranguejo para vender e comer. Eu vi crianças como as destas páginas, permanentemente tristes de fome crônica, os pequeninos rostos ausentes de qualquer alegria [...]. Eu já vi miséria em muitas partes do mundo, nos "ghettos" negros do Norte e nas aldeias do centro e do Sul de todas as nossas Américas. Já vi miséria horrível na Península Ibérica, onde crianças se entredevoram para ficar com a moeda que se atira. [...] Mas da que vi, a dos mocambos do Recife é a mais irremediavelmente sórdida, se é que pode haver tal hierarquia. (Revista Manchete. 30 de maio de 1953, p. 11-15) ${ }^{99}$

É inegável que, as imagens de crianças em condições de sofrimento e miséria (figura 35, 36 e 37) produzem, além do impacto sentimental, também a reflexão. Entre o final do século XIX e início do século XX, fotógrafos como Lewis Hine e Jacob Riis são referências na área e pioneiros no uso da fotografia como instrumento de crítica social, Riis, relataria em seu trabalho as condições miseráveis em que se encontravam os trabalhadores imigrantes nos bairros periféricos de Nova Iorque. Hine, sociólogo de formação, denunciaria com suas imagens o trabalho infantil, despertando a opinião pública para o problema (FREUND, 2006).

Assim, em seu modelo que somava comoção e denúncia, a Manchete chamava a atenção do leitor sobre o futuro das crianças - filhos de emigrantes que partiram para as metrópoles do Sul, ou que tentaram a sorte numa capital regional nordestina - para abordar o tema do migrante como elemento deslocado - e desamparado - no ambiente urbano.

O fato é que a necessidade de uma reforma urbana nas metrópoles brasileiras, colocavam várias questões em pauta, dentre elas a necessidade de colocar-se a baixo, as favelas que ameaçavam a organização das áreas centrais do Rio de Janeiro. Em 1963, realizou-se o Seminário de Habitação e Reforma Urbana, promovido pelo Ministério Trabalho e Previdência Social, resultado de debates travados entre as décadas de 1950 e de 1960. Sobre a legislação urbanística no Brasil, Luiz de Pinedo Quinto Jr., afirma que:

99 Revista Manchete. 30 de maio de 1953 - "São crianças, meu Deus" - Texto de Vinícius de Moraes e Fotos de Humberto Moraes Franceschi. Subtítulo: Nascem à revelia, vingam por acaso e morrem antes do tempo. 
(a reforma urbana) tem uma história voltada para a regulamentação da segregação sócio-espacial, não tendo ultrapassado a tradição de policiar usos e ocupações do solo urbano. O período que se encerrou em 1964 - inserido numa conjuntura de governos democráticos iniciados em 1945 - ficou conhecido como "desenvolvimentista", tendo sido também uma época altamente marcada por reformas sociais. Durante estes anos, as cidades passaram a ter uma importância fundamental nas políticas de desenvolvimento econômico e social, especialmente com a passagem do suporte rural das atividades econômicas para o suporte urbano. Em função disso, um conjunto de políticas urbanas passou a ocupar o centro dos debates e a fazer parte da pauta das administrações. As cidades brasileiras começaram a apresentar altas taxas de urbanização, enquanto a legislação e os instrumentos urbanísticos estavam defasados em relação às demandas. (2003, p. 187)

O caos urbano, a falta de moradia e a miséria promoviam não apenas o crescimento das favelas, mas também da presença de moradores de rua. A vida dura dessas pessoas seria registrada em uma matéria flagrante, "Favela no Asfalto" - moradores de rua no Rio de Janeiro (figura 38), com texto e imagens de Gervásio Batista, apresentava ao leitor uma família (mãe, filho e filha), que adotara a Praça da República como lar. No passeio público, a mulher é fotografada enquanto trabalha; lava sua roupa sem se importar com o fotógrafo. O menino aparece correndo, os flagrantes dos fotografados em movimento, no momento da ação, era uma característica das fotografias que ilustravam a as matérias jornalísticas da Manchete nesse período, em oposição ao estilo que Manzon havia empregado à Cruzeiro, com as fotografias mais elaboradas, posadas, muitas vezes com o próprio cenário meticulosamente redefinido.

$\mathrm{Na}$ reportagem de Gervásio, o texto demonstra sua surpresa ao descrever que em plena Praça da República, os moradores de rua "comem, dormem, passeiam e ali mesmo tiram o dinheiro necessário para o mísero sustento, esmolando." O repórter prossegue dizendo que "a favela, que antes se mantinha afastada, descido para o passeio público [...] Pouco a pouco, a Praça da República vai perdendo o seu encanto, para se tornar albergue de marginais e flagelados." A imagem das ações cotidianas, que convencionalmente deveriam ser vividas num ambiente privado, sendo apresentadas em um flagrante em uma calçada pública, provoca uma inversão da relação entre espaço público e privado, curioso observar que, a surpresa do repórter não é somente pela privacidade daquela família inexistir, mas também pela presença deles, ali, agredir a liberdade do uso público da Praça. A imagem e o texto se complementam, apenas pela imagem não é possível entender que, a mensagem do todo é discutir o fato de que não há mais espaço para os pobres e flagelados na cidade, pois, "Antes, era apenas a favela que fica no alto dos morros longe dos turistas despreocupados. 
Figura 38. Favela no asfalto.

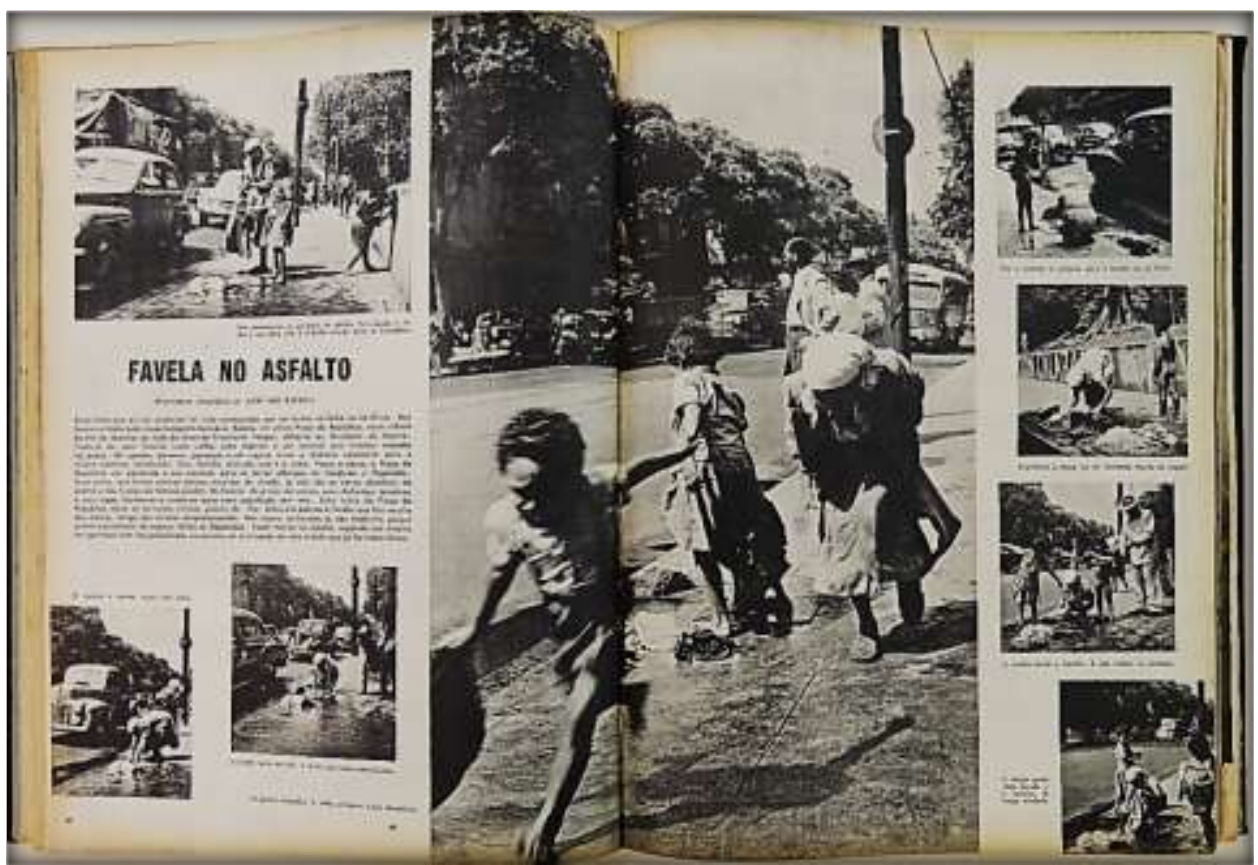

Fonte: Revista Manchete, 08 de maio de 1954, p. 38. Acervo da Biblioteca Florestan Fernandes - USP.

Figura 39. Os párias.

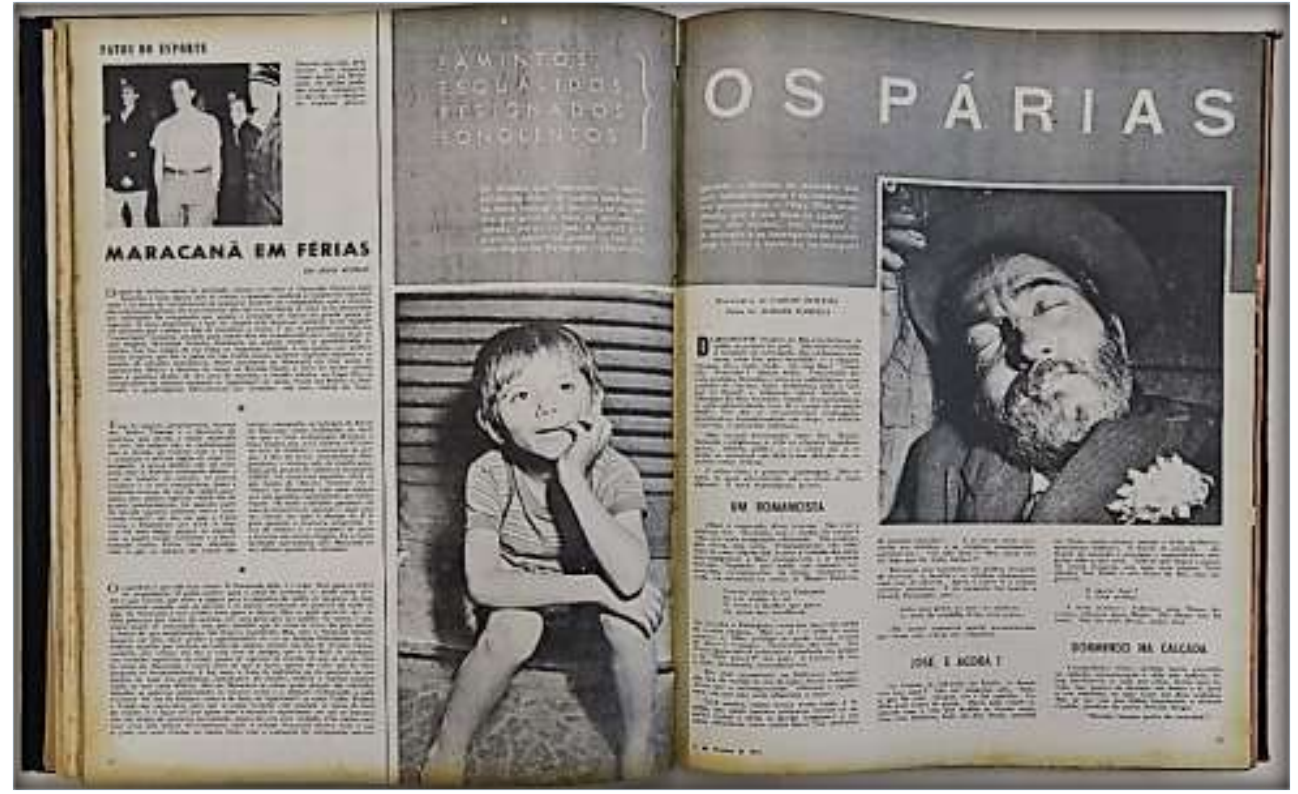

Fonte: Revista Manchete, 14 de fevereiro de 1953, p. 52, 53. Acervo Biblioteca Florestan Fernandes - USP. 
Figura 40. Os párias.2

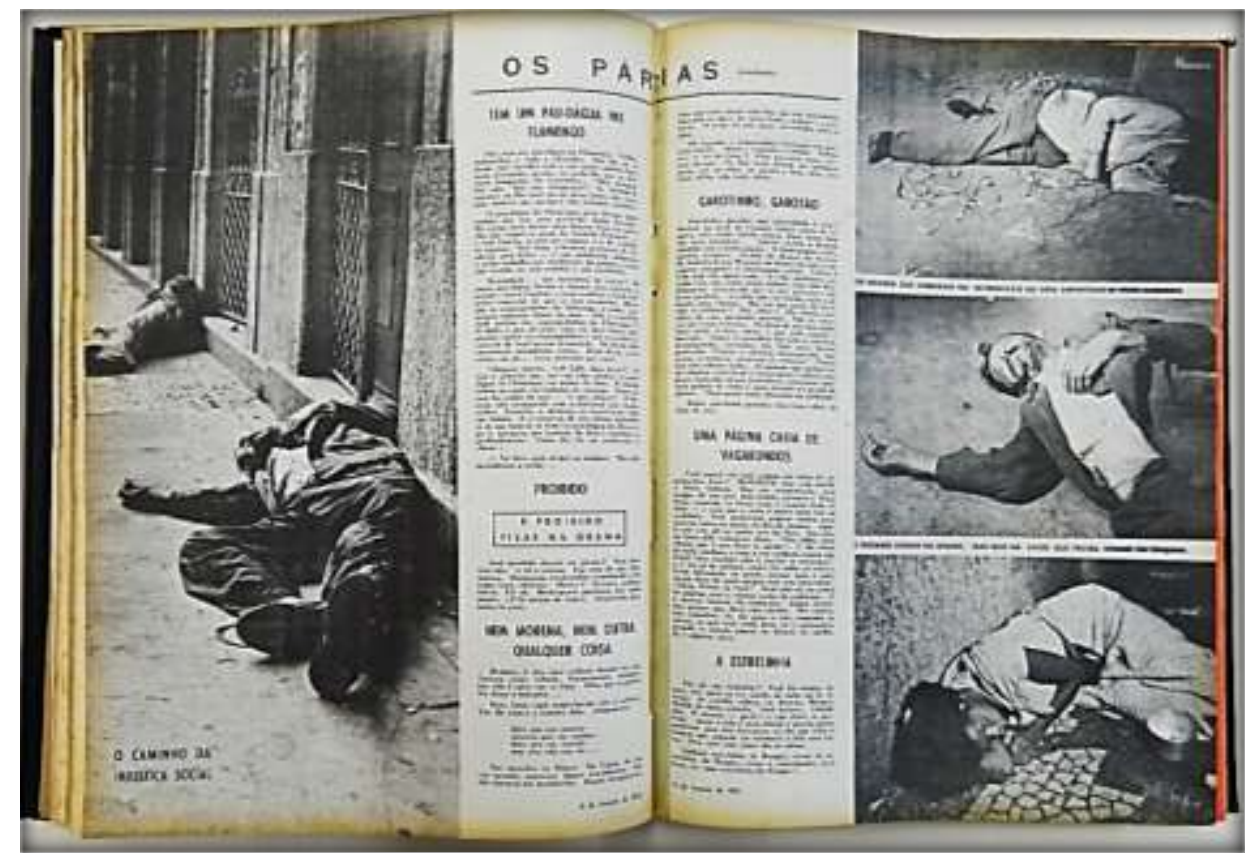

Fonte: Revista Manchete, 14 de fevereiro de 1953, p. 54, 55. Acervo Biblioteca Acervo Biblioteca Florestan Fernandes.

Mas agora, as favelas já não resolvem, porque já têm o problema de espaço. Então os flagelados ficam mesmo no asfalto, expondo sua miséria em contraste com tão propaladas conquistas da civilização de uma cidade que já foi maravilhosa". (Revista Manchete, 08 de maio de 1954, p. 38).

Na reportagem intitulada Os Párias da sociedade, pela Manchete, também de 1953, Aymoré Marella apresentava as imagens da profunda pobreza em que viviam os emigrados do sertão que acabavam por morar na rua, não entrando no mérito da questão das razões deste triste fenômeno (figura 39).

A fotografia do homem, à direita, na figura 39 em primeiro plano, com a barba cerrada, adormecido, no chão, vestido com um casaco grosso e chapéu, aparentemente mal cuidado, nos revela ainda, apenas por uma pequena fresta entreaberta da boca, a falta de um dente; a flor na lapela do homem destoa da aparente falta de higiene pessoal, indicada pelo estado dos três dedos da mão direita que ficam visíveis, bem acima da cabeça. A imagem, exercendo uma função de ampliação do texto escrito, denota abandono, fragilidade e é acompanhada por um texto de tom fatídico que descreve o triste destino daqueles que vêm para a metrópole em busca de oportunidades e encontram somente o desemprego e a degradação. A figura 40 ratifica a mensagem da anterior, pois nos quatro quadros fica ressaltada a situação de abandono dessas pessoas. 
"De Vitória, de Salvador, do Recife, - donde veio êste aqui? Não sei: ninguém sabe. Sabe-se que ele veio[...] Diariamente chegam no Rio, procincianos de todos os pontos do país. Não mais resistindo à tentação da metrópole, eles embarcam num trem, num Ita ${ }^{100}$, num caminhão e chegam. Vieram, vêm, estão vindo. Lá vem eles!” (Revista Manchete, 14 de fevereiro de 1953, p. 53)

O que há de comum nessas matérias é a constatação de que esses homens e mulheres deixaram sua terra, mas não encontraram acolhida na cidade, em ambas o retirante é visto como um “sem-lugar”, um desenraizado. Segundo o antropólogo Nigel Rapport: “[...] A percepção do migrante de ser desenraizado, de viver entre dois mundos, entre um passado perdido e um presente não-integrado, talvez seja a metáfora mais adequada dessa condição (pós-moderna)" (RAPPORT, 2002, p. 90).

Diáspora e desenraizamento caminhariam assim, necessariamente juntas, para Maria Aparecida Moraes Silva (1999) os trabalhadores migrantes, vindos do sertão, por não terem suas identidades reconhecidas, por serem subavaliados como indivíduos nas cidades para onde migram, viveriam a violenta experiência do desenraizamento sociocultural ${ }^{101}$. A percepção de Rapport quanto ao movimento diaspórico, vai de encontro à análise de Silva, pois para ele as sociedades que passam pela experiência da diáspora, tornar-se-iam por excelência, comunidades desenraizadas, criando estratégias de reconstrução de valores e padrões culturais.

Desenraizar, partir, deixar de ser nutrido pela terra. Se por um lado a migração era a solução imediata para os problemas ligados diretamente à sobrevivência material, para a sobrevivência da identidade dos indivíduos a migração seria um risco, porque uma vez desenraizado, sem identidade, o próprio migrante estaria sujeito a adotar identidades postiças, a assumir para si identidades que lhes são impostas pelos agentes sociais, pelo meio que os recebe e mesmo por aqueles que buscam compreender o fenômeno migratório.

Contudo, os rótulos que são atribuídos ao migrante, como destaca Silva, são frutos de um olhar reducionista, dos de dentro sobre os de fora; um olhar que os limita a uma interpretação reduzida "somente em termos de suas origens migrantes", como aponta Alistair Thompson:

E assim como os migrantes individuais e seus descendentes lutam contra os rótulos de identificação, as sociedades migrantes lutam contra os rótulos que definem e moldam a experiência da migração:

100 Ita (ou Itapé) era um tipo de navio que cruzava do norte até o sul do litoral do Brasil, era a forma mais fácil de chegar ao rio de Janeiro, antes do término da rodovia.

101 SILVA, Maria Aparecida de Moraes. Errantes do fim do século. São Paulo: Fundação Editora da UNESP, 1999, p. 79. 
"estrangeiro", "imigrante", "refugiado", "minoria étnica", "comunidade étnica", etc. (THOMPSON, 2002, p. 342)

Para Thompson, a manutenção do rótulo faria com que o esforço por aceitar o novo universo sociocultural, se torne um exercício que transcende o momento próprio da transposição de fronteiras, perdurando por toda a vida do migrante. Mesmo seus descendentes, já nascidos no novo ambiente, herdariam os "rótulos", as marcas dos estereótipos, posto que, por mais adaptados que estivessem, seriam eles, sempre fruto de um meio - a família, a comunidade - que adapta e preserva costumes tradições e valores do lugar de origem. Dessa forma, com uma concepção oposta à de Silva e Rapport, Thompson, concebe que o migrante jamais será um "desenraizado" pois nunca se despe por completo de suas raízes - mas um "transplantado" - perdeu seu lugar, mas não seus valores.

No bojo destas discussões sobre os efeitos da migração na construção das identidades, produzindo nos homens o sentimento de ser um "sem lugar" - o homelessness de Nkosi - será, este sim, um ponto de convergência para a análise das representações e efeitos dos processos migratórios:

Como Sócrates, o imigrante é atopos, sem lugar, deslocado, inclassificável. Aproximação essa que não está aqui para enobrecer, pela virtude da referência. Nem cidadão nem estrangeiro, nem totalmente do lado do Mesmo, nem totalmente do lado do Outro, o "imigrante", situa-se nesse lugar "bastardo" de que Platão também fala a fronteira entre o ser e o não-ser social. Deslocado, no sentido de incongruente e de importuno, ele suscita o embaraço; e a dificuldade que se experimenta em pensá-lo - até na ciência, que muitas vezes adota, sem sabê-lo, os pressupostos ou as omissões da visão oficial - apenas reproduz o embaraço que sua existência incômoda cria. Incômodo em todo lugar, e doravante tanto em sua sociedade de origem quanto em sua sociedade receptora, ele obriga a repensar completamente a questão dos fundamentos legítimos da cidadania e da relação entre o Estado e a Nação ou nacionalidade. (BOURDIER, 1998, p. 11-12)

Indo além, na caracterização do "homem sem lugar", a análise apresentada por Bourdier, ao prefaciar A Imigração Ou os Paradoxos da alteridade, de Abdelmalek Sayad (1998), nos revela outra face da experiência migratória: a do abandono. Para Sayad, migrar é abandonar, deixar para traz, abrir mão de algo que jamais será reposto; aventurar-se em busca da fortuna; é também fazer uma dura escolha: deixar para traz o sofrimento conhecido e seguir em busca do conforto desejado. A busca envolve o abandono, o aventurar-se; envolve a dura decisão de desprender-se de tudo aquilo que fez parte da elaboração dos valores individuais e coletivos. 
Figura 41. Moradores de estátua

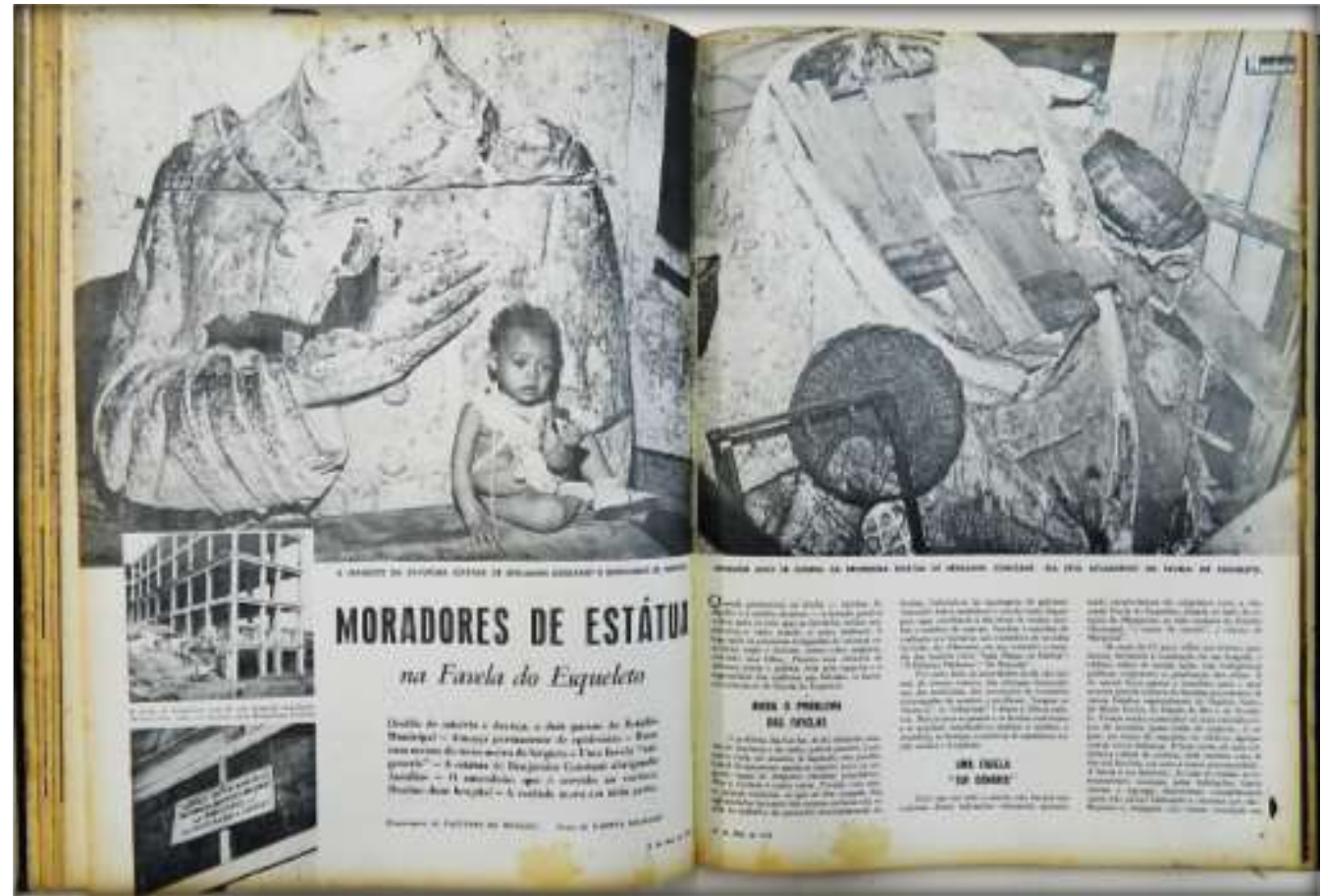

"Vindos dos estados de Espírito Santo, Minas Gerais e Nordeste..." Revista Manchete. Moradores de estátua. 16 de maio de 1953, p. 37. Acervo da Biblioteca Florestan Fernandes - USP.

Figura 42. Moradores de estátua: o perigo das epidemias.

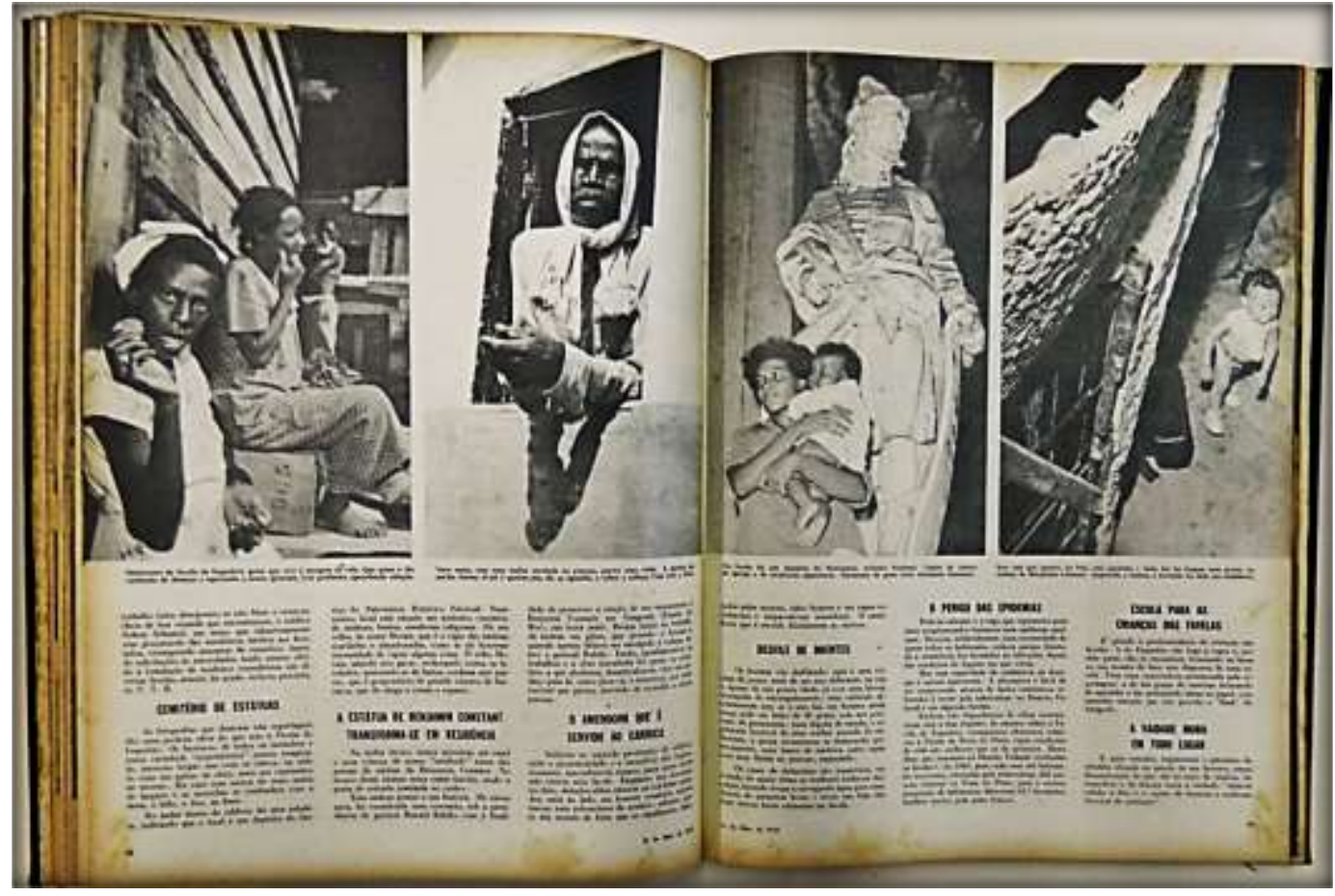

Revista Manchete. Moradores de estátua. 16 de maio de 1953, p. 37. Acervo da Biblioteca Florestan Fernandes - USP. 
Não é só a miséria, mas o estar fora do lugar, o não pertencer a um lugar, o não ter nada de seu, o desamparo, que desumaniza esses indivíduos descritos nessas reportagens. Em "Moradores de estátua", o texto de Fagundes de Menezes apresenta a situação dos migrantes nordestinos com o auxílio das fotografias de Darwin Brandão. Trata-se de moradores da Favela do Esqueleto, a qual se erguia a partir da ocupação dos escombros de um hospital que começara a ser construído, mas que havia sido abandonado.

Descrevendo suas ruelas, sua ocupação inusitada, na qual, mesmo uma estátua de Benjamin Constant se tornava abrigo para os desprovidos, a reportagem nos descreve a origem dos moradores:

Há mais de 15 anos, sobre um terreno pantanoso, iniciaram a construção de um hospital, o edifício subiu de muitas lajes, mas contingências politicas originaram a paralização das obras. E do imóvel ficou apenas o esqueleto, para o qual acorreu grande número de famílias procedentes de vários Estados, especialmente do Espírito Santo, de Minas Gerais, do Estado do Rio e do Nordeste. (Revista Manchete. Moradores de estátua. 16 de maio de 1953, p. 37)

Embora a imagem central da figura 41 coloque a delicadeza do rosto do bebê em oposição aos escombros nos quais ele está amparado, o texto não se limita a ratificar o que a imagem já havia dito. Fagundes de Menezes, ao contrário de tantos outros, não se limita a apresentar "o desfile de doentes" (figura 42) e degradação na qual se encontram os migrantes, o repórter observa o problema e indica quem, em sua opinião, está sendo omisso, não poupando para isso, a própria imprensa:

O problema das favelas, de tão debatido, através da imprensa e do rádio, poderá parecer, à primeira vista, um assunto já esgotado, sem possibilidade de apresentar qualquer aspecto novo ou original, capaz de despertar interesse jornalístico. Mas a verdade é muito outra. Porque com muito poucas exceções, os que se têm ocupado dos aglomerados humanos dos morros cariocas não se dão ao trabalho de percorrer demoradamente as favelas, limitando-se às reportagens de gabinete, repisando dados estatísticos e caindo numa linguagem vaga [...] Por outro lado, as autoridades ainda não saíram do terreno teórico, das delongas burocráticas, das entrevistas, das nomeações de comissões encarregadas de resolver o problema. Surgem os "técnicos", os "urbanistas" e ditam a última palavra. Mas os passam e as favelas continuam e se ampliam, ampliando-se também a miséria, a imundice, as doenças, a ausência de assistência social, médica e hospitalar. (Revista Manchete. 16 de maio de 1953 , p. 37)

A partir do início dos anos 40, principalmente após aprovada a Lei dos Terços, estimulando o mercado de trabalho para a mão de obra nacional, e de lá seguindo pelos anos 50, a questão urbana foi-se agravando, pois apresentava como questão urgente o problema da moradia, limitados principalmente ao sistema de habitações alugadas que, depois do congelamento do aluguel em 
1943, deram lugar ao aparecimento de loteamentos populares nas periferias distantes das cidades, e também à ocupação de áreas urbanas por famílias desabrigadas. (QUINTO JR, 2003, p. 187)

O inchaço populacional nas favelas, e a ocupação de áreas sem infraestrutura era uma ocupação realizada, muito frequentemente, por migrantes, que em busca de melhores condições de vida, por vezes, até encontravam trabalho, mas não encontravam um lugar que lhes permitisse fincar as raízes e reerguer a vida, os referenciais e a própria identidade.

Ao discutir sobre a relação entre migração e identidade, Milton Santos, não adota nem a perspectiva do desenraizamento e muito menos a do transplante cultural, para ele, o que está em questão é a perda do útero no qual os referenciais de identidade e cultura são gestados: o território.

O território em que vivemos é mais que um simples conjunto de objetos, mediante os quais trabalhamos, circulamos, moramos, mas também é um dado simbólico. A linguagem regional faz parte desse mundo de símbolos e ajuda a criar esse amálgama, sem o qual não se pode falar de territorialidade. Esta não provém do simples fato de viver num lugar, mas da comunhão que com ele mantemos. (SANTOS, 1987, p. 61)

Santos (1987) associa o sentimento de realização do indivíduo não somente às suas possíveis conquistas materiais, para o autor, não somente o sucesso e a estabilidade econômica gerariam o sentimento de auto realização, esta deve resultar de um conjunto de elementos ligados à vida material e imaterial, que incluiria, economia e cultura, sendo que ambas estariam diretamente associadas ao território, que é um determinante para a construção da identidade. Isso porque para o autor:

Cultura e territorialidade são, de certo modo, sinônimos. A cultura, forma de comunicação do indivíduo e do grupo com o universo é uma herança, mas também um reaprendizado das relações profundas entre o homem e seu meio, um resultado obtido através do próprio processo de viver. Incluindo o processo produtivo e as práticas sociais, a cultura é o que nos dá a consciência de pertencer a um grupo, do qual é o cimento. É por isso que as migrações agridem o indivíduo, roubando-lhe parte do ser, obrigando-o a uma nova e dura adaptação em seu novo lugar. Desterritorialização é frequentemente outra palavra para significar alienação, estranhamento, que são também, desculturização. (SANTOS, 1987, p. 61)

Para Milton Santos estaria aí a mais cruel das faces da migração, pois o ato de abandonar o território implicaria necessariamente em desestruturar a própria identidade. Para o autor, há uma estreita relação entre o sentimento de pertencermos àquilo que nos pertence e a formação da identidade; entre a relação que mantemos com o lugar onde vivemos e a forma como vemos a nós mesmos. Nesse processo, como destaca Santos, o impacto na identidade individual e coletiva é profundo, portanto, aceitar uma nova terra e um novo conjunto de relações cotidianas, implica 
aceitar desterritorializar-se. O processo migratório é marcado pelo esforço de reelaboração ${ }^{102}$ das identidades, colocando em questão os valores a partir dos quais o indivíduo reconhecia a si e aos seus em confronto com os valores do novo grupo e do novo espaço com o qual passa a conviver.

Todavia, apesar dos esforços para reconstruir relações e valores, muitas vezes, a visibilidade de tais grupos ainda não é plena, a sociedade insiste em vê-los como se não existissem transformações.

Embora a imprensa semanal, principalmente das duas grandes revistas ilustradas, não tivesse por princípio cobrar das autoridades e do governo uma atuação mais efetiva para solucionar os problemas de miséria absoluta na qual vivam milhares de brasileiros, nem sempre o repórter se colocava em posição neutra diante o fato, como já vimos. Nem sempre a vítima era responsabilizada por sua - má - sorte. Na reportagem “Jangada, criança, mar”, Carlos Oliveira publicaria um texto no qual cobrava o posicionamento do leitor diante da existência de um grande número de crianças esmolando. No texto, o repórter é enfático: “Dize: meterás o pau no governo, ou comprarás cocadas à negra velha para distribuir com as crianças?"

Isto não é uma reportagem. Sibila o vento nos coqueiros da praia cearense e uma mansa beleza se espalha sobre tudo às quatro horas da tarde. Mas isso não chega a ser um fato. Não, senhores. $\mathrm{O}$ fato são as crianças que pedem esmolas. [...] Caminharemos, fazendo tch-tch na areia, em direção à negra velha que vende cocadas. Mais adiante, seremos cercados por meia dúzia de crianças de barriga d'água e pernas de saracura que nos pedirão dinheiro. Darás dinheiro a estas crianças? [...] Ou meterás o pau no govêrno, que espalha pelo país um macerado exército de crianças famintas? Conheces êste país, que é tua pátria; portanto sabes que na extensão que vai do Chui ao Oiapoque as crianças crescem magricelas e frágeis como taquaras. Dize: meterás o pau no governo, ou comprarás cocadas à negra velha para distribuir com as crianças? (Revista Manchete. 18 de abril de 1953, pp. 17-19) ${ }^{103}$

Em 1958, a mesma fotografia da mãe de "Sertanejos do asfalto" de 1951 (figura 29), estampou um texto de homenagem ao dia das mães, com a legenda de "Mãe flagelada". Sob o título de "Uma foto em foco", a imagem da mãe amamentando o filho desnutrido vinha acompanhada de uma severa crítica a pouca importância dada, por parte do governo, aos flagelados

102 Sobre a questão da perda do referencial cultural, Silva apresenta-nos a perspectiva de Polanyi, que discute a desestruturação da cultura a partir da migração e, da necessidade de restauração social, a partir da produção de mecanismo que permitirão o surgimento de uma nova cultura. SILVA, Maria Aparecida de Moraes. Errantes do fim de século. São Paulo: Fundação Editora da UNESP, 1999, p. 145.

103 Jangadas, Crianças, Mar. (fotorreportagem com fotos de página inteira de pescadores numa praia cearense). Texto de Carlos Oliveira e fotos de Yllen Kerr. 
das secas - curioso observar que, embora a matéria viesse um tom de denúncia, permanecia a ideia de que a culpada pela miséria eram as secas, e não o sistema de concentração de terras; além de manter-se uma concepção assistencialista de Estado, que deveria prestar "auxílio", não se cogitando a necessidade de implementação de políticas públicas que solucionassem o problema, a matéria finalizava com a advertência: "No momento em que o Brasil está sendo preparado para comemorar o 'dia das mães', esta fotografia - retrato sem retoques de uma pobre mãe flagelada é das mais expressivas e oportunas. É uma lembrança e uma advertência”. Curioso ainda, pensar que um texto que trazia as palavras "esta é a fotografia sem retoque do que está acontecendo', estivesse ilustrado com uma fotografia tirada havia já sete anos. Como se o tempo não passasse para os sertanejos flagelados das secas.

O que se pode concluir é que a construção de um imaginário coletivo sobre o Nordeste como lugar - e do nordestino - como indivíduo - dar-se-ia não apenas em função da imposição do olhar homogeneizante e reducionista das elites e das mídias, mas também, e talvez principalmente, em razão da necessidade de ressignificação e de reconstrução de uma identidade dos indivíduos. Uma vez desterritorializados, eles, os migrantes, também passariam a aglutinar-se em torno de símbolos de uma nordestinidade que não os apresenta em suas particularidades mas que os representa como coletividade. Um desses símbolos aglutinadores, e de grande projeção midiática foi Luís Gonzaga.

Luiz Gonzaga (figura 43) foi o primeiro artista a levar os elementos das culturas nordestinas para a grande mídia. Os elementos da cultura do agreste e da cultura do sertão, não se faziam presentes como folclore, mas como estética e mote para as composições. Temas ligados à festa, ao amor, à tristeza diante da terra seca e também à difícil adaptação do migrante às metrópoles, eram frequentes em suas músicas. Mesmo a paramentação do artista não correspondia a uma representação do nordestino em particular, mas sintetizava e reinventava elementos de diferentes ambientes e costumes. Os instrumentos e os ritmos próprios da região se fazem presentes na música de Gonzaga, que utilizava a sanfona, a zabumba, o triângulo e o pandeiro, para recriar os sons do forró, do xote e para criar o baião. O resultado era a grande aceitação da música de Luiz Gonzaga que, ao povoar sua obra com elementos de diferentes tradições nordestinas, de pequenas 
identidades locais, permitiu a criação de algo novo, de uma nova nordestinidade, agora globalizante, e aceita pelos próprios nordestinos como representação legítima. ${ }^{104}$

Figura. 43. Álbum comemorativo de Luís Gonzaga

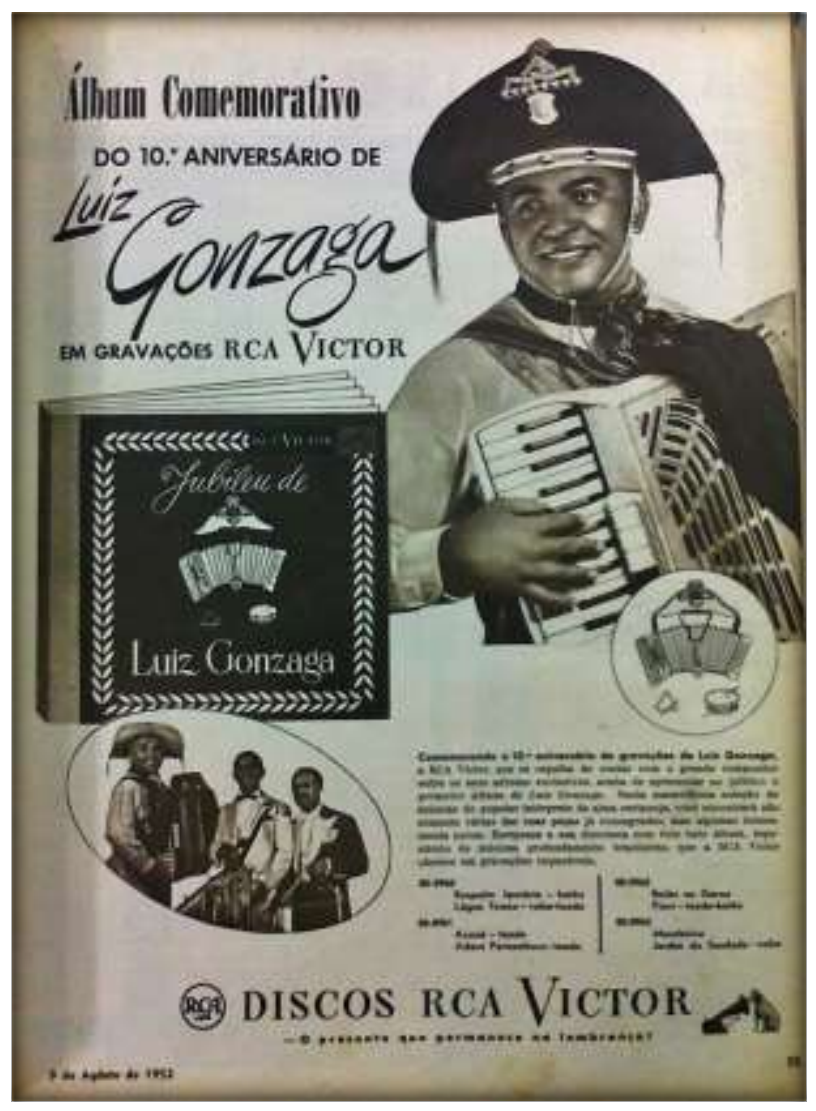

Fonte: Revista Cruzeiro, 09 de agosto de 1952. Acervo ECA-USP.

A partir de Luís Gonzaga a presença do retirante nas metrópoles, não seria percebida somente na descrição das favelas cariocas, ou da periferia paulistana, mas também, na temática das letras que o Rei do Baião interpretava. E principalmente ele, o baião, popularizado por Luiz Gonzaga e Humberto Teixeira, traria em suas letras as descrições das festas, dos costumes e das

104 São várias as matérias sobre Luís Gonzaga nas revistas. Algumas delas, destacavam a originalidade e a popularidade do baião, como "O baião conquista o mundo", de Leon Ellachar, de 30 de agosto de 1952 ou "Luis Gonzaga vai deixar o rádio”, em que o repórter afirma que Gonzaga pretendia abandonar o rádio para auxiliar no desenvolvimento de sua cidade natal, Exu, concluindo que, na verdade, Gonzaga pensaria melhor sobre o que fazer, após o término de sua turnê pela Europa. Em 06 de junho de 1953, para "O mundo em Manchete". 
brincadeiras do sertão, mas também contaria sobre a difícil adaptação do sertanejo à cidade grande, a saudade que sentia de sua terra, pois lá estavam seus símbolos identitários.

Ao apresentar o Brasil que desejava caminhar rumo ao desenvolvimento, a imprensa do período Vargas, e particularmente O Cruzeiro, embora não incluíssem nesse projeto de modernização as populações do sertão, incluiria entre seus cenários um Nordeste que se posicionava para a entrada na modernidade, ora contribuindo com ela, ora sofrendo seus efeitos. 


\section{PARTE II - O NORDESTE-HÉRCULES}

(Mas esse) é apenas um lado do Nordeste. O outro Nordeste, mais velho que ele, é o Nordeste das árvores gordas [...] esse Nordeste da terra gorda e de ar oleoso, é o Nordeste da cana-de-açúcar. [...] O Nordeste da primeira fábrica brasileira de açúcar. O Nordeste que vai do Recôncavo ao Maranhão, tendo o seu centro em Pernambuco.

Gilberto Freyre.

\section{3 - A FORÇA POTENCIAL - A PROMESSA PARA O DESENVOLVIMENTO}

O entre guerras foi um período marcado pela apologia à modernidade. Desenvolvimento, maquinismo, velocidade, urbanização, industrialização, o mundo se modernizava e o Brasil também deveria modernizar-se, pelo menos, na visão de alguns brasileiros, para os quais a Cruzeiro poderia colocar-se como porta-voz:

Depomos nas mãos do leitor a mais moderna revista brasileira. Nossas irmãs mais velhas nasceram por entre as demolições do Rio colonial, através de cujos escombros a civilisação traçou a recta da Avenida Rio Branco: uma recta entre o passado e o futuro. Cruzeiro encontra já, ao nascer, o arranha-céo, a radiotelephonia e o correio aéreo: o esboço de um mundo novo no Novo Mundo. Seu nome é o da constelação que, ha milhões incontaveis de annos, scintila, aparentemente immovel, no céo austral, e o da nova moeda em que resuscitará a circulação do ouro. Nome de luz e de opulencia, idealista e realistico, synonymo de Brasil na linguagem da poesia e dos symbolos. [...] Porque é a mais nova, Cruzeiro é a mais moderna das revistas. É este o título que, entre todos, se empenhará por merecer e conservar: ser sempre a mais moderna num paiz que cada dia se renova, em que o dia de hontem já mal conhece o dia de amanhã; ser o espelho em que se reflectirá, em periodos semanaes, a civilisação ascensional do Brasil, em todas as suas manifestações; ser o commentario multiplo, instantaneo e fiel dessa viagem de uma nação para o seu grandioso porvir; ser o documento registrador, o vasto annuncio illustrado, o film de cada sete dias de um povo, eis o programma de Cruzeiro. É pelo habito de modelar o barro que se chega a bem esculpir o marmore. Esta revista será mais perfeita, mais completa, mais moderna amanhã do que é hoje. (Revista Cruzeiro, 10 de novembro de 1928. Editorial)

A Revista Cruzeiro, em seu editorial de inauguração, expressava o espírito de seu tempo:

o desejo ser moderno. Ao final da década de 1920, o Brasil ansiava por finalmente entrar para o grupo das grandes nações, pela construção de uma sociedade civilizada e pela modernidade. $\mathrm{Na}$ década seguinte, o desenvolvimento estaria na pauta do dia, quando intensificavam-se no Brasil as relações capitalistas que foram lentamente alterando as bases do Estado oligárquico e patrimonial. 
Naquela época, alguns modelos estrangeiros de nações em desenvolvimento, em processo de modernização podiam ser observados, um, em particular chamava a atenção de grupos conservadores e mesmo do Governo em exercício: o modelo alemão. Internamente, possuíamos, nós também nossos modelos de desenvolvimento, representados pelas duas grandes metrópoles nacionais - Rio e São Paulo - com seu crescente processo urbanização e o desejo de ativar a economia, incentivando a industrialização e o mercado interno. O governo Vargas, caracterizandose por seu nacionalismo e sua postura intervencionista e centralizadora, reformulou algumas das antigas relações econômicas de mercado, tanto no âmbito nacional quanto nas relações estabelecidas no plano econômico internacional, visando alcançar o tão sonhado desenvolvimento.

Nas décadas de 1930 a 1950, para os políticos, intelectuais e imprensa o crescimento econômico constituía-se na meta a ser alcançada pelo Brasil, todavia, nem todos os estados da nação se mostravam preparados para levar à diante tal empreendimento. As duas metrópoles brasileiras e seus arredores, figuravam como os símbolos maiores de nosso desenvolvimento, os estados do Centro-oeste, permaneciam invisíveis às manchetes sobre o crescimento nacional enquanto que o Norte era representado como um rincão de natureza selvagem e remota, muito distante do modelo de civilização idealizado no período. Já o Nordeste, por sua vez, surgia sobre desenvolvimento, não como um entrave, mas como uma grande promessa, valorizado por seu potencial natural.

\subsection{Progresso e desenvolvimento nos anos 30: o modelo alemão}

Segundo Maria Luiza Tucci Carneiro:

Mesmo antes do golpe militar liderado por Getúlio Vargas, o estado apelou para um conjunto de leis de exceção. Em sua essência, elas prepararam o Brasil para receber as propostas revolucionárias do fascismo italiano e do nazismo alemão como 'novidades da modernidade'. A imprensa brasileira cuidou de reportar, com alguma admiração, as conquistas de Mussolini a partir de 1922 e de Hitler, a partir de 1933. Os nacionalismos alemão e italiano se transformaram em fontes de inspiração para o modelo de nação que se pretendia construir no país: forte e homogênea. A propaganda oficial emergiu como instrumento para o exercício do poder mascarado de 'política trabalhista', controlada por leis rígidas e um tribunal de exceção. Os conceitos e os partidos de extrema-direita proliferaram e conquistaram segmentos importantes da população. (CARNEIRO, 2012, p. 01) 
Figura 44. Itália e Alemanha.

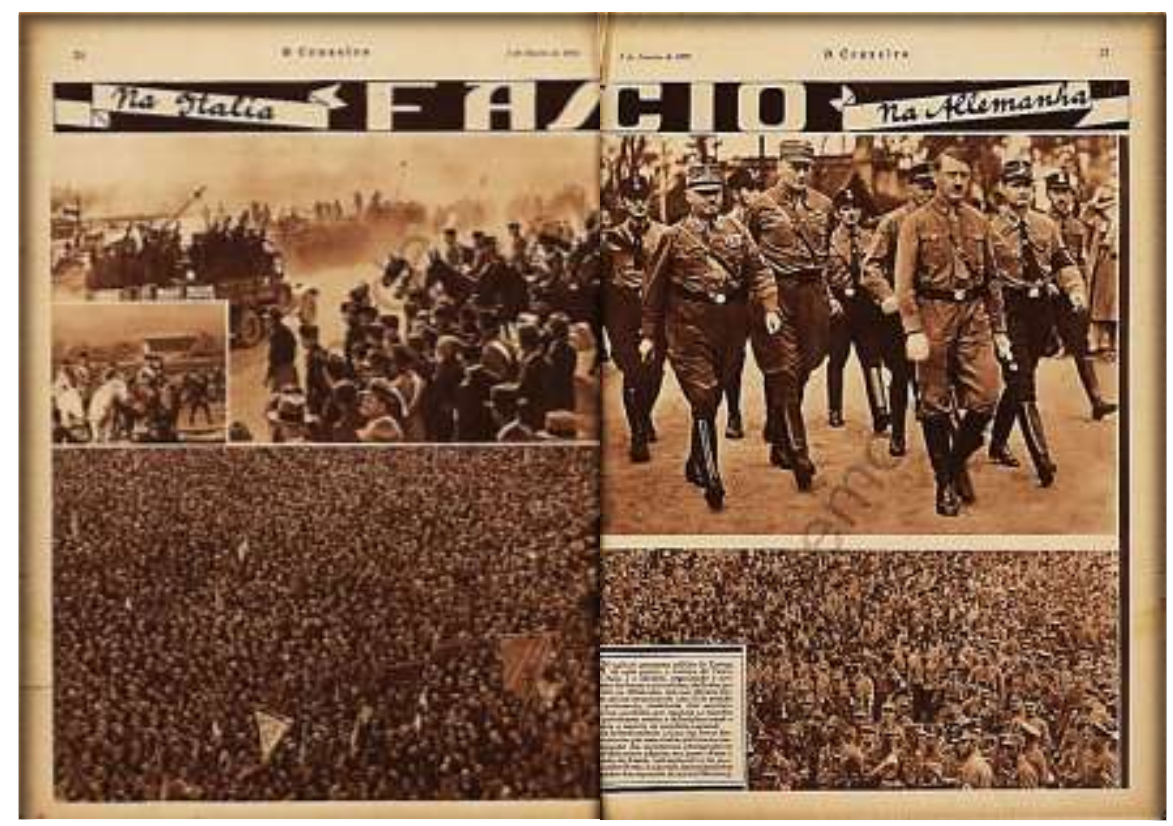

Fonte: Revista $O$ Cruzeiro, 02 de janeiro de 1932, pp. 20-21. Acervo CEDIC.

A ideologia nazi-fascista apresentava para o mundo, como resultado de sua atuação, uma sociedade aparentemente disciplinada e unida em torno da questão do progresso nacional. Essa imagem falaciosa encantou e seduziu muitas consciências e, embora em seu artigo Tucci Carneiro destaque o fascínio pela Alemanha como sendo perceptível na imprensa a partir de 1933, na edição da Cruzeiro de janeiro de 1932, via-se a poderosa imagem do povo ovacionando o exército alemão, (figura 44) liderado em marcha por seu chanceler, Adolf Hitler.

A fotorreportagem da Cruzeiro, com fotografias em página dupla, era composta por imagens adquiridas junto a uma agência internacional notícias, e apresentava a força esmagadora da massa nas ruas. Em tomadas em plongée, as imagens do povo nos conferem a sensação de imensidão, literalmente, sobre a qual - como que a desfilar sobre suas cabeças - surge, na esquerda o exército italiano, desfilando em carros, exibindo suas armas e, à direita, o exército alemão, marchando a passos firmes, liderados por um Hitler de olhar fixo e punhos fechados. O texto, que compõe a reportagem, reduz-se a um pequeno boxe à direita da segunda página, onde, de forma discreta, a revista aponta as virtudes do avanço do fascismo e do nazismo como "reações do patriotismo contra a indisciplina social e contra o espírito de sacrifício nacional:

No agitado panorama político da Europa do após guerra, a victória do Fascio na Itália e o advento, organização e progresso das forças nacionalistas, chefiadas por Hitler, na Allemanha, que nas 
últimas eleições geraes conquistaram uma forte posição no parlamento, constituem dois acontecimentos paralelos, que registram as reações do patriotismo contra a indisciplina social e contra o espirito de sacrifício nacional. Os leitores poderão ajuizar das forças desencadeadas por esses credos políticos na contemplação dos documentos fotográficos unidos nestas página, nas quaes vemos a parada do Fascio, comemorativa da marcha sobre Roma, e a parada dos nacionalistas alemães dos capacetes de aço em Hamburgo. (Revista $O$ Cruzeiro, 02 de janeiro de 1932, p. 20-21)

Nas páginas da revista, as imagens reproduzidas se sobrepunham ao texto. Na figura 45, a composição e o enquadramento escolhido tanto para a fotografia quanto para a gravura seleciona as imagens-ícone da urbanização: o rio, à direita, levando o desenvolvimento à cidade, no passado; o enquadramento em plano geral da cidade no tempo presente, destacando a presença do asfalto, do trânsito e dos prédios, ratificam e intensificam a ideia de desenvolvimento e progresso do texto, que, por sua vez, ocupa um espaço de trinta por cento da página, cumprindo à imagem o preenchimento dos setenta por cento do espaço restante numa montagem do antes e o depois, na história de Berlim.

As matérias ilustradas sobre o desenvolvimento urbano e econômico alemão, em geral, eram matérias compradas de revistas estrangeiras, que traziam para o público brasileiro elementos da cultura e das paisagens modernas de uma Alemanha que se reinventara após a ascensão do Partido Nacional Socialista; de uma Alemanha que, deliberadamente, difundia uma imagem de nação moderna, organizada e voltada para o progresso. Feiras, (figura 46) portos, arte, trabalho, progresso e modernidade: temas associados a uma concepção de sociedade civilizada eram também os temas associados à questão do desenvolvimento, durante os anos de 1930.

Ainda na revista carioca Vamos Lêr! de 14 de março de 1940, lê-se várias pequenas notícias sobre a Itália fascista, todas destacando o progresso e o valor cultural das riquezas e belezas italianas. A Exposição 'Leonardo da Vinci e as Invenções em Plena Atividade; Curso de alta cultura em Rhodes (então ilha italiana administrada pelo conde de Vecchi); O décimo ano da feira do Levante, em Bari, na Itália (Há anos tem lugar em Bari, todavia, o caminho percorrido pela feira é lembrado como forma de reforçar os laços comerciais históricos entre o Ocidente e o Oriente); Uma deliciosa visão da Itália (livro de viagem com fotos que "consiste num prazer sem igual para qualquer espírito sensível à beleza e à inteligência”); O comércio da África italiana e das possessões italianas com a Itália (mostra o crescimento da carga de matéria-prima trazida da Etiópia para a Itália bem como o aumento da exportação de manufaturados para a Etiópia, tudo, através de uma ótica extremamente positiva). 
Figura 45. Os sete séculos de Berlim.

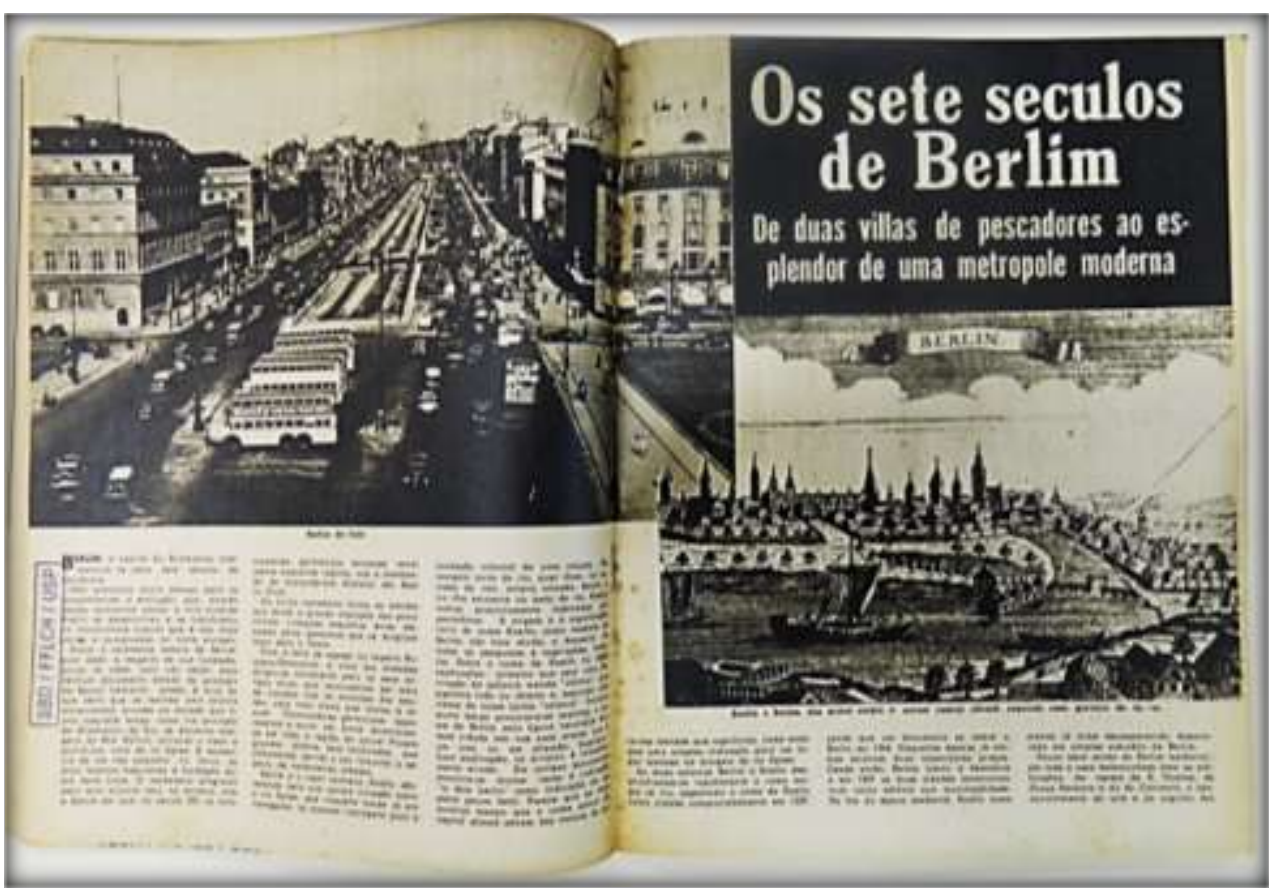

Fonte: Revista Vamos Lêr! 14 de outubro de 1937, p. 40-41.

Figura 46. Feira de Leipzig.

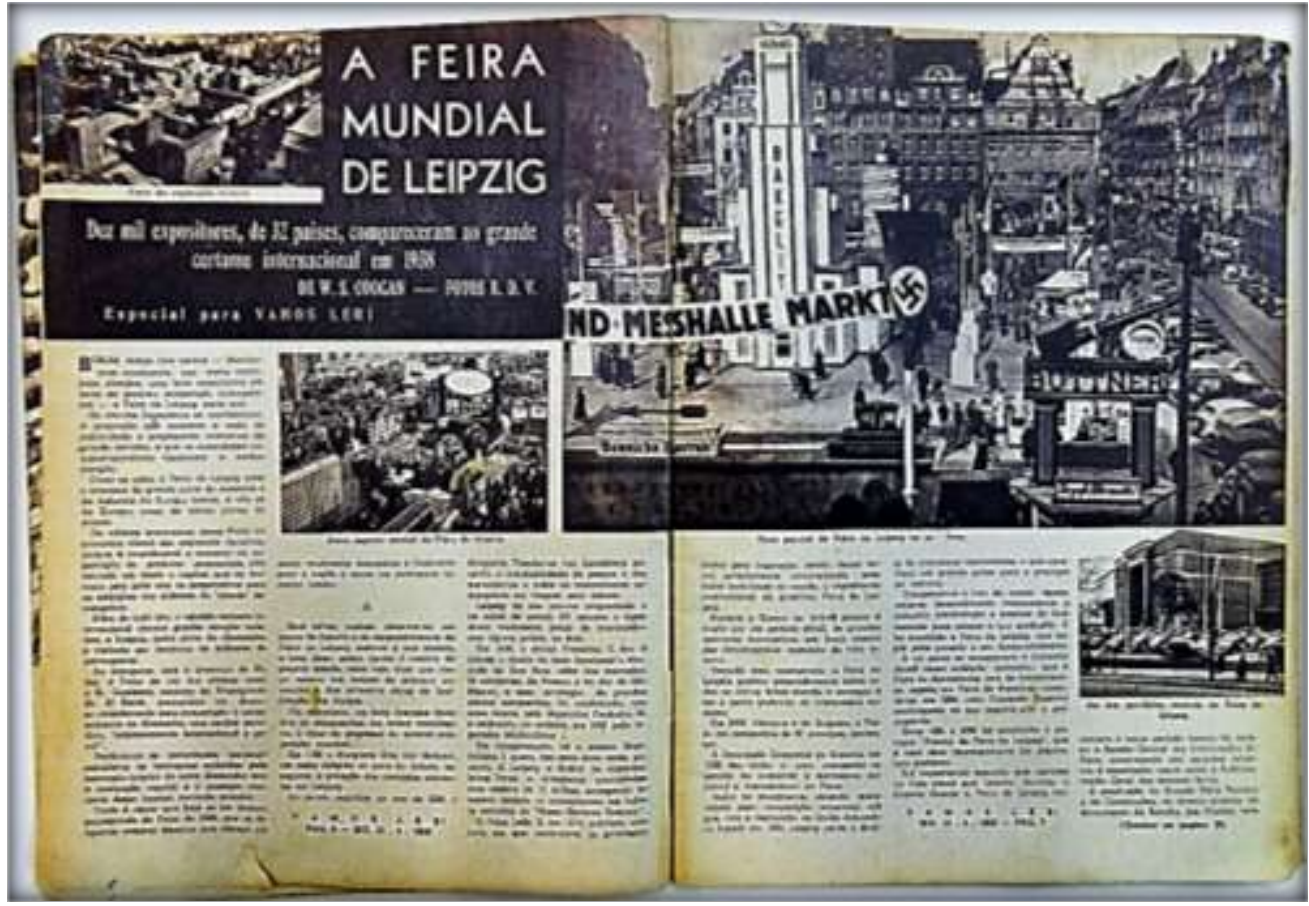

Fonte: Revista Vamos Lêr! 13 de abril de 1939, pp. 6.7, 101. Reportagem de W.S. Coogan e fotos de R.D.V. 
Em comum, traziam um discurso defendiam os resultados daquele modelo de governo e de organização social para o desenvolvimento da civilização europeia e branca.

O governo brasileiro, por sua vez, deixava clara sua simpatia pelo modelo ítalo-germânico de nacionalismo, estreitando as relações diplomáticas entre Brasil e Alemanha, "em defesa da ordem e dos fundamentos de nossas nações", como pronunciou em seu discurso o embaixador do Brasil, Sr. Muniz Aragão, ao entregar suas credenciais ao então chanceler Hitler, em 1936. No discurso, o representante do governo brasileiro ainda destacava a necessidade de estreitarem-se os laços políticos, econômicos, comerciais e culturais entre as duas nações ${ }^{\mathbf{1 0 5}}$.

Chateuabriant, o gigante da comunicação de então, havia aderido ao Estado Novo e a sua ideologia. Segundo Morais (1999), para Chateaubriand, depois de experiências infrutíferas de democracia, vivenciadas - como o voto secreto e universal, o mandato de quatro anos do governante, o pluripartidarismo - os brasileiros teriam decidido pelo regime autoritário, aprovando assim a ditadura como uma via legítima, essa seria a opinião de Chateaubriand, registrada por Morais:

Nada será mais errôneo do que dizer-se que o sr. Getúlio Vargas era até ontem um liberal. O que o nosso Chefe tem de liberal são as maneiras, são as formas exteriores de ação. Psicologicamente, não há, nunca houve autoritário mais tenaz e mais constante. A função de grande sentinela do novo regime lhe cabe em toda plenitude, até porque hoje ele é o Chefe Nacional, como Mussolini é o Duce e Hitler é o Fuehrer. (MORAIS, 1994, p. 150, ebook)

Outros porta-vozes da imprensa demonstravam igualmente sua aprovação a ideais presentes no discurso nazifascista. Se Chateaubriand, por um lado, dava seu apoio ao autoritarismo, a Folha da Manhã, por sua vez, em A Raça Branca em perigo, trazia à tona o argumento de oposição entre civilização e barbárie, no qual a Europa branca figurava como a representante da civilização e a Ásia e a África, representariam a barbárie. Transformando o avanço do desenvolvimento em um embate entre a civilização e a barbárie, ou seja, a Europa e 'os outros'. No artigo, o jornalista apontava para a situação das colônias europeias na África e Ásia. O avanço do Japão sobre a Indochina era observado como um perigo ao domínio europeu. Todavia, a matéria deixam claro que, a capacidade "civilizadora" dos japoneses não se igualaria à dos

${ }^{105}$ Em matéria publicada em 1936, o jornal A Folha da Noite, destacava ainda a pompa com a qual o embaixador teria sido recebido, valorizando o fato do próprio Hitler ter estado presente à cerimônia. O governo do Brasil e da Allemanha estreitam os laços das suas relações. A Folha da Noite, quarta-feira, 17 de junho de 1936. 
europeus: "É duvidoso que o Japão tenha capacidade para colonizar, em grau igual ao dos 'diabos brancos'. Nem é certo que os povos da Indochina e das Índias Orientaes, acceitem de boa vontade uma mudança de senhores. O seu ódio pelo Japão não é menos intenso do que pelos chineses" ${ }^{106}$. A matéria continua apontando a situação do domínio branco na África:

[...] a situação é muito diferente na África, embora mesmo ahi a propaganda contra os brancos importada da Ásia, desempenhe papel muito sério. Indianos, chinezes, árabes e japoneses encontram-se por toda parte, entregues ao commercio, desde Aden à Cidade do Cabo, não raro em alta escala. O sonho do Japão do domínio do mundo, à moda britannica, estendeu-se por toda a África. As concessões japonezas para plantação de algodão na Abyssinia mostram o que se pode esperar de tal infiltração. Entretanto, de uma maneira geral, os interesses europeus na África correm menos perigo do que em qualquer outro continente. Mas, se o Japão conseguir avançar as suas sentinellas para além da Índia e das Índias Neerlandezas, à custa dos brancos, a África ficará em posição extremamente crítica [...] Que acontecerá no dia em que toda a China cahir nas mãos dos japoneses? Appellará Londres, na hora da afflicção, para a Europa, em se auxílio? E conseguirá a Europa afastar e dominar a tempestade de propaganda que se manifestará nas plagas africanas? Em Moçambique (África oriental portugueza) já apenas 15.000 brancos para dois milhões e meio de pretos. Na África oriental britânica e francesa a proporção não é muito differente. Cerca de 1.500 asiáticos foram recentemente expulsos de Moçambique por serem considerados fermento de perturbação anti-europeia. No Tanganika, 8.500 brancos estão completmente perdidos no meio de cinco milhões de pretos e 33.000 asiáticos [...] (Folha da Manhã domingo, 13 de junho de 1937)

$\mathrm{O}$ autor aponta ainda para o fato de que, se os europeus desejassem manter o controle nas praças de África e Ásia teriam que fazer concessões, "ou terão que combater sozinhos as suas batalhas", em uma referência explícita à verdadeira função da manutenção de colônias europeias em África e Ásia. Conclui assim, apontando que "se esperarmos que comece a inevitável luta na Ásia, será tarde demais. A supremacia dos brancos na África estará em perigo" (Folha da Manhã domingo, 13 de junho de 1937). Em tempos em que o modelo de desenvolvimento era o nazifascismo, o ideal da supremacia branca, mesmo num país mestiço como o Brasil, encontrava campo fértil.

\subsubsection{Nem sempre o apoio era total}

${ }^{106}$ Folha da Manhã domingo, 13 de junho de 1937. 
Embora a imprensa apresentasse o nazi-fascismo de forma positiva, havia igualmente espaço para matérias, compradas de agências internacionais, nas quais eram feitas denúncias e apontados questionamentos sobre o risco que representava o fortalecimento do nazi-fascismo, principalmente a partir da aliança entre Itália e Japão, algumas até mesmo - como a da Revista Vamos Lêr! de abril de 1939 - contextualizavam o leitor, explicando-lhe os verdadeiros motivos do incompreensível pronunciamento japonês em favor do antissemitismo.

Durante o ano de 1938 dois acontecimentos ocorreram que influíram fortemente na transformação do anti-semitismo nazista, fazendo-o passar de um movimento nacional para um movimento internacional. O primeiro foi a conversão do líder italiano, Benito Mussolinni, ao anti-semitismo. O segundo foi a conversão publicamente anunciada, dos japoneses ao mesmo credo. A maioria dos observadores não têm podido compreender esses acontecimentos e têm apreciado mal os seus efeitos. Na realidade, muitos observadores acharam comico o ato dos japoneses, porque não há judeus no Japão. Mas o anti-semitismo japonês não tem nada de engraçado. [...] A Italia e o Japão, seguindo as pegadas da Alemanha, estão se utilizando do anti-semitismo como de uma arma para a luta por uma partilha maior da superfície da terra. (Revista Vamos Lêr! 27 de abril de 1939)

Alternavam-se nas mesmas revistas, páginas contendo duras críticas ao regime de Hitler e Mussolini, e outras que se desdobravam em elogios às magníficas conquistas culturais, educacionais e econômicas, de italianos e alemães. Sobretudo a rígida disciplina, implantada pela educação nazista, bem como o culto ao corpo saudável e à educação física, fascinava aqueles que criam nesses métodos como eficazes, para a caminhada em direção aos novos tempos. Nesse sentido, destacamos a reportagem de W. S. Coogan, adquirida e publicada pela Vamos Lêr! de junho de 1939, a revista mesmo publicando textos que alertavam sobre os perigos do nazismo, frequentemente trazia textos apologéticos, sobre os "progressos do Estado Alemão". Na reportagem, lia-se, em destaque, um pequeno texto motivador, acompanhado de uma frase do Führer alemão: 'Nos países modernos preparam-se os moços para torna-los capazes de enfrentar, com espírito esportivo, a luta pela vida - 'Quem tem mocidade tem futuro', afirma Hitler”.

Em “Corpo e Alma da Juventude Contemporânea”, reportagem publicada na Vamos Lêr! em 1939, (figura 47) via-se em página dupla, ao centro, a imagem de três moças, em contraplongée, durante a prática de um esporte, saltando, as três ao mesmo tempo em disputa pela bola. Movimento sincronizado, força, perseverança, habilidade, alegria (pois é possível notar um leve sorriso no rosto da moça que se coloca logo de frente para o leitor), ou seja, uma série de aspectos positivos, associados à juventude saudável, que o projeto dos governos autoritários desejava alcançar, estavam ali expressos. 
Figura 47. Corpo e Alma da Juventude Contemporânea.

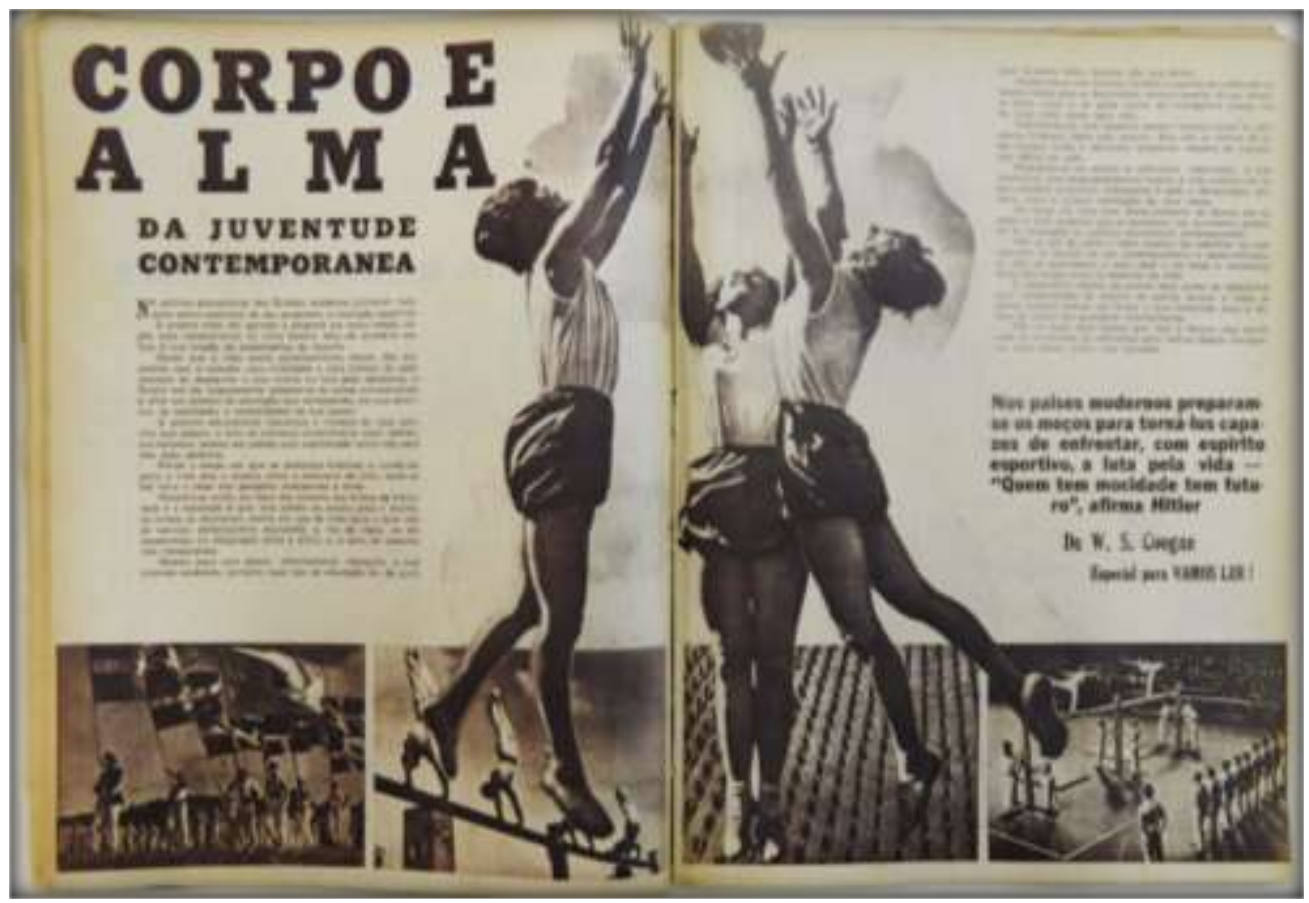

Fonte: Revista Vamos Lêr! 08 de junho de 1939, p. 36-37.

Figura 48. Corpo e Alma da Juventude Contemporânea.2

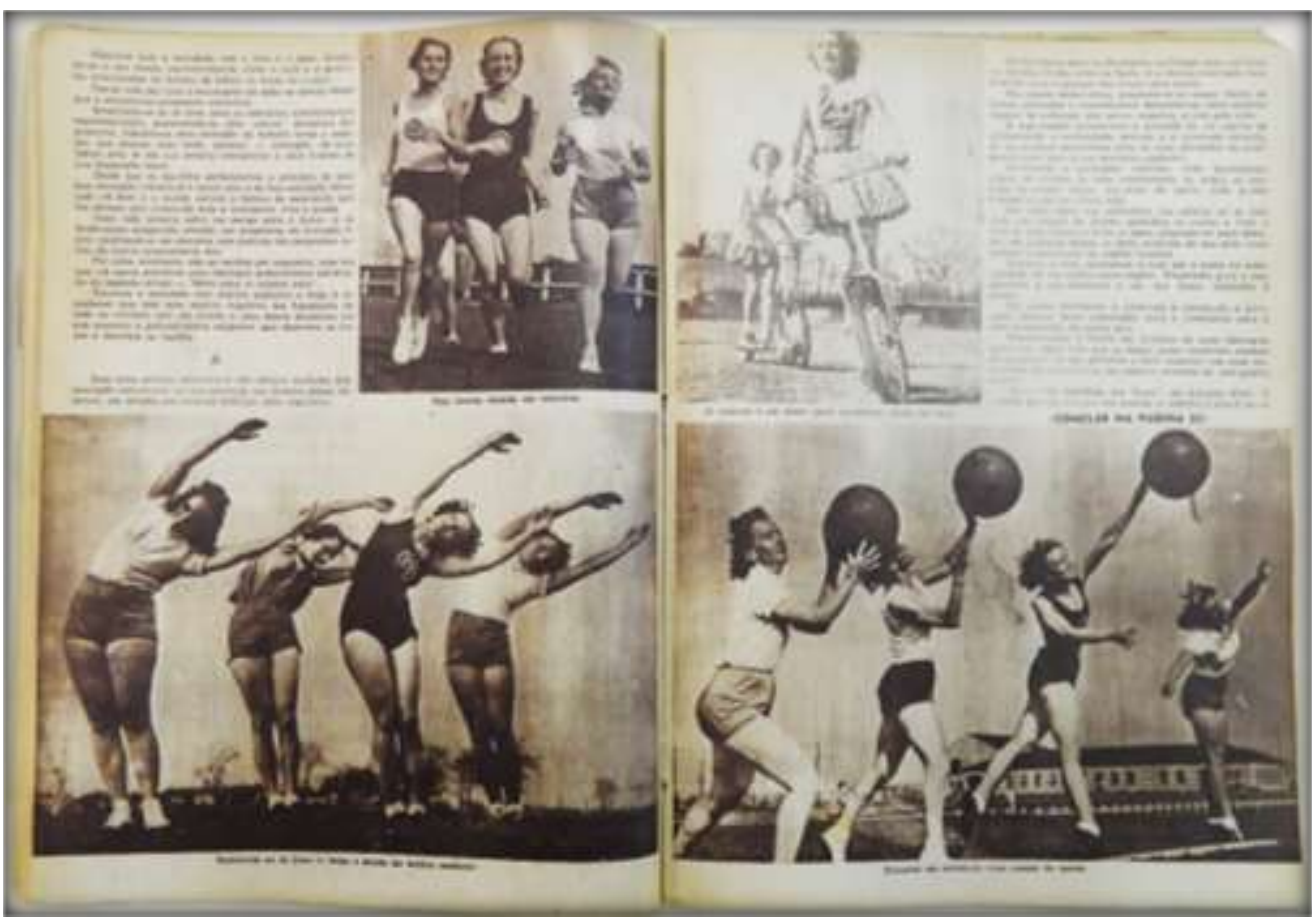

Fonte: Revista Vamos Lêr! 08 de junho de 1939, p. 38-39. 
Em quatro quadros menores, abaixo da imagem principal, vê-se a imagem de atléticos rapazes, em desfile, empunhando a bandeira, na prática de ginástica olímpica e realizando exercícios físicos de maneira sincronizada.

Nas duas páginas seguintes, novamente o destaque é à figura feminina (figura 48). A mulher disciplinada e de corpo ágil e saudável seria o símbolo de uma nova geração de cidadãos; não mais os 'bichos de biblioteca', mas jovens fortes e atléticos, preparados para a vida (e para a guerra).

Foi-se o tempo em que se pretendia habilitar a juventude para a vida com o auxílio único e exclusivo do livro, tendo-se em vista o ideal das gerações inteligentes e vivas. Pensava-se então em fazer dos homens uns bichos de biblioteca e o resultado é que, mal saídos da escola para o mundo, os jovens se chocavam contra um tipo de vida para o qual não se sentiam perfeitamente equipados e, via de regra se desesperavam na adaptação lenta e difícil, si a meio caminho não fracassavam."[...] "Nos países modernos preparam-se os moços para torná-los capazes de enfrentar, com espírito esportivo, a luta pela vida - 'Quem tem mocidade tem futuro', afirma Hitler [...]" 'O livro e o mosquete fazem um perfeito fascista', é a expressão que Mussolini, por sua vez, define, em parte a ideologia da escola da nova Itália. O essencial é que tanto as nações totalitárias como as de índole democrática, conjugam os interesses da Escola com os interesses da vida moderna e estimulam a mocidade pelas atividades físicas e intelectuais em perfeita harmonia, para um destino diverso do de antigamente. Nasceu para o mundo o verdadeiro espírito sportivo. Queira Deus não seja ele aproveitado, amanhã, em espírito bélico[...] (Revista Vamos Lêr! 08/06/1939, p. 82)

No Brasil, não seria diferente, como explicava o próprio ministro Capanema, no Estado Novo, homens e mulheres deveriam estar preparados, deveriam ter uma formação educacional e física, para que pudessem exercer as funções que o Estado lhes definia como corretas: aos homens a defesa e o desenvolvimento da nação, às mulheres a formação da família. A frequência no uso da imagem das jovens moças nas matérias sobre educação, estaria mais associada à ideia de que todos deveriam se preparar para cumprir com excelência a sua "missão", do que uma ideia de igualdade de gêneros ${ }^{107}$.

107 "Os poderes públicos devem ter em mira que a educação, tendo por finalidade preparar o indivíduo para a vida moral política e econômica da nação, precisa considerar diversamente o homem e a mulher. Cumpre reconhecer que no mundo moderno um e outro são chamados à mesma quantidade de esforço pela obra comum, pois a mulher mostrouse capaz de tarefas as mais difíceis e penosas outrora retiradas de sua participação. A educação a ser dada aos dois há, porém, de diferir na medida em que diferem os destinos que a Providência lhes deu. Assim, se o homem deve ser preparado com têmpera de teor militar para os negócios e as lutas, a educação feminina terá outra finalidade que é o preparo para a vida do lar. A família constituída pelo casamento indissolúvel é a base de nossa organização social e por isto colocada sob a proteção especial do Estado. Ora, é a mulher que funda e conserva a família, como é também por suas mãos que a família se destrói. Ao Estado, pois, compete, na educação que lhes ministra prepará-la 
À medida que os acontecimentos internacionais avançavam, o uso da disciplina para alimentar o "espírito bélico" ficou patente. Com a entrada da América na guerra, tanto a imprensa quanto o governo Vargas, por diversas razões, se viam inclinados ou mesmo obrigados a abandonar o tom de apoio e admiração à Alemanha, mas não exatamente a abandoná-la como modelo.

Embora, em 1942, tenhamos a fotorreportagem em página dupla, definindo a Juventude Hitlerista como um instrumento de destruição das relações familiares, "educação para a morte", (figura 49) no ano seguinte, na mesma revista, vemos longa matéria apologética, ilustrada, sobre a Juventude Brasileira (figura 50), organismo criado pelo governo Vargas, nitidamente inspirado em sua versão original, alemã. Na observação das duas matérias, é possível notar que os elementos que as compõem são muito semelhantes: jovens em marcha desfilando, destaque para a figura feminina, a bandeira, o apoio popular, a postura atlética; na primeira, o texto se coloca numa relação disjuntiva às imagens, pois embora sejam apresentadas fotografias com imagens-ícone de uma juventude voltada para a disciplina, progresso e nacionalismo, o texto, os associa à preparação do cidadão para servir ao nazismo- e não à pátria. "A mulher não é mais um elemento da família, mas uma máquina de ter filhos". "A Alemanha quer moças fortes para a maternidade estatal”. As frases são fortes, as denúncias são duras, mas as imagens mostram apenas rostos sorridentes, incluindo o de Hitler, que aparece abraçando uma jovem, em uma fotografia, legendada com: "Reconhecidamente inimigo das mulheres, Adolf Hitler, o ministro paranóico da Alemanha, fotografa-se assim, para efeito de propaganda" (Revista O Cruzeiro, 18 de setembro de 1943, p. 4-5). Lidos separadamente, texto e imagem, na figura 49, não comunicariam a mesma mensagem, pois os mesmos códigos de seleção e enquadramento utilizados para a construção positiva da Juventude Brasileira (figura 50), foram utilizados na montagem de 'Educando para a morte'(figura 49). O Estado Novo no Brasil promoveu a criação de instrumentos de controle como o DIP (Departamento de Imprensa e Propaganda), criado em 1938 e a Juventude Brasileira, que viriam para completar o projeto de identidade forjada pela homogeneização de princípios definidos e controlados arbitrariamente pelo Estado.

conscientemente para esta grave missão". A fala é de Capanema, em Schwartzman, S. Tempos de Capanema. Rio de Janeiro: Paz e Terra; São Paulo: Edusp, 1984, p.107. 
Figura 49. Educando para a morte.

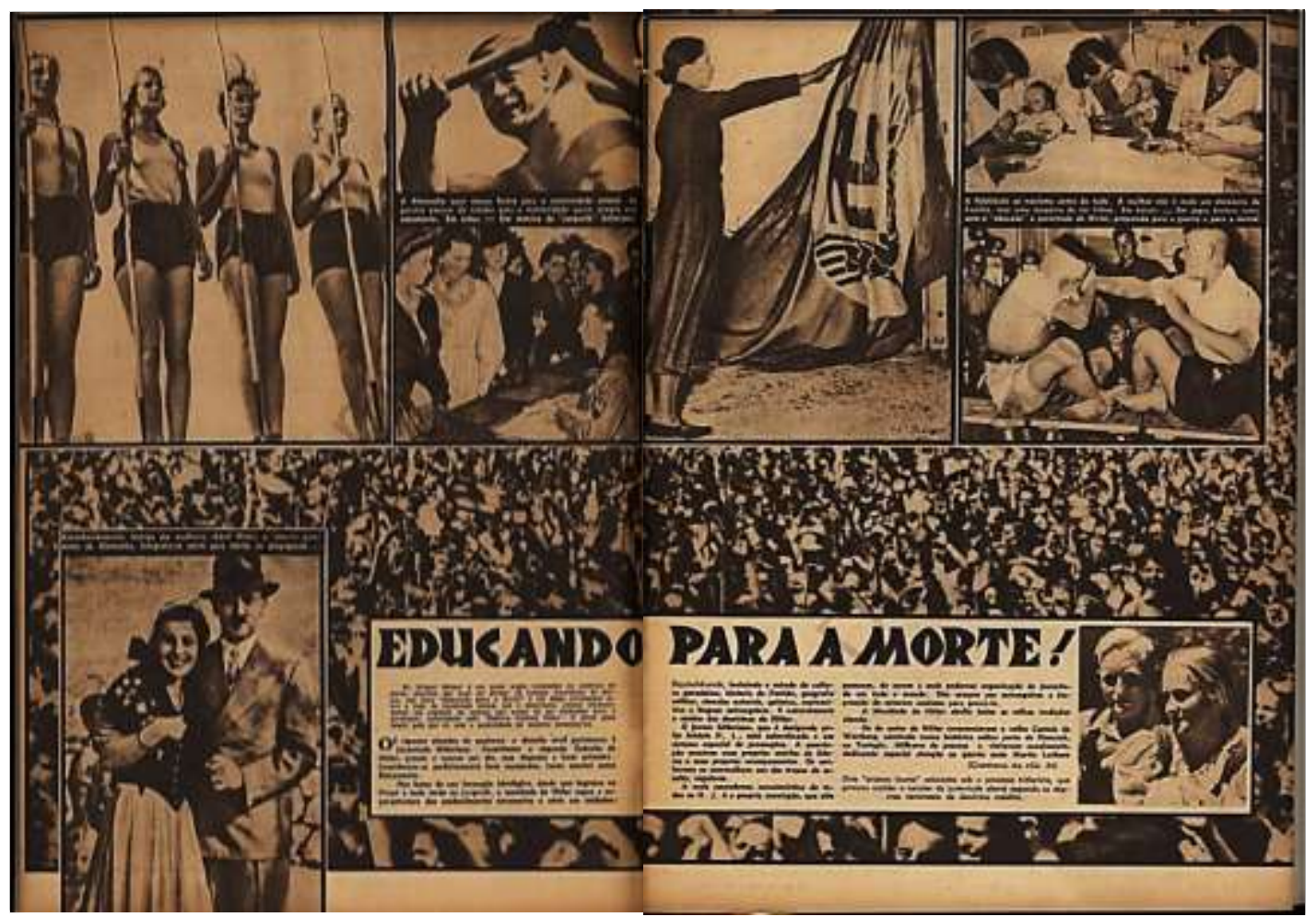

Fonte: Revista $O$ Cruzeiro, 30 de outubro de 1942, pp. 24, 25 e 34. Acervo CEDIC.

Figura 50. O desfile da juventude.

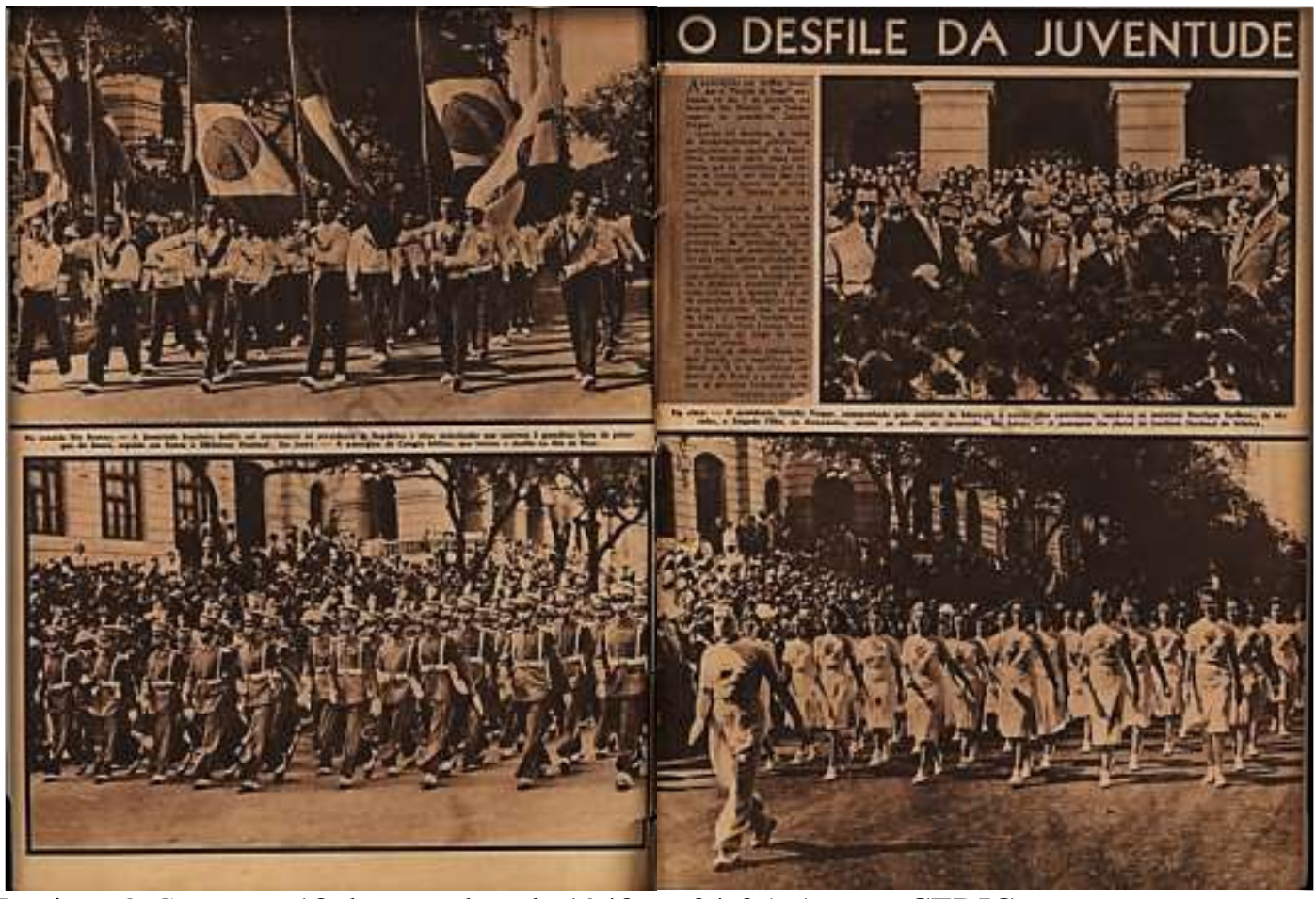

Fonte: Revista O Cruzeiro, 18 de setembro de 1943, p. 04-05. Acervo CEDIC. 
Criada a partir do Decreto Lei de n n $^{\mathbf{2}} .072$, em 08 de março de $1940^{\mathbf{1 0 8}}$, que dispunha sobre a obrigatoriedade da educação cívica, moral e física da infância e da juventude, a Juventude Brasileira corresponderia à instituição nacional responsável por ministrar tal disciplina, nas escolas e agremiações.

Seu objetivo era "criar no espírito das crianças e dos jovens o sentimento de que a cada cidadão cabe uma parcela de responsabilidade pela segurança e pelo engrandecimento da Pátria, e de que é dever de cada um consagrar-se ao seu serviço com o maior esforço e dedicação [...]"109. Ou seja, a Juventude Brasileira representava um braço do Estado, submetido diretamente ao Ministério da Educação e Saúde, com o poder de fiscalizar e intervirem questões ligadas à educação física e cívica - incluindo-se aí, a preparação elementar dos jovens, em idade escolar, como soldado - tanto nas escolas quanto em agremiações. Longas matérias, com grandes fotos chamativas, apresentando jovens sorridentes, em práticas esportivas eram publicadas nas revistas ilustradas mais vendidas da época, a fala apontava a associação entre saúde e progresso, mas numa perspectiva de "melhoria da raça":

Pela primeira vez, já arregimentada, a Juventude Brasileira desfilou quarta-feira última, graciosa e marcial perante milhares de cariocas que quiseram testemunhar com sua presença a gratidão legítima pelos grandes esforços despendidos pelos organizadores do estado Novo, em prol de uma raça sadia e forte e um revigoramento da população nacional. (Revista O Cruzeiro, Rio de Janeiro, 07 de setembro de 1940)

Vale lembrar que nesse momento de 1940, o governo Vargas já havia encampado o Jornal da Noite, do qual fazia parte a Vamos Lêr! que tornava-se assim, um veículo para a reafirmação da ideologia do regime vigente; por sua vez, até o início dos anos de 1940, O Cruzeiro, de Chateaubriand, também flertava, tal qual o governo varguista, com alguns dos princípios de desenvolvimento e melhoria da raça, presentes na ideologia tal como o do governo alemão.

Ainda sobre a Juventude Brasileira, ideais e princípios ligados ao nacionalismo e ao higienismo estariam nitidamente presentes em seus fundamentos:

108 Decreto Lei n. 2072 - de 08 de março de 1940 - Dispõe sobre a obrigatoriedade da educação cívica, moral e física da infância e da juventude, fixa as suas bases, e para ministrá-la organiza uma instituição nacional denominada Juventude Brasileira. Boletim do Ministério da Agricultura, tópico Legislação. Publicado também na Revista Vamos Lêr!, Rio de Janeiro, 14/03/1940, ano V, nº 189.

109 Revista Vamos Lêr!, Rio de Janeiro, 1940, nº 189. 
Art $1^{\circ}$ A educação cívica, moral e física é obrigatória para a infância e a juventude de todo o país, nos termos do presente decreto-lei.

Art $2^{\circ}$ A educação cívica visará a formação da consciência patriótica. Deverá ser criado, no espírito das crianças e dos jovens, o sentimento de que a cada cidadão cabe uma parcela de responsabilidade pela segurança e pelo engrandecimento da pátria, e de que é dever de cada um consagrar-se ao seu serviço com maior esforço e dedicação.

Parágrafo único - É também papel da educação cívica formar nas crianças e nos jovens do sexo masculino o amor ao dever militar, a consciência das responsabilidades do soldado e o conhecimento elementar dos assuntos militares, e bem assim dá às mulheres o aprendizado das matérias que, como a enfermagem, as habilitem a cooperar, quando necessário, na defesa nacional. (Revista Vamos Lêr!, 1940, n. 189)

Além de gozar de total autonomia, atuando dentro das instituições de ensino, a Juventude Brasileira, possuiria seu próprio uniforme, brasão e hino. Ciência, higienismo, alimentação correta, corpos saudáveis, eis a imagem do progresso. A Juventude Brasileira podia ser identificada por seus uniformes e distintivos que deveriam ser usados por todos. Impossível não associá-los à Juventude Hitlerista, ativa entre os anos de 1922 e 1945, todavia, havia diferenças fundamentais entre ambas, como: para o caso alemão, a associação do órgão a funções e objetivos políticomilicianos; a questão do jovem como controlador e delator do que fosse considerado como transgressão social; enquanto que para o caso brasileiro, a Juventude, conforme o decreto 2.072, vinculava-se ao Ministério da Educação e Saúde e não ao Ministério da Guerra como, aliás, constava no projeto de 1938, que não fora aprovado. Quanto às semelhanças, o treinamento para os esportes, a valorização da educação física e, principalmente, o apelo nacionalista para a formação de um cidadão-soldado, não podem deixar de ser percebidas ${ }^{110}$.

Interessante, também é observar uma clara definição dos papéis de gênero, bem como a valorização dos ideais higienistas:

(Art. $3^{\circ}$ Parágrafo único) A educação moral procurará ainda formar nas crianças e nos jovens de um e outro sexo os sentimentos e os conhecimentos que os tornem capazes da missão de pais e de mães da família. Às mulheres, dará de modo especial a consciência dos deveres que as vinculam ao lar, assim como o gosto dos serviços domésticos, principalmente dos que se referem à criação e à educação dos filhos.

(Art. $4^{\circ}$ Parágrafo único) - Buscará ainda a educação física dar às crianças e aos jovens os hábitos e as práticas higiênicas que tenham por finalidade a prevenção de toda a sorte de doenças, a

110 SCHWARTMAN, S; BOMENY, H; COSTA, V. Tempos de Capanema. São Paulo: Editora Paz e Terra e Editora da Universidade de São Paulo, 2000. 
conservação do bem-estar e o prolongamento da vida. Será, neste particular, objeto de especial atenção o esclarecimento do papel que, na manutenção da saúde, desempenha a alimentação, e bem assim dos preceitos que sobre ela devem ser continuamente observados. (Boletim do Ministério da Agricultura, 1940, ano 29, p. 95-96)

Eis aqui um momento importante para ser observado. O Estado, ao assumir publicamente este discurso, adota uma posição que aponta para uma compreensão de progresso associado, não mais a uma visão eugênica de oposição entre raças superiores e inferiores, mas aproxima-se de um discurso que aposta mais na ciência do que na raça, na busca pela formação de uma nação forte; seria, contudo, ainda o pensamento higienista, aliado a uma disciplina militar, que estariam na base desse projeto de educação para a juventude.

\subsection{O modelo brasileiro de desenvolvimento - Rio e São Paulo}

Paralelamente à propaganda de apologia às cidades alemãs - pelo menos até a declaração de guerra - as capitais nacionais, sobretudo as duas metrópoles nacionais, frequentavam as páginas ilustradas como modelo brasileiro de desenvolvimento e progresso. A fotografia das metrópoles brasileiras, nas páginas das revistas, acompanhava o padrão das imagens-ícone do Brasil daqueles dias. Símbolo incontestável das belezas e do desenvolvimento urbano nacional, a cidade do Rio de Janeiro, com o perfil da Baia da Guanabara (figura 51) era uma das vistas mais reproduzidas do Brasil, muito antes das revistas ilustradas, esse recorte da paisagem já se encontrava nos cartões postais, como no Álbum do Rio de Janeiro Moderno (1857), de Sebastien Auguste Sisson, composto por 12 cromolitografias ovais com paisagens, que consagraram a Baia de Botafogo como imagem símbolo da capital do Império. Unindo a visão da urbanização à da natureza exuberante, as fotografias selecionadas ressaltam as avenidas e prédios da Cidade Maravilhosa. Na figura 51, uma incomum imagem alaranjada de São Paulo surge no primeiro número da Cruzeiro, enigmática, a imagem da cidade 'da cor do tijolo' só pode ser compreendida com o auxílio do texto de Guilherme de Almeida, que a acompanha: 
Figura 51. Viagem Maravilhosa.

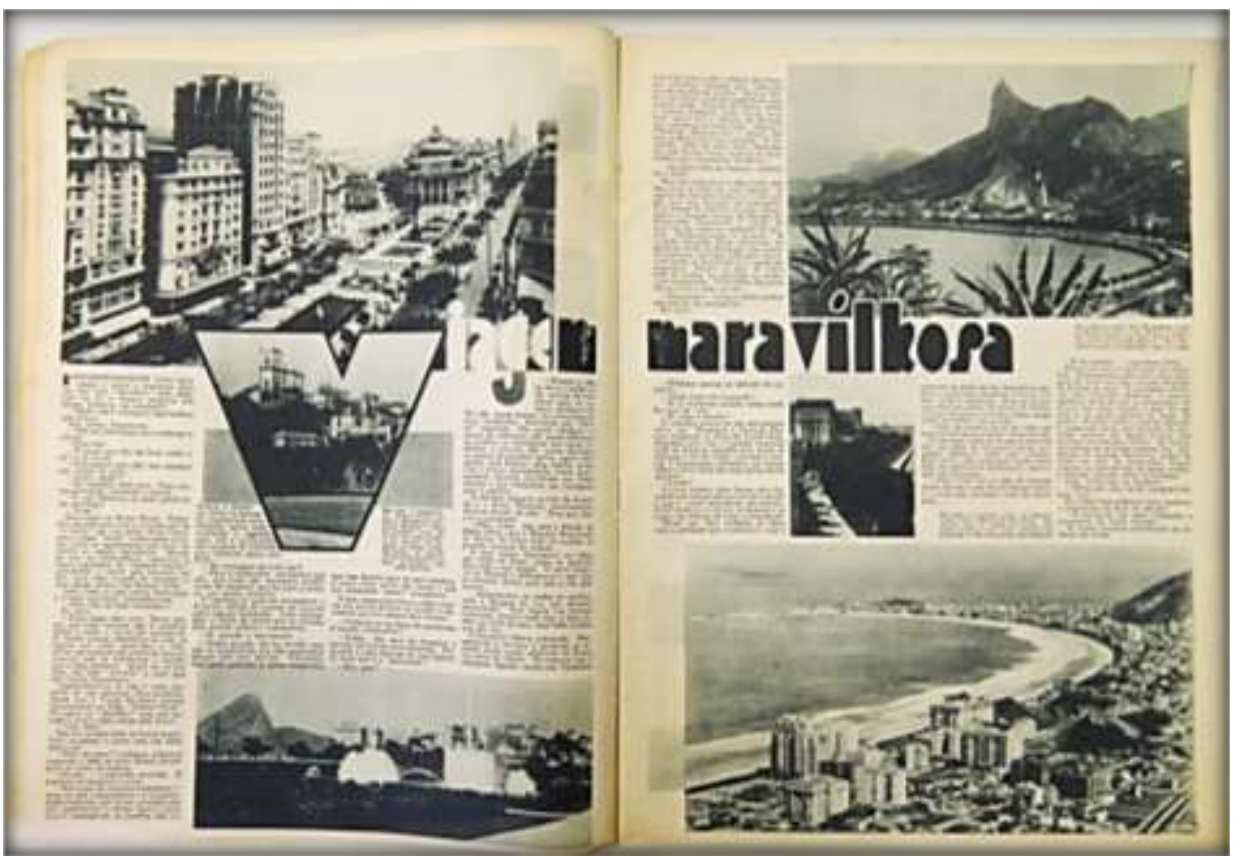

Fonte: Revista O Cruzeiro. 09 de novembro de 1933. Acervo - IEB.

Figura 52. A côr de São Paulo.

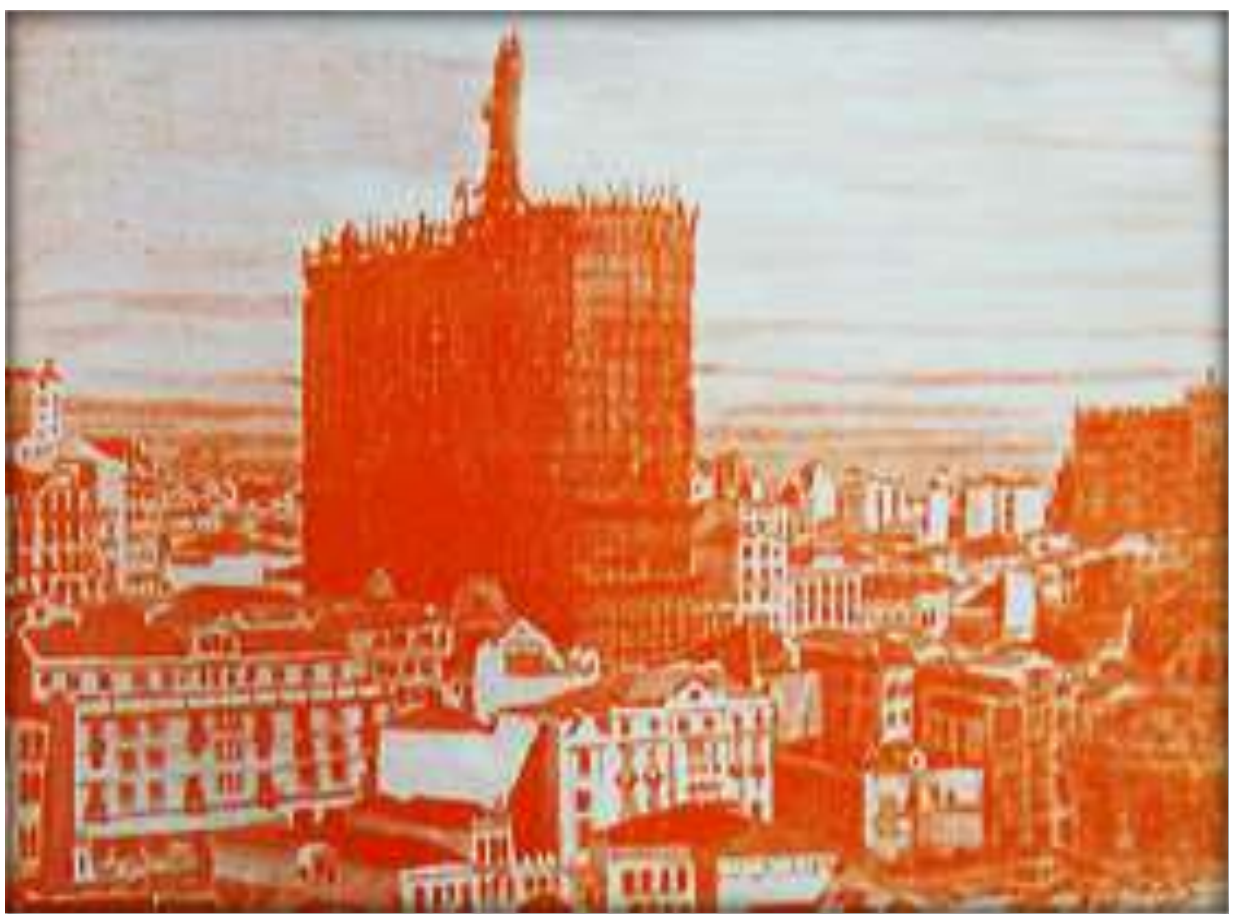

Fonte: Revista O Cruzeiro, 10 de novembro de 1928. Texto de Guilherme de Almeida. 
Figura 53. Vista aérea de Recife

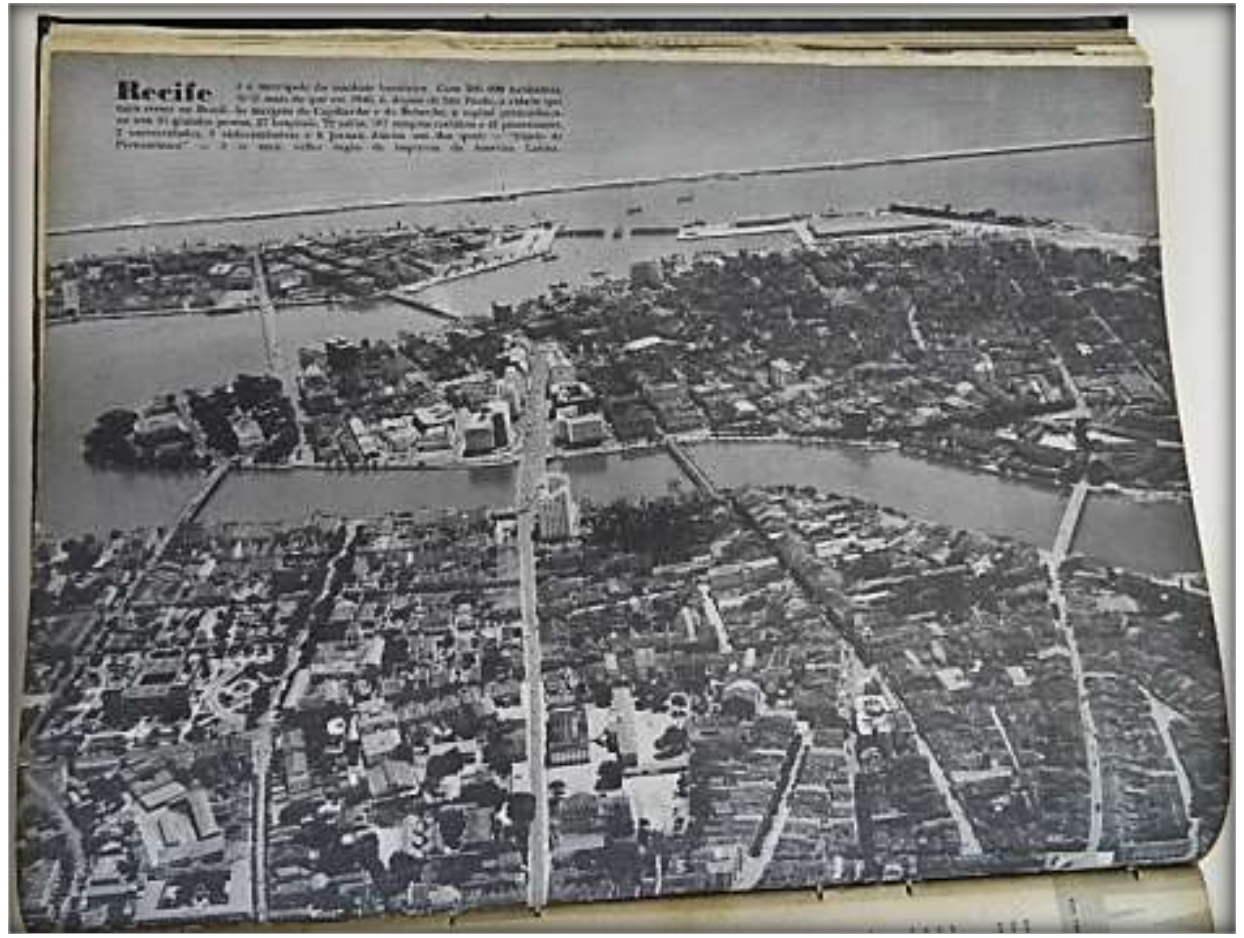

Fonte: Revista Manchete, 16 de agosto de 1952. Acervo biblioteca Florestan Fernandes - USP

Figura 54: Rio e São Paulo: roteiro econômico e social.

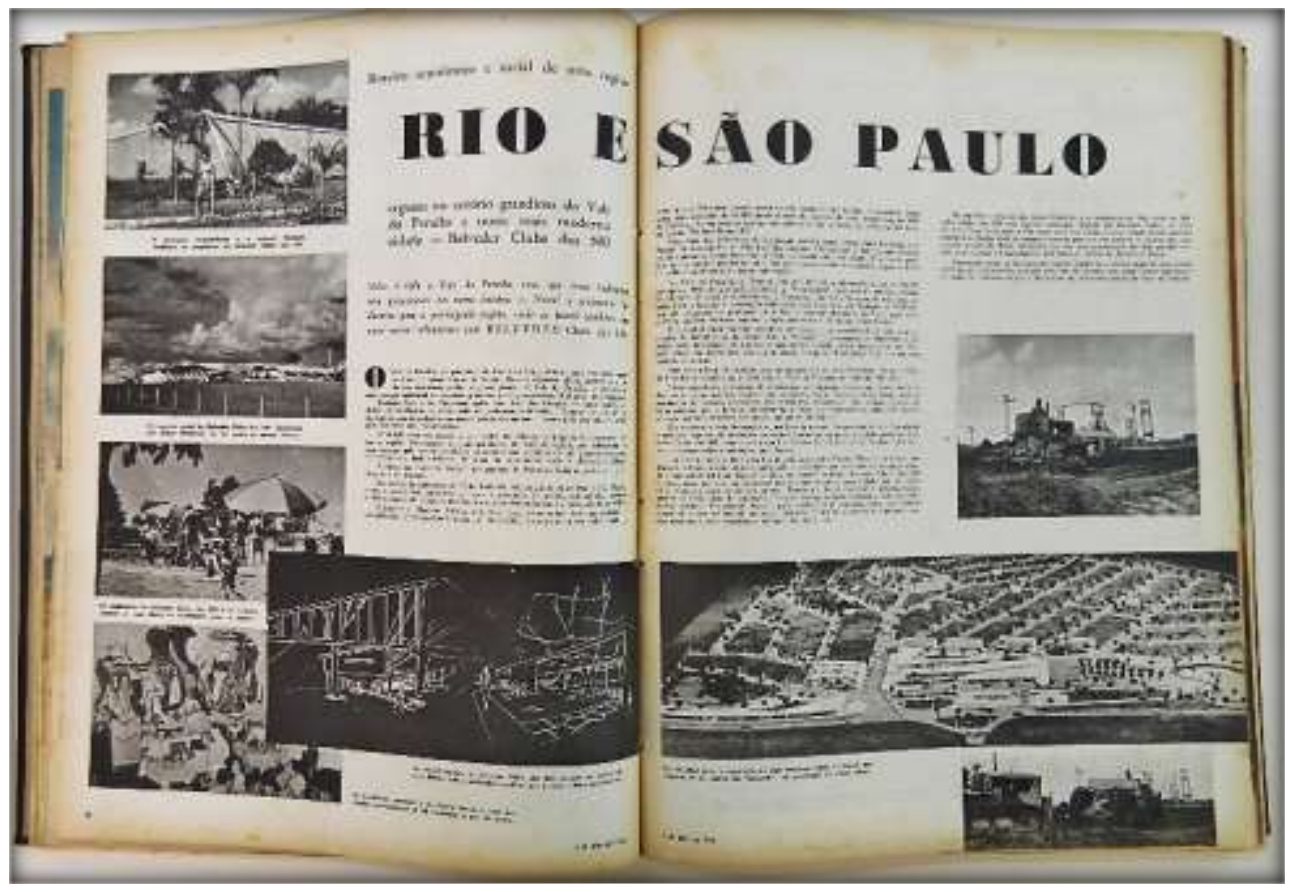

Fonte: Revista Manchete, 03 de julho de 1954. Acervo biblioteca Florestan Fernandes - USP 
Poetas estrábicos - um olho em Londres, outro em São Paulo - têm cantado esta cidade em toda a gamma do cinzento. Vêem cinza neste céo de redoma que guarda a fuligem dos bairros trabalhadores, cinza nesta garôa bohemia, cinza nestes asphaltos e nestas pedras, cinza nestes telhados de ardosia, cinza nestes cerebros tristes. Cinza: côr do tédio, côr do spleen. E concluem: São Paulo é melancólico. É Bugres, em cujos canaes de nenuphares doentes Rodembach cantou e morreu como um cysne... A cidade que constróe uma casa de duas em duas horas, a cidade que se estende e se avoluma e sóbe, num record assombroso, a capital da terra rôxa, veste, para os olhos limpos e entendidos que sabem vêr, uma "toilette" que Lanvin ou Vionnet descreveriam assim: "Vestido de esporte em Jersey 'brique dégradé', cinco tons..." "Brique" - côr de construcção. Côr dos cubos de terra cosida que se apinham, das telhas acolhedoras que se imbricam, dos vergões que o progresso abre nas glébas uteis, da poeira que erguem na estrada as modernas bandeiras de tractores e caminhões... Côr activa do trabalho, côr alegre de construcção. Côr com que o sol edifica o dia e fabrica a noite. Tijôlo - côr de São Paulo [...] (Revista Cruzeiro, 11 de novembro de 1928)

O crescimento e o avanço econômico da capital paulista chamavam a atenção do Brasil desde as primeiras décadas do século XX, mas o processo de urbanização e industrialização das capitais nordestinas também eram registrados, por exemplo, na contracapa da Manchete, em seu ano de lançamento, fotos aéreas de diversas capitais foram publicadas (figura 53). São Paulo em particular, concentrava grande parte das atenções, por ser a responsável pela maior parte da produção nacional. Em 1927 o Departamento Estadual do Trabalho publicara um boletim no qual apresentava um Recenseamento Operário da Capital, realizado pela Delegacia da Ordem Política e Social (DOPS) no qual já registravam um número equivalente a 203.736 operários trabalhando na cidade sendo 3.629 o total de fábricas e estabelecimentos industriais. O ritmo acelerado do crescimento do Rio de Janeiro e de São Paulo, era assunto para as revistas desde os anos de 1920. Em 1954, durante o aniversário da capital paulista, muitas fotos aéreas mostrando sua extensão foram publicadas, no caso da reportagem de 03 de julho, da Manchete, o crescimento da importância da cidade, também como polo cultural - título que pertencia até então ao Rio de Janeiro - também é destacado.

Esse grande incremento da produção e da urbanização trariam não somente a redefinição do espaço socioeconômico da cidade como também de suas relações com as cidades ao seu redor; mas sua posição em relação à representação de Brasil. Nesse sentido, entendemos a cidade de São Paulo como cidade-centro, partindo da interpretação de Braudel, apresentada por François Fourquet (1991) em Cidades e economias-mundo segundo Fernand Braudel, onde a cidade-centro é aquela que centraliza o essencial da riqueza e a acumula; essa cidade estaria no centro dos circuitos mercantes, apoiando-se numa rede de cidades associadas e a ela submissas. O processo de urbanização e industrialização, sem dúvida, promoveria o surgimento de uma gama tão variada 
de produtos e serviços que em poucas décadas tornariam São Paulo, inquestionavelmente o centro da vida econômica no país. Um símbolo desse desenvolvimento paulista, que se estendia em direção a todo o Brasil, eram as ferrovias (figura 55).

Imagem-ícone do desenvolvimento paulista desde o início do século XX, a ferrovia, com todo o esforço industrial que exigia para estender-se pelo país, seria a representação por excelência do progresso. Em visita à Companhia Paulista Ferroviária em Rio Claro (figura 55), a equipe da Cruzeiro registra com empolgação o que via, nas instalações de força e fundição: "as impressões fortes se sucedem: aqui, um forno engole e funde, à nossa vista, uma tonelada de ferro em dez minutos. A Companhia Paulista não é apenas um padrão de ferro viário. É também um esplêndidos campo experimental”. (O Cruzeiro, 09 de novembro de 1933).

Figura 55. Percorrendo as instalações da Cia Paulista.

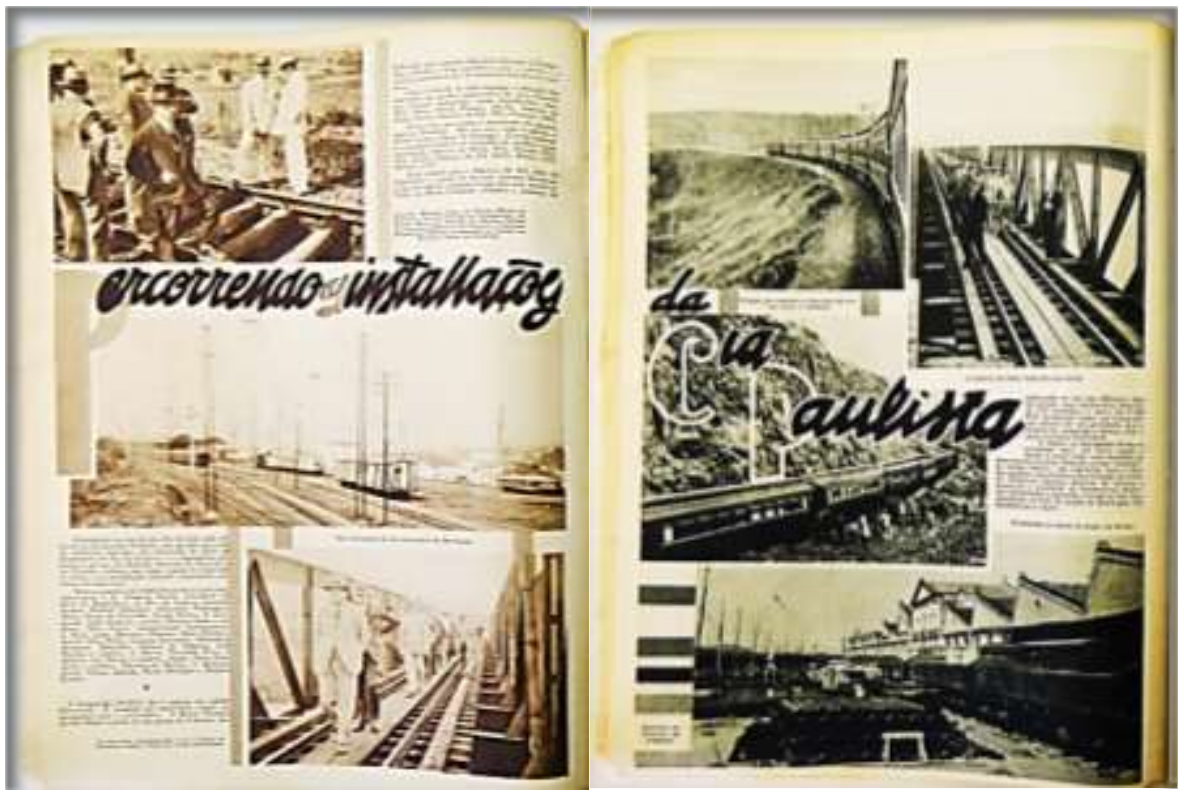

Fonte: $O$ Cruzeiro, 09 de novembro de 1933- Acervo-IEB.

Um marco para a consolidação da imagem de São Paulo como capital moderna, na imprensa, e no imaginário coletivo foi, sem dúvida, o ano de 1954, e a intensa cobertura dos eventos comemorativos e também sobre a história da cidade de São Paulo, aniversariante em seu quarto centenário. Durante todo o ano de 1954, as revistas enfatizaram a majestade das obras comemorativas do quarto centenário da cidade de São Paulo (figura 56). Na cidade, a grandiosidade dos festejos - "Um milhão de pessoas na inauguração da Exposição do IV 
Centenário" - matéria sobre o ritmo da cidade, traziam expressões como: "São Paulo que não pode parar...", a "cidade em que se anda o dia inteiro..."; "as pessoas não param, não se sentam." Fotos do aeroporto, do parque do Ibirapuera, das chaminés e do perfil de arranha-céus do centro da cidade, ilustravam o encanto produzido pela a grandiosidade e pelo ritmo veloz da cidade.

Os festejos comemorativos da passagem do IV Centenário de São Paulo iniciaram no dia 23. Nas principais praças públicas, à noite, bandas civis procedentes de todos os recantos do Estado, apresentaram-se ao povo em retretas gostosas lembrando outros tempos, enquanto os jovens faziam o "footing" em volta do corêto, lançando olhares langorosos para as moças casadoiras. [...] O grande acontecimento social do dia 24 foi a realização do Grande Prêmio "IV Centenário" a maior prova turfística já realizada na América Latina. (O Cruzeiro, 16 de janeiro de 1954, p. 85)

A fotografia da cidade, em plano geral privilegia uma composição que destaca, os representantes da urbanidade e da modernidade. Os arranha-céus do centro da cidade, o concreto e o asfalto como representação do desenvolvimento mas, sobretudo, o fervilhar humano, o trânsito intenso de pessoas e veículos (figura 56). Aqui, a imagem prescinde de texto.

Enquanto a Cruzeiro dava destaque aos eventos sociais do aniversário da cidade, a Manchete enaltecia-lhe a trajetória. A fotografia que abre a reportagem "400 anos sem rugas" (figura 57) apresenta uma monumental imagem aérea da cidade em página dupla.

E por mais que ela cresça, parece sempre pequena para conter os seus habitantes. Parece impossível que a população "caiba" no número de casas da cidade. Daí o espanto de Fiorelo La Guardia, exprefeito de Nova Iorque: "Mas isto é o paraíso dos pedestres!", exclamou êle quando em visita a São Paulo. De fato, vivem as suas ruas dia e noite congestionadas. Aqui, ao contrário do Rio, os veículos não têm "vez". Continuamente, os administradores são obrigados a restringir o trânsito de autos nas ruas centrais, transferir o ponto terminal dos coletivos para a periferia e os pedestres vão avassalando o centro. (Revista Manchete, 23 de janeiro de 1954, p. 32)

O enquadramento escolhido confere à imagem a ideia de imensidão. Ambas revistas apresentam a cidade como um universo amplo, um prodígio da engenhosidade paulista. No desenvolvimento das matérias as fotografias vão se seguindo, mostrando 'São Paulo ontem e hoje', fazendo do registro imagético uma testemunha da história. A fotografia, entendida como uma testemunha, era chamada a depor em favor de diferentes causas. No período entre as décadas de 1930 e 1940, a propaganda sobre um Brasil em franca modernização e desenvolvimento transcendia as fronteiras nacionais e encontrava eco nas representações sobre o Brasil em diferentes suportes. 
Figura 56. Quarto centenário. Tire o chapéu para São Paulo.

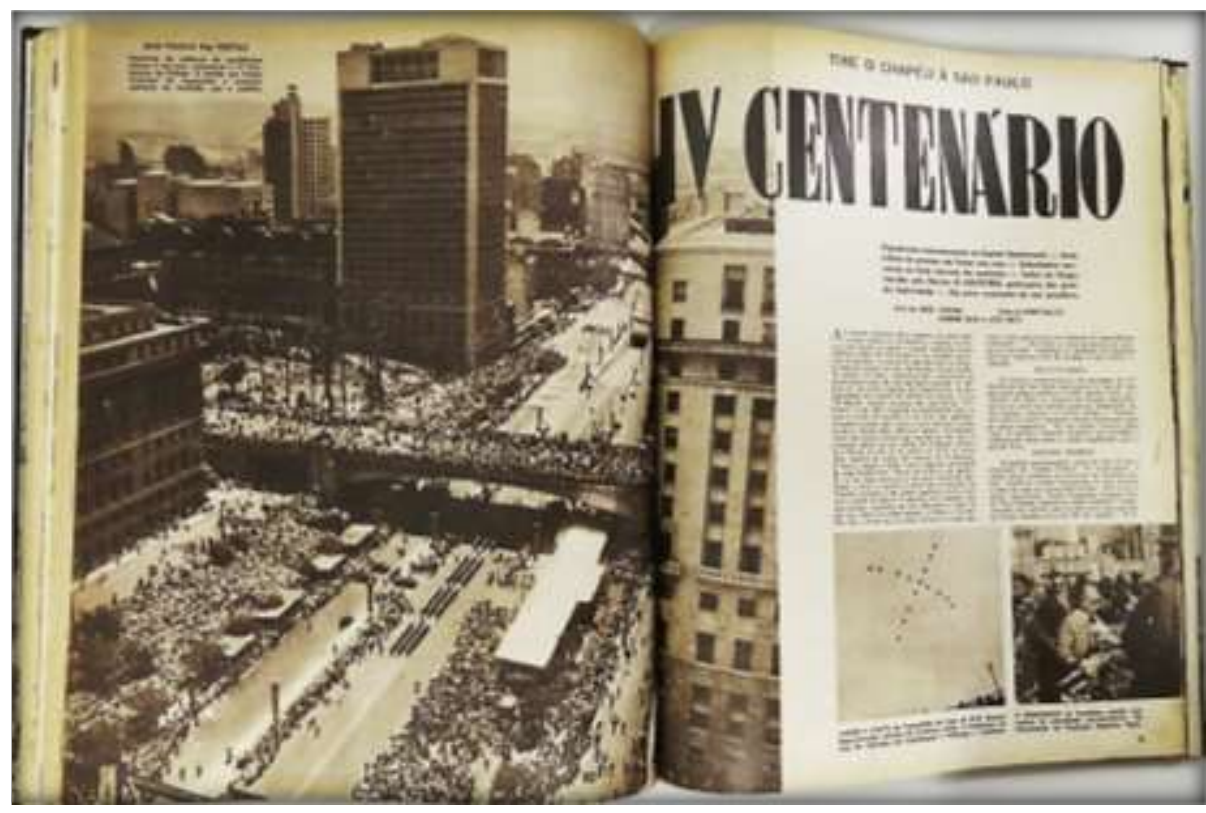

Fonte: O Cruzeiro, 16 de janeiro de 1954. Acervo ECA. Texto de Jorge Ferreira e fotografias de Henri Ballot, Eugênio Silva e José Pinto.

Figura 57. 400 anos sem rugas.

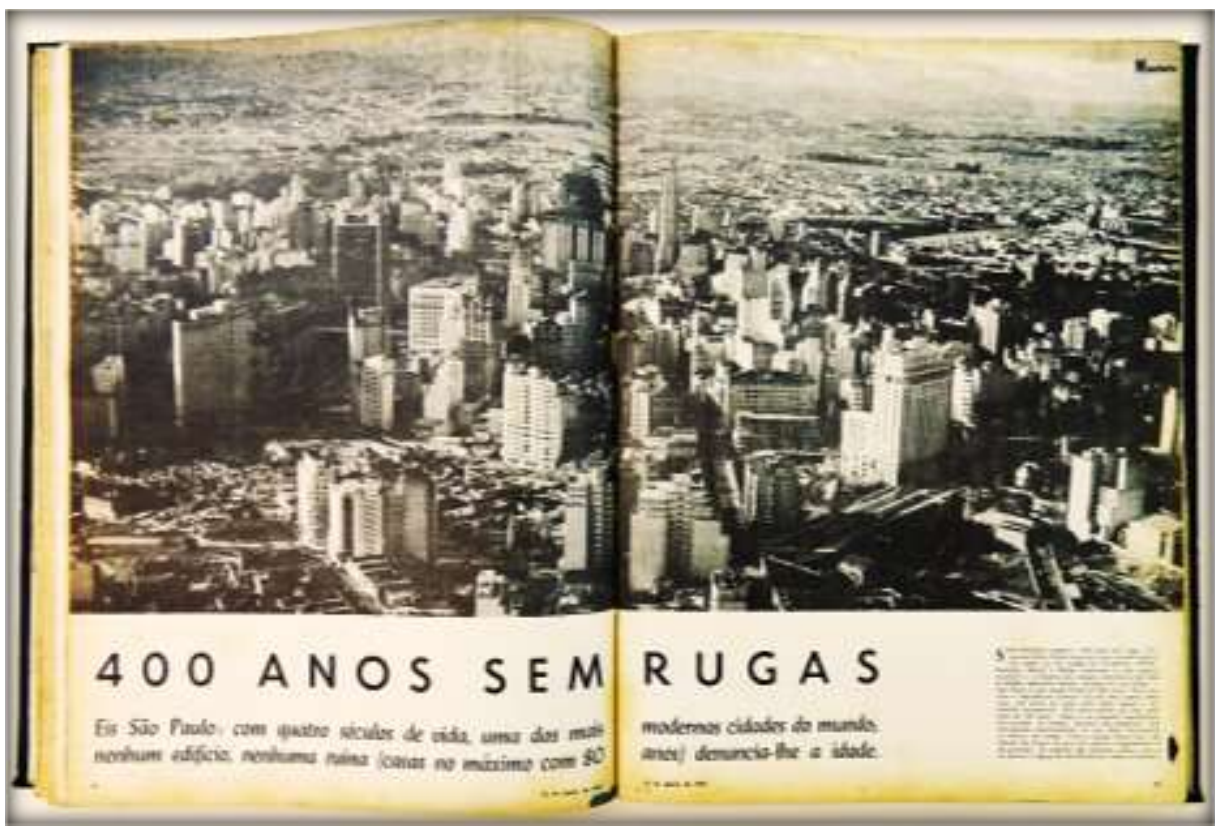

Fonte: Revista Manchete, 23 de janeiro de 1954, p. 14-15. Acervo Biblioteca Florestan Fernandes - USP. 
A presença de reproduções de paisagens brasileiras em revistas e jornais estrangeiros era comum, mas há um caso particular, no qual, não apenas paisagens e perfis brasileiros eram reproduzidos, mas imagens que buscavam transmitir a ideia de um Brasil em desenvolvimento, sendo reproduzidas não apenas em revistas, mas nos manuais escolares, e por decreto. Era o caso dos manuais escolares portugueses. No caso português, era no currículo de Geografia em que as representações de um Brasil desenvolvido eram veiculadas. Caberia a essa disciplina apresentar aos jovens portugueses o Brasil, seu potencial em riquezas naturais, e "sua importância para Portugal", como definia um tópico obrigatório do currículo oficial para os manuais da $3^{\mathrm{a}}$ classe, definido pelo decreto 16.730/1929. A dita "importância para Portugal" era desenvolvida nos manuais para os pequeninos da terceira série como a importância do Brasil como potência agrícola, sua parceria comercial com Portugal e ainda, sua importância como nação receptora de emigrados portugueses, que contribuiriam com a economia nacional, enviando dinheiro para suas famílias em solo português.

As duas imagens (figura 58) mostram a Colheita do café em São Paulo. No texto de ambos os livros há a valorização da agricultura brasileira e o destaque ao seu sucesso produtivo, motivador da emigração. Em António G. Mattoso, lê-se:

"Quando os portugueses conheceram ainda melhor as riquezas do Brasil, a emigração aumentou e o desenvolvimento da agricultura pelas grandes plantações de cana de açúcar e de café tornou-se verdadeiramente notável. [...] Pode-se dizer que, a despeito de sua independência, o Brasil é ainda hoje a nossa melhor colónia. Tal é a importância que para nós tem o Brasil." (Compêndio de Geografia Econômica António G. Mattoso. Livraria Sá da Costa - Editora. Lisboa. 1939, p. 63)

As duas imagens mostram representações de São Paulo (figura 59). Em Geografia. Portugal, colónias portuguesas, Brasil e regiões polares, temos uma gravura, com a indicação. São Paulo - Um Arranha-céu. Vários livros trazem fotos da área central de São Paulo, destacando-lhe a modernidade. Schwalbach destaca o fato do Brasil já ter sido conhecido como país de economia agrícola, e que hoje, seria um país rico em atividade mineradora.

Entre Santos e São Paulo - na Serra do Mar. (figura 60) Os dois manuais trazem imagens da Ferrovia São Paulo - Santos, sendo que o texto de Alves de Moura, Evaristo Vieira, Américo Palma destaca os problemas de falta de mão de obra e de vias de comunicação, apontando que o país vem desenvolvendo a indústria, com refinarias e incentivos ao comércio. (Compêndio de Geografia. $2^{\circ}$ ciclos dos liceus. Alves de Moura, Evaristo Vieira, Américo Palma. Livraria Didáctica. Lisboa. 1949, p. 317) 
Rio de Janeiro. O Rio de Janeiro, mais precisamente a vista do Corcovado e Baía da Guanabara, são as imagens mais reproduzidas nos manuais portuguesas do período estudado (figura 61). No Geografia de Portugal. Coleção escolar Progredidor, destacamos a legenda que informa ter sido a foto, tirada pelo próprio autor. No Progredidor, destacamos um interessante texto que resume a forma como o Brasil era visto pelo ensino oficial em Portugal durante o Estado Novo português:

O Brasil foi a mais florescente colónia portuguesa. Desde há muito tempo que os portugueses, atraídos pelas suas riquezas, para lá emigraram em grande número, o que faz com que entre os seus 43 milhões de habitantes, 2 milhões sejam portugueses. É por isso o Brasil como que um prolongamento de Portugal. Nele se fala a nossa língua: nele predominam, principalmente, a nossa raça e os nossos costumes. De entre todas as nações é ela a que mais deve merecer o nosso carinho, não só por este grande número de portugueses que nela exercem a sua atividade e que a pouco e pouco vão transferindo para a sua Pátria o que conseguem angariar, mas também pelas tradições históricas que nos ligam e pelo grande comércio que com ela temos, pois trocamos o nosso vinho do porto, as nossas conservas e nossas frutas pelo seu café, o seu tabaco e sua borracha. O Brasil é entre as nações da América uma grande potência. (Grifo nosso). Geografia de Portugal. Coleção escolar Progredidor. Resumo pelo professor Eduardo Moura, Nova edição, 1944, p. 28

Importante lembrar que Brasil e Portugal, mantiveram, durante os anos de 1930 e 1940, uma relação bastante amistosa, dado que no contexto de polarização ideológica, política e militar, colocava o governo português numa situação muito semelhante a do governo brasileiro, posto que "Portugal, (se mantinha) neutro, mas com a tradicional simpatia da população pela Inglaterra, apesar da inclinação pessoal de Salazar pelas Potências do Eixo"111. O isolamento português, no período do governo salazarista, destoava da fala amistosa e dos esforços de se aproximarem do Brasil. Defendendo a importância da aproximação entre os dois países, a importância do Brasil para Portugal, e principalmente, a veiculação de uma imagem positiva do Brasil em Portugal, podia ser observada no currículo e nos manuais escolares das séries iniciais.

Em um período em que a propaganda nacionalista de Salazar era imposta e se fazia presente por toda parte, e que mesmo a Europa era representada nos manuais portugueses de forma esvaziada $^{112}$, como uma somatória de países sem identidade, as referências positivas ao Brasil,

\footnotetext{
${ }^{111}$ ARAÚJO, Heloísa Vilhena de. Guimarães Rosa: diplomata. Brasília: Fundação Alexandre de Gusmão, 2007, p. 25. 112 AFONSO, J. A e MAGALHÂES, J. "Manuais de leitura, história e geografia e a ideia de Europa (1930-1945). Do mundo português à Europa física a administrativa das naçôes". En GENOVESI, G.: L'immagine e l'idea di Europa nei manuali scolastici (1900-1945). Atti del I Convegno internazionale. SPICAE (Societas pro Investigatione Comparata Adhesa Educationi), Cassino, Franco Angeli, 1999, pp.191-204.
} 
ilustradas com imagens que se remetiam ao mesmo conjunto de temas que aludiam ao progresso e ao desenvolvimento, chamam a atenção.

As imagens se remetiam tanto à exuberância natural e ao potencial agrícola brasileiros, quanto ao seu desenvolvimento urbano - como nas foto reproduções do Cristo Redentor, do Pão de Açúcar seguido da vista panorâmica da cidade do Rio de Janeiro em segundo plano, ou os arranha-céus de São Paulo - acompanhadas ainda por palavras elogiosas, destacando o seu progresso bem como a relação de amizade mútua. Tal interesse em apresentar aos jovens portugueses um Brasil tão positivo deveria, necessariamente, associar-se a um objetivo maior.

A razão para a presença de um discurso positivo em relação ao Brasil, residia no interesse português no estreitamento dos vínculos comerciais entre as duas nações, pois há muito o vínculo diplomático e comercial entre Portugal e Brasil se encontrava em processo de reconstrução.

Podemos recuar, na contextualização dessa necessidade de recomposição das relações entre os dois países, ao ano de 1889, quando da proclamação da república brasileira e à decisão do novo Estado republicano em realizar a grande naturalização, que resolvia o problema brasileiro, de impedir uma evasão de estrangeiros, mas desagradava enormemente às nações europeias que tinham no Brasil grandes colônias de emigrados, dentre elas, Portugal. Na intenção de não perder os laços com os portugueses emigrados, a política diplomática portuguesa, passa então a priorizar três princípios em relação ao Brasil: "1 - coesão de laços familiares dos cidadãos de nacionalidade portuguesa (residentes no Brasil); 2 - a não ingerência nos assuntos internos do Brasil; 3- o fortalecimento da comunidade lusa enquanto patrimônio nacional" (RIBEIRO, 2006, p. 148).

Somemos ao desejo de manter-se aceso o sentimento pátrio dos portugueses emigrados, a importância das remessas de capitais dos portugueses residentes no Brasil, para suas famílias em Portugal; e também a importância do Brasil como parceiro comercial. Segundo Ribeiro (2006), àquela época $43,13 \%$ do vinho exportado por Portugal, tinha o Brasil por comprador e, $82 \%$ da matéria-prima importada por Portugal era oriunda do Brasil. Tentou-se assim, um tratado comercial em 1892 e outro em 1922; o primeiro não chegou a ser firmado, e o segundo teve aprovação de apenas algumas de suas propostas. 
Figura 58. Manuais portugueses. Café.
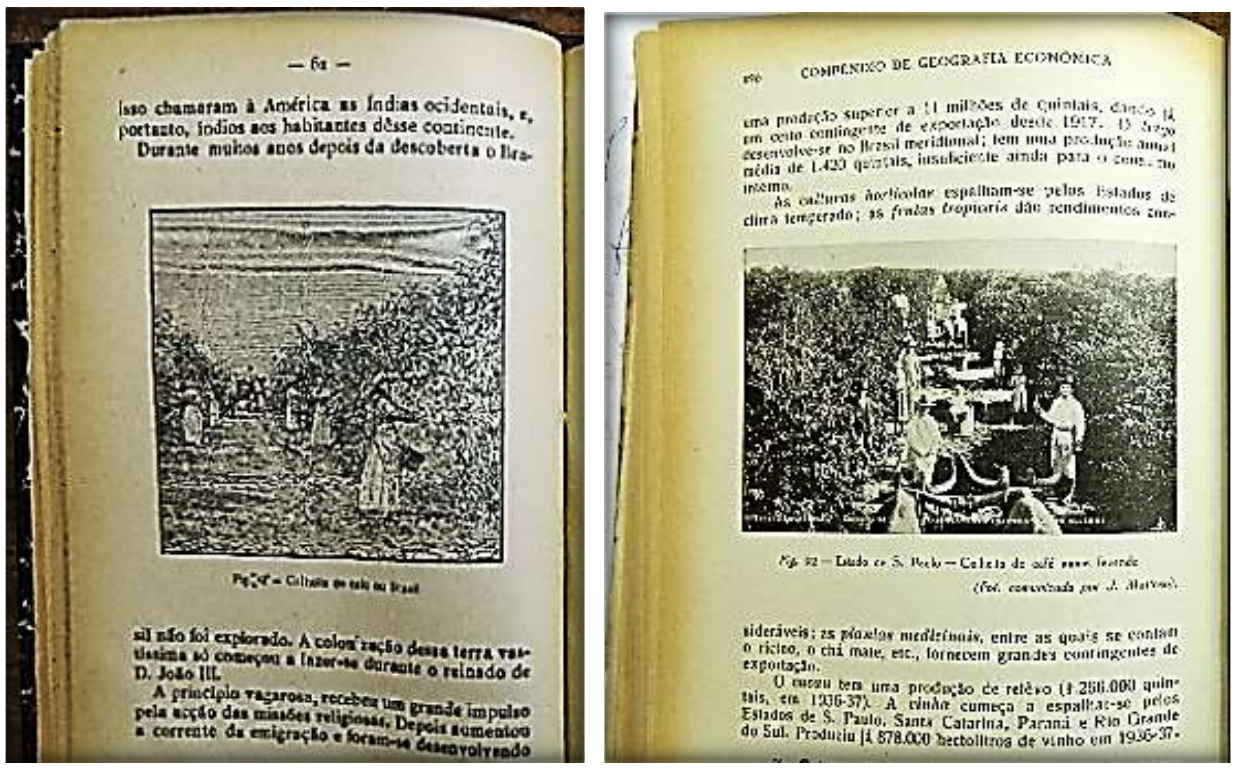

Fonte: Noções de Geografia. $3^{\mathrm{a}}$ e $4^{\mathrm{a}}$ classes. Acacio Guimarães. Livraria Popular de Francisco Franco. Lisboa. 1930; Compêndio de Geografia Econômica António G. Mattoso. Livraria Sá da Costa, Lisboa. 1939.

Figura 59. São Paulo.
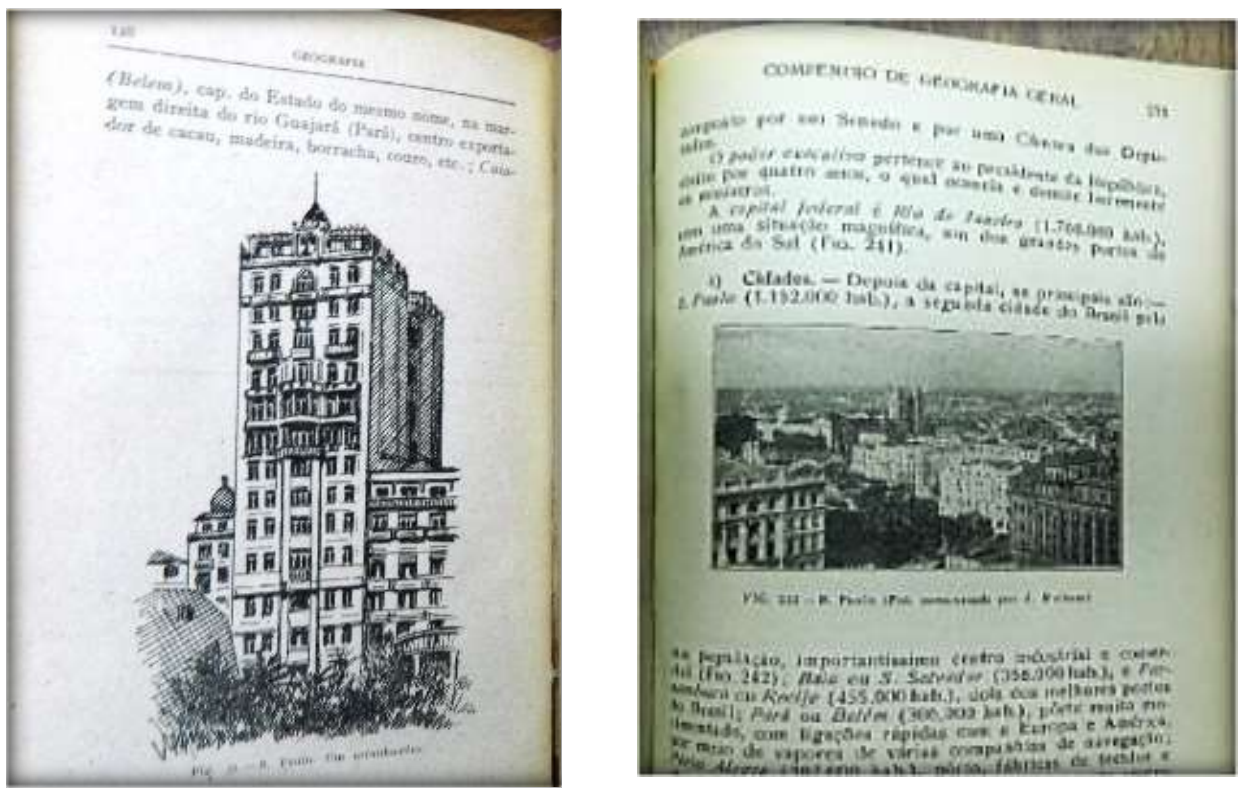

Fonte: Geografia. Portugal, colónias portuguesas, Brasil e regiões polares. Luis Schwalbach. Livrarias Aillaud e Bertrand. Paris - Lisboa. Livraria Chardron, Porto e Livraria Francisco Alves, Rio de Janeiro, [193- ${ }^{113}$; Compêndio de Geografia Geral. Antônio Mattoso. Livraria Sá da Costa. 9a edição. Lisboa, 1939.

${ }^{113}$ Vários manuais encontravam-se, nos registros da Biblioteca Municipal de Braga, Portugal, com a indicação de data incerta. 
Figura 60. Estrada de Ferro entre Santos e São Paulo.
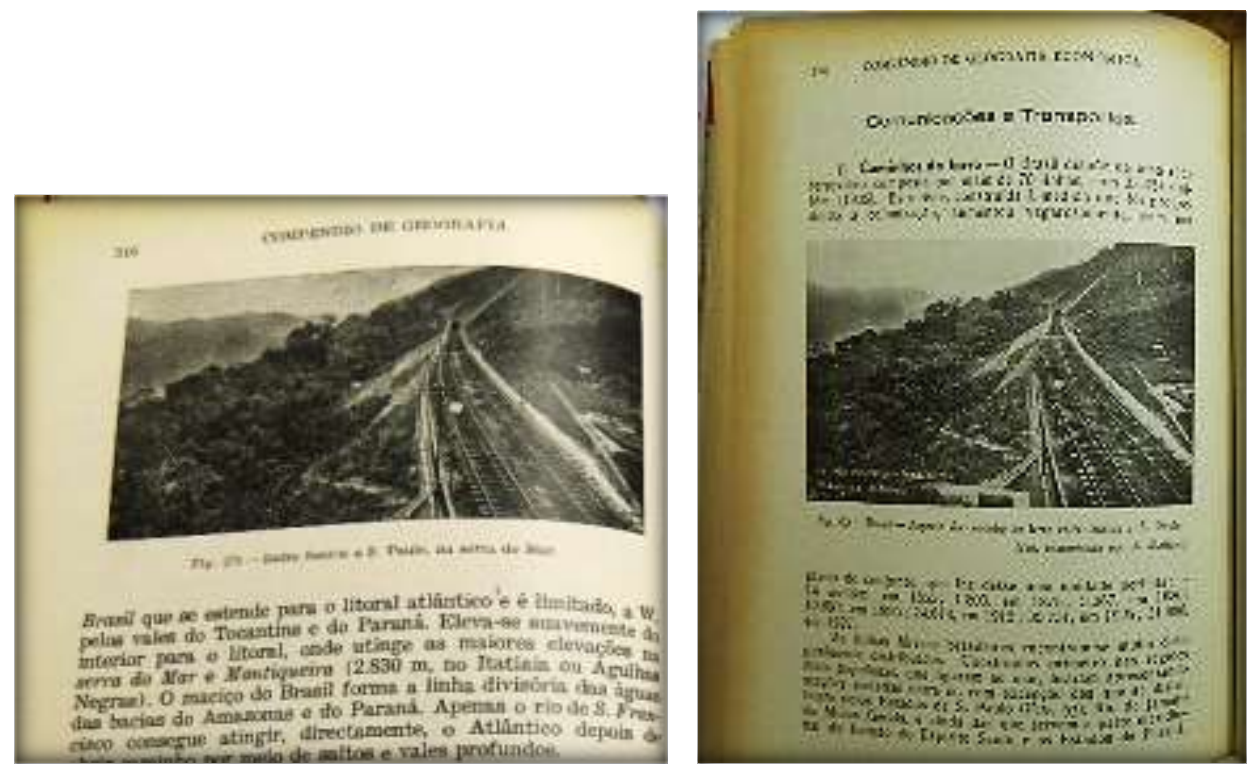

Fonte: Compêndio de Geografia. $2^{\circ}$ ciclos dos liceus. Alves de Moura, Evaristo Vieira, Américo Palma. Livraria Didáctica. Lisboa. 1949; Geografia. Portugal, colónias portuguesas, Brasil e regiões polares; Luis Schwalbach. Livrarias Aillaud e Bertrand. Paris - Lisboa. Livraria Chardron, Porto e Livraria Francisco Alves, Rio de Janeiro, [193-].

Figura 61. Rio de Janeiro.
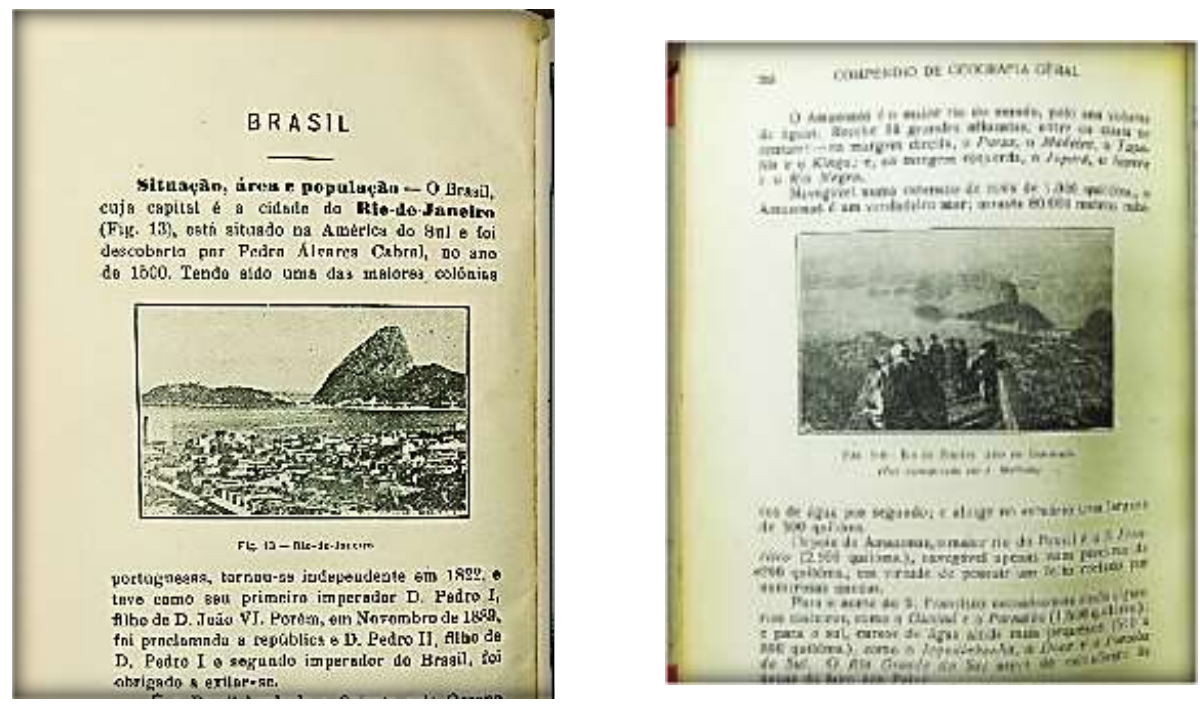

Fonte: Geografia de Portugal. Coleção escolar Progredidor. Resumo pelo professor Eduardo Moura, Nova edição, 1944. Compêndio de Geografia Geral. Ensino Técnico Curso Comercial. Antônio Mattoso. Livraria Sá da Costa. 9ª edição. Lisboa. (Com mapas anexados) 1939. 
O tratado de 1922, em comemoração ao primeiro centenário da independência do Brasil, nasceu fortemente marcado pelo discurso das Duas Pátrias. A tentativa de acordo foi marcada pela visita do presidente português ao Brasil para as festividades do centenário da independência, e que em discurso fez questão de destacar que:

Aos portugueses interessava uma aproximação para garantir, fundamentalmente: 1- os direitos de cidadania dos portugueses residentes no Brasil, com a concessão da dupla nacionalidade; 2- a legalização dos direitos de propriedade literária e artística, pois o mercado brasileiro era importante para o mercado livreiro português; e 3- a setorização das áreas de exportação do café e outros gêneros tropicais produzidos tanto pelo Brasil quanto pelas colônias portuguesas em África.

Brasil e Portugal são duas Pátrias irmãs, cada uma vivendo em sua casa, tendo um passado até há cem anos comum e um futuro, em muitos pontos diverso, mas em todos outros, equivalente. Os brasileiros sentem-se em Portugal como na sua pátria. Os portugueses, em vastos núcleos de trabalhadores, sentem-se no Brasil como na sua própria terra. (MENDES; MIRANDA, 2006, p. 183)

Nesse cenário, embora o presidente português, em visita ao Brasil, falasse em identidade luso-brasileira, entre alguns grupos populares, o antilusitanismo ${ }^{114}$ era forte e acentuado, em parte, pela crise econômica vivida ao término da Primeira Grande Guerra. Para o bem ou para o mal, as opiniões eram várias e divergentes: na visão do Estado brasileiro, o imigrante tornara-se muito importante para a produção; para os paulistas de famílias tradicionais, o imigrante era apenas mais uma engrenagem da locomotiva; para os intelectuais que observavam o fervilhar do modernismo, o imigrante era peça fundamental na construção da miscigenada cultura brasileira; e para os radicais de esquerda, o imigrante era um intruso, não era nem irmão e nem brasileiro.

Todavia, se por um lado existia quem visse com maus olhos a aproximação entre os dois países, havia também, conforme Santos (2011), aqueles que a defendiam:

Deste novo espírito de aproximação, realçamos ainda o surgimento de diversos autores e até de diplomatas e políticos, como Coelho de Carvalho, Zózimo Consiglieri Pedroso, António Maria de Bettencourt Rodrigues, entre outros que defendiam a luso-brasilidade e o reforço da comunicada identidade luso-brasileira. (SANTOS, 2011, p. 6)

\footnotetext{
114 Sobre o antilusitanismo no Brasil, veja também a pesquisa de Robertha Pedroso Triches A labareda da discórdia: o antilusitanismo na imprensa carioca. Revista de Ciência Política, número 36, Julho / Agosto 2007.
} 
Ao lado desses intelectuais, teremos durante a vigência do Estado Novo português e também do brasileiro, a presença de Gilberto Freyre na defesa da formação de uma comunidade luso-brasileira, refletindo sobre o tema em sua obra de 1940: O mundo que o português criou, sendo o responsável pela consolidação do conceito de luso-brasilidade.

Seria, contudo, em 1933 que a aproximação entre Portugal e Brasil ganharia um novo e importante impulso. Os anos de 1930 trouxeram outros contextos que promoveriam a aproximação entre as duas nações, como a consolidação, tanto em Portugal, quanto no Brasil, de regimes com objetivos ideológicos similares, pois tanto Oliveira Salazar, quanto Getúlio Vargas "definem como objetivo implementar um novo projeto de regeneração nacional e uma nova concepção da postura do seu país perante a ordem mundial e os restantes actores” (SANTOS, 2011, p. 7).

Enquanto governo de Getúlio Vargas, buscando novas opções produtivas, investe na industrialização, o governo português seguiria o caminho oposto. Desde sua ascensão ao poder, assumindo a pasta das Finanças e dos Negócios Estrangeiros em 1926, Oliveira Salazar adotara uma postura em prol das alianças tradicionais, voltada para uma economia majoritariamente rural, desejando a autossuficiência em relação ao mercado europeu. Nesse contexto, interessava a Portugal a manutenção da histórica parceria com a Inglaterra e a formalização da aproximação com o Brasil, tanto por sua posição geopolítica, quanto pelo desejo de formação de uma comunidade luso-brasileira. Segundo Santos:

Oliveira Salazar considerava crucial o reforço do laço bilateral transatlântico, para salvaguardar os elos culturais e históricos existentes face a outras influências no território brasileiro, mas também para permitir que a voz da lusofonia ganhasse maior poder reivindicativo inter pares no sistema mundial, tornando-se num parceiro internacional com uma posição geopolítica privilegiada ao nível transatlântico mundial. (SANTOS, 2011, p. 8)

O resultado dos esforços para a aproximação entre Brasil e Portugal foi a aprovação da importação de frutas vindas das colônias portuguesas, isentas de sobretaxas de alfândega benefício que o Brasil já concedia à Argentina e aos Estados Unidos. Durante a Segunda Grande Guerra, as relações estreitar-se-iam ainda mais, quando a cooperação portuguesa foi decisiva para as relações internacionais brasileiras, pois, a partir da entrada do Brasil na guerra, e com o fechamento das embaixadas brasileiras nos países do Eixo, Portugal assumiria a responsabilidade pelos brasileiros residentes em Itália e Alemanha. Para o Brasil, a aproximação também traria benefícios, uma vez que os produtos da recente industrialização poderiam ter como mercado 
consumidor, não somente Portugal, mas todo o território colonial português. A dificuldade de expansão do mercado exportador brasileiro iria encontrar situação mais adversa ainda com o início da Segunda Grande Guerra, quando, segundo Schiavon, chega-se a uma situação em que "em 1940, dos 67 países com os quais o Brasil mantinha relações comerciais - pelo menos na teoria apenas oito perfaziam um total de 92,36\% das exportações brasileiras no momento citado" (SCHIAVON, 2010, p. 93). Consolidada na diplomacia e na educação visual, a consolidação de um Brasil em desenvolvimento parecia se realizar.

\subsection{Finalmente, o Nordeste como promessa}

Após um biênio difícil, de 1940 a 1941, o crescimento industrial adquiriu novo ritmo, amparado por emissões e pela expansão de crédito do Banco do Brasil. Em 1943, os acordos bilaterais firmados com o governo norte-americano auxiliariam ainda mais na estabilização da economia, bem como na amortização da dívida.

Paralelamente a esse processo, outras iniciativas importantes foram sendo tomadas no sentido da intervenção do Estado na economia. O Conselho Federal de Comércio Exterior (CFCE), criado em 1934 como um aparato pioneiro de planejamento econômico, foi fortalecido no Estado Novo. A ele caberia decidir, em que áreas seriam aplicados os escassos recursos externos. Já com o objetivo de controlar as finanças estaduais e municipais, foi criado em 1937 o Conselho Técnico de Economia e Finanças. A mesma preocupação de cunho regulador foi estendida ao setor energético, com a criação do Conselho Nacional do Petróleo (CNP), em 1938, e do Conselho Nacional de Águas e Energia Elétrica (CNAEE), em 1939. A criação do CNP, encarregado da administração das jazidas descobertas na Bahia e do abastecimento de combustíveis e do CNAEE, encarregado de fixar tarifas e dar concessões para a produção de energia, foi acompanhada pela promulgação de uma extensa legislação nacionalista ${ }^{115}$.

O fato do mercado internacional não estar propício para as exportações brasileiras, só fortalecia o projeto varguista de desenvolvimento da indústria nacional, sobretudo a de base.

115 Informações do banco de dados do Centro de Pesquisa e Documentação em História Contemporânea do Brasil. Faculdade Getúlio Vargas. A Era Vargas. Cd-rom e acesso eletrônico em http://www.cpdoc.fgv.br/nav_historia/htm/ev_main.htm\#top 
Figura 62. Turbilhão de Paulo Afonso.

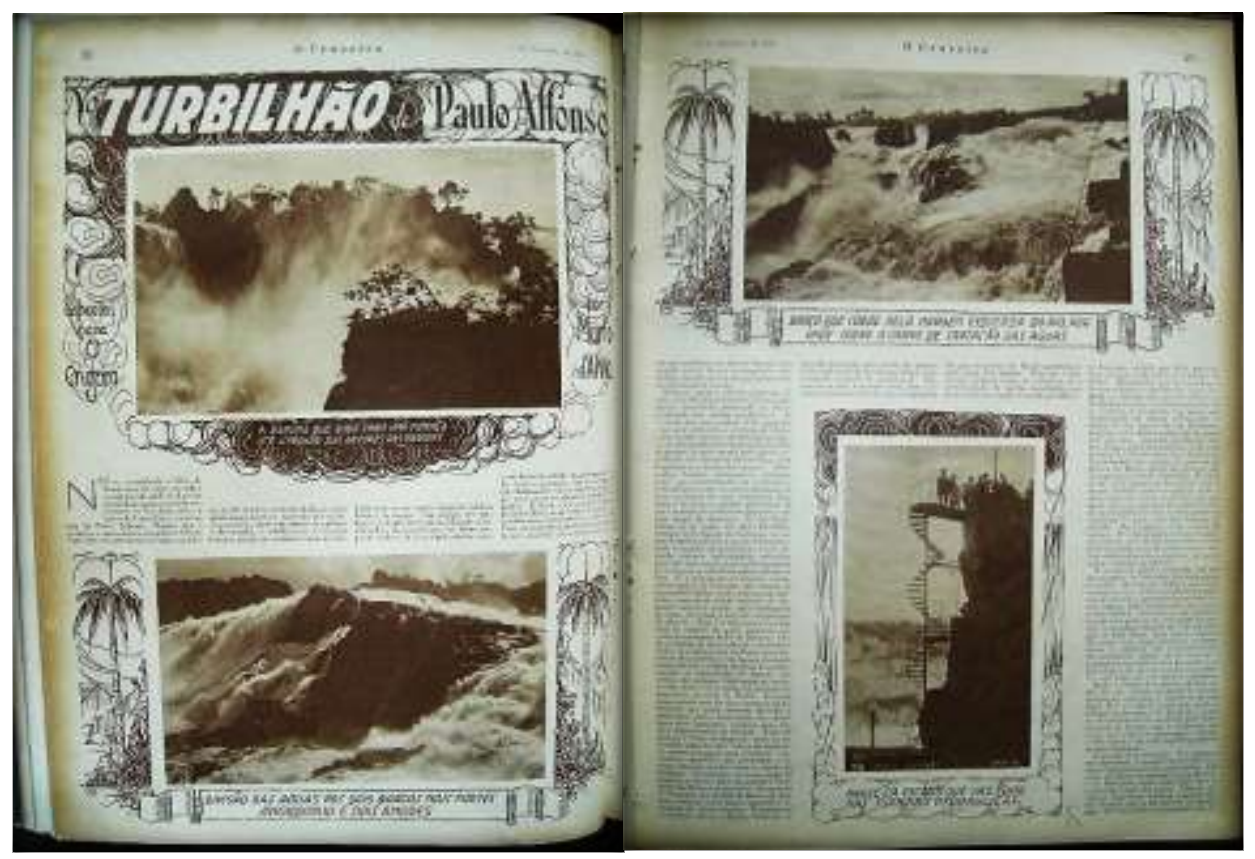

Fonte: Revista O Cruzeiro, 07 de novembro de 1929, p. 22-23.

Figura 63. Um novo surto de prosperidade.

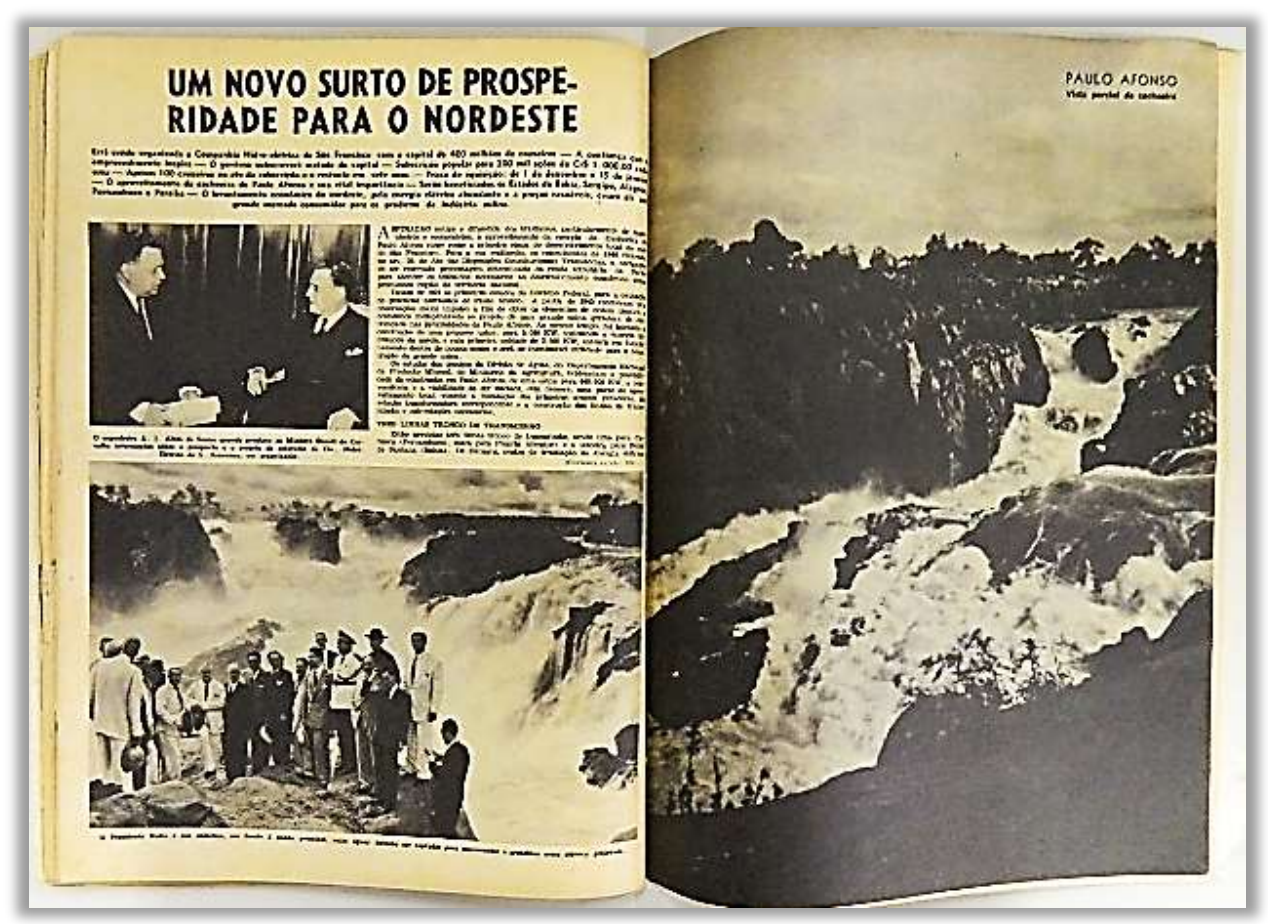

Fonte: Revista $O$ Cruzeiro, 13 de dezembro de 1947, p. 118-119. Acervo ECA. 
As estradas, usinas, linhas férreas e arranha-céus eram apresentados não apenas como um signo, mas como símbolo do desenvolvimento. A presença dessas imagens prescindia da presença ou do auxílio de discurso explicativo ou de contextualização. A imagem da usina em página dupla, por si só já comunicava a mensagem: "o desenvolvimento chegou”.

A matéria de 1929 da Cruzeiro, (figura 62) por Márcio D’Alva trazia, em página dupla, quatro fotografias de Paulo Afonso; três delas das quedas da cachoeira e uma, com uma longa escada em caracol, orientada pela legenda "Parte da escada que vae dar nas turbinas hydraulicas". A matéria fazia, em linguagem poética e rebuscada, elogios à engenhosidade brasileira e à grandiosidade da obra. A hidrelétrica de Paulo Afonso foi notícia e motivo de otimismo nacional não somente no tocante à questão da produção de energia como também na perspectiva de desenvolvimento que o complexo hidrelétrico traria para a região (figura 63).

A Revista Manchete (figura 64) também iria compartilhar do fascínio por Paulo Afonso, ressaltando-lhe, a importância, mas dessa vez, não seria o gigantismo da hidroelétrica e nem a promessa de desenvolvimento para o Nordeste que atrairia a atenção da revista, mas a desigualdade produzida em seu entorno. Sob o título Miséria e riqueza de Paulo Afonso, a reportagem de Darwin Brandão.

Passados quatrocentos anos, o Brasil descobriu o São Francisco e sua força hidráulica. Então surgiu nas margens da cachoeira de Paulo Afonso a maior obra brasileira dos últimos tempos: a construção da usina hidroelétrica. Isto dito assim parece não ter a menor importância. Mas tem. E é fácil se explicar. O rio da unidade nacional, nos seus 3.161 quilômetros de curso, serve a cinco estados brasileiros - Pernambuco, Bahia, Alagoas, Sergipe e Minas. Construída a grandiosa usina na fronteira Bahia e Alagoas, as linhas aéreas levarão força elétrica para cinquenta (50) cidades do Nordeste, inclusive as capitais - movimentando a indústria, iluminando as habitações, proporcionando conforto ao homem. Quem conhece o Nordeste sabe o que significa isto. Porque o São Francisco é enorme, é fabuloso, suas águas são revoltas e nunca param. Mas, alguns quilômetros para o interior, a partir de suas margens tudo é seco, não há água nem vegetação. Disciplinado e aproveitado racionalmente, o grande rio realizará a redenção do Nordeste e do nordestino. (Revista Manchete, 07 de março de 1953, p. 40-41)

A matéria segue, mostrando que com a instalação da hidroelétrica, houve grande crescimento econômico na região, atraindo muitas pessoas. A vila, oficialmente contaria com três mil moradores, todavia, mais de quinze mil, estariam vivendo em Paulo Afonso, a maioria já não conseguia emprego, vivendo do que Brandão define como as "sobras" de Paulo Afonso. Na figura 65, é possível vermos, no canto direito, as imagens de um caminhão e vários homens em pé, como aponta o autor, nem todos conseguirão trabalho. 
Figura 64. Miséria e riqueza de Paulo Afonso.

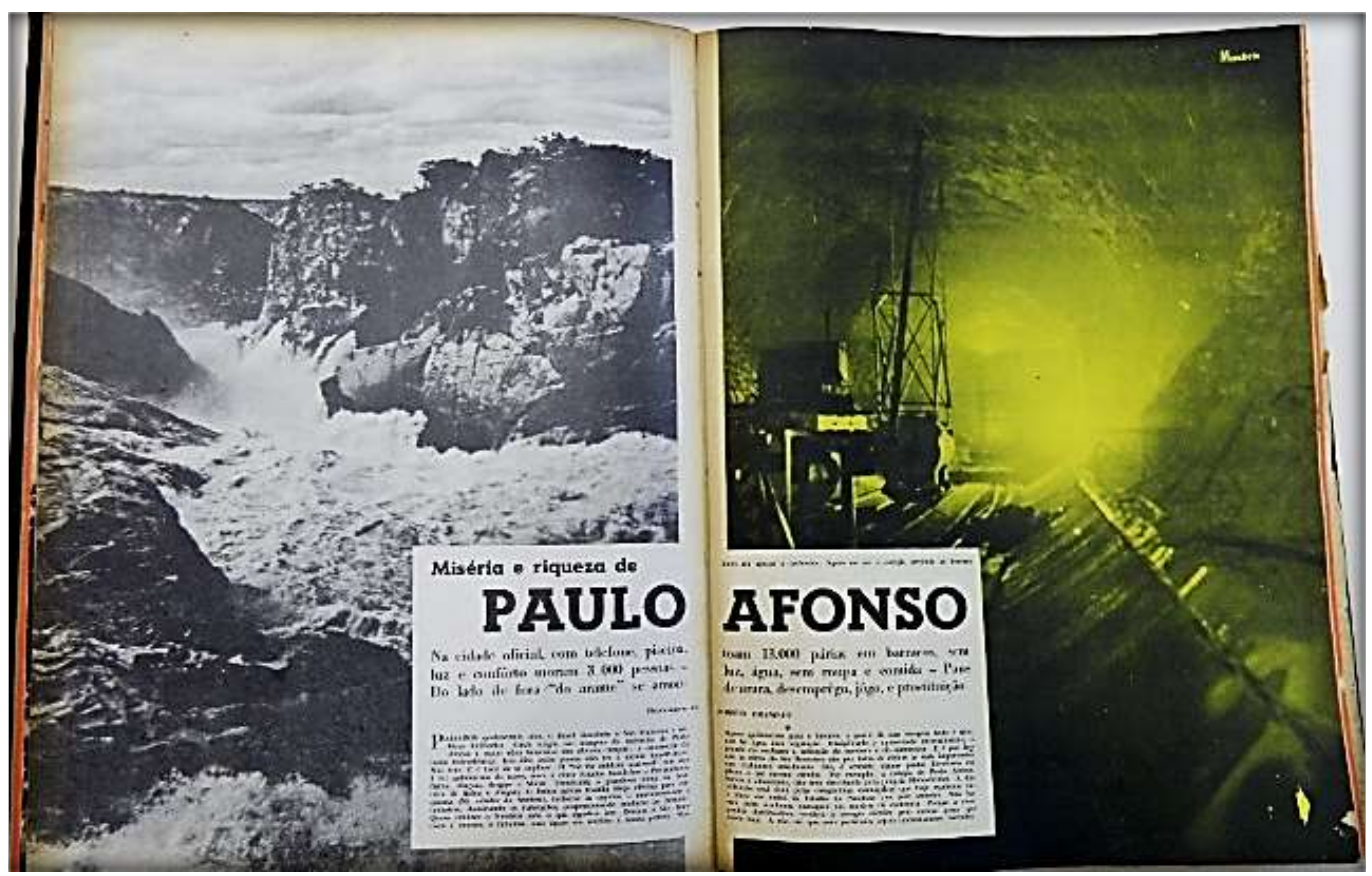

Fonte: Revista Manchete, 07 de março de 1953, p. 40-41.

Figura 65. Miséria e riqueza de Paulo Afonso. 2

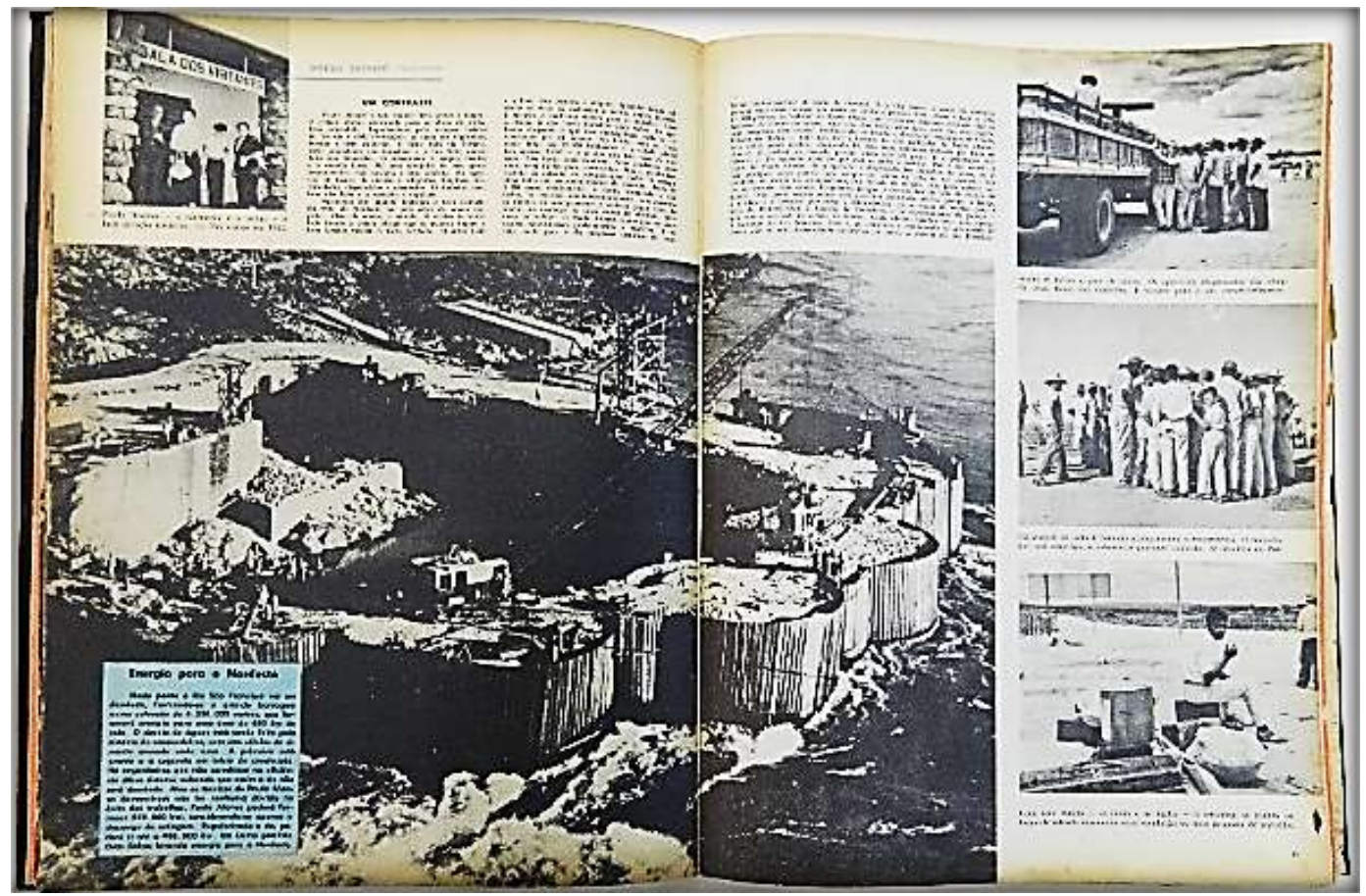

Fonte: Revista Manchete, 07 de março de 1953, p. 42-43. 
O que acontecia na Bahia acontecia também em outras regiões em que os investimentos para a industrialização produzia um implemento na oferta de empregos e melhoria de infraestrutura.

Mesmo estando ainda longe de alcançar um cenário de igualdade social, a política econômica de Vargas promovia o incremento da industrialização. No caso da energia, era necessário que essa pudesse chegar a um número maior de pessoas em uma abrangência maior do território nacional. Saretta (2004) nos apresenta a posição do jornal paulistano O Estado de S. Paulo, diante das diretrizes da política econômica de Vargas. O autor destaca que no editorial de 03 de junho de 1952, intitulado A Industrialização do Brasil, o OESP afirmava que:

[...]reconhecia os esforços de Vargas para dotar o país das indústrias essenciais à consolidação do setor secundário, e lembrava que existia uma barreira das mais importantes para tal, que seria a inadequada oferta de energia elétrica. Segundo o editorial a oferta não crescia por conta do Código de Águas, "legislação ditatorial, referente ao aproveitamento das quedas d'água e pela legislação posterior concernente à importação de aparelhagem produtiva. (SARETTA, 2004, p. 12)

O editorial propunha ainda, segundo Saretta, que créditos especiais fossem concedidos à Light \& Power Co e outras do ramo, na tentativa de superar a deficiência da oferta de energia elétrica, o que, na opinião do jornal, faria com que a industrialização ficasse a marcar passo, e jamais passasse de um sonho, uma aspiração.

Energia elétrica, petróleo, minérios, enfim, as riquezas naturais seriam o combustível necessário para o desenvolvimento da indústria de base nacional. Se para representar o Brasil desenvolvido a imprensa se valia das imagens das metrópoles - Rio e São Paulo - para a representação, de um Brasil com potencial para alcançar o desenvolvimento industrial, na área energética, encontraremos as imagens do potencial produtivo nordestino. As instalações, os funcionários e o lago negro de petróleo elementos da figura 67 que nos apresentam uma nova imagem para a Bahia.

Na Manchete, de fevereiro de 1953, vemos no destaque da foto, duas moças entre os inscritos num curso sobre refinação de petróleo. "A mulher brasileira na batalha do petróleo. Helena e Glória fazem um curso de refinação" (Revista Manchete, 07 de fevereiro de 1953, p. 7)

A complicada estrutura, da primeira página da figura 66, e seu emaranhado tubular, contrasta com a imagem das moças, que sorridentes, representam a renovação e a modernização no campo do trabalho. 
Figura 66. A Bahia também dá gasolina.

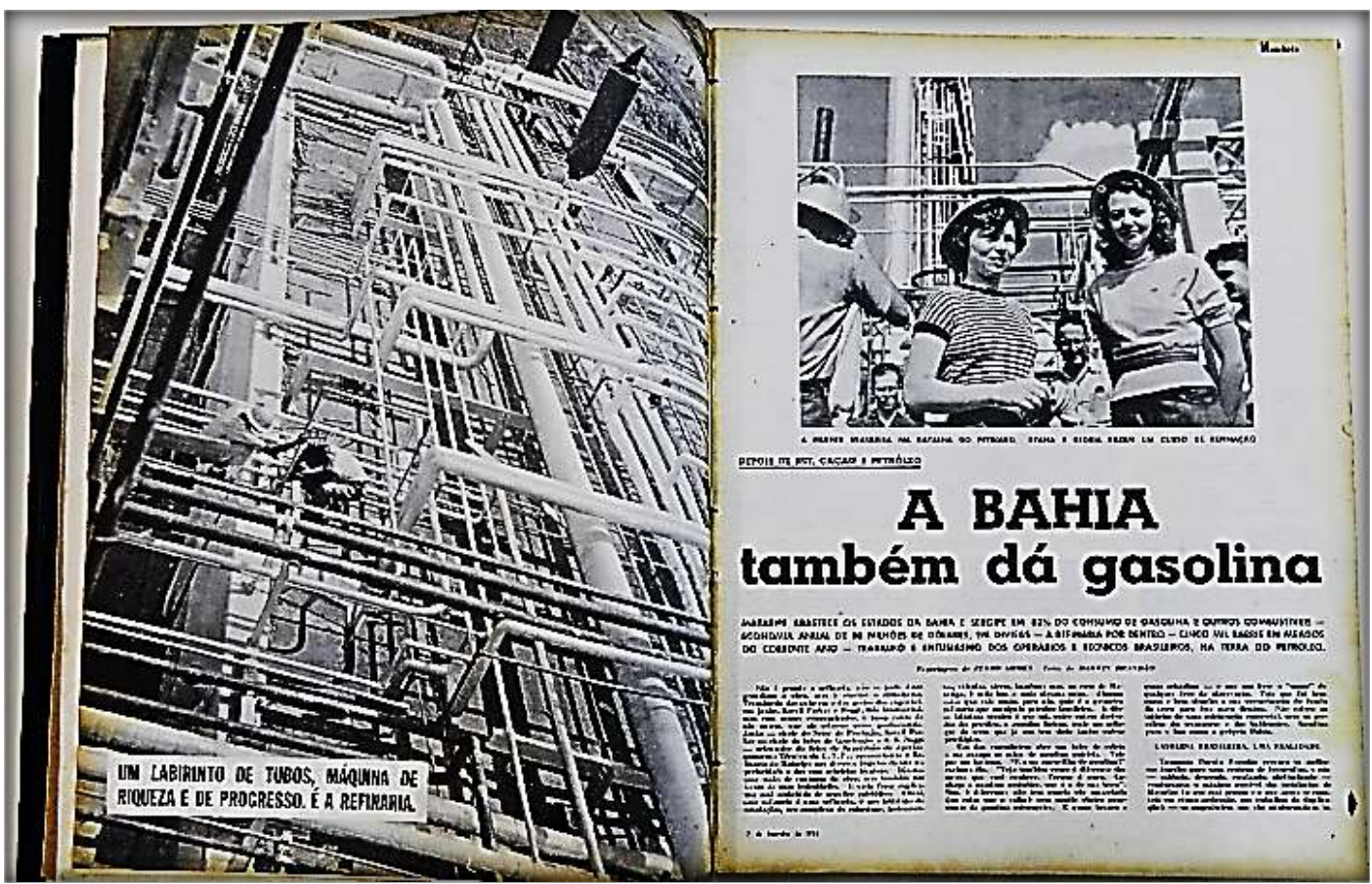

Fonte: Revista Manchete, 07 de fevereiro de 1953, p. 06-07.

Figura 67. Petróleo.

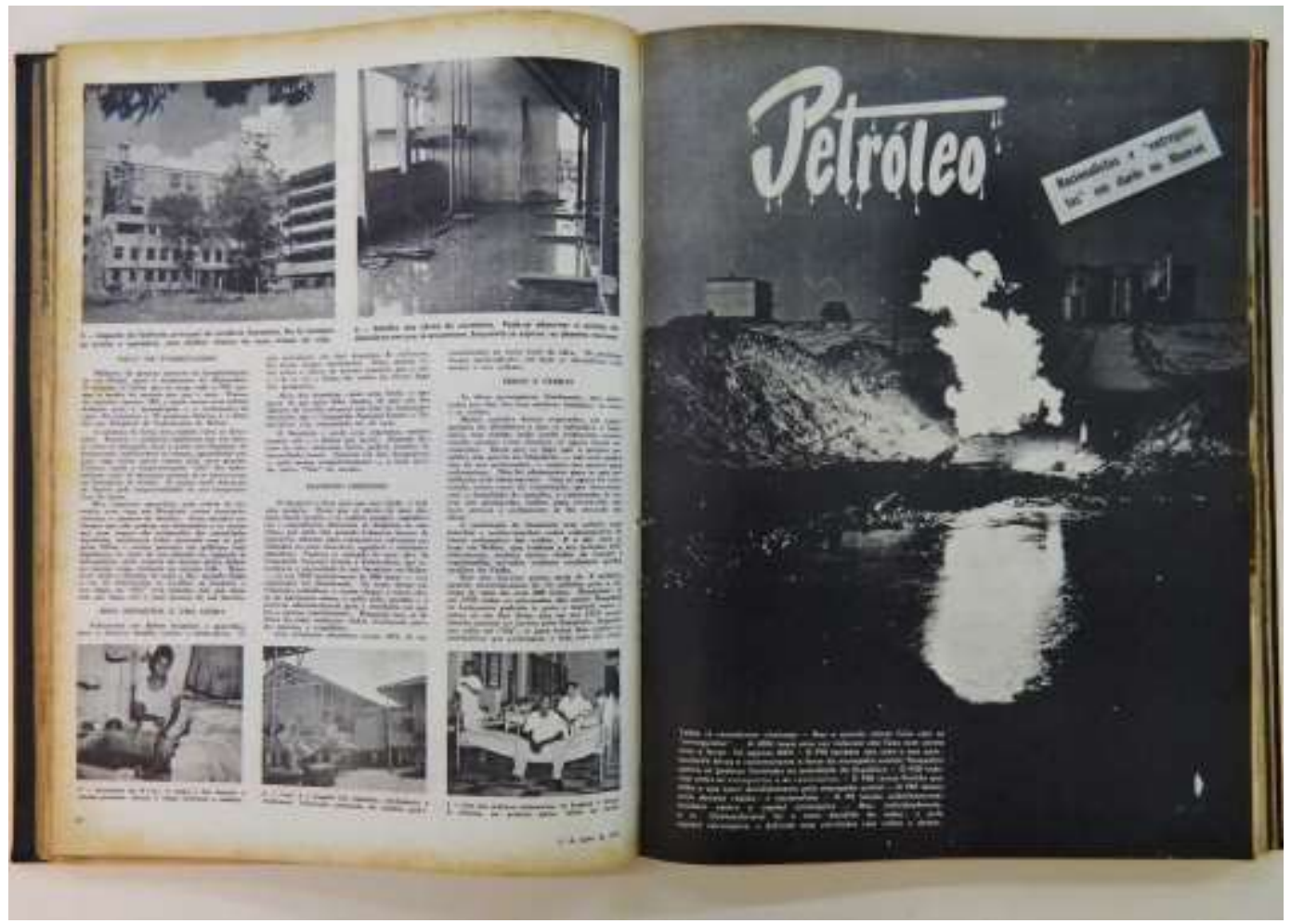

Fonte: Revista Manchete, 13 de junho de 1953, p. 22-23. 
Uma nova geração de profissionais especializados, com formação técnica, preparados para realizar o que a imprensa e também o Estado, acreditavam ser uma nova etapa no desenvolvimento econômico nacional. O texto complementa a imagem, indicando o otimismo em relação a tudo o que a exploração do petróleo na Bahia poderia trazer para o estado e para o país. Frases como "é uma maravilha de gasolina!” Ou "Gasolina pura e boa, como a própria Bahia”, indicam a euforia em torno da refinaria de Mataripe:

Mataripe abastece os estados da Bahia e Sergipe em $80 \%$ do consumo de gasolina e outros combustíveis - economia anual de 10 milhões de dólares em divisas - a refinaria por dentro - cinco mil barris em meados do ano corrente - trabalho e entusiasmo dos operários e técnicos brasileiros, na terra do petróleo. [...] Não é grande a refinaria, não se pode dizer grandiosa a obra mas é enorme o entusiasmo. [...] (os técnicos da refinaria) dão-nos uma visão de conjunto da obra, mas também nos levam ás suas intimidades. /e cada frase explicativa está embebida de orgulho patriótico. Afinal, uma refinaria é uma refinaria, é um labirinto de tubulações, um complexo de máquinas, instrumentos, válvulas, Tôrres, bombas; mas, no caso de Mataripe, é tudo isso e mais alguma coisa. Alguma coisa que vale muito para nós, pois é a primeira refinaria que manipula petróleo brasileiro. E desse labirinto técnico é que sai, entre outros derivados, a gasolina baiana, mais um milagre da terra que já nos tem dado tantos outros privilégios. Um dos engenheiros abre um tubo de coleta e me ensopa as mãos de gasolina patrícia. Vale por um batismo. "É uma maravilha de gasolina!" exclama ele. "Veja também como é diferente das outras que você conhece. Porque é pura. Conheça a gasolina autêntica, que é a de sua terra." Sim, é diferente, não tem aquela cor amarelada (ou coisa que o valha) nem aquêle cheiro penetrante da gasolina estrangeira. É quase branca e quase cristalina - e que nos livre o "quase" de qualquer erro de observação. Pois que foi bem curta e bem simples a sua peregrinação do fundo da terra para este novo destino. Não sofreu as injúrias de uma misturação comercial, nem os percalços do transporte e das baldeações. Gasolina pura e boa como a própria Bahia. ${ }^{116}$

Na verdade, desde o início de seu governo, Vargas fez questão de expressar seu interesse pela indústria de extração mineral e pela regulamentação da situação da produção agrícola no Nordeste, como caminho para o desenvolvimento. Em seu longo discurso sobre o primeiro ano de governo provisório, o presidente dizia:

Nenhum outro dos problemas que dizem respeito ao desenvolvimento econômico do país sobreleva em importância ao da exploração das nossas jazidas minerais. Por isso mesmo, consiste nosso maior interesse resolvê-lo, principalmente no que toca à siderurgia, cuja criação em grande escala é obra de patriotismo incentivar sem tardança. Ao lado das medidas que o exame dos importantes assuntos focalizados exige, muitas outras se nos impõem como natural decorrência do plano de reconstrução delineado. Algumas, de ordem administrativa, como a regulamentação dos poderes atribuidos às inerventorias federais e municipais; outras, de ordem econômica, como o combate ao regime dos latifúndios, entrave permanente à prosperidade agrícola de certas regiões, e às sêcas do Nordeste,

116 Depois de Rui, cacau e petróleo a Bahia também dá gasolina. Revista Manchete. 07 de fevereiro de 1953 , p. 7-9. Reportagem de Pedro/Gomes e Fotos de Darwin Brandão. 
ocasionadoras de constantes flagelos e obstáculo ao enriquecimento das zonas atingidas, periàdieamente sujeitas às alternativas da miséria e da fartura. (VARGAS, 2007, p.136)

Segundo Regina Meyrer, a redução quase contínua das exportações brasileiras nos primeiros anos da década de cinquenta, portanto, para realizar o projeto de incremento da produção industrial, o governo integrar Estado criara uma infra-estrutura e os organismos responsáveis por administrar, financiar e orientar, o planejar, fazendo a projeção futura das necessidades de investimento público (em energia, petróleo, carvão, siderurgia, transportes, comunicações) para o desenvolvimento da indústria pesada. A classificação das indústrias de base e o elenco de incentivos que a CDI (Conselho de Desenvolvimento Industrial) havia elaborado no início dos anos 50, seriam fundamentais para os trabalhos do BNDE, do CDE (Conselho de Desenvolvimento Econômico), e dos grupos executivos no governo seguinte. (MEYRER, 2007, 79).

Voltando a observar o lugar das notícias sobre o desenvolvimento da indústria na região Nordeste, sairemos um pouco das fronteiras da região Nordeste, mas continuando em seu entorno, encontraremos em 1945 uma grande reportagem dava destaque à extração de mica na região da Serra de Santa Maria do Suaçuí (Norte de Minas Gerais) a pouco mais de 400 quilômetros de Teixeira de Freitas (Bahia).

As duas estrelas da Cruzeiro, Davi Nasser e Jean Manzon, também retrataram a força e as mazelas do extrativismo mineral. "No Eldorado da Mica", (figura 68) as lentes de Manzon dão ao tema grandiosidade e dramaticidade. Em seu estilo, de fotografias encenadas, que buscavam reconstruir ações e sensações do cotidiano dos fotografados, Manzon transforma o trabalho de extração de mica, dos operários da Serra de Santa Maria do Suaçui, sertão de Minas Gerais, em uma aventura epopeica. Com destaque para o incomum, a matéria inicia com uma fotografia inusitada, do responsável pelo pagamento dos operários, que fazia sua contabilidade sobre uma mesa literalmente forrada por notas de cruzeiro, seguras por um revólver; sobre o ombro direito do homem, um atento papagaio, que não seria somente um mascote: "Se alguém bota a mão, mesmo de leve, o papagaio dá o alarme.”

A fotografia da sala onde o guarda estaria tirando um cochilo - repleta de revólveres pendurados pela parede - juntamente com a página dos homens carregando um fardo com dinamite, criam o cenário de perigo, que contrasta com as fotografias de cenas domésticas, (figura 69) dos alojamentos dos engenheiros americanos. 
Figura 68. No El-Dorado da Mica.

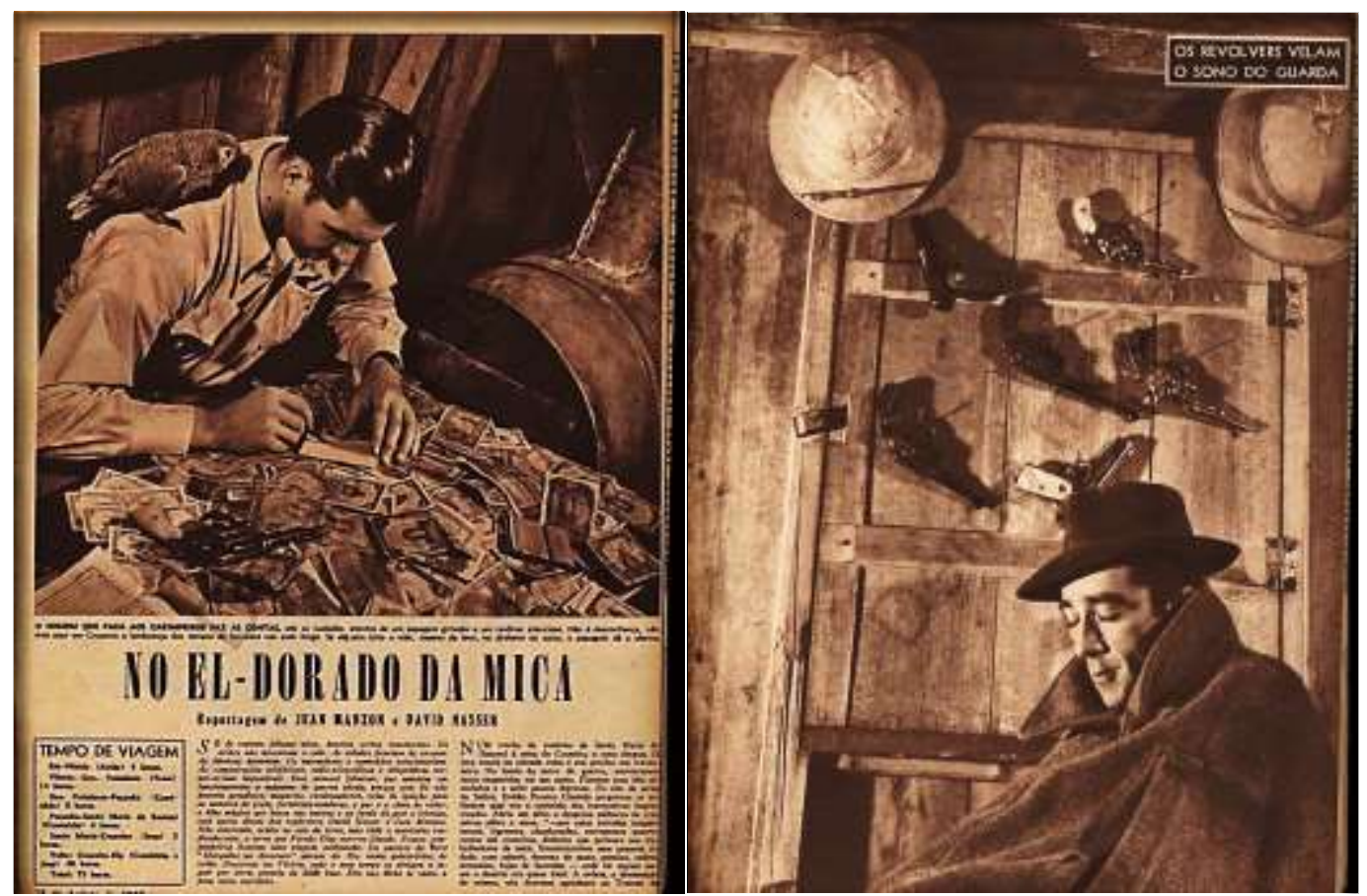

Fonte: Revista $O$ Cruzeiro, 18 de agosto de 1945, p. 09 e 11Acervo CEDIC PUC.

Figura 69. Cenas domésticas e Transporte da mica.

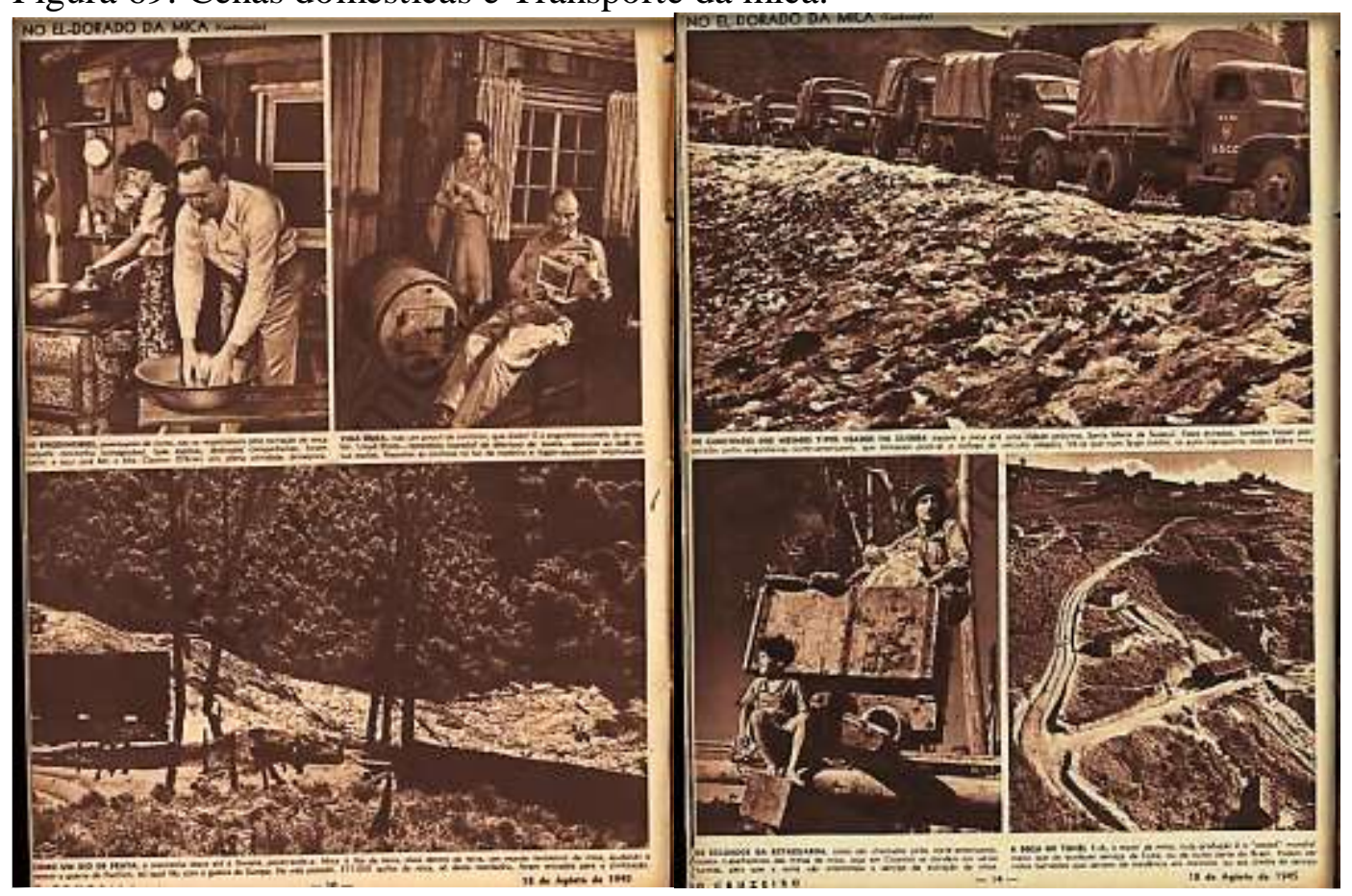

Fonte: Fonte: Revista $O$ Cruzeiro, 18 de agosto de 1945, p. 10 e 14. Acervo CEDIC PUC. 
Figura 70. Os operários: homens e mulheres.

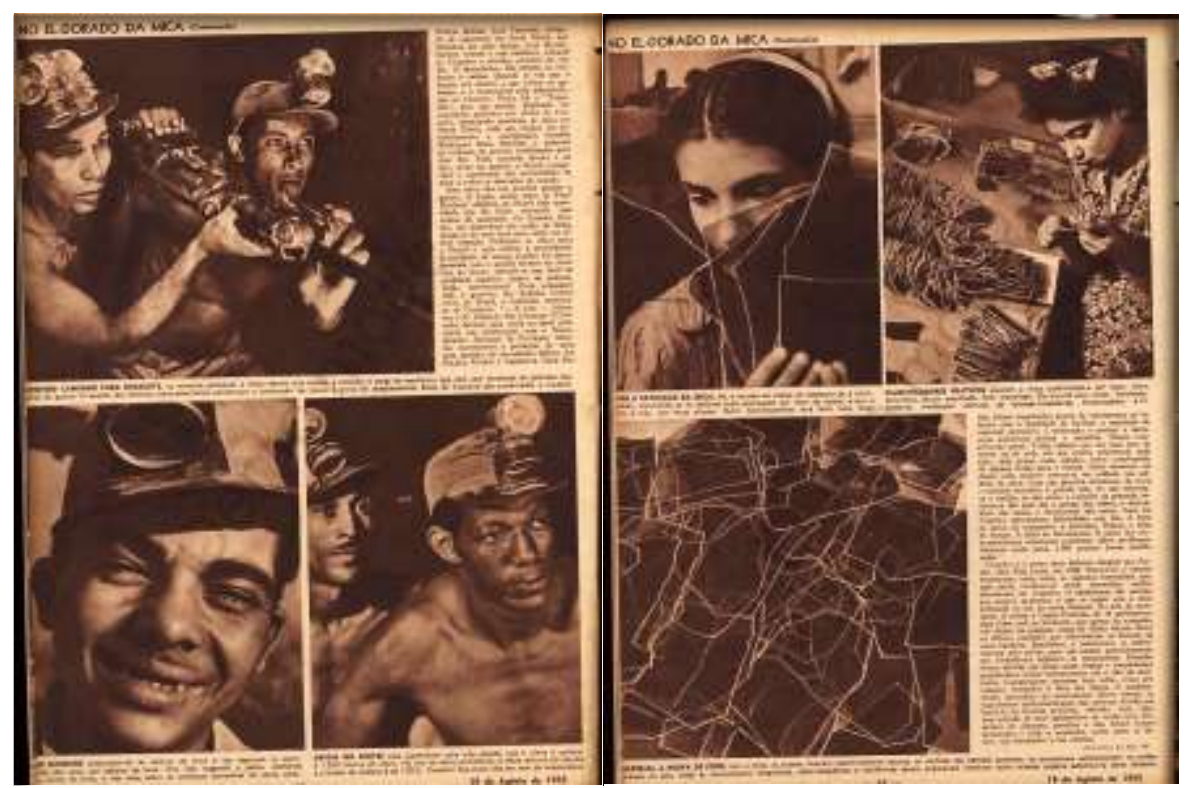

Fonte: Revista $O$ Cruzeiro, 18 de agosto de 1945, p. 12 e 16. Acervo CEDIC PUC.

Figura 71. No interior da mina. Operário ferido.

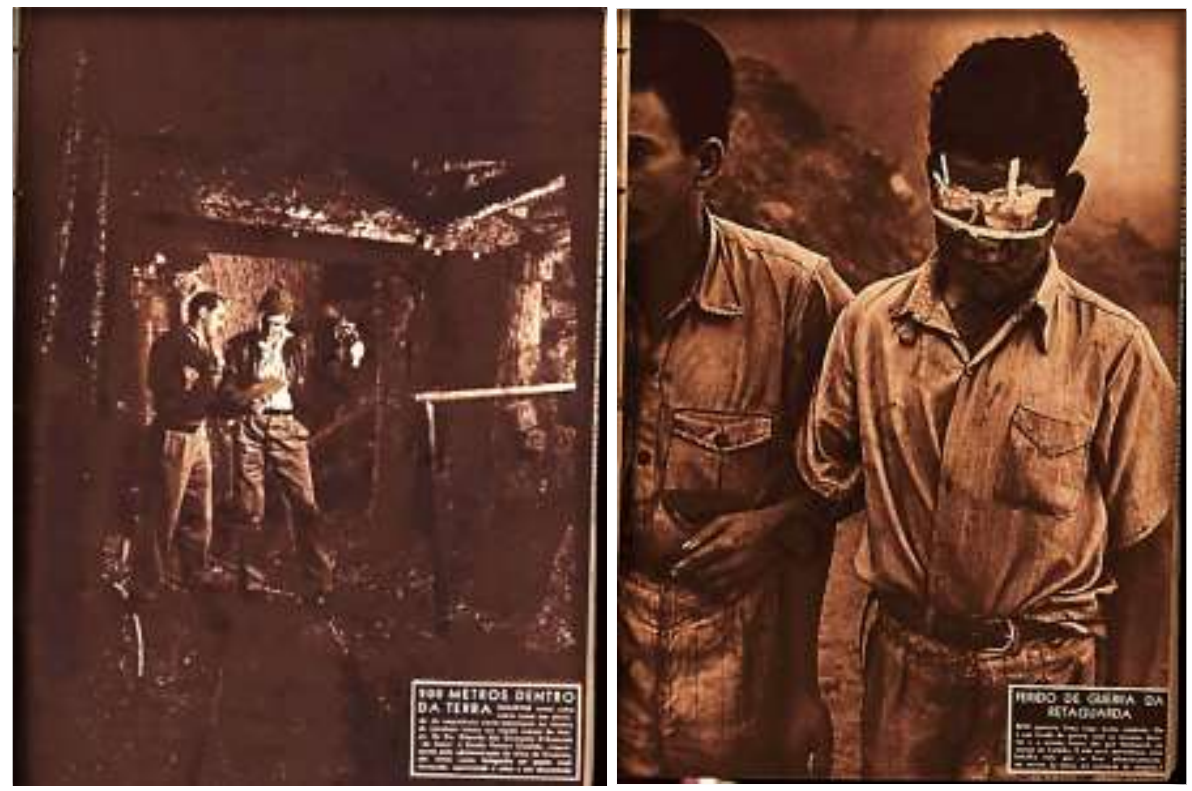

Fonte: Fonte: Revista $O$ Cruzeiro, 18 de agosto de 1945, p. 13 e 15. Acervo CEDIC PUC. 
O trabalho desses engenheiros e operários seria descrito a partir do registro fotográfico dos caminhões transportadores, mas também dos rostos dos operários, homens e mulheres (figura 70). O tom dramático, ficaria a cargo das imagens do interior da mina escura, (figura 71) foto que, como a icônica fotografia de Ferrez, no interior de uma mina de ouro, em 1888, encanta pelo trabalho com a luz, e pela capacidade de comunicar ao leitor sobre o exotismo do ambiente que envolve a mineração; e também pela fotografia do rapaz que ficara cego, num acidente na mineradora, a fotografia, é acompanhada pelo boxe, com o texto de Nasser, que destaca e define como heroico o esforço do operário ferido: "Este operário ficou cego, numa explosão. Êle é um ferido de guerra, com os mesmos direitos e a mesma honra dos que tombaram no campo de batalha. E não será, porventura, uma batalha esta que se fere, silenciosamente, no ventre da terra, na extração de minério? (Revista O Cruzeiro, 18 de agosto de 1945, p. 15)

Embora o governo Vargas movesse forças rumo à industrialização, investindo no potencial para o extrativismo mineral no interior do Brasil, continuávamos a ser um país fundamentalmente agrícola, e a investir em agricultura, pois da agricultura vinham nossas divisas, e da agricultura dependia o abastecimento do mercado interno. ${ }^{117}$ Em discurso oficial, em 1940, sobre os esforços do governo para alcançar o equilíbrio entre o desenvolvimento industrial e agrícola, lemos:

[...] e muito resta realizar para que a vossa capacidade empreendedora atinja o seu máximo desenvolvimento, aproveitando a fertilidade do solo e as riquezas desta terra privilegiada. [...] $\mathrm{O}$ equilíbrio da vossa economia permite maior expansão nas atividades agrárias, industriais e extrativas. O Governo Nacional, estimando essa contribuição no seu justo valor, não deixará de fazer o quanto estiver ao seu alcance, para incrementar tão promissor surto de progresso. (VARGAS, 2007, p.189).

A imprensa publicava imagens dos símbolos do sucesso da agricultura brasileira, e aí, mais uma vez, o Nordeste merecia destaque, tanto para as reportagens quanto para os anunciantes. A chamada "Uma usina de Pernambuco planta 6.000 alqueires de cana, produz 13.800.000 quilos de açúcar por safra!” trazia informações sobre o crescente mercado interno do açúcar, sendo uma matéria promocional dos produtos da Ford.

${ }^{117}$ Sobre a questão de modernização da agricultura em função do mercado externo, em Seca e poder, Celso Furtado afirma que: "No mundo inteiro, a agricultura não é regulada pelo mercado. O que é regulado pelo mercado são os excedentes agrícolas. Toda agricultura importante é mais ou menos subsidiada ou tem preços administrados." Citando ainda os casos do Japão, França e Estados Unidos para exemplificar os casos dos investimentos do Estado na agricultura para o desenvolvimento da produção para o abastecimento interno. TAVARES, Maria da Conceição (org) Seca e poder: entrevista com Celso Furtado. São Paulo: Editora Fundação Perseu Abramo, 1998. 
Figura 72. Ford. Açúcar.

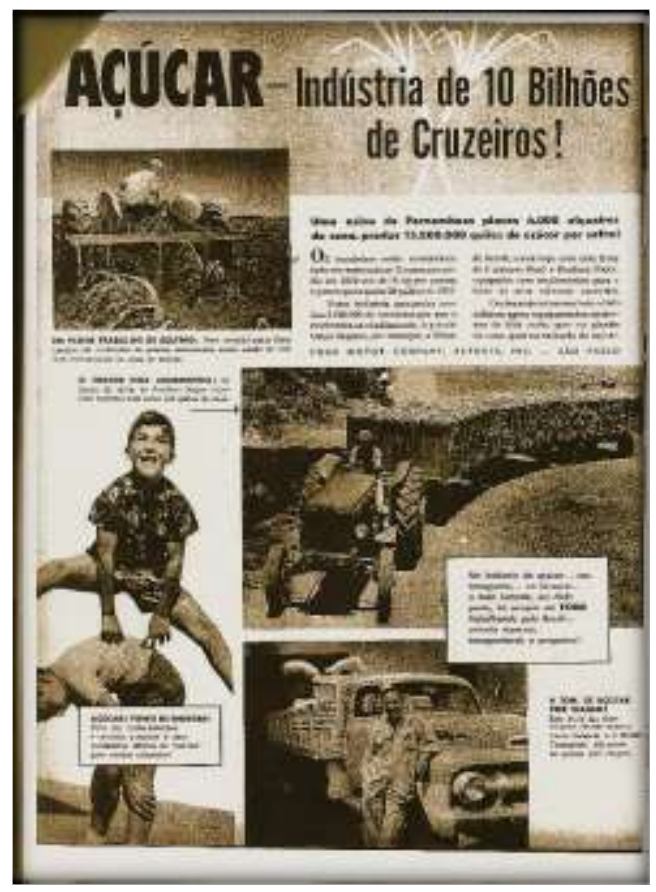

Os brasileiros estão consumindo cada vez mais açúcar. O consumo médio em 1939 era de $16 \mathrm{Kg}$ por pessoa e passou para quase 28 quilos em 1952! Nossa indústria açucareira produz 2.000.000 de toneladas por ano e moderniza-se rapidamente. A grande Usina Salgado, por exemplo, a $54 \mathrm{Km}$ de Recife, conta hoje com uma frota de 9 tratores Ford e Fordson Major, equipados com implementos para o trato de seus extensos canaviais. Centenas de usinas em todo o país utilizam agora equipamentos modernos de tôda sorte, quer no plantio da cana, quer na extração do açúcar. (Revista Manchete, 19 de março de $1955, \mathrm{~s} / \mathrm{n})$

Fonte: Revista Manchete, 19 de março de 1955, s/n. Acervo Biblioteca Florestan Fernandes.

Figura 73. Cacau

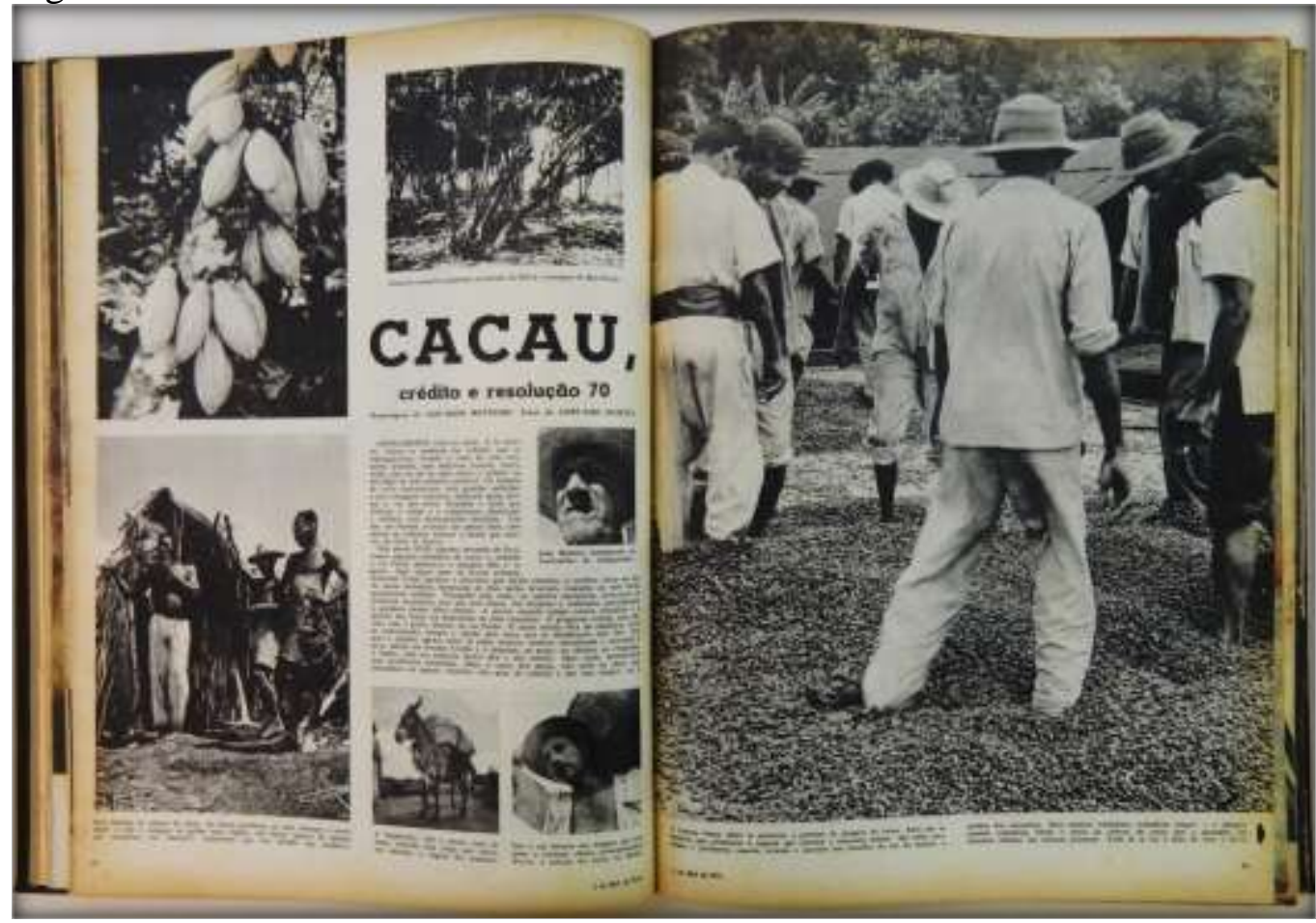

Fonte: Revista Manchete. 03 de abril de 1954. Acervo Biblioteca Florestan Fernandes 
A novidade não era o uso da imagem na propaganda, prática bastante antiga, mas sim, o uso da linguagem jornalística para dar credibilidade às informações sobre o produto ${ }^{118}$. (Figura 72).

O cacau da Bahia é destaque na figura 73, as fotografias de Gervásio Batista, para a Manchete, mostra na primeira página cinco fotografias, a maior, com a imagem do cacau e as quatro seguintes, representando o trabalhador da cultura do cacau. Embora de dimensões modestas, as imagens mostram o rosto marcado dos trabalhadores: a fotografia em close up de um senhor idoso, vai acompanhada da legenda "João maduro, trabalhador característico de antigamente" e a fotografia logo abaixo, em contra plongée, em plano fechado, mostra um homem que carrega um grande cesto, trata-se de um migrante regional: "Este é um homem que emigrou; a centenas destes, principalmente, deve-se a cultura do cacau na Bahia". O texto de Salvador Monteiro, acompanha o teor de comparação - passado e presente - e denúncia em relação ao trabalho pesado, que os semblantes tristes e cansados que as fotografias de Gervásio Batista indicam: "O cacau existia fora do comércio, livre de especulações, íntegro e velado pela mata que se desdobrava sem fim[...] Hoje o cacau tem prêço, vale ouro." (Revista Manchete. 03 de abril de 1954).

\subsection{Nacionalismo, produção e educação}

Se para o Estado, a terra, no Nordeste, se mostrava rica em recursos, acenando para uma promessa de desenvolvimento econômico regional, o homem, o nordestino e sobretudo o nordestino sertanejo, ainda necessitava de auxílio para alcançar o tão desejado progresso.

No Boletim do Ministério da Agricultura, do ano de 1941, lê-se nota sobre a:

[...] necessidade de ser proporcionada à criança rural uma educação consentânea com a realidade do campo, a fim de preparar a infância para uma vida melhor no próprio ambiente rural. [...] A escola rural transmitirá os conhecimentos fundamentais de leitura, escrita, cálculo e os elementares de ciências naturais e sociais, partindo sempre dos interesses imediatos da localidade. A essas

118 Segundo Meyrer: "A Ford publicava frequentemente na revista anúncios de página inteira, às vezes duas, explicando a atuação da empresa no país, desde os anos 20. Era descrita sua contribuição para o estágio atual do desenvolvimento brasileiro e a sua crença no futuro da nação. Evidencia-se a sua importância no transporte de mercadorias, nos motores das indústrias, nas máquinas agrícolas, entre outros”. MEYRER, Marlise Regina. Representações Do Desenvolvimento nas Fotorreportagens Da Revista O Cruzeiro (1955-1957) Tese Doutorado em História, pela Pontifícia Universidade Católica do Rio Grande do Sul, 2007 
disciplinas se ajuntarão noções de agricultura e ainda educação física, canto e religião. Tem ainda o dever de despertar em seus alunos o sentimento de brasilidade, de ser uma escola de nacionalismo, mostrando os deveres de cada um de nós para com a pátria. (Boletim do Ministério da Agricultura, 1941, ano 30, p. 116-118)

Fortalecendo-se os laços cívicos entre o homem e a sua terra, aliado ao preparo instrumental das ciências, acreditava-se ser possível possibilitar maior fixação do homem ao campo, como se este o deixasse por falta de civismo ou de conhecimento. Em 1941, os boletins do governo comemoravam também a inauguração de uma escola rural no sertão de Pernambuco. Visando atingir o objetivo de levar a educação formal às crianças do sertão, o Ministério manteria e estimularia a criação de clubes agrícolas escolares, que atentariam não somente para a formação intelectual da criança, mas também à sua saúde, uma vez que caberia a tais escolas ensinar à elas bons hábitos de higiene pessoal, além de suprir-lhes a deficiência nutricional.

No discurso do documento oficial, duas ideias nos chamam a atenção: a preocupação em demonstrar que o Estado pretendia levar o sistema de ensino ao meio rural, permitindo o acesso à boa formação, sem a necessidade de deslocamento aos grandes centros; e, em segundo lugar, o destaque à necessidade de implementar uma educação higienista no sertanejo. O projeto, portanto, teria nitidamente o objetivo de fixar futuramente o indivíduo do campo à sua região de origem, uma vez que este teria, em tese, instrumental necessário para vencer as dificuldades que a vida no campo poderia lhe impor a partir da aquisição do instrumental científico de uma educação moral, uma educação formal e uma educação higienista, pois uma política que busca uma "vida melhor no próprio ambiente rural" iria de encontro às ideias apontadas anteriormente, veiculadas igualmente pelo Conselho de Imigração e Colonização, de que o problema do sertanejo seria o desconhecimento, a falta de preparo para vencer os problemas naturais.

A necessidade de educar o sertanejo pode ser compreendida como uma postura ideológica, que não confere ao saber do sertanejo o estatuto de conhecimento, vendo como exigência fundamental para o desenvolvimento do Nordeste uma total mudança de práticas e hábitos por parte dos Nordestinos. Em relato do Boletim do Ministério da Agricultura, vemos uma análise 
sobre o regime alimentar do sertanejo ${ }^{119}$, que mesmo sendo arrolado em sua diversidade, é considerado como pobre:

A alimentação do homem rural: Quem analisa o modo de se alimentar do homem do campo chega, forçosamente, a esta conclusão: - o roceiro é o homem que mais come e menos se alimenta. Desde o abastado fazendeiro até o humilde homem da enxada o mal é o mesmo e a causa idêntica: falta de orientação. $\mathrm{O}$ homem rural, que tem nas portas de sua casa tudo o que é necessário para uma alimentação perfeita, despreza essa dádiva da natureza e vai, não raro, buscar nas cidades o seu alimento, porque no dizer dele, "na roça passa-se mal de boca". [...] Nos Estados do Nordeste domina no regime alimentar do homem rural a carne de sol ou charque de vento, farinha de mandioca e de milho, carne de cabrito, abóbora doce, rapadura, banana, coco, caju, goiabada, goiaba e outros frutos. As secas reduzem ainda mais os alimentos ao cará, imbu, macaiba, taioba, maniceba, além de alguns frutos a ela resistentes como a mucuna e outros. (Boletim do Ministério da Agricultura. Fev. 1941, ano 30, p. 93)

Complementando o quadro para a formação de sertanejo, o governo informava também em seus boletins sobre sua preocupação com a área da saúde que, de fato, não oferecia estrutura suficiente ${ }^{120}$. Cientes disso, algumas medidas emergenciais eram anunciadas:

O Departamento de Saúde do Estado faria, também, a vacinação antivariólica e antitísica dos retirantes, tanto na capital, como, de preferência, nos postos de interior, fornecendo as vacinas. A vacinação contra a febre amarela seria realizada pelas autoridades sanitárias federais, a bordo, durante a viagem ou à chegada, nos alojamentos de Belém ou Manaus. (Revista de Imigração e Colonização, ano III, agosto de 1942, p. 41)

Sendo prometidos à população, postos em diversas áreas com carência de atendimento, como por exemplo, as cidades do estado do Ceará:

Postos de higiene mantidos pelo Estado do Ceará:

Posto de Higiene de Sobral

Posto de Higiene de Juazeiro

Posto de Higiene de Quixadá

Posto de Higiene de Aracati

Posto de Higiene de Baturité

Posto de Higiene de Pacoti

Posto de Higiene de Maria Pereira

Posto de Higiene de Acaraú

Posto de Higiene de Crateús (Revista de Imigração e Colonização, ano III, agosto de 1942, p. 41)

119 Muitas foram as pesquisas que tentaram compreender nossas diferenças econômicas como produto de extensa equação que envolveria os costumes, as condições geográficas, a escolarização dentre outras variáveis. No campo das pesquisas sobre o regime alimentar do brasileiro, notabilizaram-se as informações colhidas por Josué de Castro.

${ }^{120}$ Revista de Imigração e Colonização, ano III, agosto de 1942, p. 40. 
A esses postos podem ser acrescentados aqueles que eram mantidos pela IFOCS, como: Hospital de Santo Antonio dos Pobres, instituição de caráter particular de Iguatu. É interessante observar que o estado do Ceará contribuiu fracamente para esse movimento, em comparação com os contingentes fornecidos pela Bahía, Alagoas, Minas Gerais e Pernambuco.

Por outro lado, se o discurso oficial veiculava a ideia de que a ciência já apontara o que deveria ser feito e o governo já iniciara a sua parte, como explicar a manutenção das levas de migrantes? Como os porta-vozes da sociedade interpretariam a manutenção do mesmo cenário de problemas? Pelo que se observa nos argumentos oficiais, a justificativa estaria na inépcia do povo. Além do objetivo do governo de demonstrar o dever cumprido, o discurso assistencialista da revista traz consigo a proposta de que acreditassem os leitores do relato que as medidas de medicação e saneamento somadas às pesquisas sobre a natureza do solo e comportamento do clima levariam finalmente o sertão ao progresso. A ciência, nessa perspectiva, seria a principal arma contra o atraso e contra suas filhas, a pobreza e a miséria. A desigualdade e a exploração não entravam em questão. As verbas direcionadas às áreas atingidas pelas secas durante o governo Vargas tinham, afora o período das secas, o objetivo inicial de promover pesquisas que visavam um melhor aproveitamento dos solos nordestinos, principalmente no semiárido. Muitos destes projetos eram desenvolvidos apenas no formato de estudos, outros, aplicados a propriedades experimentais, trariam, contudo novas esperanças à região; divulgavam-se as possibilidades de um novo horizonte, pois, "a ciência mudaria a realidade da seca", velha conhecida do sertanejo. Na Revista de Imigração e Colonização, podemos acompanhar a publicação dos relatórios de diferentes iniciativas-piloto para o desenvolvimento da economia, desde a produção de novos gêneros - como as uvas.

Trabalhos como o do agrônomo Pimentel Gomes, que elaborara um vasto estudo sobre as técnicas experimentais aplicadas aos solos da região Nordeste, foram frequentemente discutidos e publicados pelo Boletim do Ministério da Agricultura, a partir de 1940. Vários apontamentos, como o da fertilidade dos solos de aluvião, ou mesmo da possibilidade de ser o solo do baixo Jaguaribe, no Ceará, exportado como adubo, eram publicados. As pesquisas apontariam ainda para três principais formas de aproveitamento do solo, diziam eles: “O problema nordestino tem três 
soluções: a irrigação; a economia das águas das chuvas, isto é, o método de lavoura seca; e o cultivo de plantas resistentes às secas". 121

O sertão já sofrera com uma antiga compreensão de que a miséria seria seu destino manifesto, a ele imposto pelo clima. Desde o início do século XX era possível observar o crescimento de trabalhos com uma estrutura discursiva que apresentava a associação entre o clima e o atraso da região. Contudo, era necessário superar a antiga visão norteada pelo determinismo geográfico de Ratzel, para a qual o clima condicionava as emigrações do sertão nordestino; assim, compreendia-se anteriormente que:

É preciso considerar, por um lado, que as migrações do nordeste ocorrem sempre em consequência do fenômeno climático que aflige periodicamente aquela região. As secas matam as plantações, aniquilam os rebanhos e reduzem, por tanto, a um nível muito baixo os meios de subsistência do sertanejo. Este apela para o único recurso que lhe resta - a migração. (Revista de Imigração e Colonização, ago. 1942, p.23).

Era perceptível o otimismo em relação aos resultados dos estudos científicos, alimentando a ideia de que a ciência dominaria ou mesmo já dominara os problemas climáticos $^{122}$ e, consequentemente, seus efeitos junto às populações do sertão nordestino:

Climatologicamente, o nordeste brasileiro é um dos territórios sul-americanos há mais tempo conhecidos. As primeiras observações meteorológicas aí feitas - contam-nos Delgado de Carvalho - são devidas a G. Marcgraf, médico de Maurício de Nassau, e datam do século XVII. À parte o flagelo periódico das secas, cujos efeitos o homem vai atenuando e vencendo, o clima nordestino é um dos melhores do Brasil. E do mundo. (Boletim do Ministério da Agricultura, 1940, p. 3)

A Revista Brasileira de Geografia de julho-setembro de 1951 apresenta um longo artigo de Hilgard O'Reilly Sternberg, consultor técnico de Conselho Nacional de Geografia. No texto, o pesquisador fala sobre os jovens cientistas que pesquisam as chuvas artificiais no Ceará como solução para as longas estiagens, baseados em experiências e tecnologias norte americanas daquele tempo.

121 Boletim do Ministério da Agricultura, 1940, ano 29, jan/jul, p. 52.

122 Sobre a possibilidade de realização de agricultura irrigada, de qualidade no sertão nordestino, Celso Furtado, comenta que: "Na minha época de Sudene, os israelenses fizeram estudos sobre o Piauí e ficaram perplexos. Disseram: 'Se nós tivéssemos essa qualidade de água nos subterrâneos que vocês têm aqui, estaríamos no vergel'! Não era brincadeira o lençol de água subterrânea que eles encontraram! Há também o rio Paraíba. A água não é problema, e isso é o mais terrível, pois se sofre tanto com a seca e a água está ali - só que mal utilizada.". TAVARES, Maria da Conceição (org) Seca e poder: entrevista com Celso Furtado. São Paulo: Editora Fundação Perseu Abramo, 1998 
Figura 74: Josué de Castro.

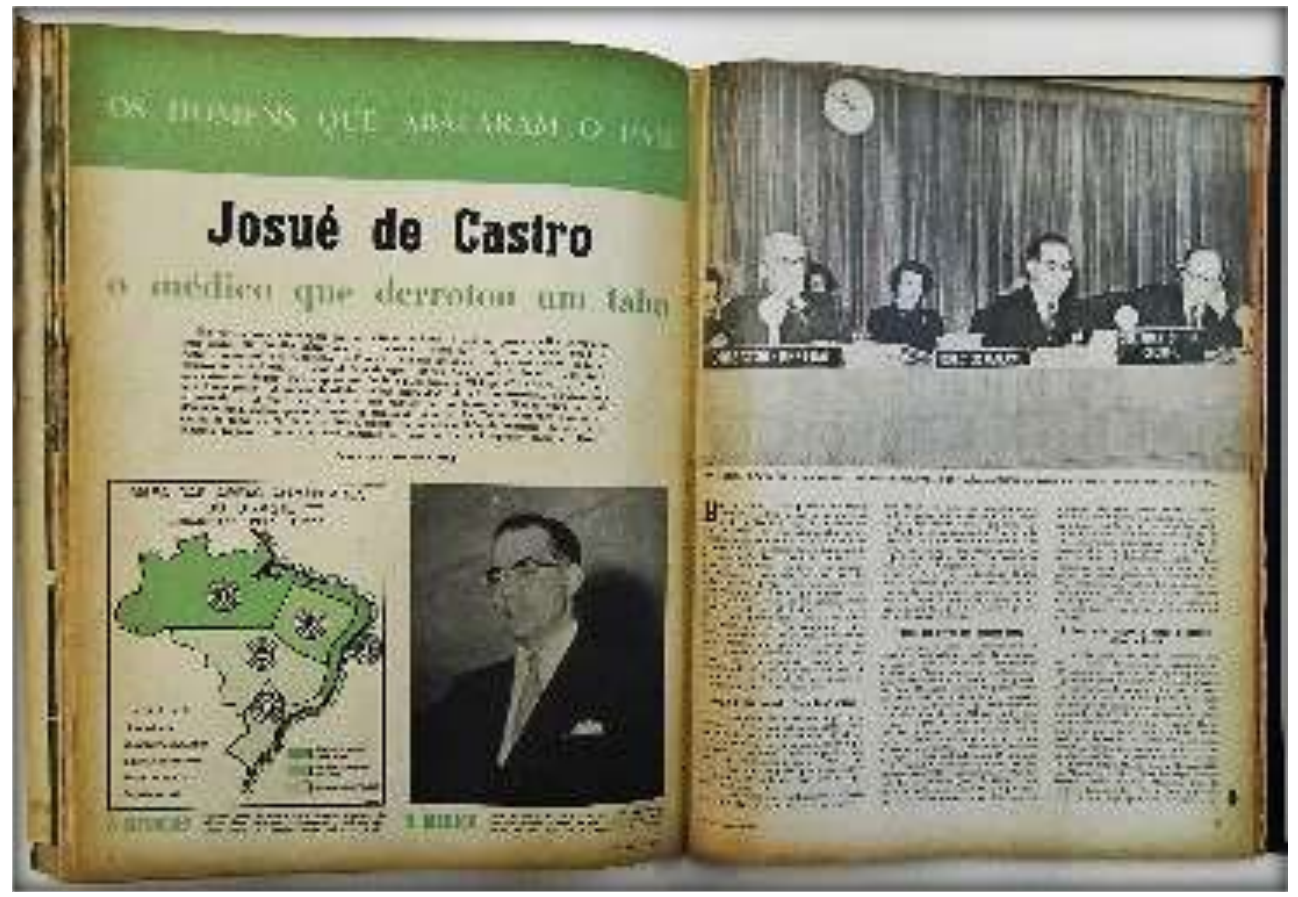

Fonte: Revista Manchete, 21 de março de 1953.

Figura 75. Retirantes da violenta sêca de 1877. Percy Lau.

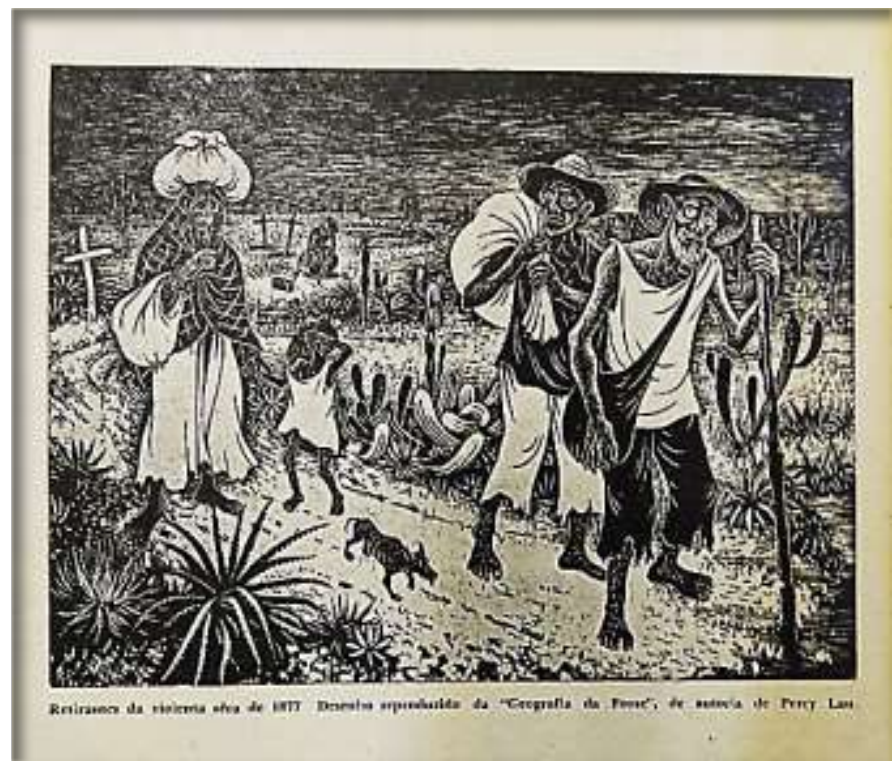

Fonte: Revista Manchete, 21 de março de 1953, p. 46. Detalhe do desenho de Percy Lau. 
No mesmo texto, o pesquisador mostra dados que comprovam o potencial produtivo do solo do sertão e ainda questiona em qual dimensão o homem seria também responsável pelas secas, e não apenas sua vítima.

As novas verdades da ciência sobre a fome e a miséria no sertão foram tema da reportagem de Homero Homem sobre as ideias do pernambucano Josué de Castro.

Sob o título: "os homens que abalaram o país", o repórter apresentava as credenciais do médico e pesquisador que por vinte anos havia estudado a questão da fome, no Brasil e no mundo. Em três páginas, a matéria é apresentada ao leitor com a valorização do texto informativo na segunda página, uma fotografia em meio primeiro plano, de Josué de Castro, e uma ilustração intitulada "Mapa das áreas alimentares" (figura 74). O mapa, por sua vez, constituía-se num mapa do Brasil subdividido em cinco regiões-alimentares: 1 - área amazônica /área de fome endêmica; 2 - nordeste açucareiro (litoral nordestino) / área de fome endêmica; 3 - sertão nordestino / área de epidemia de fome; 4 - centro oeste (Centro-oeste, parte de São Paulo e Minas Gerais) / área de sub-nutrição; extremo sul (Sul e litoral paulista) / área de sub nutrição.

O mapa traz uma regionalização muito original e particular do território brasileiro, e expressa os resultados da pesquisa de Castro, que é taxativo ao afirmar que "Nosso povo está morrendo de fome", apontando os responsáveis: O latifúndio açucareiro e cacaueiro, seriam os causadores da fome no Nordeste, e não o solo ou a falta de preparo do agricultor. Na página final, a matéria termina com um desenho de Percy Lau, (figura 75) anteriormente publicado em Geografia da Fome, livro de Josué de Castro de 1946. Trata-se da representação de uma família de retirantes, os homens trazem os olhos muito abertos, com expressão de desespero, o caminho, marcado pelo chão seco e pelas cactáceas, é pontuado pelas cruzes dos túmulos daqueles que não conseguiram seguir a viagem. Ao contrário das ilustrações de Percy Lau para Tipos e aspectos do Brasil, de 1939, esta não possui a mesma verossimilhança, mas afeta pela intensidade das expressões.

Na face hercúlea do Nordeste promissor, rico em matéria prima para o desenvolvimento industrial brasileiro, as imagens da natureza nordestina se reconciliam com o imaginário coletivo, que lhe concede representações mais otimistas. Quanto aos homens, aos sertanejos, esses ainda permaneciam vistos como um obstáculo para o progresso Como solução para a superação desse obstáculo, as vozes mais otimistas viam na ciência a principal arma contra o atraso e suas filhas: a 
pobreza e a miséria. A desigualdade e a exploração raramente entravam em questão. Todavia, as representações do Nordeste não se resumiriam à caatinga ou minério. Havia ainda um outro Nordeste, onde a beleza, a história e a cultura dos nordestinos do sertão ao litoral ganharia dimensões de representação da própria brasilidade. 


\section{4 - O EXOTISMO, A MAGIA E O BERÇO DA BRASILIDADE}

“O que eu gostava, quando viajava, era viver com o povo e vê-los viver um modo de vida diferente do meu. Eu estava interessado no que não era eu. Ou naquilo que era eu, nos outros"

Pierre Verger.

\subsection{A imprensa ilustrada, o Brasil e a guerra}

A guerra trouxe uma nova dinâmica para as revistas ilustradas, sobretudo para $O$ Cruzeiro. Grandes matérias, ilustradas com imagens adquiridas por meio de agências internacionais eram publicadas desde o início do conflito, contudo, a partir da oficialização da entrada do Brasil na guerra, as fotorreportagens produzidas - com fotografias estrangeiras ou nacionais - eram cada vez elaboradas.

Figura 76. O povo brasileiro em guerra.

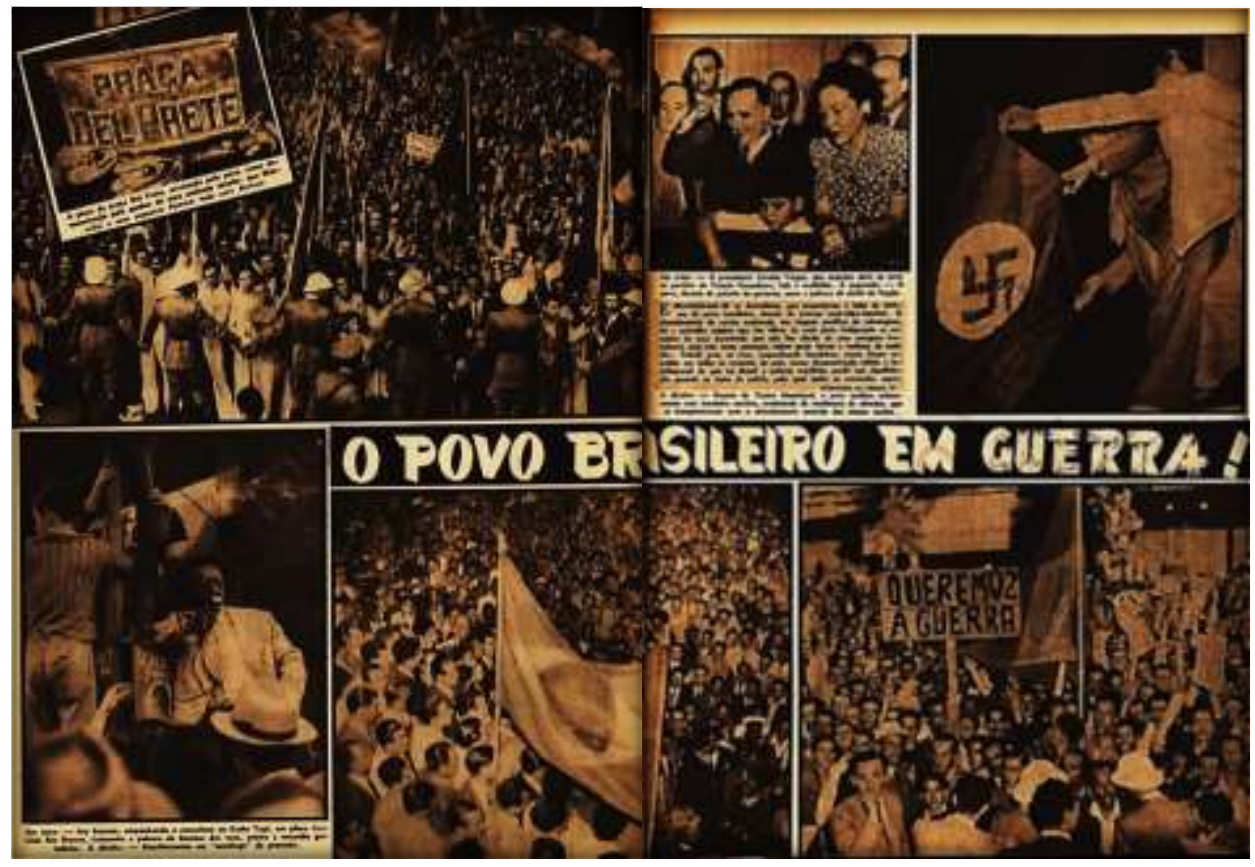

Fonte: Revista O Cruzeiro, 29 de agosto de 1942, p. 16, 17. Acervo CEDIC.

O Brasil entrava em guerra e a revista estava ali para registrar. No alto da figura 76, no boxe, à esquerda, lê-se: "Ary Barroso, empunhando o microfone da Radio Tupi, em plena Avenida Rio Branco, transmite a palavra do homem das ruas, contra a covardia germânica. À direita: 
Manifestantes em 'meetings' de protesto". O objetivo do texto em consonância com as imagens, era mostrar que o povo comum, e também as pessoas célebres - as autoridades e os artistas estavam unidos em torno de um objetivo comum:

Enganaram-se os derrotistas, que propalavam a falta de civismo do povo brasileiro, deante da ameaça nazi-fascista. $\mathrm{O}$ afundamento de navios nacionais, em viagem pacífica de cabotagem, foi a centelha mágica que fez vibrar da mais justa indignação os corações de uma juventude que não faz alarde de uma coragem truculenta, mas não teme ameaças, sejam quais forem e venham de onde vier. Saindo para as ruas, empunhando bandeiras, vozes foram erguidas em todos os recantos do país, numa demonstração nítida e insofismavel de que no Brasil a palavra sacrificio perde sua significação quando se trata da patria [...] (Revista O Cruzeiro, 29 de agosto de 1942, p. 16-17)

A Campanha para Dar Asas a Juventude Brasileira - campanha nacional da aviação percorreu todas as regiões do Brasil, durante a década de quarenta. Criada por Assis Chateaubriand e Joaquim Pedro Salgado Filho, Ministro da Guerra do governo Vargas, a campanha consistia em conseguir doação de aviões ou auxílio financeiro para a construção e ampliação de hangares. Nas matérias sobre os esforços da aeronáutica brasileira, seguia-se o mesmo roteiro: enquadramentos que sugerem a presença de multidões, imagens do povo, autoridades e militares. O objetivo era mostrar a aprovação dos esforços de guerra por todos os espectros da sociedade. As imagens do Asas para a Juventude eram publicadas semanalmente, principalmente durante o período da guerra, e o Recife não ficou de fora.

Na figura 77, na página da direita vemos a imagem de Chatô batizando mais uma aeronave: “O sr Assis Chateaubriand falando quando do batismo do 'George Canning'. A matéria fotográfica, apresenta o batismo de quatro novas aeronaves; cerimônia da qual participaram o ministro canadense Jean Desy, em visita ao Brasil; o diretor dos Diários Associados, Assis Chateaubriand; o interventor de Pernambuco, Agamemnon Magalhães dentre outras autoridades. Na figura 78, em mais um batismo, a Cruzeiro noticiava a homenagem ao historiador cearense, o Barão Studart, que passava a ceder seu nome à aeronave. A campanha de Chateaubriand permaneceu na revista mesmo após o término da guerra, em março de 1950, Luciano Carneiro escreveu matéria sobre o Asas, reportando as ações dos pilotos civis do aeroclube de Pernambuco. Para realizarem um vôo com quatro aeronaves - de Pernambuco para Buenos Aires - contaram com o apoio de Assis Chateaubriand, que disponibilizou-lhes o combustível de ida e volta. 
Figura 77. Asas para a Juventude em Recife

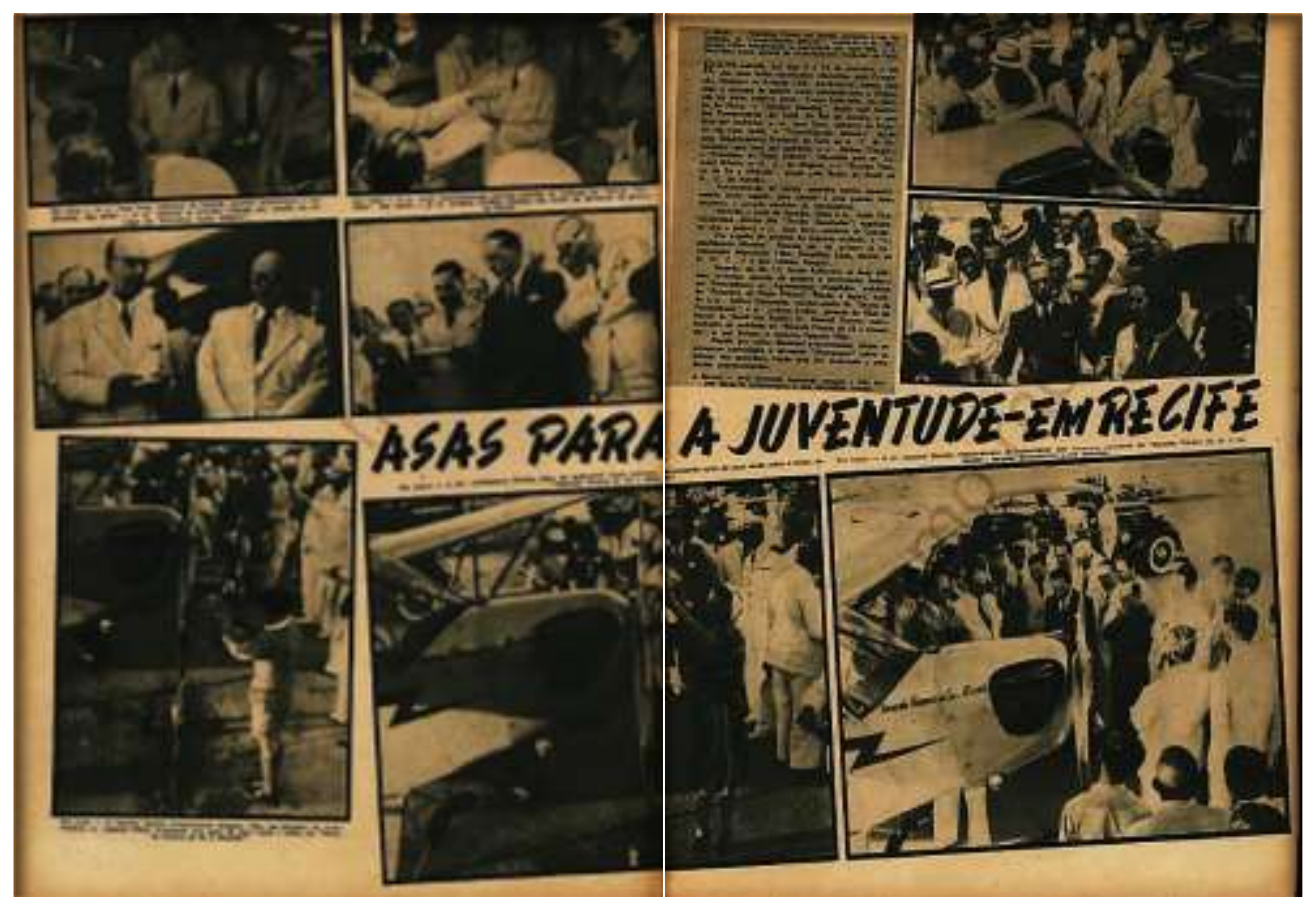

Fonte: Revista $O$ Cruzeiro, 29 de novembro de 1941. Acervo CEDIC PUC.

Figura 78. Asas para a Juventude de São Paulo.

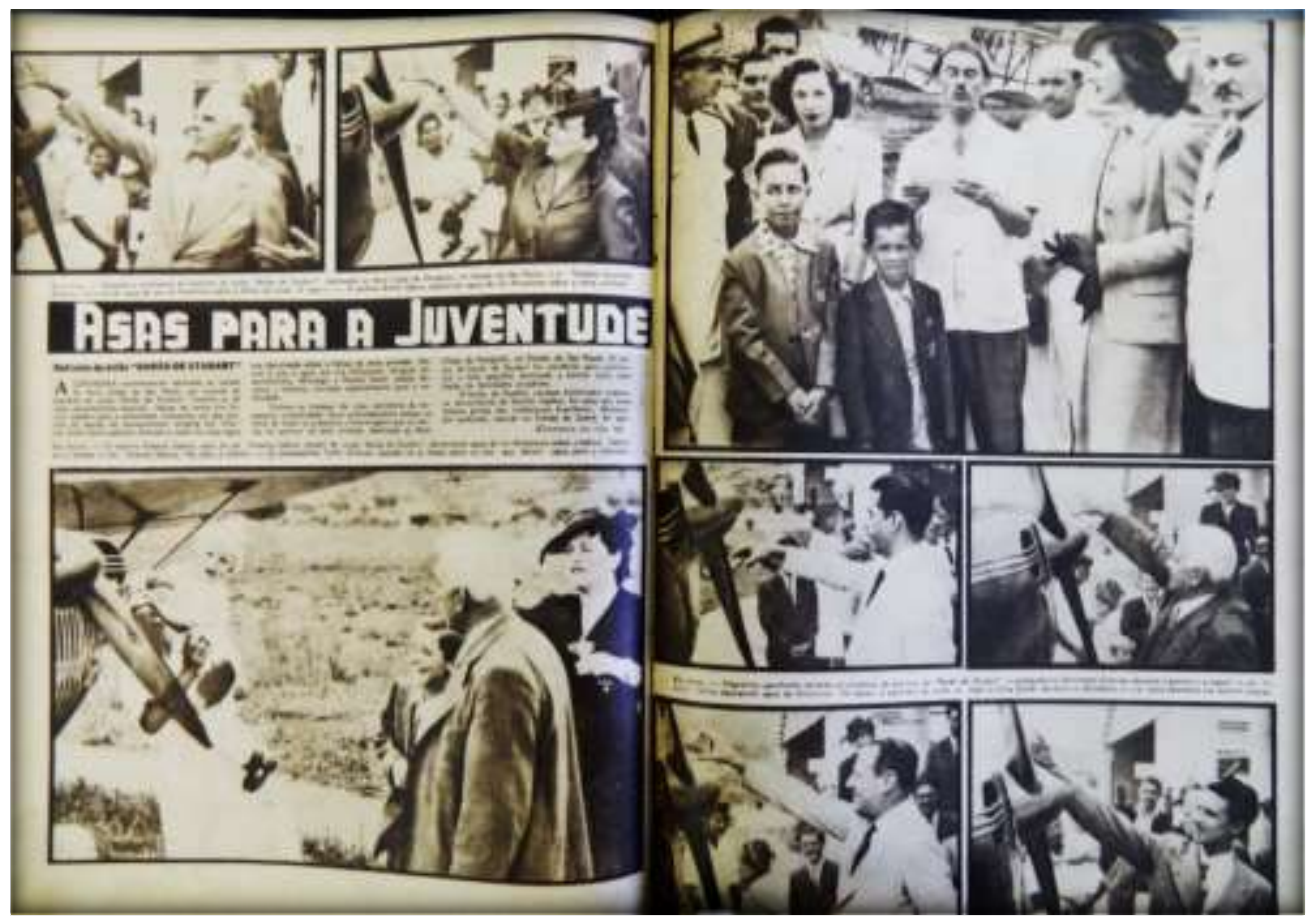

Fonte: Revista O Cruzeiro, 27 de fevereiro de 1943, Acervo CEDHIS UFU. 


\subsection{Civilização e barbárie: o mundo moderno e o distante mundo selvagem}

Durante a guerra, muita coisa na Cruzeiro havia mudado. As imagens femininas nas capas, apareciam com uniformes de militares ou voluntárias, as reportagens de temas mais sérios ocupavam maior espaço na revista, até as Garotas do Alceu, de Alceu Penna, vestiram uniforme. Ainda no humor, nas tirinhas-enquete, Nássara, queria saber: e se Hitler caisse nas suas mãos? Em resposta à pergunta, na edição de 26 de outubro de 1943, o cartunista Álvarus, respondia à pergunta da seguinte forma:

Meu velho Nássara, nada de matar o homem. Matá-lo seria para nós, os cartunistas, o desaparecimento de um dos nossos melhores modelos. O mais acertado seria encerrá-lo numa gaiola, e exibi-lo com entrada paga em todos os vilarejos e cidades do mundo e com o resultado, ajudar a reconstruir o que arruinou. Mussolini também poderia acompanha-lo de pá e vassourinha para fazer diariamente a limpeza da gaiola. Sempre seu. Álvarus. (CARVALHO, 2001, p. 88)

Além do bom humor de Nássara, o ano de 1943 trouxera a contratação de Jean Manzon, uma grande reforma editorial e o início da produção, de fotorreportagens com profissionais brasileiros - ou fixados aqui - o que significava profissionalizar a fotografia jornalística, buscando temas de interesse aqui mesmo, no Brasil. Imagens e lugares que despertassem a curiosidade do público e a criatividade dos fotógrafos, estariam em foco; a revista, mais do que nunca, a partir da metade da década de quarenta, voltar-se-ia para a missão anunciada quando de seu lançamento: a Educação do olhar. As fotorreportagens da Cruzeiro, a partir desse momento, ratificariam o compromisso de educar o olhar da sociedade ensinando-lhe o que é moderno e o que é antiquado; o que é civilizado e o que é bárbaro; quem éramos nós e o que havíamos deixado de ser:

[...] o campo de acção da revista é mais vasto, a sua interpretação dos acontecimentos deve subordinar-se a um criterio muito menos particularista do que o do jornal. Um jornal póde ser um órgão de um partido, de uma facção, de uma doutrina. Uma revista é um instrumento de educação e de cultura: onde se mostrar a virtude, animá-la; onde se ostentar a belleza, admirá-la; onde se revelar o talento, applaudi-lo; onde se empenhar o progresso, secundá-lo. O jornal dá-nos da vida a sua versão realista, no bem e no mal. A revista redu-la á sua expressão educativa e esthetica. $\mathrm{O}$ concurso da imagem é nella um elemento preponderante. A cooperação da gravura e do texto concede á revista o privilegio de poder tornar-se obra de arte. A politica partidaria seria tao incongruente numa revista do modelo de Cruzeiro como num tratado de geometria. Uma revista deve ser como um espelho leal onde se reflecte a vida nos seus aspectos edificantes, attraentes e instructivos. Uma revista deverá ser, antes de tudo, uma escola de bom gosto. (Revista Cruzeiro, ano I, número 1, página 3. Editorial de abertura do primeiro número da revista. Acervo do Museu de Arte de São Paulo). 
Ao pensarmos sobre o roteiro de interesses dos leitores das revistas ilustradas - as classes letradas e urbanas do Brasil de então - podemos estabelecer uma comparação entre o caso da atração e o interesse despertado por lugares como a Amazônia e o Nordeste àquele despertado pelo Oriente, nas sociedades urbanas e mais abastadas da Europa do século XIX; qual seja, uma representação do Oriente elaborada pelo Ocidente, de maneira praticamente desconectada da realidade. Para Edward Said, essa representação foi necessária para que o Ocidente identificasse a si mesmo, encontrando um "outro", o oriental, que o ajudasse, por diferenciação, a se reconhecer. Assim, se constrói uma ideia exótica e romântica que o Ocidente tem do Oriente. Para Said ${ }^{123}$, a construção das representações sobre o Oriente estaria fundamentada a partir na cristalização de imagens e estereótipos que o associavam àquilo que fosse inferior, bizarro e subdesenvolvido. Para o autor, o Oriente seria uma invenção do Ocidente, criada como uma imagem invertida em um espelho, para legitimar a identidade de desenvolvimento e racionalidade eurocêntrica. Da mesma forma, podemos dizer que o Nordeste e a Amazônia, estereotipados, eram mera invenção do Sudeste, que os criara como uma imagem invertida de si mesmo, para reforçar sua positividade.

A nascente imprensa da fotorreportagem, nos anos cinquenta, embora tenha sido responsável por dar novas dimensões às imagens do Nordeste, não abandonou os antigos ícones e representações. Um dos grandes objetivos das reportagens era apresentar, como dizia o editorial da revista Manchete, "o Brasil que o Brasil não conhece". Utilizando-se do valor atrativo do "distante" e do "desconhecido", o Nordeste e, posteriormente, a Amazônia, surgiriam como lugares remotos, onde os homens e a natureza seriam diferentes de tudo aquilo que o homem do universo urbano e racional do Sudeste conheceria. Ao discutir este tema das representações em relação aos latinoamericanos, Mary Anne Junqueira (2001), nos coloca diante da questão do olhar com o qual a imprensa, na figura da revista Seleções, da americana Reader's Digest, olhava a América Latina:

Ao olhar para os territórios da região, a revista os considerava "vazios", abandonados, sem a transformação necessária para atingir o progresso e o desenvolvimento de um mundo moderno. Como conseqüência, o latino-americano, com raras exceções, era visto como passivo, sem interesse e iniciativa. O oposto do norte-americano que havia "resolvido o problema dos territórios vazios"

\footnotetext{
${ }^{123}$ Em sua obra, Said discute a formação da representação do Oriente, produzida pelo Ocidente, partindo dos diversos estereótipos cristalizados na fala de pensadores e, principalmente da literatura, ele promove uma reflexão sobre o conceito e sobre a possibilidade de compreendermos de fato, o que é cultura, e, principalmente, como compreender a cultura "do outro" (SAID, 1991).
} 
norte-americanos e dos índios ainda no século XIX. Dentro dessa ordem de idéias, eram reforçados em Seleções estereótipos sobre a América Latina e os latinoamericanos que se formaram ao longo dos séculos passados e que, muitas vezes, foram (re)construídos não só pela mídia, mas também por romancistas, intelectuais, cientistas, naturalistas, pensadores, etc. (JUNQUEIRA, 2001, p. 324)

Nas páginas da Seleções, o Brasil, em sua porção interior e também outras partes da América, era definido como a "fronteira", não num sentido meramente geográfico, mas fundamentalmente num sentido cultural. Aparece aí o conceito de wilderness; termo de difícil tradução literal, mas que representaria "o território ainda inexplorado”, “terras selvagens”, “área de oportunidades" ou "área ainda descivilizada". No caso da Vamos Lêr! e da Cruzeiro, nos anos de 1930 e 1940, a África, por muito tempo, fora a mais constante representação do wilderness.

As reportagens e sobretudo as imagens eram adquiridas de agências estrangeiras, não eram produzidas por fotógrafos da revista. Em enquadramento frontal e de perfil, (figura 79) os fotografados são apresentados em recortes que lembram a sequência de posições utilizadas nos estudos de botânica: o espécime em detalhe, em ângulo frontal e em perfil de noventa graus, as imagens são apresentadas em uma versão com um recorte e outra de corpo inteiro. A forma como o elemento humano é apresentado, lembra também as fotografias e gravuras de perfis humanos utilizados para estudos antropológicos no século XIX. As imagens dessa matéria não comunicam elementos do contexto cultural, social ou histórico, cabe ao texto fazê-lo.

O velho Congo, o Congo primitivo e selvagem - a Darkest Africa de Stanley - o Congo das aldeias fortificadas, dos ritos ocultos, dos feiticeiros adivinhos, psychagogos e mandriões, dos costumes estranhos e milenários, dos ornamentos bárbaros e das dansas delirantes ... não existe mais. Assim fala, em tom desiludido, a maioria dos que visitam recentemente a terra dos Bantu. É verdade que através de uns dois milhões e meio de quilômetros quadrados do império colonial belga, não mais se encontram palissadas e fossas em torno das aglomerações. [...] é verdade que alguns ricos reizinhos negros que, há dois ou três anos, se faziam transportar em macas, a cabeça ornada de plumas, uma pelle de cervo aos rins, um colar de dentes de cachorro ao pescoço e missangas nos punhos e nos artelhos, não viajam hoje senão de jaquetão e em seis-cylindros! [...] (O Cruzeiro, 15 de fevereiro de 1930)

Apresentando uma África que estaria se descaracterizando em função da colonização, o texto associa os elementos que considera como sendo típicos da africanidade, elementos de uma ordem mágica e misteriosa, em oposição à chegada das cidades, telégrafos e automóveis, que corresponderia à civilização dos costumes africanos. 
Figura 79. No coração da África selvagem.

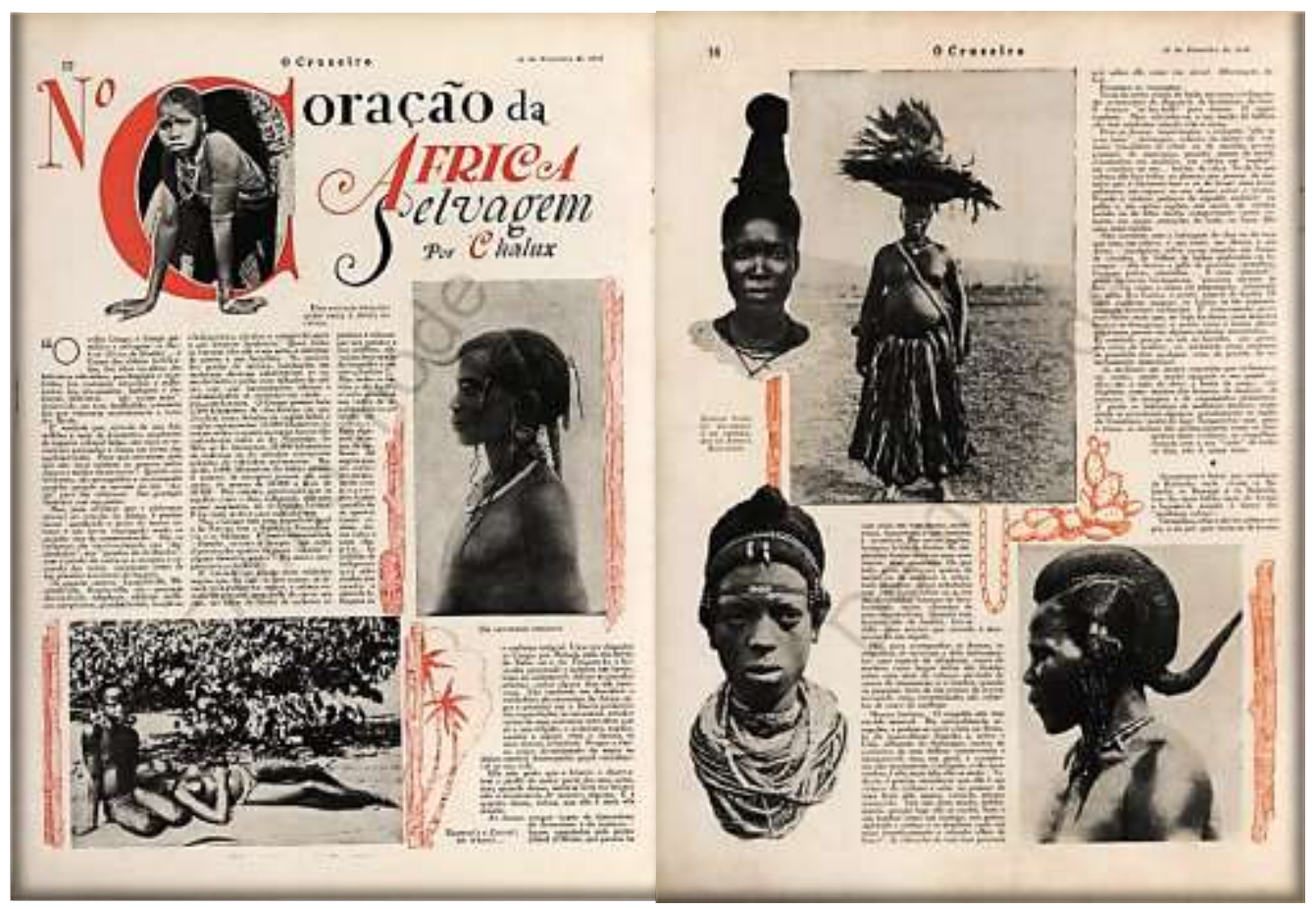

Fonte: O Cruzeiro, 15 de fevereiro de 1930, p. 12 e 14. Acervo CEDIC PUC.

Figura 80. No mystério e no silêncio das selvas africanas.

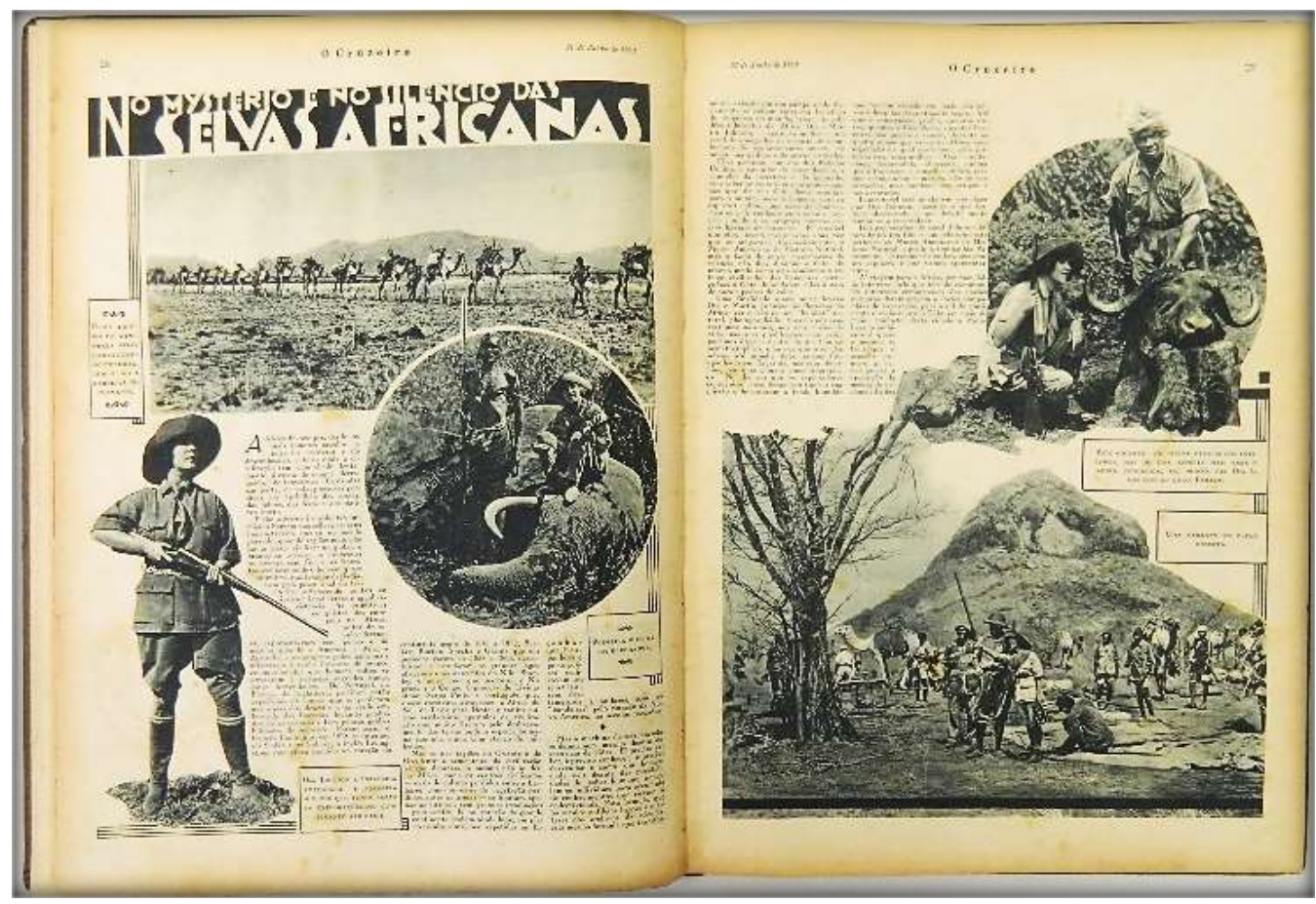

Fonte: Revista o Cruzeiro, 21 de junho de 1930. Acervo IEB USP. 
$\mathrm{Na}$ reportagem da figura 80, mais elementos considerados típicos do imaginário sobre a África estão presentes na composição da página: o caçador branco (que no caso é uma mulher), os grandes mamíferos abatidos, as tribos de 'selvagens' que auxiliam e acompanham o caçador; o elemento africano propriamente dito - meio físico e humano - não é protagonista, mas coadjuvante da ação do 'homem branco', personagem central da narrativa comunicada pelas imagens e ratificada pelo texto.

Já a apresentação da África na matéria de 1954, (figura 81) embora estejam ali presentes alguns dos mesmos elementos de antes - o homem branco, o homem africano de uma sociedade tribal, a caçada, os grandes mamíferos - a forma de se lhes apresentarem por meio das lentes fotográficas, começa a mudar, nota-se uma abordagem antropológica, todavia, não mais daquela antropologia impregnada de evolucionismo social, mas de uma antropologia social. O elemento africano protagoniza de maneira mais pontuada, as cenas apresentadas, sendo que o elemento branco, aparece demonstrando uma atitude de aproximação, (figura 82) interação, numa atitude de observação, estudo, análise. Com texto de Hernest Hemingway ${ }^{124}$ e imagens de Earl Theisen, a matéria, adquirida pela Cruzeiro, descreve parte da viagem de cinco meses empreendida pelo escritor norte-americano, sua esposa Mary e o fotógrafo Earl Theisen, pela região do Quênia.

Com a companhia de vinte e dois acompanhantes entre batedores, caçadores e guerreiros massai; Hemingway relata seu reencontro com a África e com seu filho, que vivia em Tanganica (atual Tanzânia). Na matéria, (figura 83) ${ }^{125}$ ele relata brevemente suas impressões sobre a caçada a um rinoceronte, mas se atém longamente a comentar sobre a cidade de Nairóbi, que o surpreendeu pelo caos instaurado, em função dos conflitos:

Havia Nairobi com alguns bares [...] e havia uma guerra na região superior, onde era necessário andar armado. A necessidade de trazer armas em Nairobi era frequente. Mas, em Nairobi muitas pessoas andam armadas em pleno dia, nos bares que pareciam altamente protegidos e cuja defesa constava estar confiada às autoridades competentes. Uma pessoa vai arar na prisão por seis meses, com todas as formalidades, caso perca uma pistola ou deixe que a furtem. (O Cruzeiro, 13 de fevereiro de 1954)

\footnotetext{
124 Não seria a viagem de 1953, a primeira viagem de Hemingway à África. O escritor já havia estado lá, vinte anos antes, quando conheceu parte do continente e retirou elementos para escrever As neves do Kilimanjaro.

${ }^{125}$ Embora o texto venha com o título e o sub título fazendo alusão ao rinoceronte (A morte do rinoceronte assassino e O homem é o alvo do rinoceronte), o animal é o tema de algumas poucas linhas, no boxe superior, quando Hemingway conta, como um caçador os parou na estrada e os convidou à atirar num rinoceronte que estava como um alvo fácil próximo à eles. Hemingway atirou, acertou o animal, e posou para a foto, no pequeno quadro superior direto da página.
} 
Figura 81. Safari.

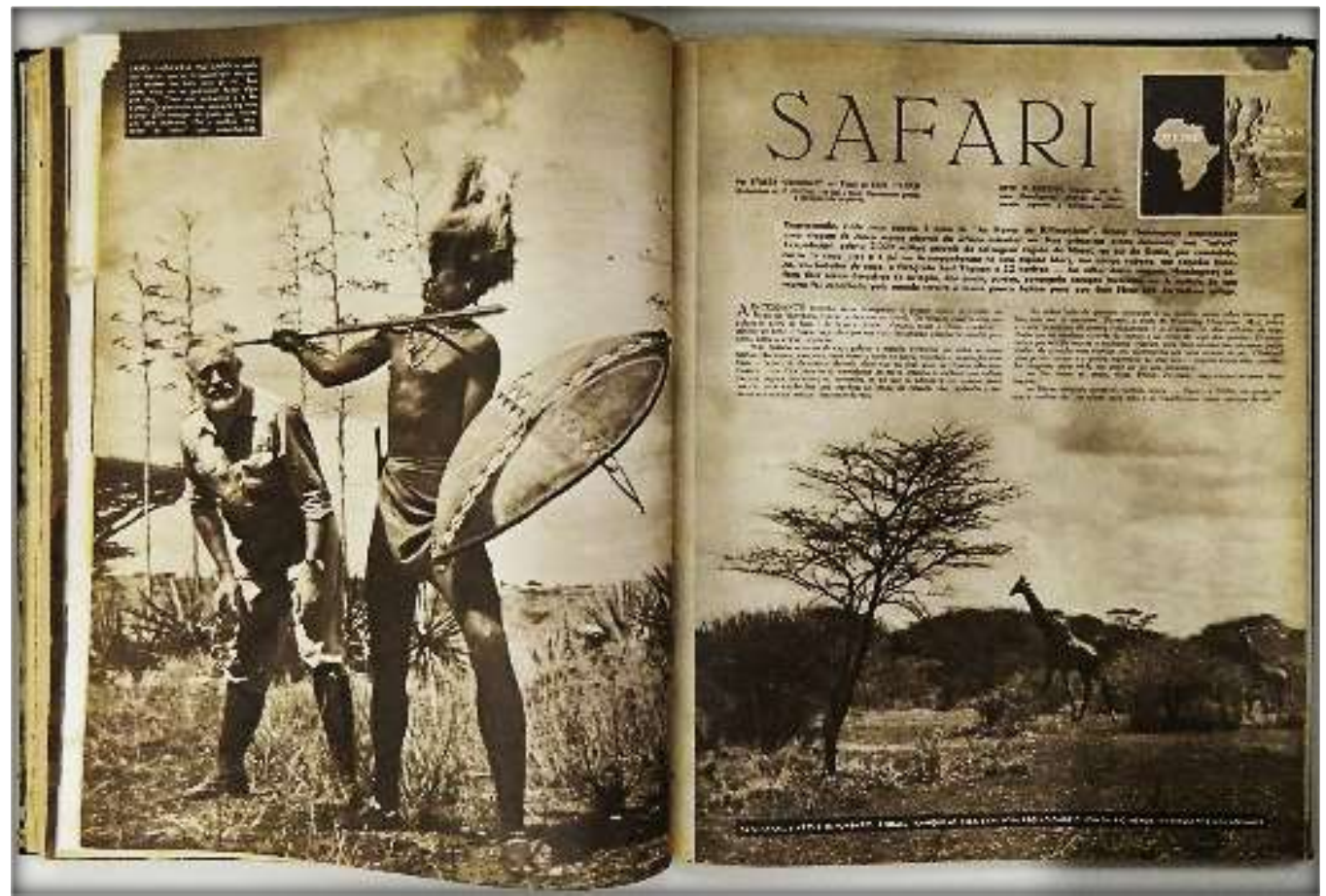

Fonte: O Cruzeiro, 13 de fevereiro de 1954. Acervo ECA.

Figura 82. O leão foi morto.

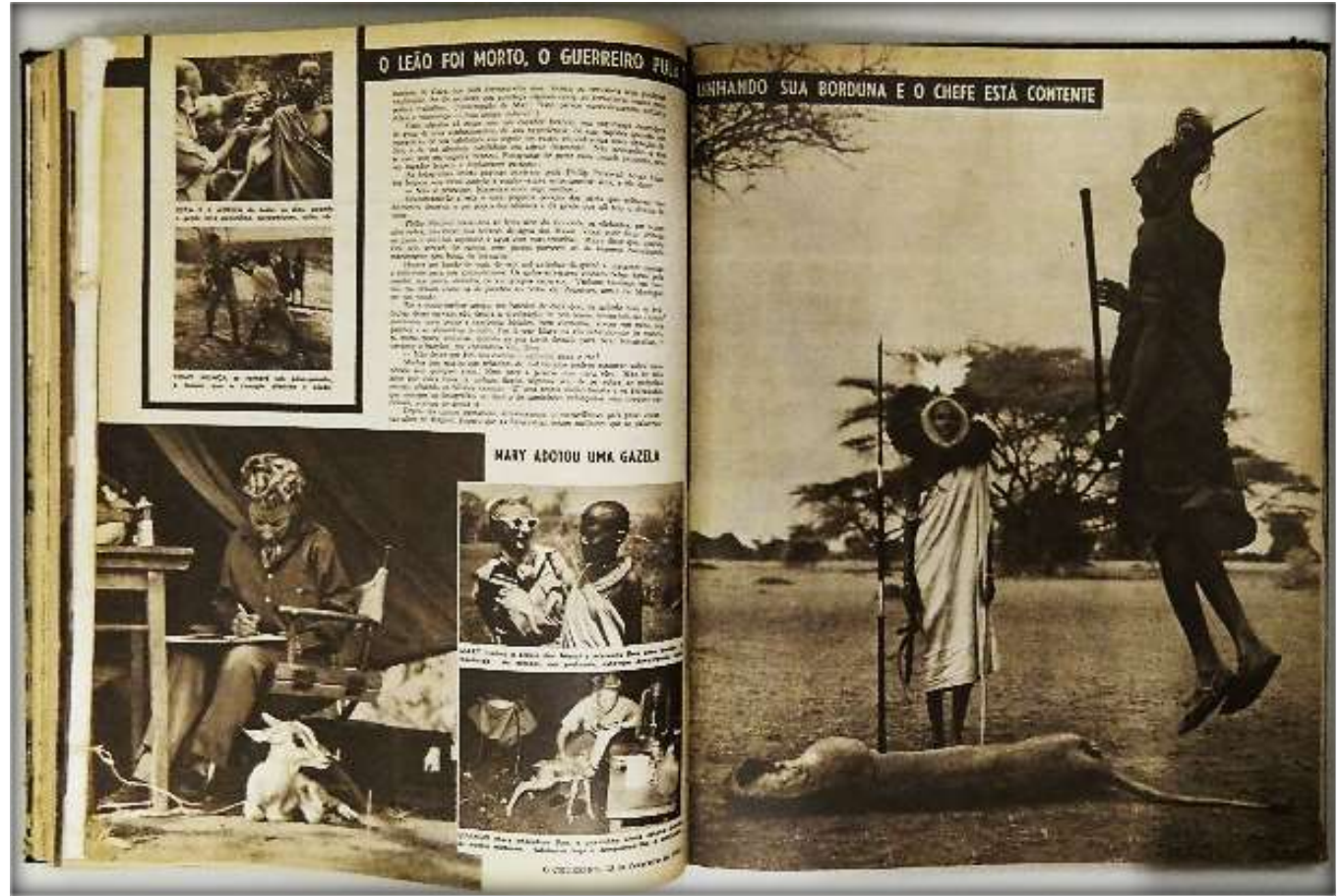

Fonte: O Cruzeiro, 13 de fevereiro de 1954. Acervo ECA. 
Figura 83. O Hemingway e o rinoceronte ferido.

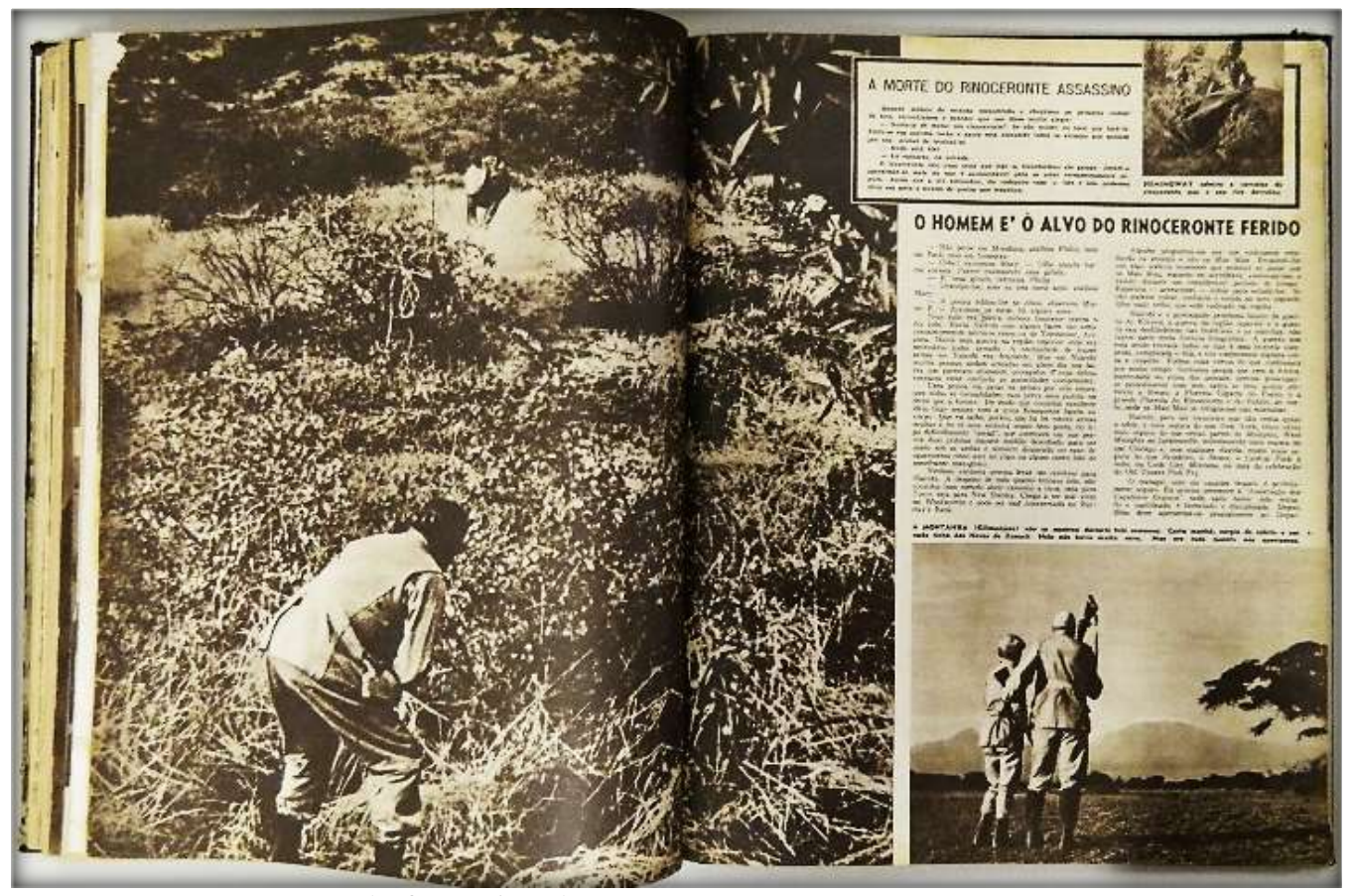

Fonte: $O$ Cruzeiro, 13 de fevereiro de 1954. Acervo ECA.

Figura 84. Meus sonhos africanos.

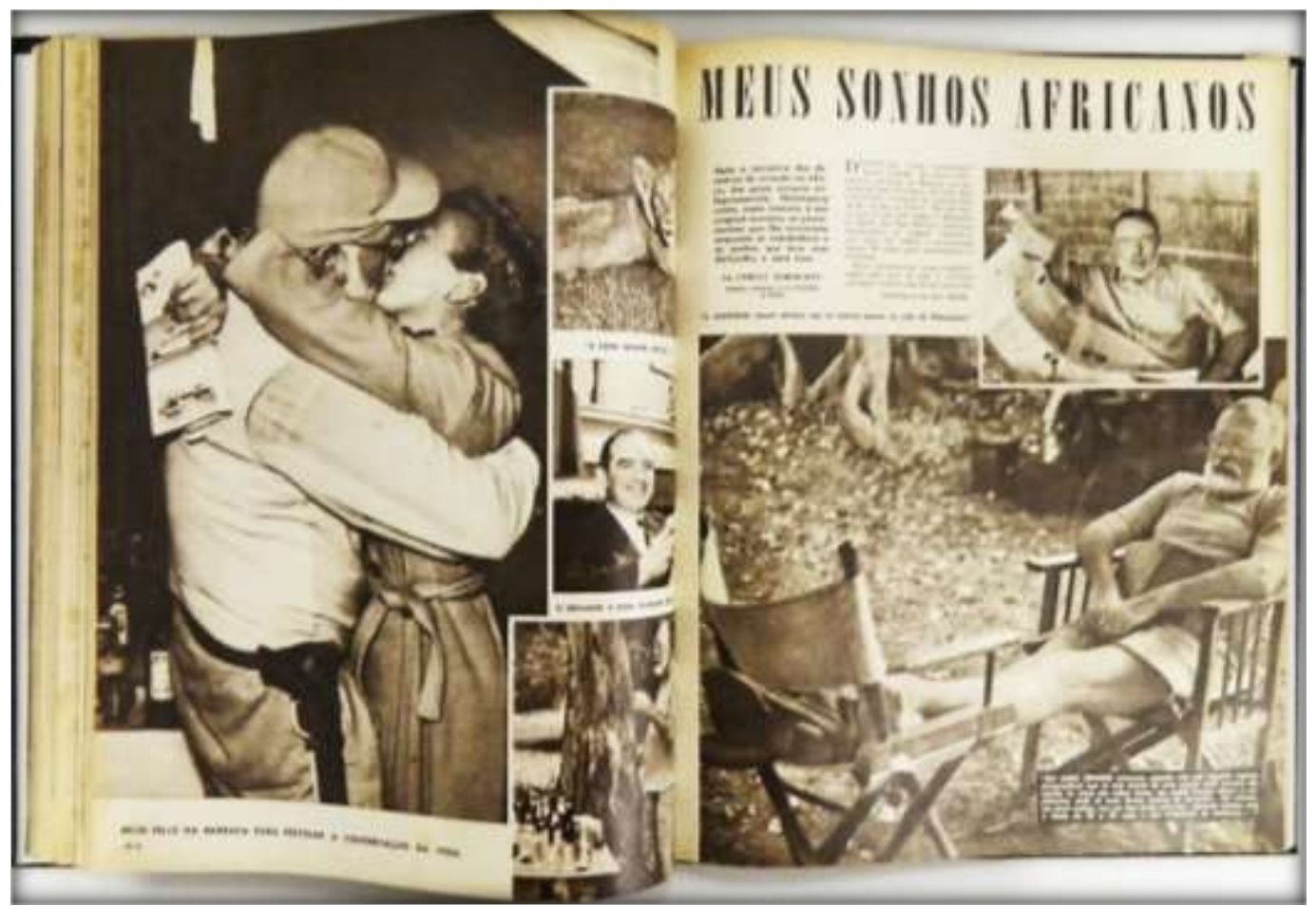

Fonte: Revista $O$ Cruzeiro, 17 de abril de 1954. Acervo ECA. 
Algumas edições depois, após alguns acidentes de avião aos quais sobreviveu, é a vez de serem publicadas as impressões do escritor sobre a vida, a dele e a que pulsa na África (figura 84). O olhar do leitor, que procura por imagens de lugares distantes, pode ser comparado ao olhar do turista. Esse, busca por seu oposto, pelo contraste, lugares e modos de ser que são, todavia, decodificados a partir de signos que orientam o olhar. Dessa forma, o olhar do turista seleciona somente aquilo que seu próprio código de valores pode captar, constituindo-se apenas numa amostra da frequência da África como representação do distante e do exótico ${ }^{126}$. As matérias da Cruzeiro de 1930 a 1954 traziam os códigos-chave para a compreensão do espaço africano pelo olhar do leitor: os grandes mamíferos, os nativos das tribos, o caçador branco e mesmo a celebração da vida, em meio à natureza selvagem, como se a África se resumisse a isso. As imagens apresentam uma África folclorizada, na qual o elemento humano é destituído de sua condição de agente histórico produtor de cultura e promotor de transformações, lembrando a ideia de uma África ahistórica ${ }^{127}$.

\subsection{Amazônia e Nordeste, wildernesses brasileiros.}

\subsubsection{Amazônia.}

Retomando a pesquisa de Junqueira (2001), tem-se que, com relação às representações do Brasil, a região mais claramente classificada como wilderness, no caso da Seleções - revista analisada pela autora - seria a Amazônia, mas é interessante observar que não somente ela, mas

\footnotetext{
${ }^{126}$ Sobre o tema do olhar do turista, ver também Osborne, Peter. Travelling Light: Photography, Travel and Visual Culture. Manchester and New York: Manchester University Press, 2000, pp. 70-121; e Kubalek, Paul. The tourist gaze. Chelsea College of arts and Design. MA Graphic Design Communicatios, 2008.

${ }^{127}$ Num primeiro momento, antes das ciências humanas discutirem de que maneira as culturas africanas se organizaram ou se re-organizaram após a diáspora atlântica, foi necessário vencer a ideia de que a África era um continente sem efervescência e densidade cultural, sem História. Isso porque, desde Hegel, as sociedades asiáticas e africanas eram vistas como sociedades estáticas. Joseph Ki-Zerbo lembra em sua História da África Negra a posição radical de Hegel, que em seu curso sobre a Filosofia da História dizia que: A África não é uma parte histórica do mundo. Não tem movimentos, progressos a mostrar, movimentos históricos próprios dela. Quer dizer que a sua parte setentrional pertence ao mundo europeu asiático. Aquilo que entendemos precisamente pela África é o espírito a-histórico, o espírito não desenvolvido, ainda envolto em condições de natural e que deve ser aqui apresentado apenas como o limiar da história do mundo. KI-ZERBO, Joseph. História da África Negra. Volume I. Lisboa, Publicações EuropaAmérica, 1972, p. 10.
} 
toda e qualquer área que se apresentasse distante do modelo europeu de sociedade civilizada. A partir da leitura de Junqueira (2001) podemos estabelecer um paralelo com o olhar também sobre o sertão nordestino que, tal qual a Amazônia, seria identificado como "zona de fronteira", como um de nossos espaços de wilderness, gerando grande curiosidade por parte dos leitores. Alguns elementos utilizados na representação da África, eram revisitados na composição do cenário amazônico.

Em 1929, em matéria escrita para a Cruzeiro, o historiador alemão Otto Sandkuehler, de passagem pelo Brasil, escreve sobre a Amazônia, intitulando sua reportagem: "Nos mysterios das selvas: caçadas nos sertões do Brasil”, (figura 85) na qual utiliza o mesmo recurso linguístico - o termo mysterio - empregado anteriormente (figura 80) para apresentar o texto sobre a África, além de elementos visuais, como a apresentação da natureza e dos indígenas. Na reportagem de 1954, de Frederico Chateaubriand, sobre Ester Pitaluga, (figura 86) a mulher que comandou seringueiros durante a campanha da borracha, há uma ilustração em página dupla, em cores fortes, na qual encontramos elementos comuns à representação do espaço africano: o líder branco - no caso uma mulher, como na figura 80 - a roupa caqui, o chapéu, a arma, o nativo por lhe auxiliar na empreitada e, finalmente, a floresta.

Euclides da Cunha também escreveu a respeito da curiosidade despertada pela Amazônia. Em 1905, o escritor realizou viagem como chefe da Comissão Mista Brasileiro-Peruana de Reconhecimento do Alto Purus, cujo objetivo era coletar dados que contribuíssem para o monitoramento e a demarcação das fronteiras entre o Peru e o Brasil. Fruto de sua viagem e seus estudos sobre a Amazônia, Euclides da Cunha escreveu Um Paraíso Perdido, obra inacabada, na qual, comenta o fascínio que a Amazônia exercia sobre os imaginários de sua época:

A Amazônia selvagem sempre teve o dom de impressionar a civilização distante. Desde os primeiros tempos da colônia, as mais imponentes expedições e solenes visitas pastorais rumavam de preferência às suas plagas desconhecidas. Para lá os mais veneráveis bispos, os mais garbosos capitães-generais, os mais lúcidos cientistas. (CUNHA, 2000, p. 123)

Para Euclides, tanto o sertão quanto a Floresta Amazônica representariam a vitória da natureza sobre o homem. No caso do sertão, Euclides a via como um impiedoso adversário, o sertanejo, homem valente, porém bárbaro, seria incapaz de superá-lo: 
Figura 85. Amazônia. Nos mystérios das selvas.

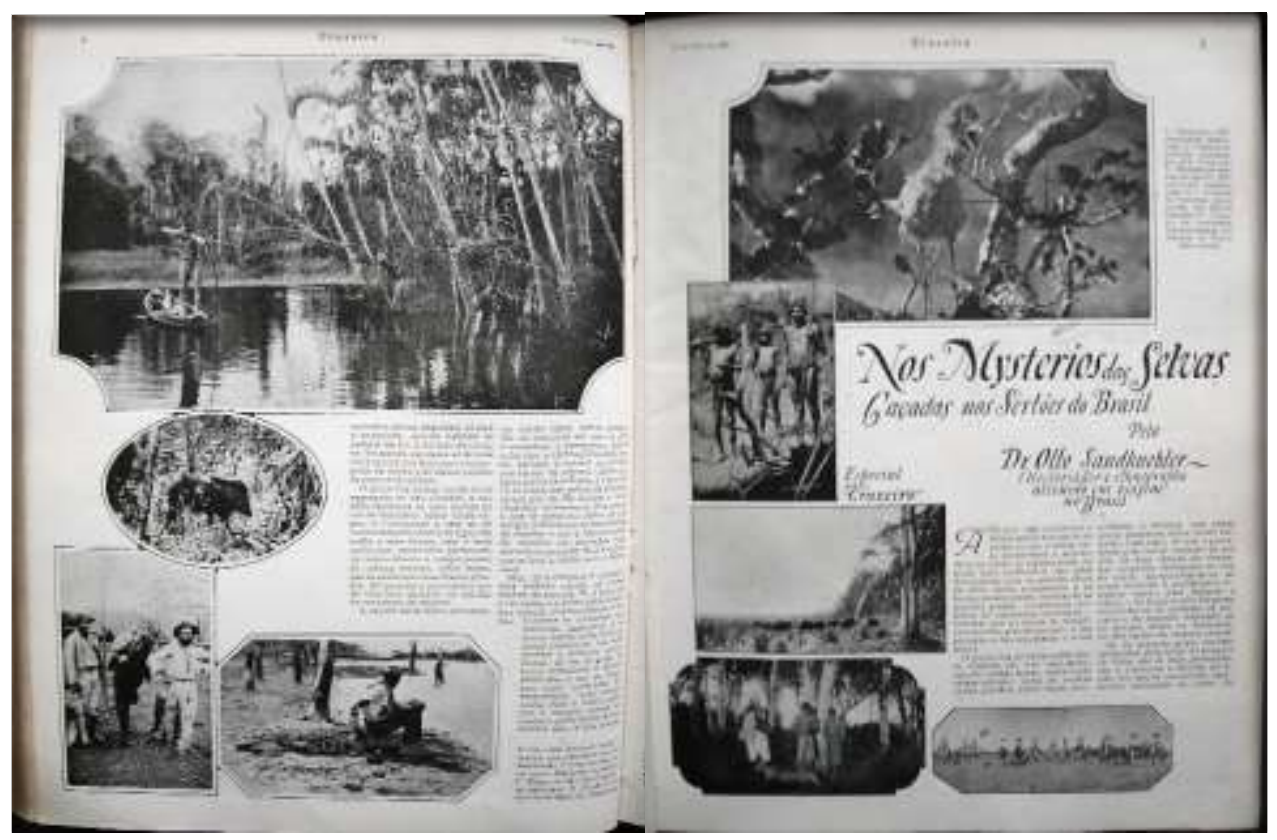

Fonte: Revista $O$ Cruzeiro, p. 03-04, 20 de abril de 1929. Acervo MASP.

Figura. 86 A deusa da borracha.

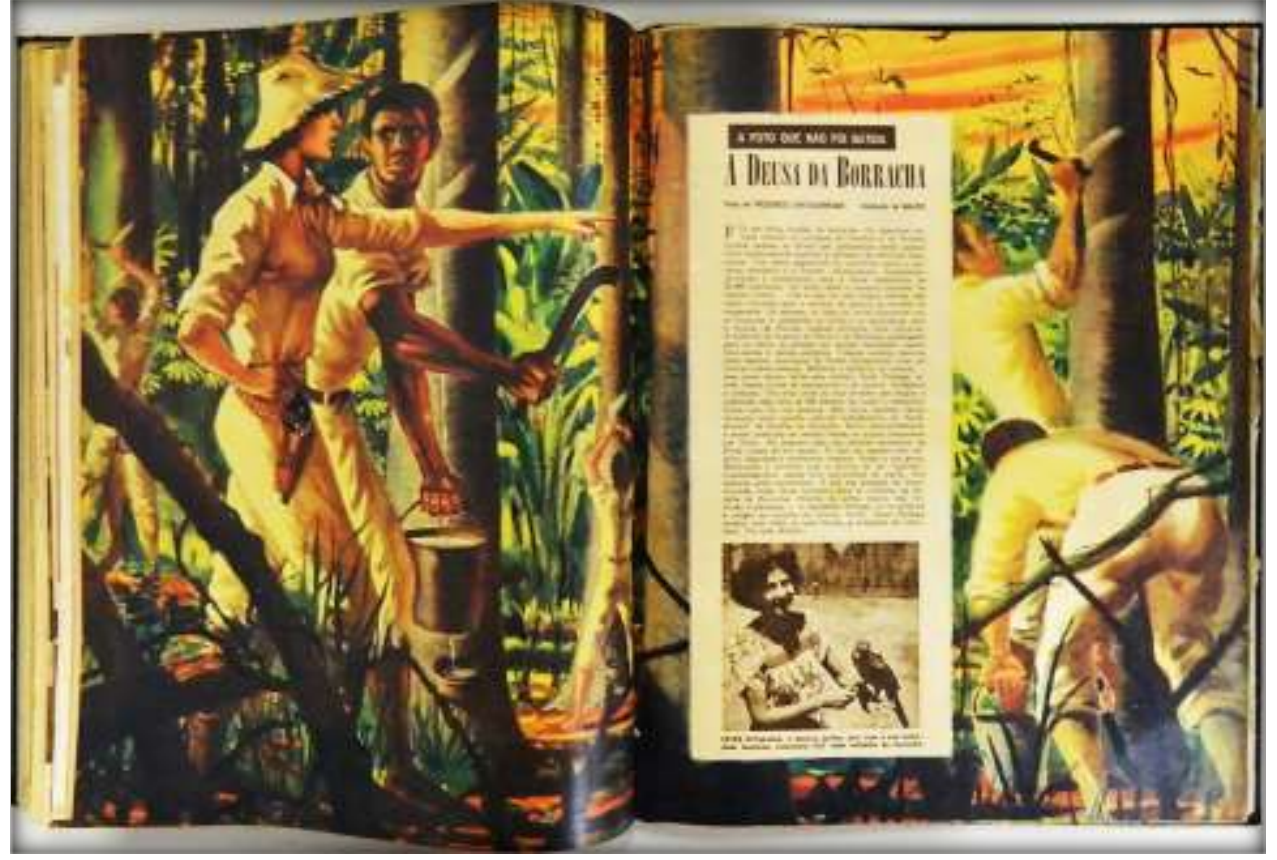

Fonte: Revista O Cruzeiro, 17 de abril de 1954. Acervo ECA - USP. 
Por fim tudo se esgota e a situação não muda. Não há probabilidade sequer de chuvas. A casca das marizeiras não transuda, prenunciando-as. $\mathrm{O}$ nordeste persiste intenso, rolando, pelas chapadas, zunindo em prolongações uivadas na galhada estrepitante das caatingas e o Sol alastra, reverberando no firmamento claro, os incêndios inextinguíveis da canícula. O sertanejo, assoberbado de reveses, dobra-se afinal. Passa certo dia, a sua porta, a primeira turma de "retirantes". Vê-a, assombrado, atravessar o terreiro, miseranda, desaparecendo adiante numa nuvem de poeira, na curva do caminho... No outro dia, outra. E outras. É o sertão que se esvazia. Não resiste mais. Amatula-se num daqueles bandos, que lá se vão caminho em fora, debruando de ossadas as veredas, e lá se vai ele no êxodo penosíssimo para a costa, para as serras distantes, para quaisquer lugares onde o não mate o elemento primordial da vida. (CUNHA, 1982, p. 197)

No caso da Amazônia, não haveria como domesticá-la, é o homem quem é moldado pelo comportamento da natureza: “A volubilidade do rio contagia o homem” (CUNHA, 2000, p. 113).

Depois há o incoercível da fatalidade física. Aquela natureza soberana e brutal, em pleno expandir das suas energias, é uma adversária do homem. No perpétuo banho de vapor, de que nos fala Bates, compreende-se sem dúvida a vida vegetativa sem riscos e folgada, mas não a delicada vibração do espírito na dinâmica das idéias, nem a tensãosuperior da vontade nos atos que se alheiem dos impulsos meramente egoísticos. Não exagero. Um médico italiano - belíssimo talento - o Dr.Luigi Buscalione $^{128}$, que por ali andou há pouco tempo, caracterizou as duas primeiras fases da influência climática - sobre o forasteiro - a princípio sob a forma de uma superexcitação das funções psíquicas e sensuais, acompanhada, depois, de um lento enfraquecer-se de todas as faculdades, a começar pelas mais nobres [...] (CUNHA, 2000, p 125-126).

Um olhar curioso, como o do turista que procura pelo seu oposto, iria nortear as lentes dos semanários em busca de cenários exóticos. Nesse contexto, a Amazônia, e em especial, a natureza amazônica, era apresentada como um prodígio, como uma maravilha que poucos teriam tido a oportunidade de vislumbrar. Era o que expressava a, reportagem da edição de 22 de julho de 1950, de Jorge Ferreira com imagens de Roberto Maia, "Inferno ou Paraíso", (figura 87) na qual, lia-se no texto:

A Amazônia é, não há que negá-lo, agressiva. Com um solo superpovoado botanicamente, onde a floresta, díspare nas espécies, luta pela própria vida, procurando as árvores, quase que indistintamente, um lugar ao sol, na verdadeira acepção do termo, forma um intricado sistema de vegetação que exige sacrifícios para ser penetrado. (O Cruzeiro, 22 de julho de 1950)

No contraponto, a reportagem “As damas do roncador”, (figura 88) com texto de José Leal e fotografias de José Medeiros, para a Cruzeiro, era escrita a partir da perspectiva da Amazôniafantástica, publicada sob o grande alarde de trazer imagens nunca antes vistas, pois:

${ }^{128}$ Luigi Buscaglione foi o autor de Una escursione botanica nell'Amazzonia, 1901. 
Figura 87. Inferno ou paraíso?

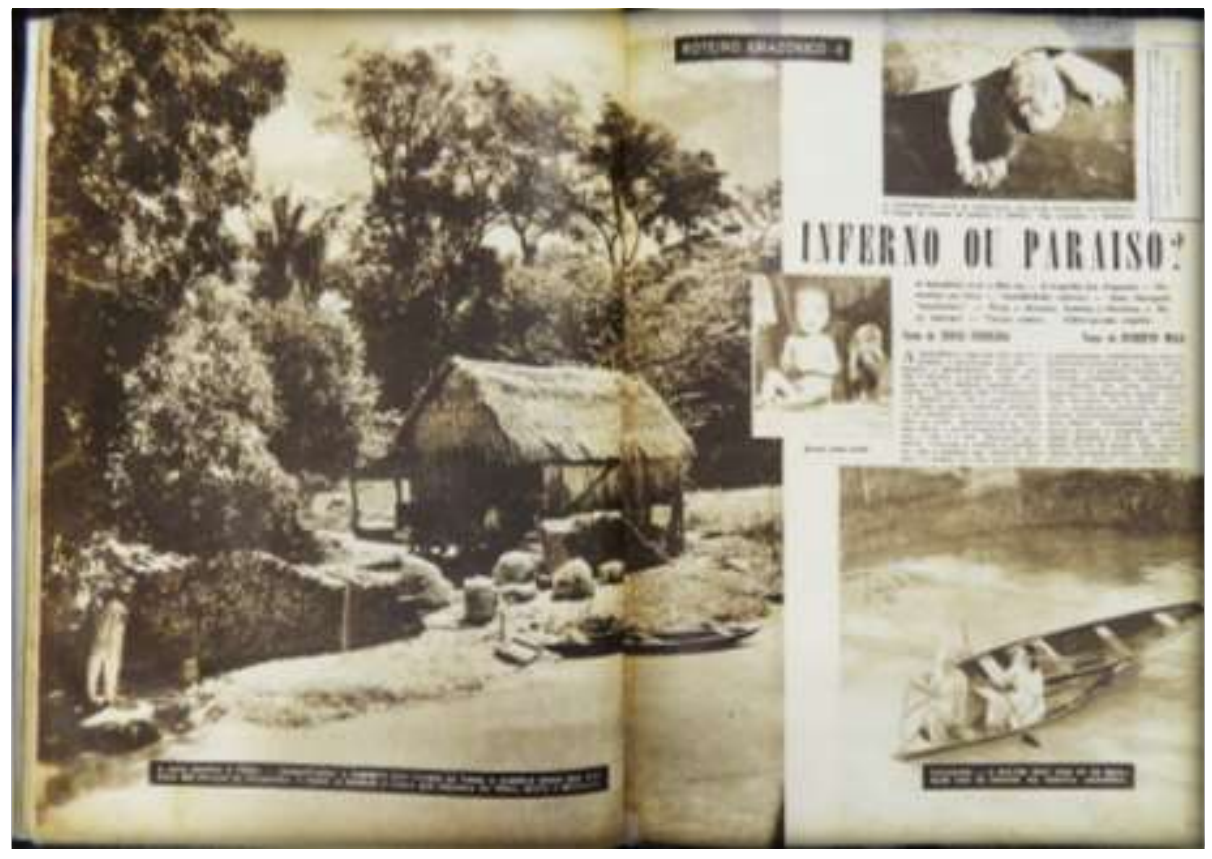

Fonte: Revista Cruzeiro, 22 de julho de 1950. Acervo CDHIS.

Figura 88. As Damas do roncador.

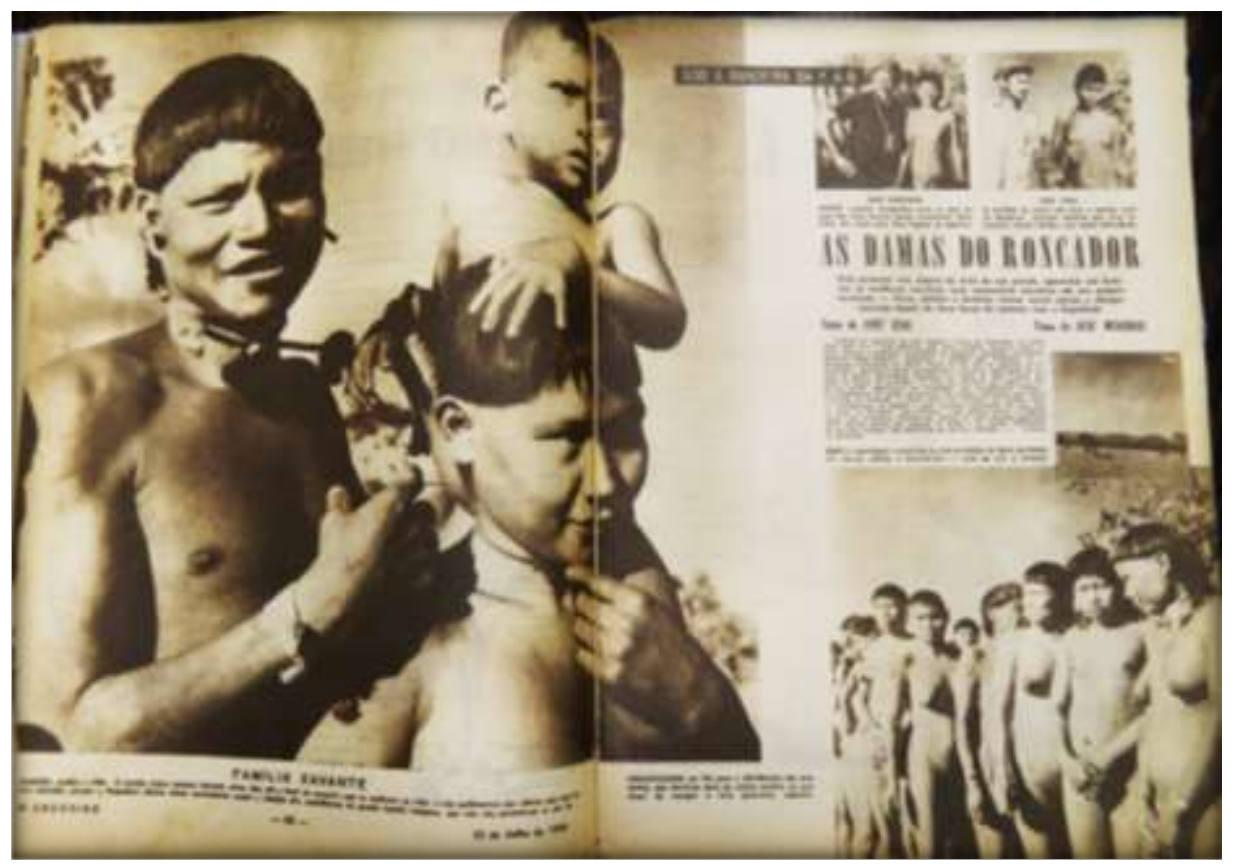

Fonte: Texto de José Leal e imagens de José Medeiros. O Cruzeiro, 22 de julho de 1950. Acervo CDHIS. 
"Pela primeira vez, depois de mais de um século, aparecem aos brancos as mulheres xavantes num memorável encontro em seu próprio território", as imagens de José Medeiros apresentavam as mulheres, em uma nudez curiosamente permitida - uma vez que, no interior da revista, apenas alguns perfis com uma nudez sugerida, eram publicados, mas, para o corpo do indígena, a apresentação do corpo nu acontecia sem o uso de artifícios visuais.

Interessante notar que, pouco mais de quarenta anos antes, Euclides da Cunha havia descrito em Paraíso Perdido, uma Amazônia que não considerava inóspita, mas sim exótica e primitiva:

Desaparecem as formas topográficas mais associadas à existência humana. Há alguma cousa extraterrestre naquela natureza anfíbia, misto de águas e de terras, que se oculta, completamente nivelada, na sua própria grandeza. [...] A evolução é, desse modo, tangível. Delatam-se até os nomes originais, extravagantes alguns, mais eloqüentes todos, das primitivas e das recentes fundações. $\mathrm{Na}$ terra sem história os primeiros fatos escrevem-se, esparsos e desunidos, nas denominações dos sítios. De um lado está a fase inicial e tormentosa da adaptação, evocando tristezas, martírios, até gritos de desalento ou de socorro; e o viajante lê nas grandes tabuletas suspensas às paredes das casas, de chapa para o rio: Valha-nos Deus, Saudade, São João da Miséria, Escondido, Inferno... De outro um forte renascimento de esperanças e a jovialidade desbordante das gentes redimidas: Bom Princípio! Novo Encanto, Triunfo, Quero Ver! Liberdade, Concórdia, Paraíso... (CUNHA, 2000, p. 146, 154-155)

Embora não a veja como "inóspita", ela aparece como imenso obstáculo ao processo de civilização. Segundo Euclides da Cunha "A flora ostenta a mesma imperfeita grandeza"; a fauna por outro lado é "singular e monstruosa"; o rio "É um estranho adversário, entregue dia e noite à faina de solapar a sua própria terra" (CUNHA, 2000, p. 116 - 120).

E eis aí a principal percepção de Euclides sobre a Amazônia: tratar-se-ia de um lugar sem História, em razão da ínfima e movediça presença humana. A natureza selvagem e incontrolável, impedia ao homem sua fixação: “Aquela natureza soberana e brutal, em pleno expandir das suas energias, é uma adversária do homem" (CUNHA, 2000, p. 125). Sem homem e sem cidades, não haveria civilização e sem civilização, não haveria história.

A impressão dominante que tive, e talvez correspondente a uma verdade positiva, é esta: o homem, ali, é ainda um intruso impertinente. Chegou sem ser esperado nem querido - quando a natureza ainda estava arrumando o seu mais vasto e luxuoso salão. E encontrou uma opulenta desordem. [...] As gentes que a povoam talham-se pela braveza. Não a cultivam, aformoseando-a: domam-na. $\mathrm{O}$ cearense, o paraibano, os sertanejos nortistas, em geral, ali estacionam, cumprindo, sem o saberem, uma das maiores empresas destes tempos. Estão amansando o deserto. E as suas almas simples, a um tempo ingênuas e heróicas, disciplinadas pelos reveses, garantem-lhes, mais que os organismos robustos, o triunfo na campanha formidável. (CUNHA, 2000, p. 116, 146) 
Tal e qual o elemento humano no discurso sobre a África, o elemento humano indígena, da Amazônia, era apresentado a partir da chave do exótico e do selvagem. Será sua distância em relação aos moldes da civilização que serão destacados: a nudez, as vestes cerimoniais, as danças, os objetos. Quanto mais isolados, quanto mais alheios aos costumes da civilização, mais interessantes se tornavam para as lentes dos fotógrafos da revista.

A natureza e os costumes considerados primitivos, eram temas frequentes dos elementos selecionados para as fotografias. Algumas dessas matérias renderam imagens icônicas como a fotografia de um índio que apontava sua flecha para cima, como que querendo alvejar o avião que sobrevoava sua aldeia, avião no qual, encontrava-se a equipe de reportagem e o fotógrafo Jean Manzon, da Cruzeiro que registrava a cena. ${ }^{129}$

Temas polêmicos, que polarizavam a opinião pública, eram acompanhados em séries, que seguiam por vários exemplares, como o romance e o casamento entre o sertanista Ayres Câmara Cunha e a índia Diacuí, explorando as imagens da índia em meio aos seus e ao seu espaço entre os anos de 1952 e 1953. Tais imagens representam uma estética do outro, na qual, o índio, em particular é tomado como objeto de curiosidade, e não como um indivíduo, um igual. Para Costa, em geral as imagens selecionadas revestiam-se de um interesse particular, seja em função da raridade ou do inusitado do assunto tratado (COSTA, 2004, s/n). ${ }^{130}$

Nas fotografias, o foco não era somente para os corpos nus, trazendo apenas adornos e adereços, mas para as ações cotidianas: como pescam, como processam o que comem, quem trabalha, como vivem. Um olhar de curiosidade mais antropológica podia ser notado nas matérias da segunda metade dos anos quarenta em diante.

\footnotetext{
${ }^{129} \mathrm{Na}$ dissertação de mestrado Bem na foto: A invenção do Brasil na fotografia de Jean Manzon, a autora cita a imagem, interpretando-a como uma analogia da oposição entre civilização e barbárie. MARTINS, Ana Cecilia Impellizieri de Souza. Bem na foto: A invenção do Brasil na fotografia de Jean Manzon. Dissertação de Mestrado. Pontifícia Universidade Católica do Rio de janeiro, RJ, 2007.
}

130 Tamanha seria a insistência com o tema, que acompanhara o casal, do namoro, quando se conheceram na tribo, até o casamento, a vinda de Diacuí para a cidade e a fatídica separação, que na edição da Manchete de 23 de maio de 1953 , lia-se uma matéria sobre dois jovens índios de uma tribo de Goiás, que circulavam por Copacabana. A matéria falava sobre a vida dos dois rapazes, que perambulavam pela cidade e que haviam sido presos, por não terem documentos ou endereço. Na legenda da foto central, onde um guarda fardado postava-se em pé segurando os meninos, um em cada braço, lia-se: O público, saturado de Diacuí, não dá bola para Potuca e Dorica. Revista Manchete, 23 de maio de 1953, $\mathrm{s} / \mathrm{n}$. 


\subsubsection{Nordeste}

Com o Nordeste não seria muito diferente. Os recantos do Nordeste, tal qual o Amazonas, se transformariam em cenário exótico, por sua natureza selvagem, mas, muito mais atraentes por preservarem uma cultura desconhecida, ou pouco conhecida, pelos leitores do Brasil moderno.

Em matéria publicada na Folha da Manhã, em 1933, podemos observar esta percepção do sertão nordestino como universo exótico e distante:

Nada como as grandezas e as misérias do interior bahiano espanta mais o indivíduo acostumado às pompas e ao conforto das grandes cidades do Sul do Brasil. Mas o contraste não é unicamente violento em relação ao Rio ou a São Paulo. Em relação também a própria cidade de Salvador. [...] Antes de tudo, sente-se a grandiosidade da natureza. "Chega até o automóvel que galopa o cheiro do matto molhado, aquelle cheiro de selva e de "jungle" que se respira nas páginas de Kipling." Grandezas e Misérias do interior da Bahia. Donatello Greico, enviado especial das Folhas na excursão presidencial._ ${ }^{131}$

Como o olhar do turista, que se constrói por meio da diferença e do contraste ${ }^{132}$, em relação a uma imagem de Brasil-moderno, o Nordeste e a Amazônia seriam, sem dúvida, o contraste, o inverso, o "outro". Dessa forma, assumindo que um mesmo objeto pode adquirir diferentes conotações, e constituir deferentes representantes, se por um lado o imaginário sobre o Nordeste era composto por um conjunto de representações de conotação negativas, voltadas para o flagelo das secas e a esterilidade do solo, também possuía um outro conjunto de representações que o apresentavam; composto por imagens do potencial produtivo e também por sua riqueza para o 'olhar do turista'. A capacidade física e humana do Nordeste apresentar para o Brasil-moderno um mundo exótico, de contraponto, constituía-se em um de seu campo de representações.

Há que se atentar ainda para o fato de que a questão da construção de uma identidade nacional ainda estava em aberto, o que possibilitou aos temas ligados à cultura ganharem destaque, tornando-se um caminho para a reflexão de um povo sobre si mesmo. Assim, após a mudança na linha editorial da Cruzeiro, há uma predominância dos temas ligados à cultura e ao povo brasileiro;

131 Folha da Manhã, sexta-feira, 01 de setembro de 1933. Acervo Folha. Disponível em http://acervo.folha.com.br/fdm. Acesso em 10 de fevereiro de 2010.

132 Kubalek, Paul. Chelsea College of Arts and Design. MA Grafic Design Communications, 2008. Acesso em 10 de maio de 2011. Disponível em http://www.kubalek.at/download/KubalekPaul-MAGDCTheTouristGazeEssay_end.pdf 
passaram assim a ser frequentes matérias cujos temas circulam entre a cultura tradicional do povo baiano, a religiosidade, o modo de vida, o passado; mas também sobre a imperscrutável Amazônia, no qual, nas palavras de Euclides, "o homem parecia um intruso impertinente"133.

A Cruzeiro assumia uma leitura mais antropológica sobre o Brasil, ocupando-se mais dos costumes, das crenças e práticas sociais do que dos assuntos ligados à agenda da alta sociedade.

Se a Amazônia-paraíso, ou a Amazônia-inferno, que com sua flora potente impedia a chegada do homem e da civilização, o Nordeste em seu aspecto cultural, era apresentado como lugar, no qual o tempo teria parado. Jangadeiros, pescadores, lavadeiras, compunham imagens que se remetiam a um mundo passado e não ao mundo moderno. Era o olhar sobre o passado que insistiria em permanecer.

\subsection{Cangaço - $\mathrm{O}$ western brasileiro}

Mas, de todas as imagens criadas sobre o Nordeste e o nordestino, a que mais teria marcado o universo da imprensa e dos imaginários, seria, sem dúvida, a do cangaceiro. A insistência em características como a valentia, mandonismo local, violência e defesa da honra ajuda a explicar parte desse mundo, porém analisados apenas por esses aspectos os autores acabam empobrecendo o universo do sertanejo, muito mais complexo do que realmente é apresentado.

Albuquerque, em A Invenção do Nordeste, discute esta questão apontando que:

O banditismo ou o cangaço é também outro tema que, eleito pelo "discurso do Norte" para atestar as consequiências perigosas das secas e da falta de investimentos do Estado na região, de sua não modernização, adquire uma conotação pejorativa que vai marcar o nortista ou o nordestino com o estigma da violência, da selvageria. (ALBUQUERQUE JR, 1999, p. 61)

Comentando esta situação, Albuquerque aponta que:

O cangaço e o messianismo, notadamente Canudos, participam decisivamente na construção da imagem do Norte e do nortista para as populações do sul, devido à repercussão das reportagens de Euclides da Cunha sobre o movimento, publicadas em $O$ Estado de S. Paulo. Na década de vinte, o fenômeno do Padre Cícero também reforça essa imagem de fanatismo e loucura religiosa, que o repórter Lourenço Filho, que descreve o que "vê" em várias reportagens em que as imagens e enunciados euclidianos surgem constantemente. (ALBUQUERQUE JR, 1999, p. 60) 
Albuquerque destaca o olhar lançado para o cangaço e em geral para o sertão, por meio do qual o homem e a cultura assumiam características bizarras. Comentando especificamente sobre a matéria do O Estado de S. Paulo sobre o cangaço, afirma que:

[...] seu olhar (de Lourenço Filho) assustado e racionalizante recai sobre "os quadros de bizarria, disparates e estranhamentos". Ele seleciona aquilo que sai "fora do costume", que é "exótico", o que é "típico" [...] "as mulheres que catam insetos nas cabeças dos meninos", "o costume de encostar os pés nas paredes" etc. (ALBUQUERQUE JR, 1999, p. 60)

No caso, temos que inicialmente, “o cangaço virá reforçar essa imagem do nortista como homem violento ${ }^{134}$ e do Norte como uma terra sem lei, submetido ao terror dos 'bandidos e facínoras"” (ALBUQUERQUE JR, 1999, p. 61). Todavia, o que observamos no teor das reportagens é que o cangaço produzia uma reação paradoxal da imprensa que, se por um lado o via como produto de violência bárbara, por outro, ressaltavam-se-lhe as cores heroicas, as histórias de vida de homens que tudo perderam e passaram a fazer justiça com as próprias mãos. Podemos dizer que a imprensa se remete ao cangaço, bem como o cinema também o fará, resgatando elementos que seriam de um Brasil arcaico, que só subsistiram incrustados no sertão nordestino; região que, segundo Albuquerque, delinearia, no imaginário social "um ente cultural, uma personalidade, um ethos" (ALBUQUERQUE JR, 1999, p. 87).

$\mathrm{Na}$ verdade, estamos falando sobre homens que procuravam defender seus valores, suas famílias e mesmo suas próprias vidas por meio dos recursos sobre os quais podiam lançar mão. A ausência da justiça social, de um sistema que de fato visse e tratasse a todos como iguais estimulara, desde tempos remotos, a utilização da violência e da "justiça feita pelas próprias mãos" como o único recurso para certas causas na região dos sertões nordestinos. Todavia, a violência não era o único recurso utilizado para a resolução dos problemas dos homens dos sertões, pensar que tudo se resolvia "na ponta da faca", é compreender o sertanejo como um tipo predisposto ao ataque, à violência; é vê-lo como o oposto dos homens "civilizados” do restante do país. É fundamental que se compreenda a violência, presente em vários aspectos da vida nos sertões como produto de um

\footnotetext{
${ }^{134}$ Em Raízes de Minas, Simeão Ribeiro Pires, referindo-se às características da região, resume, em poucas linhas, essa ideia: "Visavam todos a uma vida de aventuras honradas ou de assaltos, nos ermos distantes do poder real e de suas autoridades. Era o Sertão lenda. Bravio e de paixões. Em uma única palavra, o Sertão dos facinorosos na expressão de Diogo de Vasconcelos” PIRES, Simeão Ribeiro. Raízes de Minas. Montes Claros: Edição do Autor, 1979.
} 
processo, e jamais seja pensada de maneira descontextualizada. A violência é um subproduto do processo político e, como tal, não é inerente a ninguém.

Todavia, o próprio Albuquerque entende que o destaque dado ao cangaço só viria reforçar essa ideia do nortista como homem violento e do Nordeste como uma terra sem lei, submetido ao terror dos "bandidos e facínoras", tal qual nas leituras coloniais. Na opinião de Albuquerque, para os setores urbanos da região e, principalmente, fora dela, o cangaceiro é interpretado a partir da oposição litoral versus interior, ou entre espaço civilizado e espaço primitivo. As narrativas sobre os cangaceiros seguem, neste discurso, uma estrutura narrativa em que inicialmente, são adjetivados o mais pejorativamente possível (facínora, sicário, bárbaro), aproximam-no da animalidade (fera, bicho, praga), arrolam os crimes enfatizando sua gratuidade, a simultaneidade (caráter devastador, calamidade) recorrendo àqueles crimes mais arquetípicos (assassinos de velhinhos, violação de moças desprotegidas, queima de crianças assistidas por mães, castração de noivos na frente da futura esposa). Nessas narrativas o cangaço é destituído de qualquer conteúdo social, é produto de "um instinto" quase animalesco, por um prazer sádico de matar, de violar, de incendiar e de saquear. Assim, escondem-se os motivos sociais do cangaço, procurando minar a solidariedade popular e denunciar o apoio dos coronéis tradicionais a tal prática.

A leitura de Albuquerque valoriza uma das faces deste paradoxo, mas o que encontramos nas fontes foram duas faces: a do nordestino cangaceiro que "vira as costas" às leis e a do nordestino cangaceiro que, tendo sido esquecido pela lei, pelos direitos e pela ordem, envereda no cangaço.

Em 1937, a Vamos Lêr! trazia a seguinte matéria, publicada pouco tempo depois do brutal confronto que redundou nas mortes de Lampião e sua companheira, Maria Bonita:

A HISTÓRIA SOCIAL DO CANGAÇO: O cangaço e o quadro social das caatingas - Do patriarca rural ao coronel político - Um padre cangaceiro, do Século XIX - A valentia de Antonio Thomaz - Brigas de família e código de honra cabocla - Antonio Silvino, "Lampião" e "Corisco".

O cangaço tem sua região limitada, entre o são Francisco e o Vale do Cariri, da Serra do Quicuncá a do Martins e daí à Borboruna, à Baixa Verde e à dos Dois Irmãos circunscreve-se o cenário do banditismo caboclo. É uma região fechada, ainda à civilização. Núcleos de povoação esparsos e ralos. (Vamos Lêr!', 1937, s/n)

Já de início há a apresentação do lugar distante, do "lugar exótico", como espaço fechado à civilização. Civilização aqui, tal qual no conceito de Norbert Elias, seria a herança europeia; 
assim, o sertão é tão distante do mundo tido como civilizado e urbano do Centro-Sul, quanto mais distante estiver dos valores e modelos instituídos pelas sociedades europeias do século XIX.

Pobre e inculta. Sofredora de torturas climatericas, de aridez de riqueza, desamparo subito da fertilidade tropical... o vaqueiro nasce fadado à luta áspera e contínua... compreende-se por que Euclydes da Cunha resumiu essa tragédia dizendo que o homem daí, ao nascer, é "condenado a viver". (Vamos Lêr!, 1937, s/n)

A matéria seguia identificando a natureza, mais uma vez, como responsável pelo tipo humano da região, além de ser compreendida como igualmente responsável pelo sofrimento do sertanejo. Assim, esquecendo as questões de divisão desigual de condições e recursos, restitui-se a narrativa secular do sertão como espaço sem lei:

COMO NA CALABRIA E NO FAR-WEST Só o isolamento do sertão explica a sobrevivência dos bandoleiros. Noutros países já aconteceu, de modo idêntico, justamente também em trechos de território para onde a ausência de riqueza fácil não atraiu de pronto a civilização. $O$ banditismo da Calábria, os assaltantes do "Far-west", as inquietações criminosas da Escócia resistiram enquistados em países civilizados e ricos, até que a estrada, a fabrica, a escola, os telégrafos, a policia organizada, toda a maquina enfim do progresso destroçou as suas causas complexas de retardamento.

No Brasil, o caso do cangaço tem essa mesma explicação. Apresenta-se pintado a cores próprias, mas que apenas são tiradas do meio físico e social a que se acomoda.

O SERTANEJO DISPENSA O DELEGADO. A justiça nas mãos da sociedade, retirada das mãos do indivíduo, é uma conquista do progresso dos grupos humanos. Só uma organização aparelhada torna-se possível. E, condição indispensável, é necessário também que o "espírito de autoridade pública", a abdicação a fazer justiça por suas mãos já tenha penetrado a consciência individual.

No Nordeste, o homem conta consigo mesmo para a justiça. Ela se confunde com a vingança. Cada homem está educado moralmente para essa solução. No código de virilidade do nordestino, a pena de morte está inscrita como única solução de um sem número de ofensas. (Vamos Lêr!, 1937, s/n) Recordarmos, contudo que a associação do sertão a uma terra "sem lei" sem dúvida correspondia a uma representação anterior ao fenômeno do cangaço; ela remonta ao período inicial da colonização, como já dissemos no início deste capítulo. Nas palavras de Edineila Chaves: "partindo de uma visão etnocêntrica, eles (os viajantes) imprimiam no espaço denominado sertão as insígnias da barbárie" (CHAVES, 2004, p. 151).

A violência, dessa forma, era interpretada como um produto do meio, uma consequência da ausência, não de recursos, mas de preparo daqueles indivíduos para uma vida civilizada em sociedade. 
Em certos casos matar é louvável. Há naquelas consciências primitivas uma idealização selvagem do herói e do bravo. Explica-se assim o fato de, em cada caboclo da caatinga, poder-se suspeitar a perspectiva de um bandoleiro: basta-lhe a sede de vingança cabocla num inimigo, ou mesmo o convite de um cangaceiro que passe pela estrada. (Revista Vamos Lêr! n 107, 1938, s/n)

Temos as histórias do Padre Pedro que, instituindo uma ética própria para julgar os cangaceiros, açoitava bandidos, desde que não fossem estupradores nem ladrões; a de Antonio Thomaz, cangaceiro antigo, filho de fazendeiro, que andava pelo sertão com seus escravos; e a de Antonio Silvino, jagunço-cangaceiro, peça importante na guerra entre duas famílias, eram também descritas como situações "bizarras" do universo sertanejo. À medida que se tornava um tema de grande apelo e curiosidade entre os leitores, o cangaço assumiria cada vez mais a condição de uma das mais fortes representações do espírito rude e violento do sertanejo. Mas a narrativa sobre os cangaceiros vai muito além de uma apresentação de comportamentos exóticos, bárbaros e violento, nas páginas das revistas, e para além delas, nas telas das galerias de arte e nas telas dos cinemas, o cangaceiro seria representado como o bandido-justiceiro, como no tipo, descrito por Hobsbawn em sua análise sobre o banditismo social:

O ponto básico a respeito dos bandidos sociais é que são proscritos rurais, encarados como criminosos pelo senhor e pelo Estado, mas que continuam a fazer parte da sociedade camponesa, e são considerados por sua gente como heróis, como campeões, vingadores, paladinos da justiça, talvez até mesmo como líderes da libertação e, sempre como homens a serem admirados, ajudados e apoiados. É essa ligação entre o camponês comum e o rebelde, o proscrito, o ladrão, que torna o banditismo social interessante e significativo. (HOBSBAWN, 2001, p. 33)

Observando o texto, é possível perceber que diferentes personagens poderiam ver no cangaço elementos com os quais se identificassem, fossem fazendeiros ou miseráveis; bandoleiros ou simplesmente seus ajudantes ou simpatizantes; os sertanejos identificar-se-iam com o cangaço. É importante, porém, ressaltar que se, por um lado, o cangaceiro tornava-se o representante do espírito violento do sertão, por outro - tomando-se, por exemplo, as Histórias de Cordel - notamos que o cangaceiro passaria, no imaginário sertanejo a identificar-se com a figura do herói renegado, do justiceiro, justamente por encontrar-se o sertão alijado, não das benesses do pensamento civilizador, mas de um projeto democrático de desenvolvimento e educação.

Dessa forma, retomando a narrativa de Albuquerque Jr., concordamos com sua perspectiva parcialmente, posto que, se por um lado, o cangaceiro, de fato seria o representante da barbárie, da violência, da ausência de valores civilizados, como aponta o autor ao fazer a leitura do cangaço 
pelas lentes da imprensa e mesmo da literatura, não podemos negar que tanto para os sertanejos, como para uma parte dos leitores do Centro-Sul, como constatamos nas revistas semanais, o cangaceiro era também uma espécie de anti-herói, justiceiro em um sistema desregrado - e não em uma cultura desregrada ${ }^{135}$.

O fascínio pelo cangaço e por seus líderes pode ser percebido ao observarmos as matérias na imprensa escrita - jornais e revistas. Virgulino Ferreira da Silva, o Lampião, foi o representante mais significativo do ciclo do cangaço no Brasil. Lampião foi o "monarcha" do cangaço de 1920 a 1938 quando, junto com seu bando e sua companheira, Maria Gomes de Oliveira, a Maria Bonita, foi morto pela volante, liderada pelo Tenente João Bezerra e pelo Sargento Aniceto Rodrigues da Silva em Angico, no sertão de Sergipe. Com a morte de Cristino Gomes da Silva Cleto, o cangaceiro Corisco, o vingador de Lampião, em 1940, chega ao fim o ciclo do cangaço e começa a mitificação desses personagens.

O jornal O Povo, de 04 de junho de 1928, trazia em destaque a reportagem de página inteira, cedida pelo A Noite, intitulada A palavra de Lampeão. O manarcha selvagem dos Sertões, na qual o próprio rei do cangaço afirmava: "Não sou cangaceiro por maldade minha, mas pela maldade dos outros" (O Povo, 1928, online).

Lampião é chamado pelo jornal de "terror das polícias" e "flagello das populações sertanejas". A entrevista é longa e, nela, o capitão dos cangaceiros falava de sua infância, de sua entrada para o cangaço, que segundo ele, sempre existira nos sertões, e também sobre sua relação com a imprensa. A matéria, trazia o subtítulo: "Episódios romanescos da vida do Quadrilheiro Famoso" ${ }^{136}$, começava de forma literária:

Cahia o crepúsculo sobre o escampado arido e esbrazeado daquelle recanto sertanejo do Estado do Ceará. Do pé da serra do Araripe o engenho de rapadura Boavista, a cinco léguas da cidade de Missão Velha, quando o senhor José Alves Feitosa ali chegou [...] gentis e acolhedores, os senhores de engenho o receberam, prodigalisando-lhe o conforto de uma hospedagem, onde elle repousaria da viagem exhaustiva.

Ahi, foi que se approximou de Lampeão.

Este assomara a porta, desarmado, fitando o recém-chegado, que o interpellou logo: - É o capitão Virgulino Ferreira?

135 O cangaceiro na obra de Glauber Rocha terá exatamente este perfil, será o anti-herói, cumprindo uma missão messiânica, como aponta o próprio Albuquerque. Porém, não somente no sertão western do cinema é que o cangaceiro assume a face de herói, de vingador, também a imprensa, várias vezes dar-lhes-á este tratamento, como pôde ser observado nas matérias de Manchete, O Cruzeiro e Vamos Lêr!

136 Jornal $O$ Povo, segunda-feira, 04 de junho de 1928, p. 05. Entrevista escaneada e disponível em http://www.opovo.com.br/extras/80anos/entrevistas/lampiao.pdf. Acessado em 10 de maio de 2008. 
- A's suas ordens.

- Já o conhecia através de photographias.

- Ah! Foram esses retratos, de que o senhor fala, que me inutilizaram. Si não tivesse deixado photographar-me, seria desconhecido e já poderia ter desaparecido, sumindo-me no mundo, indo para longe, ganhar a vida tranquilamente, sem attribulação dessa angustia constante de ser perseguido... (O Povo, 1928, online)

Lampião se refere às fotos tiradas por Benjamin Abrahão Botto, fotógrafo do Correio Cearense. Abrahão foi secretário do Padre Cícero em Juazeiro do Norte e conheceu Lampião em 1926, quando aquele fora até lá para receber a patente de capitão, concedida por Arthur Bernardes após solicitação do próprio padre Cícero. Após a morte do padre Cícero em 1934, Benjamim solicitou a Lampião permissão para acompanhar o bando e filmar-lhes o cotidiano. Em As encenações da História, Schwarzman define este tipo de atividade como:

Atividade dos "cavadores", comum no cinema brasilero entre os anos 1910 e 1930. Esses "mascates de vista", como eram chamados, eram em grande parte estrangeiros e faziam filmes por encomenda sobre as cidades, filmes de propaganda, filmes de família, ou propunham temas de interesse, como apresentar a imagem de Lampião e seu bando, assunto que suscitava grande curiosidade popular. (SCHWARZMAN, 2003, p. 179) ${ }^{137}$

O trabalho de Benjamin, após concluído, foi recolhido pelo Departamento de Imprensa e Propaganda do governo Vargas, que via no filme um risco em razão da imagem heróica e valente que este construía em torno da figura de Lampião ${ }^{138}$. Mas a matéria prossegue e, dando sequência à fala de Lampeão sobre a questão do fim de sua privacidade, a partir do momento em que se tornou "pessoa pública”, segue-se suas reflexões sobre as relações de fidelidade:

- E o senhor é perseguido? Dizem na capital que a polícia...

- ... não persegue porque sou amigo dos officiaes. É verdade, mas, ainda sim, as trahições, o senhor comprheende.

No ano passado, Esaías Arruda, meu grande amigo, chefe político cearence, surprehendeu-me numa tocaia [trecho ilegível] deste Estado com um cerco policial terrível, de que me livrei não sei como. Estas cousas são que magoam... uma traição, o diabo!

137 Ressaltamos que a curiosidade que se tinha sobre a vida dos cangaceiros não existia somente entre o povo, também a intelectualidade compartilhava deste sentimento. Na literatura, vários foram aqueles que se dedicaram a desvendar um pouco da alma do sertanejo, por meio da recriação do universo do cangaço. O primeiro seria Franklin Távora, com seu "O Cabeleira", nos anos de 1920, teríamos "Cangaceiros" de José Lins do Rego, e ainda Seara Vermelha, este, de Jorge Amado, fortemente marcado pela ideologia do partido comunista. Apenas destacando a continuidade do interesse pelo cangaço, temos ainda Memorial de Maria Moura, de Rachel de Queirós, de 1992.

$138 \quad$ Pouco tempo depois de apreendido o material, Benjamin foi assassinado com quarenta e duas facadas. $\mathrm{O}$ crime nunca foi esclarecido e a história do cinegrafista acabou sendo transformada em filme, em 1999; Baile Filmado, dirigido por Paulo Caldas e Lírio Ferreira conta a história de Benjamin lançando um olhar não apenas sobre o que teria sido o cotidiano entre o bando de Lampião, mas tentando entender o universo do sertão nordestino. Sobre o assunto, ler Schwarzman, 2003, p. 165-182. 
Gosto dos officiaes e odeio os chefes de polícia [...] (O Povo, 1928, online)

A entrevista vai dando ao público a imagem de um homem que não é avesso à lei, e sim ao abuso de poder; e que, de certa forma, acabou por trilhar o caminho do crime em virtude das ações daqueles que teriam submetido sua família a uma tragédia:

- Disse-me, ha pouco, que se pudesse abandonaria o cangaço...

- Sim. Por que eu não vivo a vida do cangaço, por maldade minha.

É pela maldade dos outros, dos homens que não têm a coragem de lutar corpo a corpo como eu e vão matando a gente na sombra, nas tocaias covardes.

Tenho que vingar a morte dos meus paes. Era meninote quando os mataram. Bebi o sangue que jorrava do peito de minha mãe e, beijando-lhe a bocca fria e morta, jurei vinga-los...

É por isso, que de rifle ás costas, cruzando as estradas do sertão deixo um rastro sangrento na procura dos assassinos de meus paes.

Não ficou no assassinato de meu pae e de minha mãe, a maldade dos homens, a quem deve a sociedade responsabilizar pelos meus crimes?

Os meus inimigos que não têm coragem de matar-me, assassinam cruelmente os meus parentes, como ha pouco mataram uma tia minha e duas irmães...

É por isso que eu sou cangaceiro.

Não sei quando hei de deixar os horrores desta vida onde o maior encanto, a maior belleza seria extinguir a maldade daquelles que roubaram a vida de minha mãe e de meu pae e de minhas irmães. [...] (O Povo, 1928, s/n)

O destino trágico, a valorização da fidelidade nas relações fraternais e o amor à família, são elementos que aparecem na entrevista e que recriam nitidamente o perfil de um herói errante. Esta é uma representação do cangaceiro, muito presente, não apenas na imprensa nordestina, mas também do Sudeste, sendo que é percebida mais significativamente nas matérias de variedades, nas revistas semanais dos anos quarenta e cinquenta. Dentre as artes plásticas, a série Retirantes, de Cândido Portinari, teria ganho grande projeção. Durante os anos de 30 e quarenta, Portinari teria exposto sua obra no Pavilhão Brasil da Feira Mundial em Nova Iorque de 1939 e no Museu de Arte Moderna de Nova Iorque (MoMA), além dos famosos murais para a Biblioteca do Congresso em Washington. É esse Portinari, já consagrado internacionalmente que, Em 29 de abril de 1944, a página de abertura da Revista Cruzeiro era feita por uma matéria escrita por Otto Maria Carpeaux, intitulada "Evolução de Portinari”" (figura 89) Nela, o jornalista apresentava suas impressões diante de duas das telas da coleção "Retirantes", de Portinari:

Portinari gosta de surpreender-nos. [...] Uma tarde, soubemos, descobrimos no atelier nova surpresa - um grande quadro de assunto social, representando uma família de retirantes. "Gente pobre", disse o mestre, e abandonou-nos às impressões subjetivas. Uns se assustaram, outros, declararam este 
quadro a obra-prima do pintor. Confesso que me inclinava para o lado destes outros; mas, poucos dias depois, veio outra surpresa, representando o mesmo assunto, agravado por um menino morto; e senti irresistivelmente que esta segunda realização era ainda maior. (Revista Cruzeiro, 29 de janeiro de 1944, p. 02)

O jornalista segue dissertando sobre a capacidade de Portinari impressionar com sua técnica. Para Carpeaux, as pinturas de Portinari sempre trazem um tema, e por isso, tocam fundo o observador, mas ainda impressionado pelo menino morto, ele continua a argumentação:

O que importa, parece é o conteúdo do assunto. [...] Quero apenas chamar a atenção para certos detalhes formais, dos quais depende - em parte - a impressão que atribuímos ao assunto, e que constituem, ao mesmo tempo, diferenças decisivas entre a "Gente pobre" e o "Menino morto". "Gente pobre". O quadro é realizado como as "Santas Famílias" dos velhos italianos: grupo de família, de composição fechada, contrastado contra o fundo duma paisagem. O motivo quase religioso é tanto mais impressionante quanto as deformações corporais das pessoas são detalhes naturalistas, consequência da miséria, da fome, de doenças mortais. [...] "Menino morto". Lembroume logo outro motivo dos velhos italianos: a "Pietá". O centro, aqui, é a mãe com o pequeno morto no colo. Aqui também, uma das pessoas se afasta, um pouco, do conjunto; é a criança à direita, que olha fora do quadro e parece perguntar: "Quando soa a minha hora?" Mas essa impressão aqui é muito menos forte, o quadro mais silencioso. (Revista Cruzeiro, 29 de janeiro de 1944, p. 02)

Em 1952 colaboraria em uma belíssima publicação da Cruzeiro, tendo o cangaço por tema.

Na edição de 01 de novembro de 1952, lia-se em um pequeno boxe, no canto inferior direito da revista o seguinte anúncio:

A partir do próximo número, a revista O CRUZEIRO dará início à publicação do romance de José Lins do Rêgo - CANGACEIROS, a mais dramática interpretação do homem sertanejo na sua vida de crime organizado - e cangaço. É um homem da terra escrevendo sobre um dos fenômenos sociais de maior repercussão na vida brasileira. Para ilustrar os capítulos dêsse romance, a revista $\mathrm{O}$ CRUZEIRO convidou Cândido Portinari, que realizou um verdadeiro mural sobre a terra e os cangaceiros. Êsse romance será publicado em rotogravura em cores. (O Cruzeiro, 01 de novembro de 1952, p. 36)

Apresentadas sempre em páginas duplas, (figura 90 a 93) em impressões coloridas, as ilustrações de Portinari traziam cenas que conferiam contexto e movimento ao boxe com o texto de José Lins do Rêgo. Cenas típicas das histórias contadas pelos jornais e pela tradição popular da época. Cenas de emboscadas; de despedidas entre o cangaceiro e sua amada; cenas da vida cotidiana do sertanejo, que sentado à porta, conta os causos sobre os feitos de Lampião. 
Figura 89. Evolução de Portinari.

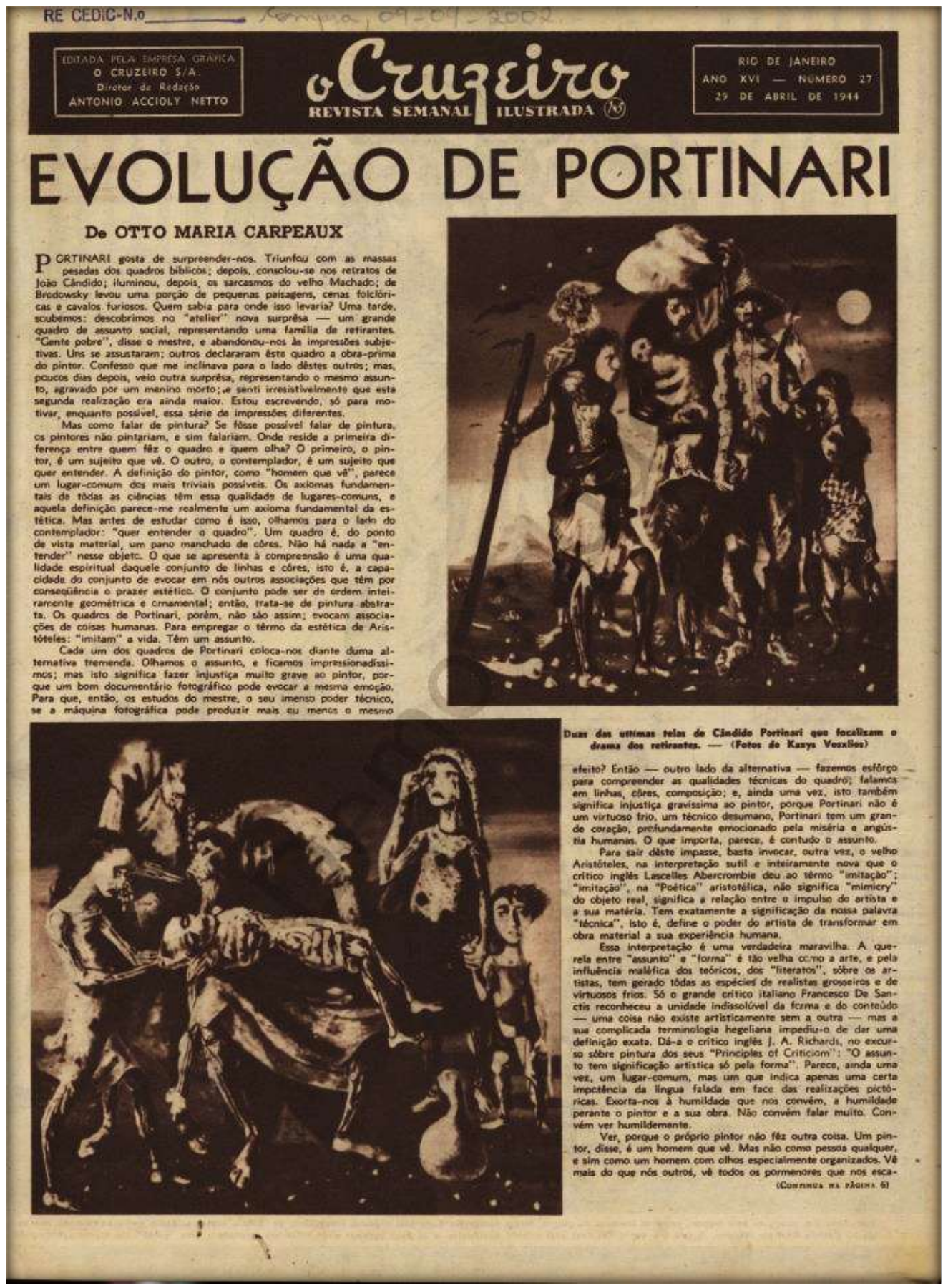

Fonte: Revista Cruzeiro, 29 de janeiro de 1944, p. 02CEDIC PUC. 
Figura 90. Cangaceiros.

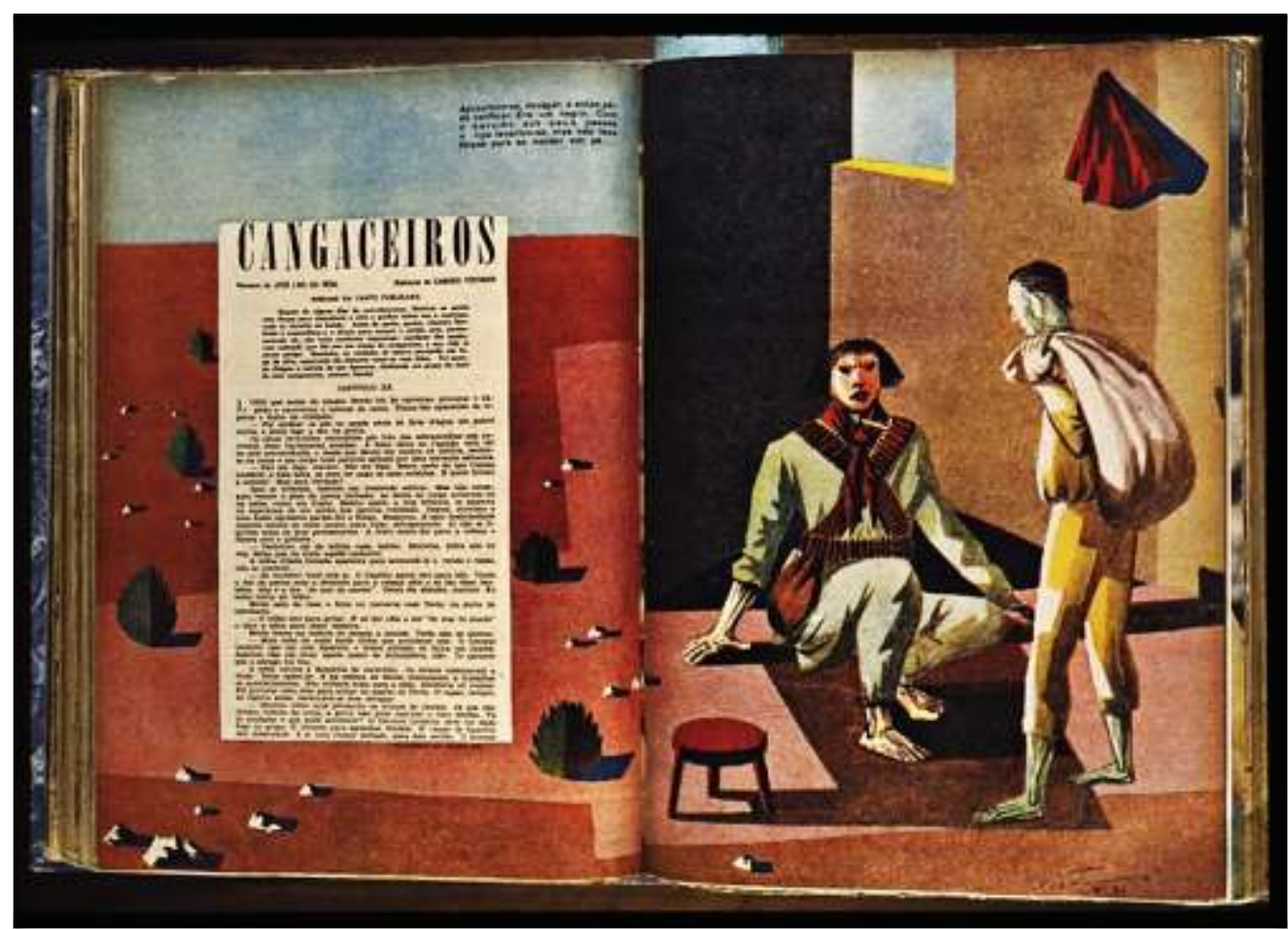

Fonte: Novela de José Lins do Rêgo, ilustrada por Cândido Portinari e editada pela Revista O Cruzeiro. 29 de novembro de 1952, Capítulo XX.

Figura 91. Cangaceiros.2

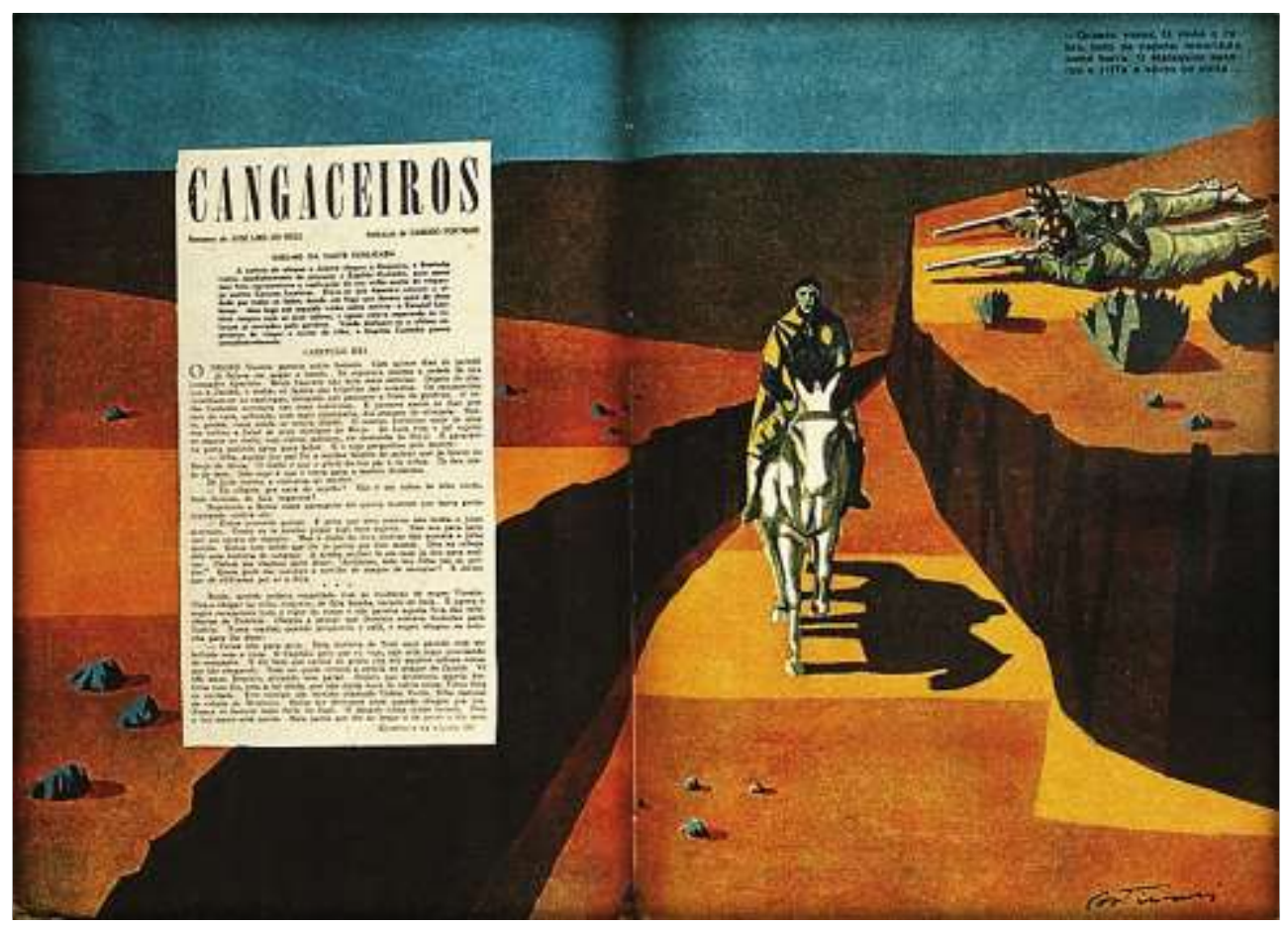

Fonte: Novela de José Lins do Rêgo, ilustrada por Cândido Portinari e editada pela Revista O Cruzeiro. 06 de dezembro de 1952. Capítulo XXI 
Figura 92. Cangaceiros.3

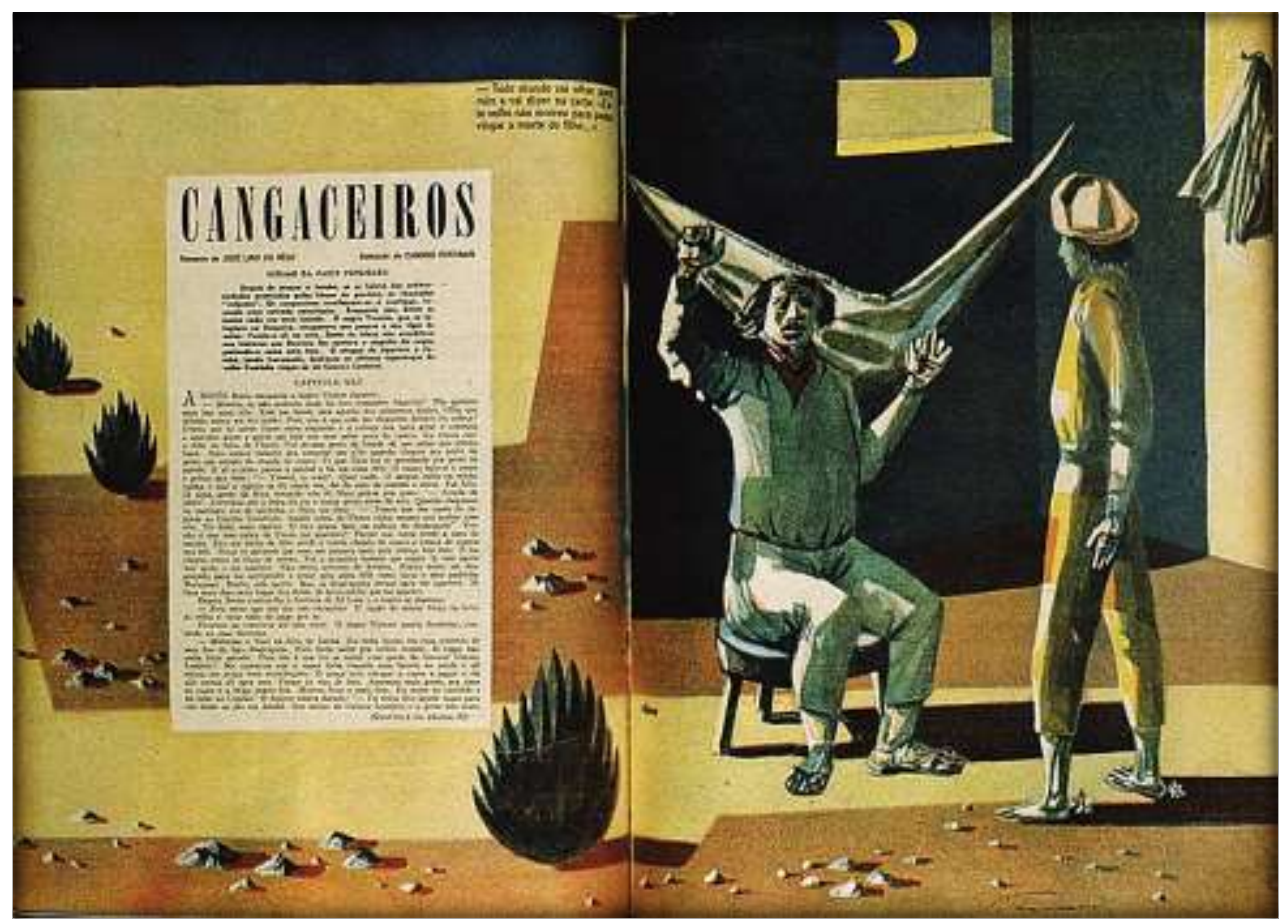

Fonte: Novela de José Lins do Rêgo, ilustrada por Cândido Portinari e editada pela Revista O Cruzeiro, 13 de dezembro de 1953. Capítulo XXII

Figura 93. Cangaceiros.4

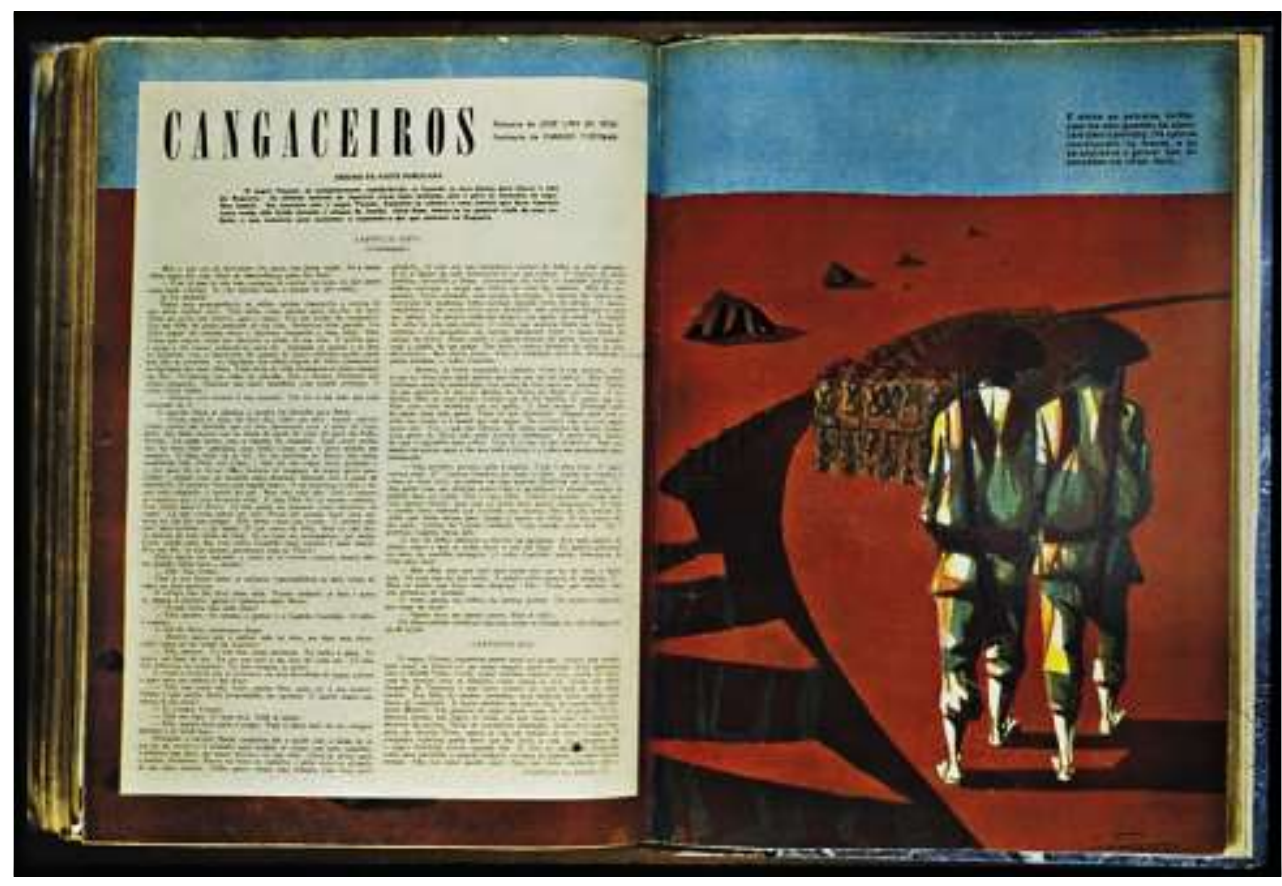

Fonte: Novela de José Lins do Rêgo, ilustrada por Cândido Portinari e editada pela Revista $O$ Cruzeiro, 1953. Capítulo XXVI. Lampião Aceso. Acesso em 10 dez 2013. Disponível em: http://lampiaoaceso.blogspot.com.br/2010_11_01_archive.html. 
No romance, a figura do cangaceiros é construída como a do anti-herói, um cavaleiro que faz justiça com as próprias mãos. Em uma sociedade onde a justiça e a igualdade não existem, o cangaceiro rouba dos ricos e acaba por ajudar aos pobres, que, embora hesitantes aceitam o dinheiro "fruto de roubo", como insiste uma das personagens, mas que seria a única saída para aqueles que se viam espoliados por governantes corruptos, como lembra Hobsbawn em Bandidos, ao iniciar sua análise sobre o cangaço no Brasil: "é melhor infringir a lei, que morrer de fome" (HOBSBAWN, 2001, p. 22).

Ainda em 1953, a reportagem de Luciano Carneiro intitulada "Porque Lampião entrou no cangaço", publicada na Revista $O$ Cruzeiro de 3 de outubro, seguia mantendo a representação de um Lampião-justiceiro; na reportagem, Carneiro buscava as razões que teriam levado Virgulino a se tornar um cangaceiro, e vai em busca de quem lhe pudesse narrar a história. ${ }^{139}$ Tendo como principal fonte a entrevista concedida a ele por João Ferreira, único irmão de Lampião que não entrou para o cangaço, Carneiro descreve a história da querela entre os Ferreira e seu vizinho José Saturnino (MILITÃO, 2013).

O tema do cangaço povoou o imaginário sobre o sertão por décadas, em 1959 a revista $O$ Cruzeiro exibia longa matéria sobre os parentes de Lampião, que reclamavam o direito à cabeça de Lampião e de Maria Bonita, que permaneciam expostas no Museu do Instituto Nina Rodrigues. O entrevistado, Antonio Ferreira de Magalhães, advogado criminalista e primo de Lampião, residente no Recife, lideravam o pedido dos mais de trezentos parentes do casal Lampião e Maria

${ }^{139}$ Em 1953, a Manchete também lançaria uma longa fotorreportagem sobre Lampião, intitulada A verdadeira história do rei dos cangaceiros, na qual além das imagens canônicas de Lampião e seu bando armado, constava também a aterradora fotografia, tirada em 1938, de suas cabeças decepadas. Apoiadas em quatro degraus, e com placas de identificação, as onze cabeças, três chapéus e o rifle de Lampião, apareciam expostos em uma feira popular no sertão Nordestino. As cabeças viajaram por várias cidades do sertão, e se tornavam uma atração por onde passavam. Sobre esse fato, disse Aurélio Buarque de Holanda:

[...] batem chapas, apressados, do povo e dos pedaços humanos expostos na feira horrenda. Feira que, por sinal, começou ao terminar a outra, onde havia carne-de-sol, o requeijão de três mil réis o quilo, [...] as pinhas doces, abrindose de maduras, [...] e as alpercatas sertanejas, de vários tipos e vários preços. [...] ao olho frio das codaques interessa menos a multidão viva do que os restos mortais em exposição [...] O espetáculo é inédito: cumpre eternizá-lo, em flagrantes expressivos. Um dos repórteres pousa espetacularmente para o retratista, segurando pequenas melenas desgrenhadas os restos de Lampião. Original. (HOLANDA, Aurélio Buarque de. Feira de Cabeças. Suplemento Cultural, Diário Oficial, Estado de Pernambuco, Ano IX, p. 15, Julho de 1995). 
Bonita, incluindo-se aí filha, netos, primos; na fala do entrevistado, novamente, mais um pouco do Lampião-herói e descrito:

Lampião era uma figura máscula e fascinante. Tinha a personalidade e o magnetismo de um verdadeiro chefe. No contato pessoal, era um homem simples e amável, dedicado a todos da sua família. Êle se tornou um "fora-da-lei" por fôrça das circunstâncias. O seu pai, que era um homem bom e pacato, sofreu perseguições sem conta, por questões políticas, e teve de mudar com tôda a família, várias vêzes, abandonando as suas terras, o que, para um sertanejo, é o pior castigo. Por fim, tendo ido viver em outro Estado, Alagoas, nem mesmo assim pôde ficar em paz. Foi assassinado pela Polícia. A mãe de Lampião morrera poucos dias antes, também em consequiência da perseguição que lhes era movida. Diante disso, Virgulino tornou-se Lampião. Não tinha para quem apelar, não tinha a quem pedir justiça. Resolveu fazer justiça pelas próprias mãos e não pôde mais parar. (O Cruzeiro, 06 de junho de 1959) ${ }^{140}$

Mas em pleno ano de 1959 a fala do entrevistado deixa transparecer uma leitura que não é mais a da frenologia ou da craniometria, Lampião é visto com um olhar sociológico a crítica é justamente quanto a insistência do Instituto em manter as cabeças de Lampião e Maria Bonita como "peças" que serviriam para uma possível compreensão científica da violência e da barbárie. Os familiares, por seu turno, desejavam justamente resgatar-lhes os direitos de cidadãos, mesmo que depois de mortos:

Êle foi um produto do meio e das condições sociais da época. Não era um tarado, um assassino nato, um lombrosiano. Uma vez morto, à traição, envenenado, pois não é verdade que tenha morrido em combate ou que tenha sido pegado desprevinido, tanto êle quanto Maria Bonita foram decapitados, como se sabe. As suas cabeças continuam, até hoje, expostas no Museu Nina Rodrigues. Agora, pergunto: por quê? Acaso todos os sêres, mesmo os criminosos executados pelas autoridades, não têm direito à sepultura? Isto é um desrespeito a um ser humano, um escárnio para todos os seus parentes, um estigma para a sua filha, que hoje está casada e vive dignamente, e para os seus quatro netos. Que pensarão essas crianças, que tremendo choque emocional terão elas quando, mais crescidas, puderem tomar conhecimento da tragédia dos seus avós e do humilhante espetáculo das suas cabeças expostas como troféus de tribos africanas? Pergunto mais: que interêsse podem ter essas cabeças mumificadas para a ciência? Se foram objetos de estudo, êsses estudos já devem ter sido feitos, pois já lá vão vinte e um anos. Quais os resultados dêsses estudos? Além do mais, que direito tem o Instituto Nina Rodrigues? (O Cruzeiro, 06 de junho de 1959) ${ }^{141}$

140 Em Memória Viva apresenta O Cruzeiro. Disponível em http://www.memoriaviva.com.br/ocruzeiro/. Acesso em 20 de junho de 2008.

141 Em Memória Viva apresenta O Cruzeiro. Disponívl em http://www.memoriaviva.com.br/ocruzeiro/. Acesso em 20 de junho de 2008 . 
A matéria segue e dá voz ao Instituto, na figura do professor Estácio de Lima, responsável pelo Museu, que concorda com a fala do familiar de Lampião, e que justamente por concordar, acha fundamental que lá as cabeças permaneçam. Explicava o professor que:

As cabeças de Lampião e Maria Bonita foram ofertadas ao Museu, há vinte e um anos, pelo Prof. Lajes Filho, catedrático da Cadeira de Medicina-Legal de Alagoas. Aqui também estão as cabeças de Corisco, Azulão, Zabelê, Canjica e Maria, todos cangaceiros. Compreendo perfeitamente os sentimentos da família de Lampião. Mas precisamos, principalmente no campo científico, nos guiar pela razão, em vez de nos deixar dominar pelo sentimento. As cabeças estão conservadas pelo método egípcio de mumificação. Elas são documentos inestimáveis de uma época da criminalidade brasileira. Daqui a cem anos, elas ainda demonstrarão que Lampião não era um assassino nato, um lombrosiano. Êle era fruto de condições sociais, políticas e econômicas. Foi uma vítima do seu tempo e do seu ambiente. Essas cabeças são uma lição de tôdas as horas de que fenômenos, como o cangaceirismo, não podem nem devem ser exterminados com armas, mas sim com a criação de fatôres que não propiciem a sua eclosão. Dizem que elas não têm utilidade científica. Então, nada do que se encontra nesse Museu tem utilidade. Temos aqui corpos inteiros mumificados, esqueletos, fetos, monstros etc. Todos os restos mortais que aqui estão pertenceram a gente que também tem parentes, ou descendente. Deveríamos nesse caso enterrar tudo, não só dêste Museu, como de todos os outros que existem no mundo, inclusive as múmias egípcias. Por outro lado, é preciso lembrar que êste Museu é um centro científico. As cabeças não estão expostas em público, nem sofrem qualquer desrespeito. Em janeiro do ano passado estiveram aqui tôdos os professôres de MedicinaLegal e Antropologia do Brasil, reunidos em Congresso Nacional. Examinaram as cabeças e nenhum foi contra a sua conservação. Elas são peças científicas, como o são, por exemplo, os cérebros de Einstein e de Lenin, também conservados. (O Cruzeiro. 06 de junho de 1959)

Embora entre a família e o Instituto a questão circule entre a relação do direito individual e dos direitos da ciência, o que nos interessa é observar que, se por um lado, o fascínio pelo cangaço permanecesse forte, por outro, nos vintes anos que se passaram, a forma de compreender o fenômeno sofrera uma visível transformação.

[...] a lembrança deles não se apagará com o sepultamento dos despojos. Como já disse, porém, não há nenhum motivo de estigmatização, pois, hoje Lampião é visto e julgado não como assassino vulgar, mas como um produto do estado de coisas na sua época e no seu meio. Sabemos que os cangaceiros eram, não só recuperáveis, como um valioso material humano. E que fizeram os que hoje gritam pelas cabeças em prol dos cangaceiros que sobreviveram, aquêles que foram irmãos de luta e de sofrimento de Lampião? Nada. No entanto, eu fiz. Escrevi relatórios pedindo o indulto para todos ao Presidente da República. Rebelei-me contra o julgamento que queriam fazer em Volta Sêca, um julgamento de adulto, provando que êle era menor e depois lhe conseguindo a liberdade condicional. Trabalhei pela recuperação de todos e pela sua integração na sociedade. Continuo em contato com êles, ajudando-os nos seus problemas. Aí estão, vivos, trabalhando decentemente, com famílias constituídas, Labareda, Saracura, Cacheado, Velocidade, Deus Te Guie e muitos outros. Sabem quem são os guardas do Museu, os homens responsáveis inclusive pelas cabeças de Lampião e Maria Bonita? Labareda e Saracura, seus antigos companheiros, adimitidos por mim como funcionários de tôda a confiança. Nenhum dos antigos cangaceiros protesta, nenhum vê qualquer 
desrespeito pelo seu antigo chefe, todos compreendem o que aqui está. Os cangaceiros, meus amigos, são homens excepcionais, corretos, leais, sem o menor perigo de reincidência no crime, pois não são anormais. Foram presos exemplares e agora são cidadãos exemplares. (O Cruzeiro. 06 de junho de 1959)

A matéria encerrava destacando-se a força da imagem de Lampião como um líder:

Lampião foi incontestàvelmente um líder, um homem de grandes qualidades de chefia, um rebelado contra um sistema de coisas que imperava (e ainda não desapareceu de todo) no sertão nordestino. Dêle disse o Major Optato Gueiros, que o combateu:

- Lampião foi um gênio militar perdido. Um grande homem que o meio e as circunstâncias tornaram bandido". (O Cruzeiro. 06 de junho de 1959)

A diferença pode parecer sutil, porém compreender o cangaço como produto de um contexto social e não como fenômeno condicionado pelo tipo de indivíduo que seria o sertanejo é uma mudança que contribuía para a visualização de uma cultura nordestina menos monolítica; a visão unilateral da miséria e da violência dava espaço, mesmo que timidamente, ao vislumbre de outros Nordestes.

Embora o tema do cangaço tenha, desde seu surgimento como fenômeno social, chamado a atenção da imprensa, dos estudiosos e das mídias, poderíamos afirmar que seria no cinema onde o cangaço, como representação do nordestino ou de uma nordestinidade encontrara o terreno mais fértil para se desenvolver, sendo explorado já na década de 1920 em duas fitas pernambucanas: Filho Sem Mãe e Sangue de Irmão. Nos anos 1930, foram rodados os filmes Lampião, Fera do Nordeste e Lampião, o Rei do Cangaço, de Abraão Benjamin (1936). Entre os anos de 1930 e 1950, o cangaço e os cangaceiros, representaria uma força ancestral; é o Nordeste primitivo, arcabouço da herança de índios e negros, brotando do interior mais recôndito dos sertões, com toda a sua fúria. Conforme Sá ${ }^{142}$ :

Em A Estética do Cangaço de Marcelo Peixoto (2000) retrata a dimensão estética do cangaço, cuja narrativa está estruturada pela fala de Frederico Pernambucano de Mello, que também assina o

142 SÁ, Antonio Fernando de Araújo. Lampião revisitado: Cangaço, cinema e identidade. Revista Olho da História. Revista de Ciência, Cultura, cinema e Sociedade. Salvador, Bahia, n.11, dezembro, 2008. A análise baseiase ainda nas pesquisas de Adriano Oliveira e de Marcelo Vieira. OLIVEIRA, Adriano Messias de. O cangaço no cinema brasileiro dos anos 90: um certo olhar sobre nossa identidade cultural. Belo Horizonte: Faculdade de Filosofia e Ciências Humanas/ Curso de Comunicação Social, 2001 (Dissertação de Mestrado). VIEIRA, Marcelo Didimo Souza. Filmes do cangaço: a representação do ciclo na década de noventa no cinema brasileiro. Campinas: UNICAMP / Instituto de Artes, 2001 (Dissertação de Mestrado). 
roteiro. Sua principal tese é que o cangaço e sua dimensão estética simbolizam o irredentismo dos primórdios da colonização, representados pelos levantes indígenas, pelos quilombos e revoluções liberais. Realizado para a Mostra do Descobrimento da Fundação Bienal de São Paulo, em 2000, o vídeo mostra que, para além do medo e do pavor, o impacto estético do traje do cangaceiro na memória daqueles que um dia o encontraram, seja pela sofisticação na utilização de jóias e perfumes, seja pela sua característica carnavalesca [...] Para Mello, a força plástica do cangaço inclusive influenciou a vestimenta das próprias forças volantes, como podemos ver em fotos de época. (SÁ, 2008, p. 07)

O cinema também abraçava o cangaço, reproduzindo materialmente o universo do cangaço com suas roupas decoradas e bordadas, chapéus e rifles (figura 94), e dando-lhe tom de drama épico, colocando em questão, mesmo que indiretamente o tema da identidade, acima de tudo, por ser esta a questão do momento; nela, nacional e regional ora se somavam ora se opunham. Temas como o futebol e o carnaval eram frequentes símbolos da brasilidade. Em seu artigo São Paulo 30 60: quatro movimentos, Samuel Kruchin, ao discutir as representações do nacional, no cinema, expões a seguinte opinião:

[...] há [...] a extensão, a impregnação do regionalismo, que marcou o panorama cultural do país a partir dos anos 30 como desdobramento e afirmação de uma identidade nacional preconizada pela modernidade. Constrói-se, portanto uma caracterização do nacional que passa obrigatoriamente pela tradução das diversas expressões regionais da cultura, consubstanciadas em tipos sociais emergentes de um quadro definido, historicamente, pelo universo arcaico, provinciano, rural: o cangaço, o caipira, o gaúcho, o caiçara. (KRUCHIN, 1989, p. 41)

A imprensa daria ampla cobertura à trajetória do filme $O$ Cangaceiro, que acabou por ser internacionalmente reconhecido, tendo seus atores - principalmente suas estrelas, Vanja Orico e Alberto Ruschel - alçados à categoria de celebridades. No caso de Vanja, em em outubro de 1953, a atriz concedeu à Manchete, uma longa entrevista, ilustrada por foto de página inteira, em primeiro plano, como ares de estrela de cinema americano (figura 95) e ainda destacando-lhe o interesse para com os estudos do folclore, tema que nos anos cinquenta ganhava cada vez mais projeção.

É bom dizer que Vanja é moça de boa cultura e talvez intelectual demais nas conversas que mantém. Fala francês, inglês, italiano e espanhol. Está descobrindo o folclore e ainda indagando tudo a todo folclorista que encontra. Indagando e recolhendo coisas, Câmara Cascudo forneceu material para a moça e disse um bocado de coisas sobre cantigas e costumes do povo brasileiro. (Revista Manchete 17 de outubro de 1953, p. 14)

Já o cineasta Lima Barreto, pretendia produzir outro sucesso, que superaria $O$ Cangaceiro. 
Figura 94. Filme: O Cangaceiro

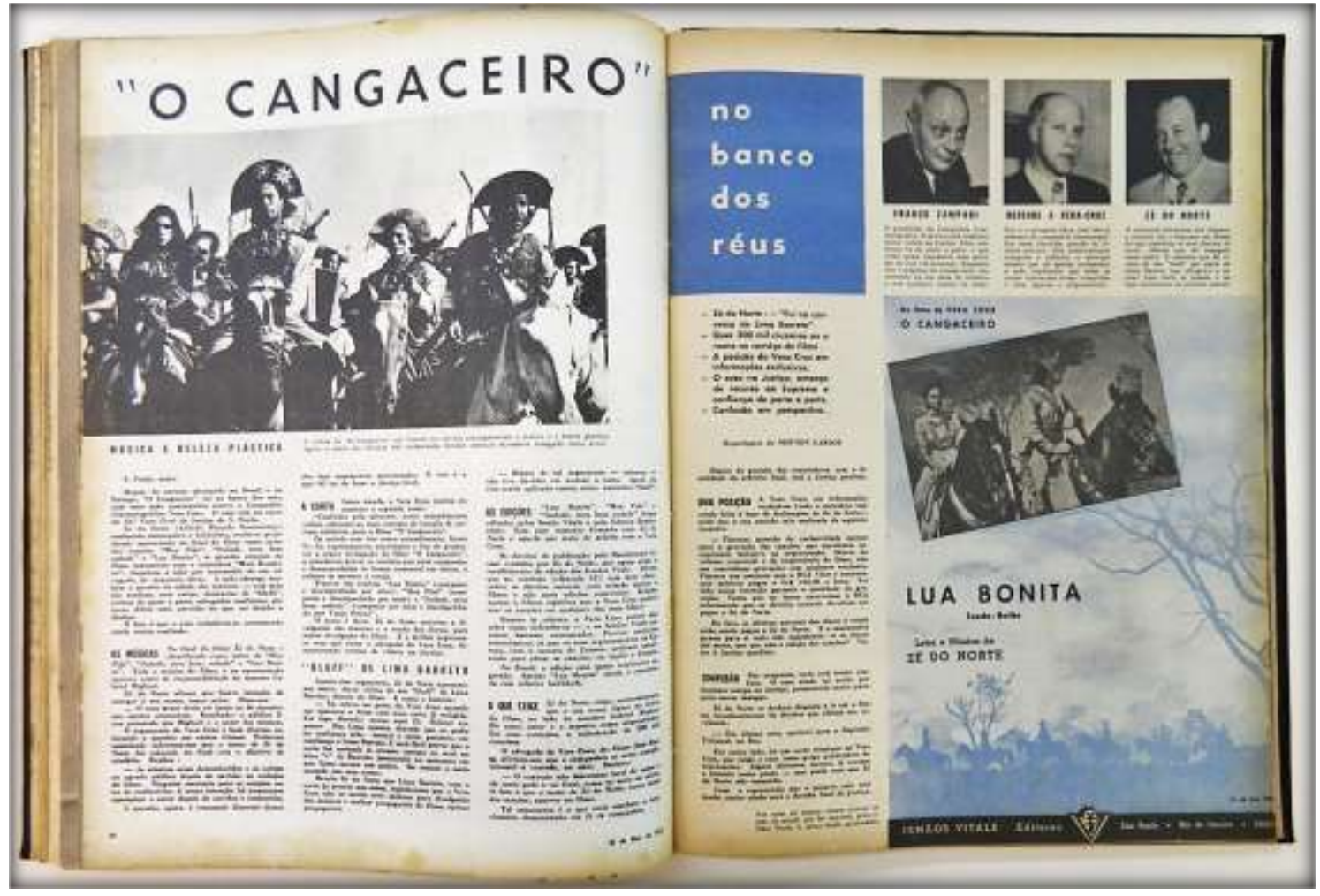

Fonte: Revista Manchete 30 de maio de 1953. Acervo Biblioteca Florestan Fernandes.

Figura 95: Vanja Orico.

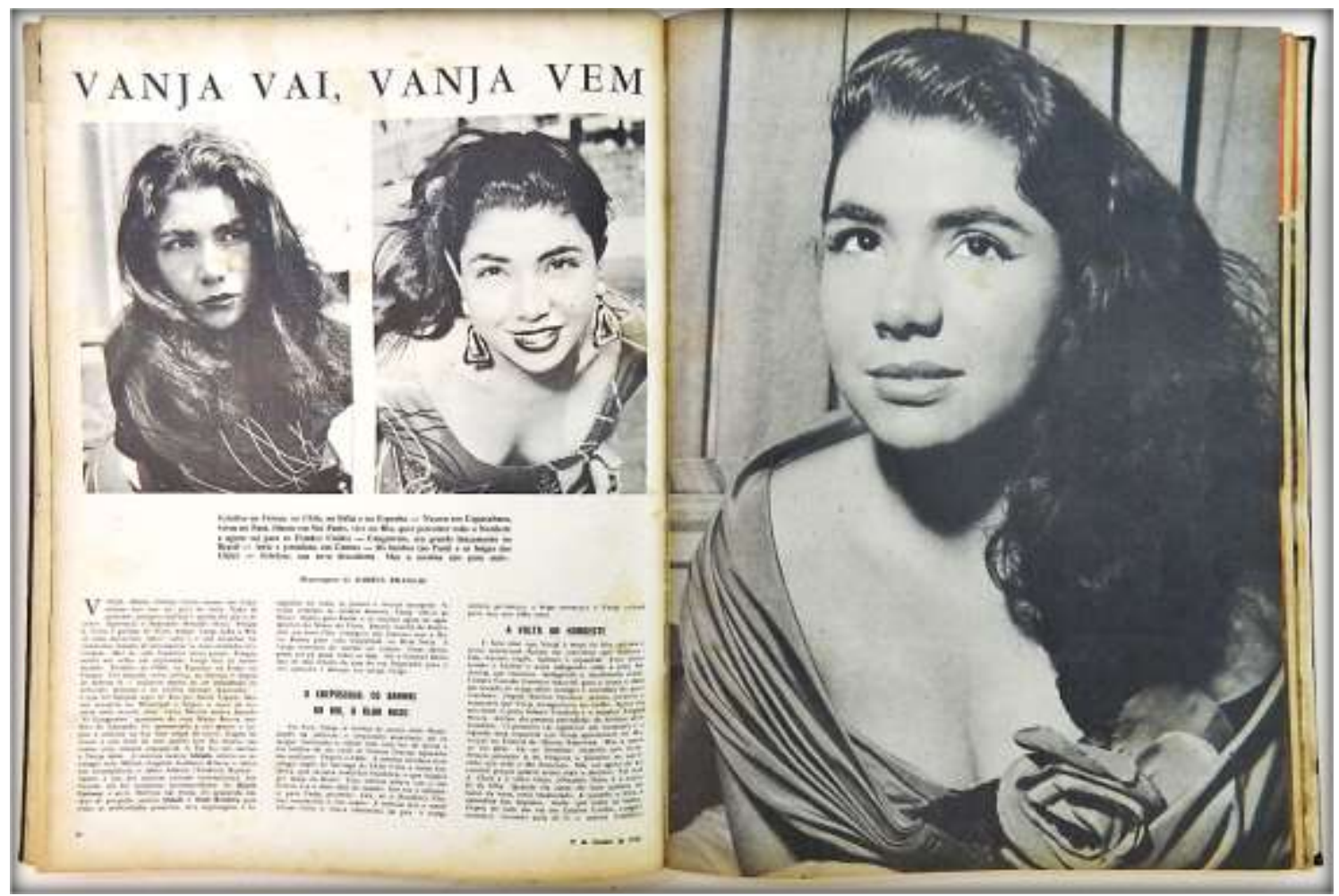


Fonte: 17 de outubro de 1953, p. 14. Acervo Biblioteca Florestan Fernandes.

Na reportagem de David Brandão com fotos de Gervásio Batista intitulada "Meu sertanejo vai abalar o mundo", a dupla entrevista Lima Barreto, e o cineasta revela suas intenções: "O sertanejo não será o filme que o Brasil espera: será o filme que o mundo necessita. Em 1956, irei à Cannes buscar o primeiro prêmio do cinema. [...] O Cangaceiro bateu todos os recordes de bilheteria no Brasil, tanto de filmes nacionais como de estrangeiros. Rendeu até agora, cerca de 40 milhões. Foram vendidos 25 milhões de entradas. Creio que não repetirei dessa vez o mesmo êxito de bilheteria, porque $O$ Cangaceiro atingiu o teto. Mas meu novo filme terá êxito muitíssimo maior.” (Revista Manchete 11 de junho de 1955.) Com o projeto de realizar gravações em locações externas, na Bahia e Ceará, O Sertanejo, enfrentou uma série de problemas financeiros que impossibilitaram a Vera Cruz a seguir com o projeto de filmar a história de Antonio Conselheiro. Após anos de tentativa, Lima Barreto acabou por desistir do projeto.

No início dos anos 1950, notícias sobre O Cangaceiro, alternavam-se com matérias sobre o que foi o cangaço, e sobre o que dele restara. Dentre essas reportagens, uma que mereceu destaque foi a da passagem de Volta Sêca pelo Rio de Janeiro. Na entrevista, o ex-cangaceiro, apresentado como uma avis rara.

O ex-companheiro de Lampião, contara à Revista Manchete que viera ao Rio acompanhado da mulher e da filhinha de dois meses - Rose Mary - a passeio, andara pela cidade, tomou cerveja mostrou vontade de conhecer Luz Del Fuego, puxara conversa com as pessoas da rua e gostou do seu nome ser tão conhecido.

Contou sobre sua vida, que nascera na Bahia, em 1928 e que entrou para o cangaço quando ainda menino. Mariano - do bando de Lampião - levou-o para ajudá-lo a levar uns animais na casa do delegado da cidade, onde o "capitão" estava sendo recebido. Tendo gostado do serviço do menino, ter-lhe-iam dado como escolha: "ou fica no bando ou morre”. Volta Sêca escolheu ficar. A partir daí descreve que tentou fugir, mas foi recapturado e novamente ameaçado, até que resolveu ficar de uma vez por todas. Curiosa, a repórter se arrisca e pergunta quantas pessoas ele teria matado, obtendo a seguinte resposta:

- "Eu não. Nunca matei ninguém. O rifle é que matava".

A matéria segue com outras histórias do ex-cangaceiro, destacando sempre a questão da imposição da vontade de Lampião e das medidas exemplares adotadas por ele contra aqueles que 
rompiam com suas normas e suas ordens. Termina contando o desentendimento de Volta Sêca com o líder, sua deserção do bando e sua captura e condenação, aproximadamente aos 14 anos de idade.

Figura 96. Volta Sêca no Rio.

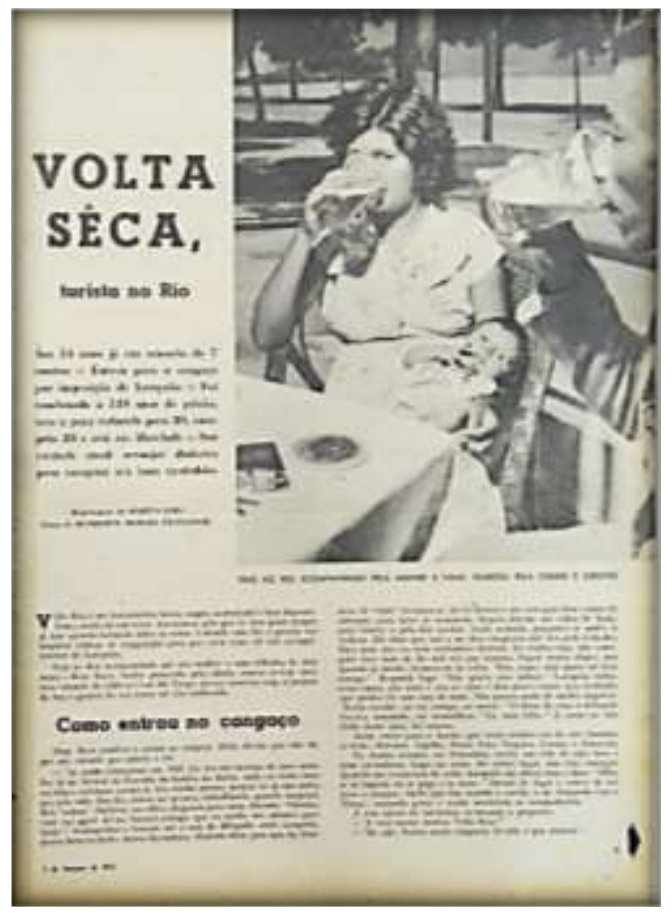

A fotografia apresenta, o ex-cangaceiro numa situação trivial, sentado, ao lado da esposa e o bebê, apreciando uma bebida ao ar livre na Cidade Maravilhosa. Todavia, a relação de complementaridade entre o título da matéria de Marita Lima e a fotografia de Humberto Franceschi, produz um bem humorado trocadilho, entre o nome do entrevistado, e a sede, que estariam matando, ali, na mesinha do bar.

Revista Manchete, 7 de fevereiro p. 11. Acervo Biblioteca Florestan Fernandes. FFLCH-USP.

Figura. 97 O cangaceiro Volta Sêca

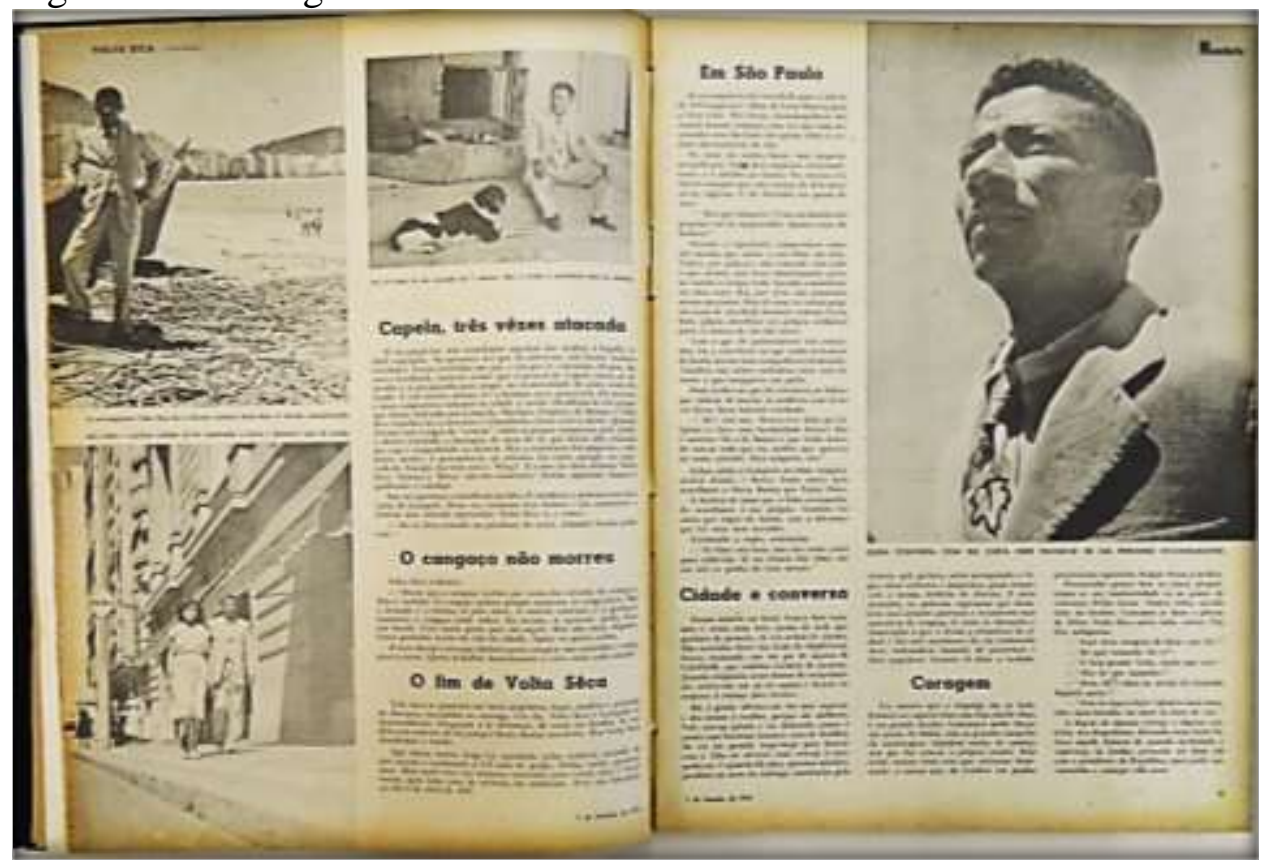

Revista Manchete, p. 12-13. Acervo Biblioteca Florestan Fernandes. FFLCH-USP. 
Mas, o que nos chama a atenção na entrevista do ex-cangaceiro é sua lucidez quando perguntado sobre o cangaço:

Volta Sêca esclarece: "Dizem que o cangaço acabou por causa das estradas de rodagem. Não é verdade. O cangaço acabou porque mataram os cangaceiros. Mas a situação é a mesma, lá pelo norte. A miséria continua e a qualquer momento o cangaço pode voltar. Eu mesmo, se quisesse, podia fazer um bando. Tem muita gente para me seguir. Mas não estou disposto. Estou gostando muito da vida da cidade. Agora eu quero calma. O meu desejo é arranjar dinheiro para comprar um caminhão e voltar para o norte. Quero trabalhar honestamente e viver como todo mundo". (Revista Manchete, 07 de fevereiro de 1953, p. 12-13)

O cangaceiro é a soma da rusticidade com o fantástico. Ele, o cangaceiro, seria a materialização do Hércules-Quasímodo de Euclydes. Ora heroico e destemido, protagonista de aventuras - por vezes fantásticas, como nas narrativas de cordel sobre as demandas de Lampião; ora faminto, vivendo em esconderijos, vitimado pela perseguição e odiado por todos.

\subsection{Religião e religiosidade pelas lentes da fotorreportagem}

Dentre os temas alusivos à cultura nordestina como uma cultura ancestral, podemos afirmar que o mais recorrente era o do candomblé que, além da ancestralidade, trazia consigo também o estigma de uma prática tida como exótica, aos olhares daqueles que ignoravam os seus significados.

A análise das principais revistas ilustradas dos anos 1950 nos mostra que o candomblé esteve no centro de fotorreportagens polêmicas. Na revista francesa Paris Match e, depois, na brasileira $O$ Cruzeiro, imagens inéditas do ritual de iniciação de três yaôs eram apresentadas a partir de textos preconceituosos, elaborados por jornalistas que desconheciam a religião. Com grande alarde e vendagens históricas, o tema tornava-se atrativo também para outra gigante do mercado da época: a revista Manchete, que entraria no debate associando o candomblé ao charlatanismo e à herança de uma cultura ancestral supostamente selvagem. Sob a ótica da História das Representações, pretendemos entender a forma como essas publicações provocaram a emersão de velhos preconceitos que associavam África à barbárie e que atingiram e ainda atingem a compreensão e a aceitação das religiões de matriz africana.

O desconhecimento e o preconceito acompanharam as interpretações sobre as religiões afro-brasileiras por muito tempo, o candomblé, com seu conjunto de símbolos e cerimônias, desde os tempos da colônia, conviveu com os olhares e os julgamentos daqueles que se negavam a vê-lo 
como uma manifestação cultural rica e complexa. Durante a primeira metade do século XX, duas linhas de pensamento divergentes tinham o candomblé no centro de suas atenções: a antropologia cultural, com os estudos sobre a retenção de elementos culturais africanos na formação da cultura brasileira e os antigos adeptos do Darwinismo Social, que acreditavam na existência de uma linha evolutiva entre as culturas, na qual as culturas europeias se encontrariam no topo - a evolução, a civilização - e as culturas africanas na base - o exótico, a barbárie.

Essa oposição entre civilização e barbárie e, principalmente, o impulso de olhar para a cultura afro como um produto exótico, não se restringia ao Brasil; em 12 de maio de 1951, uma reportagem que tinha por foco o ritual de iniciação dos seguidores do candomblé na Bahia, era publicada pela revista francesa Paris Match, ilustrada com fotos do famoso cineasta francês Henri George Clouzot, a reportagem seria causadora de uma grande polêmica, da qual tomariam parte intelectuais como Roger Bastide - então professor da Universidade de São Paulo - praticantes do candomblé e a sociedade como um todo.

A revista francesa, em tom sensacionalista, alardeava a publicação inédita de fotos de um "ritual sangrento de iniciação", demonstrando nitidamente seu objetivo de impactar, de apresentar um produto exótico ao público francês; não havia na matéria a intenção de informar, analisar ou interpretar, mas sim de chocar; essa intenção fica explicitada pelas palavras utilizadas na Manchete, pois essas são muito mais fortes que as próprias imagens, que, na primeira página, limitam-se a um conjunto de três cenas de um suposto pai-de-santo baiano identificado por Pai Rufino.

Roger Bastide, estudioso do candomblé, foi quem mais enfaticamente posicionou-se contra a reportagem da Paris Match e tornou pública sua indignação por meio de dois textos publicados na revista Anhembi, que começava a se tornar uma referência entre a intelectualidade de então. A revista que fora fundada por Paulo Duarte, logo após sua saída do Jornal O Estado de S. Paulo (OESP), em 1950, abrira espaço para intelectuais brasileiros e estrangeiros divulgarem suas pesquisas acadêmicas. Quanto ao protesto de Bastide, Fernando Tacca, autor de uma longa pesquisa sobre o tema, nos conta que:

O primeiro artigo criticava duramente a reportagem francesa, enquanto o segundo, a partir da leitura do livro de Clouzot, relativizava essa crítica, pois, de certa forma, Bastide encontrou espaço para debate acadêmico, que está no seu famoso livro, publicado em 1958, Candomblé da Bahia: rito nagô, um clássico da antropologia. Nesse livro, reeditado recentemente, também existe um compêndio de sua obra. (TACCA, 2006, p. 64) 
Um terceiro artigo, chamado "Uma reportagem infeliz", publicado em dezembro de 1951, não se encontra no compêndio de suas publicações. Nesse artigo, Bastide diz que foi um dos primeiros a criticar a reportagem francesa e que, como os brasileiros não se manifestaram sobre a reportagem da revista $O$ Cruzeiro, ele se sentia à vontade para assim fazê-lo e, mais, pergunta: "onde estão os Albertos Cavalcantis e Edsons Carneiros que não se manifestaram sobre a reportagem de Paris Match?” (TACCA, 2006, p. 64).

Conforme a narrativa de Tacca, o fotógrafo e antropólogo Pierre Verger teria sido procurado pela $O$ Cruzeiro para fornecer-lhes imagens melhores que as da Paris Match sobre os rituais, mas não quis colaborar. Para a imprensa o que estava em jogo não era a aceitação do candomblé como expressão cultural legítima, com seus códigos, símbolos e rituais ou a manutenção de uma imagem distorcida, associada à barbárie; a imprensa estava preocupada com o número de tiragens vendidas e o volume de anunciantes conquistados, O Cruzeiro não iria desistir do projeto.

Utilizando-se do poder dos Diários Associados - empresa da qual O Cruzeiro fazia parte, e já desejando transformar a matéria num grande acontecimento polêmico, os editores decidem veicular o assunto, que faria parte da edição da revista de setembro, em chamadas do matutino Diário de Notícias antes mesmo da chegada da $O$ Cruzeiro nas bancas. Essa atitude já foi o suficiente para que religiosos conservadores e praticantes do candomblé começassem a se posicionar e a polemizar sobre o assunto, mesmo antes da publicação da revista, e era justamente o que os Diários Associados desejavam. Conforme sua pesquisa, Tacca nos descreve:

O lançamento da reportagem de $O$ Cruzeiro foi precedido de ampla divulgação na Bahia, com boxes em jornais, anunciando a chegada da revista a Salvador. Foram cinco edições entre os dias 11 e 14 de setembro de 1951, sendo que, nesse último dia, antes da chegada da revista, foi publicada uma das imagens mais fortes na contracapa do jornal Diário de Notícias, de Salvador. Se a própria reportagem já seria um choque, a inserção de chamadas, antes da chegada da revista, criaria um clima de verdadeira tensão no meio do candomblé. Os dados de tiragem da revista revelam que, nessa edição, ela passou de 300.000 para 330.000 exemplares. A revista sabia, assim, do impacto que estava causando com a reportagem. (TACCA, 2006, p. 64)

Trezentos e trinta mil exemplares equivaleria, em números absolutos a um número muito maior de leitores, tomando-se como possibilidade o fato da revista ser lida nas residências, por vários membros da mesma família; em escritórios; cafés e outros lugares em que fosse compartilhada. Portanto, não é exagero dizer que uma tiragem de mais de trezentos mil exemplares atingiria a mais de um milhão de pessoas. Um tema lançado pelo Cruzeiro alastrava-se como 
pólvora com facilidade, ainda mais um tema como esse que trazia novamente à tona a questão do desconhecimento e da intolerância em relação às religiões afro-brasileiras.

Em 15 de setembro, a revista $O$ Cruzeiro publicava a sua matéria sobre o assunto ${ }^{143}$, trazendo fotos que foram consideradas chocantes.

Ocupando praticamente toda a primeira página da matéria, fotos de um momento do rito de iniciação de uma yaô, o momento era o da raspagem de sua cabeça. No interior da revista, outras 35 fotografias foram incluídas, apresentando parte das etapas seguintes do ritual; o sacrifício da ave sobre a cabeça, a pintura do corpo, a meditação em estado de transe, dentre outras. As imagens eram fortes. De autoria de José Medeiros, tecnicamente, as fotografias eram perfeitas; realizadas sob baixa luminosidade traziam, mesmo assim, alto grau de definição entre o preto profundo e o branco. As expressões da mãe-de-santo - Mãe Riso - durante a epilação, o olhar da jovem yaô, a riqueza de detalhes mostram o apuro técnico do material. Todavia, ao contrário da riqueza de detalhes das imagens, o texto extremamente pobre de esclarecimento e informação, recai apenas no sensacionalismo, a começar pelo próprio título da matéria: As noivas dos deuses sanguinários.

A fotorreportagem feita em Salvador, com fotos de José Medeiros e texto de Arlindo Silva, teve grande repercussão, primeiramente porque trazia elementos de grande força simbólica e que só poderiam ser interpretados a partir da compreensão da lógica interna daquela religião e também porque traziam imagens de um ritual considerado sagrado para os praticantes, e que deveria ser visto somente pelos iniciados. O texto de O Cruzeiro não tinha nenhum comprometimento com o esclarecimento do leitor leigo, pois, como de costume, para as fotorreportagens o texto jornalístico não era o mais importante. Assim, não eram feitas pesquisas, a força da mensagem estava em aliar fotografias impactantes à livre interpretação de um objeto completamente desconhecido para o repórter, abrindo caminho para toda a sorte de preconceitos e interpretações demonizantes. 
Figura 98. As noivas dos deuses sanguinários.

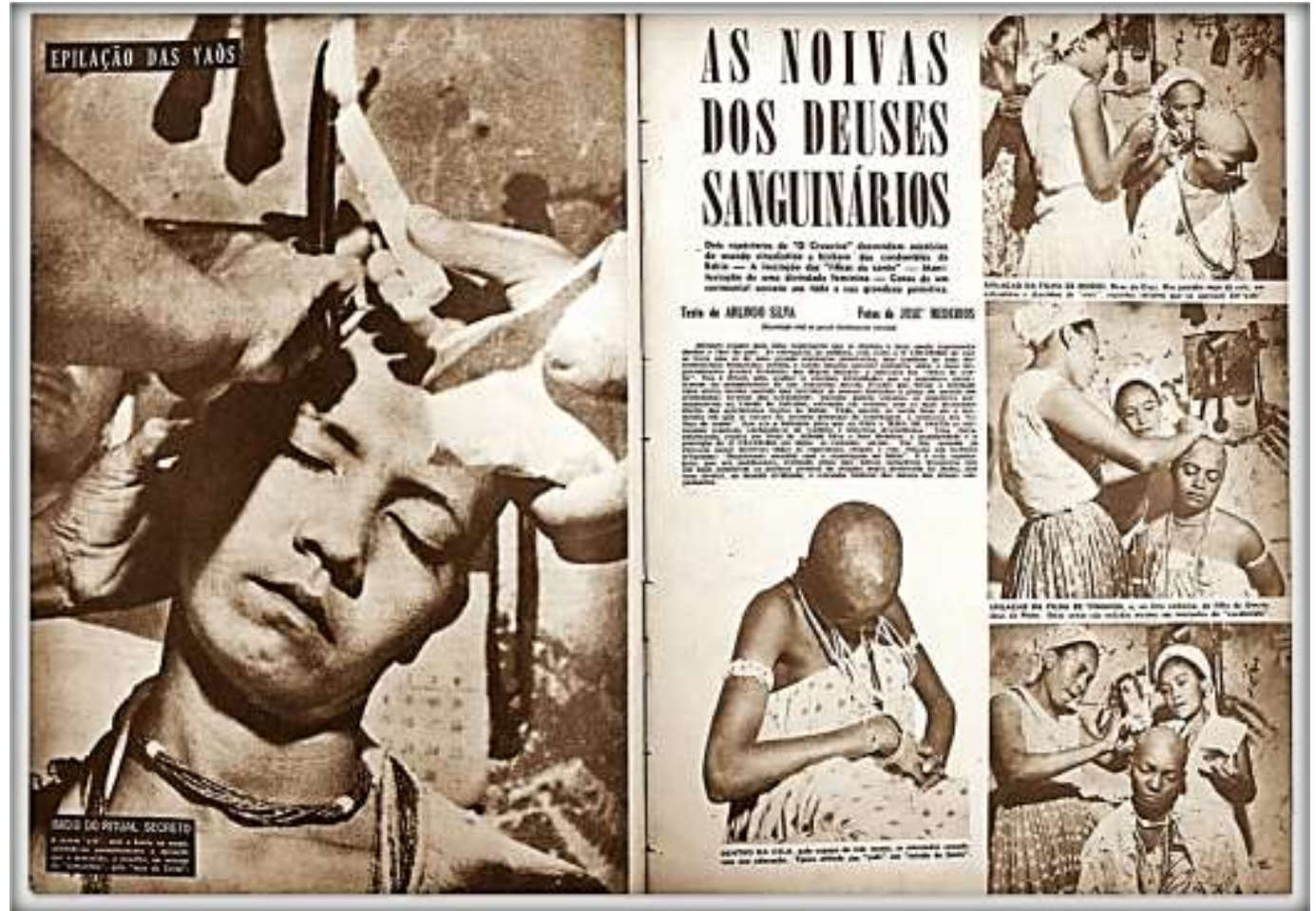

Fonte: Texto de Arlindo Silva e fotos de José Medeiros. O Cruzeiro, 15 de setembro de 1951.

Figura 99. Iniciação de yaôs.

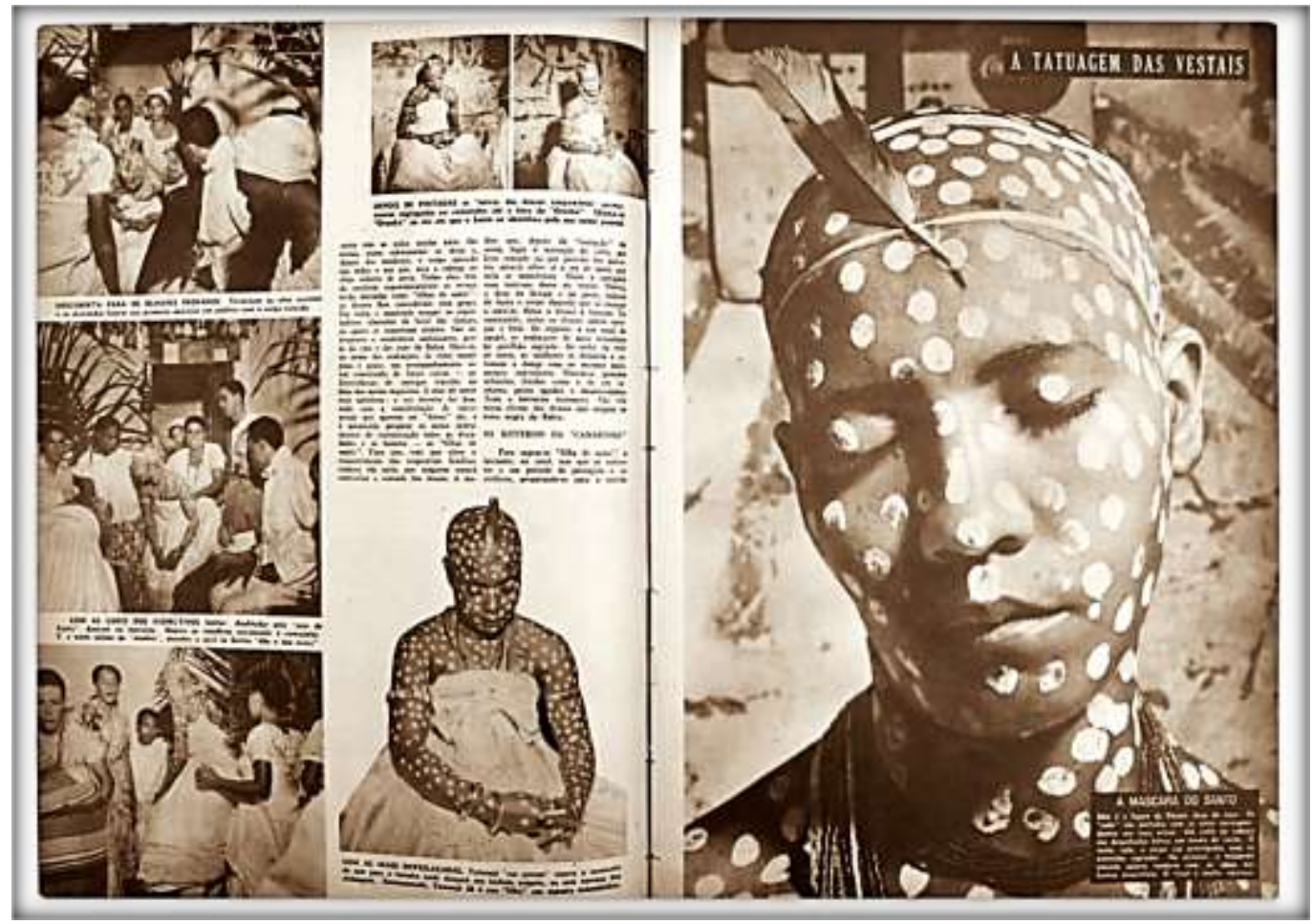

Fonte: Fonte: Texto de Arlindo Silva e fotos de José Medeiros. O Cruzeiro, 15 de setembro de 1951. 
Segundo Tacca (2006), entre os intelectuais, a matéria foi entendida como sensacionalismo ${ }^{144}$, mas teria caído "como uma bomba nos meios religiosos baianos, cujos representantes abominaram a ideia de os segredos do candomblé serem revelados" (TACCA, 2006, p. 66) e, principalmente, a forma irresponsável como teriam sido apresentados.

Embora todo ritual religioso, em todas as religiões, traga o sacrifício como elemento primordial, seja ele moral, físico ou material, as imagens daquela cerimônia, descritas de maneira preconceituosa, provocaram forte impacto, pois deliberadamente dava-se destaque a elementos que suscitavam associações errôneas, como o sangue e a ave morta. No título este elemento vinha associado a um impulso violento e "sanguinário" dos deuses, e não ao princípio de energia vital, como de fato é compreendido pelos praticantes, da mesma forma o transe, a reclusão, são apresentados de maneira completamente descontextualizada, provocando revolta e surpresa tanto entre os não praticantes quanto entre os praticantes do candomblé.

Segundo Tacca, a reação foi tão intensa que começou a circular uma notícia de que as iniciadas fotografadas haviam enlouquecido após a publicação das fotos, que o terreiro teria sido destruído e que a mãe-de-santo havia sido assassinada. Embora até hoje, cinquenta anos depois, essas histórias de perda da razão, violência e assassinato das envolvidas ainda circulem pela internet, as pesquisas e as entrevistas com os parentes das envolvidas demonstraram que o desfecho da história foi bem diferente. A reação da Federação Baiana de Cultos Afro-brasileiros foi, na época, contrária à decisão de Mãe Riso, que permitira a realização das fotos, mas ela não foi expulsa da comunidade, nem assassinada, faleceu apenas em 1993, aos 73 anos (TACCA, 2006), sendo homenageada pela comunidade do candomblé no Rio de Janeiro ${ }^{145}$.

\footnotetext{
144 Segundo Tacca, o impacto da reportagem de O Cruzeiro, teria sido maior entre o leitor comum. Em sua reportagem, $O$ Cruzeiro não teria citado a sua congênere Paris Match, que publicara a matéria inicial, e essa omissão teria acontecido por duas principais razões: primeiro, o candomblé não era uma questão nacional, e sim local, tanto que a principal divulgação da reportagem se deu precisamente em Salvador; segundo, teria havido um interesse maior entre os intelectuais pela polêmica instaurada sobre a reportagem de Paris Match - interesse maior do que pela reportagem de $O$ Cruzeiro -, tendo sido a francesa, traduzida, na íntegra, pelo jornal A Tarde, de Salvador, em julho de 1951.

${ }^{145}$ Um trabalho fotográfico sobre a Bahia com o texto de Roger Bastide e fotos de Verger, foi publicado na revista A Cigarra - Magazine que fazia parte Diários Associados. Chamava-se "Candomblé", publicado em junho de 1949, pp.49,18 e 24.
} 
Com reportagem de Edmar Morél e fotografias de Edgard Medina ${ }^{146}$ a reportagem Eu fui girar na linha da umbanda, de 1944, pela Manchete, descrevia uma cerimônia, no Templo do Caboclo Cobra Coral, afirmando ser: uma reportagem absolutamente autêntica", no templo de umbanda cuja fama seria grande e e apontando que seu grande mérito, entre outros, seria o de estar sendo fotografado pela primeira vez.

Apenas a "Casa de Exu" - o templo do diabo - e a "Bandeja do mistério", apesar de visitados por Edmar Morél e Edgard Medina, não puderam ser focalizados por ordem expressa de "Babalaô". A macumba que apresentamos aos leitores foi surpreendida em pleno funcionamento, sendo, desta maneira, colhidos detalhes inéditos do impressionante cerimonial.

O destaque, das lentes de Medina era para o exotismo da paramentação do pai de santo e para a organização do ritual, as danças, que marcariam as imagens. A distribuição das fotografias em enquadramentos que incluem vários personagens em ação dão ao leitor uma visão que coloca a cerimônia em movimento. As cenas eram descritas a partir do que o repórter imaginava estar vendo, não há explicações mais precisas, dadas ao repórter, por parte dos praticantes, deixando livre a interpretação e imaginação de quem as escrevia. Na figura (100), lê-se a observação de Morél: "Um dos fanáticos vai cair em transe. A sua fisionomia está desfigurada. Sacode a cabeça aflitamente e tem-se a impressão que esse velho cambone enlouqueceu." Pela nomenclatura, tratava-se de um terreiro de umbanda, pois Morél destaca a presença dos cambones - subordinados - que auxiliavam o pai-de-santo e também das sambas, que cantavam (figura 101), durante a cerimônia. A imagem final, apresenta o Caboclo Cobra Coral, num enquadramento em plano americano, em um meio perfil, como que girando o tronco, conferindo a impressão de flagrante, intensificada pelo olhar de um certo espanto do Caboclo, que tem bem visíveis na fotografia a plumagem de suas roupas e a espada de Ogun, que empunha na mão direita.

Danças, cantos e reverências são as expressões corporais registradas, sendo que o destaque às penas e plumagens, aos pés descalços e ao chão de terra, remetem a composição a uma ideia de ambiente primitivo.

\footnotetext{
${ }^{146}$ Em Cobras Criadas, Luiz Carvalho se refere à matéria "Eu fui girar na linha da umbanda", como a grande reportagem da dupla Morél e Medina, no mês de abril de 1944, destacando ainda a matéria fotográfica "Jangadas do nordeste". Todavia, embora Carvalho aponte que: "Eu", no caso, era ninguém menos que Josephine Baker, a quem Morél apresentou o terreiro de Mão Dedé, em Belford Roxo, na Baixada Fluminense"; na reportagem, Morél diz tratarse do Terreiro do Caboclo Cobra Coral - e não Terreiro da Mãe Dedé, como afirma Carvalho - além de não fazer nenhuma referência à presença de Josephine Baker.
} 
Figura 100. Eu fui girar na linha da umbanda

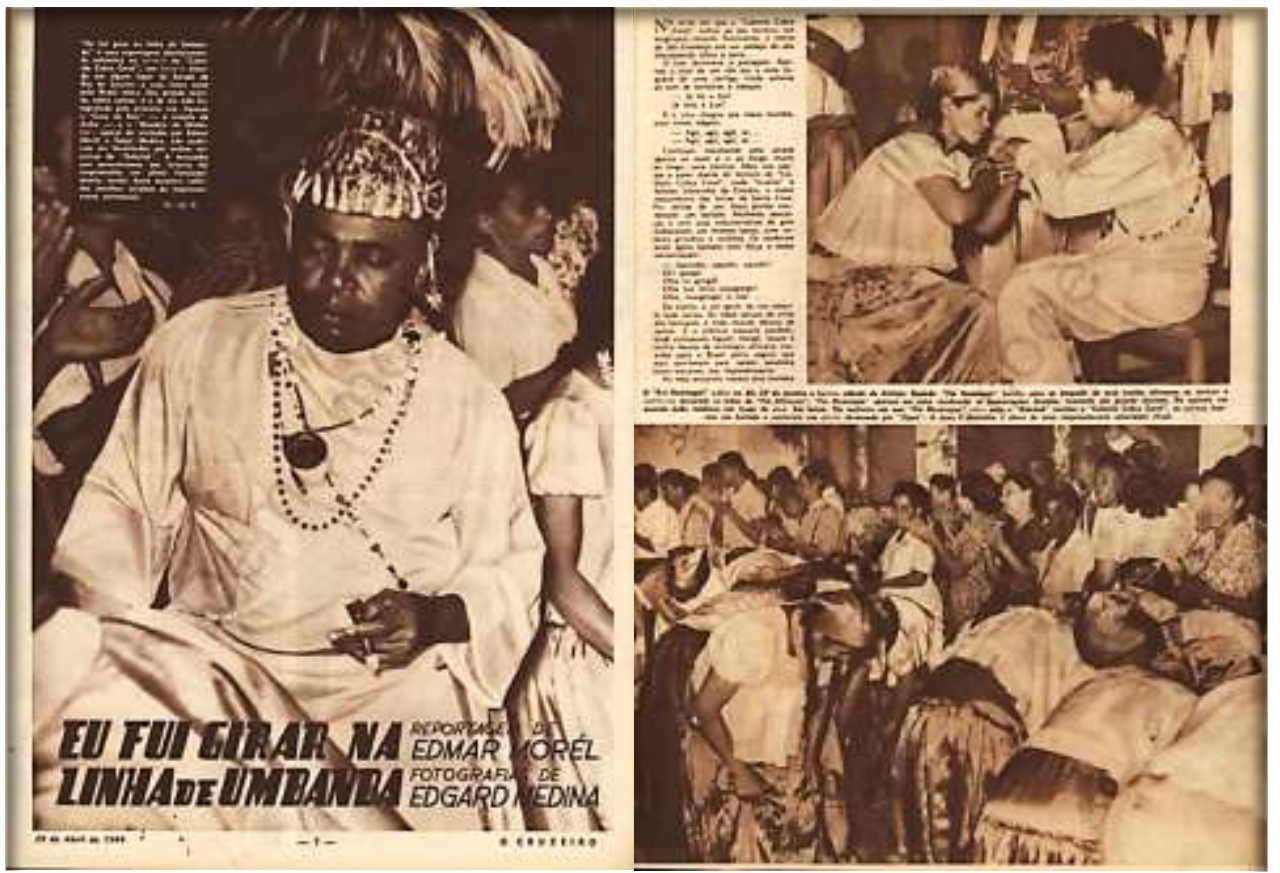

O Cruzeiro, 29 de abril de 1944, pp. 7-14. Acervo CEDIC PUC

Figura 101. Pai de santo, durante cerimônia.
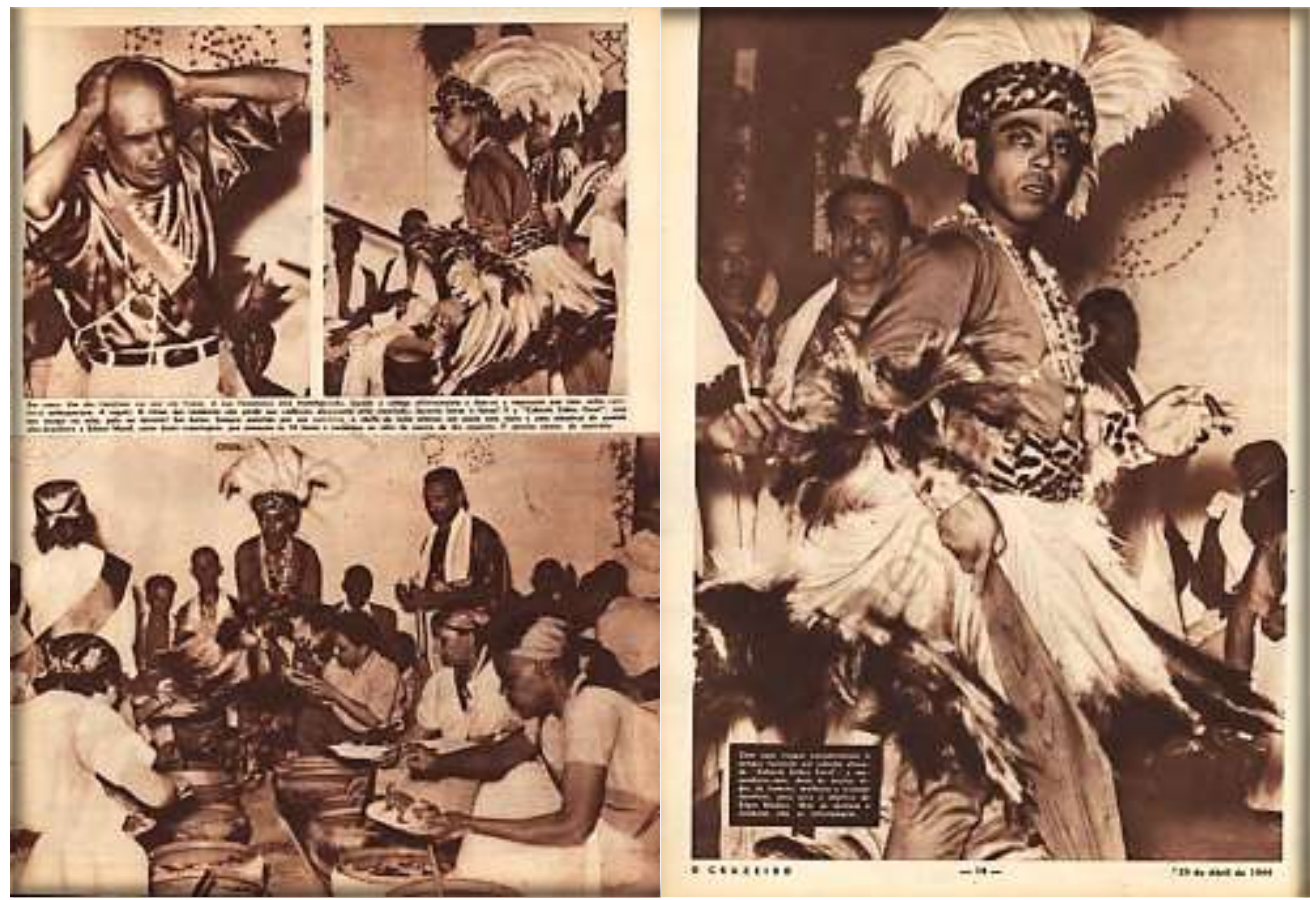

O Cruzeiro, 29 de abril de 1944, pp. 7-14. Acervo CEDIC PUC 
Interessante observar que, no universo do ocultismo, não somente o candomblé e a umbanda chamavam a atenção das revistas. Matérias sobre práticas religiosas de grupos do interior do país, ou mesmo as particularidades das igrejas protestantes da população negra norte americana, frequentavam as páginas da Cruzeiro.

Ainda no ano de 1944, o mundo do desconhecido e do sobrenatural também foi alvo das investigações de David Nasser e Jean Manzon. Na reportagem Detetive do Além, as lentes de Jean Manzon registravam o médium Chico Xavier em diferentes situações, em transe, sentado dentro de uma banheira, em busca de almas ou em close up, franzindo o cenho. As imagens conferiam grande destaque para o rosto, pois nos olhos, e também nas mãos, marcavam-se os gestos e as expressões características da ação do transe mediúnico.

O texto de Nasser oscila entre a descrição e a ironia: "Chico Xavier se concentra! Suas mãos ossudas espremem a testa. Seu pensamento vaga pelas regiões perdidas do além. Por que será que nunca vem o espírito de um pintor, de um músico? Ou de um matemático? (Figura102) Revista Cruzeiro, 12 de agosto de 1944, p.04).

Figura 102. Detetive do além

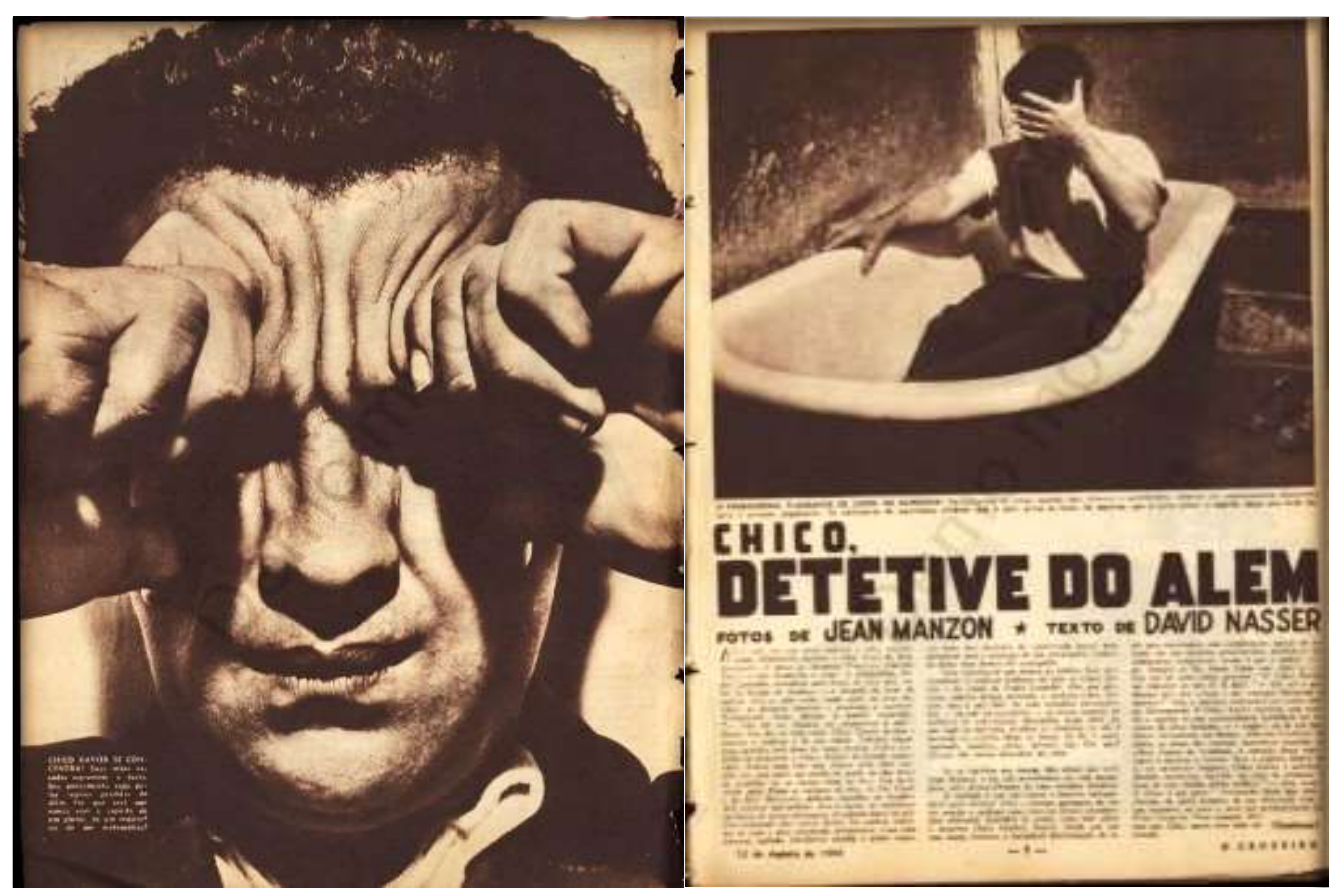

Fonte:

Embora as imagens ocupem a maior parte das oito páginas de reportagem, o texto da entrevista de Nasser com Chico Xavier traz alguns poucos momentos em que o repórter faz as 
vezes de mediador, e auxilia o olhar do leitor, apresentando uma opinião, e uma análise sobre o entrevistado: "Chico parece ser um bom sujeito. Suas ações, mesmo além do terreno religiosos propriamente dito, são ações que o recomendam como alma pura e de nobre sentimentos. (Revista Cruzeiro, 12 de agosto de 1944, p.03).

Em 1953 a Revista Manchete publica uma reportagem na qual o autor resgata velhos preconceitos, colocando-se descrente e intolerante quanto ao valor do candomblé como manifestação cultural.

“Cresce a macumba no Brasil?" Em fins do século XIX havia vinte candomblés na Bahia; hoje existem lá tantas casas de culto fetichista quantas são as igrejas - O espantoso progresso do batuque no Rio Grande do Sul - Causas principais da disseminação da macumba entre nós." (Revista Manchete, 04 de abril de 1953, p. 33-34)

Resgatando os estudos de Nina Rodrigues, o repórter da Manchete inicia apontando para o fato de Salvador ter menos igrejas do que se pensa e mais terreiros do que o que declara, resgatando a "contabilidade" de Nina Rodrigues que estimou, em seu tempo, entre quinze e vinte candomblés na capital baiana. Em seguida, aponta os estudos de Edison Carneiro que em 1948 contabilizara cem terreiros. Segundo a reportagem de Krebs, a secretaria de Segurança declarava acreditar que existissem quatro vezes mais do que estimara Carneiro; e segue analisando da seguinte forma o crescimento dos terreiros:

Aparentemente existe um contra-senso entre tal ascensão e o decréscimo do analfabetismo, se considerarmos tais religiões (candomblé e umbanda) como próprias de uma classe inculta ou ignorante. De fato a estatística demonstra que o fetichismo aumenta enquanto cresce o índice de alfabetização. Por que o fenômeno desse crescimento?

Pelo raciocínio corrente, o lógico seria esperarmos uma marcha diretamente proporcional entre os dois. A baixa de um determinaria a baixa do outro. No entanto, o inverso é o que se verifica. (Revista Manchete, 04 de abril de 1953, p. 33-34)

Associando candomblé a "práticas das camadas incultas" e retomando a velha associação preconceituosa entre África e barbárie, o repórter - completamente avesso ao conceito antropológico de cultura - além de identificar como cultura somente aquilo que se remete à tradição europeia, associa diretamente alfabetização e analfabetismo às escolhas individuais da expressão da religiosidade; apoia ainda seus argumentos em estudos sobre Pernambuco, Rio Grande do Sul e Bahia, para sustentar sua própria interpretação sobre o "estranho fenômeno": 
A primeira delas, e que nos parece fundamental, é o contato direto com a divindade, proporcionado pelo culto fetichista. Nas outras religiões monoteístas, de maneira geral, este contato da criatura com o Deus único é muito remoto, estabelecendo-se através da prece, e da comunhão em algumas. [...] Ora, no fetichismo brasileiro, herdado dos africanos, tudo se passa ao contrário. $\mathrm{O}$ "crente" se é "feito", isto é se é "filho" ou "mãe", ou "pai" de santo pode receber -e recebe geralmente - no seu próprio corpo a visita da divindade, é o fenômeno do transe [...] Já pensaram, alguma vez, os que não têm intimidade com o assunto, na fôrça convincente deste fato? (Revista Manchete, 04 de abril de 1953, p. 33-34)

O jornalista argumenta ainda sobre os motivos que levariam ao crescimento dessas religiões, o fascínio pelo sobrenatural e, citando Herskovits, aponta também como razão a ideia de um sentido, uma missão, para a vida das pessoas. Conclui com Gilberto Freyre:

Para finalizar diremos que, no fundo de tudo está a maior de todas as causas. É a massa do sangue negro que corre nas veias de uns $33 \%$ de nossa população negra pura e mulata. É o mestiçamento psicológico da maioria branca, denunciado por Gilberto Freyre, maioria branca que em grande parte se criou junto com o preto, que mamou leite branco nos seios generosos das babás negras, que se iniciou no amor com a carne trigueira das mucamas jovens. Ou que possui algumas, muitas talvez, dessas brasileiríssimas "Nega Fulô", tão bem cantadas por Jorge de Lima. (Revista Manchete. 04 de abril de 1953 p. $33-34)^{147}$

A reportagem não só não aceita que haja valor cultural do candomblé, mas ainda o entende como um retrocesso nocivo. Obviamente, temos aqui, a reprodução da ideia do "outro" como exótico, bizarro e inferior. Podemos estabelecer uma comparação entre o caso das representações de manifestações culturais do Nordeste e o da construção da representação do Oriente pelo Ocidente, como processos elaborados de maneira praticamente desconectada da realidade. Vale relembrar aqui a reflexão de Edward Said sobre a relação entre Ocidente e Oriente como uma construção do outro a partir de imagens estereotipadas; de maneira que, estabelecendo um paralelo, podemos dizer que o Nordeste estereotipado também seria mera invenção do Sudeste.

Este episódio é apenas um entre muitos que trouxeram à tona o confronto entre um projeto de cultura europeia burguesa e o desejo de manutenção de manifestações culturais legítimas em nossa cultura. Como afirma Albuquerque Jr, ao trabalhar com o OESP como uma de suas fontes para o estudo das representações sobre o Nordeste, tal leitura burguesa, europeizante e preconceituosa, seria produto de um exercício de imposição de superioridade, no qual uma elite 
branca desejava virar as costas para o que de fato era a cultura brasileira, desejando impor como modelo de desenvolvimento para o Brasil os valores e costumes europeus. Para Albuquerque Jr, desde os anos de 1920 o nordestino apareceria na imprensa como "um bom tipo para espetáculos de humor"; na mesma medida a cultura e a religiões afro-brasileiras teriam na mídia apenas o espaço legado ao bizarro e ao exótico.

\subsection{Figuras típicas e costumes que desaparecem.}

Em "Figuras que desaparecem", de 1928, (figura 103) a Cruzeiro nos apresenta os tipos populares que estariam desaparecendo da cena cotidiana das ruas de Pernambuco, em função do desenvolvimento, tratava-se uma seção na qual eram publicadas imagens de tipos característicos da organização da vida tradicional de comunidades urbanas ou rurais; o vendedor ambulante, o artesão tecelão de cestos, a quituteira; todos em processo de serem substituídos pelos novos personagens da vida moderna.

Em seu trabalho, A Revista O Cruzeiro na virada da década de 1930, Leslie Ursini explora essa questão, afirmando que o ponto de observação da revista é o da modernidade e do desenvolvimento, anunciando a chegada de um futuro inexorável, sendo que, portanto, nessa perspectiva, o antigo, o tradicional, o "typo", figuras típicas, representariam o passado, aquilo que está fadado a desaparecer.

O espaço urbano aparece livre de tudo o que represente uma ligação muito forte com o passado. $\mathrm{O}$ passado que deve ser expurgado é aquele que acabou de passar, aquele que deixa o seu eco, o seu cheiro e a sua sombra. As coisas que devem ser dissipadas porque não podem ser levadas para o futuro, sob a pena de descaracterizá-lo como novo, são classificadas como passadas, ultrapassadas. Como uma última moda. (URSINI, 2000, p. 96)

Várias matérias se ocupavam de apresentar ao leitor esses tipos humanos que estariam por desaparecer por serem personagens de uma ordem antiga, indivíduos 'fora do lugar', originários de um mundo que estaria em processo de desaparecimento, dando passagem para a nova ordem do mundo moderno. Várias foram as matérias que abordavam modos de vida que resistiram ao tempo, mas tendiam a desaparecer, como o do Homem do São Francisco, de 26 de julho de 1947 ou o modo de vida das quituteiras, e vendedoras de tabuleiro, em "Como no tempo da colônia", de 02 de agosto de 1952. 
Figura 103. Figuras que desaparecem. Typos e costumes.

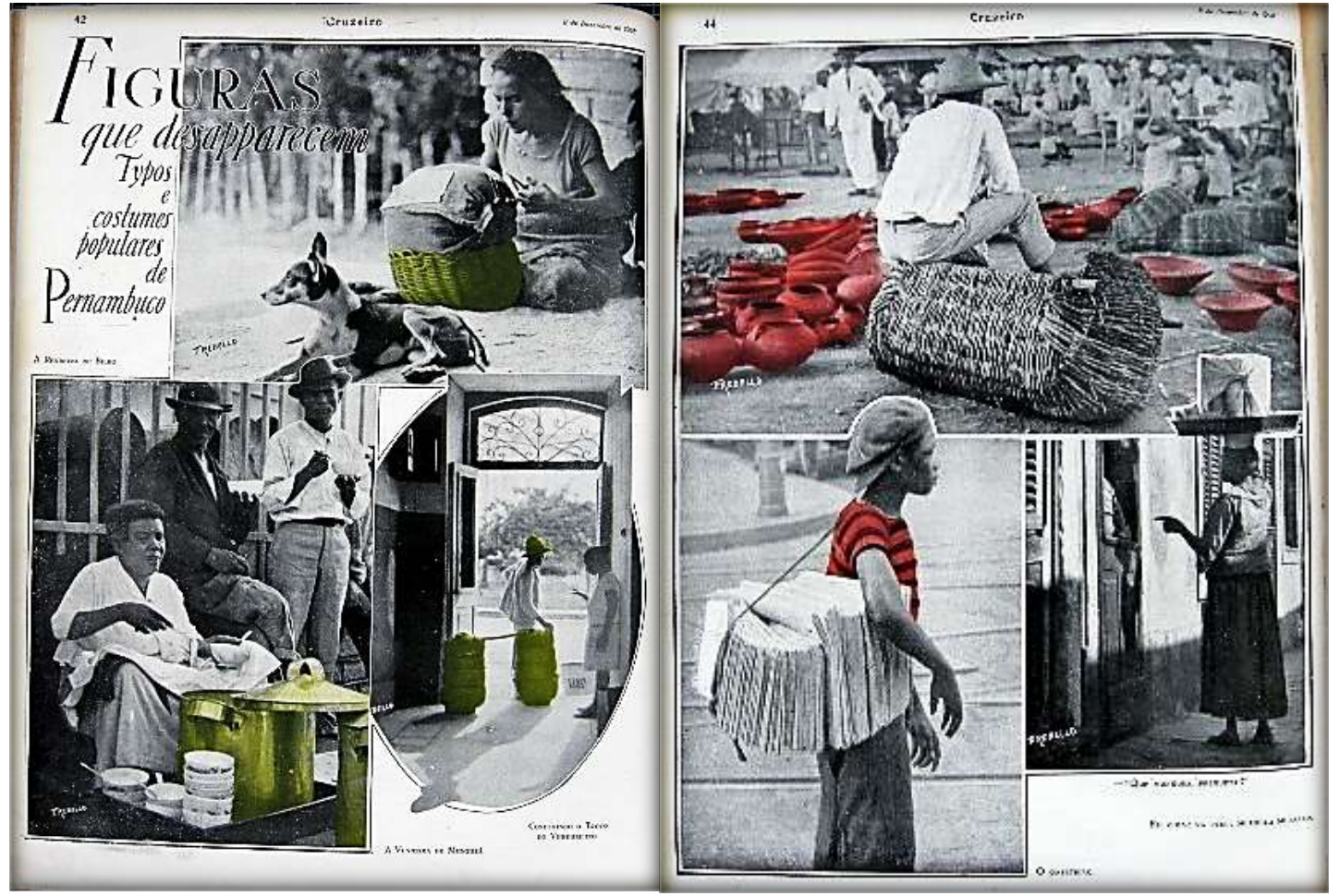

Fonte: Revista $O$ Cruzeiro 08 de dezembro de 1928, pp. 42, 43, 44,. Acervo MASP

Figura 104. Figuras typicas nacionais.

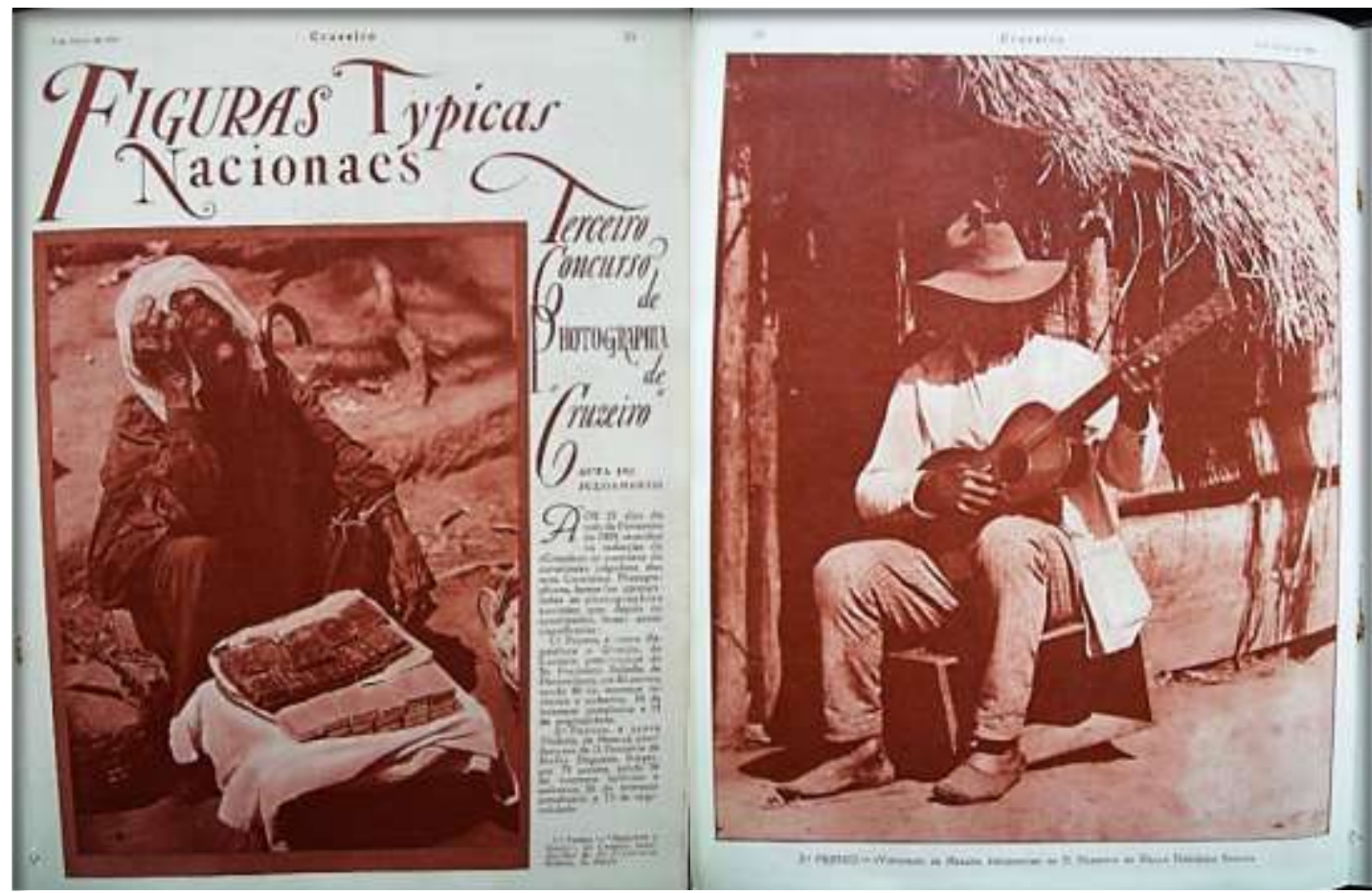

Fonte: Revista $O$ Cruzeiro, 09 de março de 1929, p. 25-26. Acervo MASP. 
Embora a presença do nordestino como um "tipo" para o humor de fato existisse, não seria esta a única forma na qual ele apareceria nas páginas das revistas semanais dos anos de 1940 e 1950. O Nordeste como notícia e imagem é imensamente mais frequente nas páginas de Manchete e de $O$ Cruzeiro, do que o Nordeste como alvo de zombaria ${ }^{148}$.

Em Nordeste, obra de 1937, Freyre coloca sua obra em prol da desmistificação da representação de um Nordeste exclusivamente como região da seca. Apresenta-nos o Nordeste como um conjunto regional, indo além do já conhecido Nordeste árido dos sertões, descreve-nos suas terras férteis e úmidas, onde teria surgido, para Freyre, a mais pródiga cultura, mãe de uma sociedade criadora de valores políticos, estéticos e intelectuais. Apontando a natureza como um, mas não o único e nem o mais importante fator para a compreensão do homem do Nordeste, o autor constrói um discurso sobre a pluralidade do espaço nordestino a partir da observação das relações entre: natureza, região e sociedade, tendo como fio condutor desta reflexão as imagens e as marcas dos caminhos pelos quais passara o açúcar, sua história e sua influência na constituição do que fora e do que então havia se tornado o Nordeste. A obra como um todo é perpassada pela reflexão sobre a decadência de uma sociedade outrora rica e que agora, convivia com o estigma de uma paisagem uniformizada pela imagem do empobrecimento.

Para Freyre, o Nordeste sim seria o berço da veia criativa da cultura brasileira e não poupa de suas críticas alguns dos ícones do que se considerava como patrimônio de nossa memória histórica e cultural, pois para ele, Aleijadinho, expressão máxima do barroco mineiro, seria um mulato-ressentido, cujas criações denotavam impotência e reatividade - refutando também a imagem das bandeiras paulistas como fonte da identidade nacional, uma vez que para Freyre elas nada seriam se nas manchas da terra massapé, não se concentrassem, desde o XVI, as energias criadoras. Para ele, portanto, a identidade nacional não estaria em uma expressão cultural específica, mas em uma maneira particularmente híbrida e plástica de combinar as mais diferentes tradições sem pretender fundi-las em uma síntese completa e definitiva (DUARTE, 2009).

\footnotetext{
${ }^{148}$ Observando as tiras de humor da $O$ Cruzeiro, o nordestino raramente aparece, destacamos porém uma em particular em que uma esposa carrega o marido cangaceiro nas costas pelo sertão e lê-se: "Ser mulher é saber se sacrificar pelo seu bom marido e senhor, mas com muita sutileza e humildade, para que ele não perceba esse seu gesto de cumprimento do dever". Sem dúvida, o tom absurdamente irônico da tira, utiliza-se de um conjunto de pré-conceitos para provocar o riso, e ao mesmo tempo, a crítica. Todavia, é importante observarmos que, na busca por representar um homem que não reconheceria o valor de uma mulher, o personagem escolhido foi um cangaceiro. O Cruzeiro, Carlôs Estêvão, 30 de julho de 1960.
} 
E não seria somente em relação ao lugar do Nordeste na construção da identidade nacional que Freyre iria divergir de alguns de seus contemporâneos. Defensor da teoria da miscigenação como fator positivo para a formação do povo e da cultura brasileira, Freyre irá ainda destacar a importância do elemento africano na formação da cultura brasileira em seu clássico Casa Grande \& Senzala. Contudo, embora em tempos de nacionalismo a ideia de que teríamos uma rica cultura nacional, fosse bem vinda; a defesa da ideia de que esta cultura teria nascido da forte presença e influência do elemento africano, não seria bem aceita, principalmente em meio a um momento histórico de valorização da "raça branca".

Na matéria Idéas e Factos: Casa Grande \& Senzala, publicada em 1934, na Folha da Noite, Roquette Pinto, o respeitado fundador da Rádio Sociedade do Rio de Janeiro, em seu "Boletim de Ariel", relata aos leitores do periódico suas impressões sobre o então recente e substancioso trabalho de Gilberto Freyre, dizia o radialista: "Casa Grande \& Senzala nasceu obra clássica. Ninguém dará mais um passo, em matéria sociológica referente a este paiz sem consultar o volume, a menos que deseje andar errado, como quem se exercita em buscar, no escuro, os objectos que um raio de luz facilmente denuncia" ${ }^{149}$.

Roquette Pinto enaltece a metodologia de análise do autor e também a forma como os princípios da sociologia teriam sido utilizados, destacando que "Gilberto Freyre não se apressou. Só penetrou no andar de cima depois de bem senhor das difficuldades do rez do chão. Eis ahi a origem do brilho desse volume sem par" (Folha da Noite, 1934, p.3). Contudo, o jornalista discorda da importância dada à cultura africana, uma vez que, para ele:

A verdade, porém, é que o Brasil de hoje sahiu muito pouco da senzala. Elle está recheiado de coisas negras, o seu cabello não nega, etc; mas toda a massa enorme de coisas que a escravidão derramou na gente, não veio de facto da senzala. Veio mesmo da própria Casa Grande, para onde os mais bem dotados filhos da senzala eram immediatamente conduzidos, a começar pela "mãe preta". (Folha da Noite, quinta-feira, 22 de fevereiro de 1934, p. 03)

Considerando a integração entre as raças como um processo de aculturação do negro, Roquette Pinto, segue argumentando em favor do convívio entre brancos e negros tendo a Casa

149 Folha da Noite, quinta-feira, 22 de fevereiro de 1934. Boletim Ariel, p. 03. Acervo Folha. Disponível em http://acervo.folha.com.br/fdn. Acesso em 10 de novembro de 2013. 
Grande e não a senzala como cenário. Embora a miscigenação fosse um processo impossível de ser negado, a valorização da matriz negra e dos elementos do passado - associados a uma cultura menos urbana, menos europeia - não tinham seu valor reconhecido por alguns, mas ainda assim, possuía seus defensores.

\section{7 South american way.}

A identidade artística construída por Carmen Miranda, sintetizou a representação da latinidade: o 'jeito de ser sul-americano' (South American Way) - título de uma canção, interpretada por Carmen Miranda e o Bando da Lua no filme Down Argentine Way (Serenata Tropical), de 1940 - materializado nas cores e ritmos brasileiros. A letra foi adaptada por Aloysio de Oliveira de uma canção composta para a revista Street of Paris. Nela, elementos da cultura popular soteropolitana - o tabuleiro da baiana, o vatapá, o caruru, o mungunzá são valorizados definindo-os como o 'jeito de ser, sul-americano'.

\footnotetext{
"Ai, ai, ai, ai

É o canto do pregoneiro

Que com sua harmonia

Traz alegria

In South American Way

Ai, ai, ai, ai

E o que traz no seu tabuleiro

Vende pra ioiô

Vende pra iaiá

In South American Way

E vende vatapá

$E$ vende caruru

E vende munguzá

E vende umbu

No tabuleiro tem de tudo que convém

Mas só lhe falta, ai, ai berenguendéns
}

"The brasilian Bombshell” (a Granada Brasileira), a Pequena Notável, foi, sem dúvida a representação do Brasil mais difundida por todo o planeta, durante os anos de 1940 e 1950. A imagem de Carmen era frequente em inúmeras capas e reportagens sobre música, cinema, moda, comportamento e temas afins. A cantora e atriz, que emigrada de Portugal com apenas um ano, viveu e representou o Brasil a partir de elementos como as cores, as formas e a exuberância da natureza tropical, sintetizadas através das formas, cores, texturas e acessórios, ficou famosa por seu figurino exótico, sua presença magnética em cena e por sua interpretação do samba brasileiro. 
Em seus shows, bem como em suas aparições no cinema, os elementos tropicais de seu figurino eram, literalmente, sua marca registrada, de tal maneira que o turbante enfeitado com frutas e flores coloridas simboliza, até hoje, ao mesmo tempo, Carmen e o Brasil. Na matéria de agosto de 1941, Carmen fala do amor, a revista ocupa quatro páginas para apresentar ao leitor detalhes do figurino para seu novo filme, desenhado por Alceu Pena famoso ilustrador e designer, tendo se tornado um dos mais expressivos designers do país, com sua seção as Garotas do Alceu, publicada na revista $O$ Cruzeiro:

Carmen Miranda continua a ser o grande sucesso do momento, depois de sua atuação em "Uma noite no Rio". Agora está filmando "Honeymoon in Havana", no qual veste as seis "toilettes" que aqui apresentamos. As duas baianas foram desenhadas por nosso colaborador Alceu Pena, quando de sua estada na América." (Revista O Cruzeiro 02/08/41).

Os figurinos valorizam os símbolos da feminilidade (figura 105) e os elementos associados ao clima tropical, como os motivos floridos, as cores fortes e a utilização de tecidos leves. Para Bragança e Macedo (1999), o corpo da baiana, tal qual o próprio povo baiano (representante do povo brasileiro, e no caso de Carmen Miranda, representante de todo o povo latino-americano) seria formado por uma 'mistura'. Na composição visual do traje, (figura 106) a mistura estaria: frutas e flores - natureza (nas roupas, cabeça ou mesmo no tecido do sofá no qual foi fotografada); turbante - a matriz africana e a referência à natureza tropical; colares e pulseiras de contas - as tradições indígena e africana, uma vez que os cordões de contas baianos ${ }^{150}$ estão diretamente ligados ao culto aos orixás; a saia rodada - das sinhás do período colonial, e que foram adotadas pelas negras de tabuleiro ${ }^{151}$; e as modernas sandálias de salto plataforma, que conferiam alguns centímetros à mais para a brasileirinha ${ }^{152}$ de estatura pouco privilegiada.

150 Sobre a simbologia, a confecção e a história dos colares de contas baianos ver LODY, Raul. Joias de axé. Fios de contas e outros adornos do corpo. Rio de Janeiro: Bertrand Brasil, 2010.

151 Entre os finas do século XIX e a primeira metade do século XX, as negras de tabuleiro que usavam branco eram mulheres ligadas ao candomblé. Usando saias brancas, rodadas, que lembravam as saias das antigas sinhás, as vendedoras utilizavam outros tipos de adornos que as caracterizavam como as pencas ("balangandans"), com pequenas joias e amuletos de proteção, que ficavam na cintura da vendedora ou dentro do tabuleiro. CUNHA, L. e MILZ, T. Joias de Crioula. São Paulo: Edição Terceiro Nome, 2011.

152 Carmem Miranda deixou Portugal com apenas alguns meses de idade e jamais retornou ao país onde nascera. A imprensa brasileira referia-se à ela como "cantora brasileira", o que nos parece justo. 
Figura 105. Carmen

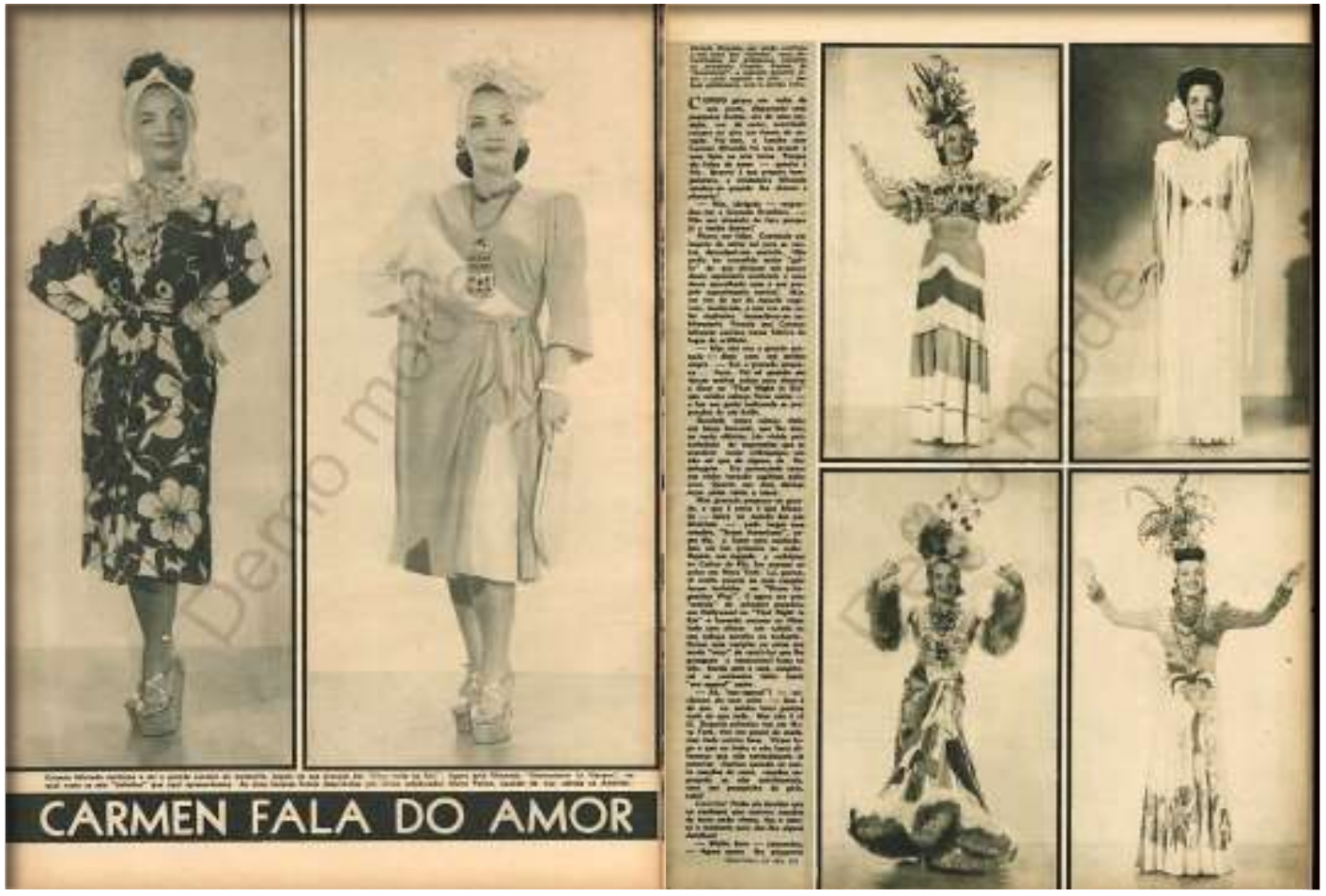

Fonte: (Roupinha - 02/08/41

Figura 106. Carmen Miranda no cinema.

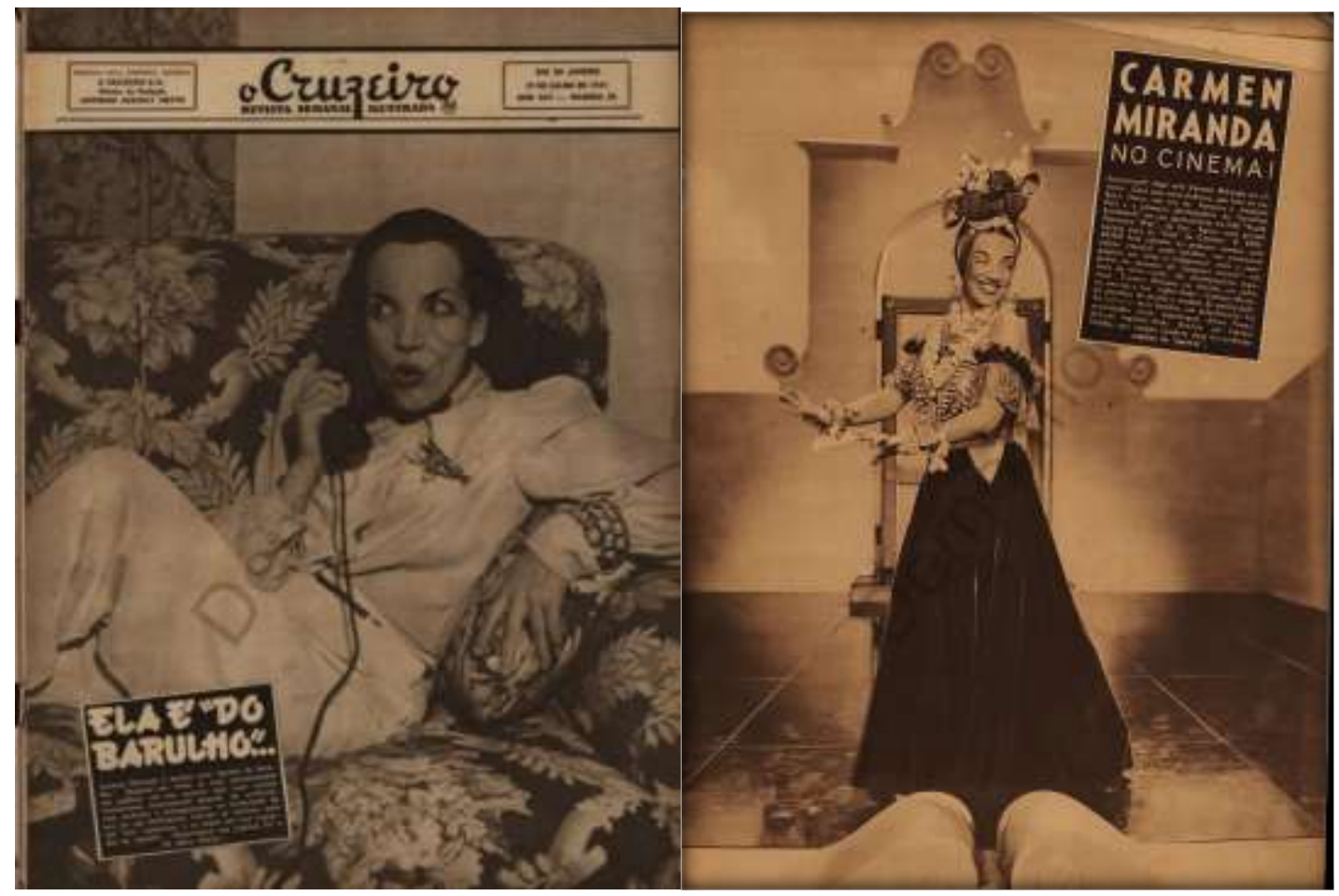

Fonte: No cinema - 30/mar / 1940 
Na composição da música, Carmen traria a mistura do samba carioca - com os músicos do Bando da Lua reproduzindo uma estética do malandro do Rio de Janeiro - às letras que cantavam as belezas, os costumes, os sabores e as belezas da Bahia. "Na performance da baiana estabelece, as marcas da fronteira que se apresenta entre o morro e a cidade, em um corpo branco que revela a alma mestiça do povo brasileiro (BRAGANÇA, 2008, p. 154).

Vale lembrar, contudo, que a Bahia de Carmen não é a Bahia real, como também não é real a baiana de Carmen, mas sim uma composição, um produto, elaborado artisticamente para comunicar uma ideia, uma identidade estilizada, representada por meio dos elementos do mosaico composto por natureza tropical, baianidade, brasilidade.

Em julho de 1941, Carmen Miranda concedia à Cruzeiro uma entrevista em sua casa, em Hollywood, Estados Unidos. A matéria do correspondente Marius Swenderson, apresentava um conjunto de 08 fotografias de Carmen em sua nova casa. A matéria começa com as impressões de Marius, durante o trajeto para chegar à residência de Carmen, destacando sua importância para os norte-americanos:

Um rapagão loiro, munido de um grande megafone, vai apregoando durante o caminho os nomes dos ilustres moradores. Os mais afamados astros desfilavam, enquanto o ônibus, em marcha reduzida, permite fazer uma apreciação regular dos luxuosos palacetes, onde se escondem os ídolos das multidões. Entramos finalmente em Monte Mar Terrace (residência de Carmen), [...] Um murmúrio corre pelos turistas todos. Louvores espoucam ao nome de Carmen. É a admiração para quem soube apresentar a novidade mais sensacional dos últimos anos a este povo que é tão difícil de satisfazer em seus gostos. (Revista Cruzeiro, 19 de julho de 1941, p. 54)

A reportagem segue, com o autor descrevendo sua entrevista com a artista, sua empolgação em relação à carreira no cinema - Carmen fez mais de 14 filmes - suas turnês, destacando, repórter, em uma das legendas de imagem: "Carmen Miranda é a primeira artista brasileira, que realmente triunfa no cinema norte-americano.”. (Revista Cruzeiro, 19 de julho de 1941, p. 53)

Segundo Bragança, a indústria cultural, mediante a articulação de uma rede de meios de comunicação de massa, que incluía sobretudo o rádio e o cinema nos anos 1930 e 1940, teve papel imprescindível na organização de um repertório simbólico que dialogava com a ideia do nacional popular (2008, p. 153). Importante lembrar que desde os anos de 1920, o cinema norte-americano concentrava as atenções do público. Por meio de suas produções, toda construía-se uma estética da vida urbana e moderna: comportamentos, reações, roupas, cabelos, tipos de relacionamentos e mesmo ações políticas. Para todas as ações correspondia um modelo devidamente apresentado e representado pelas estrelas de Hollywood. 
Em março de 1945, a matéria de Gilberto Souto traz imagens do filme The Three Caballeros (no Brasil o filme recebeu o título de 'Você já foi à Bahia?'). Trata-se de um filme da Disney Animations Studios, de 1944. No filme, o (figura 107) Pato Donald (representando os Estados Unidos da América) realiza uma viagem pela América Latina. O pato é ciceroneado pelos personagens Ze'Carioca (representando o Brasil) e Panchito Pistoles (um galinho que representa o México).

Na passagem pelo Brasil, a arquitetura das sacadas (figura 107), as ruas estreitas e tortuosas do centro histórico baiano, as igrejas baianas se somam ao Corcovado e às praias de Rio de Janeiro - praias, onde o Pato se encanta pelas "belas moças de maiô" (figura 108), pois as mulheres são as personagens que, caracterizadas, vão marcando a identidade da população por onde os Caballeros passam.

Quando aparece Aurora Miranda, a encantadora "Iaiá", vendedora de cocada. Os dois seguem-na até um terreiro, onde acompanhada de alguns malandros e baianas, ela canta "Os quindins de Iaiá". Donald e Zé Carioca aderem à folia, e o primeiro oferece à Iaiá um "bouquet" de orquídeas; iaiá paga-lhe com um beijo e Donald desmaia... Cada vez mais intensa a dança prossegue, atingindo até as casas, árvores, etc, que também começam a sambar! Iaiá e os dançarinos se afastam, até que o livro se fecha, quase atingindo Donald e Zé Carioca, que se salvam a tempo! (Revista Cruzeiro, 17 de março de 1945, p. 64)

A presença masculina se faz sentir na figura dos músicos que acompanham Aurora Miranda. Segundo Mauad (2002), Los tres Caballeros, corresponde a etapa de um projeto norte-americano que, já há muito, vinha se processando: uma a aproximação entre as Américas. O desejo pela aproximação seria um tema vinculado à necessidade de reforçar, ou mesmo construir, uma ponte entre identidades aparentemente diferentes, criar uma via de comunicação entre a multiplicidade de culturas e temporalidades que compõem o mosaico de costumes e tradições do americano.

\subsubsection{A Bahia}

Ainda sobre a questão da identidade, e mais precisamente sobre a questão da formação do brasileiro, a partir da união das três raças, em 1951 Freyre publicava na Manchete um texto que, como ele próprio afirmava, ratificava a "velha ideia" da mistura das três raças, na qual o elemento negro, somado ao elemento europeu e indígena, teria produzido uma cultura mais rica e positiva do que em qualquer outra cultura da América, no caso, ao referir-se à Bahia: 
Figura 107. Você já foi à Bahia?

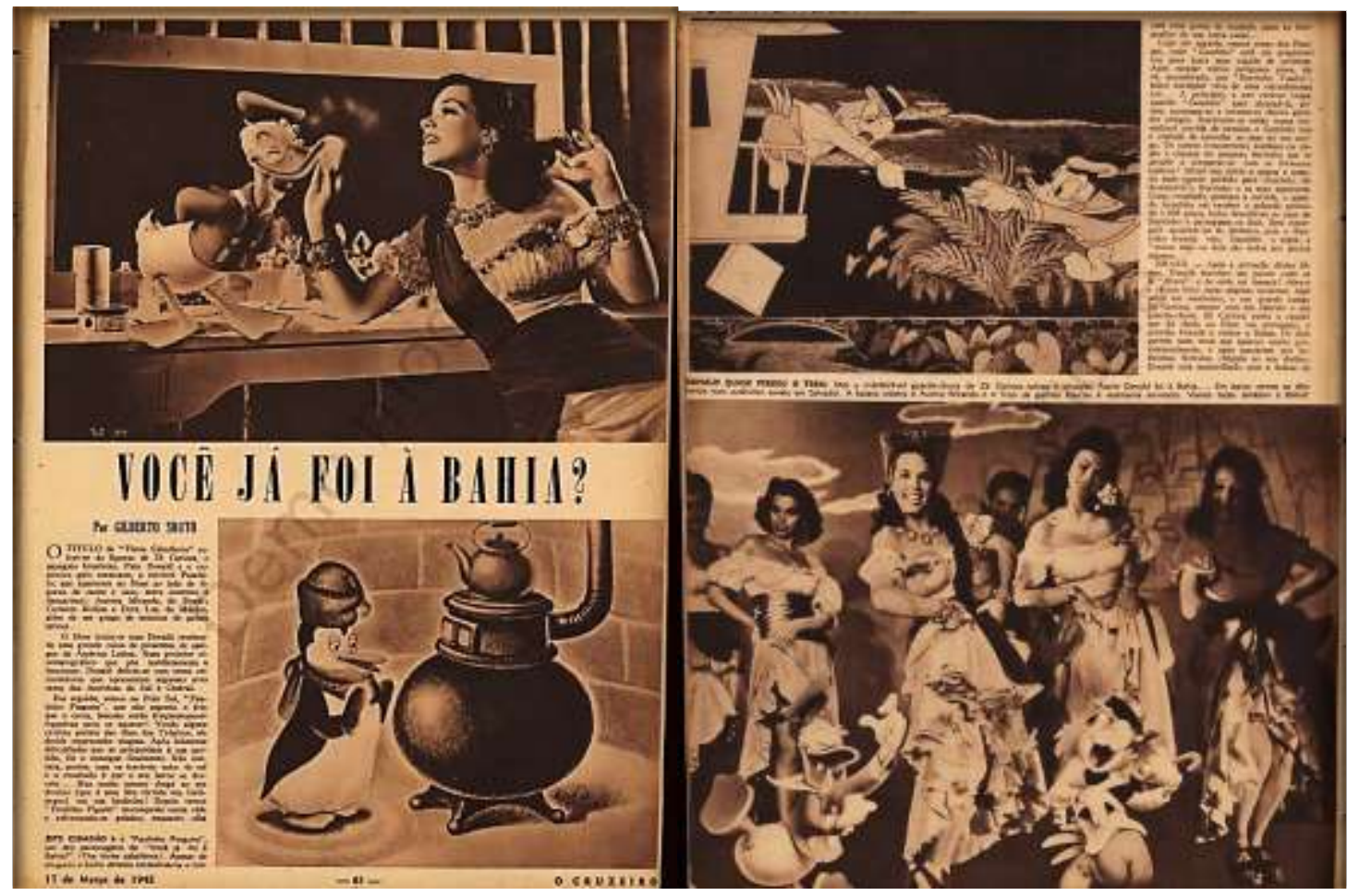

17 de março de 1945, p. inicial, 60 e 63. Acervo CEDIC-PUC.

Figura 108. Pato Donald na Praia

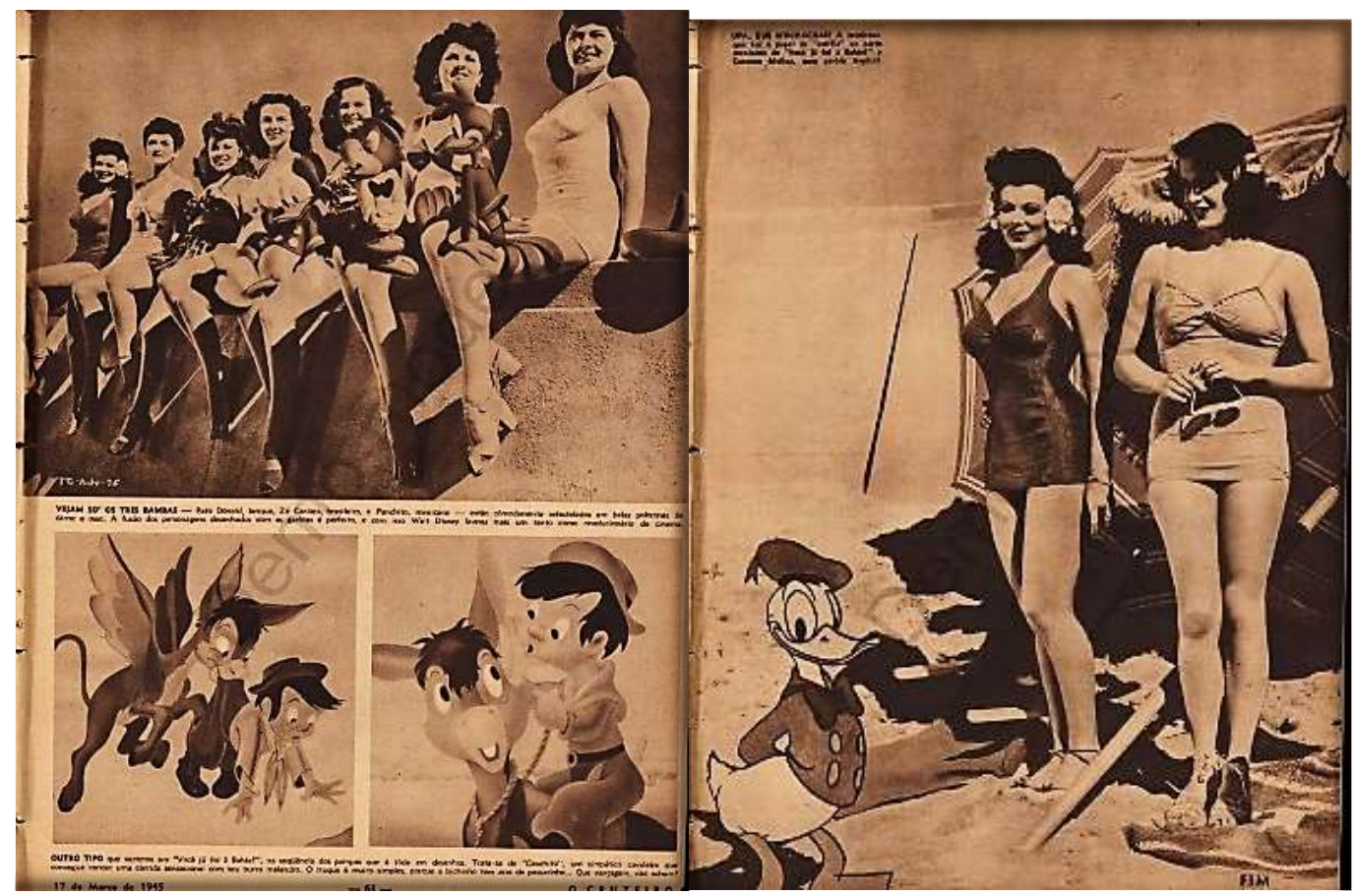

17 de março de 1945, p. inicial, 60 e 63. Acervo CEDIC-PUC. 
Mestre Métraux me honrou um desses dias com uma visita; e falou-me da Cidade de Salvador com um entusiasmo que me fêz perdoar seu desencanto imenso com o Recife. Ou com o que o progresso tem feito, nos últimos anos, à minha própria cidade que é o Recife. Mas Salvador é quase tanto o meu amor de brasileiro, de americano, de latino como o Recife, fiquei contente em ouvir o sábio suíço: "Não existe hoje na América cidade que se compare com Salvador. Palavras que, ditas por um Métraux, merecem que os sinos da Bahia repiquem de regozijo [...] É minha velha opinião. E quando um brasileiro ou um americano ou um europeu ou um indiano ou um japonês vê Salvador sem descobrir o que essa velha cidade de gente macia, de quitutes e de cores vivas representa como harmonia do homem com o trópico, do mestiço consigo mesmo, da Europa com a África e com o meio indigenamente americano, tenho pena do viajante sem olhos, sem ouvidos e sem paladar para o gôzo de combinações tão novas e tão felizes do que é velho com o que é novo, do que é intelectual com o que é instintivo, do que é europeu com que é tropical na civilização humana. Na Bahia se antecipa como em nenhuma cidade de hoje o mundo fraternalmente mestiço para que o homem caminha, se a bomba atômica não lhe interromper a marcha. (Revista $O$ Cruzeiro, 15 de dezembro de 1951, p. 10)

Freyre prossegue na argumentação, destacando uma ideia importante: para ele, na Bahia, como em nenhum outro lugar, a miscigenação teria produzido uma cultura coesa e de convivência democrática $^{153}$.

Salvador da Bahia é uma antecipação e um exemplo. Antecipação de convivência democrática, através de miscigenação. Exemplo de solução pacífica para os problemas de desajustamento entre os homens, tantos deles causados pelos ódios de raça, de casta, de seita que quase não existem numa cidade não só de todos os santos como de todas as raças. (Revista O Cruzeiro, 15 de dezembro de 1951, p. 10)

Freyre escreve o texto citado para $O$ Cruzeiro, em 1951, e nele, aponta a questão do ódio de raça como um problema que precisaria ser superado pela humanidade - e que já teria encontrado solução, na Bahia. ${ }^{154}$

153 Segundo Lühning: Em meados de 1949, a Unesco aceitou a ideia de realizar investigações sociológicas e antropológicas no Brasil por sugestão de Artur Ramos, responsável pelo Departamento de Ciências Sociais da Unesco (Maio,1999, p. 142) cuja direção assumira. A Unesco, como outros organismos internacionais, mostrava uma preocupação grande com a questão do racismo após os acontecimentos da Segunda Guerra Mundial. Via-se o Brasil como um país que poderia trazer importantes contribuições para a discussão do tema por considerar a sua auto definição como democracia racial, embora se percebesse que ainda carecia de mais pesquisas para comprovar essa visão, construída em especial a partir da obra de Gilberto Freyre. Lühning, Angela. Verger, Bastide e Métraux: três trajetórias entrelaçadas. Revista USP • São Pau Lo, n. 95, pp. 128-141, Setembro/Outubro/Novembro 2012. p. 1.

${ }^{154} \mathrm{O}$ trabalho de pesquisa de Verger, Gautherot, Bstides, Métraux, pelo Nordeste brasileiro se distinguiam do realizado anteriormente por Mário de Andrade. A missão de Pesquisas Folclóricas Mario de Andrade (1938), teve por objetivo registrar, elencar e impedir, por meio das possibilidades da tecnologia de registro dos anos 30 - a filmagem, a fotografia, a gravação - que a modernidade e sua marcha desenfreada rumo à mudança dos costumes, relegasse ao esquecimento as diversas manifestações folclóricas da tradição e do passado de sociedades tradicionais brasileiras. A missão tinha o objetivo de elencar, coletar e proteger do desaparecimento, enquanto que o trabalho de Verger, Bastide e Métraux, encontrava-se mais próximo dos princípios da Antropologia Culturalista, que buscava localizar e compreender as permanências do passado, cristalizado, vivo e entranhado no presente. 


\begin{abstract}
A Bahia estava no centro das atenções, em 1950, principalmente após a quinta sessão da Conferência Geral da Unesco, realizada em junho de 1950 em Florença, aprovar a realização da pesquisa sobre as relações raciais no Brasil. Lühning descreve esse momento: Artur Ramos tinha falecido alguns meses antes, sem que tivesse sido delineado o escopo do projeto. Métraux, com larga experiência de trabalho etnográfico nas Américas, assumira pouco antes a direção do recém-criado Setor de Relações Raciais do Departamento de Ciências Sociais da Unesco. Junto com seu assistente, o antropólogo Ruy Coelho, ex-aluno de Roger Bastide da Universidade de São Paulo, e de Melville Herskovits, da Northwestern University (EUA), tornou-se responsável pela coordenação do projeto de pesquisa da Unesco a ser realizado no Brasil. Logo em seguida ocorreu a inserção do antropólogo Charles Wagley e outros pesquisadores americanos no projeto ainda em construção, a partir de um convênio entre a Columbia University e o estado da Bahia, sob a coordenação de Anísio Teixeira, secretário de Educação do governo Otávio Mangabeira, com a participação do pesquisador Thales de Azevedo. Assim foi construído o formato mais amplo do projeto, que, além da Bahia, previa incluir também São Paulo e cidades menores do interior da Bahia para poder comparar as várias observações. No final de 1950, Roger Bastide é incluído no projeto, que ganha assim os seus contornos definitivos (LÜHNING, maio, 1999, pp. 144-5).
\end{abstract}

E é com base na ideia de uma identidade mestiça que Gilberto Freyre (2001) lança em sua obra a necessidade de explicar e promover a unidade política e cultural do Brasil, ressaltando sua diversidade cultural e regional, no que diz respeito, aos valores luso-brasileiros. Ou seja, difunde a ideia de que apesar da contribuição ameríndia e africana a identidade histórica do Brasil é moldada “pela cultura, língua e religião portuguesas, responsáveis pela deglutição do outro, incorporando aquilo que, diverso, é responsável pela riqueza de uma nação.” (MENEZES, 2011, online) tal reflexão influenciou vários intelectuais da época, tanto no Brasil quanto em outros países. Essa tal identidade existente entre o Brasil e as colônias portuguesas, e a imagem de um imenso país composto pela diversidade e dinamismo teve influência, por exemplo, tanto em Roger Bastide ${ }^{155}$ (Brasil terras de contrastes - 1980) como no próprio Pierre Verger (Fluxos e Refluxos, 1968) e mesmo a série de reportagens Acontece que são baianos sobre A dinastia dos Xaxás de Souza, de 1951, em parceria com Gilberto Freyre.

Acontece que são baianos, vem apresentada por uma grande fotografia de um flautista, homem negro, africano, e por pequenas fotos de pessoas dançando. As imagens, de um ambiente urbano - o homem com camisa, jaleco e gravata - (figura 109) rompe com a representação de uma África selvagem e tribal, ao mesmo tempo em que mantém a apresentação da dança, como elemento referencial para a identificação do ambiente africano no qual iria se desenvolver a pesquisa.

\footnotetext{
${ }^{155}$ De acordo com Lühning, "em 1944 Bastide já tinha realizado a sua primeira pesquisa de campo em viagem pelo Nordeste brasileiro, que resultou na publicação de Imagens do Nordeste Místico.", o livro seria lançado primeiro em português e, somente muitos anos depois, em francês. Sua atenção, em relação à Bahia, teria sido aguçada após seu encontro com o amigo Roger Bastide, que revela para Verger a visão de uma cultura ainda fortemente marcada pela matriz africana. Sobre esse assunto ver em LÜHNING, Ângela. Verger, Bastide e Métraux: três trajetórias entrelaçadas. REVISTA USP • São Paulo, n. 95. Setembro/outubro/novembro 2012, p. 130
} 
Figura 109. Acontece que são baianos.

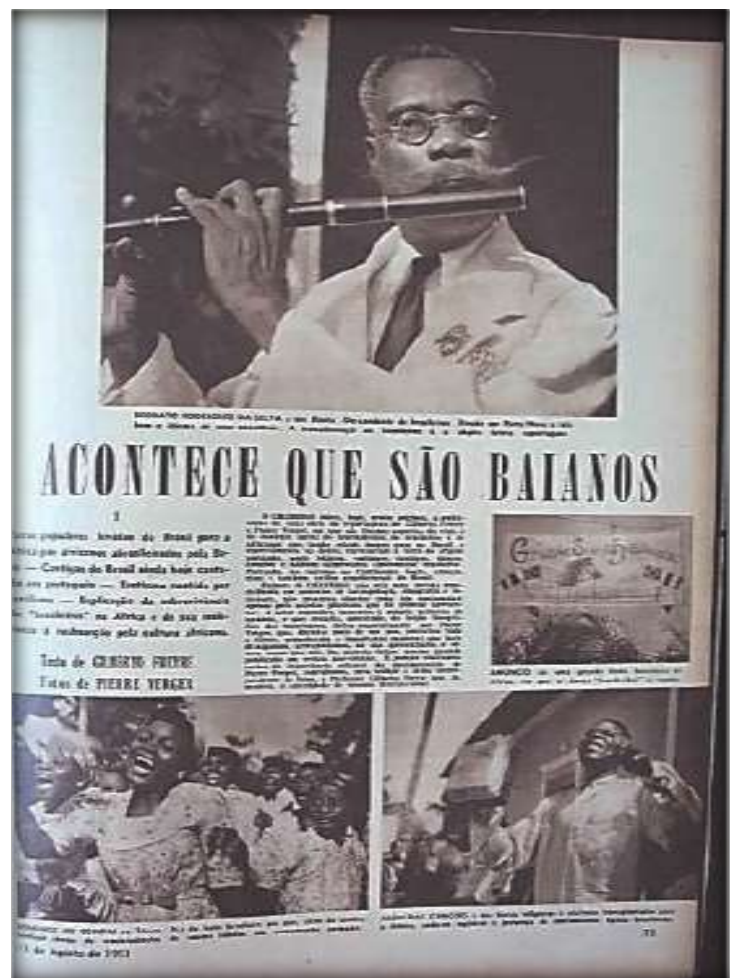

Fonte: Revista Cruzeiro, 11 de agosto de 1951, p. 72. Acervo MASP.

Figura 110. A dinastia dos Xaxás de Souza.

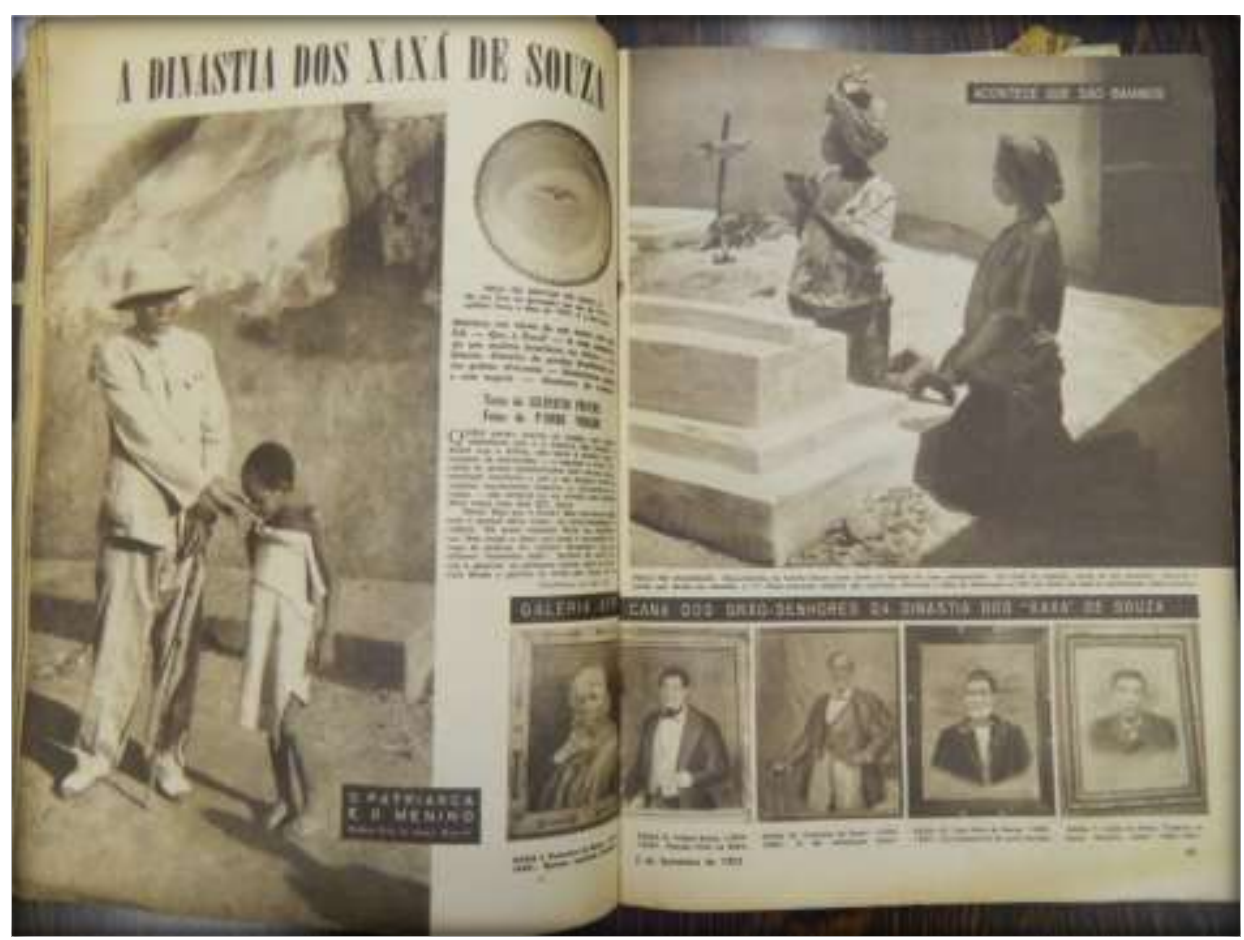

Fonte: Revista Cruzeiro, 08 de setembro de 1951, p. 62-63. Acervo CEDHIS- UFU 
A série de reportagens trouxe um riquíssimo conjunto de imagens e análises sobre a cultura e os costumes da população da cidade de Uidá, antiga Fortaleza de São João Baptista de Ajudá, no Benin, África.

O CRUZEIRO inicia, hoje, nestas páginas, a publicação de uma série de reportagens de Gilberto Freyre e Pierre Verger, em que são fixados aspectos da vida e da conduta social de descendentes de brasileiros e de africanos que, tendo estado longos anos no Brasil, e especialmente na Bahia, regressaram à terra de origem portanto, nesse retôrno, costumes, cantigas, danças, canções e hábitos alimentares tipicamente brasileiros. Portanto, no regresso ao Continente Negro, crenças, ritos e também estilos arquiteturais do Brasil. Embora O CRUZEIRO não seja uma revista especializada em assuntos de antropologia, etnografia e sociologia, não procurou abordar tema tão apaixonante apenas pelo aspecto pitoresco que êle pudesse apresentar. (O Cruzeiro 11 de agosto de 1951, p.72).

O objetivo do trabalho de Pierre Verger e Gilberto Freyre era mostrar que as influências culturais entre África e Brasil não aconteceram somente do continente africano para as áreas receptoras de mão de obra escrava, mas também no caminho inverso - Brasil - África - saberes e costumes também haviam migrado, sendo possível observar-lhes as marcas ainda naqueles dias.

Quem passar, mesmo de raspão, pelo assunto fascinante que é a história das relações do Brasil com a África, não tanto à sombra como à margem da escravidão - o regresso a terras africanas de pretos abrasileirados pelo contato com a sociedade brasileira e até a ida àquelas terras de mulatos maciamente baianos ou astutamente cariocas - não deixará de ser atraído pelo mistério dêste nome com dois XX: Xaxa. Xaxa! Mas que é Xaxá? Mas discute-se ainda hoje o porquê dêste nome. Os africanologistas divergem. Há quem suponha Xaxá um brasileirismo: Foa chega a dizer que xaxá é a corruptela africana de palavra do "patois" brasileiro" que significava "moedeiro falso". Herissé dá outro sentido à palavra: os africanos teriam dado ao brasileiro Souza o apelido de Xaxá por causa do seu modo vivo de andar: passos curtos e apressados. Olivier ou "Olliveira" oferece ainda outra explicação colhida pelo pesquisador Pierra Verger na sua última viagem a terras africanas: os indígenas da África passaram a chamar de Xaxá o mulato vindo do Brasil porque era como Souza parecia chama-los senhorialmente para o trabalho quando dizia em português: Já-já! Aos ouvidos africanos já-já se abrandara em xaxá. (Revista Cruzeiro, 08 de setembro de 1951, p. 63)

O conjunto de matérias publicadas pela Cruzeiro descreve as formas de sociabilidade, bem como os movimentos e significados de ações do cotidiano desses descendentes de africanos amaciados pelo Brasil, mais precisamente, pela Bahia. É possível perceber na escrita fotografia de Verger valoriza o elemento humano, apresentando, no contexto de suas ações e relações, semelhanças com o povo da Bahia (figura 109). Na escrita de Freyre, nota-se a valorização da cultura brasileira como um dado de civilização dos costumes tradicionais dos povos do Benin, mais 
especificamente, a cultura baiana como dado diferenciador, tornando esses retornados, indivíduos representantes de costumes mais policiados. ${ }^{156}$

Embora o interesse internacional, como aponta Lühning, pelo estudo das relações culturais entre Brasil e África fosse significativo, havia ainda o interesse da revista, voltado para o aspecto exótico e pitoresco, capaz de alimentar o olhar curioso de quem viajava pelo mundo por meio dos textos e das imagens da revista. O próprio texto demonstra essa função de alimentar o olhar do leitor, ao descrever minuciosamente o conjunto de utensílios da casa:

Outros brasileirismos haviam se desenvolvido na África sob sua proteção de grande senhor, além deste, de natureza moral. Brasileirismos de ordem material: o gôsto pela cachaça, o vício elegante do charuto o costume da rêde aristocrática, por exemplo. Em companhia da família Souza, e em excursão rural, o inglês Forbes conheceu esplêndida fazenda conservada por um negro livre que fora escravo na Bahia. Aí se cultivava, ao lado de coqueiros ou palmeiras - para o azeite - e inhame e algodão, o milho brasileiro: base de tantos quitutes afro-brasileiros inclusive o cuscuz nortista. $\mathrm{E}$ na casa do baiano, bebia-se café, não em xícaras de porcelana, mas em vasos de prata sólida. Café e vinhos finos. Era, na hospitalidade, essa casa de agricultor baiano na África, uma espécie de casagrande do norte do Brasil mais opulentamente patriarcal do modo de servir quitutes, vinho e café.

No conteúdo das reportagens, Freyre destaca a importância do saber-fazer, dos retornados, que com as técnicas trazidas do brasil moldaram a arquitetura das cidades, como Lagos, onde construíram "grandes mesquitas e catedrais"

O inglês, como bom inglês, raciocinou logo: Se africanos de volta dos Brasis podem levantar tôrres como esta, por que não escolher o Gôverno de Lagos um grupo de rapazes africanos mais inteligentes para que sejam enviados à Inglaterra a fim de estudarem engenharia? Foi o que se fêz. levantada por um africano que aprendera a arte de construir com mestres de obras do Brasil. (O Cruzeiro 25 de agosto de 1951, p.102)

156 O termo policiada é utilizado aqui como na interpretação de Sergio Buarque de Holanda à expressão presente em Luís dos Santos Vilhena, o autor de Atitudes de Inovação no Brasil, 1789-1801; quando este se refere à "muita gente policiada que havia então na Bahia". Conforme o comentário de Holanda o vocábulo, naquele contexto, carregaria bem mais o sentido de "civilizada", "cultivada" ou "refinada. Utilizamos o termo para destacarmos, do olhar de Freyre, a compreensão de que os costumes dos súditos dos xaxás - após o intercâmbio cultural com os retornados - teriam cambiados para um modelo cultura mais urbano, menos influenciado pela tradição ancestral e mais voltado às relações multiculturais, como seria, para Freyre, a Bahia do século XIX. Sobre a interpretação de Holanda para Vilhena, ver em MONTEIRO, Pedro Meira. Sergio Buarque de Holanda e as palavras: uma polêmica. Lua Nova[online]. 1999, n.48, pp. 145-159. 
Além da arquitetura, outros saberes, trazidos do Brasil, mais precisamente da Bahia, são identificados e valorizados pelo autor como as Festas:

Festas populares levadas do Brasil para África por africanos abrasileirados pela Bahia - Cantigas do Brasil ainda hoje cantadas em português - Erotismo contido por familismo - Explicação da sobrevivência do "brasileiros" na África e de sua resistência à reabsorção pela cultura africana. Não é de admirar que dentre os elementos de cultura brasileira levados à África por africanos abrasileirados por longo contato com o Brasil, destaquem-se as festas. As festas populares, com sua gorda e bonita substância folclórica. As festas profanas, das quais nem sempre é fácil separar as religiosas propriamente ditas. Quase todos os africanos "brasileiros" voltaram à África, da Bahia. Às vêzes de outros pontos do Brasil, mas "via Bahia". Abaianados, portanto. Amaciados, urbanizados, polidos pela Bahia. E quem diz Bahia ou baiano diz festa, bôlo,doce, mulata, alegria e até pecado: os sete pecados mortais refugiados à sombra de todos os santos. Diz música, dança, canto, foguete, capoeiragem, pastel enfeitado com papel de cor e caprichosamente recortado, caruru, violão, balangandã, chinelinha leve na ponta do pé da mulher (em contraste com o tamanco pesadamente português do homem), saia de roda, camisa ou cabeção picado de renda, de mulatas, de quadraronas provocantes. Não é de admirar que as cantigas em língua portuguêsa do Brasil um tanto estropiada pela distância e pelo tempo [...] descendentes de "brasileiros" ou "baianos", estejam salpicadas de brasileirismos de dia de festa.(Grifo nosso) (O Cruzeiro 11 de agosto de 1951, p. 72)

Importante observar que Freyre destaca não só a influência na mudança da cultura material, mas também na mudança dos valores morais, atribuindo a presença dos brasileiros a uma mudança positiva:

Entretanto justiça seja feita ao brasileiro Souza: em vida procurara acabar com o costume africano do sacrifício humano. Também com a pena de morte por crimes como destrição de certa serpente, considerada sagrada, por indígenas descuidados. Sacrifício humano e pena de morte repugnavam ao descendente de africanos amaciado, abaionado, cristianizado pelo Brasil. (Grifo nosso). (Revista Cruzeiro 11 de agosto de 1951, p. 82)

Macio, amaciado, polido pela Bahia, aos usar tais termos, consideramos que Freyre, ao escolher não utilizar a expressão "civilizado pela baia" esteja indicando que, não entendia a relação entre as duas culturas como uma oposição entre civilização e barbárie, mas como um processo de troca e de interferência mútua. Freyre entende que o fluxo pelo qual elementos culturais brasileiros - baianos - se instalam alterando os costumes no Benin, produziriam transformações significativas. E Freyre as qualifica. Embora não descreva o resultado de tais mudanças como "mais civilizado", define-os, por diversas vezes, como "mais macio", "mais polido", estabelecendo, talvez uma relação mais próxima da oposição entre desenvolvimento e atraso.

Dessa forma, ao observar o imaginário do período sobre o Nordeste como espaço de interesse do olhar e espaço produtor de cultura, o que se observa é a presença marcante 
representações de um Nordeste exótico. O Nordeste como terra de fronteira, como wilderness, ou o Nordeste do cagaço, corresponderia a um exotismo associado à uma oposição entre civilização e barbárie, alimentando a curiosidade e a fantasia dos contos, canções e romances, por constituir-se num universo em oposição ao das cidades e das sociedades modernas, mesmo o cangaceiro e o sertanejo desse Nordeste exótico geram a curiosidade do olhar, pois representam o inusitado, o fantástico. Já o Nordeste das igrejas antigas e das figuras típicas, representaria uma materialização da memória, uma possibilidade de estar-se no presente diante do passado - exercício importante num Brasil que buscava por construir a sua identidade. Por fim, o Nordeste assumindo a posição de representante do Brasil, por meio da imagem da Bahia e do povo e da cultura baiana. Tanto para a antropologia, que, na busca por entender a sociedade brasileira mestiça, toma a Bahia como campo para análise, como para as mídias em dimensão mundial. Um Brasil e uma brasilidade, modelo para exportação, no qual a Bahia era reelaborada e apresentada não como uma Bahia real, mas uma Bahia estilizada, que soma elementos do Rio de Janeiro - eterno cartão postal do Brasil como o samba e o morro, e elementos da natureza tropical. Um Brasil de luz, beleza, alegria e fatura, representado, justamente, por elementos da cultura do Nordeste. 


\section{CONSIDERAÇÕES FINAIS}

Ao decidirmos trabalhar com a questão das representações coletivas sobre os nordestinos e o Nordeste, seguimos os rastros das antigas imagens cristalizadas sobre a região e as gentes do Nordeste, objetivando compreender seu lugar na construção dos referenciais do repertório imagético de nossa sociedade

Inicialmente, a seca e o sertão, mostraram-se como os grandes representantes do Nordeste e do sertanejo do semi-árido, que desde o final do século XIX, fortemente marcado pelo pensamento das teorias raciais, o chegava ao Sul e ao Sudeste como a representação de um ambiente inóspito, distante, bárbaro. As levas de retirantes eram descritas como hordas de flagelados, vítimas de um desastre natural que não podem evitar; mesmo recebendo pouca atenção, algumas vozes insistiam em destacar as razões sócio-políticas do fenômeno da migração, negando a ideia de um Nordeste impróprio para o desenvolvimento. O mais importante nesse contexto, foi perceber que o estranhamento em relação ao retirante, sua identificação com a barbárie, não seria produto de um discurso produzido incialmente pelas populações do Sudeste, mas sim um discurso produzido por uma ordem voltada para o modelo europeizante da sociedade, modelo desejado e imitado tanto nos centros urbanos do Sudeste quanto nos centros urbanos do Nordeste. A imprensa, do final do XIX e início do XX, nas capitais nordestinas, referia-se assim aos retirantes como indesejáveis invasores bárbaros, uma vez que representavam o oposto daquilo que almejavam - o modelo burguês, urbano e europeu de sociedade. Nessa perspectiva, esta imagem permaneceria viva, enquanto o homem europeu fosse visto como modelo superior. Em relação ao homem do Nordeste, a representação de alguns tipos como a presença da memória colonial, ou do passado vivo, não deixava de ser a constatação da existência de seu valor cultural.

Havia contudo, nos estudos e esforços sobre a memória e a história do povo brasileiro, a valorização da arquitetura do Nordeste e mesmo a valorização das figuras típicas, características da velha ordem urbana dos finais do XIX e que ainda podiam ser vistas pelas ruas das capitais nordestinas.

O ponto de transformação na relação entre o Nordeste e suas representações residiria, portanto, no momento de transição de uma política de valorização da mão-de-obra estrangeira para uma política de nacionalização da mão-de-obra; o que viria a acontecer durante os anos de 1940, no governo Vargas. 
A partir dos anos 1940, a imagem euclydiana do Nordeste-sertão, do sertanejo como "o outro", de hábitos e psicologia tão distintas das dos homens do Sul, a noção de um sertão estéril e bárbaro, começa a ser substituída pela busca das razões da estagnação econômica, do atraso da região. Jacques Lambert, Roger Bastide, Caio Prado, abrem caminho para Celso Furtado e outros membros da CEPAL, que, no final da década de 1950, irão não somente pensar o Nordeste a partir de uma perspectiva de integração da região num programa de desenvolvimento nacional, como de fato, buscarão implementar projetos visando o desenvolvimento da região. É frente a esse cenário que, nas revistas ilustradas surge, diante dos olhos dos brasileiros, outro Nordeste, um Nordeste das grandes obras de exploração de petróleo, da construção de grandes hidrelétricas, um Nordeste de diversidade cultural, e também de cenários descritos como exóticos e de histórias de valentia e violência narradas no formato do western norte-americano.

Juntamente com a valorização da mão de obra e da exploração do potencial energético do Nordeste, dois elementos fundamentais na equação que levaria o país em direção ao desenvolvimento, temos a revitalização das discussões sobre identidade, permeadas, principalmente a partir do pós-guerra, pelos trabalhos de estudiosos como Roger Bastide, Gilberto Freyre e Pierre Verger, que além de estudarem as raízes profundas da cultura brasileira, veiculavam seu pensamento por meio da mídia impressa.

Dessa forma, chegamos aos anos 1950 diante de um imaginário no qual as representações de Nordeste não podem ser associadas somente à negatividade das secas. O otimismo em torno do desenvolvimento econômico e o deslumbramento diante da presença de elementos da brasilidade baiana nas telas de cinema do mundo todo, fariam com que o Nordeste abandonasse a tradução singular que tivera outrora, para assumir uma imagem plural.

A escolha das fontes - as revistas ilustradas - surgiu em função do desejo de compreender de que maneira um poderoso veículo formador de opinião construíra tais representações. Embora a literatura, a música, o cinema, as artes plásticas também tenham representado e interpretado o Nordeste, escolhemos as revistas, pois cada um destes meios possui sua própria lógica interna, seus objetivos comunicacionais e seu público. No caso das revistas ilustradas, além de incorporarem ao seu texto os acontecimentos ligados às artes - literatura, pintura, música - seu alcance fora, desde os anos de 1930, muito amplo. Se considerarmos os números das tiragens recorde em relação à proporção da população alfabetizada e urbana no Brasil da segunda metade do século XX, perceberemos que uma tiragem de 200 mil exemplares, como nos primeiros anos da Manchete ou 
mesmo a de um milhão de exemplares, da Cruzeiro, quando da morte de Vargas, atingiria um número muito maior de leitores - estimemos em seis vezes mais, por exemplo - uma vez que uma mesma revista, via de regra, era lida por várias pessoas - em família, no consultório, no salão de beleza, no clube, na biblioteca, num café, etc.

Assim, no estudo das representações sobre o nordestino e sobre o Nordeste, duas questões fundamentais se impõem: a primeira, a compreensão de que muitas das imagens e ideias associadas a ambos permaneceram cristalizadas por décadas, amparadas por uma aparato ideológico e uma visão sobre raça, e civilização que se manteve firme até o final da Segunda Grande Guerra.

A segunda e mais importante questão é a compreensão de que, à medida em que as sociedades mudam, um mesmo objeto poderá ser ressignificado, portanto, a transformação sóciopolítica pela qual passara o mundo após a Segunda Grande Guerra, trouxe consigo outra visão de sociedade e cultura que irá impactar também no Brasil, dando visibilidade a outras formas de interpretação dos espaços e costumes.

Não se trata de negar a permanências de antigos significados: o Nordeste das secas, o nordestino como um homem vencido pela natureza constituem-se em duas fortes imagens, consolidadas no final do século XIX e que ainda se mantém firme no imaginário brasileiro, todavia, o que defendemos aqui, é a compreensão da ampliação desse referencial imagético, principalmente, a partir dos anos cinquenta, quando o Nordeste, na imprensa do Sudeste, passa a ser identificado por meio de outras falas, por outras imagens.

Na apresentação de um Nordeste exótico, natureza e homem são elementos que constituem as composições imagéticas, ambos remetendo cenários e paisagens a um tempo pretérito que caminhava para o desaparecimento à medida em que dava-se o inexorável avanço da modernidade. É possível também perceber que para ambos, homem e natureza, a presença do passado tanto em forma de natureza selvagem quanto na forma de tradições culturais centenárias, era interpretado ora como preservação - do meio, ou da memória - ora atraso, barbárie - tanto na descrição do sertão como um purgatório, quanto na descrição das manifestações religiosas afro-brasileiras como resquício de tradições bárbaras.

Entre a segunda metade da década de 1940 e durante os anos de 1950, a efervescência de uma nação que procurava se entender e construir sua autoimagem foi o campo fértil para a 
proliferação de velhas e novas representações sobre o Nordeste brasileiro. Do debate sobre as secas, a migração e o potencial produtivo do sertão seco, ao confronto entre a valorização das tradições de matriz africana e os resquícios de um pensamento spenceriano e eurocêntrico que as via como degeneração; mas os objetos podem ser ressignificados, a sociedade se transforma, busca novas respostas para velhas perguntas e se apropria de novos elementos para realizar a sua interpretação da realidade. O desenvolvimento econômico, a narrativa culturalista, a estética hollywoodiana, novos elementos se somam na construção das representações de nosso Hércules-Quasímodo, que até onde observamos, se nos apresenta com duas faces, mas talvez tenha outras tantas e, talvez, para percebê-las, precisamos continuar a realizar a difícil tarefa de educar-nos o olhar. 


\section{REFERÊNCIAS}

\section{$\underline{\text { Acervos }}$}

BFF - Biblioteca Florestan Fernandes Biblioteca da Faculdade de Filosofia, Letras e Ciência Humanas da USP.

Coleção da Revista de Imigração e Colonização. Ano I. 1940-Ano VII. 1946.

Coleção Boletim do Ministério da Agricultura.

BFF - Biblioteca Florestan Fernandes Biblioteca da Faculdade de Filosofia, Letras e Ciência Humanas da USP.

Coleção Revista Manchete. Rio de Janeiro: Bloch Editora - 1952-1954.

BFF - Biblioteca Florestan Fernandes. Biblioteca da Faculdade de Filosofia, Letras e Ciência Humanas da USP.

Coleção da Revista Vamos Lêr! Rio de Janeiro: S.A. A Noite. - 1937 a 1940.

BMASP - Biblioteca do Museu de Arte de São Paulo - MASP.

Coleção da Revista $O$ Cruzeiro. Revista Semanal Ilustrada. O Cruzeiro S.A: Rio de Janeiro - 1929-1954.

BMA - Biblioteca Mário de Andrade - SP.

Coleção da Revista $O$ Cruzeiro. Revista Semanal Ilustrada. O Cruzeiro S.A: Rio de Janeiro 1929-1954.

CEDHIS - Centro de Documentação e Pesquisa em História Universidade Federal de Uberlândia. Coleção da Revista $O$ Cruzeiro Revista Semanal Ilustrada. O Cruzeiro S.A: Rio de Janeiro $-1940-1954$.

CEDIC - Centro de Documentação e Informação Científica - Pontifícia Universidade Católica de São Paulo.

Coleção da Revista O Cruzeiro. Revista Semanal Ilustrada. O Cruzeiro S.A: Rio de Janeiro 1929-1945.

CEM - Centro de Estudos Migratórios. Pastoral do Imigrante de São Paulo.

Coleção de documentos xerografados. Jornal O Migrante.

IEB - Instituto de Estudos Brasileiros da Universidade de São Paulo.

Coleção Revista $O$ Cruzeiro. Revista Semanal Ilustrada. O Cruzeiro S.A: Rio de Janeiro1929-1954.

IHG - Instituto Histórico e Geográfico de São Paulo. Coleção de Jornais anos 20-30. Bangú Jornal. 


\section{Colecão Particular}

Coleção Revista Memória. Publicação do Departamento de Patrimônio Histórico da Eletropaulo. 1987-1993.

\section{$\underline{\text { Acervos online }}$}

Álbum do Rio de Janeiro Moderno (1857), de Sebastien Auguste Sisson. Acervo Digital Biblioteca nacional. Acessado em 10 de maio de 2012. Disponível em: http://objdigital.bn.br/acervo_digital/div_iconografia/icon395084/galery/index.htm

Acervo Folha - Grupo Folha de S. Paulo. Folha da Manhã e Folha da Noite. Acessado em 10 de outubro de 2012. Disponível em http://acervo.folha.com.br/.

Acervo Jornal O Povo - Ceará. Acessado em 20 de janeiro de 2013. Disponível em: http://www.opovo.com.br/acervo/.

Arquivo Municipal de Bento Gonçalves. Acesso em 10 de maio de 2012. Disponível em http://www.bentogoncalves.rs.gov.br

Banco de dados do Centro de Pesquisa e Documentação em História Contemporânea do Brasil. Faculdade Getúlio Vargas. A Era Vargas. Cd-rom e acesso eletrônico em http://www.cpdoc.fgv.br/nav_historia/htm/ev_main.htm\#top

Jornal do Commercio - JC Cultural - Caderno C: Especial Gilberto Freyre II - Recife, quartafeira, 13 de março de 2000. Versão eletrônica, JC On Line. Disponível em http://www2.uol.com.br/JC/_2000/2003/cu1503b.htm. Acessado em 05 de maio de 2008.

Museu da Imigração do Estado de São Paulo. Acessado em 10 de janeiro de 2013. Disponível em: http://museudaimigracao.org.br/acervodigital/

Portal Memória Viva. Acessado em 10 de janeiro de 2012. Disponível em: http://www.memoriaviva.com.br/

\section{Manuais Escolares Brasileiros}

ESPINHEIRA, Ariosto. Viagem através do Brasil. Vol. II. Nordeste. Ilustrações do autor. São Paulo - Caieiras/Rio de Janeiro: Melhoramentos, 1939.

FRAZÃO, Manoel José Pereira. Noções de Geographia do Brazil. Rio de Janeiro: Typ. Esperança de J. D'Aguiar, 1883. 
HOMEM DE MELO. Geographia - Atlas do Brasil e das cinco partes do Mundo. 2a parte: Os Estados do Brasil. Rio de Janeiro: F. Briguieta e Cia, $2^{a}$ edição revista e muito aumentada, 1923.

LACERDA, Joaquim Maria. Curso methodico de Geographia physica, politica e astronomica: composto para uso das escolas brazileiras. Rio de Janeiro: B. L. Garnier, 1884. $3^{\mathrm{a}}$ ed.

MENEZES, Estácio de Sá. Noções Elementares de Geographia. Rio de Janeiro: S. L. Garnier Livreiro Editor, 1885. (sem ilustrações)

PARANÁ, Sebastião. Os estados da república. Para uso nos gymnasios e nas escolas normaes. Coritiba: Editores - Buzeti-Mori e Filhos, 1911, primeira edição. (sem ilustrações)

PINTO, Alfredo Moreira. O Brazil em 1885. Províncias do Brazil. Rio de Janeiro: Livraria Nicolau Alves, Segunda Edição, 1885.

REVISTA DE IMMIGRAÇÃO E COLONIZAÇÃO, ano III, agosto 1942, Rio de Janeiro, Brasil. SCROSOPPI, Horácio. Chorographia do Brasil. Rio de Janeiro: Livraria Francisco Alves, 1927. VILLA-LOBOS, R. Chorographia do Brazil. Rio de Janeiro: Laemmert A. C., 1906. $5^{\text {a }}$ ed.

\section{Manuais Escolares Portugueses}

CARVALHO, Pedro. Geografia de Portugal. Para a $4^{\mathrm{a}}$ classe do ensino primário e admissão aos liceus. Porto: Porto, 194- (data incerta)

CHAVES, Albano. Resumo de Geografia. Porto: Porto, 1930. Colecção Instrutiva.

GENOVESI, G.: L'immagine e l'idea di Europa nei manuali scolastici (1900-1945). Atti del I Convegno internazionale. SPICAE (Societas pro Investigatione Comparata Adhesa Educationi), Cassino, Franco Angeli, 1999, pp.191-204

GUIMARÃES, Acacio. Noções de Geografia. Ensino Primário elementar. $3^{\mathrm{a}}$ e $4^{\mathrm{a}}$ classes. Livraria Popular de Francisco Franco. Lisboa. 1930.

MATTOSO, António G. Compêndio de Geografia Econômica. Lisboa: Livraria Sá da Costa, 1939a.

Compêndio de Geografia Geral. Ensino Técnico Curso Comercial. Lisboa: Sá da Costa, 1939b. $9^{\text {a }}$ ed. (com mapas anexados).

MOURA, Alves de; VIEIRA, Evaristo; PALMA, Américo. Compêndio de Geografia. $2^{\circ}$ ciclos dos liceus. Lisboa: Livraria Didáctica, 1949.

MOURA, Alves de; PALMA, Américo. Geografia Económica. Livraria Didáctica. Lisboa, 1954. $6^{\mathrm{a}}$ ed. 
MOURA Eduardo. Geografia de Portugal. Coleção escolar Progredidor. Nova edição, 1944.

SCHWALBACH, Luis. Geografia. Portugal, colónias portuguesas, Brasil e regiões polares; Livrarias Aillaud e Bertrand. Paris - Lisboa. Livraria Chardron, Porto e Livraria Francisco Alves, Rio de Janeiro, 193- (Data incerta).

\section{$\underline{\text { Sobre os manuais portugueses }}$}

CLAUDINO, S. Os compêndios escolares de Geografia no Estado Novo: Mitos e realidades. Finisterra Revista portuguesa de Geografia, volume XL, n. 79, 2005. Disponível em: <http://www.ceg.ul.pt/finisterra/numeros/2005-79/79_15.pdf>. Acessado em 20/06/2012.

FERNANDES, M. G. Manuais Escolares de Geografia: Imagens, cartografia e divisões regionais. Catálogo da terceira exposição de manuais escolares de Geografia do ensino básico e secundário, FLUP, 2008. Disponível em 〈http://ler.letras.up.pt/uploads/ficheiros/4928.pdf〉. Acessado em 20/07/2012.

MAGALHÃES, J. O Manual Escolar no Quadro da História Cultural: para uma historiografia do manual escolar em Portugal. Sísifo. Revista de Ciências da Educação. Unidade de Ciências da Educação da Universidade de Lisboa. Set/Out/Nov/Dez, n. 01, p. 05-14, 2006. Disponível em <http://sisifo.fpce.ul.pt/pdfs/01sisifopt01.pdf>. Acessado em 20 de junho de 2012.

MAGALHÃES, Justino. (2008). O manual escolar como fonte historiográfica. Repositório da universidade de Lisboa. Disponível em <http://repositorio.ul.pt/bitstream/10451/5958/1/O\%20manual\%20escolar\%20como\%20fonte\%2 Ohistoriogr\%c3\%alfica.pdf $>$. Acessado em 20/06/2012.

\section{$\underline{\text { Sobre Processos, Decretos e Tratados }}$}

Processo $n^{\circ}$ 2005.30.00.712535-8, Classe: 51201 - ORD/PREV/COM/BEM. Autor: Francisco Barbosa Cavalcante, Réu: Instituto Nacional de Seguro Social - INSS. Poder Judiciário Federal, Seção Judiciária do Estado do Acre. p. 04.

BALTAZAR, Isabel. Ritmo Novo. O tratado de comércio entre Portugal e Brasil de 28 de Agosto de 1933. In: CASTRO, Zília Osório de; SILVA, Júlio Rodrigues da; SARMENTO, Cristina Montalvão (eds.) Tratados do Atlântico Sul: Portugal-Brasil, 1825-2000. Colecção Biblioteca Diplomática do MNE - Série A Ministério dos Negócios Estrangeiros, Universidade Nova de Lisboa. Faculdade de Ciências Sociais e História, Portugal, 2006, p. 205-237. Disponível em <http://www.fcsh.unl.pt/chc/pdfs/Atlantico\%20Sul.pdf>. Acessado em 20/06/2012.

MENDES, José Sacchetta Ramos; MIRANDA, Tiago C. P. dos Reis. O tratado do primeiro centenário ou a retórica das "duas pátrias". In: CASTRO, Zília Osório de; SILVA, Júlio Rodrigues da; SARMENTO, Cristina Montalvão (eds.) Tratados do Atlântico Sul: Portugal-Brasil, 18252000. Colecção Biblioteca Diplomática do MNE - Série A Ministério dos Negócios Estrangeiros, 
Universidade Nova de Lisboa. Faculdade de Ciências Sociais e História, Portugal, 2006, pp. 165196. Disponível em <http://www.fcsh.unl.pt/chc/pdfs/Atlantico\%20Sul.pdf>. Acessado em 20/06/2012.

MINISTÉRIO DA INSTRUÇÃO PÚBLICA. Direcção Geral do ensino primário e normal. $2^{\mathrm{a}}$ Repartição. Diário da República. Eletrônico. Disponível em <http://www.dre.pt/sug/1s/indiceslista-diplomas.asp?tipo=decreto\&ano=1928\&trim=4. Acessado em 20/06/2012.

RIBEIRO, M. Vivência das crises - Vencer a crise. Tratado de Comércio e navegação entre Portugal e o Brasil (14.01.1892). In: CASTRO, Zília Osório de; SILVA, Júlio Rodrigues da; SARMENTO, Cristina Montalvão (eds.) Tratados do Atlântico Sul: Portugal-Brasil, 1825-2000. Colecção Biblioteca Diplomática do MNE - Série A Ministério dos Negócios Estrangeiros, Universidade Nova de Lisboa. Faculdade de Ciências Sociais e História, Portugal, 2006, pp. 143157. Disponível em <http://www.fcsh.unl.pt/chc/pdfs/Atlantico\%20Sul.pdf>. Acessado em 20/06/2012.

SANTOS, P. As Relações Portugal-Brasil na primeira metade do século XX (1910-1945). Repositório do Instituto Politécnico de Viseu, 2011. Disponível em $<$ http://repositorio.ipv.pt/bitstream/10400.19/826/1/PAULA\%20SANTOS.pdf>. Acessado em 20/06/2012.

SCHIAVON, C. A política externa econômica luso-brasileira durante a década de trinta do século XX: análise do tratado de comércio e navegação de 1933. Historiae. Revista de História. Rio Grande do Sul, RS, FURG, v. 1, n. 1, 2010. Disponível em <http://www.seer.furg.br/index.php/hist/article/download/2359/1241 . . Acessado em 20/06/2012.

NEVES, Frederico de Castro. Getúlio e a seca: Políticas emergenciais na era Vargas Revista brasileira de História, São Paulo, v. 21, n. 40, 2001. Disponível em: $<$ http://www.scielo.br/scielo.php?script=sci_arttext\&pid=S0102-

01882001000100006\&lng=en\&nrm=iso>. Acesso em 14/ 01/2014.

\section{$\underline{\text { Geral }}$}

ALMEIDA, Ivete Batista da Silva. O olhar de quem faz: São Paulo durante a revolução de 1932. São Paulo: I.B.S.A/ Café, 2001.

AMERICANO, Jorge. São Paulo nesse tempo (1915-1985). São Paulo: Melhoramentos, 1962.

ANDRADE, Manuel Correia de. "Gilberto Freyre e o Impacto dos Anos 30”. Revista USP - Dossiê Intérpretes do Brasil - Anos 30. São Paulo, n. 38, 1998.

BAPTISTA, Dulce Maria Tourinho. Nas terras do Deus dará: Nordestinos e suas redes sociais em São Paulo. Tese de doutorado. Departamento de Ciências Sociais, PUC/SP, 1998. 
BARTHES, Rolland. Mitologias. São Paulo: Difel, 1985.

BRUNO, Ernani da Silva. Memórias da Cidade de São Paulo - 1.553- 1.958. São Paulo: DPH/PMSP, 1981.

BUENO, Eduardo (org). Os nascimentos de São Paulo. Rio de Janeiro: Ediouro, 2004.

CAPELATO, Maria Helena Rolim; PRADO, Maria Lígia. O bravo matutino: imprensa e ideologia no jornal “O Estado de S. Paulo”. São Paulo: Alfa-Ômega, 1980.

CUNHA, L. e MILZ, T. Joias de Crioula. São Paulo: Edição Terceiro Nome, 2011.

DECCA, Maria A. Guzzo. A Vida Fora das Fábricas - Cotidiano Operário em São Paulo (1920/1934). Rio de Janeiro: Paz e Terra, 1987.

DEL PRIORE, Mary; VENÂNCIO, Renato Pinto. O Livro de Ouro da História do Brasil. Rio de Janeiro: Ediouro, 2001.

DIAS, Maria Odila leite da Silva. Quotidiano e poder em São Paulo no século XIX. São Paulo: Brasiliense, 1995. $2^{\mathrm{a}}$ ed.

ERIKSEN, Thomas Hylland e FINN, Sivert Nielsen. História da Antropologia. Petrópolis, Rio de Janeiro: Vozes, 2007.

FAUSTO, Boris. História do Brasil. São Paulo: EDUSP, 2003.

KI-ZERBO, Joseph. História da África Negra. Volume I. Lisboa: Publicações Europa-América, 1972.

LAPA, José Roberto do Amaral (org.). História Política da República. Campinas: Papirus, 1990.

LESSA, Carlos. O Rio de todos os Brasis: Uma reflexão em busca de auto-estima. Rio de Janeiro: Record, 2000.

LODY, Raul. Joias de axé. Fios de contas e outros adornos do corpo. Rio de Janeiro: Bertrand Brasil, 2010.

LONGHI, Carla Reis. Mãos que fizeram São Paulo: A história da cidade contada em recortes biográficos. São Paulo: Celebris, 2003.

LUCENA, Célia Toledo. Bairro do Bexiga: A sobrevivência cultural. São Paulo: Brasiliense, 1984.

MACHADO, António de Alcântara. Brás, Bexiga e Barra Funda. In: Novelas Paulistanas. São Paulo: Ediouro, 2005.

MAGNANI, S. L. O Movimento Anarquista em São Paulo. In: O Movimento anarquista em São Paulo (1906-1917). São Paulo, Brasiliense, 1982. 
MEYRER, Marlise Regina. Representações Do Desenvolvimento nas Fotorreportagens Da Revista O Cruzeiro (1955-1957) Tese Doutorado em História, pela Pontifícia Universidade Católica do Rio Grande do Sul, 2007

PRADO JR., Caio. Evolução política do Brasil - Colônia e Império. São Paulo: Brasiliense, 1999.

QUINTO JR., Luiz de Pinedo. Nova legislação urbana e os velhos fantasmas. Revista Estudos Avançados, volume 17, número 47, 2003, pp. 187-196.

RAHMEIER, Andrea Helena Petry. Alemanha e Brasil: as relações diplomáticas em 1938. PUCRS, IX Encontro Estadual de História, ANPUH-RS, 2008.

RIBEIRO, Octavio. Barra pesada. Rio de Janeiro: Editora Codecri, 1944

SALLES, Iraci Galvão. Trabalho, progresso e sociedade civilizada. São Paulo: Hucitec: Brasília, Instituto Nacional do Livro, Fundação Nacional Pró-memória, 1986.

SANTOS, Carlos José Ferreira. Nem tudo era italiano: São Paulo e pobreza 1890-1915. São Paulo: Annablume; FAPESP, 1998.

SCHWARCZ, Lilia Moritz (org.). História da vida privada no Brasil: contrastes da intimidade contemporânea. São Paulo: Companhia das Letras, 1998.

SCHWARZMAN, S. As encenações da História. Revista História. São Paulo, vol. 22, n.1, 2003.

SCHWARZMAN, S.; BOMENY, H.; COSTA, V. Tempos de Capanema. São Paulo: EDUSP/Paz e Terra, 2000.

SEVCENKO, Nicolau. Literatura como missão: Tensões sociais e criação cultural na Primeira República. São Paulo: Brasiliense, 1983.

SEVCENKO, Nicolau. Orfeu Extático na metrópole: São Paulo sociedade e cultura nos frementes anos 20. São Paulo: Cia das Letras, 1992.

SKIDMORE, Thomas. Brasil: de Getúlio a Castelo. Rio de janeiro: Paz e Terra, 1982, $7^{\text {a }}$ ed. Brasil: de Castelo a Tancredo. Rio de janeiro: Paz e Terra, 1988, $7^{\mathrm{a}}$ ed.

TAVARES, Maria da Conceição (org.) Seca e poder: entrevista com Celso Furtado. São Paulo: Editora Fundação Perseu Abramo, 1998

TOTA, Antonio Pedro. O Estado Novo. São Paulo: Brasiliense, 1994.

WEIL, S. Attente de Dieu. Paris: La Colombe, 1950 In BOSI, Eclea. A atenção em Simone Weil. Revista Psicologia USP, v. 14, nº 1, São Paulo, 2003. 
WISSEMBACH, M.L. Da escravidão à liberdade. Dimensões de uma privacidade possível. In: NOVAIS, Fernando (org). História da Vida Privada. Vol. III. São Paulo: Companhia das Letras, 1998.

Yi-Fu Tuan. Espaço e lugar - A perspectiva da experiência. São Paulo: DIFEL, 1983.

\section{Imprensa e Imagem}

ABREU, Alzira Alves. A modernização da imprensa (1970-2000). Rio de Janeiro: Zahar, 2002.

ANDRADE, Joaquim Marçal Ferreira de. História da fotorreportagem no Brasil: A fotografia na imprensa do Rio de Janeiro de 1839 a 1900. Rio de Janeiro: Elsevier, 2004, $3^{\text {a }}$ reimpressão.

ANGOTTI-SALGUEIRO, Heliana. A construção de representações nacionais: os desenhos de Percy Lau na Revista Brasileira de Geografia e outras "visões iconográficas" do Brasil moderno. Anais do Museu Paulista. Volume. 13. n. 2. Julho. Dezembro de 2005.

BOAS, Sérgio Vilas. O estilo magazine: o texto em revista. São Paulo: Summus, 1996.

BRAGANÇA, M. de Carmen Miranda e a Caberetera Mexicana. Corpo, fronteira e mediação em torno do nacional-popular na cultura latino-americana. In: Revista Fronteiras - Estudiáticos, Unisinos, v. X, nº 3, set/dez, 2008.

CARDOSO, José Leandro Rocha. Aconteceu, virou Manchete. Revista Brasileira de História, vol.21, n. 41, São Paulo, 2001.

CARDOSO, Rafael (org.). O design brasileiro antes do design: aspectos da história gráfica, 18701960. São Paulo: Cosac Naif, 2005.

CARDOSO, Rafael. Uma Introdução à História do Design. São Paulo: Edgard Blücher, 2004.

CARNEIRO, Maria Luiza Tucci. O Brasil diante dos nazistas. Revista de História.com.br, 2012. Acesso em 10 de outubro de 2012. Disponível em: <http://www.revistadehistoria.com.br/secao/capa/o-brasil-diante-dos-nazistas. Acessado em 10/06/2009.

CARVALHO, Luiz Maklouf. Cobras Criadas: David Nasser e o Cruzeiro. São Paulo: SENAC, 2001.

COSTA, Helouise; BURGI, Sérgio (orgs). As origens do fotojornalismo no Brasil: Um olhar sobre O Cruzeiro 1940-1960. São Paulo: Instituto Moreira Salles, 2013.

COSTA, Helouise. A fotografia moderna no Brasil. São Paulo: Cosac Naif, 2012. 
COSTA, Helouise. Diacuí: a fotorreportagem como projeto etnocida. Revista Studium 17, UNICAMP: Campinas, 2004. Disponível em <http://www.studium.iar.unicamp.br/17/01.html>. Acesso em 14 de janeiro de 2013.

COSTA, Helouise. Aprenda a ver as coisas: fotojornalismo e modernidade na revista O Cruzeiro. Dissertação de mestrado. São Paulo: ECA/USP, 1992

. Um olhar que aprisiona o outro: o retrato do índio e o papel do fotojornalismo na revista O Cruzeiro. Imagens, v. 2. Campinas: Unicamp, 1994.

COZER, Raquel. 2013. A vida de hoje não admite leituras demoradas. Olavo Bilac, em 1901. Folha de São Paulo. Blog Folha 11 de março de 2013. Disponível em http://migre.me/hMGmB. Acesso em 20 de dezembro de 2013.

FRANCISCHETT, Leandra. 50 anos do assassinato de Aída Curi - O fotojornalismo fazendo escola na revista O Cruzeiro. Revista da Biblioteca on-line de Ciências da Comunicação. Portugal, 2008.

FREUND, Gisele. La fotografia como documento social. Editorial Gustavo Gili: Barcelona, 2006.

GASKELL, Ivan. História das Imagens. In: BURKE, Peter (org). A escrita da História. Novas perspectivas. São Paulo: EDUNESP, 1992.

GONÇALVES, José Esmeraldo; BARROS, J. A. (orgs.) Aconteceu na Manchete: as histórias que ninguém contou. Rio de Janeiro: Desiderata, 2008.

JUNQUEIRA, Mary A. Representações políticas do território latino-americano na Revista Seleções.Revista Brasileira de História. vol. 21, n. 42, 2001.

KOTSCHO, R. A prática da reportagem. São Paulo: Ática, 1986.

KUBALEK, Paul. The tourist gaze. Chelsea College of arts and Design. MA Graphic Design Communicatios, 2008. Acesso em 10 de maio de 2011. Disponível em http://www.kubalek.at/download/KubalekPaul-MAGDC-TheTouristGazeEssay_end.pdf

LAGE, Nilson. Estrutura da notícia. São Paulo: Ática, 1987.

. Linguagem jornalística. São Paulo: Ática, 1998.

MANZON, Jean. Flagrantes do Brasil. Bloch Editôres S.A.: Rio de Janeiro, 1956.

Retrato vivo de uma grande aventura. Rio de Janeiro: Aprazível Edições, 2006/2007.

MARTINS, Ana Cecilia Impellizieri de Souza. Bem na foto: A invenção do Brasil na fotografia de Jean Manzon. Dissertação de Mestrado. Pontifícia Universidade Católica do Rio de janeiro, RJ, 2007. 
MARTINS, Ana Luiza. Revistas em revista: Imprensa e Práticas Culturais em Tempos de República, São Paulo (1890-1922). São Paulo: Editora da Universidade de São Paulo, Fapesp, 2008.

MENESES, Ulpiano T. Bezerra de. Rumo a uma "História Visual". In: MARINS, José de Souza; ECKERT, Cornélia; NOVAES, Sylvia Caiuby (orgs). O Imaginário e o poético nas Ciências Sociais. Bauru: Edusc, 2005.

. Fontes visuais, cultura visual, História visual. Balanço provisório, propostas cautelares. Revista Brasileira de História. v. 23, n.45, pp. 11-36, 2003.

MORAIS, Fernando. Chatô: o rei do Brasil. São Paulo: Companhia das Letras, 1994.

NASSER, David e MANZON, Jean. Mergulho na aventura. Rio de Janeiro: Empresa Gráfica "O Cruzeiro" S.A., 1945.

NETTO, Accioly. O Império de Papel: os bastidores de O Cruzeiro. Porto Alegre: Sulina, 1998.

OSBORNE. Peter. Travelling Light: Photography, Travel and Visual Culture. Manchester and New York: Manchester University Press, 2000

OLIVEIRA, Cláudia de; VELloSO, Monica Pimenta e LINS, Vera. $O$ moderno em revista. Representações do rio de Janeiro de 1830 a 1930. Rio de Janeiro, Garamond, 2010.

PEREGRINO, Nadja Fonseca e MAGALHÃES, Angela. Fotoclubismo no Brasil. O legado da sociedade fluminense de fotografia. Rio de Janeiro: SENAC Nacional, 2012.

SÁ, Antônio Fernando De Araújo. O Sertão de Pierre Verger Revista Patrimônio e Cultura Material. Projeto História no 358 40, junho de 2010. 357 - 391.

SALIBA, Elias Thomé. Raízes do Riso. São Paulo: Cia das Letras, 2002.

SALIBA, Elias Thomé. As imagens canônicas e a História. CAPELATO, Maria Helena, MORETTIN, Eduardo, NAPOLITANO, Marcos, SALIBA, Elias Thomé (orgs.). História e cinema: dimensões históricas do audiovisual. São Paulo: Alameda, 2007.

SERPA, Leoni Terezinha Vieira. A máscara da modernidade: a mulher na revista O Cruzeiro (1928-1945). Passo Fundo: Universidade de Passo Fundo, 2003.

SILVA, Marcos. Prazer e poder do amigo da onça. Paz e Terra: Rio de Janeiro, 1989.

SODRÉ, Muniz, FERRARI, Maria Helena. Técnica de reportagem; notas sobre a narrativa jornalística. São Paulo: Summus, 1986.

TACCA, Fernando de. O Cruzeiro versus Paris Match e Life Magazine: um jogo espetacular. LÍBERO - Revista do Programa de Pós-graduação da Faculdade Cásper Líbero - Ano IX, n. 17. Jun. 2006. 
TRICHES, Robertha Pedroso. A labareda da discórdia: o antilusitanismo na imprensa carioca. Revista de Ciência Política, n. 36, Jul./Ago. 2007.

URSINI, Leslye Bombonatto. A Revista O Cruzeiro na virada da década de 1930. Mestrado. Antropologia Social. UNICAMP: Campinas, 2000.

VAN DER LINDEN, Sophie. Para ler o livro ilustrado. São Paulo: Cosac Naify, 2011.

\section{$\underline{\text { Nordeste }}$}

AB'SABER, Aziz. Sertões e sertanejos: uma geografia humana sofrida. Dossiê Nordeste Seco. Revista de Estudos Avançados. Ano 13, v. 36, 1999.

AGUIAR, Manoel Pinto de. Abastecimento: crises, motins e intervenção. Rio de Janeiro: Philobiblion, 1985 (Coleção Redescobrimento do Brasil, 4).

ALBUQUERQUE JR, Durval Muniz. A invenção do Nordeste e outras artes. Prefácio de Margareth Rago. Recife: FJN, Massangana; São Paulo: Cortez, 1999.

ANDRADE, Ana Maria Ribeiro de; CARDOSO, José Leandro Rocha. Aconteceu, virou manchete. Revista brasileira de História [online]. vol. 21, n.41, pp. 243-264, 2001. ISSN 18069347. Disponível em: <http://dx.doi.org/10.1590/S0102-01882001000200013>. Acessado em 14/05/2007.

ARAÚJO, Heloísa Vilhena de. Guimarães Rosa: diplomata. Brasília: Fundação Alexandre de Gusmão, 2007.

ARAÚJO, Ricardo Benzaquem. Guerra e Paz: Casa Grande \& Senzala e a obra de Gilberto Freyre nos anos 30.Rio de Janeiro, Editora 34, 1994, pp. 137, 147-149. In: DUARTE, Regina Horta. (org.) Com açúcar e com afeto: Impressões do Brasil em Nordeste de Gilberto Freyre. Revista Tempo. Rio de Janeiro, no 19, ano 2009.

BARADEL, Alex (org.). O Brasil de Pierre Verger. Rio de Janeiro: Fundação Pierre Verger, 2006.

BOLLE, Willi. Grandesertão.br: O romance de formação do Brasil. São Paulo: Duas Cidades; 34, 2004.

BOURDIEU, Pierre. Sociologia. São Paulo: Ática, 1983.

BRAIT, Beth (org). O sertão e os sertões. São Paulo: Arte \& Ciência, 1998.

CASCUDO, Luís da Câmara. Vaqueiros e cantadores. Belo Horizonte: Itatiaia; São Paulo: Universidade de São Paulo, 1984.

CENTRO DE ESTUdOS MIGRATÓRIOS DE SÃO PAULO. Migrantes: êxodo forçado. São Paulo: Paulinas, 1980. 
O fenômeno migratório no limiar do terceiro milênio. Vozes: Petrópolis, 1998.

CHAVES, Edineila Rodrigues. O Sertão de Rio Pardo: sociedade, cultura material e justiça nas Minas oitocentistas. Dissertação (Mestrado em História). Belo Horizonte: FFCH-UFMG, 2004.

CLEMENTE, Marcos Edílson de Araújo. Cangaço e Cangaceiros: Histórias e ImagensFotográficas Do Tempo De Lampião. Fênix - Revista de História e Estudos Culturais. Outubro/Novembro/Dezembro de 2007. v. 4, Ano IV, n. 4, p. 1-18.

COSTA, Liduina Farias Almeida. O sertão não virou mar: Nordestes, globalização e imagem pública da nova elite cearense. São Paulo: Annablume; Fortaleza: Universidade Estadual do Ceará, 2005.

CUNHA, Euclides. Os sertões. São Paulo: Abril Cultural, 1982.

. Um Paraíso Perdido. Ensaios amazônicos. Brasília: Senado Federal, 2000.

. A margem da História. Belém: UNAMA, 2001.

CURRAN, Mark J. História do Brasil em cordel. São Paulo: EDUSP, 2003. $2^{\text {a }}$ ed.

DUARTE, Regina Horta. Com açúcar e com afeto: Impressões do Brasil em Nordeste de Gilberto Freyre. Tempo - Revista do Departamento de História da UFF, Rio de Janeiro, no 19, 2009.

ESTRELA, Ely Souza. Os sampauleiros: Cotidiano e representações. São Paulo: Humanitas FFLCH - USP; FAPESP; Bauru: EDUC, 2003.

FERREIRA, A.L.A.; DANTAS, G.A.F. Os indesejáveis na cidade: as representações do retirante da seca (Natal, 1890-1930). Scripta Nova - Revista Eletrônica de Geografia y Ciências Sociales. Universidad de Barcelona, nº 94, Migración y Cambio Social, 01 de agosto de 2001.

FUNDAÇÃO DA CASA JOSÉ AMÉRICO. Discurso “José Américo no contexto da problemática da região semi-árida do nordeste brasileiro”. 14 de junho de 2005. Disponível em: <http://www.alanepb.org/downloads/osterne_11.pdf>. Acesso em 10/05/2010.

FONTES, Paulo. Um Nordeste em São Paulo. São Paulo: FGV, 2008.

FOURQUET, François. Cidades e economias - mundo segundo Fernand Braudel. Espaço e Debate. n. 33, 1991.

FREYRE, Gilberto. O Mundo que o português criou: aspectos das relações sociaes e de cultura do Brasil com Portugal e as colônias portuguesas. Rio de Janeiro: José Olympio, 1940. 164p.

Manifesto Regionalista. Recife: Massangana, 1996. $7^{\mathrm{a}} \mathrm{ed}$.

Nordeste: Aspectos da influência da cana sobre a vida e a paisagem do nordeste do Brasil.São Paulo: Graal, 2004. $7^{\mathrm{a}}$ ed. revista.

FURTADO, Celso. Seca e poder: Entrevista com Celso Furtado. São Paulo: Perseu Abramo, 1998. 
1999.

O longo amanhecer: Reflexões sobre a formação do Brasil. Rio de Janeiro: Paz e Terra,

GEBARA, Ivone. A mobilidade da senzala feminina: As mulheres nordestinas - Vida melhor e feminismo. São Paulo: Paulinas, 2000.

HOBSBAWN, Eric. Bandidos. Barcelona: Crítica, 2001.

HOLANDA, Aurélio Buarque de. Feira de Cabeças. Suplemento Cultural. Diário Oficial, Estado de Pernambuco, Ano IX, p. 15, Julho de 1995.

IEB USP. Vocabulario Portuguez e Latino. Verbete Sertaõ. Disponível

em<http://www.brasiliana.usp.br/pt-br/dicionario/edicao/1>. Acessado em 05/05/2013.

IOKOI, Zilda Márcia Gricoli (coord.) Industrialização, urbanização e migrações em São Paulo séculos XIX e XX. Série Iniciação. São Paulo: Dept ${ }^{\circ}$ História FFLCH/USP, 1995.

JANNUZZI, Paulo de Martino. Migração e mobilidade social migrante no mercado de trabalho paulista. São Paulo: Autores Associados; Campinas: IFCH/UNICAMP, 2000.

JESUS, Alysson Luiz Freitas de. O sertão e sua historicidade: versões e representações para o cotidiano sertanejo - séculos XVIII E XIX. História e Perspectiva, Uberlândia, n. 35, Jul/Dez, 2006, p. 256-259.

JORNAL DO COMMERCIO - JC Cultural - Caderno C: Especial Gilberto Freyre II - Recife, quarta-feira, 13 de março de 2000. Versão eletrônica, JC On Line. Disponível em: <http://www2.uol.com.br/JC/_2000/2003/cu1503b.htm>. Acessado em 05/05/2008.

KRUCHIN, Samuel. São Paulo 30-60: quatro movimentos. Espaço \& Debates, Revista de Estudos Regionais e Urbanos. Ano IX, n. 27, 1989, p. 28-46.

KUBALEK, Paul. Chelsea College of Arts and Design. MA Grafic Design Communications, 2008. Disponível em: <http://www.kubalek.at/download/KubalekPaul-MAGDC-

TheTouristGazeEssay_end.pdf>. Acessado em 10/05/2011.

LACERDA, Carlos. Visão da sêca do nordeste. Um relato. Um testemunho. Um programa. Rio de Janeiro: Coleção Tribuna da Imprensa, [195-]

LAMBERT, Jacques. Os dois Brasis. Brasiliana v. 335. São Paulo: Nacional, 1978.

LEMOS, Maria Alzira Brum. O doutor e o jagunço: Ciência, mestiçagem e cultura em Os Sertões. Marília: UNIMAR; São Paulo: Arte \& Ciência, 2000. (Coleção Estudos Acadêmicos).

LEVY, Maria Estella Ferreira. Cem anos de movimentos populacionais: São Paulo em destaque. Revista Brasileira de Estudos da População - ABEP-NEPO UNICAMP. v. 13, n. 1, 1996.

LIMA, Ariza Maria Rocha. Aseca, o sertanejo e a ginástica sueca na batalha da borracha (19421945). In: CAVALCANTE, Maria Juraci Maia et al. História e Memória da Educação no Ceará. Fortaleza: Imprensa Universitária, 2002. 
LOPES, Jader. Então, somos mudantes: espaço, lugar e territórios de identidade em crianças migrantes. Tese apresentada ao Programa de. Pós-Graduação em Educação da. Faculdade de Educação da Universidade Federal Fluminense, 2003.

LÜHNING, Angela. Verger, Bastide e Métraux: três trajetórias entrelaçadas. Revista USP. São Paulo, n. 95, pp. 128-141, Set./Out./Nov. 2012.

MACHADO, António de Alcântara. Novelas Paulistanas. Rio de Janeiro, Livraria José Olympio, 1979. $6^{\mathrm{a}}$ ed.

MARQUES, José de Oliveira. Revista de Imigração e Colonização, publicação oficial do Conselho de Imigração e Colonização do governo Vargas, 1940, abril, p. 206-207.

MARTINS, Dora; VANALLI, Sônia. Migrantes. Migração interna no Brasil. "Baianos" $e$ "paraíbas". A reforma agrária resolve? São Paulo: Contexto, 2001 (Coleção repensando a geografia).

MELO, J. C. Secas Ferrovias e mão de obra. Revista RAÍZES, Campina Grande, Ano XV, n . 12, jan. 1996.

MENEZES, Marilda Aparecida; GONÇALVES, Alfredo José (orgs.). Centro De Estudos Migratórios de São Paulo. Migração no Brasil: O peregrinar de um povo sem terra. São Paulo: Paulinas, 1986.

MENEZES, Vanessa Alves. A contribuição do fotógrafo Pierre Verger no processo identitário do Nordeste brasileiro. Anais do V Fórum Identidades e Alteridades. I Congresso Nacional Educação e Diversidade. Universidade Federal de Sergipe, Itabaiana/Sergipe, 2011. Acesso em 20 de novembro de 2013. Disponível em: http://200.17.141.110/forumidentidades/Vforum/caderno_resumos_V_forum.pdf

MILITÃO, Marcello André. Por Que Virgulino Tornou-Se Lampião: Uma Análise das Relações de Poder no Nordeste Brasileiro Durante a Primeira República. Curso de História da UFPR, 2007. Disponível em: http://www.historia.ufpr.br/monografias/2007/2_sem_2007/marcello_andre_militao.pdf. Acesso em: 10 de dezembro de 2013.

MISSE, Michel. Malandros, Marginais e Vagabundos \& a acumulação social da violência no Rio de Janeiro. Tese apresentada ao Instituto Universitário de Pesquisas do Rio de Janeiro, em 20 de dezembro de 1999.

MOTA, Carlos Guilherme. Nordeste, 1817. Estudos. São Paulo: Perspectiva, 1972.

MOURA, Mariluce. A prosa viva de um senhor cientista. Revista Pesquisa FAPESP. Edição Impressa, n. 114, ago. 2005.

NEVES, Erivaldo Fagundes. Sampauleiros traficantes: Comércio de Escravos do Alto Sertão da Bahia para o Oeste Cafeeiro Paulista. Revista Afroásia, UFBA, n. 24, 2000. 
NEVES, Frederico de Castro. A memória do Nordeste e o Nordeste na memória. Comunicação datilografada. Acervo do Centro de Estudos Migratórios, 2001.

NÓBREGA, Cida; ECHEVERRÍA, Regina. Verger: Retrato em Preto e Branco.Salvador: Corrupio, 2002.

OLIVEIRA, Adriano Messias de. O cangaço no cinema brasileiro dos anos 90: um certo olhar sobre nossa identidade cultural. (Dissertação de Mestrado). Belo Horizonte: Faculdade de Filosofia e Ciências Humanas/ Curso de Comunicação Social, 2001.

OLIVEIRA, Francisco de. Elegia para uma re(li)gião. SUDENE, Nordeste. Planejamento e conflitos de classes. Rio de Janeiro: Paz e Terra, 1977.

OLIVEIRA, Lucia Vanir Alves. O migrante nordestino, a cultura e a formação de territórios em Caldas Novas/Goiás. Dissertação de Mestrado. Uberlândia: Universidade Federal de Uberlândia, 2005.

PAIVA, Odair da Cruz. Introdução à História da Hospedaria de Imigrantes em seus aspectos Institucionais. Guia do Acervo. São Paulo: Memorial do Imigrante/Museu da Imigração, 2000.

. Brasil, na hospedaria de Imigrantes (1888-1993). A migração para o Estado de São Paulo. São Paulo: Memorial do Imigrante, 2001. (IEB).

. Caminhos Cruzados: Migração e construção do Brasil moderno (1930-1950). Bauru: EDUSC, 2004.

Migrações internacionais pós Segunda Guerra Mundial: A influência dos EUA no controle e gestão dos deslocamentos populacionais nas décadas de 1940 e 1960. In: Anais do XIX Encontro Regional de História da ANPUH - Seção São Paulo, 2008, São Paulo, vol. 1.

PAIVA, Odair da Cruz; MOURA, Soraya. Hospedaria de Imigrantes de São Paulo. São Paulo: Paz e Terra, 2008.

PEREIRA, Paulo Casar Xavier. São Paulo, uma ou várias cidades e Histórias? FAUUSP. Disponível em: <http://sitemason.vanderbilt.edu/files/jPx4K4/Pereira\%20Paulo\%20Cesar\%20Xavier.pdf>. Acessado em 11/10/2013.

PIRES, Simeão Ribeiro. Raízes de Minas. Montes Claros: Edição do Autor, 1979.

PÓVOA NETO, Helion. Nordeste, nordestinos. Questão migratória e política regional. Dissertação de Mestrado. Rio de Janeiro: Universidade Federal do Rio de Janeiro, 1988.

QUINTO JR., Luiz de Pinedo. Nova Legislação Urbana e os Velhos Fantasmas. Revista Estudos Avançados, v. 17, n.47, 2003. 
RIBEIRO, Rafael Winter. Seca e determinismo. Anuário do Instituto de Geociências da UFRJ, 1999, vol. 22, pp. 60-91. Disponível em:

<http://www.anuario.igeo.ufrj.br/anuario_1999/vol22_60_91.pdF>. Acessado em 10/02/2012.

RIBEIRO JR., José. Colonização e monopólio no Nordeste brasileiro. São Paulo: Hucitec, 2004.

RIGAMONTE, R.C. Sertanejos contemporâneos: entre a metrópole e o sertão. São Paulo: Humanitas, 2001. Prefácio de José Guilherme Cantor.

ROCHA, Antonia Sarah Aziz. O Bairro à sombra da Chaminé. São Paulo: PUC, 1992.

SÁ, Antonio Fernando de Araújo. Lampião revisitado: Cangaço, cinema e identidade. Revista Olho da História. Revista de Ciência, Cultura, cinema e Sociedade. Salvador, Bahia, n.11, dezembro, 2008.

SÃO PAULO, MASP/Secretaria do Estado da Cultura/Secretaria Municipal da Cultura São Paulo, Onde Está Sua História. 1981.

SCARANO, Julia Maria; LEMKE, Franke. Repertório de Legislação referente à introdução de imigrantes (1822-1899). Anais de VII Simpósio Nacional da ANPUH, São Paulo. ANPUH, 1974. In: LEVY, Maria Estella Ferreira. Cem anos de movimentos populacionais: São Paulo em destaque. Revista Brasileira de Estudos da População - ABEP-NEPO UNICAMP. Vol. 13, n1, 1996.

SARETTA, Fausto. O Estado de São Paulo e Getúlio Vargas: Política e economia (1951/1954). IX Encontro Nacional da Sociedade Brasileira de Economia Política, 2004, Uberlândia v. 1. 2004. p. $1-20$.

SERVIÇO PASTORAL DOS MIGRANTES (org). Travessias na desordem global. Fórum social das migrações. São Paulo: Paulinas, 2005.

. Migrações: discriminação e alternativas. São Paulo: Paulinas, 2004.

SILVA, Célia Nonata. Mandões e Bandidos na capitania das Minas. (Tese de doutorado) Universidade Federal de Minas Gerais, UFMG, 2004.

SILVA, Maria Aparecida de Moraes. Errantes do fim do século. São Paulo: Fundação Editora da UNESP, 1999.

SILVEIRA, Rosa Maria Godoy. O regionalismo nordestino: Existência e consciência da desigualdade regional. São Paulo: Moderna, 1984.

STERNBERG, Hilgard O’Reilly. Aspectos da seca de 1951, no Ceará. Revista Brasileira de Geografia, ano XIII, número 3, julho-setembro de 1951, pp. 330-344.

SUDENE $\mathrm{n}^{\circ}$ 24. Série População e Emprego. Tendências das migrações no Nordeste de 19401980.

TAVARES, Odorico. Canudos Cinquenta Anos Depois (1947). Salvador: Conselho Estadual de Cultura/Academia de Letras da Bahia/Fundação Cultural do Estado, 1993, p. 39-53. In: SÁ, 
Antônio Fernando De Araújo. O Sertão de Pierre Verger. Revista Patrimônio e Cultura Material. Projeto História. n. 358 40, junho de 2010. p. 357-391.

TEÓFILO, Rodolfo. A Fome. Cenas da seca do Ceará. Organização e notas de Waldemar Rodrigues Filho; posfácio de Lira neto. São Paulo: Tordesilhas, 2011.

The New York Times, of rubber and blood in brazilian Amazon. 23 de novembro de 2006. Disponivel em: <http://www.nytimes.com/2006/11/23/world/americas/23brazil.html?_r=2\&pagewanted= 2\&oref=slogin $>$. Acessado em 10/03/2008.

THOMPSON, Alistair. Histórias (co)movedoras: História Oral e estudos de migração. Revista Brasileira de História, São Paulo, n. 44, v. 22, 2002.

URSINI, Leslie. A Revista O Cruzeiro na virada da década de 30. Dissertação de mestrado, IFCH UNICAMP, 2000.

VASCONCELOS, Sandra Guardini Teixeira. Migrantes nos espaços (sertão, memória e nação). Revista do CESPUC, Belo Horizonte, UFMG, v. 22, n. 30, jan./jun. 2002 . p. 67-81.

VARGAS, Emiliana. Os discursos de Vargas e as políticas sociais no Brasil de 1930 a 1940. Dissertação apresentada ao Programa de Pós-Graduação em Serviço Social da Universidade Federal de Santa Catarina, 2007.

VASSALLO, Lígia. $O$ sertão medieval: origens europeias do teatro de Ariano Suassuna. Rio de Janeiro: Francisco Alves, 1993.

VIEIRA, Marcelo Didimo Souza. Filmes do cangaço: a representação do ciclo na década de noventa no cinema brasileiro (Dissertação de Mestrado). Campinas: UNICAMP / Instituto de Artes, 2001.

VILLA, Marco Antônio. Vida e morte: história das secas no Nordeste nos séculos XIX e XX. Revista Brasileira, São Paulo, v. 22, n 43, pp. 2451-254, 2002.

ZAIDAN F. Michel. O fim do nordeste \& outros mitos. São Paulo: Cortez, 2001. (Coleção Questões de nossa época, v. 82).

\section{$\underline{\text { Teoria }}$}

BLOCH, Marc. Introdução à História. Lisboa: Publicações Europa-América, 1993. Edição revista, aumentada e criticada por Étienne Bloch.

BRAUDEL, Fernand. História e Ciência Sociais. Lisboa: Presença, 1990. $6^{\text {a }}$ ed.

BOURDIER, Pierre. Um analista do inconsciente. In: SAYAD, Abdelmalek. A Imigração ou os paradoxos da alteridade. São Paulo: EDUSP, 1998.

BURKE, Peter (org.). A escrita da História: Novas Perspectivas. São Paulo: Universidade Estadual Paulista, 1992. 
BURKE, Peter. A Escola dos Annales 1929-1989: A Revolução Francesa da Historiografia.São Paulo: UNESP, 1997.

CARDOSO, Ciro Flamarion; VAINFAS, Ronaldo (orgs). Domínios da História: Ensaios de teoria e metodologia. Rio de Janeiro: Campus, 1997.

CHARTIER, Roger. A História cultural: entre práticas e representações. Lisboa: Difel, 1990.

. A História de Hoje: dúvidas, desafios, propostas. Revista Estudos Históricos, Rio de Janeiro, vol. 7, n. 13, 1994, p. 108.

Fontes, 1998.

; LE GOFF, Jacques; REVEL, Jacques (dirs). A história nova. São Paulo: Martins Escribir las prácticas (Foucault, De Certeau, Marin). Buenos Aires: Manantial, 2006.

Paulo: IEA, 1991.

. O Mundo como representação. Revista de Estudos Avançados. Ano 11, v. 5, São

DAVIS, Natalie Zemon. O retorno de Martin Guerre. Rio de Janeiro: Paz e Terra, 1987.

FREITAS, Marcos César de. (org.). Historiografia brasileira em perspectiva. São Paulo: Contexto, 1998.

GEERTZ, Clifford. A interpretação das culturas. Rio de Janeiro: Guanabara, 1989.

GINZBURG, Carlo. Mitos, emblemas e sinais: Morfologia e história. Trad. Federico Carotti. São Paulo: Cia das Letras, 2003.

HOBSBAWN, Eric. Sobre História. São Paulo: Cia das Letras, 1998.

HUNT, Lynn. A nova história cultural. São Paulo: Martins Fontes, 1995.

LADURIE, Montaillou. Povoado Occitânico 1294-1394. Tradução Maria Lúcia Machado. São Paulo: Companhia das Letras, 1997.

LE GOFF, Jacques. Memória e História. Campinas: UNICAMP, 1996.

LE GOFF, Jacques; NORA, Pierre. História: Novas Abordagens. Rio de Janeiro: Francisco Alves, 1976.

. História: Novos Objetos. Rio de Janeiro: Francisco Alves, 1976.

História: Novos Problemas. Rio de Janeiro: Francisco Alves, 1976.

LEBRUN, Gerard. O avesso da dialética: Hegel à luz de Nietzsche. São Paulo: Companhia das Letras, 1988. 
LEFORT, Claude. As Formas da História: Ensaios de antropologia política. São Paulo: Editora Brasiliense, 1990. $2^{\mathrm{a}}$ ed.

LEITE, Dante Moreira. O caráter nacional brasileiro: História de uma ideologia.São Paulo: Ática, 1992. $5^{\mathrm{a}}$ ed.

MARIN, Louis. On Representation. Translated by Catherine Porter. Stanford, California: Stanford University Press, 2001.

MINTZ, Sidney W.; PRICE, Richard. O nascimento da cultura afro-americana: uma perspectiva antropológica. Rio de Janeiro: Pallas: Universidade Candido Mendes, 2003.

MOSCOVICI, Serge. Representações sociais: investigações em psicologia social. Petrópolis, Rio de Janeiro: Vozes, 2007

NOVAES, Adauto (org.). Tempo e História. São Paulo: Cia das Letras; Secretaria Municipal de Cultura, 1992.

ORTIZ, Renato. Cultura brasileira e identidade nacional. São Paulo: Brasiliense, 1985. . A moderna tradição brasileira. São Paulo: Brasiliense, 1994.

PESAVENTO, Sandra Jatahy. O imaginário da cidade: Paris, Rio de Janeiro, Porto Alegre - Visões literárias do urbano. Porto Alegre: Universidade; UFRGS, 1999.

. História \& História Cultural. Belo Horizonte: Autêntica, 2012.

RAPPORT, Nigel. Em louvor do cosmopolita irônico. Revista de Antropologia, v. 45, n.1, São Paulo, 2002.

ROJAS, Carlos Antonio Aguirre. Tempo, duração e civilização. Percursos braudelianos. São Paulo: Cortez Editora, 2001.

SANTOS, Milton. O Espaço do cidadão. São Paulo: Nobel, 1987.

. Pensando o espaço do homem. São Paulo, EDUSP, 2004, $5^{\text {a }}$ ed.

SAID, Edward. Orientalismo: O Oriente como invenção do Ocidente. São Paulo: Cia das Letras, 1991.

SAYAD, Abdelmalek. A imigração - Ou os paradoxos da alteridade. Prefácio de Pierre Bourdieu. São Paulo: EDUSP, 1998.

ZIMMERMANN, Tânia R. Apontamentos sobre Civilização e Violência em Norbert Elias. Revista História em reflexão, Revista do Programa de Pós-Graduação em História da Universidade Federal da Grande Dourados, v. 2, p. 55-65, 2008. Disponível em <http://www.historiaemreflexao.ufgd.edu.br/indice.php>. Acessado em 10/12/2012. 